\title{
Economic Geology of the
}

\section{Central City District}

\section{Gilpin County, Colorado}

By PAUL K. SIMS, A. A. DRAKE, JR., and E. W. TOOKER

GEOLOGICAL SURVEY PROFESSIONAL PAPER 359

Prepared on behalf of the U.S.

Atomic Energy Commission

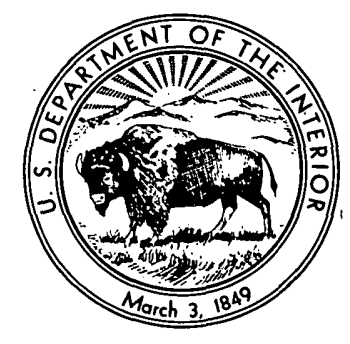


UNITED STATES DEPARTMENT OF THE INTERIOR

STEWART L. UDALL, Secretary

GEOLOGICAL SURVEY

Thomas B. Nolan, Director

The U.S. Geological Survey Library has cataloged this publication as follows:

\section{Sims, Paul Kibler, 1918-}

Economic geology of the Central City district, Gilpin County, Colorado, by Paul K. Sims, A.A. Drake, Jr., and E. W. Tooker. Washington, U.S. Govt. Print. Off., 1963.

x. 231 p. illus., maps, diagrs., tables, and portfolio (maps (part col.) diagr.) $29 \mathrm{~cm}$. (U.S. Geological Survey. Professional paper 359) Prepared on behalf of the U.S. Atomic Energy Commission. Bibliography : p. 226-227.

(Continued on next card)

\section{Sims, Paul Kibler, 1918-}

Economic geology of the Central City district, Gilpin County, Colorado. 1963. (Card 2)

1. Geology, Economic-Colorado-Central City district. 2. Oredeposits-Colorado-Central City district. 3. Mines and mineral resources-Colorado-Central City district. I. Drake, Avery Ala, 1927joint author. II. Tooker, Edwin Wilson, 1923- joint author. III. Title: The Central City district, Gilpin County, Colorado. (Series) 


\section{CONTENTS}

Abstract

Introduction. . .

Purpose and scope of report........................

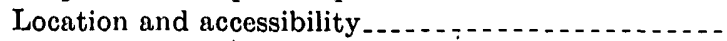

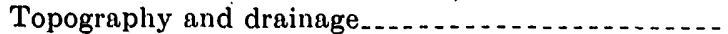

Climate and vegetation..............

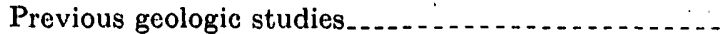

Fieldwork

Acknowledgments.

Production

History of mining

History of ore treatment..........

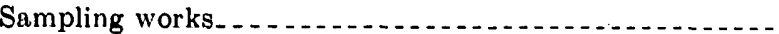

General geology $\ldots \ldots \ldots$

Precambrian rocks.

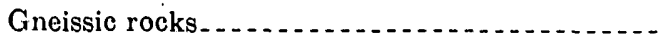
Microcline-quartz-plagioclase-biotite gneiss. Biotite gneisses. . . . . . . . . . . . . . . . . . Lime-silicate gneiss and related rocks....... Amphibolite

Cordierite-amphibole gneiss. ..............

Granitic rocks..................................

Granodiorite. . . . . . . . . .

Quartz diorite and associated hornblendite Biotite-muscovite granite.

Pegmatites.

Tertiary igneous rocks

Leucocratic granodiorite porphyry

Alkalic syenite porphyry ....................

Quartz monzonite porphyry

Bostonite porphyry . . . . . . . . . . . . .

Trachytic granite porphyry . . . .

Quartz bostonite porphyry .................

Radioactivity of the porphyritic rocks

Structure of the Precambrian rocks. . . . . . . . . .

Foliation and lineation.

Folds.......

Structure of the Tertiary igneous rocks

Joints. . . . . . . . . .

Faults

Character and classification. ..............

Faults of pre-Laramide(?) age Northwestward-trending faults............ North-northeastward-trending faults. . ....

Faults of Laramide age................... Eastward-trending faults. ............. IEast-northeastward-trending faults........ Northeastward-trending faults.............

Origin and sequence of development Summary of geologic history . . . .

Ore deposits

Veins

Stockworks_

Page
1
2
3
3
4
4
4
5
5
5
8
9
11
11
11
11
13
13
14
14
14
14
14
14
15
15
15
15
16
16
16
16
16
17
17
17
18
18
19
20
21
21
21
22
22
22
22
22
23
24
24
25
25

Ore deposits-Continued Page

Mineralogy . .

Pyrite

Sphalerite...........

Galena

Chalcopyrite ............... 27

Marcasite

Molybdenite $\ldots \ldots$

Chalcocite

Covellite

Bornite

Tetrahedrite-tennantite $\ldots \ldots \ldots \ldots$

Enargite

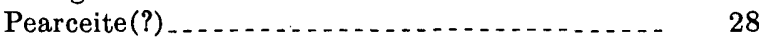

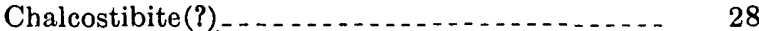

Ruby silver. ...

Gold ............. 28

Silver. . . . . .

Native bismuth

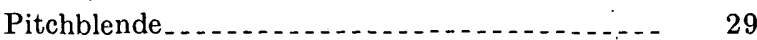

Hematite $\ldots$

Hydrous iron oxides. . . . . . . . . . . . . 29

Wolframite . . . .

Ferberite $\ldots \ldots$

Sylvanite

Fluorite

Autunite and meta-autunite............... 29

Metatorbernite and torbernite............ 29

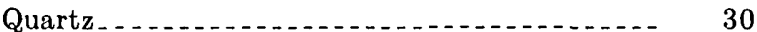

Kasolite . . . . . . . 30

Ankerite, siderite, rhodochroșite, and calcite...- $\quad 30$

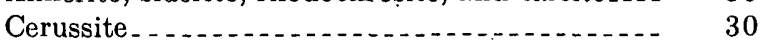

Smithsonite ........ 30

Malachite and azurite

Barite

Epsomite(?)

Copper sulfates............. 30

Zippeite, johannite, and gypsum........... 30

Relation of gold and silver to sulfide and gangue

minerals

Fineness of gold and silver..................

Classification of veins . . . . . . 33

Pyrite veins ................. 33 General character and appearance . . . . . . $\quad 33$ Grade .............. 34

Galena-sphalerite veins................. 35 General character and appearance . . . . . $\quad 35$ Grade............. 36

Local variants of ores. Telluride-bearing veins $\ldots \ldots$ Enargite-bearing veins Fluorite-bearing veins . . . . 38 Uranium-bearing veins . . . . . . . 38 
Ore deposits-Continued

Hypogene mineral zoning . . . . . . . . . . . . . Central zone..................................

Intermediate zone ... . . .

Peripheral zone.............................

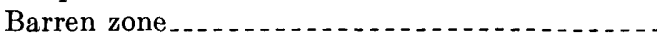

Paragenesis of vein minerals............. Uranium stage . . . . . . . . . . . . . Pyrite stage Base-metal stage

Minor elements in ores. . . . . . . .

Minor elements in sulfide minerals. . . . . . . . . . .

Ore shoots .

General character

Size and shape.

Regional attitude............................

Structural controls.......................

Physical character of the wallrock .......

Structure of the wallrock . . .

Irregularities along a fault ...............

Vein intersections or junctions...........

Explosion breccias. . . . . . . . . . . . . .

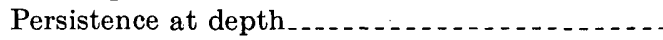

Wallrock alteration ..........................

Distribution of alteration products.........

Mineralogic and chemical changes in the wallrocks.

Supergene alteration

Gold enrichment..............................

Silver enrichment $\ldots \ldots \ldots$

Genesis of ores. . . . . .

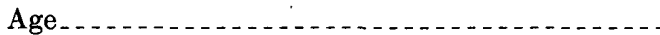

Origin of sulfide ores.

Origin of uranium ores . . . . . . . . . . . .

Origin of telluride ores.......................

Suggestions for prospecting . .

Future of district. ........

Descriptions of mines and veins

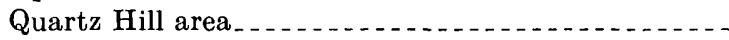

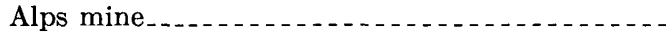

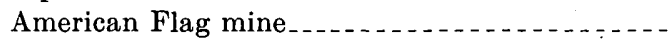

Barker mine . . .........................

Barnes mine . . . . . . . .

Baxter mine

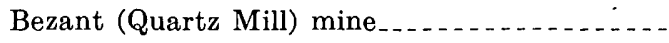

Blanche M mine.........................

Bon Ton (Quartz Hill) mine.............

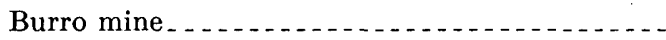

Burroughs lode..................................

California-Hidden Treasure-Gardner iode . . . . -

Camp Grove mine. . . . . . . . . . . . . . . . .

Charter Oak mine ..........................

Climax mine . . . . . . . . . . . . . . . . .

Columbia tunnel.............

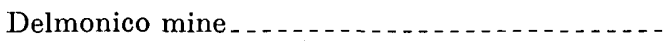

East Calhoun mine

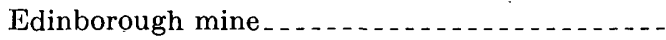

Egyptian mine . . . . . . . . .

Eldorado (Quartz Hill) mine.

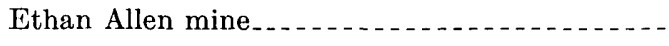

Fairfield mine .....................

Fourth of July mine

Gauntlet mine
Page Descriptions of mines and veins-Continued Quartz Hill area-Continued

Gem-Golden Dollar vein

Golden Dollar mine.

Stewart mine............................

Gem mine. . . . . . . . . . . . . . . . . . .

German (Quartz Hill) and Belcher mines.....

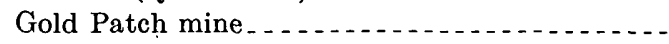

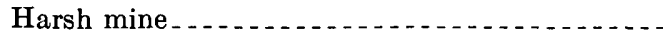

Hayes and Wheeler tunnel.

Hecla mine. . . . . . . . . . . . . . . . . . .

Illinois mine.

Ivanhoe mine

Kansas lode

Kent County mine......................

Kirk mine . . . . . . . . . . . . . . . . . . . .

LaCrosse tunnel and the Patch ...........

Last Chance mine . . . . . . . . . . . . . . . .

Mammoth mine........................

Mercer County mine...........

Missouri mine .........

Pozo mine . . . . .

Prompt Pay mine....

Quartz Hill tunnel..................................

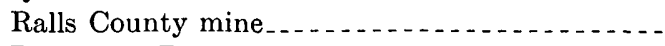

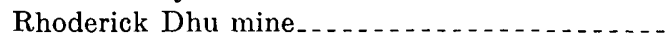

San Juan mine . . . . . . .

Symonds Fork (Forks) mine . . . . . . . . . . .

Taylor-Leavenworth mine . . . . . . . . . . . .

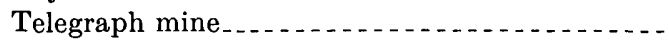

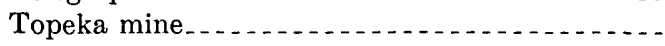

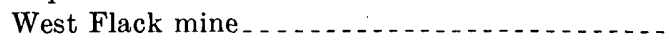

Wood mine. . . . . .

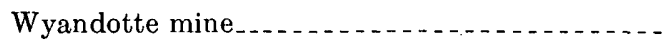

Nevada Hill and Prosser Gulch areas...........

Ashtabula mine......

Coeur d'Alene mine....

Corydon mine

Dyke mine

Essex mine

Eureka mine

Gold Collar mine (Hydrant claim) . . . . . .

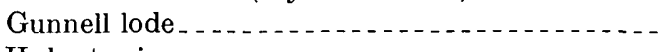

Hubert mine.....

King mine .

Lamberson and Warren mine..........

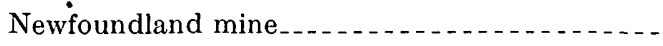

Oranoake mine

Post Hole mine...........

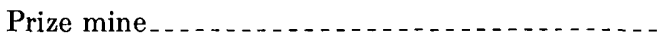

Ready Cash and Independence mines.......

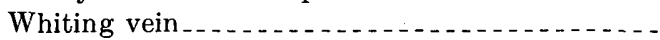

Upper Russell Gulch area...

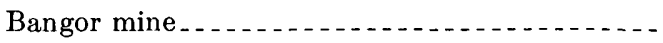

Becky Sharp mine............

East Pewabic mine

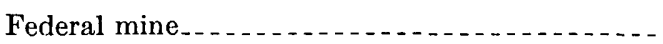

Forfar mine......

Golden Opportunity tunnel. . . . . . . . . . . . .

Gopher vein .......... 120

Hall mine

Hillhouse-Columbus vein . . . . . . . . . . . . . . 122

Incidental mine

Iron mine

Page 
Descriptions of mines and veins-Continued

Upper Russell Gulch area-Continued

Iron Duke mine. . .

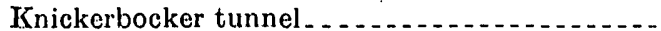

Lillian mine......

Lotus mine . . . . . . . . . . . . . . . . . . . .

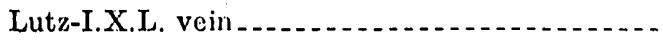
Minnesota-Michigan Boy-Gettysburg vein .....

Missouri mine.....

Old Town mine..............................

Pewabic mine...........

Richardson mine...............................

Rocky Mountain Terror mine............

Russell vein......................................

Slide mine. ................

Springdale (Gold Rock) mine............

Willis Gulch and lower Russell Gulch areas.....

Ace in the Hole mine.... . . . . . . . . .

Alva Adams mine...........

Anchor mine.

Argo mine. . .

Aurora mine. .

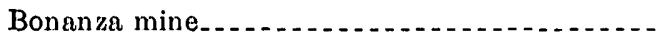

Chase mine . . . . . . .

East Notaway mine....

Gibson mine $\ldots$

Gladstone mine:-...

Gulch mine

Hampton mine . . . . . . . . . .

Hazeltine mine . . . . .

Iowa mine ...........

Iroquois mine . . . . . . .

Justice vein . . . . . . . . . . . . . . . . . .

Kokomo mine . . . . . . . . . . . . . . . .

Meeker-Success mine

Pearce (Morris) mine...

Pittsburg mine

Powers mine.........

Saratoga mine......

Silver Dollar vein...........................

Star of the West mine...

Togo mine.............

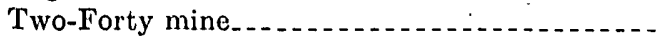

Unknown mine number F-VI-2 . . . . . . . .

War Dance mine . . . . . .

West Notaway mine.

Widow Woman (American Girl) mine. ......

Williams tunnel . . . . . . . . .

Central, Marnmoth, Gregory, Bobtail, and Bates hills

Americus mine.

Bates vein .

Bobtail tunnel........

Brooklyn mine.

Buell (U.P.R.) mine.........................

Carr vein. . . . . .

Chemung-Belmont mine..............

Clay County mine

Cousin Jack mine.

East Boston mine.

Fisk mine

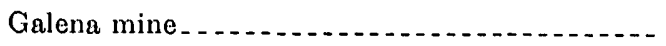

Gaston mine

German mine.
Descriptions of mines and veins-Continued

Central, Monmouth, Gregory, etc.-Continued Page

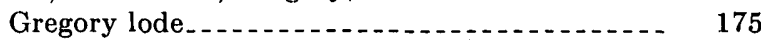

Hartford tunnel. . . . . . . . . . . . . . 176

Homer mine

Maine-Hamlet mine..................... 177

McAllister mine.

National tunnel . . . . . . . . . . . .

Nemaha-Cotton mine . . . . .

Next President mine . . . . . . . . . . . . . . . . . . 181

O.K. mine $\ldots$

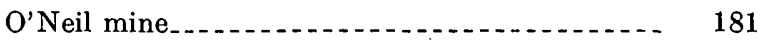

Rialto mine

Rialto Extension mine................... 183

Running Lode mine.......... 183

Sleepy Hollow mine....................... 183

Tierney (Centennial) tunnel_._. . . . . . . . 185

Unexpected mine. . . . . .

Vasa mine $\ldots \ldots$.

Chase Gulch, Maryland Mountain, and Winnebago

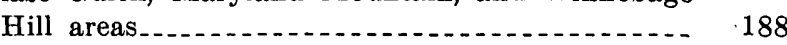

Advance tunnel

Allie tunnel $\ldots \ldots$

Belden tunnel ........

Billings-Alces mine

Casto vein . . . . . .

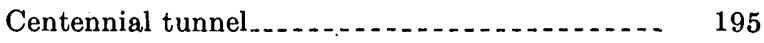

Centre tunnel ....... 197

Cliff tunnel . . . . .

Cliff Extension mine.

Freedom mine

Gold Cup and Keystone group

Gulnare mine

Hayseed tunnel

Huddleston mine. . . . . . . . . . . . . . . . . 203

Mont d'Oro tunnel..... 203

Robert Emmet mine. . . . . . . . . . . . . . . . . 203

Sans Souci mine......... 204

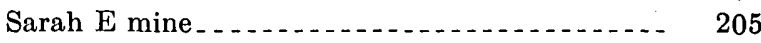

Troublesome mine.

Tucker mine........... 206

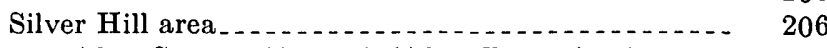

After Supper (Banzai) (After Dinner) mine ... 207

American Eagle tunnel. . . . . . . . . . . . . . 208

Blackjack mine....................... 210

Boer tunnel........

Brack Hollow mine.

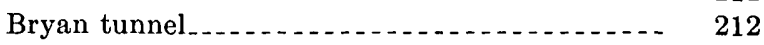

Champion mine...... 212

Chihuahua mine........ 212

Coaley mine.

Cyclops mine....... 213

Democrat mine.... 215

Dumas-Kinney tunnel............... 216

Elsinore mine

Fannie mine.

Jennie Blanche mine . . . . . . . . . . . . . . 219

Little Giant mine.......... 219

Marquette mine...... 220

Mayflower mine...

Peru mine . . . . . . . . . . 220

Polly mine..... 221

Pride of the West mine...........

Silent Friend mine ........................ 221 
Descriptions of mines and veins-Continued

Silver Hill area-Continued

Sixteen-to-One mine.

Wheeler tunnel

Wheel of Fortune mine.......

Nigger Hill area

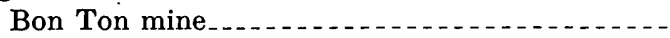

Boodle mine . . . .

Carroll mine . . . . . . . .

Claire Marie mine . . . . . .

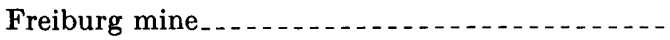

Maggie M mine.

Polar Star claim.
Descriptions of mines and veins-Continued

Nigger Hill area-Continued Page

Roosevelt mine....................... 225

St. Anthony and R.H.D. mines _.......... 225

Tom Martin mine _........ 225

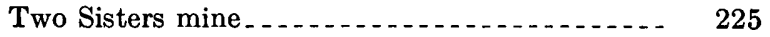

Upper Chase Gulch area

Boss vein ............................ 225

Estella mine . . . . .

Gallup mine.......................... 226

Mint mine........... 226

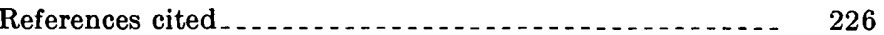

Index

\section{ILLUSTRATIONS}

[Plates are in plate volume]

Plate 1. Map of the Central City district, Colorado, showing location of mines and distribution of veins and igneous rocks of Tertiary age.

2. Traces of faults and veins.

3. Composite map of the workings on the Kansas, Burroughs, and California veins.

4. Geologic map of the Quartz Hill tunnel.

5. Geologic maps and sections of the Essex mine.

6. Composite map of the northern part of the Argo tunnel.

7. Geologic map of part of the 300 level, Iron mine.

8. Composite geologic map and section of the upper levels of the Old Town mine.

9. Geologic map of part of the Pewabic mine.

10. Geologic maps of part of the Springdale mine.

11. Geologic maps of part of the Meeker-Success mine.

12. Geologic map of the Bobtail tunnel workings.

Figure 1. Index map of the Front Range, showing location of the Central City district.

2. Graph showing value of metal production from the Central City district, 1904-53

3. Graph showing number of mines (by years) in operation, Central City district, 1910-52

4. Generalized geologic map of the Central City district

5. Stereodiagram showing average attitudes of principal joint sets

6. Contour diagrams showing concentration of poles of joints measured in the Central City district.

7. Photograph of a pyrite vein, Mammoth mine

8. Photograph of massive galena-sphalerite ore, Carroll mine

9. Photograph of breccia type ore, Carroll mine

10. Photograph of breccia type ore, Fannie mine

11. Map of Central City district, showing zoning of mineral deposits

12. Zonal distribution of vein-forming minerals

13. Generalized sequence of deposition of principal vein-forming minerals

14. Assay map of part of the 228 level, Carroll mine

15. Diagram illustrating the terms used to describe the dimensions of ore shoots .

16. Generalized longitudinal section of the Eureka mine

17. Geologic section through part of Quartz Hill

18. Schematic sketches showing the relation of ore bodies to vein intersections and junctions . . .

19. Geologic map of northwest end of stope above the 228 level west, Carroll mine, showing junction of Boodle and Carroll veins

20. Generalized geologic section along the Argo tunnel.

21. Generalized mineral stability ranges across the altered wallrock zones in the Central City district

22. Composite map of the Alps mine

23. Sections of the Alps mine...

24. Geologic maps of parts of the Alps mine

25. Geologic map of part of the Bezant mine

26. Longitudinal section of the California and Hidden Treasure mines

27. Composite map of the Egyptian and Ralls County mines.

28. Vertical longitudinal section of the Egyptian and Ralls County mines

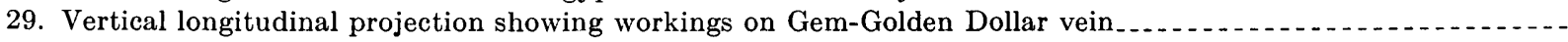

Page 
Fraure 30. Geologic map of the 128 level, Golden Dollar mine

31. Geologic map of the Hayes and Wheeler tunnel

32. Longitudinal section of the Gold Coin-Kansas mine $\ldots$

33. Composite map of the Kent County mine

34. Longitudinal projection in plane of Kirk vein, Kirk mine

35. Geologic map of part of the La Crosse tunnel . . .

36. Geologic map of 125 level, Mammoth mine $\ldots$

37. Composite map of the Topeka mine and adjoining mines

38. Vertical section through the Topeka shaft

39. Map of 200, 350, and 400 levels, Eureka mine

40. Composite map of the Hubert and Shafts mines . . .

41. Longitudinal sections in the plane of the Middle Hubert, and Shafts veins, Hubert mine...

42. Sections of the Prize mine

43. Longitudinal projection in plane of vein, Forfar mine

44. Geologic map of the Golden Opportunity tunnel. .

45. Composite map of the Incidental mine

46. Composite underground map of the Iron, Richardson, Bangor, and Becky Sharp mines.......................

47. Longitudinal projection in the plane of the Iron vein of parts of the Iron, Richardson, and Becky Sharp mines.-

48. Composite map and sections of the Lotus mine and part of the Minnesota mine

49. Vertical longitudinal section of the Lutz-I.X.L. vein

50. Composite underground map of the Old Town and adjacent mines

51. Longitudinal section in the plane of the Old Town vein, Old Town mine

52. Geologic and longitudinal sections of the Pewabic shaft

53. Longitudinal section in the plane of the Russell vein, showing parts of the Old Town and Federal workings:...

54. Vertical longitudinal section of the Springdale mine.

55. Geologic section of the Springdale shaft

56. Vertical longitudinal section of the Chase mine-

57. Geologic map of the 555 level, and sections of the East Notaway mine

58. Longitudinal projection of the Justice mine

59. Vertical longitudinal projection showing assay data of the Meeker-Success mine

60. Composite map of the Pittsburg mine

61. Section of the Pittsburg shaft $\ldots$

62. Vertical longitudinal section of the Pittsburg mine

63. Map of the 225 crosscut, Powers mine.....

64. Vertical longitudinal section of the Saratoga mine

65. Longitudinal section in the plane of the vein, Silver Dollar mine

66. Vertical longitudinal section of the Two-Forty mine

67. Geologic map of unknown mine No. F-VI-2.

68. Vertical longitudinal section of the War Dance mine

69. Geologic maps of 122,203 , and 249 levels and shaft section, Widow Woman mine

70. Geologic map of the Williams tunnel.

71. Vertical longitudinal section of the Bates-Hunter and Becker-Bates mines

72. Geologic map of the Cousin Jack mine .

73. Vertical longitudinal section of the Gregory lode.

74. Composite map of the Nemaha-Cotton mine

75. Vertical longitudinal sections along Cotton (left) and Nemaha (right) veins, Nemaha-Cotton mine

76. Vertical longitudinal section of the O'Neil mine .

77. Map and sections of the Sleepy Hollow mine

78. Vein maps of the 9 th and 11 th levels, Sleepy Hollow mine

79. Geologic map of the Tierney tunnel.

80. Geologic map of the Advance tunnel

81. Geologic map of the Allie tunnel

82. Geologic map of the Belden tunnel

83. Ceologic map of the Billings-Alces mine

84. Geologic map of the Centennial and Centre tunnels

85. Geologic map of the Cliff tunnel.

86. Geologic map of the Cliff Extension mine

87. Geologic map of the Gulnare mine

88. Geologic map of the Hayseed tunnel

89. Geologic map of the Sans Souci mine

90. Geologic map of the Sarah $\mathbf{E}$ mine.

91. Composite map of the After Supper mine

92. Geologic map of the American Eagle tunnel. 
Figure 93. Geologic map of the Boer tunnel.

94. Geologic map of the lower adit, Chihuahua mine

95. Geologic map of the Dumas-Kinney tunnel.

96. Geologic map of the Elsinore tunnel

\section{TABLES}

TABLE 1. Metals produced from Gilpin County, Colo., 1859-1903

Metals produced from the Central City district, exclusive of ure

3. Mines reported to have produced ore valued at more than $\$ 500,000$

4. Mines reported to have produced ore valued between $\$ 100,000$ and $\$ 500,000 \ldots$

5. Principal Precambrian rock units, Central City district, in order of probable relative age

6. Primary and secondary vein minerals, Central City district.

7. Gold content of mineral separates from veins in Central City district

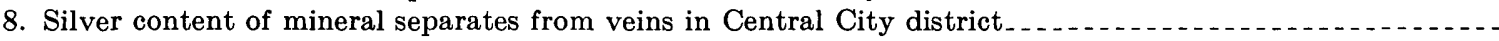

9. Gold and silver content of pure mineral separates.

10. Gold and silver fineness of retort bullion from representative mines, Central City district. . . . . . . . .

11. Gold, silver, and copper content of representative shipments of smelting ore from pyrite veins

12. Silver-gold ratios in ores of the pyrite veins

13. Metal content of typical ores from galena-sphalerite veins . . .

14. Chemical analyses, fire assays, and semiquantitative spectrographic analyses of some ores, Central City district

15. Standard sensitivities for the elements determined by the semiquantitative method, given in percent.....

16. Semiquantitative spectrographic analyses and chemical analyses of some sulfide minerals, Central City district.

17. Quantitative spectrographic analyses of sphalerite, Central City district

18-39. Ore produced from mines.

18. Alps mine, 1863-97.

19. Alps mine, 1902-54

20. Barnes mine, 1902-54

21. Bezant mine, 1902-54

22. Burroughs lode, 1887-1954_..

23. California and Hidden Treasure mines, 1890-1954

24. Gardner vein, 1902-54

25. Egyptian mine, $1887-1954$

26. Golden Dollar mine, 1902-54.

27. Stewart mine, 1902-54...

erman and Belcher mines, exclusive of uranium, 1891-1954

29. Kansas lode, 1902-54.

30. Kirk mine, 1897-1954

31. Pozo mine, 1904-54

32. Quartz Hill tunnel, 1902-54.

33. Ralls County mine, 1902-54

34. Topeka mine, 1902-54

35. Eureka mine, 1905-54

36. Gold Collar mine, 1902-54

37. Gunnell mine, 1887-1954

38. Concrete mine, 1902-54 $\ldots \ldots \ldots$

39. Hubert mine, 1887-1954

40. Some assays of breccia ore, 850 level, Hubert mine

41-46. Ore produced from mines.

41. Prize mine, 1902-54

42. Grand Central (East Whiting) mine, 1902-54

43. Federal mine, 1902-54 $\ldots \ldots$

44. Forfar mine, 1902-54

45. Hall mine, 1902-54

46. Perrin mine, 1902-54

47. Sampling-works assays of crude ore and concentrates from Perrin mine, 1929-36 
TABLE 48-63. Ore produced from mines.

48. Incidental mine, 1902-54

49. Iron mine, 1902-54

50. Lotus mine, 1902-54.

51. Gettysburg mine, 1902-54

54. Richardson mine, 1902-54

55. Russell vein, 1902-54.

56. Springdale mine, $1902-54$

57. Anchor mine, 1902-54

58. Argo mine, 1902-54

59. Aurora mine, 1909-54

60. Chase mine, 1902-54

61. East Notaway mine, 1902-22

62. Gladstone mine, $1902-54 \ldots \ldots \ldots$

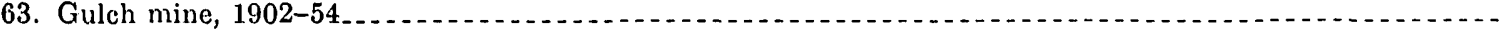

64. Sampling-works assays of some smelting ore from Gulch mine

65. Hampton mine, 1902-54 .

66. Sampling-works assays of some smelting ore from the Hampton mine

67. Sampling-works assays of some concentrates from the Hampton mine

68. Iowa mine, 1902-54.

69. Justice mine, 1902-54

70. Sampling-works assays of some ores from the Kokomo mine

71. Meeker-Success mine, 1902-54.

72. Assays of some ore from the Meeker-Success mine

73. Pittsburg mine, 1902-54

74. Powers vein, Powers mine, 1902-54

75. New Brunswick vein, Powers mine, 1902-54

76. Sampling-works assays of some ore from the Powers vein

77. Saratoga mine, 1902-54

78. Assays of some smelting ore from the Saratoga mine

79. Silver Dollar mine, 1902-54

80. Assays of some ore from the Bilver Dollar mine

81. Togo mine, 1902-54 . . .

82. Sampling-works assays of some ore from the Togo mine

83. Two-Forty mine, 1897-1954

84. Sampling-works assays of some ore from the Two-Forty mine

85. Sampling!works assays of some concentrates from the Two-Forty mine

86. War Dance mine, 1902-54.

87. Assays of some telluride ore from the War Dance mine, 1908-11.

88. Assays of some sulfide ore from the War Dance mine.....

89. West Notaway mine, 1902-54

90. Sampling-works assays of some ore from the West Notaway mine, 1898-1908

91. Widow Woman, Cherokee, and Florence mines, 1930-50

92. Bates vein, 1902-54.

9. Bobtail tunnel, 1902-54............

95. Colorado-Carr mine, $1902-54 \ldots$

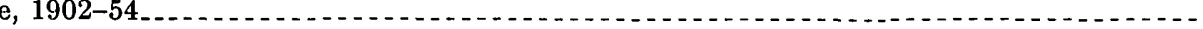

96. Cousin Jack mine, $1902-54$

98. Assays of some ore from the Maine-Hamlet mine 99-109. Ore produced from mines.

99. McAllister mine, 1902-54

100. Nemaha-Cotton mine, 1902-54

101. O.K. mine, 1902-54

102. O'Neil mine, 1902-54

103. Sleepy Hollow mine, 1902-54

104. Tierney tunnel, $1902-54$

105. Allie tunnel $1902-54 \ldots$

106. I.X.L. mine, $1889-1954$

107. Winnebago mine, $1905-54$

108. Dean and Casto mines, $1907-54$

109. Bullion and Gold Cưp mines, 1908-54. 
TABLE 110. Sampling-works assays of selected shipments of crude ore and concentrates from the Gold Cup mine, 1919-29.

111. Ore produced from the Hayseed tunnel, 1902-54

112. Ore produced from the Tucker mine, 1902-54

113. Ore produced from the After Supper mine, 1899-1954

114. Assays of some ore from the After Supper mine

115. Ore produced from the American Eagle mine, 1902-54

116. Ore produced from the Blackjack mine, 1902-54

117. Sampling-works assays of ore from the Blackjack mine, 1923-34

118. Ore produced from the Champion mine, 1902-54

119. Sampling-works assays of selected shipments of ore from the Champion mine, $1918-35$

120. Gold, silver, and lead production from the Chihuahua mine, 1934-54.

121. Semiquantitative spectrographic analyses of vein samples, Chihuahua mine . . .

122. Ore produced from the Cyclops mine, 1911-54 .

123. Sampling-works assays of ore from Cyclops vein 1890-91

124. Sampling-works assays of crude ore from Cyclops mine, 1923

125. Ore produced from the Dumas claim, 1902-54

126. Ore produced from the Jennie Blanche claim, 1908-54

127. Sampling-works assays of ore from Peru mine, 1924-34

128-131. Ore produced from mines.

128. Polly Mine, 1902-54

129. Sixteen-to-One mine, 1902-54

130. Bon Ton mine, Nigger Hill, 1902-54

131. Maggie M, Spur Daisy, Claire Marie, and Two Sisters mines, 1892-1954_ 


\title{
ECONOMIC GEOLOGY OF THE GENTRAL GITY DISTRICT, GILPIN COUNTY, COLORADO
}

\author{
By P. K. Sims, A. A. Drake, Jr., and E. W. Tooker
}

\section{ABSTRACT}

The Central City district, in Gilpin County, Colo., is on the east flank of the Front Range, about 30 miles west of Denver. The district is the most important mining camp in the Front Range mineral belt, and has yielded more than $\$ 100$ million worth of gold, silver, uranium, and base-metal ores since 1859 . Gold accounts for about 85 percent of the dollar value of the ore. In recent years mining activity has been slack, but from 1950 to 1955 the search for uranium ores stimulated prospecting and development.

The district lies within a terrane of Precambrian crystalline rocks, which constitute the core of the Front Range. The rocks are an interlayered and generally conformable succession of gneissic, granitic, and pegmatitic units. Microcline-bearing gneiss, interlayered biotite gneisşes, and pegmatite are the dominant rock units and generally form the walls of the ore deposits, but several other varieties of felsic and Intermediate rocks occur locally. Many small dikes and Irregular plutons of porphyritic igneous rocks, early Tertiary in age, cut the Precambrian bedrock. The most abundant types of these rocks are leucocratic granodiorite porphyry, quartz monzonite porphyry, bostonite porphyry, and quartz bostonite porphyry.

The Precambrian crystalline rocks are folded along north. east-trending axes that plunge gently either to the northeast or the southwest. Most folds are broad and open and have moderately to gently dipping limbs. The Central City anticline, the axis of which nearly bisects the district, is the domInant structure in the district; except locally near overturned anticlines the rocks dip away from its crest.

The bedrock is cut by abundant, closely spaced, intersecting faults, which constitute a complex meshlike network. Most of the faults dip steeply and have dominant strike-slip displacements. The faults are of two distinct ages. The oldest faults formed before the emplacement of the early Tertiary igneous rocks; these strikes northwest and north-northeast, and locally contain siliceous breccias which are typical of the breccla reefs of the Front Range. A younger group of faults formed during the Laramide orogeny, near the close of the period of early Tertiary igneous activity; these can be grouped into three main sets which strike respectively northeast, eastnorthenst, and east. Most faults formed independently of preexisting structures in the bedrock, but some follow axial planes of folds and others follow earlier joints. The younger fault sets probably resulted from regional compression acting in a general east-west direction.

The veins and minor stockworks that constitute the ore deposits were formed largely as fillings in the faults. The veins range from simple, well-defined filled fissures to complex, branching lodes consisting of subparallel fractures, loops, and "horsetailing" fractures. They commonly range from 1 to 3 feet in width. A large pipelike stockwork, the Patch, which probably formed by volcanic explosive activity, was mineralized by the same solutions that yielded the tabular vein deposits.

The deposits contain a simple suite of metallic and gangue minerals and are valued principally for their gold and silver content. The common metallic minerals are pyrite, sphalerite, chalcopyrite, tennantite, and galena; minerals of more restricted occurrence include enargite, pitchblende, and gold tellurides. Quartz and cryptocrystalline silica are the dominant gangue minerals, but several rhombohedral carbonate minerals, fluorite, and barite are present locally: In addition to being in rare tellurides, the gold occurs in the free state and in the structure of certain metallic vein minerals; the silver is in discrete sulfosalts but more commonly is in the structure of metallic minerals.

The veins can be classified mineralogically as pyrite and galena-sphalerite veins. Although the two vein classes are distinctive, they grade into one another through gradual changes in the proportions of the metallic mineral content, and some veins change along strike from one mineralogic class to the other.

The pyrite veins consist dominantly of pyrite and quartz, but locally contain variable quantities of chalcopyrite, tennantite, enargite, sphalerite, and galena. Pyritized wallrock is a common gangue. The pyrite veins can be subdivided on the basis of the quantity and proportion of the contained base-metal sulfides into: (1) type $A$, pyrite veins that are nearly devoid of base-metal sulfides and sulfosalts, (2) type $B$, pyrite veins that contain abundant copper minerals, and (3) type $C$, pyrite veins that contain substantial quantities of sphalerite, galena, and copper minerals. Gold and silver are more abundant in pyrite veins of types $B$ and $C$ than in veins of type $A$.

The galena-sphalerite veins consist dominantly of galena and sphalerite in different quantities and contain sparse quantities of pyrite and copper minerals. Silver is ubiquitous and locally abundant and gold is sparse.

A concentric zonal arrangement of the ores is clearly shown by the geographic distribution of the pyrite and galenasphalerite veins. A core area (central zone) of pyrite veins, 3 miles in maximum diameter, is surrounded by a peripheral zone of galena-sphalerite veins. The pyrite veins in the central zone are types $A$ and $B$; the latter type occurs near the outer margins of the zone. The transitional veins in the intermediate zone are pyrite veins of type $C$.

Although the veins were formed during a single period of mineralization, the minerals were deposited in three stages, 
each of which is characterized by a distinctive suite of ore minerals. The stages from oldest to youngest are: uranium, pyrite, and base-metal stages. During the uranium stage, pitchblende and minor amounts of pyrite were deposited along with a quartz gangue; during the pyrite stage, pyrite and quartz were formed; and during the base-metal stage, sphalerite, chalcopyrite, tennantite, enargite, galena, and minor pyrite were deposited along with quartz and at places carbonate minerals, fluorite, and barite. Most of the gold and silver were introduced during the base-metal stage, and veins are rarely commercially profitable where minerals characteristic of this stage are absent. The paragenetic sequence of the ore minerals is consistent throughout the district. Recurrent movements along the fractures, which appear to have occurred almost synchronously, followed the deposition of minerals of the uranium and pyrite stages. The earlier vein minerals were fractured and brecciated by these movements and subsequently were recemented by ore and gangue minerals of a later stage.

The wallrocks adjacent to the veins were altered to varying degrees. A zone of hard sericitized rock adjacent to the vein is succeeded outward by a zone of soft argillized rock, which grades into the fresh rock. Commonly the total width of the alteration envelope exceeds the width of the vein filling, but there is some variation. In general, the alteration zone is wider around pyrite veins than around galena-sphalerite veins, and pyrite is abundantly disseminated in bleached and sericitized rocks adjacent to pyrite veins. Except for water, little net gain or loss of chemical constituents occcurred during alteration.

Valuable ore minerals were deposited in ore shoots of varying size and attitude within structurally controlled openings along the fractures. The ore shoots plunge in a consistent direction in relation to the Central City anticline. Most of the valuable ore bodies in the area west of the axis plunge westward, and many ore shoots in the area east of the axis plunge eastward. Although the ore bodies were localized by several types of structural controls, most of them formed at vein intersections or junctions. Many others were localized primarily by the lithologic character and structure of the wallrocks. These ore bodies commonly plunge nearly parallel to the trace of the intersection of the vein fissures and the foliation of the wallrocks.

Supergene alteration was relatively more important in the Central City district than in adjacent mining districts in the mineral belt. Gold was enriched in the upper oxidized parts of the veins, commonly to depths ranging from 50 to 175 feet, and silver and copper were locally enriched below the oxidized zone.

The ore deposits are closely associated in space with the early Tertiary porphyritic igneous rocks, and were formed immediately after the youngest of these rocks, quartz bostonite porphyry. Accordingly, we believe the ores were derived from hydrothermal fluids related to the early Tertiary magmatic activity. Initially the hydrothermal solution altered the walls; then at appropriate temperature, pressure, and concentration it deposited the ore and gangue minerals.

The principal deposits, the zoned gold- and silver-bearing sulfide veins, were formed during the pyrite and base-metal stages of mineralization, presumably from a common, deepseated source that apexed beneath the core of the district. During the pyrite stage, quartz-pyrite veins were deposited near the source, in the central and intermediate zones, whereas during the base-metal stage, lead-, zinc-, copper-, gold-, and silver-bearing minerals were deposited in a zone that overlapped the outer parts of the area affected by the pyritic mineralization and extended outward farther from the source. Reopened parts of the pyrite veins were filled with sulfides of copper, lead, and zinc and sparse gangue minerals to form composite veins; and lead and zinc along with gangues were deposited in abundance on the periphery of the district. The spatial relation of the pitchblende deposits to quartz bostonite porphyry indicates that most of the uranium probably was derived directly from several separate, relatively shallow bodies of quartz bostonite magma, rather than from the main mag matic source that yielded the zoned sulfide veins. Probably the telluride veins also were derived from a separate, local source.

The thermal pattern of the district at the time of mineralization, determined by sphalerite and fluid inclusion geothermometry, was complex but consistent in gross aspects. A steep thermal gradient that shifted position within the intermediate and peripheral zones separated two areas of relatively uniform thermal regime, the inner one being on the order of $600^{\circ} \mathrm{C}$ and the outer one being in the interval 150 $300^{\circ} \mathrm{C}$. Most of the gold- and silver-bearing base metal sulfide ores were deposited in the intermediate and peripheral zones, where the character of the ore-forming solutions changed most drastically. The solutions that penetrated the barren core probably were undersaturated with respect to base-metal sulfide.

The Central City district has been intensively prospected and probably all veins have been found and explored to shallow depths. The most likely additional source for substantial amounts of ore is therefore the downward projection of known ore shoots, particularly in veins that have been proved to contain large, valuable ore bodies. Deep exploration probably can be done most successfully from the tunnels that have been driven under the district from the adjacent Idaho Springs district. This type of exploration and development is expensive, however, and requires careful economic evaluation before the beginning of mining.

About 225 mines are described in the section on the mines: Those that were accessible during the years 1952-55 were mapped during this investigation, because prior to this study few geologic maps of mine workings were available.

\section{INTRODUCTION}

The Central City district is the most commercially important of several mining districts in the Front Range mineral belt, a region of coextensive early Tertiary intrusive rocks and mineral-producing districts, which extends for about 50 miles from Breckenridge in Summit County to Jamestown in Boulder County (fig. 1).

The total output of the district exceeds $\$ 100$ million. Most of the ore values are in gold, but substantial returns have been received from silver, lead, copper, and zinc. Small quantities of high-grade uranium ore have been produced, but its total value is not known.

Since the discovery of gold in Gregory Gulch in 1859 , the district has been of vital importance to the development of the Rocky Mountain region. Until 
the middle 1880 's, the metal output of the district exceeded the combined total of all other mining districts in Colorado. Since 1914, production has declined sharply, and since the late thirties it has been negligible. In recent years most of the mining activity has been for base-metal and uranium-bearing ores.

\section{PURPOSE AND SCOPE OF REPORT}

In response to the urgent need for uranium following World War II, the Central City district and adjoining mining areas, in Gilpin and Clear Creek Counties, were selected for study by the U.S. Geological Survey, on behalf of the Division of Raw Materials of the U.S. Atomic Energy Commission. At that time the Central City district was the principal domestic source of high-grade pitchblende ore in the United States and it was believed that a detailed geologic survey of the district and adjacent mining districts should be undertaken as a part of the evaluation of the uranium resources of the United States. Because of the close association of the uranium ores with the precious- and base-metal ores, the study included all the valuable metals.

This report presents a comprehensive description of the ore deposits at Central City and includes detailed information on the accessible mines as well as a summary of the data available on those mines which were not open at the time of the study. A description of the general geology of the district, which will include a geologic map, and a comprehensive report on wallrock alteration of this and adjacent areas, will be given in later publications. Because of the current interest in the uranium deposits of the district, these deposits are described in detail in a separate report (Sims and others, 1963).

\section{LOCATION AND ACCESSIBILITY}

The Central City district is in southern Gilpin County, Colo., in the central part of the Front Range (fig. 1). The principal towns-Central City (population 371 in 1950) and Black Hawk (population 166 in 1950) - are about 30 miles west of Denver. Except for the extreme eastern part of the district, which is in the Black Hawk $71 / 2$ minute quadrangle, the district lies within the Central City $71 / 2$ minute quadrangle. The district is immediately north of the Idaho Springs district and the arbitrary boundary between the districts is located at latitude $39^{\circ} 46^{\prime} 25^{\prime \prime}$. The Central City district occupies an area of 12 square miles and is bounded on the north by latitude $39^{\circ} 49^{\prime} 25^{\prime \prime}$, on the east by longitude $105^{\circ} 28^{\prime} 15^{\prime \prime}$, and on the west by longitude $105^{\circ} 32^{\prime}$. The district includes the Nevada, Gregory, and most of the Russell

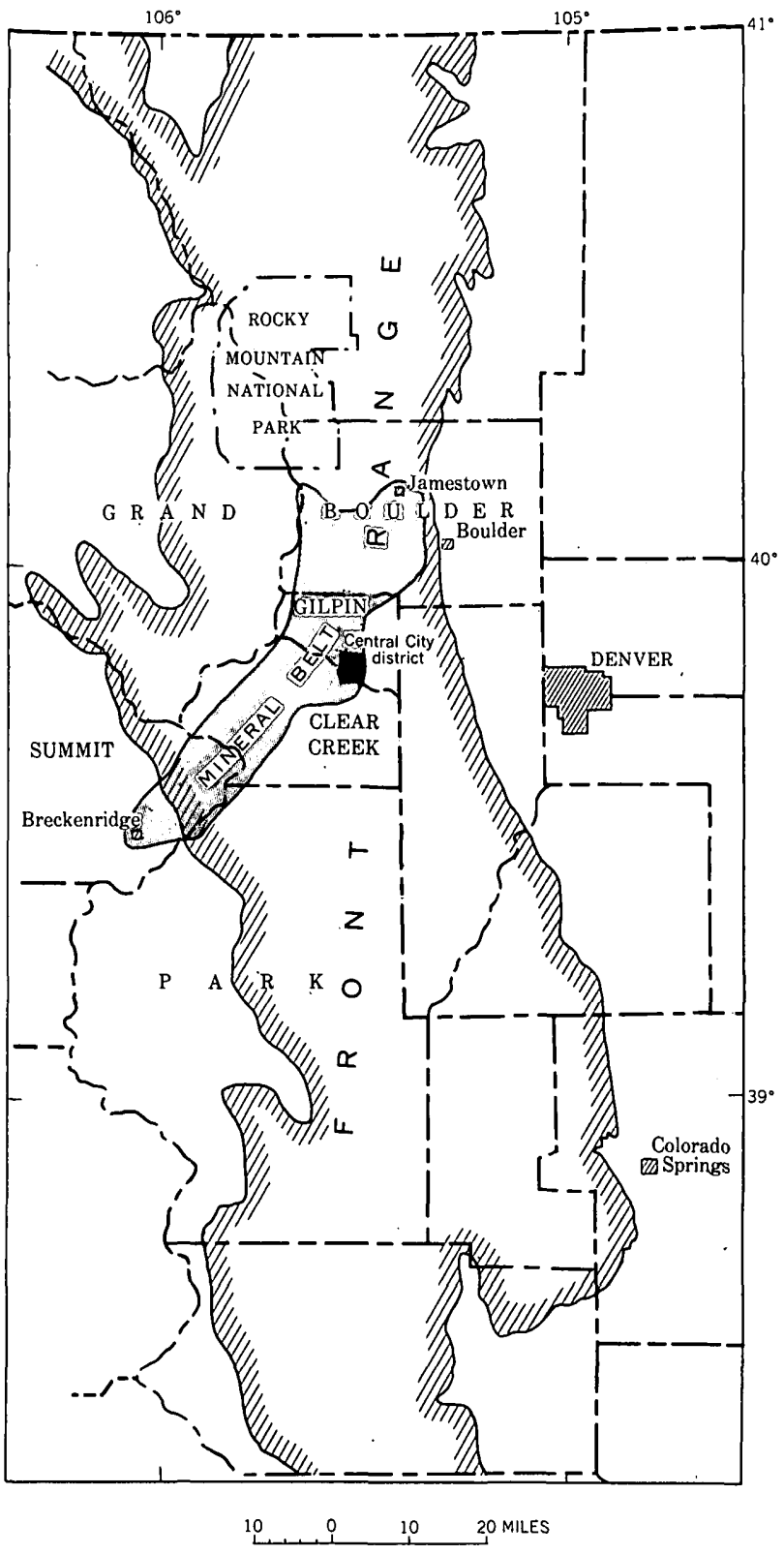

Fradra 1.-Index map of the Front Range, showing location of the Central City district.

Gulch, Pleasant Valley, and Lake mining districts, which were established in the region in the early days of mining.

All parts of the district are easily accessible. The region has many good automobile roads and a network of secondary mine roads that are for the most part passable. State Highway 119 passes through Black Hawk and State Highway 279 extends from Central City to Idaho Springs. The narrow-gage railroads that formerly served the mining district, and others in this part of the Front Range, have all been abandoned; the nearest railheads are at Rollins- . 
ville, about 12 miles north of Black Hawk, and at Golden, 15 miles to the east.

\section{TOPOGRAPHY AND DRAINAGE}

The district is on the east slope of the Front Range, near the east edge of a rugged glaciated area that extends westward to the crest of the range. The east slope of the Front Range is a dissected upland, which in the Central City district ranges in altitude from about 9,750 feet in the western part to about 8,000 feet in the eastern part. North of Central City and Black Hawk, along North Clear Creek, the local relief is as much as 1,000 feet, but throughout most of the district the local relief is only moderate and this part of the area is characterized by gently rolling high hills.

North Clear Creek, the principal stream in the district, flows through the northern part of the district. Its principal tributaries are eastward-flowing streams which occupy Chase, Gregory, and Russell Gulches. Except for North Clear Creek, which heads near the crest of the range, the streams are intermittent; and the absence of permanent streams in the valleys of the districts has been a serious handicap to mining and milling.

\section{CLIMATE AND VEGETATION -}

The climate of the region is temperate, and extremes in either temperature or precipitation are rare. The mean annual temperature at Idaho Springs, the nearest point of meteorologic observations, is $43^{\circ} \mathrm{F}$, and the mean annual precipitation is about 16 inches. The summer months are moderately cool, and numerous thunderstorms occur during July and August. The fall months are typically dry and cool, and the winter months are cold. The heaviest snowfalls of the year are in March and April.

The vegetation cover of the region varies. Near Central City and Russell Gulch, where the land has been heavily logged for fuel and mine timbers, vegetation is sparse and, where present, consists largely of aspen. The margins of the district have been less intensely logged and the land is covered by a moderate growth of coniferous trees.

\section{PREVIOUS GEOLOGIC STUDIES}

Because of its scientific and economic importance, particularly during the early days of mining in the West, much has been written on the geology of the Central City district by geologists and engineers of private mining companies and by government geologists. The most comprehensive and authoritative source of information on the geology of the region has been U.S. Geological Survey Professional Paper
94 (Bastin and Hill, 1917). Many important contributions, however, have been made by local mining men, particularly P. R. Alsdorf, George Collins, Richard Pearce, and Forbes Rickard; and their competent observations have contributed greatly to our knowledge of the ores of the district. Much information is contained in unpublished private reports for companies or individuals; some of these reports were available to the writers, but many were not.

Several papers were published before and at the turn of the century, particularly concerning the uranium deposits. The most important of these are publications by Pearce (1898), Rickard (1913), Moore and Kithil (1913), Alsdorf (1916), and Bastin (1915; 1916). In 1910, 1911, and 1912 the U.S. Geological Survey first studied the district. This work, carried out by E. S. Bastin with the assistance of J. M. Hill and C. W. Henderson, resulted in the publication of Professional Paper 94. About the time of the Geological Survey's studies, an important paper by Collins (1913) was published; another paper, a discussion of a report by Lovering (1930), was published at a later date (Collins, 1930). During the twenties, T. S. Lovering of the U.S. Geological Survey began studies in the Front Range, and as a part of this work he mapped some of the mines in the Central City area, particularly those that were opened by the Argo tunnel. This work, in conjunction with data from other mining districts of the Front Range mineral belt, was published as Professional Paper 223 (Lovering and Goddard, 1950).

In 1944, at first on behalf of the Manhattan Engineering district and later on behalf of the U.S. Atomic Energy Commission, the U.S. Geological Survey began an investigation of the uranium deposits of the Front Range, particularly those near Central City. From 1944 to 1951 this work consisted principally of reconnaissance investigations for radioactivity and detailed studies in mines known to contain uranium-bearing ores. Most of this work, particularly the earliest, was not published owing to the nature of the investigations and the security requirements. Some of the work, however, was published (King and others, 1953; and Moore and Butler, 1952). In 1951 detailed studies were made by F. C. Armstrong of the U.S. Geological Survey in the Quartz Hill and Justice Hill areas in the Central City district and some of the results of his work are incorporated in this report. From 1949 to 1954, George Phair of the Geological Survey made independent investigations of uranium in the Front Range, primarily concerning the relation of uranium to Tertiary porphyritic intrusive rocks (Phair, 1952). 


\section{FIELDWORK}

A comprehensive study of the geology and ore deposits of the Central City district by the U.S. Geological Survey, on behalf of the U.S. Atomic Energy Commission, was started in 1952 and continued through the 1953 and 1954 field seasons and a part of the summer of 1955 . About 40 man-months was devoted to fieldwork in the area and an approximately equal time was devoted to laboratory studies and the preparation of reports. Sims and Drake did most of the geologic mapping and study of the ore deposits; Tooker studied the wallrock alteration in the district, as a part of a larger study in this part of the mineral belt, and assisted in the geologic mapping. Most of the general section of this report and some mine descriptions were written by Sims; many mine descriptions were written by Drake; the section on wallrock alteration was written by Tooker.

During the survey about 12 square miles was mapped. The geologic mapping was done on a special topographic base (scale 1:6,000) prepared by the Geological Survey from aerial photographs taken in 1951. In addition, all accessible mines were mapped at scales of $1: 240,1: 480,1: 960$, and $1: 1,200$; a total of about 50,000 linear feet of underground workings were mapped. In the laboratory about 500 polished sections and 350 thin sections were studied.

\section{ACKNOWLEDGMENTS}

During the fieldwork we were ably assisted by R. H. Moench, A. E. Dearth, Max Schafer, A. R. Krueger, J. R. McDonald, and Peter Buseck of the Geological Survey; and Moench and Dearth did indepenclent mapping in parts of the district. J. D. Wells (1960) provided many data on the Tertiary igneous rocks in the district, gained from his studies in the region. P. B. Barton, Jr., of the U.S. Geological Survey, assisted in studies of the geothermometry and origin of the ore deposits and did independent experimental research on sphalerite geothermometry. Ruth Willson, Rosina Yoder Clifford, and Mary Beth Stapp assisted in the compilation of the data. The polished and thin sections used in this investigation and the many hundreds of chemical, spectrographic, and radiometric analyses were prepared by the U.S. Geological Survey. Names of analysts are given in the text.

Local mining people cooperated fully during this investigation and provided many maps of inaccessible workings and data on the history and production. We are indebted especially to Henry deLindy, C. L. Harrington, Claude McKay, Van McKay, R. R. Hinckley, Henry Ress, and W. C. Russell, Jr.
Most of the production data was kindly furnished by A. J. Martin of the Statistics Branch, Economics Division, U:S. Bureau of Mines, Denver, Colorado. Sampling-works assay records of the Idaho Springs Sampling Works for the years 1919-39 were provided by W. Price Briscoe.

\section{PRODUCTION}

The Central City district is one of Colorado's major metal-producing districts, having a production valued at about $\$ 100$ million. Gold has accounted for about 85 percent of the dollar value of the ore, silver for nearly 10 percent, and copper, lead, and zinc for the remainder. In recent years the base metals have been proportionally more valuable. The value of the uranium production is not known, but it is small relative to that of the precious metals and base metals.

The metal production for the years 1859 to 1903 is given in table 1 . These data were compiled by C. W. Henderson and published in the report by Bastin and Hill (1917, p. 174-175). They include the record of production from the northern districts of Gilpin County, which probably is less than 5 percent of the total for the county. The production for the years 1904 to 1953, exclusive of uranium, (table 2) was compiled by us from records of the U.S. Bureau of Mines files, Minerals Yearbook, and Mineral Resources of Colorado (Vanderwilt, 1947). Except for a few years, these totals include only production from the Central City district. Although the records for these years are nearly complete, they do not include important quantities of ore shipped in small lots to the several sampling works.

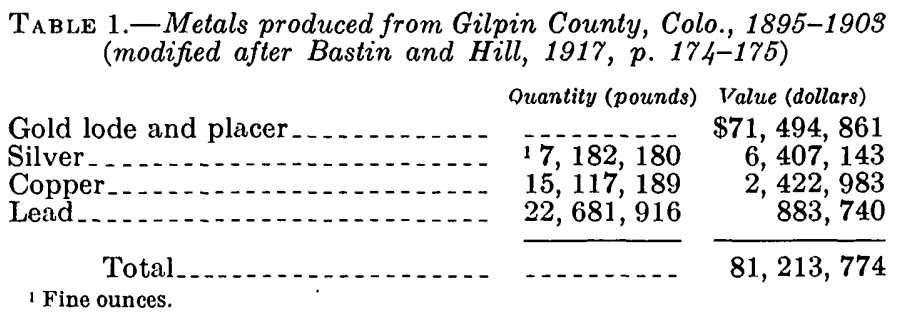

The uranium produced from the district is estimated to be about 110,000 pounds of $\mathrm{U}_{3} \mathrm{O}_{8}$, most of which came from two mines on Quartz Hill (Sims and others, 1963).

The metals shipped from the district exceeded $\$ 1$ million for most years from 1860 to 1913 and exceeded $\$ 2$ million for a few years (Bastin and Hill, 1917, p. 174). The maximum yield for a single year was 1871 , when ores valued at $\$ 3,359,240$ were shipped from all districts in Gilpin County. Owing to the stable price of gold, ore produced from the Central 
TABLE 2.-Metals produced from the Central City district, exclusive of uranium, 1904-59

\begin{tabular}{|c|c|c|c|c|c|c|c|}
\hline Year & $\begin{array}{l}\text { Ore sold }{ }^{1} \text { or } \\
\text { shipped (tons) }\end{array}$ & $\begin{array}{c}\text { Gold (troy } \\
\text { ounces) }\end{array}$ & $\begin{array}{l}\text { Silver (fine } \\
\text { ounces) }\end{array}$ & Copper (pounds) & Lead (pounds) & Zinc (pounds) & Total value \\
\hline $\begin{array}{l}1904 \ldots 5 \\
1905 \\
1906 \\
1907 \\
1908\end{array}$ & $\begin{array}{r}108,892 \\
181,882 \\
108,045 \\
85,381 \\
114,269\end{array}$ & $\begin{array}{l}52,401 \\
69,540 \\
51,991 \\
43,192 \\
49,656\end{array}$ & $\begin{array}{l}355,181 \\
339,535 \\
240,382 \\
204,938 \\
186,565\end{array}$ & $\begin{array}{l}439,986 \\
509,545 \\
597,577 \\
879,326 \\
630,911\end{array}$ & $\begin{array}{l}125,731 \\
519,841 \\
510,791 \\
555,968 \\
538,143\end{array}$ & $\begin{array}{r}113,000 \\
191,574 \\
\hdashline-1 .-1\end{array}$ & $\begin{array}{r}\$ 1,352,620 \\
21,757,814 \\
21,380,248 \\
21,219,339 \\
21,231,154\end{array}$ \\
\hline $\begin{array}{l}1909 \ldots 10 \\
1910 \\
1911 \\
1912 \\
1913\end{array}$ & $\begin{array}{r}103,339 \\
50,718 \\
100,787 \\
111,781 \\
92,709\end{array}$ & $\begin{array}{l}40,147 \\
25,164 \\
36,730 \\
41,839 \\
32,702\end{array}$ & $\begin{array}{l}170,302 \\
112,498 \\
291,596 \\
314,822 \\
272,831\end{array}$ & $\begin{array}{r}484,880 \\
485,846 \\
947,003 \\
1,018,527 \\
833,155\end{array}$ & $\begin{array}{r}661,046 \\
502,266 \\
118,780 \\
1,350,489 \\
1,207,705\end{array}$ & $\begin{array}{r}23,08 \overline{8} \\
25,377 \\
8,589\end{array}$ & $\begin{array}{r}1,009,944 \\
2664,730 \\
21,105,291 \\
21,289,082 \\
21,023,564\end{array}$ \\
\hline $\begin{array}{l}1914 \\
1915 \\
1916 \\
1917 \\
1918\end{array}$ & $\begin{array}{r}51,552 \\
354,052 \\
37,005 \\
30,982 \\
16,788\end{array}$ & $\begin{array}{l}27,259 \\
27,434 \\
21,752 \\
18,831 \\
13,336\end{array}$ & $\begin{array}{l}140,020 \\
128,492 \\
111,927 \\
110,381 \\
119,216\end{array}$ & $\begin{array}{l}725,430 \\
483,626 \\
548,963 \\
519,531 \\
347,048\end{array}$ & $\begin{array}{l}464,664 \\
636,338 \\
489,725 \\
780,383 \\
751,930\end{array}$ & $\begin{array}{r}12,980 \\
11,008 \\
-141,490 \\
28,099\end{array}$ & $\begin{array}{l}2756,206 \\
2745 ; 137 \\
2692,148 \\
2703,592 \\
2536,553\end{array}$ \\
\hline 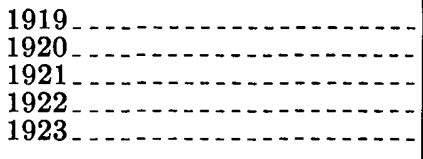 & $\begin{array}{r}16,127 \\
10,513 \\
3,512 \\
12,063 \\
2,881\end{array}$ & $\begin{array}{l}9,892 \\
4,313 \\
1,866 \\
2,016 \\
1,159\end{array}$ & $\begin{array}{l}71,317 \\
41,911 \\
17,940 \\
43,590 \\
44,712\end{array}$ & $\begin{array}{r}205,640 \\
86,261 \\
13,186 \\
20,904 \\
19,034\end{array}$ & $\begin{array}{r}523,472 \\
434,762 \\
91,644 \\
246,109 \\
228,943\end{array}$ & 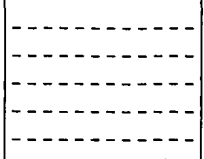 & $\begin{array}{r}2350,355 \\
2185,482 \\
262,324 \\
2101,616 \\
279,438\end{array}$ \\
\hline $\begin{array}{l}1924 \ldots 1 \\
1925 \\
1926 \\
1927 \\
1928\end{array}$ & $\begin{array}{r}3,126 \\
6,444 \\
6,670 \\
3,257 \\
12,526\end{array}$ & $\begin{array}{l}1,751 \\
3,562 \\
1,830 \\
1,194 \\
2,881\end{array}$ & $\begin{array}{r}13,288 \\
18,276 \\
37,853 \\
7,605 \\
17,371\end{array}$ & $\begin{array}{r}24,618 \\
28,700 \\
11,150 \\
8,710 \\
30,306\end{array}$ & $\begin{array}{r}151,725 \\
194,000 \\
241,700 \\
92,635 \\
107,931\end{array}$ & $\begin{array}{r}13,400 \\
10,000 \\
33,000 \\
510,064 \\
12,000\end{array}$ & $\begin{array}{r}461,342 \\
+108,028 \\
484,811 \\
435,969 \\
481,070\end{array}$ \\
\hline $\begin{array}{l}1929 \ldots 1 \\
1930 \\
1931 \\
1932 \\
1933\end{array}$ & $\begin{array}{r}57,541 \\
131,939 \\
255,608 \\
278,905 \\
47,437\end{array}$ & $\begin{array}{r}5,262 \\
6,512 \\
14,935 \\
15,462 \\
3,812\end{array}$ & $\begin{array}{r}28,908 \\
20,670 \\
20,569 \\
24,720 \\
8,012\end{array}$ & $\begin{array}{r}108,420 \\
66,300 \\
95,000 \\
46,000 \\
12,500\end{array}$ & $\begin{array}{r}120,904 \\
94,300 \\
92,300 \\
189,000 \\
84,000\end{array}$ & $\begin{array}{r}5210,021 \\
7,000 \\
379,416 \\
84,000 \\
--.--\end{array}$ & $\begin{array}{l}4150,880 \\
4156,235 \\
4326,768 \\
{ }^{4} 337,685 \\
685,515\end{array}$ \\
\hline $\begin{array}{l}1934 \ldots 1 \\
1935 \\
1936 \\
1937 \\
1938\end{array}$ & $\begin{array}{r}112,353 \\
356,313 \\
346,317 \\
105,167 \\
40,523\end{array}$ & $\begin{array}{r}7,273 \\
20,681 \\
21,491 \\
11,639 \\
9,554\end{array}$ & $\begin{array}{l}34,924 \\
76,856 \\
77,760 \\
44,356 \\
33,383\end{array}$ & $\begin{array}{l}32,600 \\
44,000 \\
31,800 \\
19,600 \\
22,200\end{array}$ & $\begin{array}{r}165,000 \\
229,900 \\
328,700 \\
184,850 \\
81,000\end{array}$ & $\begin{array}{r}-12,000 \\
20,000\end{array}$ & $\begin{array}{l}285,480 \\
791,932 \\
3831,084 \\
3456,246 \\
3361,859\end{array}$ \\
\hline $\begin{array}{l}1939 \\
1940 \\
1941 \\
1942 \\
1943\end{array}$ & $\begin{array}{r}17,228 \\
27,755 \\
26,043 \\
15,281 \\
6,873\end{array}$ & $\begin{array}{r}8,219 \\
8,687 \\
13,090 \\
5,238 \\
1,382\end{array}$ & $\begin{array}{l}50,506 \\
47,558 \\
17,641 \\
14,598 \\
22,112\end{array}$ & $\begin{array}{r}106,200 \\
151,800 \\
138,000 \\
115,900 \\
95,200\end{array}$ & $\begin{array}{r}187,400 \\
230,800 \\
38,000 \\
112,300 \\
237,000\end{array}$ & $\mid \begin{array}{c}-\cdots-1 \\
-\cdots \\
-131,000\end{array}$ & $\begin{array}{l}3441,801 \\
3366,557 \\
3489,145 \\
3215,259 \\
3108,393\end{array}$ \\
\hline $\begin{array}{l}1944 \\
1945 \\
1946 \\
1947 \\
1948\end{array}$ & $\begin{array}{r}3,087 \\
926 \\
36,226 \\
2,634 \\
196\end{array}$ & $\begin{array}{r}468 \\
255 \\
342 \\
302 \\
59\end{array}$ & $\begin{array}{r}14,226 \\
2,835 \\
3,230 \\
. \quad 4,470 \\
388\end{array}$ & $\begin{array}{r}36,800 \\
5,600 \\
4,800 \\
5,100 \\
-\end{array}$ & $\begin{array}{r}197,000 \\
90,000 \\
117,100 \\
140,000 \\
6,000\end{array}$ & $\begin{array}{r}170,000 \\
46,000 \\
57,000 \\
60,000 \\
\end{array}$ & $\begin{array}{r}366,604 \\
324,727 \\
135,076 \\
143,106 \\
13,490\end{array}$ \\
\hline 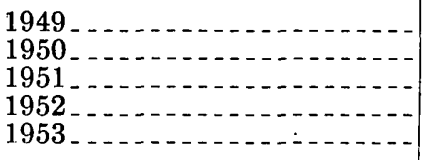 & $\begin{array}{r}3974 \\
3108 \\
955 \\
47 \\
466\end{array}$ & $\begin{array}{r}67 \\
82 \\
171 \\
19 \\
148\end{array}$ & $\begin{array}{r}576 \\
315 \\
1,240 \\
46 \\
951\end{array}$ & 2,000 & $\begin{array}{r}18,000 \\
6,000 \\
16,000 \\
1,600 \\
3,800\end{array}$ & 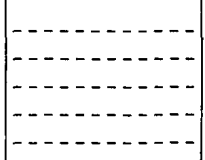 & $\begin{array}{r}25,710 \\
23,965 \\
29,875 \\
1965 \\
17,112\end{array}$ \\
\hline Total $\ldots \ldots$ & $3,166,163$ & 737,588 & $3,963,399$ & $11,039,683$ & $14,497,675$ & $1,810,106$ & $22,123,326$ \\
\hline
\end{tabular}
1 Includes production from both lodes and placers; the placer production is small.
2 Production data furnished by the U.S. Bureau of Mines. Published with $\underset{8 \text { Total production for Gilpin County. It includes production from northern part }}{\text { permission. }}$ of County.

4Data from "Minerals Yearbook. Part 1."

o Data from "Mineral Resources of Colorado" (Vanderwilt, 1947).

City district was not appreciably influenced by changes in economic conditions during the early period of activity, and it remained at a normal level even during panics and minor recessions.
A steady decline in production began in 1914 and continued until 1921; production remained at a low level until 1935 (fig. 2). For a few years during this period the ores had a value of less than $\$ 100,000$; the 


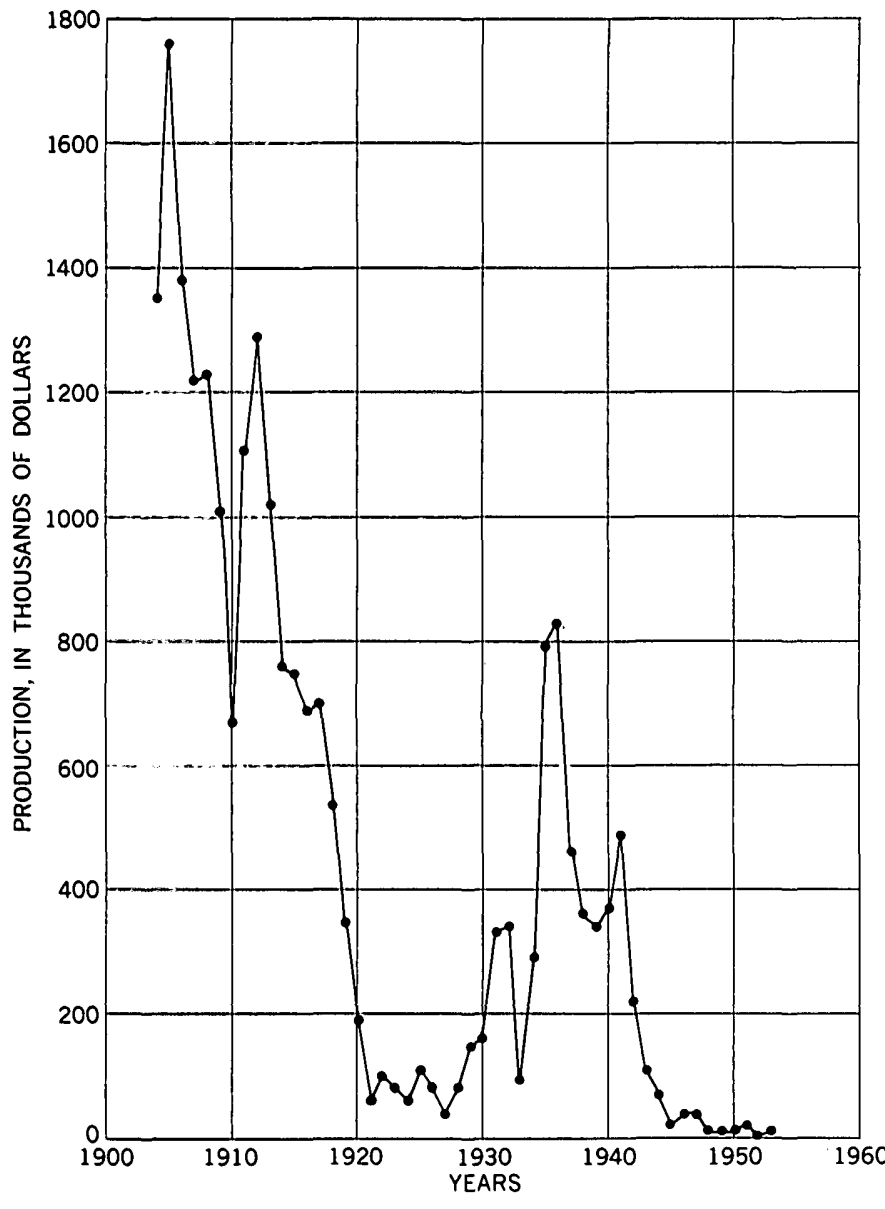

Fioure 2.-Graph showing value of metal production from the Central Clty district, 1904-53. Sources of data, by years, are given In table 2.

low for a single year was in 1927 when the production was valued at only $\$ 35,969$.

During the later thirties, production was increased substantially over previous years because of the increase in the price of gold and a larger labor market, and in 1936 and 1937 the ore shipments had an annual value of about $\$ 800,000$, the highest yearly returns since 1913. The annual production remained at a substantial but slightly lower level until 1942 when restrictions were placed on the mining of gold and the labor market was greatly reduced.

Production was low during and subsequent to World War II, and reached an all time low value of less than a thousand dollars in 1952 . In 1953 production was increased slightly, largely because of the impetus provided by capital raised for uranium mining; and this trend continued through 1955 .

Although ore has been produced from about 500 mines in the district, a substantial proportion has 654827 o- $63-2$

come from a relatively few. Prior to 1902, government records for individual mines were kept systematically only during the years 1887-92 (U.S. Minit reports); therefore accurate data are not available for the total production from any mine during the period when the greatest quantity of ore was mined. Reliable estimates from the best sources for these years have been given, however, by Fossett (1880) and the Mining Reporter (1899), and these data, together with that for the years since 1902, give a fair order of magnitude for the production of individual properties.

The large producing mines of the district (table 3) can be grouped into three categories, according to their relative production. The mines in group 1 probably have yielded about one-third of the total output, and the mines in group 2 nearly one-sixth of the total. Probably half of the total production can be accounted for by the 26 mines listed in all 3 groups.

Several mines in the district are reported to have yielded ores valued between $\$ 100,000$ and $\$ 500,000$, and these are tabulated in table 4 .

TABLE 3.-Mines reported to have produced ore valued at more than $\$ 500,000^{1}$

\begin{tabular}{l|l} 
Bobtail & Production greater than $\$$ million \\
California & Kansas-Burrough \\
Gregory & Old Town \\
Gunnell & Prize \\
\multicolumn{1}{|c}{ Saratoga } \\
Baxter-Bates & Production between $\$ 1$ million and $\$ 3$ million \\
Fisk & $\begin{array}{l}\text { Leavenworth } \\
\text { Forks }\end{array}$ \\
$\begin{array}{l}\text { German-Belcher } \\
\text { Hubert }\end{array}$ & $\begin{array}{l}\text { Pewabic } \\
\text { Iron }\end{array}$ \\
& $\begin{array}{l}\text { Pittsburg } \\
\text { Running Lode } \\
\text { Topeka }\end{array}$
\end{tabular}

\begin{tabular}{l|l} 
& Production between $\$ 500,000$ and $\$ 1$ million \\
Alps & Clark-Gardner \\
Bates-Hunter & Eureka \\
Buell & Kent County
\end{tabular}

1 Sources: Mining Reporter (1899); Fossett (1880); and U.S. Bureau of Mines.

TABLE 4.-Mines reported to have produced ore valued between $\$ 100,000$ and $\$ 500,000^{1}$

American Flag

Belden tunnel

Billings

Bonanza tunnel

Camp Grove

Cashier

Centennial tunnel

Chase

Clay County

Climax

Cook

Egyptian

Eureka

Fairfield

Flack

Galena

1 Sources: Mining Reporter (1899); Fossett (1880, p. 584); and U.S. Bureau of Mines.

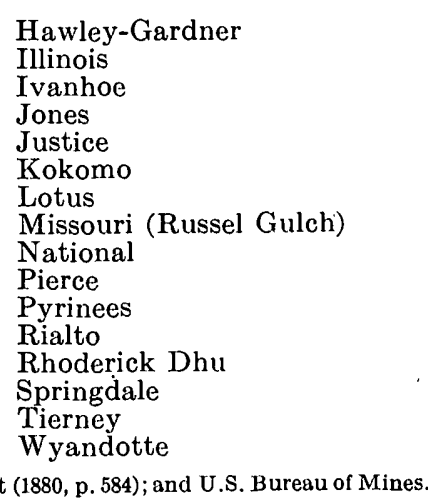




\section{HISTORY OF MINING}

Mining activity in the Central City district and adjacent areas played an important role in the development of the Rocky Mountain area, and its history has been described by many writers. An excellent summary of the history of mining, and attendant milling and smelting practices, as known to that time, is given by Bastin and Hill $(1917$, p. 67-79; 153-170). Other accounts of a general nature or of particular phases of the historical development have been given by both historians and pioneer mining engineers. Of particular interest and importance are the publications by Hollister (1867), Fossett (1880), Hall (1889-95), and Rickard (1897); and for a lengthy account of the mining history, the reader is referred to these publications.

Placer gold was found near the present site of the town of Idaho Springs, in Clear Creek County, in January 1859, and in May of the same year the first lode discovery in the Rockies was made in Gregory Gulch, at the location of the now famous Gregory claim, between the present sites of Black Hawk and Central City. This discovery precipitated a rush to the area, and other valuable lodes were soon found. On May 15, 1859, the Bates lode was discovered, and on May 25, the Gunnell, Kansas, and Burroughs. The Bobtail lode was discovered in June. Early in June, W. Green Russell had commenced washing gold in the gulch that now bears his name.

A second stampede to the district, larger than the first, took place in the summer of 1860 ; and during the early part of the summer prospectors bound for the new gold field arrived on the present site of Denver at the rate of 100 a day. As a result of the influx, the diggings became overcrowded, with consequent hardships. Newcomers to the diggings found all the veins known to that time being worked, and lacking the knowledge or enterprise to spread out and find other veins for themselves, they wanted the claims reduced to 25 feet in length. This attempt fortunately was generally unsuccessful, for each location was small to begin with, commonly being only 100 or exceptionally 200 feet in length. Many claims, however, were subdivided, and some were eventually patented with a length of only 25 feet.

The small size of the early claims, which resulted from the relative richness of the outcrops, was detrimental to an orderly and progressive development of the mines; and many problems arose concerning dumps, rights-of-way, drainage, and trespass. Consolidation of properties was retarded by inflated capital and exorbitant demands of the many different owners. Another serious problem that was not recognized at the time, but which has been emphasized subsequently, resulted from the fact that most of the ore bodies plunge at moderate angles and consequently passed from one property onto another as depth increased. Inevitably this led to many frustrations and at times expensive lawsuits. Similar problems arose later because of the intersection or interlacing of veins at depth along their dip.

During the early years of the camp mining was confined to the placer gravels and to the surface gossans of the veins. The ores obtained were soft and free milling; they could be mined cheaply and amalgamated with the aid of simple devices. As mining progressed and depths of 50 to 100 feet were reached, the oxidized ores gave way to primary sulfides which could not be treated profitably by such crude methods. Consequently for several years mining activity depended largely on the successes and failures of various milling and smelting processes, which are described on pages 9-11.

As all the veins were gold bearing, silver was not recognized as a valuable ore mineral until mining had been extended to the underlying primary sulfide ores. The rich silver veins on Silver Hill, north of Black Hawk, were not discovered until 1877 or 1878.

A marked stimulus was given to the development of mining by the completion of the Union Pacific Railroad to Cheyenne, Wyo., in 1867, and particularly by the completion in 1870 of the Denver Pacific line between Denver and Cheyenne. In the same year the Kansas Pacific Railroad reached Denver. Also in 1870 the narrow-gage railroad was completed from Denver to Golden, and in 1872 it was extended to Black Hawk and in 1873 to Floyd Hill on Clear Creek. In 1877 the Gilpin County tramway, a 24-inch gage road, was completed; this served all the large mines of Black Hawk, Central City, and Russell Gulch.

Owing to the generally low topographic relief, the mines in the Central City district were developed principally by shafts. As mining progressed to greater and greater depths the handling of water and hoisting became a serious problem. Although the water inflow, with a few exceptions, is not excessive, it was difficult if not impossible, to keep the mines dry and at the same time hoist sufficient quantities of ore to pay for the operations. Most of the mines were dewatered by bailing; a few were drained by steam pumps or by Cornish pumps. The California mine was sunk to a depth of 2,250 , the deepest shaft in the district, prior to 1900 . While working on the lower levels the miners bailed for two shifts and hoisted 
ore for one shift (George Collins, written communication). Steam pumping was not feasible because of the highly acidic mine waters and because much of the steam condensed by the time it reached the bottom of the shaft. Other mines of lesser depth were not generally faced with such insurmountable water and hoisting problems, but nevertheless they too found that mining costs increased markedly as depth increased.

About the turn of the century, the Argo (Newhouse) tunnel was started at Idaho Springs to intersect the veins at Central City at depth and provide drainage and easy haulage to the mills at Idaho Springs. Later two other tunnels-the Big Five and the Iucania-were started from near Idaho Springs, but they failed to penetrate far enough to reach the valuable veins in the Central City district (pl. 1). Although a few delays were necessary for negotiations with mine owners, the Argo tunnel was advanced rapidly and it was almost completed by 1907 . Despite the rapid progress of the tunnel and the fact that it cut many of the larger more productive veins of the district, the tunnel did not prove to be a stimulus to the development of mining in the district. Many mines that had shut down to await connection with and drainage by the tunnel were never reopened. Also, as discussed later in this report, the tunnel passed under the relatively barren core of the Central City district, and it failed to cut the ground most favorable for the occurrence of valuable ore bodies: Laterais were driven on the more productive veins, both to the west and the east, and mining from the tunnel level took place sporadically until 1942, when the tunnel was closed because of an accidental breakage into old stopes on the Kansas vein that resulted in its being largely blocked by stope fill from abandoned deep shaft workings.

Aside from the mining operations at the Argo tunnel, the mining activity since the early 1900 's was done largely by small companies and by leasors. Notable exceptions are the Fifty Gold Mines Corp., which mined the Gregory, Bobtail, Fiske, Mammoth, Cook, and other properties; and the Chain O'Mines, Inc., which consolidated several properties on Quartz Hill. The Fifty Gold Mines Corp. consolidated several properties in the vicinity of the Bobtail tunnel about 1905 and mined them for several years. The Chain O'Mines began mining of a pipelike body of low-grade ore called the Patch in 1929 , and continued to operate it on a large scale until 1937.

The number of mines in operation in the district has shown a marked decrease since 1910 (fig. 3), from 89 in 1910 to 23 in 1919 ; since 1919 the decrease has been less marked. In 1952, because of an increased interest in uranium ore, the trend was reversed and about the same number of mines were in operation as during the early years of World War II.

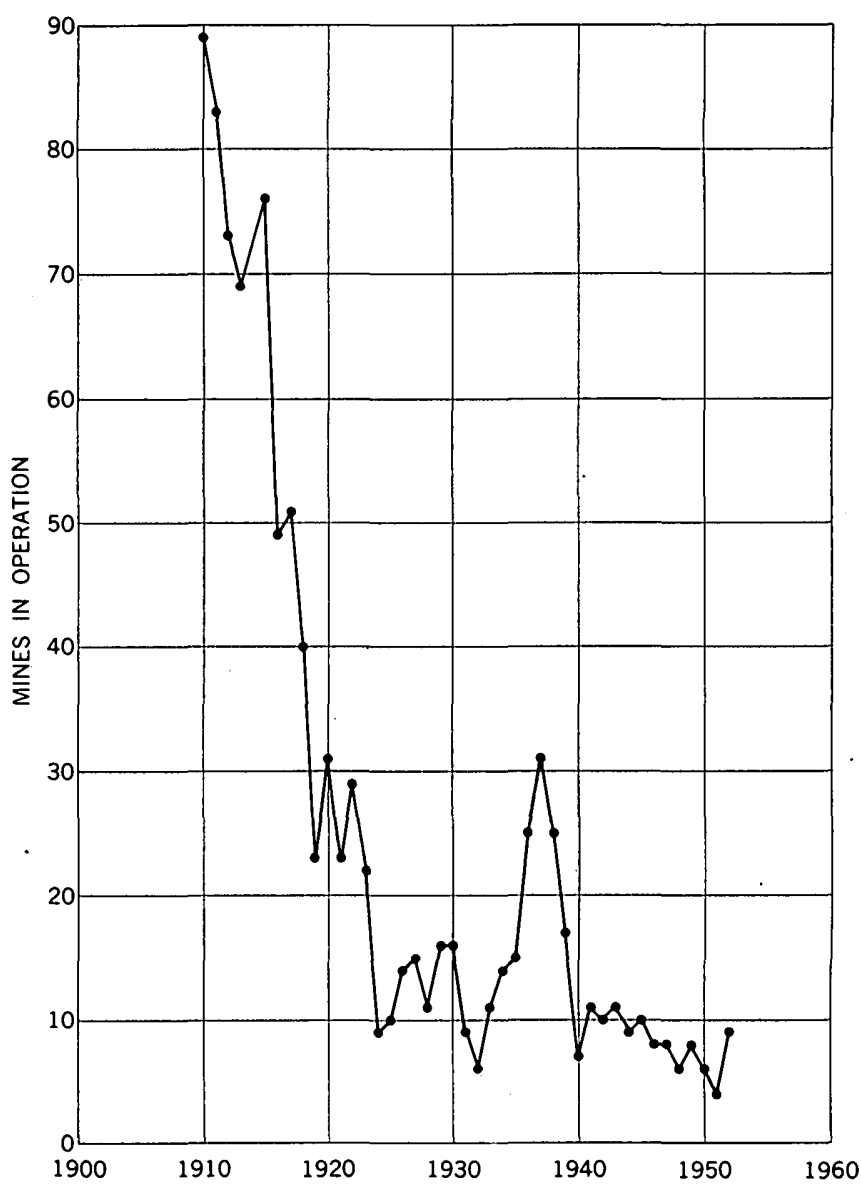

Fioure 3.-Graph showing number of mines (by years) in operation, Central City district, 1910-52.

\section{HISTORY OF ORE TREATMENT}

After the oxidized ores in the near-surface parts of the veins were exhausted in the early years of mining activity, the history of the district has paralleled the history of development of methods of ore treatment. For a detailed account of ore beneficiation and smelting, the reader is referred to the reports by Raymond (1870), Rickard (1893), Rogers (1883), Egleston (1876), Downey (1911), Collins (1910), Draper (1911), Parmalee (1912; 1915), Roller and Curran (1914), and Pearce $(1914,1916)$. An excellent summary of ore treatment, exclusive of recent practices; is given by Bastin and Hill (1917, p. 153-163).

The pioneers of the camp mined the surface gossans of the veins and worked the placer gravels. These ores were soft and free milling; and they could be 
mined cheaply and amalgamated with the aid of such simple devices as sluices, cradles, arrastres, and crude stamp mills. A common practice was to wash the ore in sluices; the loosened gold was recovered in riffles and the harder quartz that was washed down to the end of the sluice was saved for subsequent treatment in stamp mills or arrastres.

Primary ores were found at depths generally less than 100 feet. These ores are hard and much of the gold is finely distributed through the sulfides and gangue; consequently they are much less readily amalgamated than the oxidized ores. In an attempt to free the gold from its matrix various methods of fine crushing were attempted. An early device consisted of a small mortar whose pestle was attached to a sapling; another device was the "woodpecker mill" (Bastin and Hill, 1917, p. 153). In July 1859 the arrastre was introduced, and shortly afterwards the first stamp mill, a crude affair with six stamps that was set up at the mouth of Chase Gulch and run with waterpower. To provide the needed water for ore treatment, a ditch extending from the mouth of Silver Creek, at the base of the high peaks of the Front Range, was started during the first year of the camp; and in 1860 it was providing water for the operations at Nevadaville, Russell Gulch, and Black Hawk.

Two or three stamp mills driven by steam and several mills driven by waterpower were started in 1859 , and by July 1860, there were 60 stamp mills and about 30 arrastres operating in the Gregory Gulch area. The mills were, of course, of small capacity; the largest mill that operated in 1860 had 18 stamps.

The difficulties in amalgamating the primary ores by the crude devices then in existence resulted in the closing of many mines, particularly in 1861. Many prospectors and companies that were operating in the district became discouraged by the relatively low savings from the sulfide ores and left the camp. The failures of the stamp mills led to a period that Raymond (1870, p. 347-348) has called the "process mania," which lasted from 1864 to 1867 . During this time many inventions for the purpose of amalgamating the gold were tried, but each was unsuccessful.

In 1866, Nathaniel P. Hill, of Black Hawk, completed successful experiments on the smelting of Gilpin County ores, and in 1868 he opened the Hill smelter, which consisted of a calcining furnace and a small reverberatory (Bastin and Hill, 1917, p. 161). A complete description of this plant has been given by Egleston (1876). In 1878, the smelter was moved from Black Hawk to Argo, a suburb of Denver; it was dismantled in 1910 .
Bastin and Hill (1917, p. 162) describe the history of smelting practices as follows:

While the Hill smelter at Blackhawk had the distinction of being the first successful smelter of the district and with its successor at Argo played a most important part in the development of this region, several other smelters were also in operation at different times. In 1872 there were in operation the Swansea matte smelter at Swansea, near Empire; a matte smelter at the Whale mill (now a part of the Stanley mill), near Idaho Springs; and a lead smelter at Golden (Bayley and Sons or Golden City Smelting Works). In 1873 a lead smelter (Denver Smelting Works) was established at Denver. In 1875 the Collom Co., which already had separating and concentrating works at Idaho Springs and Blackhawk, completed a lead smelter at Golden. The Golden Smelting Co's plant was constructed at Golden in the same year. This plant, which started in September, was first operated as a lead smelter, but as the supply of galena proved inadequate, it was altered to a copper-matte smelter. Golden became for a short time a smelting center of some importance. In 1880 three plants were in operation there, but from 1884 to 1888 inclusive, only one was in operation. In 1901 the Golden semipyritic plant was built by F. R. Carpenter according to plans developed at Rapid City and Deadwood, S. Dak., for the purpose of treating highly pyritic ores from Gilpin and Clear Creek Counties. The smelter, operated for several years by the Clear Creek Mining and Reduction Co., smelted large quantities of ore from the Saratoga mine, which the company controlled, also ore bought in the open market. In April, 1910, this plant, after the addition of a reverberatory, was reopened as the North American semipyritic plant for the treatment of copper and pyritic ores of Gilpin, Clear Creek, and other counties, and was operated intermittently until November 1911. Its building is still intact, but none of the other plants at Golden are standing.

About the time the owners of the Argo plant were planning to go out of business, a new matte smelter, styled the Modern, with McDonald furnace, went into blast on October 2, 1909, at Utah Junction, a short distance from Globeville, on ores purchased in the market from Clear Creek, Gilpin, Lake, and other counties, but it was closed in April 1910, and was never operated again, being dismantled in 1915-16.

In recent years most of the ore from the district has been treated at the plant of the American Smelting and Refining Co., at Leadville, Colo. Some zinc concentrates have been shipped to the company's plant at Amarillo, Tex.

Simultaneously with the successful completion of smelters, improved milling processes were developed to handle the "mill dirt," which is of such a character that its metal content is most economically saved by some form of concentration or amalgamation. This ore contrasts with the "smelting ore," which is generally higher in grade and can most profitably be processed by smelting directly. The three principal types of mills at the time of the study by Bastin and Hill (1917, p. 154-161), and prior, were (1) the old-style Gilpin County stamp mill, (2) the fast-drop stamp 
mill of the California type, and (3) the plant in which amalgamation is wholly discarded and concentration is supplemented by flotation or cyanidation. An excellent discussion of the Gilpin County and California-type stamp mills, which compares the advantages and efficiency of each, is given by Rogers (1883, p. 2955) and Rickard (1893, p. 137-147).

The mills in operation since 1900 have mostly employed amalgamation-concentration-wholly discarded in recent years-and gravity concentration and selective flotation. Aside from the Chain O' Mines Inc. mill, which had a reported capacity of about 1,500 tons per 24-hour day, the mills have had small capacities; most of them handled less than 50 tons per day.

Although a few mills in operation since 1950 have been operated by mining companies, most mills in the area-particularly along Clear Creek at Idaho Springs-have operated entirely on custom ore.

\section{SAMPLING WORKS}

Public sampling works that purchased ores in lots of any size were an important factor in the development of mining in the Central City and adjacent mining districts. In the early days these works served as agents or brokers for smelters at Swansea, Wales, in Germany, and in the middle western and eastern states of this country. Later they obtained ores for the Black Hawk smelter; and still more recently for smelters at Denver and Pueblo, Colo., and at other localities.

The Chamberlain sampling works was built at Black Hawk in 1878, and it was operated continuously until about World War I, purchasing ores from various mines and selling the ore to the Argo smelter and to other smelters. The Chamberlain sampling works at Idaho Springs was opened in 1883. In 1919, a sampling works for the American Smelting and Refining Co. was established at Idaho Springs, and it, was in operation until 1939.

As described by Bastin and Hill (1917, p. 164):

The sumpling works pays the miner for his ore according to certain schedules or contracts based on the assay of the ore for the precious metals, the base metals, and other components that aid or interfere with smelting, the charges for sampling, freight, and smelting being deducted. An attempt is made to crush, sample, assay, and pay for the ore in one or two dnys, and in this promptness of payment lies the great advantage of the sampling works to the small producer. The miner can, if he so desires, watch all the operations of the sampler, and he has his own or a public assayer check the assaying of the sampler. If the ore is shipped direct to the smelter a much longer time elapses beforc payment for it can be received, and as a rule only the larger producers can brook this delay; moreover, the smelters do not handle less than carload lots. A considerable quantity of the ore received by the samplers is delivered irregularly in small lots, by the wagon load, with no contract as to grade, tonnage, price, or time of delivery, and in acting as a purchasing agent for ore of this class the sampler serves perhaps its most useful purpose. The engineer may use the sampler as a testing plant for small lots of ore of questionable grade; if those small lots do not carry sufficient quantities of metals to pay freight and treatment charges, he is out only the price of sampling, and the ore or rock can be transferred to an amalgamating or concentrating mill or thrown on the dump.

\section{GENERAL GEOLOGY}

The Central City district lies within a terrain of Precambrian crystalline rocks (fig. 4), which constitute the core of the Front Range. These rocks are intruded by many small dikes and irregular bodies of porphyritic igneous rocks of early Tertiary age and are cut by abundant, steep faults which contain the ore deposits of the district.

As the physical character and structure of the Precambrian rocks had a marked influence on the development of the fault pattern and on the localization of ore, a summary of the salient features of these rocks is given in the following sections. Also, the early Tertiary intrusive rocks are described only briefly, for a detailed description of them has been given by Wells (1960).

\section{PRECAMBRIAN ROCKS}

The Precambrian rocks are an interlayered and generally conformable succession of gneissic, granitic, and pegmatitic units (table 5). The dominant rocks, and those most commonly found along the vein walls, are biotite gneisses and microcline-bearing gneiss; pegmatite is widespread in both of these rock units and forms many large mappable bodies in the biotite gneisses (fig. 4). The other rock units occur as sparse, small layers, lenses, or sheets in the dominant gneisses. The mineral assemblages in the rocks correspond to the upper range (sillimanite-almandine subfacies) of the almandine amphibolite metamorphic facies as defined by Fyfe, Turner, and Verhoogen $(1958$, p. 228,230$)$.

\section{GNEISSIC ROCKS}

The gneissic rocks are mainly microcline-bearing gneiss and biotite gneisses, but include interlayered rock units of varying composition-lime-silicate gneiss and related rocks, cordierite-amphibole gneiss, and amphibolite (table 5). 


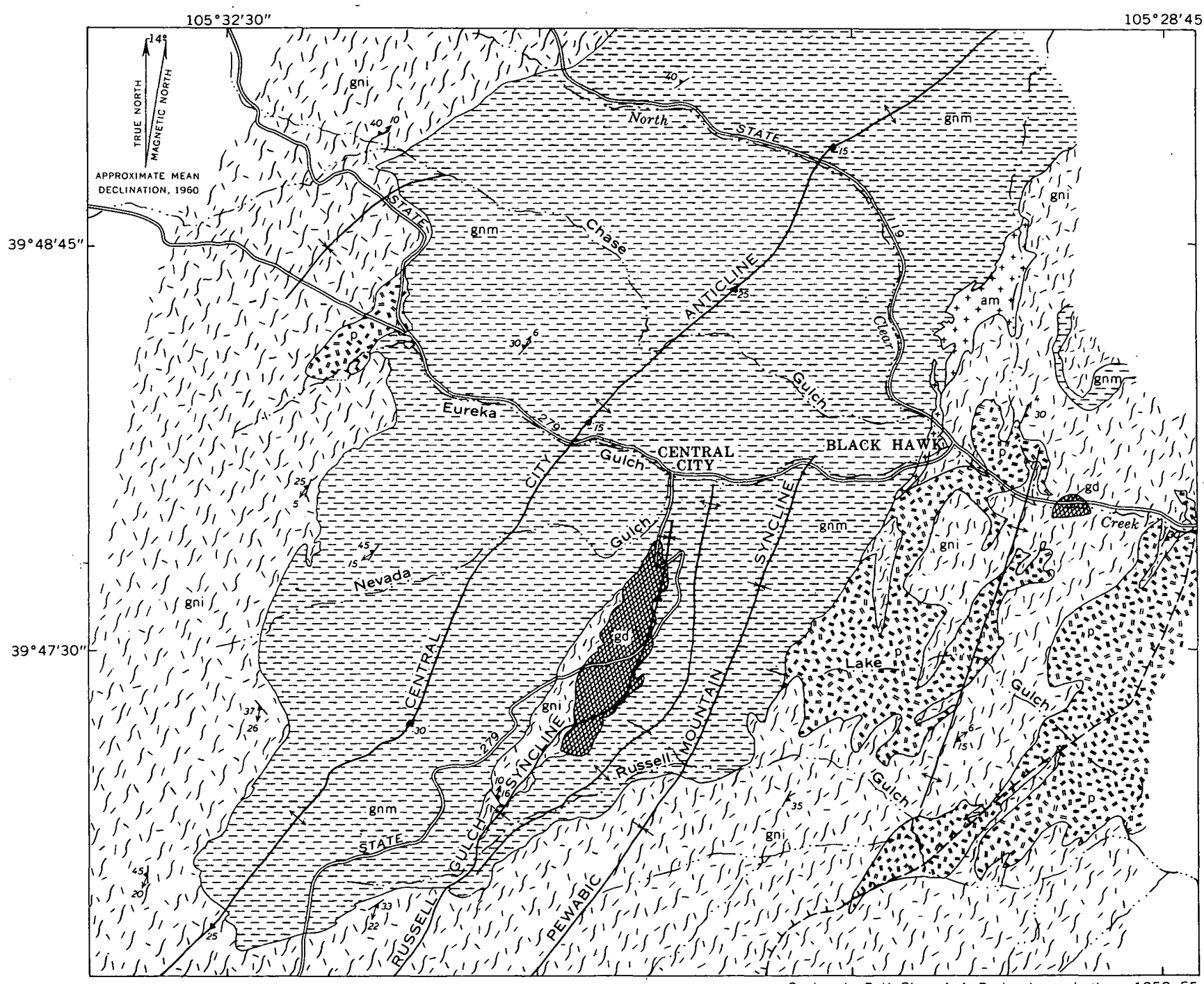

EXPLANATION

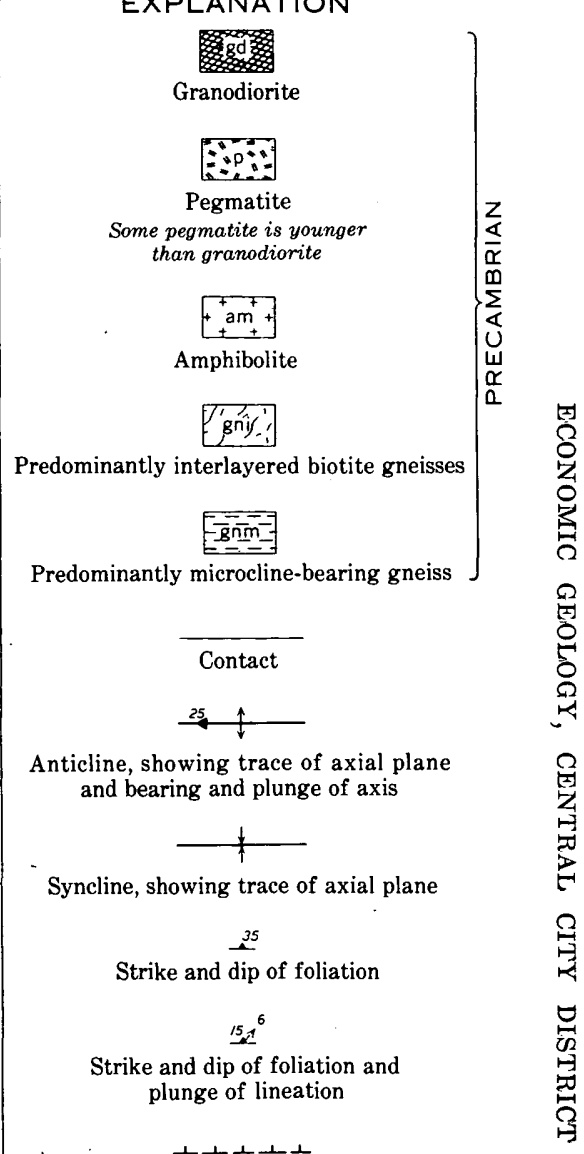

Approximate boundary between area of

predominant open folds and area of

predominant closed folds. Hachurs
point toward area of open folds

2000

2000 4000 FEET 
TABLe 5.-Principal Precambrian rock units, Central City district, in order of probable relative age ${ }^{1}$

\begin{tabular}{|c|c|}
\hline Rock units & Comments \\
\hline $\begin{array}{l}\text { Granitic rocks: } \\
\text { Biotite-muscovite granite } \\
\text { Quartz diorite and associated hornblendite. } \\
\text { Granodiorite } \\
\text { Pegmatite (includes minor granite gneiss) } \\
\text { Gneissic rocks: } \\
\text { Microcline-bearing gneiss.- } \\
\text { Cordierite-amphibole gneiss. } \\
\text { Biotite-quartz-plagioclase gneiss } \\
\text { Sillimanitic biotite-quartz gneiss } \\
\text { Lime-silicate gneiss } \\
\text { Skarn and related rocks } \\
\text { Amphibolite } \\
\text { Quartz gneiss }\end{array}$ & $\begin{array}{l}\text { Equivalent to Silver Plume granite at Silver Plume, Colo. } \\
\text { Probably equivalent to Boulder Creek granite. Lovering and Goddard (1950), } \\
\text { Also constitutes felsic layers in migmatites. Unit is correlative with granite } \\
\text { gneiss and pegmatite unit of Freeland-Lamartine district (Harrison and Wells, } \\
\text { 1956). Some pegmatite is younger than biotite-muscovite granite. } \\
\text { Age relations among these rock units are unknown. Most of the rocks previously } \\
\text { were grouped in the Idaho Springs formation. The microcline-bearing gneiss } \\
\text { is the granite gneiss of Bastin and Hill (1917); it was referred to as quartz } \\
\text { monzonite gneiss in a previous report (Sims, 1956). }\end{array}$ \\
\hline
\end{tabular}

1 Rocks aro listed from youngest to oldest.

\section{MICROCLINE-QUARTZ-PLAGIOCLASE-BIOTITE GNEISS}

The microcline-quartz-plagioclase-biotite gneiss, referred to in this report as microcline-bearing gneiss, is a gray, medium-grained foliated rocks that consists chiefly of quartz, plagioclase, microcline, and biotite. Weathered surfaces characteristically are light brown or buff and contrast sharply with the drab gray colors of the biotite gneisses. At most outcrops, the rock has a well-defined foliation marked by crude alternating layers a fraction of an inch thick, one rich in biotite and another rich in quartz and feldspar, and by a subparallel arrangement of the tabular and platy minerals. At places the layering is poorly defined, giving a streaked appearance; at other places layering is absent because the biotite is more or less evenly dispersed. Certain phases containing sparse biotite are nearly massive in appearance.

The large layer that crops out along the axis of the Central City anticline (fig. 4) is about 3,000 feet thick and contains many discrete layers and lenses of biotite-quartz-plagioclase gneiss, amphibolite, lime-silicate gnieiss, skarn, and cordierite-amphibole gneiss. Aside from the biotite gneiss, which locally appears to grade across strike into the microcline-bearing gneiss, the layers are sharply delineated. Pegmatite is irregularly distributed through the gneiss. Some bodies are discrete and mappable; others grade into the gneiss along irregular contacts.

The microcline-bearing gneiss formerly was termed "granite gneiss" by Bastin and Hill (1917, p. 30-32 and pls. 1 and 3), Lovering and Goddard (1950, p. 73), and Sims and others $(1955$, p. 8).

\section{BIOTITE GNEISSES}

The two main varieties of biotite gneiss in the district-biotite-quartz-plagioclase gneiss and sillimanitic biotite-quartz gneiss-are commonly interlayered in units ranging in thickness from a few inches to a few tens of feet, and accordingly they were mapped as interlayered biotite gneisses (fig. 4).

Biotite-quartz-plagioclase gneiss is a gray, mediumto fine-grained, equigranular rock that varies in color, composition, and structure. With varying quantities of biotite, the typical biotite-quartz-plagioclase gneiss ranges from a light gray and poorly foliated rock with sparse biotite to a dark gray, schistose rock with abundant biotite. The lighter colored rocks are similar in appearance to certain phases of the microclinebearing gneiss except that they are generally finer grained. The plagioclase in the rocks generally ranges in composition from albite to andesine. Modal analyses of thin sections indicate that the rock contains 15 to 65 percent quartz, 15 to 65 percent plagioclase, and 10 to 35 percent biotite.

Sillimanitic biotite-quartz gneiss is a light- to darkgray, medium-grained, well-foliated rock that is flecked with pods of white, fibrous sillimanite. Weathered surfaces characteristically have a silvery-gray appearance. The rock varies considerably mineralogically, and modal analyses indicate that the rock contains 25 to 65 percent quartz, 15 to 50 percent biotite, 2 to 30 percent sillimanite, and a trace to as much as 10 percent muscovite. Sparse plagioclase (oligoclase), microcline, and garnet are present locally.

A few layers of biotite gneiss, rarely large enough to map, contain visible tiny garnets; this variety of the gneiss is referred to as garnetiferous biotite gneiss. Typically the rock is dark gray, medium grained, and well foliated. It contains 30 to 60 percent quartz, a trace to 50 percent plagioclase (oligoclase-andesine), 10 to 35 percent biotite, 5 to 40 percent garnet, and locally a few percent of microcline and magnetite. 
All varieties of biotite gneiss contain some pegmatite, either as thin, conformable layers and lenses along the foliation of the gneiss or as larger, discrete bodies; and all gradations exist from biotite gneiss to pegmatite. The rocks consisting of nearly equal quantities of biotite gneiss and pegmatite are termed "migmatites." Although migmatite was not mapped at the surface, it was distinguished at places underground, for it generally is a more favorable wallrock for the occurrence of ore shoots than biotite gneiss.

\section{LIME-SILICATE GNEISS AND RELATED ROCKS}

Lime-silicate gneiss is the name used in this report for a variable group of massive or layered rocks that contain garnet, quartz, pyroxene, hornblende, plagioclase, and epidote as major constituents and magnetite, sphene, apatite, and locally other minerals as minor components. The rocks typically are green, white, or mottled green, white, and red. The rocks vary from layer to layer both in composition and in color, and because of their heterogeneity can be easily recognized in the field. At most exposures lime-silicate gneiss is closely associated with skarn, quartz gneiss, and amphibolite; generally, these units are so small that they cannot be mapped separately and accordingly they were included with the associated limesilicate gneisses.

\section{AMPHIBOLITE}

Amphibolite is a distinctive dark-gray to nearly black, medium-grained, equigranular, massive or layered gneiss that consists of about equal proportions of hornblende and plagioclase. Pyroxene and quartz are minor constituents. The rock can be distinguished from quartz diorite and hornblendite by its finer grain size and more mottled appearance.

Amphibolite forms large, discrete layers and small lenses in the microcline-bearing gneiss and biotite gneisses, and also forms small lenses intercalcated with lime-silicate gneiss.

\section{CORDIERITE-AMPHIBOLE GNEISS}

Cordierite-amphibole gneiss is used herein to include unusual magnesium-rich rocks of variable composition that occur sporadically in the district. The gneiss is generally medium grained but locally is coarse grained and layered. Fresh surfaces are medium-gray and commonly greasy in appearance. Weathered surfaces range from grayish brown to reddish brown and at places are ribbed. In a previous report similar rocks were termed cordierite-anthophyllite-garnet gneiss (Sims and others, 1955, p. 7).

Typical mineral assemblages that occur within different layers of the rock include (1) quartz, cordierite, anthophyllite, almandite(?), and biotite; (2) quartz, cordierite, and biotite; (3) quartz, cummingtonite, almandite (?), plagioclase (labradorite); and (4) quartz, hornblende, cummingtonite, and plagioclase (bytownite).

The gneiss occurs as small, discontinuous layers or pods in both the microcline-bearing gneiss unit and the biotite gneisses. The contacts with adjacent rocks are sharp.

\section{GRANITIC ROCKS}

Three distinct types of granitic rocks-grandiorite, quartz diorite and associated hornblendite, and biotitemuscovite granite-occur in the district, but they are quantitatively unimportant and rarely form wallrocks of veins. The granodiorite and quartz diorite and associated hornblendite units are partly metamorphosed and deformed; the biotite-muscovite granite is undeformed.

Two bodies of grandiorite occur as thin, virtually conformable sheets in the Central City district (fig. 4). The largest sheet, exposed in Spring Gulch, south of Central City, is estimated to be about 400 feet thick; the other body, exposed in the road cut along State Highway 119, half a mile southeast of Black Hawk (fig. 4), probably is less than 200 feet thick. A mafic phase of the sheet in Spring Gulch was cut in the Hayes and Wheeler tunnel (fig. 31).

The granodiorite is dark gray, medium to coarse grained, equigranular, and generally homogeneous. It is easily recognized because of its dark color, which is imparted by abundant biotite, and its tendency to weather into sub-rounded boulders. The margins of the sheets have a well-defined foliation and lineation; the inner parts are more massive. The rock contains 15 to 25 percent quartz, 35 to 50 percent plagioclase (oligoclase-andesine), 3 to 12 percent microcline, and 18 to 25 percent biotite. Sphene and opaque iron oxides are the dominant accessory minerals.

\section{QUARTZ DIORITE AND ASSOCIATED HORNBLENDITE}

Dark-gray to black mafic rocks occur as lenses and pods in the microcline-bearing gneiss and the biotite gneisses. The bodies are poorly exposed and generally are distinguished by abundant, rounded boulders strewn over the surface.

The quartz diorite is a dark-gray to black, mediumgrained massive to foliated rock that consists dominantly of hornblende, pyroxene, biotite, plagioclase (oligoclase-andesine), and quartz. The white plagioclase gives the rock a mottled appearance. The rock can be distinguished from amphibolite by its coarser grain and more massive appearance. 
The hornblendite is a nearly black, medium- to coarse-grained, nearly massive - rock that consists dominantly of hornblende and some clinopyroxene and plagioclase. The plagioclase, commonly labradoritebytownite, forms thin anastomosing veinlets through the rock.

\section{BIOTITE-MUSCOVITE GRANITE}

Biotite-muscovite granite is a tan, pink, or gray, fine-grained, generally equigranular rock that is nearly massive. It contains about 30 percent quartz, 60 percent feldspar, with slightly more microcline than plagioclase (oligoclase), and as much as 10 percent mica.

The granite is present along the west edge of the district as small, narrow bodies, elongated in a northeasterly direction. The bodies are slightly discordant to the surrounding, older gneisses.

\section{PEgMaTITES}

Four distinct varieties of homogeneous pegmatites occur in the Central City district. These rocks are conrse-grained inequigranular rocks of granitic composition that differ from one another by slight variations in mineralogy, texture, and structure. The different varieties are not distinguished on figure 4, but they were mapped separately in the underground workings.

Most pegmatite in the district is a white to tan, coarse-grained, weakly foliated quartz-feldspar rock that contains scattered biotite or magnetite. It forms discrete, conformable bodies in all rocks older than granodiorite and thin layers along the foliation of the biotite gneisses. At places it grades into granite gneiss. The pegmatite correlates with the granite gneiss and pegmatite unit of the Freeland-Lamartine district (Harrison and Wells, 1956, p. 50-53).

A variety of pegmatite that contains muscovite and black tourmaline rather than biotite and magnetite occurs near State Highway 119 in the eastern part of the district. This pegmatite, like the more abundant pegmatite described above, occurs as thin layers and as larger discrete bodies in the biotite gneisses. The larger bodies are the more common, and locally they cut across the structure of the biotite gneisses. Owing to similarity in structural relations, the muscovitetourmaline pegmatite possibly was formed almost contemporaneously with the magnetite-biotite-bearing pegmatite.

\section{TERTIARY IGNEOUS ROCKS}

The Tertiary igneous sequence in the Central City district consists of 6 types of porphyritic intrusive rocks, which from oldest to youngest, are leucocratic granodiorite porphyry; alkalic syenite porphyry, quartz monzonite porphyry, bostonite porphyry, trachytic granite porphyry, and quartz bostonite porphyry (pl. 1). The rocks were emplaced during the Laramide orogeny, and their age has been established as early Tertiary by Lovering and Goddard (1950, p. 47). The rocks occur as dikes and small irregular plutons. In this section the distribution and megascopic appearance of the different types of porphyritic rocks are emphasized; the structure of the rocks is described in a later section. Additional data are given in the report by Wells (1960).

The leucocratic granodiorite porphyry and quartz monzonite porphyry occur almost entirely in the eastern (mainly southeastern) part of the district; the younger bostonite porphyries are mainly in the western part. Alkali syenite porphyry and trachytic granite porphyry are rare.

Brecciated wall rock fragments are common in the leucocratic granodiorite porphyry and the quartz monzonite porphyry. In some plutons these range in size from those visible only under the microscope to those sufficiently large to be mapped at a scale of $1: 6,000$.

\section{LEUCOCRATIC GRANODIORITE PORPHYRY}

Leucocratic granodiorite porphyry occurs as irregular plutons and less commonly as dikes. The largest body in the district is exposed on Gregory Hill, half a mile southeast of Central City (pl. 1), where an irregular pluton has maximum dimensions of about 1,000 feet by 2,600 feet at the surface. Several dikes of similar rock radiate from the body. The outcrop of the body is marked by a rubble of irregular, subrounded boulders. The north end of a pluton of comparable size cropś out on Banta Hill along the south edge of the district. Dikes of similar rock also radiate outward from this body, and it is cut by many younger bostonite porphyry dikes. Leucocratic quartz monzonite porphyry also forms an irregular, crescentshaped body and associated dikes near the junction of Illinois and Russell Gulches.

The granodiorite porphyry has a light-gray finegrained groundmass and light-gray feldspar phenocrysts. At places the groundmass has a purplish tinge, which contrasts with the lighter colored phenocrysts. The rock is composed of oligoclase, orthoclase, anorthoclase, quartz, and a sparse ferromagnesian mineral. Each type of feldspar occurs as phenocrysts, but oligoclase predominates greatly over the other feldspars.

The rock in the large mass on Gregory Hill contains phenocrysts of two sizes. The smaller ones are sub- 
ECONOMIC GEOLOGY, CENTRAL CITY DISTRICT

rounded equidimensional feldspars, whereas the larger ones are somewhat angular and as much as half an inch in diameter. The small phenocrysts are typical of all bodies of the porphyry.

\section{ALKALIC SYENITE PORPHYRY}

Alkalic syenite porphyry forms a short dike about 1,500 feet east of the junction of Illinois and Russell Gulches and another east of the Cherokee mine (pl. 1). The rock is light brownish gray and consists dominantly of albite, oligoclase, and potash feldspar, with sparse quartz and ferromagnesian minerals. Darkgray phenocrysts of zoned plagioclase feldspar that are commonly double wedge shaped and from oneeighth to one-half inch long have conspicuous white rims. Weathered surfaces of the rocks are typically light gray, have a polished appearance, and are pitted.

\section{QUARTZ MONZONITE PORPHYRY}

Quartz monzonite porphyry is abundant in the drainage area of Lake and lower Russell Gulches in the southeastern part of the district, and a few dikes and two small plutons with a large oval body of associated intrusion breccia are present in the northwest part of the district (pl. 1).

The quartz monzonite porphyry is a light to medium gray rock that contains subangular light gray feldspar phenocrysts in a fine-grained groundmass of potash feldspar, plagioclase, and quartz. Ferromagnesian phenocrysts are visible in some rocks. The rock contains an estimated 40 to 50 percent quartz, 25 to 30 percent potash feldspar, 20 to 30 percent plagioclase, and less than 5 percent of ferromagnesian minerals. Weathered surfaces are commonly pitted because of the removal of mafic minerals by weathering.

The intrusion breccia in upper Chase Gulch is an oval-shaped body that has surface dimensions of 1,200 feet by 2,300 feet; it consists of abundant fragments of Precambrian country rock that are embedded in a fine-grained matrix of igneous material, probably quartz monzonitic in composition. The breccia fragments are biotite gneiss, pegmatite, and locally quartz monzonite gneiss. They are rounded to subrounded and commonly 1 to 2 inches in diameter, but some fragments near the east edge of the breccia plug are 2 to 3 feet in diameter. All of the breccia fragments are partly altered to clay minerals.

\section{BOSTONITE PORPHYRX}

Bostonite porphyry forms two long, complex dikes and a few minor lenses in the Central City district. Both major dikes locally form one or both walls of important veins. The California dike, which can be traced for about $2 \frac{1}{2}$ miles from the west edge of the district to the Mammoth mine in Spring Gulch, is almost parallel to the California vein and at its east end is locally parallel to the Mammoth and other veins (pl. 1). It generally is less than 20 feet thick. The Topeka dike, which can be traced for about $31 / 2$ miles from near the Springdale mine to the Running Lode mine, is much more lenticular than the California dike. It has been exposed in the Springdale (Gold Rock) mine and in mines on Quartz Hill. At its east end, south of Lake Gulch, the Topeka dike splits into two major segments.

The bostonite porphyry is a seriate porphyritic rock that has a pink to lilac groundmass and white feldspar and sparse ferromagnesian phenocrysts. The feldspar phenocrysts are both plagioclase and potash feldspar. They commonly constitute 10 to 20 percent of the rock, and generally do not exceed a quarter of an inch in diameter. Quartz rarely constitutes more than 5 percent of the rock.

The groundmass has a bostonitic texture; the feldspar laths are interlocking and have an imperfect parallel orientation.

The bostonite porphyry can be distinguished megascopically from quartz bostonite porphyry by the mafic minerals and phenocrysts of both potash feldspar and plagioclase. Weathered surfaces are pitted because of the removal of the ferromagnesian mineral.

\section{TRACHYTIC GRANITE PORPHYRY}

A small dike of trachytic granite porphyry is exposed in pits west of the Iron mine, in upper Russell Gulch (pl. 1). The trachytic granite is' seriate porphyritic and has an aphanitic pale red to reddishbrown groundmass. It is distinguished from bostonite porphyry by containing abundant large almondshaped phenocrysts of white or pink feldspar. The texture of the groundmass is similar to quartz bostonite; it consists of stubby euhedral to subhedral plagioclase laths, subhedral potash feldspar grains, and anhedral quartz grains that fill interstices between the feldspars.

\section{QUARTZ BOSTONITE PORPHYRY}

Quartz bostonite porphyry forms dikes, some of which are several miles long and extend for some distance outside the district. The principal dikes are the Pewabic, the Wood group, the Prosser Gulch, and the Nigger Hill. Aside from the Pewabic dike, which trends east-northeastward across the district to Signal Hill, the major dikes are limited to the 
western part of the district. A small isolated dike occurs in upper Fourmile Gulch.

The quartz bostonite has two distinct phases, one of which is strongly porphyritic and the other of which is only locally porphyritic. The generally nonporphyritic phase constitutes the Prosser Gulch and Nigger Hill dikes; all others are the common porphyritic phase.

Fresh quartz bostonite porphyry is lilac colored to reddish brown and contains 10 percent or less salmonpink feldspar phenocrysts. The quartz bostonite is commonly altered, and the feldspar phenocrysts are changed to soft green aggregates of sericite or to a chalky-white clay mineral, and the groundmass bleached to gray or white. The feldspar phenocrysts are entirely potash cryptoperthite (George Phair, written communication, 1957). There are no mafic phenocrysts, in contrast to the bostonite porphyry.

Outcrops of the dikes are generally low, rounded ridges mantled with subangular fragments of quartz bostonite; even where exposures are poor the dikes generally can be traced by float. A few dikes, particularly those consisting of the nonporphyritic phase, show a faint to pronounced planar flow structure parallel to the dike walls.

Quartz bostonite porphyry is clearly younger than all other types of porphyry in the district. The Wood dike group cuts the Topeka dike of bostonite porphyry near the Wyandotte mine, on Quartz Hill, and the Nigger. Hill dikes cut a quartz monzonite porphyry dike on Nigger Hill (pl. 1).

\section{RADIOACTIVITY OF THE PORPHYRITIC ROCKS}

The Tertiary igneous sequence is one of the most radioactive groups of igneous rocks in the world, according to the present literature. The rocks are more radioactive than most of the veins and all the Precambrian rocks except the uraninite-bearing and monazite-bearing pegmatites. The radioactivity results from both thorium and uranium, which are mainly in the mineral zircon, a primary constituent of the porphyritic rocks (Phair, 1952).

The radioactivity of the porphyritic rocks varies widely and is greatest in the youngest member, the quartz bostonite porphyry. Averages of several analyses of leucocratic granodiorite porphyry and quartz monzonite porphyry indicate that both rocks contain about 0.004 percent equivalent uranium and about 0.001 percent uranium. The bostonite porphyry contains an average of about 0.006 percent equivalent uranium and 0.001 percent uranium. The quartz bostonite porphyry contains an average of about 0.011 percent equivalent uranium and 0.006 percent uranium. The averages of several analyses from the principal dikes of quartz bostonite porphyry are tabulated below:

\begin{tabular}{|c|c|c|}
\hline Dike & $\begin{array}{l}\text { Equivalent } \\
\text { uranium } \\
\text { (percent) }\end{array}$ & $\begin{array}{l}\text { Uranium } \\
\text { (percent) }\end{array}$ \\
\hline ill and Prosser Hill & $\begin{array}{r}0.018 \\
.009 \\
.012\end{array}$ & $\begin{array}{r}0.006 \\
.004 \\
.004\end{array}$ \\
\hline
\end{tabular}

As shown above, the relatively nonporphyritic phase in the Nigger Hill and Prosser Hill dikes is much more radioactive than the more common porphyritic phase in the Wood and Pewabic dikes. Samples taken from the nonporphyritic phase contain as much as 0.024 percent equivalent uranium and 0.017 percent uranium. The thorium content of 6 samples of the nonporphyritic phase analyzed by Phair (1952) ranges from 0.020 percent to 0.049 percent. The thorium-uranium ratio in both phases of the quartz bostonite, as determined by Phair, is about 6 to 1 .

\section{STRUCTURE OF THE PRECAMBRIAN ROCKS}

The distribution of the rock units and the attitudes of the foliation indicate that the Precambrian rocks are folded. The small-scale folds and linear elements in the rocks show that the major fold axes bear northeast and plunge gently either to the northeast or the southwest.

\section{FOLIATION AND LINEATION}

All the Precambrian rocks except pegmatite have a well-defined foliation and lineation.

The foliation is marked by the dimensional orientation of platy and tabular minerals and by the parallelism of layers, streaks, and lenses. The layering is the result of both compositional and textural differences, and in the metasedimentary rocks it is assumed to be parallel to the original bedding. The layering in rocks that are interlayered with the metasediments, regardless of origin, is essentially parallel to that of the metasediments.

Lineations are expressed by elongate or rodlike minerals (mineral lineation), streaks, crinkles (small crenulations whose amplitude to wave length is about $1: 1$ ), warps (crenulations whose amplitude to wave length is about $1: 2$ or greater), boudins, slickensides, and drag folds. Mineral alinement and streaks are the dominant linear elements in both the microclinebearing gneiss and the biotite gneisses, but crenulations are locally abundant in the latter. The lineations have a systematic pattern that can be related to the fold axes. Most lineations are parallel to the plunge of the northeast-trending fold axes ( $b$ axis), but a few lineations are nearly normal to these axes (a axis). 


\section{Fords}

The majority of the folds in the district are open and have steeply dipping axial planes and gently to moderately dipping limbs, but some are closed upright or overturned folds with steeply dipping limbs.

The dominant structure is the Central City anticline, a broad open fold which exposes microclinebearing gneiss along its axis and interlayered biotite gneisses with locally abundant pegmatite on its limbs (fig. 4). The anticline is at least 10 miles long and extends completely across the district. The fold axis bears about $\mathrm{N} .40^{\circ} \mathrm{E}$. and plunges gently either to the northeast or the southwest. The rocks on both limbs of the fold generally dip less than $45^{\circ}$ away from the crest (figs. 17 and 20), but locally they are steeper.

Numerous minor folds whose axes are nearly parallel to the main fold axis occur on the limbs of the Central City anticline. Most are open anticlines and synclines having maximum wavelengths of a few hundred feet, but some are closed folds having maximum amplitudes of a few hundred feet and wavelengths that are considerably smaller. The axial planes of most minor folds are steep and dip away from the axis of the main anticline. Small, tight, recumbent folds which probably do not exceed a few tens of feet in wavelength are present locally, and without exception the axial planes of these folds are nearly parallel to the prevailing dip of the foliation.

A wide belt of closed, locally isoclinal folds is present in the southeast corner of the district, and the approximate boundary between these folds and the dominantly open folds to the northwest is shown in figure 4. The axes of the closed folds bear northeast almost parallel to the axes of the major open folds. The axial planes of the folds are nearly vertical and the limbs dip steeply, generally greater than $80^{\circ}$.

Small folds with axes bearing nearly normal to the major fold axes occur throughout the district, but they do not appreciably affect the outlines of the rock units (fig. 4). These folds are dominantly minor warps and have amplitudes of a foot or less to perhaps 10 feet and wavelengths 2 to 5 times the amplitude. The folds plunge down the dip of the limbs of the northeastward-trending folds. The angle of plunge virtually coincides with the foliation surfaces; accordingly the fold plunge northwest on the northwest limb of the Central City anticline and southeast on the southeast limb.

\section{STRUCTURE OF THE TERTIARY IGNEOUS ROCKS}

The older rocks of the Tertiary igneous sequence occur principally as irregular plutons with radiating dikes, whereas the younger rocks occur almost exclusively as dikes (pl. 1). The dikes follow joints, faults, and locally other planes of weakness in the Precambrian country rock, but the factors responsible for localizing the plutons are not known. With few exceptions the igneous dikes occur in different fractures than the metalliferous veins.

Several irregular plutons of leucocratic granodiorite porphyry and quartz monzonite porphyry are in the southeastern part of the district (pl. 1). The Gregory Hill body, the largest of these, has a maximum diameter of about 2,600 feet. The plutons seem to have steep walls, and the contacts against the country rocks are generally sharp. The walls are locally brecciated, however, and at places fragments of the country rocks are incorporated within the igneous bodies. The dikes which extend outward into the country rock from the larger bodies follow joints and locally faults, and possibly these structures controlled the emplacement of the larger bodies.

The oval body of intrusion breccia, 2,200 feet long and 1,300 feet wide, which occurs in upper Chase Gulch (pl. 1) includes two small isolated masses of quartz monzonite porphyry, and seems to cut a northeastward-trending dike of quartz monzonite porphyry. The intrusion breccia consists of abundant Precambrian wallrock fragments in a fine-grained matrix of igneous material. The fragments are biotite gneiss, microcline-bearing gneiss, and pegmatite, and without exception they are altered and subrounded or rounded. Most fragments are only a few inches in maximum diameter, but some near the borders of the body are as much as $\mathbf{5}$ feet across.

The Patch, an oval pipelike body consisting of a rubble of altered breccia fragments cemented by quartz and sulfide minerals on Quartz Hill (pl. 1), is older that the bostonite porphyry which cuts through it and the sulfide mineralization. The breccia is thought to have formed by explosive activity.

The intrusive dikes are narrow bodies that rarely exceed 25 feet in width, but many are several miles long. With few exceptions, they are steep and follow joints or persistent faults which were formed before the porphyritic rocks were emplaced in the Precambrian country rocks.

Most of the dikes of leucocratic granodiorite porphyry radiate outward from large, irregular bodies of the rock. The dikes are short and follow joints of diverse trends.

The quartz monzonite porphyry forms dikes of diverse trends, and several dikes can be traced for several thousand feet. Some dikes follow faults, others 
occupy joints, and still others occur along both faults and joints A quartz monzonite porphyry dike on Bobtail Fill (pl. 1) follows the north-northeast-trending Dory Hill fault for about 2,000 feet, and other dikes in lower Lake Gulch appears to occur in northwestward-trending fractures of the Illinois Gulch fault zone (pl. 2). The most common joints occupied by the rock trend northeast.

Although the bostonite porphyry dikes are long, they are discontinuous and overlap locally. Commonly a dike consists of several lenses as much as several tens of feet thick that are connected by thin dikelets. The California dike is the most persistent dike of bostonite porphyry in the district. It extends across the western half of the district, where it strikes easterly and is consistently 15 to 25 feet thick. The CaliforniaGardner vein (pl. 1) is subparallel to and locally cuts across the dike west of the Patch. Except locally, the dike appears to follow fractures of the Illinois Gulch fault zone. The Topeka dike is much more lenticular. It consists of a discontinuous lenses or small bulbous bodies, as much as 200 feet thick, which are connected by thin dikes. Locally, as in Leavenworth Gulch, it appears to consist of small isolated plugs, but the plugs probably are connected by small dikelets or "feeders." South of Lake Gulch, the Topeka dike splits into two major segments. One segment trends easterly and is characterized by many branches, and the other segment trends northeast.

The quartz bostonite porphyry occurs as narrow dikes, some of which are very long. Most of the dikes are 5 to 10 feet wide, but the Pewabic dike is locally as much as 100 feet wide. Two of the four dikes (or dike groups) in the district trend northwest and two trend northeast. Each dike follows a prominent joint direction, but in detail occupies two or more joint sets. The Nigger Hill and the Wood group dikes trend N. $35^{\circ}-40^{\circ}$ W. The Nigger Hill dike locally occupies two sets of joints, one of which strikes between $\mathrm{N} 40^{\circ}-60^{\circ} \mathrm{W}$. and the other about N. $10^{\circ} \mathrm{W}$. The Wood dike group generally occupies N. $30^{\circ} \mathrm{W}$. and N. $50^{\circ} \mathrm{W}$. joint sets; local branches strike in other directions. The Prosser Hill, a northeastward-trending dike, has an average trend of $\mathrm{N} .50^{\circ} \mathrm{E}$. It generally occupies joints that trend N. $40^{\circ}-60^{\circ}$ E., but locally follows N. $80^{\circ}-90^{\circ}$ E. joints The Pewabic dike trends about N. $70^{\circ}$ E. south of Willis Gulch, but curves to N. $50^{\circ}$ E. near Russell Gulch. It appears to occupy three joint sets, striking about N. $80^{\circ}$ E., N. $60^{\circ} \mathrm{E}$., and $\mathrm{N} 10^{\circ} \mathrm{E}$., but because it is poorly exposed this cannot be proved.

\section{JOINTS}

Joints are well developed in both the Precambrian and the Tertiary rocks. At all exposures at least one, and commonly two or three conspicuous joint sets and other minor sets are visible. Because joints commonly occur in a systematic pattern that can be interpreted in terms of the regional deformational history, many observations were made in the field and these data were studied statistically by plotting the poles of joints on the upper hemisphere of a Schmidt equalarea net. The upper hemisphere was chosen for this plot because the pole thus plotted falls into the quadrant of its true dip direction. Because the Tertiary igneous rocks rarely form bold outcrops, most readings were made in Precambrian rocks.

Four principal joint sets and several minor setseither weakly developed or of only local occurrenceare present in the district. One of the principal joint sets, having an average attitude of $\mathrm{N} .76^{\circ} \mathrm{E}$., $80^{\circ} \mathrm{N}$., is parallel to a principal vein direction; and another of more local occurrence is parallel to eastward-striking veins. All the principal joint sets locally contain Tertiary dikes.

The four principal joint sets in the Central City district have average attitudes of (1) N. $30^{\circ} \mathrm{W} ., 80^{\circ}$ NE., (2) N. $45^{\circ}$ W.; $80^{\circ}$ NE., (3) N. $76^{\circ}$ E., $80^{\circ}$ N., and (4) N. $75^{\circ}$ W., $80^{\circ}$ N. (fig. 5). These sets, with slight variations in attitude, are dominant in almost

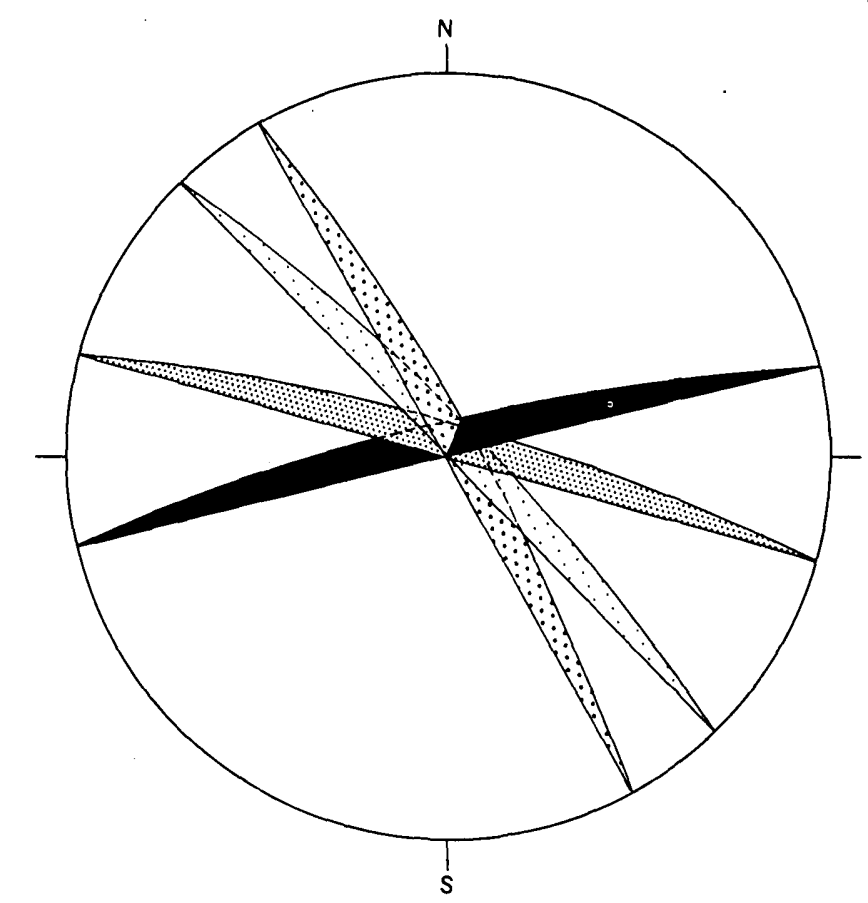

Figura 5.-Stereodiagram showing average attitudes of principal joint sets, Central City district. 
every part of the district, regardless of the local structure of the bedrock and the local fault pattern. At places, however, the two northwestward-trending sets -judging from statistical plots-seem to merge into a single set (see Drake, 1957, fig. 31).

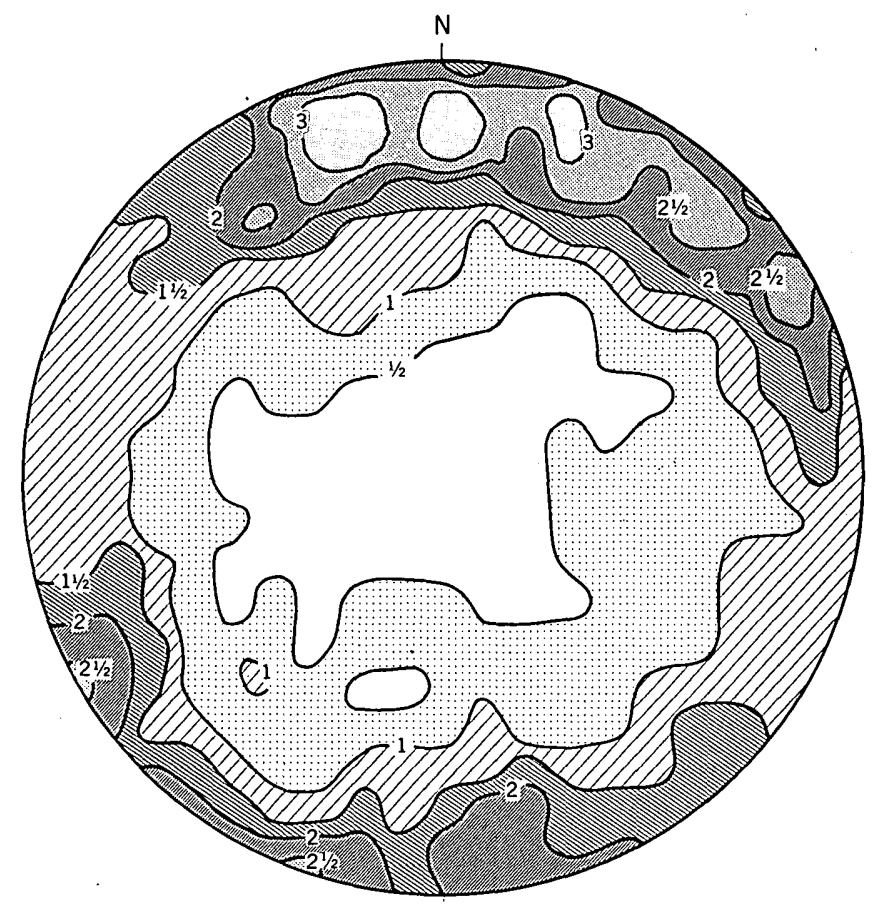

A,-SOUTH-CENTRAL PART OF DISTRICT

Contour interval $1 / 2$ of 1 percent / 2214 poles
Plots showing the concentrations of poles of joints for two different geographic parts of the district are shown in figure 6. Each of the major sets are represented in the diagram for the south-central part of the district (fig. $6 \mathrm{~A}$ ) by statistical maxima of greater

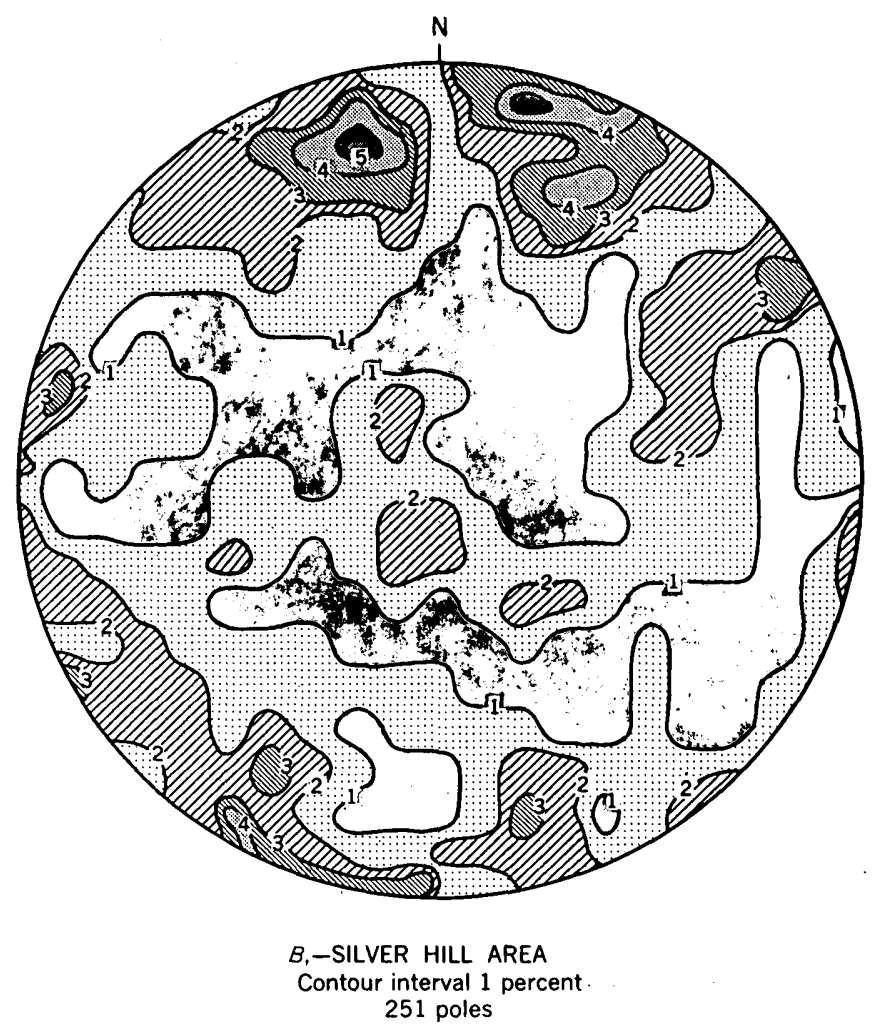

Figore 6.-Contour diagrams showing concentration of poles of joints measured in the Central City district (upper hemisphere of Schmidt equal-area net). $A$, South-central part of the district ; $B$, Silver Hill area.

than $2 \frac{1}{2}$ percent; all but the N. $45^{\circ} \mathrm{W}$. joint set is represented by strong maxima in the diagram for the Silver Hill area (fig. $6 B$ ).

In addition, minor joint sets having an attitude of N. $55^{\circ} \mathrm{NW}$., N. $10^{\circ}-15^{\circ} \mathrm{W}$, vertical, and N. $90^{\circ} \mathrm{E}$, $80^{\circ} \mathrm{N}$. are apparent. The N. $55^{\circ} \mathrm{E}$. is absent in figure $6 B$. This set appears to be prominent in the district only as far north as Eureka Gulch. The N. $10^{\circ}-15^{\circ}$ W. joint set is prominent in the upper Eureka Gulch area; it is poorly defined elsewhere. The N. $90^{\circ} \mathrm{E}$. joint set is well defined in the south-central part of the district (fig. 6A), in an area of abundant eastward-trending veins, but ill-defined elsewhere.

The joint pattern of the district is subject to multiple interpretation, and the data probably do not justify a unique interpretation for any specific set. It is probable that the principal joint sets and most of the minor sets as well were formed either during the Pre- cambrian metamorphism and folding or during later arching of the Front Range highland. The relative importance of each of the deformation periods, however, is unknown. It is likely that some joints formed in the Precambrian were reopened and other new ones were formed during later periods of deformation.

\section{FAULTS}

Faults, which form a complex intersecting network, are abundant in the district. It was established during this investigation that the faults were formed during two distinct periods of fracturing, one prior to the emplacement of the early Tertiary igneous rocks and the other after the igneous activity during the Laramide orogeny. The age of the older faults is not known precisely, but they probably formed before the beginning of the Laramide orogeny, and may have formed as early as the Precambrian. 
Character and Classification

Aside from the Blackhawk and Dory Hill faults, which contain siliceous breccias that locally stand above the surrounding terrane, the faults generally are inconspicuous in outcrop. They contain a clayey gouge that weathers readily and commonly is indistinguishable from weathered surfaces over the country rock and, at places, sulfide ore minerals that weather to a reddish-brown, porous quartz-limonite boxwork gossan. Because of the poor exposures, the fissures were mapped largely in or near prospect pits and shafts; they undoubtedly are more persistent than indicated on plate 1.

With few exceptions the faults dip steeply, have small displacements, and have a dominant horizontal relative motion of one block to another. In the following discussion right lateral (or right hand) and left lateral (or left hand) refer to the apparent movement of the two blocks viewed in plan; right lateral indicates clockwise and left lateral indicates counterclockwise separation.

The faults can be grouped according to strike into five principal sets (pl. 2). The older faults, which formed before the Laramide porphyritic rocks were emplaced, strike either northwest or north-northeast; the younger ones strike east, east-northeast, or northeast. Except for the northeast and the east-northeasttrending sets, which are grouped together, each fracture set is distinguished separately on plate 2 .

The fractures constituting each set have a distinctive movement pattern; that is, the relative motion of the walls of each set was in the same direction. The northwest- and east-trending fractures are left lateral faults, whereas the east-northeast- and northeast-trending fractures are right lateral faults. The displacement direction of the north-northeast-trending fractures is not known.

A fow faults cut and displace ore-bearing fissures and are later than mineralization. None of these has been recognized at the surface, however, and they are not shown on plate 1 . These faults are steep and trend either northeast or east-northeast. The displacement on both sets, so far as known, is left lateral, and the apparent horizontal displacement commonly is only a few inches to a few feet but is as much as 30 feet.

\section{FAULTS OF PRE-LARAMIDE(?) AGE}

The older faults are either long continuous fractures or are zones of fracturing marked by several individual fissures with a conspicuous linear alinement (pl. 2). Some are highly silicified and contain specular hematite and locally quartz, but others are rela- tively unsilicified and inconspicuous. Not uncommonly they are followed or cut by dikes of Laramide igneous rocks.

\section{NORTHWESTWARD-TRENDING FAULTS}

The northwestward-trending faults in the district strike either N. $40^{\circ}-50^{\circ}$ W. or N. $55^{\circ}-85^{\circ} \mathrm{W}$. and dip more than $55^{\circ}$ NE. Siliceous breccias are restricted to the Black Hawk fault which strikes about N. $45^{\circ} \mathrm{W}$. The fractures that constitute the Eureka Gulch, Illinois Gulch, and Russell Gulch fault zones (pl. 2) are unsilicified; locally they contain minable metalliferous veins.

The Blackhawk fault zone consists of several subparallel fractures with connecting cross fractures and is about 2,000 feet wide. The individual fractures are marked by silicified fault breccia, silicified sheared rock, white to gray quartz, and specular hematite. So far as known the fault is nearly barren of ores. The fault displaces the Precambrian rock units about 500 feet but displaces a dike of Tertiary quartz monzonite porphyry only 100 feet in the same direction (left lateral). The J. L. Emerson fault is not well exposed in the district, but it is cut in the Lucania tunnel in the Idaho Springs district, where it is about 5 feet wide and consists of dark gray silicified wallrock with abundant disseminated pyrite. It contains traces of base-metal sulfides and as much as 0.04 ounces of gold per ton. The hanging wall is silicified and pyritized for about 30 feet from the vein. The amount of displacement along the fault is not known.

The fractures constituting the Eureka Gulch, Illinois Gulch, and Russell Gulch fault zones (pl. 2) cannot be traced continuously, for they are poorly exposed and locally are intersected by many fissures of the late period of fracturing (pl. 2). The linear alinement of individual fractures indicates, however, that the exposed faults probably constitute segments of long, relatively continuous fracture zones. The faults are generally narrow and contain gouge, some breccia, and locally gangue and sulfide minerals that constitute ore. The apparent displacement of the faults rarely exceeds a few feet.

Two northeastward-striking flat faults that dip to the northwest are filled by the Topeka and Old Town veins and appear to be related to the Russell Gulch fault zone (pl. 2) and probably formed essentially contemporaneously with it. A pre-porphyry age for these faults cannot be proved in the Central City district, but they resemble similar faults in this part of the Front Range that clearly formed virtually contemporaneously with northwestward-trending breccia reef-type structures. 


\section{NORTH-NORTHEASTWARD-TRENDING FAULTS}

The principal fault of the north-northeast-trending set, the Dory Hill, strikes about N $20^{\circ}$ E. and dips steeply either side of vertical. Several discontinuous faults of approximately the same trend occur elsewhere in the district (pl. 2).

The Dory Hill fault is marked by as much as 20 feet of silicified breccia which is veined by a reticulate network of quartz and locally chalcedony, and at places the breccia forms a topographic ridge as much as 10 feet high. Weathered surfaces are locally stained reddish brown by the oxidation of pyrite and hematite. The fault extends northward beyond the limits of the district and it is inferred to extend southward to the vicinity of Idaho Springs.

The other faults belonging to this set of fractures appear to be discontinuous, but the marked alinement of individual fissures may indicate that these faults are relatively persistent (pl. 2). A zone of northnortheast-trending fractures in the western part of the district extends discontinuously from the Fairfield vein-fissure through the Mineral vein-fissure to the upper Chase Gulch area (pl. 1); and another zone in the central part of the district includes the persistent Minnesota-Michigan Boy-Gettysburg vein fissure and short fissures along its northeast projection. North of the Hayes and Wheeler mine (pl. 1), the fault is locally followed by a dike of bostonite porphyry.

\section{FAULTS OF LARAMIDE AGE}

The younger faults formed late in the Laramide orogeny and commonly intersect to form a meshlike pattern. They cut and displace the older faults and the Tertiary igneous rocks, but the apparent horizontal displacement on the fractures rarely exceeds 20 feet.

\section{EASTWARD-TRENDING FAULTS}

The faults grouped under the eastward-trending set generally strike within a few degrees of east, ranging from about N. $80^{\circ}$ E. to N. $85^{\circ}$ W., and dip steeper than $80^{\circ}$, either to the north or south. Many fissures hinge along the dip. Most of these faults occur in the area between the Eureka Gulch and Russell Gulch faults (pl. 2). Although the fissures are neither abundant nor closely spaced, they contain some of the more valuable metalliferous veins in the district, as the Gunnell, Hubert, Alps, and Saratoga.

Although the movement on the faults, as indicated by displaced porphyry dikes, slickensides, and subsidiary fractures, was dominantly strike slip, dip slip movements appear to have taken place locally. The apparent horizontal displacement rarely exceeds 10 to 20 feet.
The faults constituting this set are complex fracture zones, and many consist of two or more subparallel mineralized fractures or of several overlapping ones. The abundance of gouge, breccia, interlacing shears, and slickensides attests to repeated movements along the main fissures. The fracture zones are generally wider than most vein fissures of the district; they are commonly 3 to 5 feet wide and at places even wider.

The faults, without exception, cut across the foliation and lithologic units of the Precambrian wallrocks at a large angle, and at places they are nearly normal to the strike of the rocks.

\section{EAST-NORTHEASTWARD-TRENDING FAULTS}

The east-northeastward-trending faults strike $\mathrm{N}$. $65^{\circ}-80^{\circ}$ E. and generally dip steeply either side of vertical. North of the village of Black Hawk, the fractures uniformly strike N. $70^{\circ}-75^{\circ}$ E. and dip $60^{\circ}-80^{\circ} \mathrm{NW}$.; in the eastern and southeastern parts of the district they strike N. $70^{\circ}-80^{\circ}$ E. and dip steeply northwest to vertical; and in the western and southwestern parts they strike N. $65^{\circ}-80^{\circ}$ E. and dip steeply. Opposing dips are common in the Nevada Gulch and Quartz Hill areas. Adjacent vein fissures with opposing dips generally differ $5^{\circ}$ to $10^{\circ}$ in strike, as for example, the German-Belcher and Burro-Last Chance veins, but some are almost parallel in strike, as the Calhoun and Quartz Mill. In the western part of the district, vein fissures of this set commonly intersect eastward-trending vein fissures.

The fractures of this set generally cut the Precambrian lithologic units and foliation at a large angle, but a few fissures on Silver Hill are virtually parallel to the axial planes of tight folds.

Some faults are long and continuous. The Jefferson-Calhoun and Kansas faults are at least 1 mile long and possibly longer. The faults vary greatly in width, ranging from a few inches to about 5 feet. Gouge and breccia are less abundant than in the eastward-trending fractures.

Although the displacement along the faults is dominantly strike-slip, some movements appear to have been dip slip. The apparent horizontal displacement rarely exceeds 10 feet.

\section{NORTHEASTWARD-TRENDING FAULTS}

The northeastward-trending faults strike N. $40-55^{\circ}$ E. and dip steeply either to the northwest or the southeast. Most of them are remarkably uniform in strike along their entire length. The Homer-McAllisterBates vein system appears to be more than $1 \frac{1}{2}$ miles long. The faults in the southeast corner of the district dip steeply northwest; those occurring north of Lake Gulch are nearly vertical. 
The northeastward-striking faults are abundant and are the dominant fault set in the eastern half of the district. In the area of closed Precambrian folds in the southeast corner of the district (fig. 4), the faults are nearly parallel to axial planes, or locally to the foliation along steeply dipping limbs of folds; excellent examples are the Shamrock and Justice veins. In the area of predominant open folds and moderate dips in the eastern and northeastern parts of the district, the faults generally cut the foliation of the wallrocks at a large angle and are steep, dipping either to the northwest or southeast. A few vein fissures in the belt of tight folds on the southeast limb of the Quartz Hill anticline in the upper part of North Clear Creek are subparallel to the axial planes of the folds and dip steeply either to the northwest or southeast. An example of this type of fault is the Elsinore (fig. 96).

The fracture zones commonly are thin, rarely exceeding 2 feet in width. The walls tend to be smooth and even, although slickensides locally are present.

The movement on the faults is dominantly strike slip. The relative horizontal displacement of the walls probably does not exceed 10 or 15 feet.

\section{ORIGIN AND SEQUENCE OF DEVELOPMENT}

The two groups of faults of different ages that constitute the fault system of the district contrast sharply in general character and in continuity and unquestionably formed from different stress patterns. The older fault sets are persistent, widely spaced fractures or: zones of fractures; and several of the northwestward-trending faults extend entirely across the mineral belt. These fractures must have developed from regional stresses that affected most or all of the Front Range highland. The nature of these forces is not yet known, however, and much more work throughout the Front Range is needed for their interpretation. The younger faults, on the other hand, are relatively discontinuous and closely spaced, and they may be nearly confined geographically to the mineral belt. These faults appear to have formed from regional stresses acting in a general east-northeastward direction.

The first faults to develop were the northwesttrencling set. These are related to the "breccia reefs" or "breccia dikes" of Lovering (Lovering and Goddard, 1950, p. 79-80; Lovering and Tweto, 1953, p. 30 ), and are widely distributed throughout the length of the Front Range, particularly along the east front north of Denver. Many fractures of this set are followed by or: cut by dikes of Tertiary igneous rocks. Locally, as in the southern part of the Front Range, the faults seem to have formed along old Precambrian 654827 o-63-3 fracture zones (Glenn R. Scott, oral communication, 1957).

The north-northeastward-trending faults are also clearly older than some of the Laramide igneous rocks, for they are locally followed or cut by dikes of quartz monzonite porphyry.

Judging from the intersection of the Dory Hill and Blackhawk faults, the north-northeastward-trending faults are younger than the northwestward-trending faults. Although the Dory Hill fault is shifted laterally a few feet along individual fractures of the Blackhawk fault (pl. 1), the Precambrian rocks are offset about 500 feet along the Blackhawk fault. This is evidence, therefore, that the major movement along the Blackhawk fault was before the development of the Dory Hill fault and that the horizontal displacement of the Dory Hill fault resulted from later movements, which probably were contemporaneous with the Laramide faulting.

The younger fault sets were formed after the emplacement of the youngest Tertiary igneous rocks of the district. Although these faults appear to have formed nearly contemporaneously, they generally developed in the order: east-, east-northeast-, and northeastward-trending faults. The movement along the eastward-trending faults was left lateral, and the movement along the east-northeast- and northeastward-trending sets was right lateral. Accordingly, the fracture sets can be interpreted to represent shear fractures to a horizontal (?) compressive force oriented east-northeast, the eastward-trending set constituting the other. This postulated stress could be a local resolution of regional rotational compressive stresses oriented northeastward, as originally proposed by Lovering and Goddard (1950, p. 80-82).

The shear stresses that produced the younger fault sets locally reopened the northwest-trending fractures, but only where these fractures strike more westerly than average. The westward-striking segments of the faults are virtually diagonal to the postulated late Laramide stress direction, and hence, these segments were situated favorably for reopening.

Late fault movements took place locally along the north-northeastward-trending fractures subsequent to sulfide mineralization. The displacement along the Dory Hill fault was left lateral, the east wall having moved north about 30 feet relative to the west wall.

The younger fault sets appear to have formed largely independently of the structure of the Precambrian bedrock and only locally were they formed parallel to a recognizable preexisting fabric. Aside from the areas of tightly folded rocks, the faults of each set cut across the layering of the bedrock in both 
dip and strike. In the areas of tight folds (fig. 4), a few fissures of the northeast- and east-northeastward-trending sets were formed parallel to steeply dipping axial planes or to steep foliation surfaces, but these are neither abundant nor closely spaced. Joints, however, may well have been important, at least locally, in the development of the fault pattern. The east-northeast- and the eastward-trending vein fissures are parallel to prominent joint directions, and the eastward-trending set is subparallel to the prominent steep N. $90^{\circ}$ E. joint set that is well formed in the south-central part of the district (fig. 6). Possibly these joint sets were favorably oriented to the stresses that produced the fracture pattern and, because they represented preexisting zones of weakness, were sites of shearing and displacement.

\section{SUMMARY OF GEOLOGIC HISTORY}

The Central City district and other areas in the central part of the Front Range have had a long complex geologic history that began in the Precambrian and continued to the present. The record is incomplete, however, and many events cannot be precisely dated.

An interlayered sequence of rocks, probably of sedimentary origin, was deformed and metamorphosed in Precambrian time. The rock layers were folded into broad, open, upright anticlines and synclines and locally minor, tight, upright to overturned folds, and concurrently intruded by igneous bodies that generally formed small concordant plutons. Possibly the oldest rocks were recrystallized mimetically before they were folded. During the folding these rocks recrystallized with little change in chemical composition to mineral assemblages stable in the upper part of the amphibolite metamorphic facies. Pegmatite, which locally formed migmatites, probably was formed in the early stages of the deformation. During the deformation, granodiorite and later quartz diorite and associated hornblendite intruded the now high-grade metamorphic rocks. The stresses that accompanied the deformation continued after the consolidation of these bodies, deforming these rocks, particularly the border phases. Near the end of the deformation small bodies of biotite-muscovite granite were emplaced as generally conformable phacoliths and sheets and as crosscutting dikes.

Probably in late Precambrian time, long northwestward-trending and north-northeastward-trending fractures were developed. The northwestward-trending fractures were remarkably persistent structures that were formed throughout the Front Range highland.
The uplift of the Front Range began in Late Cretaceous time. The highland was arched along a north-northwestward trending axis, and the northwestward-trending faults were rejuvenated. Igneous activity in early Tertiary time resulted in the emplacement of porphyry dikes and irregular plutons along joints and faults in the Precambrian bedrock. These igneous rocks seem to have been intruded under tensional stresses, which allowed them to enter the openings by passive filling. Some explosive activity accompanied the intrusions, and the Patch probably resulted from explosive forces that brecciated the country rock above a body of magma. After the emplacement of quartz bostonite porphyry, the dominant ore-bearing fissures were formed; and these fissures and local parts of the older faults were mineralized by fluids given off by the cooling magmas to yield gold-, silver-, uranium-, and base-metal bearing veins.

Subsequent to the period of mineralization, a moderate thickness of rock was eroded and the veins and igneous rocks were exposed. The veins have been weathered near the surface by supergene fluids and the ore minerals have been oxidized, and as a result gold, silver, and locally copper enrichment have taken place.

\section{ORE DEPOSITS}

The ore deposits are veins and to a minor extent stockworks that were formed principally as fissure fillings. They consist mainly of pyrite, sphalerite, chalcopyrite, tennantite, and galena in a quartz gangue, and are chiefly valuable for their gold content. They are similar in structure, mineralogy, and texture to the deposits classified by Lindgren (1933, p. 530) as mesothermal.

The veins are distributed according to a well-defined, concentric zonal arrangement. A core of pyrite veins (central zone) is surrounded by a peripheral zone of galena-sphalerite veins; an intermediate zone contains transitional veins that consist of the minerals characteristic of both the central and peripheral zones. Most of the important mines are in the intermediate zone.

Although the veins were formed during a single period of mineralization, the major vein minerals were deposited in three stages, from oldest to youngest, a uranium, a pyrite, and a base-metal stage. The pyrite and base-metal stages of mineralization were of broad areal extent and produced the district-wide zoning, whereas the uranium-stage mineralization was of local extent.

The ores were formed during the Laramide orogeny, and were derived from the magmas that consolidated 
to form the porphyries of the district. Lead-uranium isotope ages of uraninite from the veins (Faul, 1954, p. 263) indicate an absolute age of mineralization of about 60 million years.

\section{VEINS}

The veins occur: in the faults constituting the fracture system of the district. Most veins are from a few hundred to a few thousand feet long, and probably extend to depths comparable with their lengths. With few exceptions, they dip more than $60^{\circ}$. One prominent vein system, the California-Gardner-Mammoth lode, has been mined locally for a distance of at least 12,000 feet and has been mined in the California mine to a depth of 2,200 feet, the deepest in the district. At this depth the vein is equally as strong as at the surface. Other veins are less persistent, and can be traced only for a few hundred to several hundred feet. Exceptionally, blind veins not known to crop ont at the surface have been found in underground workings, particularly in some of the tunnels driven at lower depths.

The veins range from simple, well-defined fissure fillings to complex, branching lodes that follow subparallel fractures, loops, and "horsetailing" fractures. The simple veins consist of a single filled fissure that generally has smooth, sharp walls bounded by a narrow, persistent zone of altered wallrock. More commonly, subsidiary veins branch from the main veins, and the complexity of the branching increases as true lodes are developed. Many veins show evidence for several periods of movement, most of which took place along the original filled fractures. All veins contain some vugs, which generally are only a few inches in maximum dimension and are lined with well crystallized sulfides, quartz, carbonates, or fluorite.

Lodes, consisting of two or more subparallel veins, are much more complex than single, filled fissures. The individual strands are commonly sufficiently closely spaced to be exposed in a drift of normal width, and the wallrock between the strands is altered and fractured. In many veins the wallrock "horses" are pyritized and cut by subparallel inchthin stringers of ore minerals, which are sufficiently abundant locally to constitute ore. In other lodes broken fragments of wallrock surrounded by a cockade growth of ore minerals forms breccia ore between two adjacent, subparallel vein strands.

Although generally consistent in strike and dip, local changes of as much as $20^{\circ}$ are common in the veins and greater deflections occur rarely. In general, changes in dip are more abrupt and numerous than changes in strike. Some veins, in both strike and dip, are shaped like cymoid curves (McKinstry, 1948, p. 314-315); others more characteristically have a horsetail pattern at changes in strike or dip.

The veins generally are 5 feet or less wide and average 1 to 3 feet but locally are as much as 30 feet wide. The widths vary greatly between different veins and may also vary along a single vein.

\section{STOCKWORKS}

The Patch, a large stockwork believed to be a mineralized pipe of explosion breccia, has been mined to a vertical depth of about 700 feet and is known to extend downward for a distance of more than 1,600 feet. It is oval in plan with an east-west axis about 750 feet long and a north-south axis about 450 feet long, and plunges steeply north.

The Patch consists of irregularly fractured and broken rock, principally Precambrian microcline-beàring gneiss. Most of the rock is angular and shows little evidence of frictional wear, but some is subrounded to rounded from differential movement. Brecciation and fracturing are strongest along the east-northeastward-trending fissures such as the Gardner vein that penetrate through both the pipelike breccia body and the unbroken wallrocks on either side. A bostonite porphyry dike (California dike) of Tertiary age extends easterly through the Patch into the adjacent wallrocks. The dike cuts the breccia; it is fractured only where cut by the younger vein fissures.

The north and south margins are locally marked by ore-bearing faults, as on the LaCrosse tunnel level (fig. 35), but elsewhere along these margins (Lovering and Goddard, 1950, p. 172) and along the east and west boundaries the breccia grades into irregularly fractured microcline-bearing gneiss.

Although nearly all the breccia fragments within the Patch are altered; and the degree of alteration appears to have little or no relation to the intensity of brecciation, mineralization seems to be related directly to the intensity of brecciation and is strongest adjacent to the through-going fissures. In the upper part of the Patch the breccia fragments are in part cemented by sulfide minerals; in the lower workings on the Argo tumnel level sulfides are sparse.

The origin of the Patch has been the subject of much speculation and some controversy among the mining men of the district, as well as among the geologists who have studied the district. Collins ${ }^{1}$ believed that the Patch's origin was somehow connected with the intrusion of the California bostonite

\footnotetext{
1 Collins, G. E., 1907, Report on the Patch area, Gllpin County.
} Colo., 19 p., report on file in Denver Public Library, Denver, Colo. 
porphyry dike and more particularly with an inferred mass of this eruptive at depth. Bastin and Hill (1917, p. 96-97) believed that the Patch fracturing was produced by the same forces and at the same time as the neighboring vein fissures, because it is situated where a large number of these fissures approach one another closely. They inferred that the shearing movements along these fissures were distributed through the intervening rock rather than being confined to the zones of fissuring. Spurr (1923, p. 882883) believed the Patch was formed by a blow-out of gases (Avant-Coureur or gas cushion) preceding the intrusion of an ore magma. Later, Lovering and Goddard (1950, p. 171) concluded that the Patch owed its origin to the upward punch of an underlying igneous pipe that followed an earlier shear zone. The present writers propose that the Patch probably is a volcanic explosion pipe that accompanied an upward punch of an underlying mass of magma. Because the breccia body plunges steeply to the north whereas the Gardner lode system dips south, and because the breccia body diverges from one lode system to another as depth increases, the shearing stress proposed by Bastin and Hill (1917, p. 96-97) seems inadequate as an explanation.

The development of the Patch is postulated by us as follows:

1. Upward punch of a magma body along a zone of weakness; the magma was accompanied by and preceded by considerable gas, resulting in a forceful explosion when the gas reached near enough to the surface to overcome the lithostatic pressure of the overlying rocks. The brecciation was followed by a pervasive alteration.

2. Emplacement of eastward-trending bostonite porphyry dike.

3. Faulting, resulting in development of vein fissures, and, in the Patch, in intensified brecciation along through-going shears.

4. Alteration and mineralization by the same fluids that formed the veins. Mineralization was largely confined to, and adjacent to, the through-going shears and the breccia formed by shearing; it was weak in other parts of the breccia body.

\section{MINERALOGY}

The deposits consist of a simple suite of metallic minerals and gangue minerals. The common metallic minerals are pyrite, sphalerite, chalcopyrite, tennantite, and galena; minerals of more restricted occurrence include enargite, pitchblende, gold tellurides, and marcasite. The gangue is mainly coarsely crystalline quartz and cryptocrystalline varieties of quartz but locally is rhombohodral carbonates, fluorite, or barite. Variously altered and fractured wallrock is an important gangue in some lodes.

The ore and gangue minerals observed by us or reported by others, particularly Bastin and Hill (1917, p. 100), are listed according to the classification adopted in Dana's system of mineralogy (Palache, Berman, and Frondel, 1951) in the following table (table 6). They include the secondary vein minerals, but do not include the minerals of the altered wallrocks.

\section{PYRITE}

Pyrite is by far the most abundant metallic mineral in the district, and it occurs in different quantities in all veins.

Most pyrite forms fine- to medium-grained, locally coarse-grained cubes and pyritohedrons that are dispersed through both the vein gangue and the adjacent altered wallrocks. Other pyrite forms lenses and veinlets composed of medium- to coarse-grained aggregates or encrustations in vugs. Rarely, some of the pyrite that is associated with marcasite occurs as anhedral colloform grains.

Although most has the normal pyrite color, some pyrite is pale yellow; the pale variety, in part at least, is closely associated with pitchblende-bearing ore, as in the Wood vein (Drake, 1957). Some pyrite, after long exposure on mine dumps, has the tarnished appearance characteristic of chalcopyrite, and probably is cupriferous. Similar tarnished-appearing pyrite occurs underground at relatively deep levels, as on level 6 of the East Calhoun mine.

Most pyrite is weakly anisotropic and shows polarization colors of pale red to pinkish green.

\section{SPHALERITE}

Sphalerite is next in abundance to pyrite and is present in most veins. It forms massive clots, lenses, or stringers and, rarely, forms terminated crystals in vugs. Generally the crystals are anhedral and coarse to medium grained. Because of its potential use as a geothermometer, sphalerite was studied in more detail than the other vein minerals; these data are given in a separate report (Sims and Barton, 1961) and are only summarized herein.

The mineral differs markedly in color, ranging from dark reddish brown or very dusky red in specimens from mines in the inner parts of the district to light gray, pale yellowish brown, or intermediate pale shades of these colors in specimens from the outer parts. In hand specimens most crystals appear relatively uniform in color, but polished "thick" sections ( 0.03 to $3 \mathrm{~mm}$ thick) viewed in transmitted 


\section{MARCASITE}

Marcasite is rare. Where observed it always is associated with pyrite, either as an intergrowth or as rims on the pyrite. Marcasite is readily distinguished from pyrite under the reflecting microscope by its pale bronze-yellow color, its tabular crystal habit, and its strong anisotropism. Much of the marcasite occurs in delicate, lacy veinlets, and it has two distinct forms: aggregates of euhedral blades and rounded forms that have a framboidal texture (Bastin, 1950, p. 30, 86).

\section{MOLYBDENITE}

Molybdenite has been described (Bastin and Hill, 1917, p. 106) from the ore at the Anchor mine and is reported (Henry Ress, oral communication) from the New Brunswick vein at the Powers mine, but it is rare in the district. At the Anchor mine the molybdenite occurs as small plates with quartz, fluorite, and pyrite. One specimen described by Bastin was a half-inch veinlet with $1 / 16^{-}$to $1 / 8$-inch bands of molybdenite on the walls, enclosing a center of quartz and pyrite.

\section{CHALCOCITE}

Chalcocite is present in the upper, near-surface parts of most veins and is the most common secondary copper mineral in the district. In polished sections the chalcocite is in part bluish gray, coarse grained, and crystalline and in part black, soft, and sooty. It commonly coats vugs, fills fractures in chalcopyrite and pyrite, and locally embays and veins all of the primary copper minerals.

\section{COVELLITE}

Covellite was observed locally in the upper parts of a few veins. For the most part it forms tiny aggregates of grains, always in association with chalcopyrite or tennantite and at places also with chalcocite. At many places it forms bluish coatings on primary sulfides, particularly galena and sphalerite.

\section{BORNITE}

Bornite has been reported (Bastin and Hill, 1917, p. 237) in association with chalcocite as thin films along fractures that cut a pyrite-chalcopyrite seam within the Phoenix-Burroughs veins. It may also occur as a primary mineral in the Quartz Mill vein and perhaps other veins.

\section{TETRAHEDRITE-TENNANTITE}

Tetrahedrite-tennantite (gray copper) is present in many veins but is abundant in only a few. It has a steel blue-gray color and a red-brown streak; in reflected light it has a distinct greenish tinge. It occurs as discrete veinlets and commonly is intergrown either with chalcopyrite or enargite. X-ray fluorescence analyses by W. W. Niles of the Geological Survey of selected samples of concentrates indicate that the mineral has a composition near the tennantite end, as indicated below:

\begin{tabular}{|c|c|c|c|}
\hline Mine & As & ${ }_{n t)} \mathrm{Sb}$ & $\underset{\text { ratio }}{\mathrm{AS} / \mathrm{Sb}}$ \\
\hline Kokomo & 19. 0 & 1. 4 & 13. \\
\hline Pittsburg & 15. 4 & 6. 3 & 2. \\
\hline$\ldots$ & 13. 2 & 10.5 & 1. \\
\hline
\end{tabular}

Enargite occurs in a few veins within an area of a square mile in lower Russell Gulch and Willis Gulch. The enargite is pink in reflected light and shows polarization colors of purple, gray, and greenish yellow. Typically it is intergrown with tennantite but at places it forms discrete blebs.

\section{PEARCEITE ( ? )}

Bastin and Hill (1917, p. 211) report "brittle silver," possibly pearceite, from the Cyclops vein on Silver Hill. This mineral was not observed by us.

\section{Chalcostibite(?)}

A mineral tentatively identified under the reflecting microscope as chalcostibite was noted in the Mammoth vein. The mineral is light gray, nearly the color of galena, and mostly subhedral. It has a strong anisotropism and shows polarization colors ranging from pink to pale-greenish gray. It occurs as blebs in pyrite, veinlets in pyrite, and irregular bodies intergrown with chalcopyrite and tennantite.

\section{RUBY SILVER}

Ruby silver, thought by Bastin to be proustite, has been described from the Cyclops vein on Silver Hill (Bastin and Hill, 1917, p. 211), and possibly it accounts for some locally high concentrations of silver in other veins. It was not noted by us.

\section{GOLD}

Native gold probably occurs in all veins in the district, but it rarely is visible megascopically. Much of the gold is a very fine grained "flour" type; and much also probably is in the structure of various sulfide minerals. Small, irregular plates, visible only under high magnification, were observed locally in association with all metallic minerals and gangue in the veins. Rarely coarse wire gold has been observed; Bastin and Hill (1917, p. 250) describe highly irregular masses of wire gold in quartz from the Klondike vein in the Topeka mine. The gold, with 
small quantities of sphalerite and galena, was not related in any way to fractures in the quartz.

\section{SILVER}

Native wire silver has been reported from the oxidized zone of the Cyclops vein on Silver Hill by Bastin and Hill (1917, p. 211) ; it was not observed by us.

\section{NATIVE BISMUTH}

A small quantity of native bismuth has been reported from the 14th level of the Topeka mine (Bastin and Fill, 1917, p. 250).

\section{PITCHBLENDE}

Pitchblende is a local constituent of some veins and at places has been mined as an ore mineral. As the mineral is describer in detail in a report by Sims and other's (1.963), it is discussed only briefly here.

The pitchblende occurs in stringers and pods, ranging from less than an inch to a few inches wide, and as fractured and brecciated fragments that are cemented by later ore and gangue minerals. It crystallizes as rotund forms that are included under the term colloform (Bastin, 1950, p. 25-32), generally in spheroidal grains or vein forms but locally in tiny pellets or: dendritic forms. Rarely, the forms are sufficiently large to be observed by the naked eye. All forms have radial and at places concentric shrinkage cracks that locally are partly filled by later sulfides. The pitchblende varies from hard, black, and dense to soft and sooty; and all gradations exist between these extremes. The hard, dense pitchblende has a pitchy luster and appears homogeneous in polished section; whereas the soft, sooty material is dull and gives a greenish-gray to dark-gray powder.

\section{HEMATITE}

Hematite is sparse; it is common only in the 13]ackhawk fault zone and it was observed in a few specimens on the Cyclops mine dump. Nearly all the fractures in the Blackhawk fault zone locally contain hematite, in association with white or milky quartz. A specimen from the Cyclops dump contained a veinlet of interlocking, tabular crystals of hematite as much as $4 \mathrm{~mm}$ wide and. 5 to 10 times as long.

\section{HYDROUS IRON OXIDES}

Red, reddish-brown, and brown hydrous iron oxides occur in the near-surface, altered parts of all veins and in surface gossans. In the gossans they form boxworks of differing texture. Individual species of the oxides were not identified.

\section{WOLFRAMITE}

Wolframite was observed in a single specimen from the Meeker mine. The mineral is gray, strongly anistropic, and has red internal reflections. Visual arc spectrum readings showed lines for tungsten, iron, and manganese (J. W. Adams, oral communication). The wolframite is intergrown with and locally embays pyrite.

\section{FERBERITE}

Ferberite was recognized at the Chihuahua mine in 1937 (Ogden Tweto, written communication, 1943), and subsequently a few tons of ferberite-bearing ore was extracted. The mineral was not observed by us.

\section{SYLVANTRE}

The tellurides of gold and silver reported from the district have been tentatively identified by Bastin and Hill (1917, p. 114-115) as sylvanite; possibly some of the telluride, however, is calaverite $\left(\mathrm{AuTe} \mathrm{Te}_{2}\right)$, for the production data from some mines that contain tellurides indicates a high gold-silver ratio. We did not have the opportunity to examine specimens of this mineral.

The tellurides are associated with chalcedonic quartz or fluorite gangue and with free gold. According to Bastin and Hill (1917, p. 115), "most of the sylvanite occurs in isolated bladelike or tabular crystals, but some is intergrown $* * *$ with antimoniacal tennantite."

\section{FLUORITE}

Fluorite occurs locally as a gangue mineral in a few veins in the lower Russell Gulch area. It forms thin stringers or rarely wider veinlike masses associated with quartz, sulfides, and locally tellurides of gold and silver. It is crystalline, fine- to mediumgrained, and white, green, or purple. In part it forms crystalline encrustations in vugs.

\section{AUTUNITE AND META-AUTUNITE}

Autunite and meta-autunite. occur in small quantities near the surface at the Blackhawk Lode No. 2 mine, on Silver Hill. They are associated with metatorbernite or torbernite and at places appear to coat, and probably replace, these minerals. So far as known they are present only in altered wallrocks adjacent to the vein; they do not seem to occur within the veins.

\section{METATORBERNITE AND TORBERNITE}

Metatorbernite and locally torbernite coat fractures and are dispersed through certain altered wallrocks in the upper parts of some uranium-bearing veins (Sims, Oster'wald, and Tooker, 1955, p. 17-18). Rarely they occur within the veins, generally coating altered pitchblende. 
QUARTZ

Quartz is the dominant gangue mineral, and it occurs in a variety of forms and colors. The most abundant and widespread variety is milky, white or light gray to colorless, anhedral, and medium- to coarse-grained. It forms ill-defined veinlets, commonly in association with crystalline pyrite, and irregular embayments in altered wallrocks; at places it forms coarse euhedral crystals that grow outward from vein walls. A variety observed in the Wood vein (Drake, 1957) is fine grained, banded, and pale yellow. Another variety, locally abundant in some pyrite type veins, is dark gray and fine grained. It forms irregular, small masses that commonly are associated with and partly replaced by copper minerals. A variety of quartz that is a common gangue mineral in many galena-sphalerite veins is fine grained to cryptocrystalline and gray, dark gray, black, or brown. At places it cements breccia ore fragments. In descriptions of some mines this quartz is referred to as chalcedonic quartz. It is probable, however, that some of this quartz is granular rather than fibrous in habit, and should therefore be referred to as flint or chert. Some cryptocrystalline quartz, particularly the quartz that occurs as late encrustations on the ore minerals, is mammillary to submammillary in habit.

\section{KASOLITE}

Kasolite is the common secondary uranium mineral in the weathered parts of uranium-bearing galenasphalerite veins. It is associated with quartz, hydrous iron oxides, and locally with torbernite or metatorbernite.

\section{ANKERITE, SIDERITE, RHODOCHROSITE, AND} CALCITE

Several rhombohedral carbonate minerals occur in some of the galena-sphalerite veins. Siderite probably is most abundant. It is dark brown and generally forms small rhombohedrons with curved faces that encrust breccia fragments of wallrock or vein walls. At places small terminated quartz crystals grow outward from the siderite crystals. Ankerite, commonly cream colored, was identified from the American Eagle tunnel in the Silver Hill area. It occurs principally as irregular massive aggregates of subhedral grains, and it is veined by an intricate network of dark gray chalcedonic quartz. Sparse brownish pink to pink rhodochrosite was observed locally, and is abundant at places in the Cherokee and Widow Woman mines. Calcite is rare. Bastin and Hill (1917, p. 249) describe a white, transparent calcite, containing galena and sphalerite, from the seventh level of the Topeka mine.

\section{Cerussite}

Cerussite is common and locally abundant in the near-surface, altered parts of galena-sphalerite veins. Commonly it forms a white, adamantine coating on aggregates of galena.

\section{SMITHSONITE}

Smithsonite was not observed in the field but was identified from shallow parts of a few galena-sphalerite veins by $\mathbf{X}$-ray diffraction methods. Probably it is sparse.

\section{MALACHITE AND AZURITE}

Malachite and less commonly azurite can be seen at places as coatings on oxidized copper-bearing veins. Probably many of these occurrences represent secondary enrichment.

\section{BARITE}

Barite is a sparse gangue mineral in a few veins on the fringes of the district; it is generally white or gray, coarse grained, and intergrown with a carbonate mineral.

\section{EPSOMITE(}

Delicate, fibrous aggregates of a white to colorless mineral, thought to be epsomite, form an efflorescence locally on the walls in many of the long-abandoned mines in the district.

\section{COPPER SULFATES}

Copper sulfates, probably mainly chalcanthite $\left(\mathrm{CuSO}_{4} \cdot 5 \mathrm{H}_{2} \mathrm{O}\right)$, locally coat the walls of abandoned mines known to contain copper-bearing veins.

\section{ZIPPEITE, JOHANNITE, AND GYPSUM}

Zippeite, associated with johannite and gypsum, has been reported from Quartz Hill (Palache, Berman, and Frondel, 1951, p. 599, 607). A pale yellow coating observed on leached pitchblende-bearing ores found on the dumps of the Wood and other mines on Quartz Hill probably is zippeite, but it was not positively identified. All occurrences of these minerals probably formed after mining operations ceased.

\section{RELATION OF GOLD AND SILVER TO SULFIDE AND GANGUE MINERALS}

Gold and silver are associated with all the primary vein-forming minerals, but the form in which the precious metals occur is not completely known. Free gold is dispersed through various minerals as minute grains, generally visible only under the microscope, but much of the gold in the ores seems to be in the structure of metallic minerals. Gold occurs as tellurides locally. Although silver locally occurs in discrete silver. sulfosalts, most of it is probably in the structure of sulfide minerals. 
Collins (1904) made the first studies of the association of gold and silver with other vein minerals in the district, primarily to shed light on the behavior of the ores when treated by simple concentration milling on the one hand and amalgamation stamp milling on the other. He collected samples from jig concentrates and jig waste, and separated the minerals by means of a lens. The results of his work are given in tables 7 and 8. Subsequently Bastin and Hill (1917, p. 116), Drake (1957), and the present writers have obtained additional data, which largely corroborate the conclusions of Collins (1904). Mineral separates prepared by Drake were made by superpanning equipment; the clean mineral separates made for the present report were prepared in a magnetic separator or were hand picked, and subsequently examined under a binocular microscope.

Although gold occurs sparsely in all the primary sulfide and gangue minerals, it is more abundant in the metallic minerals than in the gangue minerals; and according to the data of Collins the content is higher in contaminated separates of the metallic minerals than in the clean separates (table 7). Collins' data show that gold is present in all the metallic vein minerals, exceeding 0.1 ounce to the ton in all samples, and that it generally is more abundant in chalcopyrite and tennantite than in pyrite, galena, and sphalerite. Quartz without adherent metallic minerals generally has a very low gold content. The analyses by the later investigators are in general agreement with Collins' data but indicate that pyrite contains generally lower values. A detailed sampling of the Wood vein on the 538 level of the East Calhoun mine (Drake, 1957) clearly shows that the pyritic parts of the vein barren of visible base-metal sulfides have very low gold content; those parts containing substantial quantities of copper minerals and sphalerite, on the other hand, contain appreciable gold (table 9). A sample of

TABLE 7.-Gold content, in ounces per ton, of mineral separates from veins in Central City district. ${ }^{1}$

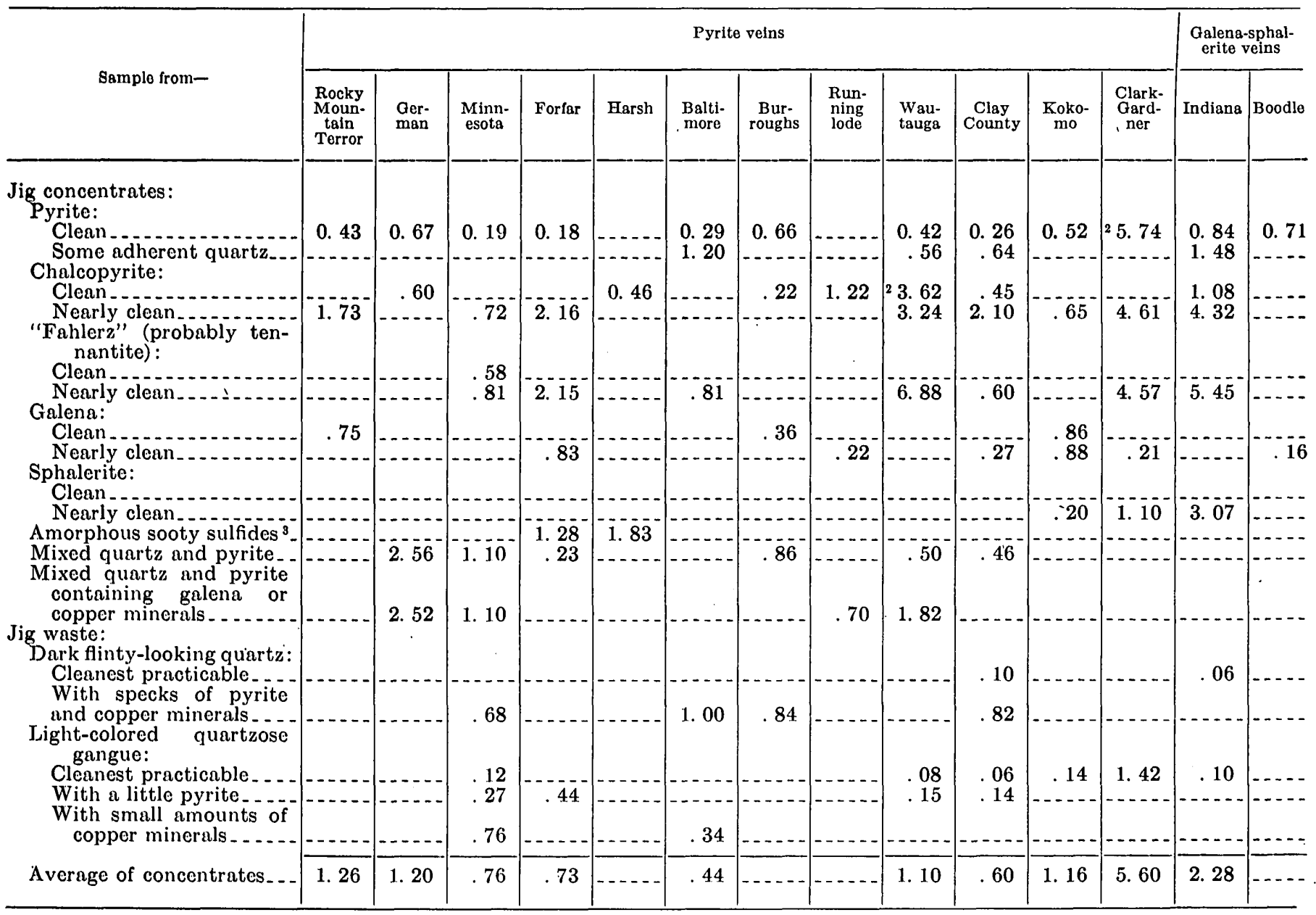

1 Data from Collins (1904, p. 492, app. C). Modified according to vein type by

2 Contains traces of quartz.

3 Probably secondary in origin. 
nearly clean, massive pyrite from the Telegraph vein; containing sparse quartz, contained only a trace of gold.

Silver is present in all sulfides and to a much lesser extent in the gangue minerals. Collins (table 8) showed that the highest silver concentrations are associated with galena and the copper minerals. Pyrite in all environments has a low content, and sphalerite generally contains low concentrations. The data of
Bastin and Hill (1917, Drake (1957), and the present writers (table 9), clearly show that a large proportion of the silver in any given vein is either in chalcopyrite or in galena, and that concentrations are low in pyrite and sphalerite. Where tennantite is present it also can be expected to contain large quantities of silver. Samples of cubic and fine-grained steely galena from the Carroll vein show nearly equal quantities of silver.

TABLE 8.- Silver content, in ounces per ton, of mineral separates from veins in Central City district ${ }^{1}$

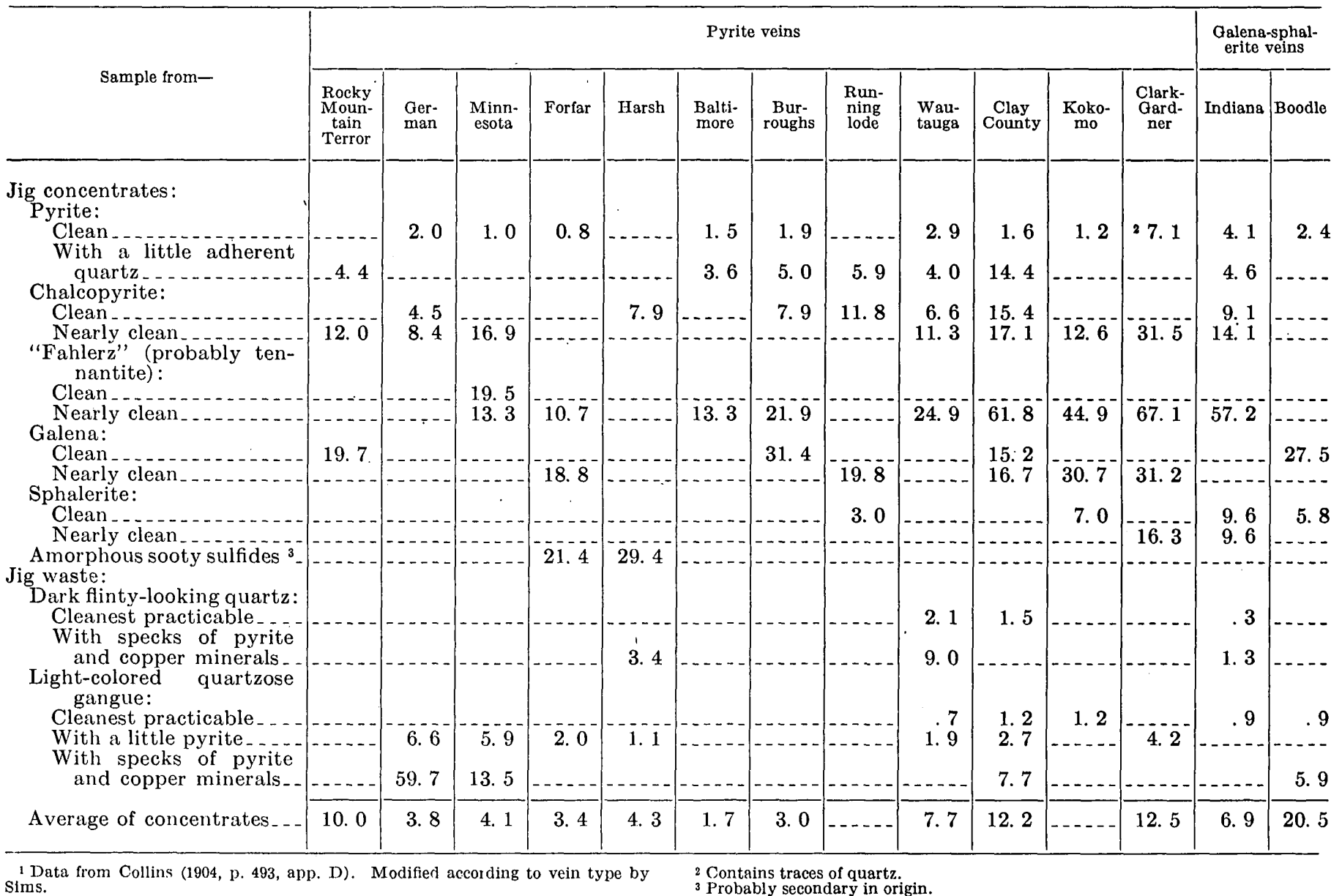

TABLE 9.-Gold and silver content, in ounces per ton, of pure mineral separates

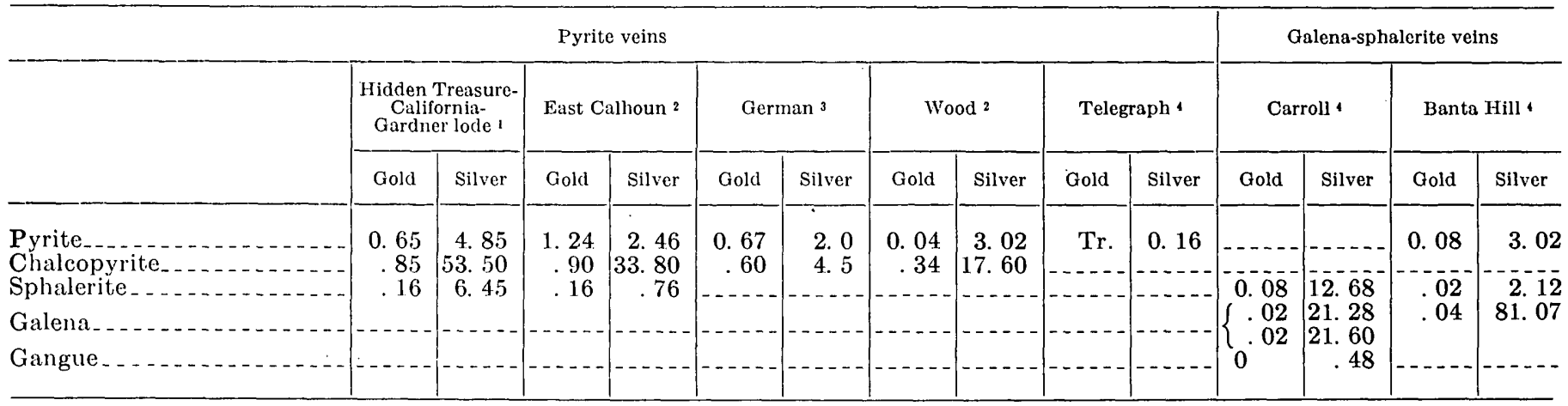

1 Bastin and Hill $\left(1917\right.$, p. 234). $\quad 2$ Drake (1957). ${ }^{3}$ Bastin and Hill (1917, p. 117-118). $\quad$ 4 Analysts: D. Skinner, E. C. Mallory, Jr. 


\section{FINENESS OF GOLD AND SILVER}

The fineness of gold saved by amalgamation in many mines that developed pyrite veins is given in table 10. The average fineness of retort bullion from mines in Gilpin County is given by Collins (1904, p. 491 ) as gold 0.787 , silver 0.198 , and copper 0.015 for 1870 to 1880 , and gold 0.778 and silver 0.207 for 1880 to 1890 .

TABLE 10.-Gold and silver fineness of retort bullion from representative mines, Central City district ${ }^{1}$

\begin{tabular}{|c|c|c|c|c|}
\hline \multirow{2}{*}{ Mine } & \multicolumn{2}{|c|}{$1870-80$} & \multicolumn{2}{|c|}{$1880-90$} \\
\hline & Gold & Silver & Gold & Silver \\
\hline $\begin{array}{l}\text { Bates } \\
\text { Bobtail } \\
\text { Buell } \\
\text { Burroughs } \\
\text { Gregory } \\
\text { Kansas...- } \\
\text { Kent Count }\end{array}$ & $\begin{array}{r}0.746 \\
.858 \\
0.800-0.860 \\
.827 \\
.810 \\
.770 \\
.730\end{array}$ & $\begin{array}{r}0.241 \\
.134 \\
0.120-0.140 \\
.162 \\
.176 \\
.200 \\
.240\end{array}$ & $\begin{array}{l}0.757 \\
.861 \\
.780 \\
.834 \\
.803 \\
.758 \\
.700\end{array}$ & $\begin{array}{r}0.214 \\
.118 \\
.200 \\
.146 \\
.174 \\
.215 \\
.277\end{array}$ \\
\hline
\end{tabular}

${ }^{1}$ After Collins (1940, p. 491, app. B).

\section{CLASSIFICATION OF VEINS}

The veins can be classified according to mineralogy into pyrite veins and galena-sphalerite veins which are distinctive but grade into one another through gradual changes in mineralogy. The transitional veins contain the minerals characteristic of both vein classes. (See p. 41.) They are pyrite veins formed by pyritestage mineralization, which were reopened and subsequently partly filled by minerals of base-metal stage mineralization. These veins were named "composite ores" by Bastin and Hill (1917, p. 112); instead of using Bastin's terminology, however, we classify these veins under two types of pyrite veins, depending upon the amounts and proportions of copper minerals and sphalerite and galena.

At places gold tellurides, pitchblende, enargite, and fluorite occur in significant quantities, but these minerals appear to be local variants of the ores and are not considered significant to the basic classification.

The vein classification adopted in this report is based on quantitative vein mineralogy; it is similar but in some important respects differs from those of previous investigators (Bastin and Hill, 1917, p. 105; Lovering and Goddard, 1950, p. 173). Individual veins are classified on the basis of observations made underground, vein specimens on dumps of inaccessible mines, assays of ore, production records of individual mines, and polished section studies. In addition, the mineralogic data given in previous reports were utilized. The distribution of the different classes of veins is shown on plate 1 .

\section{PYRITE VEINS}

The pyrite veins consist dominantly of pyrite and quartz, but locally contain chalcopyrite, tennantite, sphalerite, and rarely galena and enargite.

The pyrite veins can be subdivided on the basis of the quantity and proportions of the contained metallic minerals into: type $A$-pyrite veins that are nearly devoid of base-metal sulfides and sulfosalts, type $B-$ pyrite veins that contain abundant copper minerals, and type $C$-pyrite veins that contain sphalerite, galena, and copper minerals. Although the three types of pyrite veins are distinctive, they intergrade and their separation is somewhat arbitrary.

\section{GENERAL CHARACTER AND APPEARANCE}

The three types of pyrite veins differ somewhat in general character and appearance, mainly because of differences in the fracturing visible in the vein and differences in the quantities and proportions of the various base metals.

Pyrite veins type $A$ consist almost entirely of pyrite and gangue (fig. 7). Chalcopyrite and tennantite are

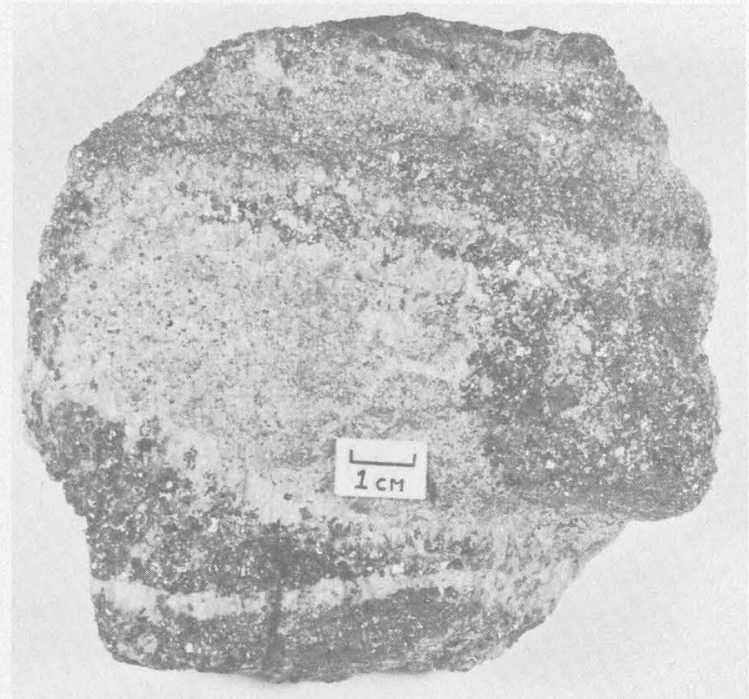

Figure 7.-Photograph of a pyrite vein, Mammoth mine. Altered wallrock, which contains abundant fine-grained crystalline pyrite, is veined and embayed by quartz (white) and pyrite. Tennantite and sparse chalcopyrite locally occur in the quartz-pyrite

rarely sufficiently abundant to be extracted profitably; sphalerite and galena are rare. Commonly the vein walls are ill-defined and the fractures occupied by the veins are indistinct. At many places closely spaced, overlapping fractures are separated by bleached and pyritized wallrock which contains stringers of pyriti- 
ferous quartz, typically an inch or less wide. Small cubes and pyritohedrons of pyrite are disseminated through the altered wallrock and quartz. The pyrite in the fractures is massive or abundantly disseminated in quartz. Gouge seams, generally an inch or less wide but locally 6 inches wide, occur at places along one or both walls or within the vein itself. Vugs, where present, are small. A vug of unusual size, observed by Bastin at the National mine (Bastin and Hill, 1917, p. 107), measured 6 inches by 4 inches by 2 feet; it was lined with quartz crystals, some of which were half an inch in diameter. Clots, small stringers, and pods of copper minerals and minor pyrite as much as 6 inches wide and a few feet long, occur in fractures that cut the altered wallrocks and pyritequartz vein material. Only a few examples of veins of type $A$ were accessible for study; these include the Mammoth vein exposed in the west face of the Bobtail tunnel, the Telegraph vein, and the Mammoth vein at the Mammoth mine. Another vein of this type, the Saratoga, was studied earlier by Bastin (Bastin and Hill, 1917, p. 267-268).

Pyrite veins of type $B$ are similar in gross appearance to veins of type $A$, but they contain much more chalcopyrite and tennantite, the vein walls are more distinct, and gouge is more abundant. The copper minerals characteristically are sufficiently abundant to be recoverable. Sphalerite is more abundant than in type $A$ veins but is not common, and galena is rare. The copper minerals are mainly concentrated in thin lenses and pods as much as several feet long that occur in fractures that clearly crosscut the earlier pyritequartz vein material. Fine-grained, gray quartz commonly is associated with the copper-rich parts of the veins. A typical vein of this type, the Pittsburg, was examined by Bastin (Bastin and Hill, 1917, p. 261262); another, the Iron vein, was mapped by one of us. An unusual type of ore-bearing material, termed "talc ore" by the miners, occurs in the veins of this type in the Iron, Old Town, and adjacent mines in upper Russell Gulch. This material, described by R. R. Hinckley (oral communication) as forming pipelike bodies, is a white, soft, plastic clay that contains scattered crystals of pyrite and chalcopyrite and commonly is rich in gold.

Pyrite veins of type $C$ contain moderate to abundant sphalerite, galena, and copper minerals. The copper occurs mainly as chalcopyrite and tennantite but locally is enargite. Stringers, clots, and larger pods of base-metal ore minerals occur in fractures that cut across the earlier pyrite-quartz vein material and the pyritiferous altered wallrock which is included as "horses" in the vein. Most of the veins on Quartz
Hill and at Nevadaville belong to type $C$, and descriptions of many of these veins are given in the section on the mines.

\section{GRADE}

The primary ores of pyrite veins are principally valuable for their gold content, but they also contain moderate quantities of silver, copper, zinc, and lead. With few exceptions, only pyrite veins of types $B$ and $C$ have been mined profitably.

The average gold content of direct shipping (smelting) ore from pyrite veins ranges from less than 1 to more than 5 ounces, but rarely exceeds 2 ounces. Representative shipments of smelting ore from several pyrite veins of different mineralogy are shown in table 11. Aside from the Pittsburg, Argo, and Carr, none of the veins listed in the table yielded substantial quantities of ore that averaged more than 2 ounces of gold per ton.

The average silver content of the same veins, judging from the shipments listed in table 11, ranges from about 2 to 12 ounces; the range in silver content is somewhat greater than the range in gold content.

The copper content of the veins ranges from traces to about 16 percent. The lower limits are not well established as copper was not recorded in the sampling-works assays if it was below the commercial limit of 1.5 percent. In general, copper is sparse in veins of type $A$, and it is somewhat more abundant in veins of type $B$ than in veins of type $C$.

The lead and zinc content are not given for the ore shipments listed in table 11, but data on these metals are given in the descriptions of individual mines. With few exceptions substantial quantities of lead and zinc occur only in veins of type $C$.

The silver-gold ratio is low in ores from the pyrite veins, as shown in table 12 . These data, compiled by Collins $(1904$, p. 490) from carefully taken samples of several economically important veins, indicate that the silver-gold ratio ranges from slightly more than 1 to about 15 , but generally is about 5 or less. Although these data clearly show, as pointed out by Collins (1904, p. 481), that the concentrating (mill) ores generally contain a greater relative proportion of silver than the sorted smelting ores, the differences in the ratios are not great. Data compiled by us from ores produced since 1904 corroborate the ratios given by Collins, but in general indicate slightly lower silver-gold ratios. We calculated the silver-gold ratios of ores from individual mines from the total production of gold and silver, reported in the production tables that accompany the mine descriptions. No attempt was made to calculate separately ratios for direct shipping (smelting) ore and for concentrates. 
TABLE 11.-Gold, silver, and copper content of representative shipments of smelting ore from pyrite veins

\begin{tabular}{|c|c|c|c|c|c|c|c|c|c|c|c|c|}
\hline \multirow{2}{*}{ Mine } & \multirow[b]{2}{*}{$\begin{array}{l}\text { Veln } \\
\text { type }\end{array}$} & \multirow{2}{*}{ Years } & \multirow[b]{2}{*}{$\begin{array}{c}\text { Quantity } \\
\text { (short tons) } \\
\text {. }\end{array}$} & \multicolumn{3}{|c|}{ Gold (o unces) } & \multicolumn{3}{|c|}{ (Silver (ounces) } & \multicolumn{3}{|c|}{ Copper (percent) } \\
\hline & & & & $\begin{array}{l}\text { Maxi- } \\
\text { mum }\end{array}$ & $\underset{\text { mum }}{\text { Mini- }}$ & $\underset{\text { age }}{\text { A ver- }}$ & $\underset{\text { mum }}{\text { Maxi- }}$ & $\underset{\text { Muni- }}{\text { mum }}$ & $\begin{array}{c}\text { Aver- } \\
\text { age }\end{array}$ & $\begin{array}{l}\text { Maxi } \\
\text { mum }\end{array}$ & $\begin{array}{l}\text { Mini- } \\
\text { mum }\end{array}$ & $\begin{array}{c}\text { Aver- } \\
\text { 8ge }\end{array}$ \\
\hline $\begin{array}{l}\text { Chase } \\
\text { Saratoga. } \\
\text { Argo. } \\
\text { Charr } \\
\text { O.K. }\end{array}$ & $\begin{array}{l}A \\
A \\
B \\
B \\
B\end{array}$ & $\begin{array}{l}1893-1908 \\
1893-1909 \\
1889-1908 \\
1893-1910 \\
1893-1908\end{array}$ & $\begin{array}{r}1193 \\
11,019 \\
130 \\
1400 \\
1185\end{array}$ & $\begin{array}{l}\text { 8. } 20 \\
8.41 \\
5.00 \\
9.06 \\
4.28\end{array}$ & $\begin{array}{r}0.29 \\
.12 \\
.50 \\
.72 \\
.30\end{array}$ & $\begin{array}{r}1.98 \\
.90 \\
2.39 \\
2.88 \\
1.13\end{array}$ & $\begin{array}{l}\text { 28. } 40 \\
13.90 \\
12.13 \\
21.20 \\
10.20\end{array}$ & $\begin{array}{l}\text { 1. } 90 \\
\text { 1. } 00 \\
\text { 2. } 50 \\
\text { 2. } 00 \\
\text { 3. } 40\end{array}$ & $\begin{array}{l}\text { 6. } 53 \\
\text { 2. } 32 \\
\text { 7. } 31 \\
\text { 7. } 62 \\
\text { 5. } 59\end{array}$ & $\begin{array}{c}(2) \\
(2) \\
16.00 \\
11.70- \\
10.25\end{array}$ & $2 . \overline{10}$ & 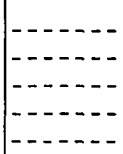 \\
\hline $\begin{array}{l}\text { Old Town } \ldots \\
\text { Perrin } \\
\text { Pewabic } \\
\text { Pittsburg } \\
\text { Rockford... }\end{array}$ & $\begin{array}{l}B \\
B \\
B \\
B \\
B\end{array}$ & $\begin{array}{l}1919-35 \\
1929-36 \\
1919-34 \\
1910 \\
1910\end{array}$ & $\begin{array}{l}139 \\
135 \\
356 \\
1435 \\
\text { (1) }\end{array}$ & $\begin{array}{r}2.85 \\
3.42 \\
2.85 \\
25.35 \\
-\end{array}$ & $\begin{array}{r}.17 \\
.33 \\
.15 \\
.52 \\
-. .-\end{array}$ & $\begin{array}{l}\text { 1. } 12 \\
\text { 1. } 84 \\
\text { 1. } 22 \\
\text { 5. } 77 \\
\text { 1. } 09\end{array}$ & $\begin{array}{r}9.35 \\
15.78 \\
10.50 \\
22.65 \\
-\end{array}$ & $\begin{array}{l}.62 \\
1.30 \\
1.00 . \\
2.00 \\
\end{array}$ & $\begin{array}{l}\text { 2. } 78 \\
6.26 \\
\text { 3. } 67 \\
\text { 8. } 93 \\
\text { 4. } 35\end{array}$ & $\begin{array}{r}1.40 \\
12.62 \\
16.00 \\
16.30\end{array}$ & $\begin{array}{r}-\cdots \\
-\cdots \\
-\cdots\end{array}$ & $\begin{array}{r}4.16 \\
1.71 \\
6.65\end{array}$ \\
\hline $\begin{array}{l}\text { Corydon } \\
\text { German (Quartz } \\
\text { Hill) } \\
\text { Gilpin-Eureka. } \\
\text { Hubert. } \\
\text { Kansas. }\end{array}$ & $\begin{array}{l}C \\
C \\
C \\
\stackrel{C}{C} \\
\stackrel{C}{C}\end{array}$ & $\begin{array}{l}1892-97 \\
1919-24 \\
1920-35 \\
1934-35 \\
1922-23\end{array}$ & $\begin{array}{r}51 \\
124 \\
64 \\
13 \\
33\end{array}$ & $\begin{array}{l}\text { 2. } 62 \\
\text { 1. } 60 \\
\text { 2. } 09 \\
\text { 4. } 00 \\
\text { 3. } 24\end{array}$ & $\begin{array}{r}1.08 \\
.30 \\
.16 \\
.09 \\
.45\end{array}$ & $\begin{array}{r}1.74 \\
.63 \\
.83 \\
1.55 \\
1.66\end{array}$ & $\begin{array}{r}15.00 \\
\text { 27. } 66 \\
11.22 \\
5.64 \\
14.45\end{array}$ & $\begin{array}{r}2.00 \\
2.85 \\
.92 \\
.31 \\
\text { 4. } 74\end{array}$ & $\begin{array}{r}5.63 \\
\\
7.99 \\
5.60 \\
2.76 \\
12.05\end{array}$ & $\begin{array}{r}8.00 \\
14.00 \\
.77 \\
.75 \\
3.29\end{array}$ & 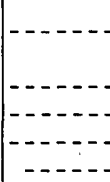 & $\begin{array}{r}7.00 \\
1.07\end{array}$ \\
\hline
\end{tabular}

1. Takon from Bastin and HIll (1917, p. 109). Other assays by Idaho Springs Sampling Works; published by permission of J. Price Briscoe.

$\checkmark$ Generally less than 1.5 percent.

These data indicate that the average silver-gold ratio for ores from pyrite veins of type $B$ is 3.4 and for ores from pyrite veins of type $C$ is 6.2 . The average silver-gold ratios for ores from several areas in the district are as follows:

$\mathrm{T}_{\mathrm{ABLE}}$ 12.-Silver-gold ratios in ores from pyrite veins ${ }^{1}$

\begin{tabular}{|c|c|c|c|c|}
\hline Mine & \begin{tabular}{|c} 
Vein classl- \\
fleation \\
(type $)^{2}$
\end{tabular} & $\begin{array}{l}\text { Veln (ex- } \\
\text { clusive of } \\
\text { smelting } \\
\text { ore) }\end{array}$ & $\begin{array}{l}\text { Concen- } \\
\text { trates }^{3}\end{array}$ & $\begin{array}{c}\text { Smelting } \\
\text { ore }\end{array}$ \\
\hline $\begin{array}{l}\text { Barnes } \\
\text { Bobtail } \\
\text { Clay County } \\
\text { Columbus } \\
\text { Forfar } \\
\text { Gregory } \\
\text { Harsh } \\
\text { Iron } \\
\text { Mammoth } \\
\text { Saratoga } \\
\text { Two-Forty }\end{array}$ & $\begin{array}{l}B \\
B \\
C \\
B \\
B \\
B \\
B \\
B \\
B \\
A \\
B\end{array}$ & $\begin{array}{r}-7.7 \\
6.3 \\
10.4 \\
5.1 \\
2.4 \\
11.6\end{array}$ & $\begin{array}{l}10.4 \\
4.4 \\
4.2 \\
4.9 \\
3.5 \\
2.3 \\
8.2\end{array}$ & $\begin{array}{r}\text { 15. } 3 \\
1.6 \\
9.9 \\
5.2 \\
1.9 \\
5.1 \\
7.4 \\
2.8 \\
4.2\end{array}$ \\
\hline
\end{tabular}

'Modifled from Collins (1904, p. 490 app. A). On the basis of ores mined prior to 1804 .

Vein classiffeation by present writers.

i Product of straight concentration miling, without amalgamation.

Average silver-gold ratios of ores from pyrite veins, Central City district

\begin{tabular}{|c|c|c|c|}
\hline \multirow{2}{*}{ Area } & \multicolumn{3}{|c|}{ Type } \\
\hline & $A$ & $B$ & $C$ \\
\hline $\begin{array}{l}\text { Quartz Hill } \\
\text { Nevada Hill and Prosser Gulch. } \\
\text { Upper Russell Gulch } \\
\text { Lower Russell Gulch-Willis Gulch } \\
\text { Central, Mammoth, Gregory, Bob- } \\
\text { tail, and Bates Hills. }\end{array}$ & $\begin{array}{l}1.8 \\
.85\end{array}$ & $\begin{array}{l}\text { 7. } 6 \\
3 . \overline{2} \\
2.9 \\
2.7\end{array}$ & $\begin{array}{c}2.9 \\
2.8 \\
6 \\
31.4 \\
12\end{array}$ \\
\hline
\end{tabular}

The high silver-gold ratio of ores from veins of type $C$ in the lower Russell Gulch-Willis Gulch area is anomalous. Many pyrite veins in this part of the district, particularly those in the Anchor, Iroquois, Kokomo, Powers, and Silver Dollar mines, have silvergold ratios ranging from about 30 to 120 ; and each is characterized by one or more of the unusual minerals fluorite, enargite, or tellurides, which may account for the anomalous ratios.

\section{GALENA-SPHALERITE VEINS}

The galena-sphalerite veins contain sparse pyrite, chalcopyrite and tennantite, in addition to the dominant minerals. Quartz, much of which is fine grained to cryptocrystalline, a variety of rhombohedral carbonate minerals, principally ankerite, siderite, rhodochrosite, barite, and locally fluorite are the gangue minerals.

\section{GENERAL CHARACTER AND APPEARANCE}

Galena-sphalerite veins vary widely in general character and appearance and differ markedly from the pyrite veins. They contain some gouge and breccia, variable amounts of gangues, and local stringers, pods, or larger shoots of base-metal sulfides. The base-metal sulfides form massive veinlets of stringers in the gangue (fig. 8) that are subparallel or interlacing and also form crudely layered ore. The layered ore commonly consists of pyrite adjacent to quartz on the walls, followed by layers rich in sphalerite, and at places by a core of galena. Small quantities of chalcopyrite and tennantite are closely associated with the 


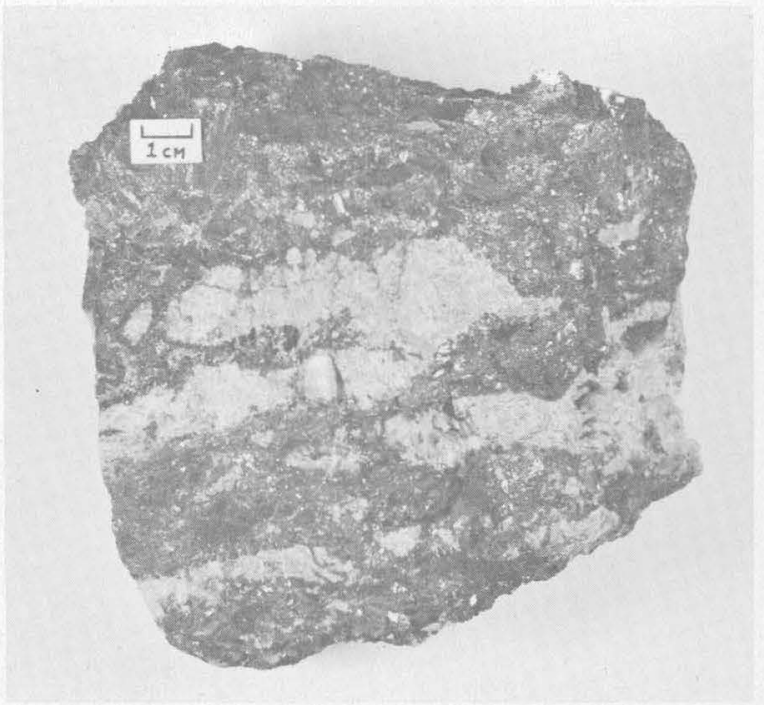

Figure 8.-Photograph of massive galena-sphalerite ore, Carroll vein 228 level west, Carroll mine. The wallrock fragments are embayed and veined by the sulfide minerals. Sparse late pyrite fills openings between galena crystals.

dominant ore minerals. The galena both embays earlier vein minerals and fills open vugs (fig. 9). Not uncommonly, terminated quartz crystals grow outward from galena. At other places the sulfides occur as small, irregular clots dispersed through the gangue; and at still other places they are in tiny, subparallel

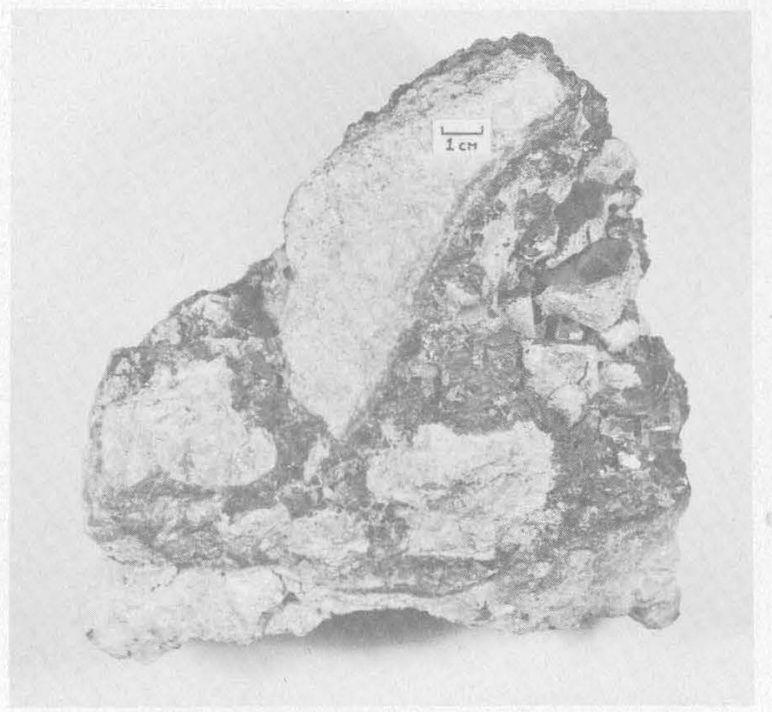

Figure 9.-Photograph of breccia-type ore, Carroll vein, 228 level west, Carroll mine. The outer margins of breccia fragments are silicified (gray); sphalerite coats and embays the silicified rims and galena is deposited on the sphalerite. The coarse galena, which is partly coated by a quartz druse, mainly fills vugs. stringers, the whole constituting low-grade ore. A few galena-sphalerite veins contain breccia-type (fig. 10) ore, consisting of altered wallrock fragments sur-

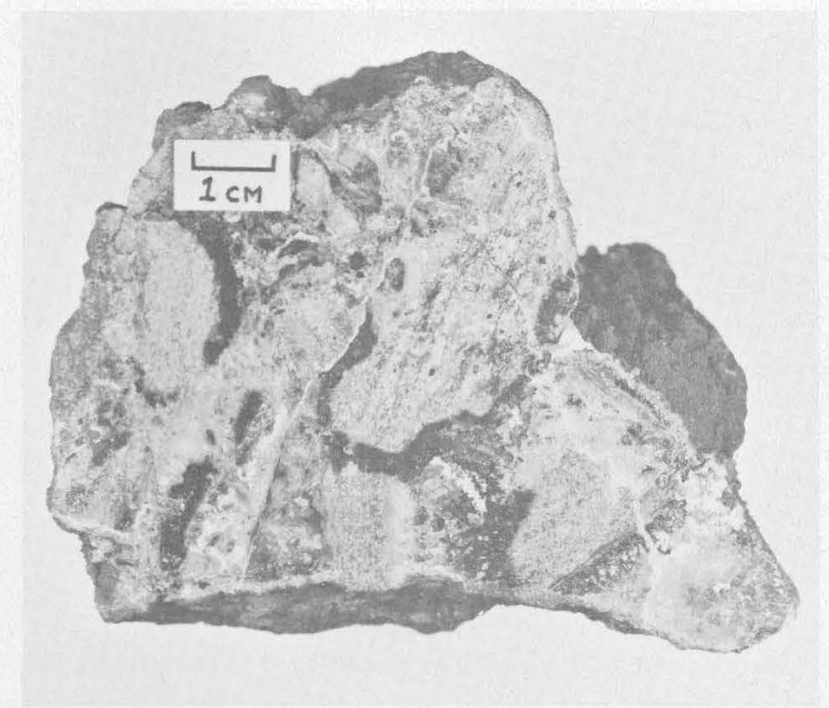

FIGURE 10.-Photograph of polished surface of breccia-type ore, Fannie mine. Quartz (light gray) and siderite (black) coat brecciated and altered wallrock fragments. Sparse sulfides embay the quartz and siderite. A late generation of calcite (white) veins the breccia fragments and the quartz-siderite filling.

rounded by quartz or carbonate minerals, sphalerite, and galena in cockade growth.

\section{GRADE}

The primary ores of the galena-sphalerite veins contain less gold and copper and more silver and lead than the ores of the pyrite veins. In addition, the silver-gold ratio is greater than for ores from pyrite veins.

The metal content of representative shipments of smelting-grade ores from galena-sphalerite veins are shown in table 13. Additional data on the grade of these ores is given in the section on mine descriptions.

The sulfide mineral assemblages and the gold and silver content of the ores in galena-sphalerite veins vary somewhat from area to area. In general, the ores from veins on Silver Hill have a high content of silver and a very low content of gold. Some of the veins, as for example the Champion, contain small quantities of base-metal sulfides (table 13). Although some veins on Nigger Hill and in Chase Gulch contain a substantial gold concentration of about one half ounce to the ton, most veins contain low gold concentrations and a few are rich in silver. Many of the galena-sphalerite veins in this part of the district 
$\mathrm{T}_{\wedge \mathrm{BLE}}$ 13.-Metal content of typical ores from galena-sphalerite veins $^{1}$

\begin{tabular}{|c|c|c|c|c|c|c|}
\hline Mino & Years & $\begin{array}{l}\text { Quantity } \\
\text { (shortt } \\
\text { tons) }\end{array}$ & $\begin{array}{c}\text { Gold } \\
\text { (ounces) }\end{array}$ & $\begin{array}{c}\text { Silver } \\
\text { (ounces) }\end{array}$ & $\underset{\text { (percent) }}{\text { Lead }}$ & $\underset{\text { (percent) }}{\text { Zinc }}$ \\
\hline $\begin{array}{l}\text { Bullion (Gulch) } \\
\text { (Eurekn). }\end{array}$ & $1920-34$ & 12 & 0.14 & 5.76 & 19.6 & 7.8 \\
\hline Garroll & $\begin{array}{c}1954 \\
1918-35\end{array}$ & $\begin{array}{l}245 \\
237\end{array}$ & .10 & 5. 28 & $\begin{array}{l}8.15 \\
5.35\end{array}$ & $\begin{array}{l}12.5 \\
1.40\end{array}$ \\
\hline Cyclops............. & 1923 & ${ }_{7}^{206}$ & $\begin{array}{l}.00 \\
.15\end{array}$ & $\begin{array}{r}104.40 \\
104.10\end{array}$ & $\begin{array}{l}5.30 \\
14.65\end{array}$ & $\begin{array}{r}1.40 \\
17.00\end{array}$ \\
\hline $\begin{array}{l}\text { Essox } \\
\text { Gold Cup...... }\end{array}$ & $\begin{array}{c}1935 \\
1920-34\end{array}$ & $42^{1.5}$ & $\begin{array}{l}.74 \\
.84\end{array}$ & $\begin{array}{r}77.00 \\
17.61\end{array}$ & $\begin{array}{l}36.80 \\
37.84\end{array}$ & $\begin{array}{r}12.50 \\
9.31\end{array}$ \\
\hline Golden Dollar. & 1039 & & .20 & 8.85 & 13. 75 & 7.50 \\
\hline Haysced... & $1820-35$ & 29 & .56 & 11.15 & 36.91 & 11.84 \\
\hline $\begin{array}{l}\text { Ivantioe } \\
\text { Jennito Blan }\end{array}$ & $\begin{array}{l}1898-1902 \\
1025\end{array}$ & $\begin{array}{l}311 \\
{ }^{3} 18\end{array}$ & .59 & $\begin{array}{l}14.00 \\
23.96\end{array}$ & ${ }_{21.10}^{(4)}$ & 1.40 \\
\hline Ready Cash & $1910-25$ & $\begin{array}{l}15 \\
93\end{array}$ & .01 & $\begin{array}{r}181.97 \\
10.47\end{array}$ & $\begin{array}{l}7.00 \\
8.6\end{array}$ & 11.44 \\
\hline
\end{tabular}

I All values are avernges of crude ore shipped for period. Except as noted assays by Idaho Springs Sampling Works. Published by permission of J. Price Briscoe.

Copper is neglielblc

a Assays furnished by company. Published by permission of United Mining and Lonsing Corp.

(3nsth and Fill $(1917$, p. 112)

- Shipments contain as much as 30 percent lead.

have substantial quantities of base-metal ore, particularly at the Carroll, Boodle, Bullion-Gold Cup, Hayseed, and Tucker mines. In Pleasant Valley, the Cherokee vein contains high-grade lead ore that has a substantial amount of both gold and silver.

The silver-gold ratio of ores from galena-sphalerite veins is high to very high; the average ratio as determined from recorded production figures for the years $1904-54$ is 75 . The ratio varies from area to area within the district, as follows:

Average silver-gold ratios of ores from galena-sphalerite veins, Central City district

Area Silvèr-gold ratio

Lower Russell Gulch-Willis Gulch 35

Central, Mammoth, Gregory, Bobtail, and Bates Hills 12.5 Chase Gulch, Winnebago Fill, and Maryland Mountain _._- $\mathbf{1 6 . 5}$

Nigger Fill _-_._-_._- 22

Silver Fill _.

LOCAL VARIANTS OF ORES

Certain veins in the district contain in addition to the common suite of metallic minerals and gangues, described on previous pages, one or more of the following group of minerals-pitchblende, gold tellurides, enargite, and fluorite. The veins containing these minerals are distinguished on plate 1 by patterns that are superimposed on the basic vein classification.

\section{TELIURIDE-BEARING VEINS}

Tellurides of gold and silver occur in a few veins in the eastern and southeastern parts of the district. They have been mined from the War Dance, Notaway, and New Brunswick veins in the lower Russell Gulch area, and have been reported from the Pittsburgh and Sleepy Hollow veins. Their presence has been suspected locally in other veins, notably the Gregory
(Pearce, 1890, p. 449). The tellurides may be more widespread than previously recognized, and they may account for some local, erratic high-gold assays throughout the district. None of the mines known to contain gold tellurides was accessible during this survey nor were specimens available for study. Information on these deposits is almost limited to that gathered by Bastin and Hill (1917, p. 114-115). Accordingly, no new data were obtained on the tellurium content of veins. The tellurides are not a normal component of the typical sulfide ores. Instead they occur in separate fractures from the main sulfide ores, and in part if not entirely occupy fractures that appear to be later than the typical sulfide-bearing fissures.

The known, significant occurrences of tellurides in the lower Russell Gulch area, between Lake and Willis Gulches, are along or near the prominent Dory Hill fault and its blind southwest projection. At the East Notaway mine, gold telluride occurs in the Notaway vein, which cuts the Homestake sulfide-bearing vein. Typically the vein consists of 1 to 3 inches of darkgray, microcrystalline quartz, fine-grained pyrite, tennantite, and varying quantities of gold telluride and native gold. Studies of polished and thin sections (Bastin and Hill, 1917, p. 115) disclosed that the pyrite, tennantite, and quartz are more abundant near the margins of the vein, and that the telluride, probably sylvanite, associated with native gold, is more abundant near the center of the vein. At the War Dance mine, gold telluride occurs in a separate "vein" from the sulfides. It is in a complex network of fractures, some of which are parallel to the sulfide vein. Some telluride-bearing ore has been found a short distance from the War Dance vein, in part in fractures which clearly are not branches from the main vein. At places the tellurides seem to replace the wallrock adjacent to the fractures. The characteristic minerals of the high-grade veinlets are purple fluorite, pyrite, and telluride. At the Powers mine, gold tellurides occur locally in tiny fractures within a poorly defined pipelike body known as the New Brunswick vein. The body, according to Henry Ress (oral communication), is about 100 feet in diameter and has a plunge length of more than 400 feet. It does not appear to pass laterally into a tabular fracture system. In general, a telluride of gold-probably sylvanite or calaverite-occurs locally in the fractures within pegmatite wallrocks and free wire gold occurs in fractures within biotite gneiss wallrocks. Sparse sulfides, including molybdenite, occur with the gold. 


\section{ENARGITE-BEARING VEINS}

Enargite is present in 13 veins in an area of about a square mile in lower Russell Gulch and is an ore mineral in a few veins. As none of the mine workings on these veins was accessible during this survey, our knowledge is based largely upon descriptions by Bastin and Hill (1917) and on studies of ore specimens found on the mine dumps.

The enargite occurs in pyrite veins mainly of types $B$ and $C$, and is a local arsenic-rich component of the normal sulfide ores. It was deposited in close association with tennantite. In a few specimens a small amount of chalcopyrite occurs with enargite, either as grains or as tiny veinlets that cut enargite as well as galena. In some enargite-bearing veins fluorite is conspicuous.

\section{FLUORITE-BEARING VEINS}

Fluorite is a local gangue mineral in Willis Gulch and vicinity in both pyrite and galena-sphalerite veins, certain rich telluride veins, and enargite-bearing veins. Judging from descriptions by Bastin and Hill (1917), fluorite typically occurs in the main sulfide veins, but at places it is in stringers that are in the walls. In the War Dance vein it forms locally massive vein fillings as much as 5 inches wide; at the Iroquois mine it occurs with quartz as vug fillings in pyritic vein material and also in stringers that cut pyritic vein material; and at the Powers mine it locally replaces biotite-quartz-plagioclase gneiss wallrocks. At the Widow Woman mine we noted that purple fluorite in both vein $A$ and the Gold vein occurs with quartz. At the Cherokee mine purple fluorite locally fills vugs in the altered wallrock adjacent to the Cherokee vein.

\section{URANIUM-BEARING VEINS}

Pitchblende and local secondary uranium minerals occur sporadically along pyrite and galena-sphalerite veins (pl. 1). The deposits on Quartz Hill were of national importance prior to World War I as they supplied most of the demand for high-grade pitchblende (Sims, 1956; Sims and Tooker, 1956; Sims and others, 1963).

The pitchblende deposits are clustered in the Quartz Hill-upper Russell Gulch, Eureka Gulch (Sims and others, 1955), lower Russell Gulch, and Silver Hill areas. About half the 60 known occurrences of radioactive minerals in the district are on Quartz Hill. The uranium minerals occur in small pods or lenses, or less commonly, in larger ore shoots along the sulfidebearing veins (Sims, 1956, p. 751). The largest known ore shoots rarely contain more than 50 tons of ore. The grade is variable, but generally high. Some of the pods mined from the veins on Quartz Hill, according to the most reliable information, contained ore averaging more than 10 percent uranium.

\section{HYPOGENE MINERAL ZONING}

A concentric zonal arrangement of the ores is clearly shown by the geographic distribution of the pyrite and galena-sphalerite veins ( $p l .1)$. A core area of pyrite veins - the central zone, is surrounded, except to the south, by an intermediate zone of transitional veins, which in turn is surrounded by a peripheral zone of galena-sphalerite veins (fig. 11).

The demarcation between zones is necessarily somewhat arbitrary, as the various classes of veins are gradational. The boundary between the central zone and the intermediate zone is placed at the transition from pyrite veins of type $B$ to pyrite veins of type $C$; and the boundary between the intermediate and peripheral zones is placed at the transition from pyrite veins of type $C$ to galena-sphalerite veins. As the veins on the margins of the district are rarely productive, they are arbitrarily placed in a barren zone.

The relative proportions of the principal vein-forming minerals and the approximate limits of distribution of each with respect to the zonal pattern, as outlined on figure 11, are shown graphically in figure 12. The diagram in no way indicates absolute quantities of minerals but it does indicate the relative abundance and the qualitative variations of each mineral. Neither pitchblende nor gold tellurides are shown on the diagram, for the distribution of these minerals shows no apparent relation to the mineral zoning.

As noted in figure 12, quartz and pyrite are ubiquitous, and chalcopyrite, tennantite, sphalerite, and galena occur in most of the veins, but in greatly different quantities. Traces of gold and silver are present throughout veins in most of the district, but minable concentrations are extremely local. Although pyrite is ubiquitous, it is relatively sparse in the veins of the peripheral zone.

The distribution of the gangue minerals and the texture of the principal gangue, quartz, accord with those in many zoned mining districts (Park, 1955, p. 228). The quartz in the central and intermediate zones is dominantly a white to gray, coarsely crystalline, massive variety, whereas the quartz in the peripheral zone is dominantly a finely granular chalcedonic variety, generally distinctly colored several shades of gray or brown. The change of one textural variety to another seems to be gradational. The rhombohedral carbonate minerals are rare in the intermediate and central zones but are locally abundant in the peripheral and barren zones. Commonly, only one species 


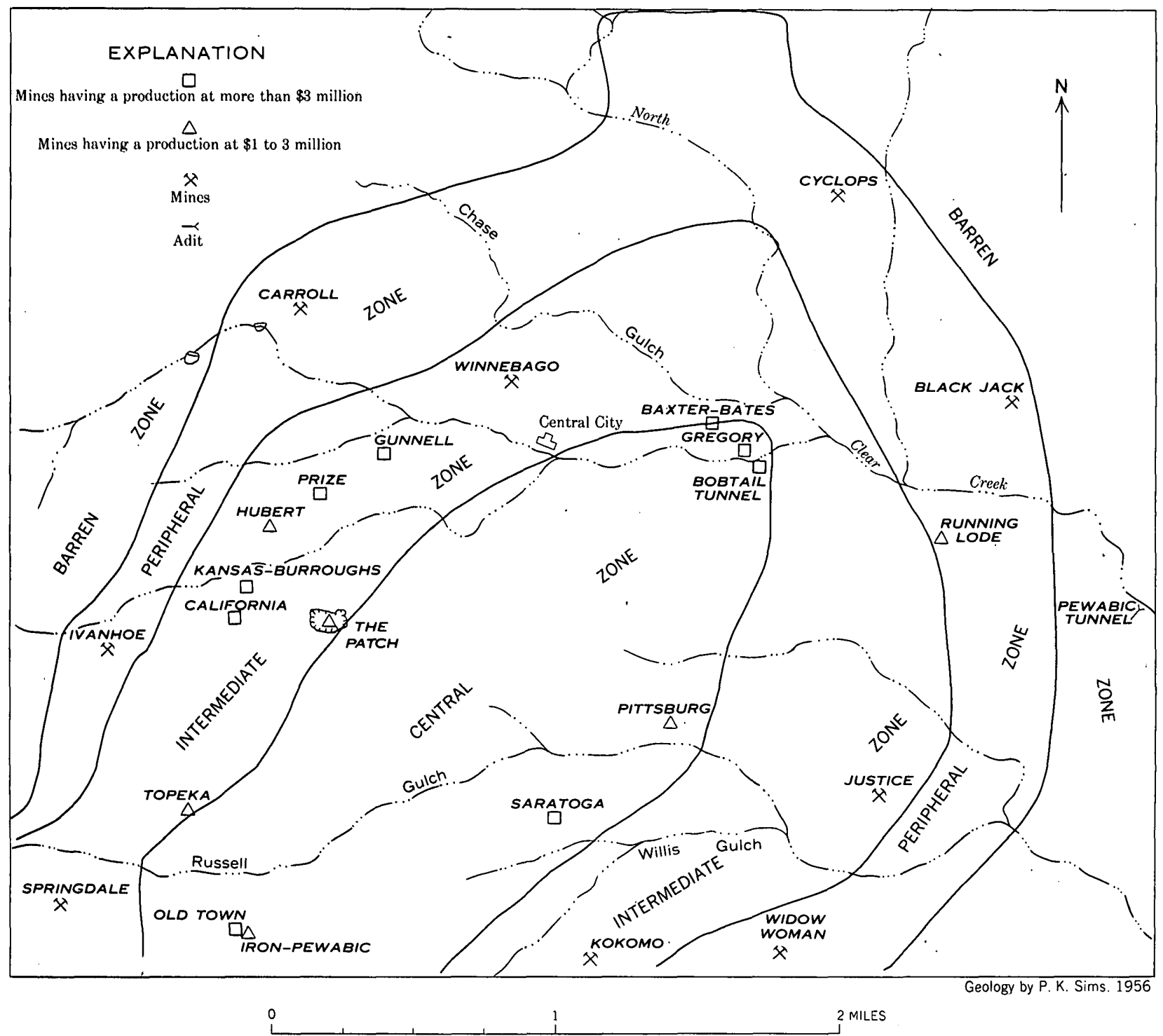

Frgure 11.-Map of Central City district showing zoning of mineral deposits.

is present, in a single vein, but much additional work needs to be done on these minerals before the distribution and relations of the species are fully known. Barite is a local gangue mineral in veins of the peripheral and barren zones.

Possibly a depth zoning also is present, but this has not been demonstrated and could not be tested during our investigation because of the absence of accessible deep mine workings.

A zonal arrangement of the ores in the Central City district, and adjacent parts of the Idaho Springs district, was first suggested by Collins (1904, p. 480). Collins found by use of silver-gold ratios that a central oval area of veins valued almost entirely for their gold content was surrounded by a circular belt of 654827 0-63-4 veins with a much higher silver-gold ratio. Around this, again, he noted a wide ring (except towards the Idaho Springs gold-silver district) of veins containing chiefly silver (Collins, 1904, p. 481, pls. 4, 9). Later, Bastin divided the veins of the district into three mineralogic types, as described earlier, and he showed the geographic distribution of these different types (Bastin and Hill, 1917, p. 115, pl. 4). Lovering and Goddard (1950, p. 170 and 173, pl. 9) contributed further to our knowledge of zoning, and they prepared a map (pl. 9) specifically showing the zonal arrangement of the ores. After a limited study of uranium deposits in several Front Range districts, Leonard (1952, p. 1274) noted that the pitchblende deposits showed a distinctive relation to the pattern 


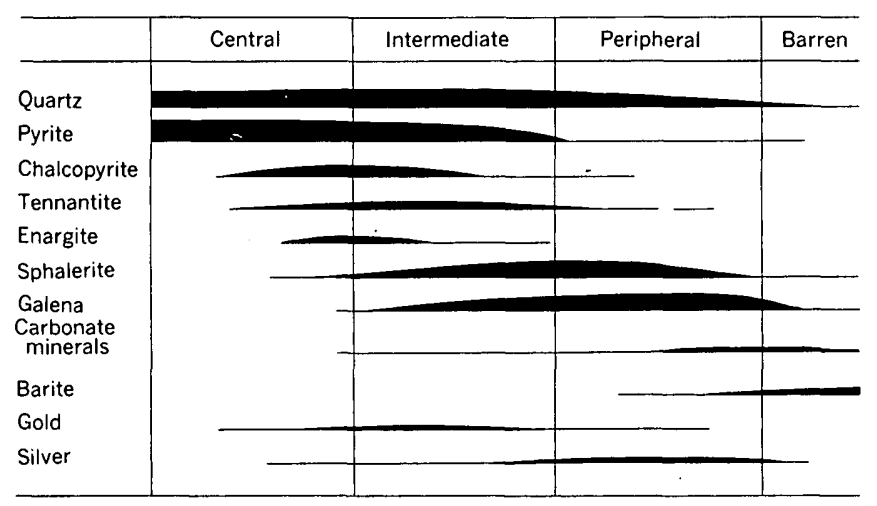

Figure 12.-Zonal distribution of vein-forming minerals.

of hypogene zoning; and concluded that "the deposits appear to be restricted to an intermediate or transitional zone between central areas of pyritic gold veins and peripheral areas of silver-lead-zinc veins" (Leonard, 1952, p. 1274-1275). Subsequent discoveries of uranium and further geologic studies in the Central City district have shown, however, that the pitchblende deposits are not restricted to the intermediate area but instead occur locally in each of the zones (Sims, 1956, p. 749).

\section{CENTRAL ZONE}

The central zone, an elliptical area about 1 mile wide and 3 miles long (fig. 11), contains pyrite veins, some of which have appreciable quantities of copper. The copper-bearing veins (type $(B)$, as can be seen by reference to plate 1 , are mainly near the outer margin; they contain most of the commercially valuable gold deposits. Without exception the deposits have a low silver-gold ratio.

Several large mines, notably the Gregory, Bobtail tunnel, Saratoga, Old Town, Iron, and Pewabic are within the central zone, near its margin.

\section{INTERMEDIATE ZONE}

In the intermediate zone surrounding the central zone the veins are pyrite veins of type $C$. The proportion of the base-metal sulfides and sulfosalts vary widely from vein to vein, but copper minerals rarely are sufficiently abundant to constitute a substantial proportion of the ore. An exception is certain veins in Willis Gulch and lower Russell Gulch, which contain abundant enargite or tennantite or both. Gold is an important constituent of the ores and the silvergold ratio is slightly greater than in the central zone. in Willis Gulch and lower Russell Gulch, which consistent in all areas except the Willis Gulch-lower Russell Gulch areas, where it is abnormally high. The gangue is largely coarsely crystalline quartz; chalcedonic quartz is present locally and carbonate minerals are uncommon.

The intermediate zone ranges in width from about 2,000 to 4,000 feet. It includes many of the larger mines of the district, particularly in the Nevada Hill and Quartz Hill areas.

The inner boundary of the zone, drawn at the transition from copper-bearing pyrite veins (type $B$ ) to lead-zinc-copper-bearing pyrite veins (type $C$ ), is well defined except in upper Russell Gulch and in the Willis Gulch-lower Russell Gulch areas (fig. 11). In upper Russell Gulch, possibly the inner boundary should pass north of the Springdale mine to exclude the Gold Rock, Denbigh, and Fairfield veins (pl. 1) because these veins, although they contain sphalerite and galena, contain much more copper than most pyrite veins of type $C$. In the Willis Gulch-lower Russell Gulch areas, the data on which the inner boundary is delimited are sparse because all the mines are inaccessible and the basis for its location is solely dump specimens and production records. Delineation in this area is further complicated by the telluride mineralization which appears to be related to latestage fluids that probably migrated upward along the blind extension of the Dory Hill fault (pl. 1).

\section{PERIPHERAL ZONE}

The peripheral zone, which surrounds the intermediate zone, ranges in width from 1,000 to 4,000 feet and averages about 2,000 feet in width. The galenasphalerite veins which characterize the area differ noticeably from area to area in their base-and precious-metals content. In general, base metals decrease in abundance outward; gold is rarely commercially important. The silver content is variable but in general increases outward, and is most abundant in veins in the Silver Hill area. The vein gangue in the peripheral zone dominantly is chalcedonic quartz, a variety of rhombohedral carbonate minerals, and locally barite; carbonate minerals are proportionately much more abundant than in the inner zones, and barite appears for the first time in this zone.

Except for the Running Lode, which is near the inner margin of the zone, none of the mines has had a production in excess of $\$ 1$ million.

\section{BARREN ZONE}

The veins that are outside of the peripheral zone (fig. 11) rarely are workable, although small sporadic pockets of silver ore have been found. Galena is the dominant sulfide mineral and calcium and iron-manganese carbonates, cryptocrystalline quartz, and barite 
are the main gangues. The area of generally barren veins extends for several miles west to the AliceYankee Hill district and a short distance northwest to the Michigan Hill area (Lovering and Goddard; 1950, pl. 2). The small Hughesville mining district lies within a mile of the north edge of the district (Lovering and Goddard, 1950, pl. 2). The east edge of the district marks the eastern limit of the Front Range mineral belt.

\section{PARAGENESIS OF VEIN MINERALS}

The veins of the district were formed during a single period of mineralization, but in three distinct stages, which were separated by recurrent fault movements that probably occurred synchronously throughout the district. These stages have been named (Sims, 1956; Sims and Barton, 1961, p. 1216-1219), from oldest to youngest, the uranium stage, the pyrite stage, and the base-metal stage.

A distinctive suite of ore minerals was deposited during each of the three stages of vein filling. Although gold and silver probably were introduced during each of the stages; most of the precious metals were deposited with the minerals of the base-metal stage.

The recurrent fault movements that occurred during mineralization resulted in the local formation of composite veins. These veins are quartz-pyrite veins, formed by pyrite-stage mineralization, which were fractured and brecciated and the fragments cemented by quartz and various sulfides during the base-metal stage. As the ores of this type are widespread through the district and occur in each of the fracture sets, we believe that the recurrent movements took place nearly synchronously between mineralization of the pyrite and base-metal stages. Veins that contain pitchblende show' in addition an earlier period of fracturing, indicated by brecciated pitchblende-bearing stringers and pods cemented by quartz, pyrite, or: base-metal sulfides. This period of fracturing also is district-wide and the fractures may have occurred nearly synchronously.

The formation of the veins by "dual mineralization". (Bastin and Hill, 1917, p. 112-114) was recognized previously. It was first described by Collins (1913, p. 224-225) ; later it was more clearly emphasized by Bastin and Fill (1917), who termed the ores formed by double mineralization "composite ores." Bastin did not recognize, however, that the uranium ores were the result of an early stage of vein filling; instead, he thought that uranium was a local variant of the pyritic mineralization. Collins (1913, p. 224-225), in comparing veins from Gilpin County with others of his knowledge, states:

There are other cases, as frequently occurs in Gilpin County, where we have pyrite-bearing veins, containing low values in gold and silver, which have been shattered or re-opened, and re-mineralized either with copper minerals. such as chalcopyrite, enargite, or tetrahedrite, or with blende and galena; in either case accompanied by gold and silver in varying proportions, but always richer than the first filling of the vein. When the rein has been shattered, the result is a brecciated mass of pyrite and altered country rock, cemented by sulfide minerals and quartz.

The generalized sequence of deposition of the principal vein-forming minerals, within all fracture sets, is given in figure 13. Other minerals for which few

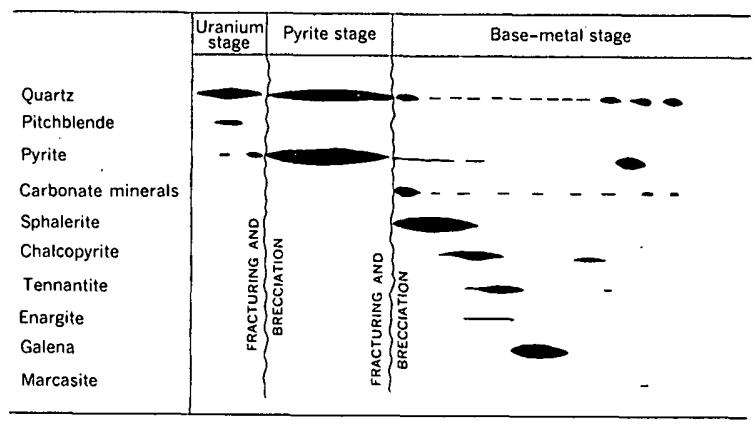

Figure 13.-Generalized sequence of deposition of principal veinforming minerals, Central City district.

data are available or which occur sparingly in the district are not listed in the paragenetic diagram but are discussed briefly in the text below. Also, the minor periods of fracturing that are locally important in some veins but which do not seem to be present in the different vein sets over a large area are not shown in the diagram. This fracturing is discussed briefly, however, and is described in some detail in the descriptions of individual veins.

The ores containing gold tellurides were not studied, and the relation of these minerals to the more common and widespread vein minerals is not definitely known. The concensus of the mining men familiar with these deposits, however, is that the tellurides formed late, probably during a separate stage of mineralization that followed the deposition of the basemetal ores. Collins (1930, p. 266), who studied many telluride-bearing veins during the time they were being mined, stated "my own impression is that the telluride ores, both in Gilpin, Clear Creek, and Boulder Counties, are later than the sulfide ore of either stage." The descriptions of telluride occurrences, both in Professional Paper 94 (Bastin and Hill, 1917) and in unpublished reports by mining engineers, add credence to Collins' conclusion. 
The quartz-hematite mineralization in the Blackhawk and Dory Hill faults (breccia reefs) apparently is earlier than the pyrite and base-metal stages of mineralization. It is inferred to have taken place during an early barren silica-iron stage, which could be pre-Laramide in age. Lovering and Tweto (1953, p. 55-57) found that vein filling in the breccia reefs in the Boulder County tungsten district preceded the formation of the base-metal veins.

\section{URANIUM STAGE}

Quartz, pitchblende, and sparse pyrite were formed during the uranium stage. Quartz was the first mineral to be deposited in the veins. Pitchblende began to form somewhat after the beginning of quartz crystallization. Toward the end of the stage pyrite began to crystallize with the quartz and pitchblende, and locally continued to form after pitchblende deposition ceased. In some veins, however, pyrite was not deposited during this stage. Locally, as in the Wood vein (Drake, 1957), minor fracturing took place during pitchblende deposition, and yielded brecciated fragments of pitchblende and quartz cemented by more quartz and pitchblende.

The pitchblende occurs mainly in small aggregates of spheroidal forms and veinlets with subrounded outlines. Details of its occurrence are described in a report by Sims (1956) and in another report by Sims and others (1963).

\section{PyRite stage}

Mineralization of the pyrite stage was the most intense and widespread of the three stages of vein filling, and the quartz and pyrite formed during this stage constitute the bulk of the vein material of pyrite veins. Replacement of wallrocks was nearly as important as fissure filling in forming some of the veins.

During the pyrite stage quartz and pyrite, with minor quantities of gold and silver, were deposited. Some of the pyrite, as in the Saratoga vein, probably is cupriferous. The quartz is mostly white or gray, massive, and medium grained to coarse grained. White or clear, terminated quartz crystals occur locally in vugs. The pyrite generally is medium grained or coarse grained and either euhedral or subhedral; both cubes and pyritohedrons formed. The pyrite embayed and corroded the quartz and minerals of the altered wallrocks. It formed as disseminations in the gangue, and as massive veinlets that range from less than an inch to several inches wide. In part the massive stringers cut pyritized wallrock.

As molybdenite and wolframite generally form early in any given paragenetic sequence (Edwards, 1954, p. 136), they may have been deposited in this stage, but this cannot be proved; neither mineral could be studied underground, and mineral specimens seen do not show the relations of these minerals to the other metallic minerals.

\section{BASE-METAL STAGE}

The base-metal stage of mineralization followed a major period of fracturing and brecciation. In contrast to the pyrite-stage mineralization, the minerals of this stage formed almost entirely as vein fillings, but metasomatic replacement of earlier formed vein minerals occurred in all veins. The minerals commonly were deposited together within the same fractures, and crystallization took place according to a systematic paragenetic sequence.

The fracturing that preceded base-metal mineralization mainly produced crosscutting fractures in the earlier pyrite-quartz veins; and filling of these fractures produced composite ores. At places, however, the minerals of the base-metal stage were deposited as crusts on earlier formed pyrite and quartz.

The minerals deposited during the base-metal stage differed quantitatively from area to area within the district. In some parts only copper minerals were deposited in abundance, and in other parts galena and sphalerite as well as copper minerals formed.

Sphalerite, the most abundant base-metal mineral in most veins, and some associated pyrite were the first metallic minerals to be deposited during the base-metal stage. The sphalerite mainly filled openings in the veins but also veined and embayed previously formed minerals; at places the sphalerite was preceded by quartz and rarely by a carbonate mineral. or barite. In several type $B$ pyrite veins, a dark-gray, massive, fine-grained quartz, which is associated with and veined by chalcopyrite, formed early in this stage. In type $C$ pyrite veins and in galena-sphalerite veins, the quartz is light gray to dark gray and fine grained.

Chalcopyrite was deposited mainly after sphalerite, largely as discrete bodies that vein or embay sphalerite and (or) pyrite. Some of it was exsolved from sphalerite upon cooling.

Tennantite locally began to crystallize before all the chalcopyrite was formed, and in many polished sections the two minerals are in part intergrown. Commonly, however, tennantite veins chalcopyrite. It is probable that at this time the rare sulfosalts of silver and copper were deposited, judging from the paragenesis of these minerals in veins in the northern part of the Idaho Springs district (R. H. Moench, written communication, 1957). 
Enargite formed locally in an area of about a square mile in the southeast, part of the district, apparently in place of chalcopyrite. It crystallized essentially contemporaneously with tennantite and commonly is associated closely with it. Evidently, as discussed elsewhere (Sims and Barton, 1961, fig. 3), the enargite and associated tennantite formed during the same epoch of mineralization as the chalcopyrite-tennantite.

Galena, which is locally abundant, was the next mineral to form. To a large extent it filled open spaces in the veins, but it also replaced earlier ore minerals. At the Oranoake mine, galena and tennantite are intergrown with a graphic texture, which probably indicates replacement of tennantite by galena.

Another generation of chalcopyrite, and minor tennantite, is later than galena. At the Delmonico and German mines, judging from dump specimens of the ores, this generation of chalcopyrite is quantitatively important. In some veins, sparse amounts of postgalena tennantite locally was deposited in vugs where the tennantite is associated with fine-grained pyrite.

A late generation of pyrite is conspicuous in some galena-sphalerite veins, particularly in veins from Nigger Fill and Chase Gulch and vicinity. The pyrite is generally fine grained and crystalline, and it veins older minerals or coats vugs. At places sparse marcasite intergrown with the pyrite and locally rims the pyrite.

Quartz was deposited locally throughout the basemetal stage, and in general is finer grained and darker in each succeeding generation. Generally quartz is most abundant where the veins were refractured and reopened; it commonly veins or heals brecciated sulfides. Details on successive generations of silica are given in the mine descriptions.

Barite, generally intergrown with a carbonate mineral and fluorite, is a locally important gangue mineral in a few galena-sphalerite veins. So far as known the barite and associated gangue minerals crystallized before sphalerite, but may also have formed intermittently during base-metal mineralization. Some of the fluorite in telluride veins may be related to telluride mineralization.

A late generation of carbonate minerals was deposited locally in some veins on the fringes of the district.

\section{MINOR ELEMENTS IN ORES}

Analyses of selected samples of typical pyrite and galena-sphalerite veins from widely scattered parts of the district are given in table 14. The content of minor elements in the ores was determined by semi- quantitative spectrographic analysis. Chemical analyses for uranium, copper, lead, zinc, and iron and fire assays of gold and silver are given for many samples to indicate the approximate quantities and relative proportions of the major metals in the ores.

Semiquantitative spectrographic analysis is a useful technique for determining the distribution of minor elements in ores and rocks because more than 60 elements commonly can be determined from the photographic record of a single arcing (Waring and Annell, 1953). The intensity of selected lines for each element on the photographic plate are compared visually with prepared standards. Alfred T. Myers has furnished the following information concerning the analyses of the ores and minerals given in this report.

The results of analysis for the elements in the samples are reported in ranges, each power of ten being divided into three ranges: The ranges are bounded by multiples of the progression 1 , $\sqrt[3]{10}, \sqrt[3]{100}, 10$ (or about $1,2,5,10$ ). The approximate midpoints of the ranges, $1.5,3$, and 7 are the figures used in reporting results, and these figures mean that the amount of an element in a sample may be expected to lie between 1.0 and 2.1 , between 2.1 and 4.6, etc. Also, in a series of reported results at least 60 percent are expected to lie within the correct range. Most of the uncertainty in the technique comes from those samples that contain an amount of an element close to the boundary of a range. Although detailed statistical studies are not avaliable, and there can be some variation from element to element, the errors probably are normally distributed and that about 20 percent of the results will be one range too high and 20 percent one range too low. For most elements, amounts in the ranges above that containing the minimum detectable amount are likely to be more reliable than those at or near the minimum detectable amount. At the opposite end of the scale of ranges of concentration the subdivisions although of the same relative reliability are so large in the absolute sense, that they have limited usefulness.

The minimum amounts detectable by the semiquantitative method are shown in table 15.

The ores of the district contain small amounts of several minor elements (table 14). All ore samples contain titanium, manganese, barium, and chromium, and most contain cobalt, nickel, molybdenum, vanadium, and zirconium. Arsenic, bismuth, gallium, antimony, strontium, yttrium, cadmium, tin, indium, and ytterbium are common and beryllium, germanium, scandium, neodymium, cerium, lanthanum, and tungsten are rare in the ores.

Most of the minor elements in the ores can be accounted for as trace elements in the major sulfide ore minerals (see p. 45); and quantitative variations are due largely to differences in the amounts of the various sulfide minerals. Arsenic and antimony result largely from the presence of tetrahedrite-tennantite in the ores. The elements beryllium, ger- 
TABLE 14.-Chemical analyses, fire assays, and semiquantitative spectrographic analyses of some ores, Central City district

\begin{tabular}{|c|c|c|c|c|c|c|c|c|c|c|c|c|c|c|c|c|c|c|}
\hline \multirow{2}{*}{ Mine } & \multirow{2}{*}{$\begin{array}{l}\text { Sample } \\
\text { No. }\end{array}$} & \multirow{2}{*}{$\begin{array}{c}\text { Labora- } \\
\text { tory } \\
\text { serial } \\
\text { No. }\end{array}$} & \multirow{2}{*}{$\begin{array}{l}\text { Equiva- } \\
\text { lent } \\
\text { uranium } \\
\text { (percent) }\end{array}$} & \multirow{2}{*}{$\left|\begin{array}{|c}\mathrm{Tranium}^{3} \\
\text { (percent) }\end{array}\right|$} & \multirow{2}{*}{$\begin{array}{c}\text { Au } \\
\text { (ounnes } \\
\text { per ton) }\end{array}$} & \multirow{2}{*}{$\mid \begin{array}{c}\mathrm{Ag} \\
\text { (ounces } \\
\text { per ton) }\end{array}$} & \multicolumn{12}{|c|}{ Semiquantitative spectrographic analyses 10} \\
\hline & & & & & & & $\mathrm{Cu}$ & $\mathrm{Pb}$ & $\mathrm{Zn}$ & $\mathrm{Fe}$ & $\mathbf{T i}$ & Mn & As & $\mathrm{Ba}$ & $\mathrm{Be}$ & $\mathrm{Bi}$ & Co & $\mathrm{Cr}$ \\
\hline 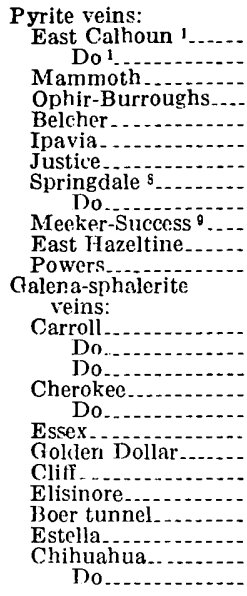 & $\begin{array}{l}\text { W-574 } \\
\text { W-589 } \\
\text { Ma-1 } \\
\text { S-552-52 } \\
\text { B-3E-1 } \\
\text { S-310-52 } \\
\text { JH-1 } \\
\text { Sp-2 } \\
\text { Sp-1 } \\
\text { M-S-S } \\
\text { 9-1 } \\
9-2 \\
\\
\\
\text { C-3-10A } \\
\text { C-S-G } \\
\text { C-3S-4 } \\
\text { SE-1 } \\
\text { SE-2 } \\
\text { E-1 } \\
\text { GD-1 } \\
\text { Cl-1 } \\
\text { El-5 } \\
4-9-2 \\
\text { D-34 } \\
\text { C-5 } \\
\text { C-6 }\end{array}$ & 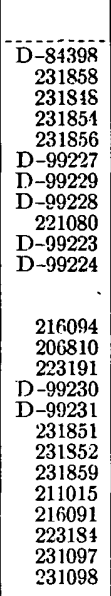 & $\begin{array}{c}0.25 \\
.006 \\
.002 \\
.008 \\
.002 \\
.001 \\
.00 \\
.048 \\
9.8 \\
.001 \\
.001 \\
.001\end{array}$ & $\begin{array}{l}.025 \\
3.04 \\
5.16 \\
.40\end{array}$ & $\begin{array}{l}.30 \\
.02 \\
.20 \\
\\
\end{array}$ & $\begin{array}{r}2566 \\
4.24 \\
6.66 \\
\\
\end{array}$ & $\begin{array}{c}37.40 \\
3.71 \\
(2) \\
1.5 \\
1.5 \\
.03 \\
3.0 \\
3.0 \\
3.7 \\
31.40 \\
.7 \\
(2)\end{array}$ & $\begin{array}{c}319.24 \\
1.5 \\
31.27 \\
1.5 \\
.(2) \\
(2) \\
(2) \\
(2) \\
(2) \\
36.32 \\
318.41 \\
319.83 \\
.007 \\
.15\end{array}$ & $\begin{array}{c}312.56 \\
.07 \\
39.32 \\
.3 \\
(4) \\
77.0 \\
7(2) \\
(2) \\
32.89 \\
32.80 \\
3.30 \\
3.03 \\
(2) .03\end{array}$ & $\begin{array}{c}\text { 3 25. } 99 \\
\text { 316. } 58 \\
(2) \\
7.0 \\
7(2) \\
(2) \\
(2) \\
(2) . \\
(2) \\
(2) \\
7.0 \\
7.0 \\
7.0 \\
(2)\end{array}$ & $\begin{array}{l}.015 \\
.07 \\
.3 \\
.15 \\
.03 \\
.03 \\
.003 \\
.03 \\
.03 \\
.03 \\
.015 \\
.007\end{array}$ & $\begin{array}{c}.07 \\
.07 \\
.03 \\
.7 \\
.07 \\
.7 \\
.07 \\
.07 \\
.7 \\
.7 \\
3.0 \\
.3\end{array}$ & $\begin{array}{l}.15 \\
0 \\
0 \\
0 \\
0 \\
.7 \\
0 \\
0 \\
0 \\
.15 \\
0 \\
0\end{array}$ & $\begin{array}{l}\mathbf{0 . 0 0 1 5} \\
.003 \\
.0015 \\
.015 \\
.0007 \\
.0015 \\
.0015 \\
.015 \\
.07 \\
.003 \\
.0015 \\
.007\end{array}$ & $\begin{array}{l}0 \\
.0007 \\
.0003 \\
.0003 \\
0 \\
0 \\
0 \\
0 \\
0 \\
0 \\
0 \\
0 \\
0 \\
0\end{array}$ & $\begin{array}{l}0.0015 \\
.3 \\
.15 \\
.003 \\
.003 \\
.007 \\
.03 \\
.015 \\
.0015 \\
.3 \\
.07\end{array}$ & $\begin{array}{l}0.0015 \\
.00015 \\
.0015 \\
.0007 \\
.0015 \\
.0007 \\
0 \\
0 \\
0 \\
.0007 \\
.0007 \\
0\end{array}$ & $\begin{array}{c}0.00015 \\
.00015 \\
.0007 \\
.0015 \\
.0015 \\
.003 \\
.003 \\
.003 \\
.003 \\
.003 \\
.003 \\
.0015\end{array}$ \\
\hline
\end{tabular}

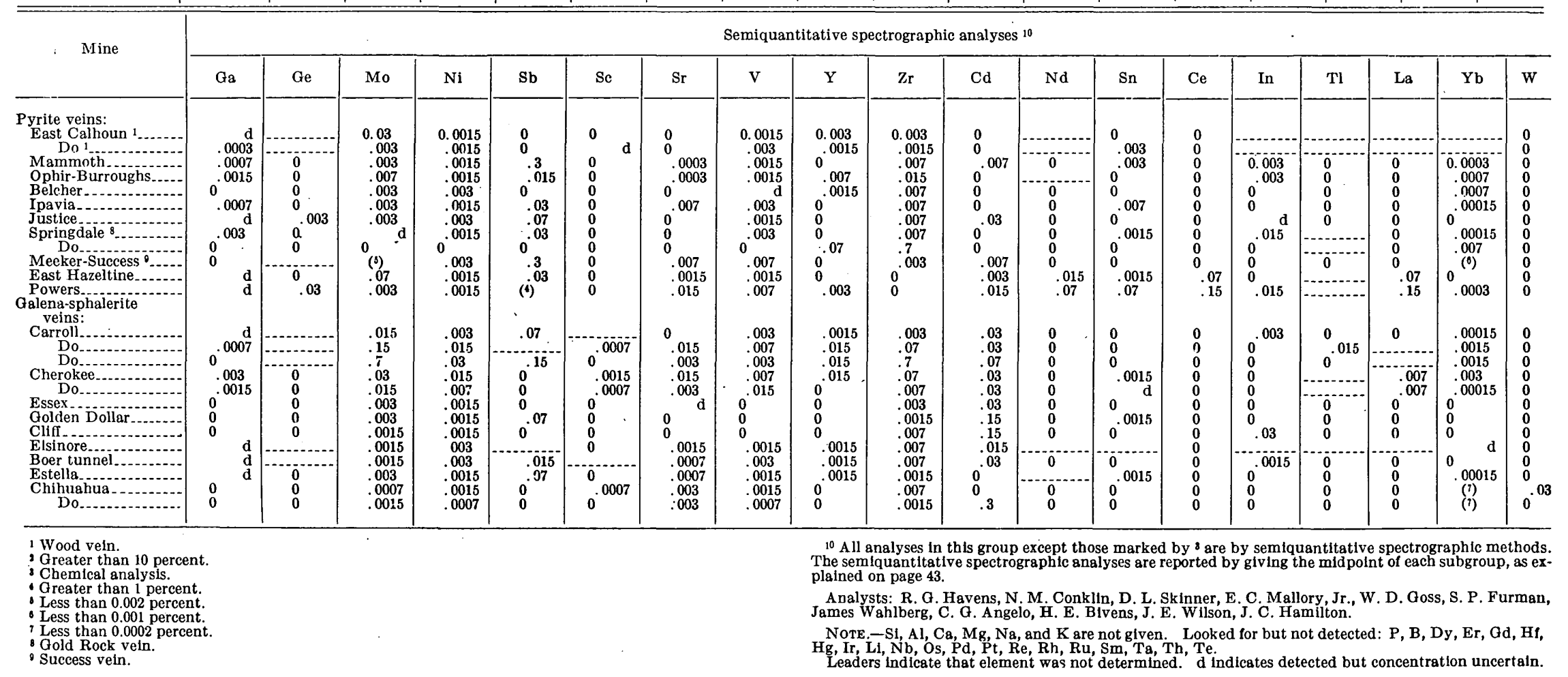


TABLE 15.-Standard sensitivities for the elements determined by the semiquantitative method, given in percent

\begin{tabular}{|c|c|c|c|c|c|}
\hline Element & Percent & Element & Percent & Element & Percent \\
\hline 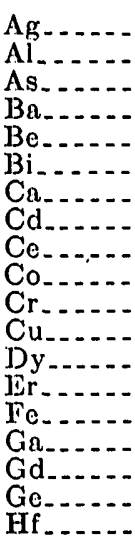 & $\begin{array}{l}0.00005 \\
.001 \\
.05 \\
.0001 \\
.0001 \\
.001 \\
.001 \\
.005 \\
.05 \\
.0005 \\
.0001 \\
.00005 \\
.05 \\
.005 \\
.001 \\
.001 \\
.005 \\
.0005 \\
.05\end{array}$ & $\begin{array}{l}\mathrm{Hg} \ldots \ldots \\
\mathrm{In} \ldots \ldots \\
\mathrm{Ir} \ldots \ldots \\
\mathrm{K} \ldots \ldots \\
\mathrm{L} \mathrm{L}_{\ldots} \ldots \ldots \\
\mathrm{Li} \ldots \ldots \\
\mathrm{Mg} \ldots \ldots \\
\mathrm{M} \mathrm{M}_{\ldots} \ldots \ldots \\
\mathrm{Na} \ldots \ldots \\
\mathrm{Nb} \ldots \ldots \\
\mathrm{Nd} \ldots \ldots \\
\mathrm{Ni} \ldots \ldots \\
\mathrm{O} \mathrm{P}_{\ldots} \ldots \ldots \\
\mathrm{P} \mathrm{P}_{\ldots} \ldots \ldots \\
\mathrm{Pd} \ldots \ldots \\
\mathrm{Pt} \ldots \ldots \\
\mathrm{Re} \ldots \ldots\end{array}$ & $-\begin{array}{l}1.0 \\
.001 \\
.005 \\
1.5 \\
.005 \\
.01 \\
.001 \\
.001 \\
.0005 \\
.05 \\
.001 \\
.01 \\
.0005 \\
.005 \\
.1 \\
.001 \\
.0005 \\
.003 \\
.005\end{array}$ & 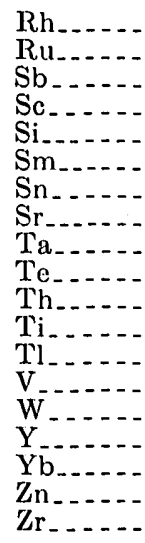 & $\begin{array}{l}0.005 \\
.005 \\
.01 \\
.001 \\
.001 \\
.01 \\
.001 \\
.0001 \\
.05 \\
.08 \\
.05 \\
.0005 \\
.01 \\
.001 \\
.01 \\
.001 \\
.0001 \\
.02 \\
.001\end{array}$ \\
\hline
\end{tabular}

1 Figher sensitivities can be obtained by a second exposure.

manium, scandium, yttrium, neodymium, cerium, lanthanum, and tungsten are not known to occur in the major sulfide minerals, however, and their presence must be accounted for in some other way. Beryllium, germanium, and possibly scandium probably are in altered wallrocks associated with the ores. Yttrium, which is ubiquitous in pitchblende from the district (Sims and others, 1963) probably can be accounted for largely by this mineral. As it also is a common minor element in the wallrocks of the district, however, some of it may be in altered wallrock "horses." The restriction of neodymium, cerium, thallium, and lanthanum to two ore samples from lower Russell Gulch may indicate that these elements are unique to the ores from this part of the district. As the wallrocks of this area are not notably different than others in the district, the elements possibly were original constituents of the ore fluid; they may occur in tennantite, a mineral known to have an open structure.

\section{MINOR ELEMENTS IN SULFIDE MINERATS}

Analysis for the minor elements in sphalerite, pyrite, and galena, the major sulfide ore minerals, was made by both semiquantitative and quantitative spectrographic methods. The semiquantitative spectrographic analyses are given in table 16 ; quantitative spectrographic analyses of sphalerite are given in table 17. Additional data on the minor elements in sphalerite and a discussion of the factors determining concentrations of them are given in a separate report (Sims and Barton, 1961, p. 1232-1235).
All the samples that were analyzed were carefully handpicked under the binocular microscope to obtain pure mineral separates. Also, a polished section was prepared of a chip of each sample to determine the kind and amounts of other sulfide or gangue minerals that were intergrown with or included within the sample.

Sphalerite contains varying quantities of several minor elements other than iron; it is sufficiently abundant in some varieties to be considered a major element. Most of the iron substitutes isomorphously for zinc in the sphalerite structure (see Kullerud; 1953; Fleischer, 1955, p: 972-975), but some of it is in chalcopyrite as exsolution blebs (p. 42). The copper reported in the analyses is mainly in chalcopyrite; in some contaminated samples it (table 17) is partly in tennantite inclusions. The lead and the antimony and arsenic presumably result mainly from contamination by galena and tennantite respectively, for tiny crystals of galena were observed in most sphalerite samples and, as noted above, a small amount of tennantite was seen in a few samples: Also, calcium, magnesium, sodium, silica, aluminum, and barium probably result from contamination by gangue minerals. The manganese, cadmium, bismuth, indium, gallium, and molybdenum probably substitute isomorphously for zinc. Manganese varies directly with the iron content; cadmium occurs in nearly equal amounts in all samples regardless of the iron content. Indium is present in all samples that contain more than one-half percent iron. Bismuth and molybdenum are erratic but generally sparse. Small quantities of mercury were detected in two samples of sphalerite.

Galena contains a small number of trace elements (table 16) ; most of the minor elements in the mineral probably result from tiny inclusions of silicate or sulfide minerals. Bismuth, cadmium, and antimony are present in most galena samples, possibly occurring in its structure; some antimony however, may result from tennantite inclusions, for this mineral commonly was observed in polished sections to be intimately integrown with galena. Of the other elements reported, silicon, aluminum, calcium, magnesium, sodium, and probably barium can be accounted for as silicate mineral inclusions, and iron, copper, and zinc probably are due to intergrown sulfides of these elements.

The dominant trace elements in pyrite are titanium, manganese, bismuth, cobalt, chromium, nickel, molybdenum, and zirconium. Cadmium, gallium, indium, and vanadium occur sparsely in some samples. 
$\mathrm{T}_{\mathrm{ABLE}}$ 16.-Semiquantitative spectrographic analyses and chemical analyses of some sulfide minerals, Central City district

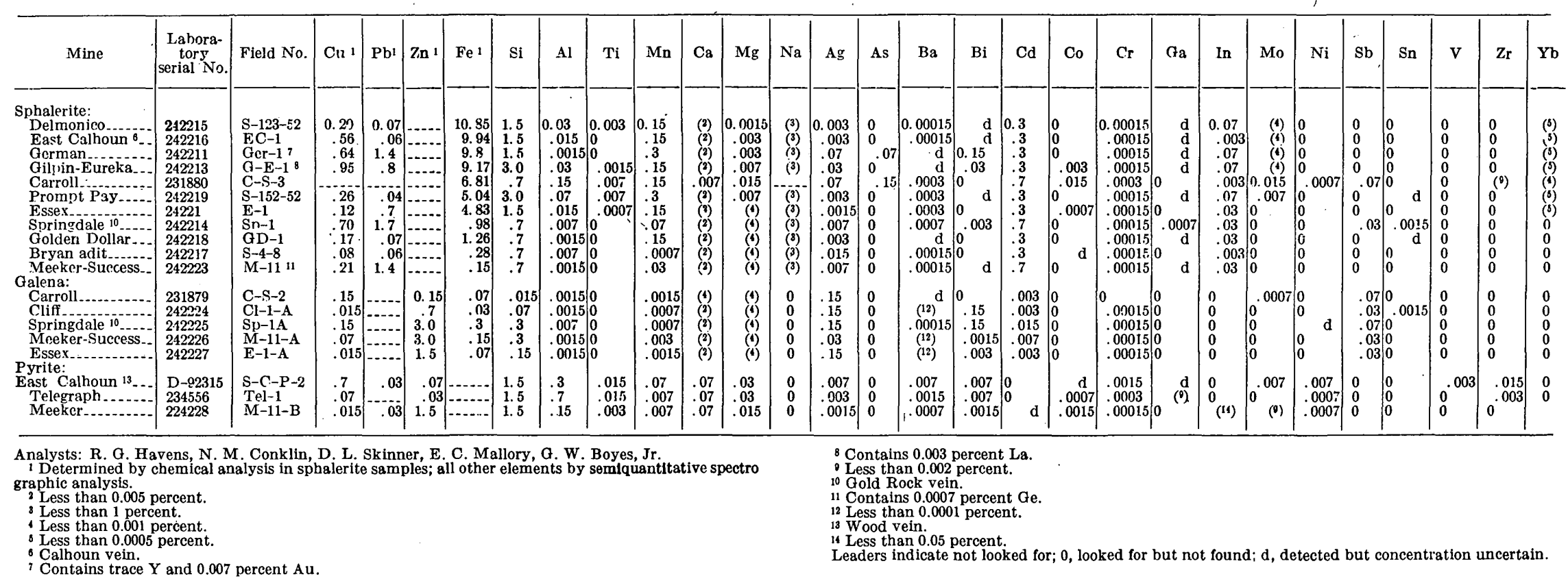


TAвLE 17.-Quantitative spectrographic analyses of sphalerite, Central City district

\begin{tabular}{|c|c|c|c|c|c|c|c|c|c|c|c|c|c|}
\hline veln and mine & $\begin{array}{l}\text { Serinal } \\
\text { No. }\end{array}$ & $\begin{array}{l}\text { Ficld } \\
\text { No. }\end{array}$ & Fe & Mn & $B i$ & $\mathrm{Cd}$ & Co & $\mathrm{Cu}$ & $\mathrm{Ga}$ & In & Mo & $\mathrm{Pb}$ & Color of sphalerite \\
\hline $\begin{array}{l}\text { East Calhoun: } \\
\text { Eust Cullioun............. }\end{array}$ & 246607 & $\mathrm{EC}-1$ & 9.0 & 0.15 & 0 & 0.25 & 0 & 0.3 & 0 & 0.06 & 0 & 0.006 & Blackish red or very dusky red. \\
\hline 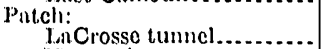 & 2465509 & Pat-1 & 8.0 & .2 & .0025 & .3 & .004 & .15 & 0 & .02 & 0 & .008 & Very dusky red. \\
\hline $\begin{array}{l}\text { Huysed............................ } \\
\text { Furficld: }\end{array}$ & 246602 & $H-1$ & 8.0 & .15 & & .3 & .0009 & .5 & 0 & .01 & 0 & 2.0 & Do. \\
\hline Finifficld ...................... & 246614 & Fair-1 & 7.0 & .2 & 0 & .2 & 0 & 1.5 & 0 & .05 & 0 & .04 & Do. \\
\hline East Culhoun...... & 246607 & $W-1$ & 6. 0 & .15 & .004 & .3 & 0 & .4 & 0 & .1 & .003 & .15 & Do. \\
\hline $\begin{array}{l}\text { Delmonico: } \\
\text { Delmonitco. }\end{array}$ & 2466108 & S123-52 & 6.0 & .15 & 0 & .2 & 0 & .3 & 0.002 & .05 & .002 & .01 & Blackish red or very dusky red. \\
\hline $\begin{array}{l}\text { Carroll: } \\
\text { Carrol }\end{array}$ & 246604 & $C-4-1$ & 6.0 & .15 & 0 & .3 & .001 & .4 & 0 & .004 & $\ldots 0006$ & .002 & Dark reddish brown. \\
\hline $\begin{array}{l}\text { Golden Dollar: } \\
\text { ciolden Dollt }\end{array}$ & & & & & & & & & & & & & \\
\hline $\begin{array}{l}\text { Ciolden Dollt } \\
\text { Unknown: }\end{array}$ & 246600 & (O.D)-1 & 4.0 & .15 & 0 & .3 & $c$ & .07 & 0 & .002 & 0 & 2.5 & Grayish red. \\
\hline$\ldots \ldots \ldots \ldots \ldots$ & 246601 & D-393 & 2.0 & .03 & 0 & 3 & .003 & .04 & & .001 & 0 & & Moderate or dark yellowish brown \\
\hline ing-13clmont........ & 246609 & $\begin{array}{l}C B-1 \\
4-104\end{array}$ & .3 & .004 & $\stackrel{0}{0}$ & .3 & 0 & .05 & $\stackrel{0}{0}$ & .015 & ${ }_{0}^{0}$ & .01 & Olive brown. \\
\hline Bir & 246605 & $S-4$ & .3 & .002 & 0 & .3 & .0006 & .04 & 0 & 0 & 0 & .002 & Light oli \\
\hline Nint & 246660 & D -328 I & .2 & .002 & 0 & 3 & .01 & .02 & 0 & & 0 & .04 & Light or medium gray. \\
\hline
\end{tabular}

I Simall quantilies of mercury present in sphalerite.

Analyst: Paul R. Barnett. Looked for but not detected: As, Sb, Sn, Ge.

\section{ORE SHOOTS}

The veins are not uniformly mineralized, and concentrations of valuable minerals form ore shoots of variable size, grade, and shape. The ore shoots generally constitute only a small proportion of any given vein. As most ore shoots are localized by the physical nature and structure of the wallrock, they tend to have a consistent direction of plunge within any given part of the district. Most of the ore shoots in the area west of the axis of the Central City anticline (fig. 4) plunge westward, whereas those in the area east of the axis plunge eastward.

\section{GENERAL CHARACTHR}

Most of the ore shoots of the district are distinctive and have moderately well defined boundaries. The gold and silver concentrations generally accompany the base-metal sulfide minerals and rarely occur in significant quantities in pyrite and its associated gangue minerals or in gouge and breccia largely barren of sulfide minerals.

The ore shoots within galena-sphalerite and pyrite veins formed by composite mineralization (types $B$ and $C$ ) generally are marked by abundant base-metal sulficle minerals. An example of an ore shoot of this type is in the Carroll vein on Nigger Hill (fig. 14). This ore shoot, noted chiefly for lead and zinc, is markedly wider and higher in grade than the remainder of the vein. The ore averaged about 5 feet in width and was as much as 9 feet wide; it contained about 15 percent combined lead and zinc and averaged about 5 ounces of silver to the ton. The remainder of the vein, on the other hand, was narrower and much lower in grade. Ore shoots are similarly delimited in many pyrite veins of type $C$; an excellent example is the ore shoot on the Meeker vein in the
Meeker-Success mine (fig. 59). The ore body plunges gently eastward. The gold and silver concentrations are associated with abundant galena and sphalerite, and the pyritic part of the vein is nearly barren. Another vein that clearly shows well-defined ore shoots within otherwise generally barren vein material is the Wood vein on Quartz Hill. It was mapped and sampled in detail and is described in a separate report by Drake (1957).

A few ore shoots in pyrite veins are poorly defined, however, and gradational into low-grade vein material. As the ore shoots of this type generally do not contain large concentrations of base-metal sulfide minerals that are visible megascopically, persistent sampling is necessary to determine their outlines. Collins (1913) has discussed in some detail the characteristics of this type of ore body and has made several suggestions regarding prospecting.

\section{SIZE AND SHAPE}

The minable ore bodies range in size from large ore shoots containing a few thousand tons and having horizontal and vertical dimensions of as much as several hundred feet, to ore shoots containing only a few tons, which are more aptly termed "pods or lenses." The terms used throughout the report to describe the dimensions of ore shoots are shown on the diagram in figure 15 .

The size of single ore bodies may be great or small according to local conditions controlling emplacement of the ore. The largest ore shoot known in the district is in the California mine (fig. 26). It has a known plunge length of 2,100 feet or more, a breadth of about 800 feet, and a stope length of about 1,000 feet; its average thickness is not known. The lower limit of the ore shoot has not been defined. Another large ore 


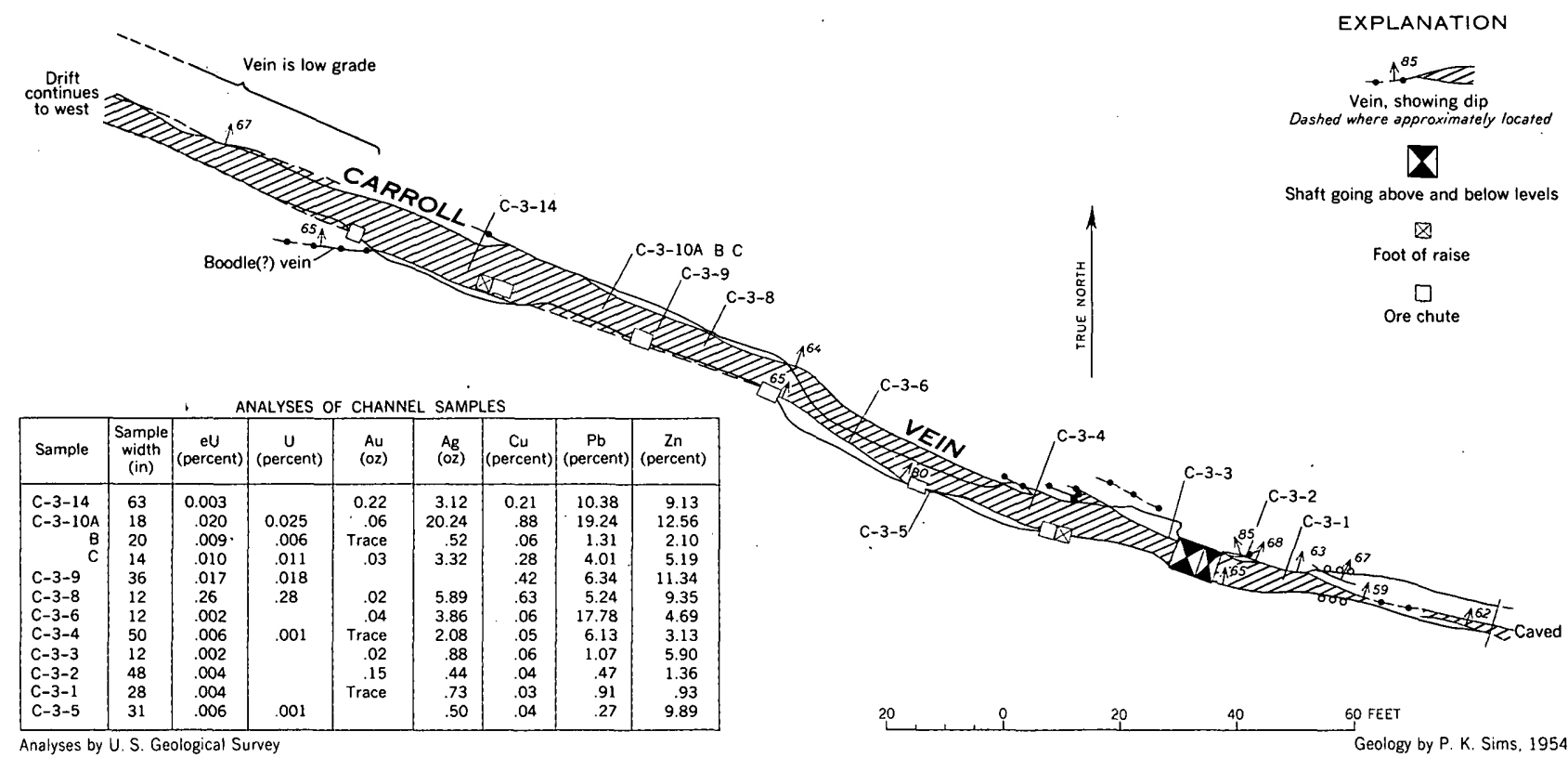

Figure 14.-Assay map of part of the 228 level, Carroll mine.

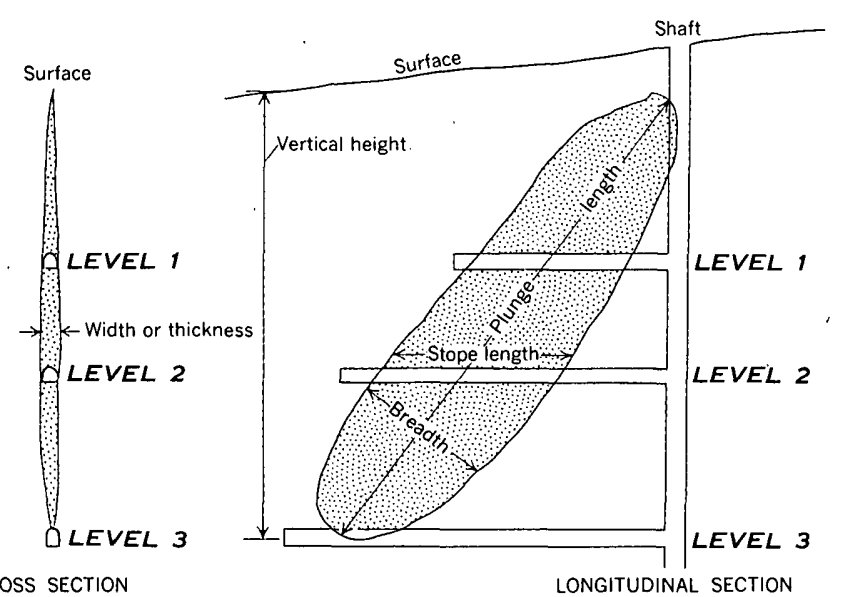

Figure 15.-Diagram lllustrating the terms used to describe the dimensions of ore shoots.

shoot at the Pittsburg mine (fig. 62) has a known plunge length of 1,100 feet and a breadth of 200 to 500 feet. The ore shoot seems to be larger in the lower levels of the mine, and according to the miners, it is equally as high in grade on the deepest level as it was above. An ore shoot of unusual dimensions was mined in the Gunnell lode (pl. 1). This ore shoot, which apexes east of the Gunnell shaft, was mined nearly continuously to the Concrete mine. It has a plungelength of about 3,000 feet and a stope length of 300 feet. Some ore shoots mined on Bobtail Hill, and adjacent areas, also were large, but little data concerning their exact dimensions are available. More com- monly the ore shoots are small and have maximum dimensions of a few hundred feet or even a few tens of feet.

The uranium ore shoots, which in part are distinct from the more common precious and base-metal ore shoots, are small and rarely exceed a few tens of feet in maximum dimension; descriptions of these are given by Sims (1956) and Sims and others (1963).

The ore shoots at the Eureka mine, in Prosser Gulch (fig. 16), which are typical of many in the district, have a well-defined rulerlike shape. They plunge about $60^{\circ} \mathrm{W}$.; so far as known the long dimensions (plunge length) have not been defined. The great stope length shown in the upper part of the mine presumably is due largely to mechanical enrichment of gold in the oxidized part of the vein.

At least one vein ore body has a pipelike shape. This body, which occurs in the Powers mine along the New Brunswick vein, is about 100 feet in diameter and extends from near the surface to a depth of more than 400 feet. The internal structure of the ore body is unusual, for it consists of many irregular, branching inch-thin veinlets, which at places coalesce, the whole resembling a spider web. The walls are poorly defined.

The ore shoots commonly constitute a small percentage of the explored ground of a single vein. Judging from available stope maps they generally comprise less than 25 percent of the explored ground, and commonly only part of the ore shoots can be economically mined. In a few mines, ore shoots comprise a large 


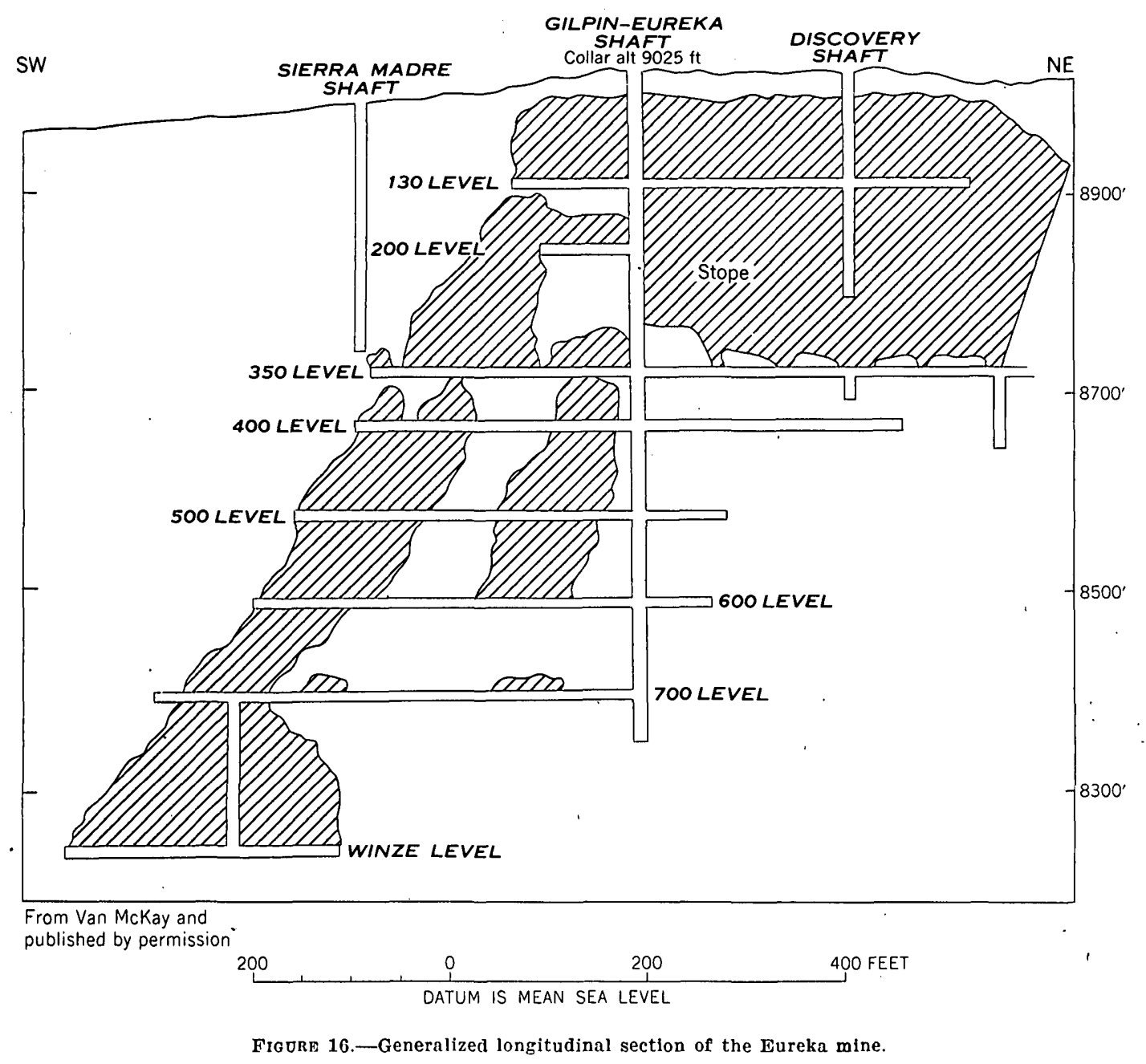

percentage of the opened ground; notable examples are the Chase mine (fig. 56) in lower Russell Gulch, the Widow Woman mine in Pleasant Valley, and the Iron mine (fig. 47) in upper Russell Gulch.

\section{REGIONAL ATTITUDE}

With few exceptions the ore shoots have a consistent direction of plunge that can be related to dips of the limbs of the Central City anticline (fig. 4), the dominant structural feature in the bedrock of the district. The ore shoots within veins on the northwest flank of the anticline consistently plunge westward, whereas the ore shoots within veins on the southeast flank mainly plunge eastward. Because of the greater complexity of the minor folds on the southeast limb of the anticline, and other factors discussed later, there are some exceptions to the generalization on this flank.

Nearly all known ore shoots in the Nigger Hill, Nevada Hill and Prosser Gulch, and Quartz Hill areas plunge westward, at angles ranging from $20^{\circ}$ to nearly vertical. The valuable ore bodies along the Carroll, Gunnell, and Prize veins plunge gently to the west and the ore bodies along the Eureka, Essex, Hubert, California, Delmonico, and Wood reins plunge steeply to the west.

The little known and relatively insignificant ore shoots in veins in the Chase Gulch, Maryland Mountain, and Winnebago Hill area are less consistent, but most plunge southwestward.

A large proportion of the ore shoots east of the axis of the Central City anticline (fig. 4) plunge eastward. Within the area of Willis and lower Russell Gulches, most of the known ones plunge steeply to moderately east or northenst. Examples of ore shoots having this plunge direction are the Chase, East Notaway, Meeker, Pittsburg, and Two-Forty mines. The dominant direction of plunge of ore shoots that have been mined in the area of Central, Mammoth, Gregory, Bobtail, and Bates Hills is northeastward, and nearly all of 
the ore shoots plunge more than $60^{\circ}$. The known ore shoots along the veins in the Silver Hill area also plunge northeastward.

\section{STRUCTURAL CONTROLS}

As the veins formed mainly by filling fissures, the ore shoots occur in what were the open parts of the faults. The amount and type of openings that were formed were determined by the amount and direction of fault movement, the physical nature and structure of the wallrock, and the irregularities along the fractures themselves. A chemical control for ore deposition can be largely discounted, for the wallrocks were altered to rather uniform sericite- and clay-bearing rocks before sulfide ore deposition.

Several geologists previously have studied the structural controls of ore bodies in the mining districts of the Front Range mineral belt. Lovering (1942, p. 7993) has summarized the known controls and has given examples of the types of various structural features that have influenced ore deposition in this vast region. Much additional data specifically concerning the Central City district have been presented by Lovering (1930), Lovering and Goddard (1950, p. 177-178), Bastin and Hill (1917, p. 95-96), and Collins (1913; 1930).

The dominant structural controls in the district are those related to vein intersections and junctions and to the physical character and structure of the wallrock. These controls, in part in conjunction with one another, account for most of the significant ore shoots. Ore shoots related to deflections in the veins, and to other irregularities along the fissures themselves, are abundant but rarely responsible for localizing large valuable ore bodies. Ore shoots that occur in stockworks are represented by the Patch, a volcanic explosion breccia.

\section{PHYSICAL CHARACTER OF THE WALLROCK}

The wallrock had a marked influence in localizing ore shoots. The chemical character of the rocks, so far as known, had little effect on ore deposition, and the explanation of most ore bodies is to be found in the mechanical reaction of the rocks to fracturing. Hard, brittle rocks are the common wallrocks of the persistent ore shoots, whereas soft, weak, plastic rocks rarely form the walls of large, high-grade ore bodies.

Within the district, the major types of wallrocks, in order of decreasing relative competency to fracturing, are microcline-bearing gneiss (the granite gneiss of Bastin and Hill), granite pegmatite, migmatite, interlayered biotite gneisses, and amphibolite and quartz diorite. Skarn and lime-silicate gneiss should react as brittle materials to fracturing and therefore should be favorable wallrocks, but these rocks were not observed to form the walls of any vein. Granodiorite probably has a relative competency similar to the biotite gneisses.

Microcline-bearing gneiss forms the wallrock of many ore shoots, and the importance of this rock in localizing ore has been emphasized previously (Bastin and Hill, 1917, p. 95-96 and 104; Lovering, 1930, p. 244-250; and Lovering and Goddard, 1950, p. 177). A layer of microcline-bearing gneiss (fig. 20), about 3,000 feet thick, crops out along the axis of the Central City anticline (fig. 4) and constitutes the wallrock for a large proportion of the veins of the district; it contains many thin layers and lenses of biotitequartz-plagioclase gneiss and other related metasedimentary gneisses. With few exceptions the ore shoots within the layer are confined to those parts of the veins having walls of the more competent microclinebearing gneiss. This relation is clearly shown at Quartz Hill. In this area the layer contains two thin continuous layers of biotite-quartz-plagioclase gneiss that lie at shallow depths (fig. 17). The ore in the German, Alps (fig. 23), Kirk, and Wood-East Calhoun mines (Drake, 1957) occurs in the competent microcline-bearing gneiss but not in the biotite-quartzplagioclase gneiss. Because the veins pinch markedly in the biotite-quartz-plagioclase gneiss layers, many mines have been bottomed in this rock (fig. 17).

In the eastern part of the district, where the country rock is dominantly biotite gneiss, some ore shoots are localized between migmatite or pegmatite walls. The regional importance of this lithologic control is little known, however, because most mines in the area where biotite gneiss and pegmatite are the dominant wallrocks are not accessible. Migmatite seems to have localized the ore at the Meeker-Success mine (p. 149 ; fig. 59).

At places a sequence of intimately interlayered granitic and metasedimentary rocks of varying competency apparently led to the formation of more open space than thick sequences of either type of rock. In the interlayered sequences, vein fissures deflect each time they pass from a unit of one competency into one of another. As vein splitting and brecciation commonly takes place where a vein curves, recurrent movement developed considerable open space at these locations. The formation of open space in this manner has been described from many localities (Newhouse, 1940; McKinstry and Svendsen, 1942). Within the Central City district, Collins (1930, p. 261 and 263-264) was the first to suggest that open space could be produced in an interlayered sequence of rock by 


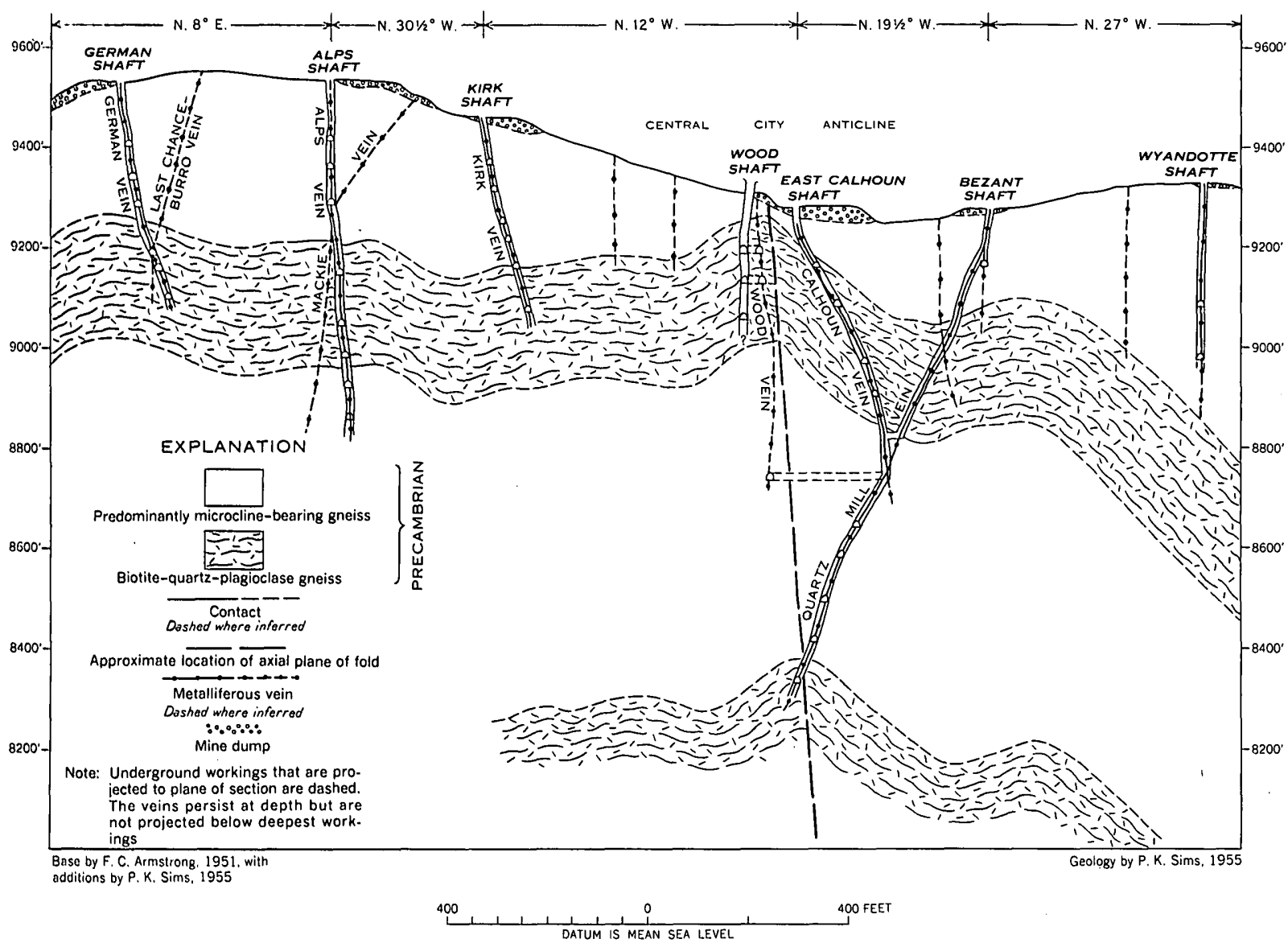

Fiodra 17.-Geologic section through part of Quartz Hill, showing relation of mine workings to layers of biotite-quartz-plagioclase gneiss within the major layer of microcline-bearing gneiss.

fracturing along the unit contacts. He states that he observed such features in some of the old bonanza stopes of the Gunnell mine. During our investigation we noted this at several mines, and an example at the Carroll mine was described previously (Sims, 1956). Another example of ore bodies located in a vein that traverses rocks of different competency is afforded by the California vein. Nearly everywhere the vein follows a dike of bostonite porphyry, and its swings from one wall to the other. Collins (1930, p. 263) reports that miners who were familiar with the mine told him that those places where the rein crossed the dike were especially favorable for ore bodies, presumably because of the increased open space produced by deflections in vein strike and dip.

\section{STRUCTURE OF THE WALLROCK}

Many veins in the district, are wide, persistent, and mineralized where they cross the foliation at a large angle; they are weak and barren where they parallel the foliation. The Gunnell lode, for example, is extensively mined where it crosses the foliation of the microcline-bearing gneiss at a marked angle, but it is nearly barren where it frays out into many small veins that parallel the axial planes of small, tight northeastward-trending folds. The veins that have been developed in the Widow Woman mine in Pleasant Valley clearly show variations in width and mineral content that can at least in part be related to similar structural relations (fig. 69). The Widow Woman vein, the principal source of ore in the mine, is nearly normal to the foliation and to tight folds in the biotite gneiss country rock, and it is generally about 2 feet wide. The Gold vein, on the other hand, is subparallel to the foliation and nearly barren; at places it consists wholly of gouge. Vein $A$ is intermediate in its relation to the Precambrian rock structure, cutting the foliation at a small angle; it also is intermediate in width and metal content.

In general, throughout the region, those veins which occupy steeply dipping faults contain the most valuable ore bodies where they cut the foliation of the wallrocks at the greatest possible angle. For example, given a general southeast dip for the rocks, the northwestward-dipping segments of a northeastward-trending fault are more favorable for ore than the south- 
eastward-dipping segments. Possibly this structural control was dominant in localizing ore within many of the steep veins near the townsite of Central City. Similar relations between vein structure and wallrock structure have been described from other areas by McKinstry and Svendsen (1942) and Koch (1956, p. 25-27).

The structure of the wallrock not only influenced the strength of the vein fissures and the occurrence of ore shoots, but it also influenced to a marked degree the angle and direction of plunge of the ore shoots. The remarkable consistency in the plunge directions of ore shoots on opposite sides of the Central City anticline axis can be attributed partly to the structure of the bedrock. The ore shoots tend to plunge parallel to the intersection of the foliation and the vein fissure; hence they plunge in a direction away from the fold crest. This relationship seems to hold even though individual ore shoots are partly due to a variety of other structural controls or combinations of structural controls. The foliation surfaces in the bedrock represent a preferred direction of weakness that becomes relatively more open during fracturing. An example from the Carroll mine on Nigger Hill was described in an earlier report (Sims, 1956).

\section{IRREGULARITIES ALONG A FAULT}

Irregularities of many types along a fault surface locally are the loci of sizable ore bodies. The irregularities of gireatest importance in the district are branching fissures and deflections in strike or dip. The deflections can be caused by intersection with foliation planes, by changes in competency of the rocks, by preexisting fractures, or other directions of weakness.

In a fault, as is well known, the irregularities of the original fracture will cause certain parts of the broken surface to rub together during movement while others pull apart. If the relative direction of movement is known, the change in attitude (deflection) which should result in opening may be expressed by a simple rule (McKinstry, 1948, p. 321) : draw a pair of arrows indicating the relative direction of movement of the two walls and draw a diagonal line connecting the tail of arrows. A swing of direction of the fracture toward parallelism with this line is favorable for the development of openings. A swing away from it toward a line connecting the heads of the arrows is unfavorable. Similar conditions occur in veins that are deflected in dip. In veins in which the hanging wall has moved down with respect to the footwall (normal fault) a steepening of the vein is favorable for the development of openings; in veins in which the hanging wall has moved up with respect to the footwall (reverse fault) a flattening of the vein is favorable for the development of openings.

Deflections in strike clearly were the loci of several small ore shoots in the district. Examples of ore localization of this type are noted in the Advance, Hayseed, Gregory, Running Lode, Golden Dollar, Hecla, Old Town, Pewabic, and Springdale mines. For details of these ore shoots the reader is referred to the section on the mines.

A few ore bodies can be related to changes in dip of a vein. As the faults that have a known vertical component of movement are largely normal faults, that is the hanging wall is displaced downward relative to the footwall, the openings of this origin are mainly on the steeper part of the veins. Ore bodies of this origin are present in the Hubert, East Pewabic, Old Town, and possibly also in the Bezant and Iron mines.

At many places deflections in strike or dip are subtle features that can be distinguished only by very detailed study. Where a control of this type is suspected, it is desirable to contour the surface of the vein with reference to an inclined datum plane (Conolly, 1936).

Splits, branches, and other subsidiary fractures related to the main veins are common and are important loci of ore locally; they are most abundant in lodes, as the Mammoth and Gunnell. Ore bodies related to these structures generally occur in thin wedges of brecciated rock close to the points of divergence of the branches. At many places, vein splits surround "horses" of country rock; commonly the horses are intensely altered and fractured and at places they contain sufficient metals to constitute ore. Lodes consisting of 2 or more subparallel veins not uncommonly are 5 to 10 or more feet wide. The ore shoots are localized to a large extent where the separate veins are closely enough spaced so that the intervening wallrock is substantially fractured and mineralized. In many lodes the intervening ground is sheeted and it contains veinlets of ore minerals that are nearly parallel to the larger veins; but in other lodes the ground between the footwall and hanging-wall veins is brecciated rather than sheeted, and the ores occur as cockade growths around the broken wallrock fragments.

Some veins pass at depth and laterally into a series of en echelon fractures and minor branch veins whose pattern is similar to the typical horsetail structure at Butte. This is well illustrated by the Concrete vein about 200 feet below the Argo tunnel level (Lovering and Goddard, 1950, fig. 30, p. 96) and by the Mammoth vein (fig. 36). In the veins that curve mark- 
edly from their general trend just before they feather out, an overlapping fracture commonly can be found a short distance into the wall away from the direction of curve. Thus, if a vein curves to the left as it feathers out, the overlapping vein will be found on the righthand side of the vein, as is illustrated by the Mammoth vein (fig. 36). In contrast to this behavior, however, many veins die out in a zone marked by many horsetail branches concentrated on one side or the other of the general trend of the vein. In such cases, the main vein has usually "jumped". a short distance in the horsetail direction. Thus, if the horsetail branches enter the right wall of the vein an overlapping vein may be found to the right, as is illustrated by the Pewabic vein (pl. 9).

\section{VEIN INTERBECTIONS OR JUNCTIONS}

Many valuable ore shoots occur at the intersection or junction of two veins; probably this structure accounts for more valuable ore bodies than any other single structural control in the district. Large ore bodies known to occur at vein intersections or junctions are in the Gunnell, Concrete, Eureka, Prize, Widow Woman, Nemaha-Cotton, Alps, Egyptian, Iron, Old Town, and other mines. The term "intersection," as used in this report, refers to vein crossings, which geometrically produce an X-shape; the term "junction" refers to veins that merge, to produce a Y-shape.

Commonly ore shoots occur where veins intersect or join at acute angles. In general, the more acute the angle of intersection the greater the brecciation and fracturing that can be expected. If one of the two intersecting faults is later than the other, it may pull the walls of the first apart slightly. As the displacement along the faults was slight, vein crossings at high angles generally did not result in large openings or in great brecciation at the place of crossing.

The position of maximum open space formed at acute vein intersections or junctions varies considerably, and as a result ore bodies are localized in many different positions with respect to the intersections. Common sites of brecciation and of ore deposition are shown by the schematic drawings in figure 18 . In several veins the ore shoots at vein junctions occur in the shank of the $Y$ as shown in figure $18 \mathrm{~A}$. The favorable ground is produced east of the junction, where the younger fault (2) was deflected by and joined the older fault (1). The brecciation diminishes westward as the stresses were taken up along the older fault surface. Typical examples of this type of ore body are in the Gunnell, Essex, and Carroll mines. The ore shoot on the Gunnell lode is described on page

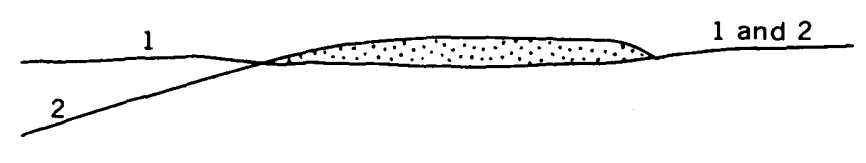

$A$

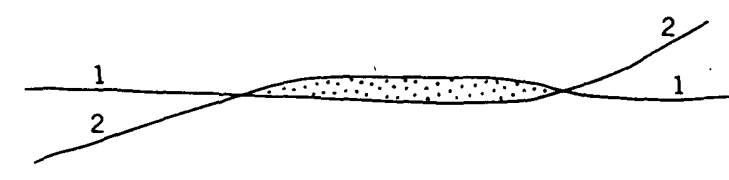

$B$

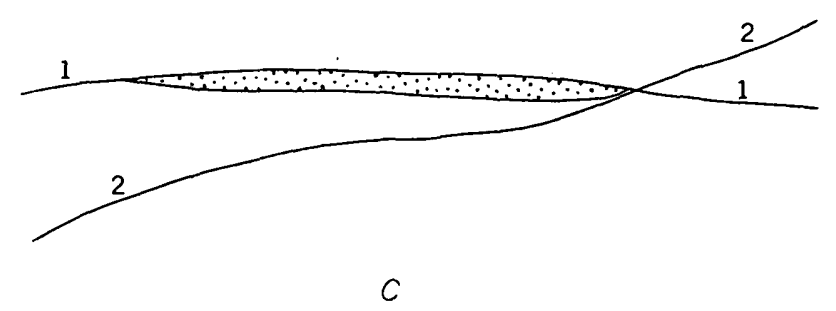

FIGORE 18.-Schematic sketches showing the relation of ore bodies to vein intersections and junctions.

111. At the Essex mine a footwall vein joins with the main (Essex) vein a short distance east of the Patterson shaft (pl. 5). East of the junction, an ore shoot about 60 feet in length is formed in the shank of the $Y$; both veins are only weakly mineralized west of the fork in the $Y$. The opening was developed largely by brecciation along the main vein, which presumably is the earlier of the two intersecting faults. A highly mineralized ore shoot at the Carroll mine occurs at the junction of the Boodle(?) vein with the Carroll vein. As shown in figure 14, a marked increase in width and tenor of the vein occurs in the shank of the $Y$-junction. For the most part the openings were formed by brecciation and the ore is largely cockade ore. Neither the Carroll nor the Boodle(?) vein is ore bearing west of their junction on the 228 level. In the stope, at a height of about 30 feet above the level (fig. 19), the wedge of rock between the veins is brecciated and sheared and constitutes ore; whereas the vein is nearly barren in the shank of the $Y$, a short distance east of the junction. 


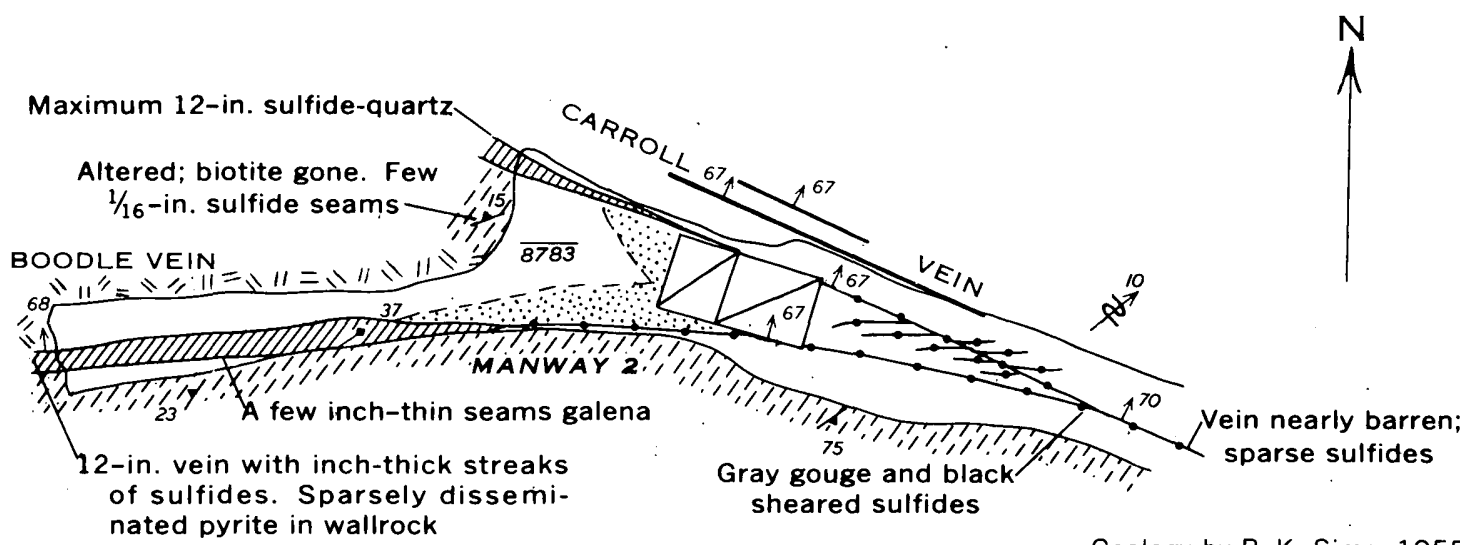

EXPLANATION

Geology by P. K. Sims, 1955

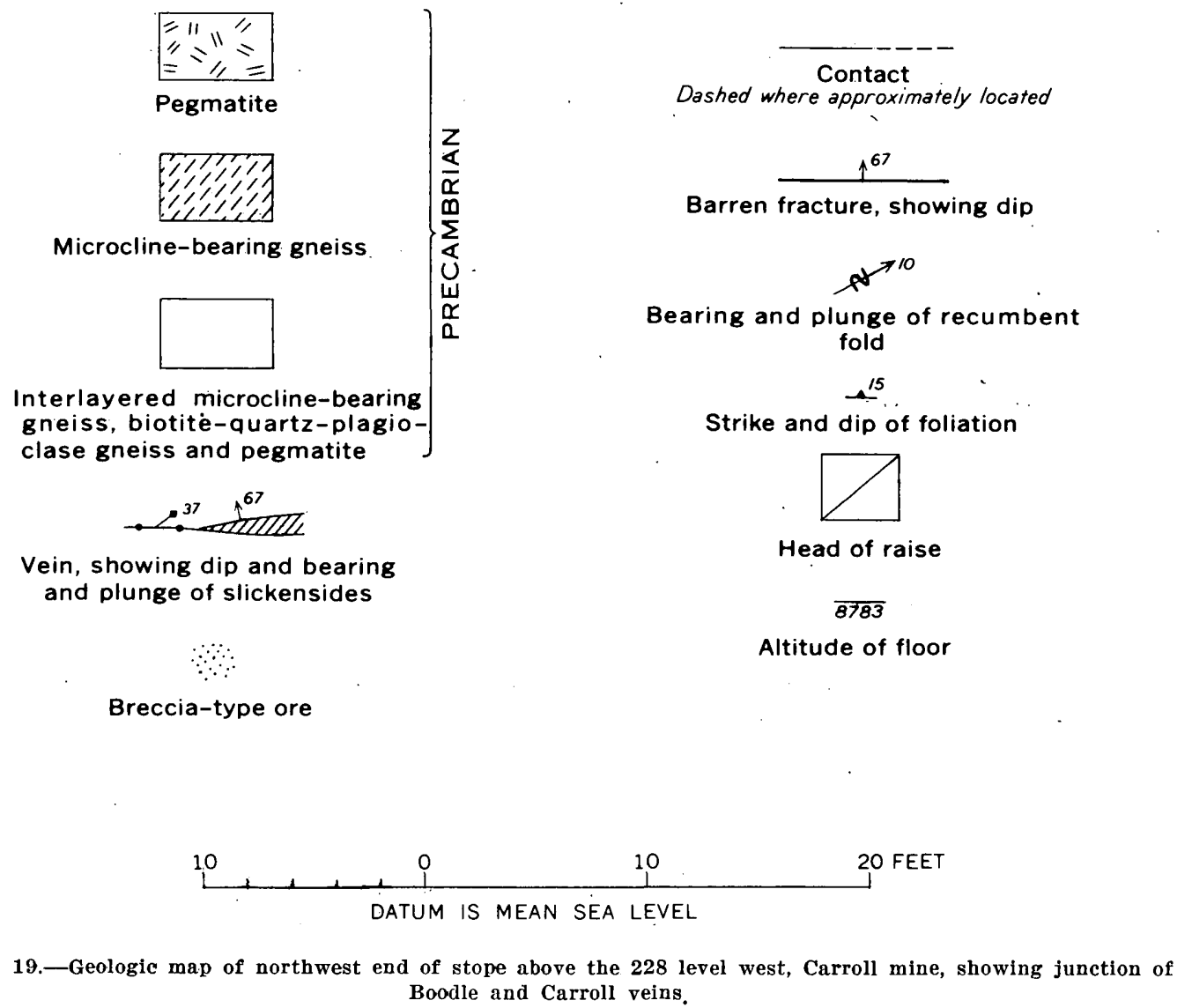

At places ore bodies of similar structural occurrence differ only in that the veins cross to form a true intersection, as shown in figure $18 \mathrm{~B}$. The younger fault (2) is deflected at the older fault (1); it follows the older break for a distance, then breaks across this fracture and resumes its normal course.

Where the convergence of two faults is very gradual, a long, narrow wedge of rock between the faults may be mineralized, as shown in figure $18 \mathrm{C}$. One or both faults away from the intersection may also con- tain ore. At the Widow Woman mine (fig. 69; see 203 level), the Widow Woman vein is ore bearing for about 100 feet west from the intersection, but vein $A$ is not productive.

\section{EXPLOSION BRECCIAS}

The volcanic explosion breccia at the Patch on Quartz Hill was a favorable host for ore deposition. It provided an ideal conduit for the mineralizing fluids, and the occurrence of ore is directly related 
to the relative permeability of the breccia. As stated previously (p. 25), the breccia pipe formed before the faults that contain the ore bodies; where the faults penetrate the breccia pipe, brecciation is intensified, the fragments are more intensively altered, and ore minerals are more abundant. The ore-forming fluids probably entered the Patch primarily along the faults and penetrated outward and upward into the breccia to form a stockwork.

\section{Persistence at Depth}

The depth to which the primary ore deposits extend probably is in excess of that observed in the deepest mine workings on any single vein, but the ultimate depth of profitable mining, with few exceptions, probably is not far below the present deepest openings.

The vertical range of known ore within the veins of the district is about 2,500 feet, between altitudes of about 9,500 feet (top of Quartz Hill) and 7,000 feet (deepest mine penetrations). The veins at the higher altitudes do not differ in any important respect from those at lower altitudes, and there is no evidence within the district for either an upper or a lower limit of effective mineralization.

Several mines in the district have reached depths in excess of 1,000 feet and one mine-the Californiahas been worked to a depth of 2,200 feet. At the lowest limit of exploration in each mine the veins are almost as strong, and so far as known, the ore shoots are comparable in size and grade to those nearer the surface; but because of the proportionally greater expense of exploration and development at these depths, mining was not profitable. According to Collins $(1930$, p. 254-259), the retort-gold content from the 2,200 level of the California vein compared favorably with that from higher levels. He states also (p. 256) that the 2,200 drift west was not extended suffciently westward to cut the ore shoot that was mined on the 2,000 level. Forbes Rickard (1898, p. 122), who examined the lowest levels of the mine, reported

In the deepest mining, that of the California mine just instanced, the lode shows no essential change of character in Its deepest developments; and although sinking on that vein has been abandoned for some years, my familiarity with its lowest levels prompts me to say that had it not been that the main working-shaft of this mine was several hundred feet away from the main ore chute (shoot) of its workings, this mine would have been working today at good profit in still lower depths. Work on this vein is now almost wholly confined to its western extension, where it has been In bonanza for the last three years, at a depth ranging from 600 to 1,000 feet.

The veins exposed in the deep workings from the Cook shaft on Gregory Hill similarly are not notably 654827 0-63-6 different in metal content from the primary ore at shallower depths. A report by W. A. Farish, quoted by Bastin and Hill (1917, p. 226), states that the Fisk-Mammoth vein still contained fair metal concentrations on the lower levels; and Collins (1930, p. 254) reports that there was good ore on the lower level of the Bobtail tunnel workings, at an altitude of about 7,100 feet. Miners who have worked in the Pittsburg mine report that the ore within the bonanza ore shoot (fig. 62) is as good or better on the 1,100 level as on higher levels. Mining was suspended because the ore shoot, which has a marked plunge to the east, was too far from the shaft at the bottom of the mine to justify the cost of further development work. The ore from the Gunnell lode mined from the Argo tunnel according to G. E. Collins (written communication) "was almost exactly the same as the average produced from the Gunnell between 1876 and 1902." Probably many of the shoots on less significant veins also continue to depths in excess of present mine openings.

Although the depth to which the ore deposits extend depends upon several factors, one of the most important of these is the type of wallrock. Near the surface open fractures may be present in all types of wallrocks regardless of relative competency. As depth increases, however, the fissures in the less rigid rocks become tight because of higher confining pressures and only those in the stronger wallrocks tend to persist. This relation of wallrock fracturing to depth is evident throughout the district, for profitably worked veins in the weak biotite gneisses are more abundant at high than at low altitudes, and all of the deeper ore shoots are confined by the harder wallrocks.

Most of the veins that have been profitably mined in the Central City district are in the microclinebearing gneiss, the most competent wallrock in the district. Mining has demonstrated that the large veins in this rock persist to the greatest depths attained in mining, but that upon entering the less competent biotite gneisses they fray out or pinch down and become unprofitable.

Because of the importance of a favorable wallrock to profitable deep mining; a geologic section was prepared along the line of the Argo tunnel (fig. 20) to show the inferred distribution of microcline-bearing gneiss and other principal rock units. As can be seen in the section, the layer of microcline-bearing gneiss that contains many of the large ore bodies in the Central City district constitutes the walls along much of the length of the tunnel. Also, aside from an area near the Patch, which is on the axis of the Central City anticline, the bottom of the gneiss layer gener- 
ally lies well below the tunnel level. We infer that high-grade ore bodies in large continuous veins such as the Gunnell, Kansas, Burroughs, California, Saratoga, and Gem, which were profitably mined at the tunnel level as well as near the surface, will persist locally until the veins pass downward out of the microcline-bearing gneiss layer into the less competent biotite gneisses. Accordingly, mining below the tunnel level here and elsewhere in the area may be feasible at places, providing that economic conditions are favorable. Other ore shoots can be expected to occur at depth where pegmatite constitutes the vein walls, but because of the erratic nature and generally small size of bodies of this rock, the ore shoots in this environment may be too small for economic extraction.

\section{WALLROCK ALTERATION}

The wallrock adjacent to every vein fissure, regardless of its size, attitude, or relative age, is altered to varying degrees. A zone of hard sericitized rock adjacent to the vein is succeeded outward by a zone of soft argillized rock, which grades into the fresh rock. The width of the total alteration envelope commonly exceeds the width of the vein filling. The altered wallrocks in the district were studied by the use of modern clay-mineralogy techniques, and the results of these investigations are to be given in a separate comprehensive report by Tooker (1963); a preliminary report was published previously (Tooker, 1956).

Because most of the mine workings accessible during our studies are relatively shallow, it is not possible to clearly distinguish between hypogene and supergene alteration. Probably most of the veins examined have been affected by solutions of both types, but owe their character mainly to hypogene altering solutions. It is clear, though, from studies in the mines on Nigger Hill (Sims and others, 1955, p. 16$17)$, that in the supergene zone of alteration the clay mineral zones are widened at the expense of the sericite zone and that montmorillonite is the most abundant alteration mineral stable in this environment. A secondary biotite with a random orientation also is characteristic of the supergene zone.

\section{DISTRIBUTION OF ALTERATION PRODUCTS}

The alteration minerals are arranged in zones parallel to the vein fissures, and the zones, although arbitrarily established, can be recognized megascopically. The zones, including the fresh wallrock, are:

Zone 1. Fresh wallrock.

Zone 2. Weakly argillized rock. The rock is hard, and the original structures and textures are preserved. The plagioclase feldspar crystals have a dull luster or may be completely converted to pseudomorphs consisting of the clay mineral montmorillonite. Biotite and quartz are unchanged.

Zone 3. Strongly argillized rock. The rock is soft and composed dominantly of clay minerals. The primary textures, if preserved, are indistinct. The zone can be subdivided on the basis of the dominant clay mineral into three subzones:

a. Montmorillonite-rich rock. Commonly occurs along weakly mineralized or altered shear surfaces, joints, or foliation surfaces. This rock constitutes the most intensely altered phase in the near-surface supergene environment. The rock is green, olive-green, or white.

b. Kaolinite-rich rock. Characteristically is white; kaolinite always is mixed with illite-sericite and rarely with montmorillonite.

c. Illite-rich. Locally includes sericite in the more intensely altered parts of the zone.

Subzone $a$ is less intensely altered than subzones $b$ and $c$, which are about equally altered. The illiterich subzone generally is nearest the vein. Biotite locally remains in zone 3 ; where altered in different degrees it ranges in color from black to brownishgreen (chlorite-biotite) to gray-white (illite-sericite). Potassic feldspar is partly altered to kaolinite, illite and minor montmorillonite; quartz is partly corroded and recrystallized.

Zone 4. Sericitized rock. Sericitized, or intensely altered rock, is hard and original structures and textures are obliterated. Quartz and some potassic feldspar are recrystallized, clay minerals are converted to sericite, and disseminated pyrite forms in the wallrocks.

In contrast to the typical alteration pattern, the wallirocks containing sparse quartz and potassic feldspar, as amphibolite, do not have a well-developed sericite-quartz zone adjacent to the vein. Instead, the altered rock in zone 4 as well as zone 3 consists dominantly of a soft, dark-green clay which has no relict textures. The clay is composed of montmorillonite, illite, mixed-layer clay (montmorillonite, illite, and hydrobiotite), and minor kaolinite. In zone 4, sparse, randomly oriented, fragile, white sericitelike and dark, well-crystallized biotite are dispersed through the green clay.

The width of the alteration envelope, and of the successive zones constituting it, commonly is greater in the central and intermediate zones than in the peripheral zone (fig. 11). In the peripheral zone the alteration sheath varies from a few inches to rarely 5 feet in width on either side of the vein, and it con- 


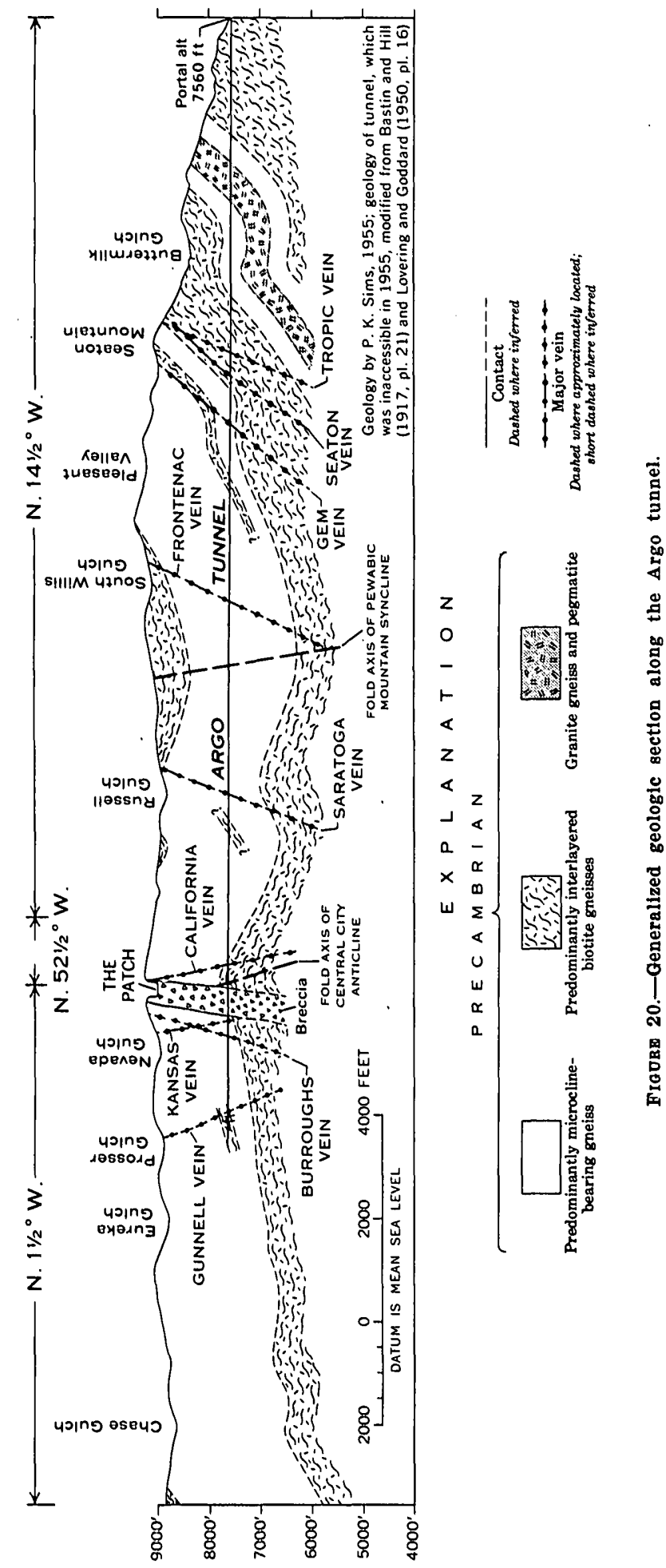

sists dominantly of clay minerals (zones 2 and 3 ). The sericite zone (zone 4) on both walls generally is narrow and rarely exceeds a few inches in width. In many veins the alteration envelope varies markedly in width along strike, widening at vein junctions and other structural openings, and pinching, at times to a featheredge, along "tight" parts of the fissures. Not uncommonly narrow parts of the veins have wider alteration halos than correspondingly wider parts of the veins. In the areas of pyrite veins in the central. and intermediate zones (pl. 1) the alteration sheath generally is several feet wide, commonly exceeding 5 feet and locally is greater than 10 feet wide. It is also uniform in width. Concomitant with a greater total width, the sericite zone (zone 4) is notably wider, and it contains moderate to abundant disseminated pyrite. In several veins in this environment the hard sericite zone exceeds 1 foot in width.

\section{MiNeralogic aND CHEMICAL CHANGES IN THE WALLROCKS}

The mineralogic changes that took place during alteration of the wallrock involved the destruction of primary silicate minerals and the formation of an assemblage of clay minerals, sericite, recrystallized quartz, and locally potassic feldspar The net chemical changes occurring during the alteration seem mainly to have been readjustments of the cations and rearrangement of the fundamental silicate structure.

The stability of the minerals under attack by the altering solutions corresponds to the reverse of Bowen's reaction series (Bowen, 1922); that is, the minerals formed early at high temperatures are least stable in the alteration environment. The stability ranges of the primary minerals and their alteration products, with regard to the zones of alteration, are shown in figure 21. Plagioclase (oligoclase-andesine) is the first mineral to show a response to the changing environment, altering to clay minerals of the montmorillonite, illite, and mixed layer types. Hornblende breaks down shortly after the plagioclase begins to change, altering either directly to hydrobiotite, chlorite-montmorillonite, or to biotite, which subsequently changes to hydrobiotite and montmorillonite. The potassic feldspars are metastable relict. constituents in zones 2 and 3 but again are stable with sericite in zone 4 ; possibly therefore the potassic feldspar in zone 4 is recrystallized. Biotite is stable to the veinward edge of zone 3 , where it alters abruptly to illite and montmorillonite clays through an intermediate chlorite or bleached mica stage. Quartz is recrystallized in zone 4, but its abundance is constant throughout all zones. Magnetite-ilmenite changes to leucoxene 


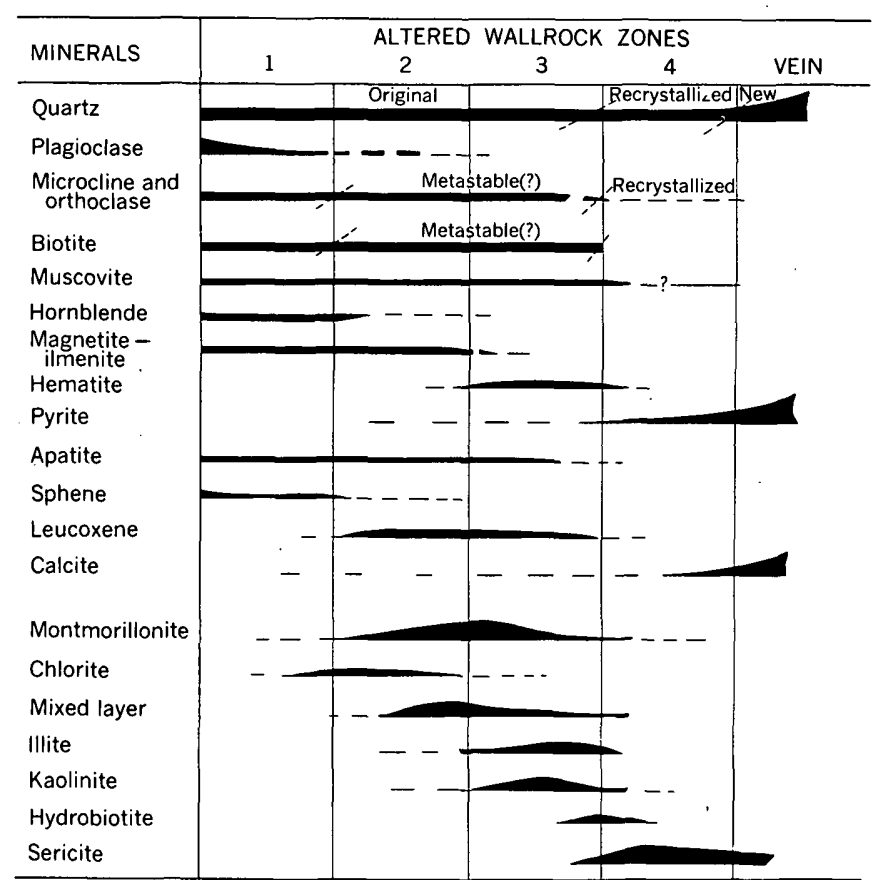

Figure 21.-Generalized mineral stabillty ranges across the altered wallrock zones in the Central City district, Colorado.

and hematite, which in turn change to pyrite; some pyrite in zone 4 appears to be an alteration product of biotite.

Individual clay minerals are not derived from specific parent silicate mineral; instead, several clay minerals may originate from the feldspars and micas. Montmorillonite and chlorite appear first in the less intense alteration environments, and other clay minerals (and sericite) appear later as the intensity of the alteration increased, simply by structural-chemical reorganization of the existing minerals. Mixed-layer clay minerals composed of a random interstratification of clay minerals are prominent in the altered rocks. Mixtures of montmorillonite-illite, montmorillonite-chlorite, and vermiculite-illite (hydrobiotite) are the most common of the mixed-layer clay minerals occurring in zones $1-4$.

The changes in chemical composition and in structure of the minerals were complex during alteration and only a brief summary is given herein, as detailed studies of these changes are described in a report by Tooker (1963).

Chemical analyses of samples taken from the altered wallrock zones show that as the vein is approached, the rock is progressively enriched in potassium, iron, aluminum, and carbon and depleted in sodium, calcium, and magnesium. Silicon concentration is re- duced in the zone 3 (clay mineral) rock but increases again in zone 4. Water as (OH) is markedly increased in zone 3 rock. Trace elements characteristically follow the distributions of the major elements, which they diadochically replace in mineral structures: barium and lead follow potassium; strontium, yttrium and lanthanum follow calcium; gallium follows aluminum; gallium and indium follow zinc; the iron group, manganese, titanium, chromium, cobalt, and vanadium follow the iron; and magnesium is distributed in silicate-oxide minerals but not in sulfides. Lead, zinc, silver, and iron have a strong affinity for sulfur and calcium for $\mathrm{CO}_{2}$ and are concentrated in the veins.

\section{SUPERGENE ALTERATION}

The upper parts of the sulfide veins, subsequent to their formation, have been altered by surficial. waters and atmospheric gases. The principal change affecting the mineralogy and economics of the ores was an enrichment of gold in-the oxidized zone and a local enrichment of silver in the zone of supergene sulfide enrichment. Uranium was leached from the oxidized zone, but it was precipitated locally at and above the water table as yellowish-green secondary minerals. The nature of supergene enrichment and the processes affecting the sulfide ores have previously been described by Bastin and Hill (1917, p. 137-152) and Lovering and Goddard $(1950$, p. $88-90 ; 175-177)$; a description of the supergene alteration of the uranium ores is given in a separate report (Sims and others, 1963).

At Central City the zone of oxidation extends to depths generally ranging from about 50 to 175 feet, and it coincides crudely with the ground above present water level. Locally a zone of secondary sulfide enrichment lies at and below the present water table. The zone of secondary sulfide enrichment rarely exceeds 200 feet in thickness and so far as known does not extend much below depths of 300 feet.

Although the depth of the oxidation zone ranges between approximate limits of 50 and 175 feet, there is considerable variation from mine to mine and area to area. Bastin states (Bastin and Hill, 1917, p. 137) that the oxidized ore in the California-Gardner vein extends $/ 85$ to 95 feet below the surface and that in many other veins oxidation extends to depths of 70 to 80 feet. In the Aurora mine oxidation extends to about 150 feet. Recent observations on Nigger Hill indicate that oxidized ore at the Carroll mine extends to a depth of about 100 feet, whereas the oxidation zone at the Two Sisters mines extends a few tens of 
feet deeper. In the Essex mine, in Prosser Gulch, the ores are oxidized to a depth of about 50 feet.

In the oxidized zone the ore minerals underwent partial disintegration, which was accompanied by the prominent development of reddish-brown, hydrous oxides of iron and an increase in porosity. Relatively insoluble minerals such as gold were partly freed from its matrix, and these minerals have largely remained as residual enrichments. The more soluble minerals were taken into solution and redistributed within the veins or carried into surface waters.

During supergene alteration oxidizing pyrite and other: sulfides generate ferric sulfate which is stable at low $\mathrm{H}$-ion concentrations. The common ore minerals-copper sulfides and sulfosalts, sphalerite, galena, silver sulfosalts-and gold are soluble in the acid sulfate waters to varying degrees. The sphalerite is ensily oxidized in these solutions and not only dissolves readily but remains in solution, even though the water changes from acid to neutral or alkaline. So far as known sphalerite was not reprecipitated in the supergene sulfide zone of enrichment in the Central City district. Copper sulfides also are easily soluble in the sulfate solutions but precipitate when the solutions become neutral or alkaline; and in certain copper-rich pyrite veins, chalcocite, minor covellite, and probably also bornite are deposited in a narrow zone of secondary enrichment, commonly together with gold. Galena behaves strikingly different in the oxidized zone. Although galena exposed at the surface is quickly filmed over with a thin coating of sulfate or carbonate, both of these compounds are so insoluble that they protect the galena from further change. Galena, coated by cerussite and locally also a thin film of smithsonite, is commonly found, therefore, in the oxidized zone of certain veins, particularly in the galena-sphalerite veins. Silver is readily soluble in acid sulfate solutions but is easily precipitated by many substances. Neutralization of the acidity is sufficient to precipitate native silver, and hydrogen sulfide readily precipitates silver as the sulfide. Where silver-bearing sulfate solutions attack sulfosalts of copper below the zone of oxidation, the silver generally reacts to form one of the complex silver sulfantimonides or sulfursenides of the ruby-silver group. Gold, though noted for its general resistance to solution, is soluble in the upper part of a vein under certain conditions that are not well understood; it may also be carried mechanically in the meteoric acid waters. It is deposited in the oxidized zone and at the top of the supergene sulfide zone.

\section{GOLD ENRICHMENT}

The ores in all types of veins are enriched in gold in the oxidized zone. Generally the gold content is increased several fold, and most of the bonanza ores that were mined by the pioneers in the district were of this origin.

The effects of enrichment are most striking in galena-sphalerite veins. The primary ores in these veins generally have a low gold content, commonly containing an average of less than 0.3 ounce to the ton. The oxidized ores, on the other hand, may contain 1 to 3 ounces of gold to the ton. The enrichment is limited to the oxidized vein, and it is largely residual, resulting from the leaching of the sulfides in the matrix. The data indicate little or no enrichment of gold below the water table (Bastin and Hill, 1917, p. 138-140).

The enrichment of pyrite veins is similar to that of galena-sphalerite veins, but bonanza ores were formed more commonly. The primary ores in many pyrite veins have a higher gold content than the primary ores of galena-sphalerite veins, but rarely is the gold content as much as an ounce to the ton.

Gold enrichment was much more important in some areas than in others. Collins ${ }^{2}$ noted that gold enrichment was greater and commonly extended to greater depths in the region adjacent to Gregory Gulch, near Black Hawk, than in other parts of the district. Collins attributed the unusual depth of the enrichment in the Gregory, Bates, and adjacent veins to the fact that the veins trend nearly transverse to Gregory Gulch, and accordingly surface waters tend to be channeled into the oxidized gossans. In contrast, gold enrichment was relatively unimportant in those veins that trend nearly parallel to the streams, as at Nevada Hill. It is interesting to note also that Gregory Gulch contained much richer placers than Nevada Gulch.

\section{SILVER ENRICHMENT}

Silver, in contrast to gold, was secondarily deposited below the oxidized zone in the zone of supergene sulfide enrichment. So far as known, secondary silver minerals are limited to ores in the galena-sphalerite veins. Silver enrichment was notable in the district only in the Silver Hill area, the dominant area of carbonate-bearing galena-sphalerite veins. Probably it also was responsible for the high silver content of the veins in upper Chase Gulch.

In weathering, the silver-bearing minerals in the zone of oxidation are freed from their matrix, and

\footnotetext{
2 Collins, G. E., undated, Early mining history in Gilpin County, private report on file in Denver Public Library, Denver, Colo.
} 
the soluble silver is readily taken into solution. As the minerals characteristic of the pyrite veins are comparatively ineffective in neutralizing the acid sulfate waters that carry the silver, the ground waters carry the silver out of these veins and disperse it. The minerals of galena-sphalerite veins, on the other hand, are effective in neutralizing the acid waters and silver is reprecipitated largely at and below the groundwater table. Carbonate minerals are particularly effective in increasing the $\mathrm{pH}$ of the solutions, and within the district silver enrichment is most conspicuous in the veins that contain appreciable quantities of these minerals. A small quantity of silver may be redeposited in the oxidized zone as native silver and other secondary minerals on unaltered residual chalcocite, enargite, and tennantite. Chalcopyrite also reprecipitates silver from sulfate solutions as a compound whose exact nature has not been determined.

Bastin and Hill (1917, p. 142) recognized two contrasted types of silver enrichment in the Central City region. In one type silver was redeposited as sulfocompounds (proustite or ruby-silver, pearceite, and polybasite) in association with secondary chalcopyrite; and in the other type it was redeposited as native silver in association with chalcocite, bornite, and covellite. The latter association is probably more important quantitatively than the former in the Central City district.

\section{GENESIS OF ORES}

The ore deposits of the Central City district are closely associated in space with the early Tertiary porphyritic igneous rocks, and were formed immediately after the emplacement of the youngest of these rocks; accordingly, in agreement with most previous investigators, we interpret the ores to have been deposited from hydrothermal fluids related to the early Tertiary magmatic activity. Judging from the pattern of the deposits and their distribution relative to the various porphyritic igneous rocks, the diverse ores probably were derived to some extent at least from different immediate sources. The sulfide ores seem to have been formed from fluids given off from a relatively deep seated source, whereas the uranium deposits and possibly the telluride deposits probably were derived from more local, shallow(?) sources.

An estimate of the depth at which the ores were deposited is at best only approximate, for the amount of cover removed since mineralization in early Tertiary time cannot be determined directly. It seems reasonable, however, on the basis of geomorphic evidence (Murray, 1956, p. 1799), the distribution and character of sediments of Tertiary age, and indirect means to assume that the ores formed at a depth be- tween one and two miles. At a presumed depth of $11 / 2$ miles the temperature resulting from the geothermal gradient can be expected to be on the order of $150^{\circ} \mathrm{C}$.

\section{AGE}

Age determinations by the $\mathrm{Pb}^{208} / \mathrm{U}^{238}$ method on uraninite from the Wood mine. and the Iron mine gave ages ranging from 57 to 70 million years, after suitable corrections were made for common lead. Age determinations by the $\mathrm{Pb}^{210}$ method on uraninite from the German mine gave an age of $58 \pm 3$ million years (Faul, 1954, table 9, p. 263).

This age agrees with the conclusion of Lovering and Goddard $(1950$, p. 47$)$ that the porphyritic igneous rocks and attendant mineralization in this part of the mineral belt are early Tertiary.

\section{ORIGIN OF SULFIDE ORES}

The zonal pattern and mineral assemblages of the sulfide ores are interpreted to have resulted from hydrothermal solutions that moved upward and outward from a source beneath the central zone. Estimates of the temperatures and pressures of these solutions and considerations of the factors contributing to a zonal deposition are discussed in separate reports (Sims and Barton, 1961; 1962), and only a brief summary of the conclusions is given in this section.

The sulfide ores and attendant wallrock alteration were developed during a complex succession of events, which can be determined in part from the paragenesis and distribution of the veins and vein minerals. Following fracturing of the crust, and development of the district fault pattern, hydrothermal solutions that were derived at depth moved upward along the fissures. These solutions rose along the fractures and in the margins of the system probably mixed with downward circulating meteoric waters and perhaps also with connate waters. Initially they were warmer than the country rock and out of equilibrium with the mineral phases of the rocks; consequently they attacked the minerals in the fissure walls changing them at first to clay minerals and with changing conditions to sericite and sparse potassic feldspar. Judging from the alteration pattern and the paragenesis of the alteration minerals (fig. 21), sericite and potassic feldspar formed largely at the expense of the clay minerals, probably as a result of increasing intensity conditions. As a result of the alterations, the vein system may have become clogged by clay minerals, quartz, calcite, and other materials, reducing the rate of circulation of the meteoric waters. Subsequently, iron obtained from the breakdown of biotite, opaque iron oxides, and other iron-bearing minerals in the walls 
eventually combined with sulfur from the hydrothermal solutions to form pyrite. Sulfidation of iron from the altered wallrocks was particularly effective in the inner parts of the region (and their downward projections) where higher intensity conditions prevailed; and in this environment pyrite was precipitated also in abundance in the fissures (pyrite-stage mineralization). Toward the periphery of the vein system, however, smaller quantities of pyrite were formed. The precipitation of the pyrite may have reduced the open space in the veins still further, and as a consequence circulation of the fluids may have been hindered. Subsequent recurrent movements along the original fracture zones, apparently nearly synchronous throughout the district, reopened the fissures and provided spaces for the deposition of the base-metal stage minerals. The openings were filled by copper, zinc, and lead sulfides, sparse pyrite, gangue minerals, and gold and silver to constitute ore bodies. Deposition of the basemetal-stage minerals was interrupted by local structural adjustments along the fissures, which shifted position from time to time, but nevertheless was suffciently consistent to yield a well-defined zonal pattern. The minerals of the base-metal stage were deposited in the new openings in the veins within an area that overlapped the earlier pyrite-quartz mineralization and extended further outward. In the outer part of the central zone and in the intermediate zone, as now defined, substantial chalcopyrite, tennantite, sphalerite, galena, and locally enargite were deposited in the reapened pyrite quartz veins; further outward, in the peripheral zone, beyond the limits of effective pyrite stage mineralization, sphalerite and galena were deposited as the dominant sulfides. Silver was deposited with the sulfides in increasing amounts outward relative to gold.

Analysis of more than 90 sphalerite samples for iron and other elements and determination of the filling temperatures of fluid inclusions in several sphalerite samples indicate that sphalerite formed at temperatures ranging from at least $620^{\circ}$ to $150^{\circ} \mathrm{C}$ (Sims and Barton, 1961, p. 1223-1232). The pattern given by the temperatures of formation is grossly regular in most of the district. In the western and northern parts sphalerites from the intermediate zone generally have iron contents indicative of temperatures of crystallization above $400^{\circ} \mathrm{C}$, and many have amounts indicative of temperatures above $500^{\circ} \mathrm{C}$, whereas those from the peripheral zone and barren zone have iron contents indicative of temperatures within the permissive range $<100^{\circ}$ to $600^{\circ} \mathrm{C}$. Fluid inclusion studies of some of the samples from the margins indicate, however, that these sphalerites generally crystallized at temperatures of about $200^{\circ}-300^{\circ} \mathrm{C}$. Despite this gross consistency, the intermediate and peripheral zones contain sphalerites of both the low- and high-iron groups, commonly in close association. For example, the sphalerite from one vein may have a vastly different iron content from a sphalerite in an adjacent vein, and many sphalerites in this environment have strongly zoned crystals (Sims and Barton, 1961, table 4). In the southeastern part of the district (lower Russell Gulch area), sphalerites from the intermediate zone, which occur with an enargite-bearing assemblage, crystallized at temperatures considerably lower than those in the same zone elsewhere in the district. The reason for this apparent anomaly is not known.

This district-wide thermal pattern indicated by the measured temperatures of crystallization was complex but consistent in its gross aspects (Sims and Barton, 1962). During sphalerite deposition a steep thermal gradient that shifted position within the intermediate and peripheral zones separated two areas of relatively uniform thermal regime, the inner one being of the order of $600^{\circ} \mathrm{C}$ and the outer one being in the interval $150^{\circ}-300^{\circ} \mathrm{C}$. Such a thermal pattern cannot be explained in terms of simple loss of heat from the ore solutions to cooler wallrocks, and presents an interesting problem in terms of heat dissipation. Probably the pattern resulted from a combination of heat-dissipation processes, the most important of which were the expansion and cooling of the hot, high pressure hypogene fluids followed by mixing of the magmatic fluids with cooler meteoric solutions (Sims and Barton, 1962). Throttling, also known as Joule-Thomson expansion, may have been the major process of heat dissipation for the higher temperature deposits.

The activity of sulfur decreased outward with temperature, but at a rate such that more sulfur-rich mineral assemblages formed toward the margins of the district. The general trend and quantitative estimates of the changes in activity of sulfur have been shown by Sims and Barton (1961, fig. 6; 1962, fig. 9). Iron-poor sphalerite and pyrite formed marginally in most of the district, and enargite and pyrite formed marginally in the southeastern part of the district.

The zonal pattern of the sulfide ores correlates with the measured changes in temperature and pressure of the ore-forming fluid, but the factors responsible for deposition of the vein minerals remain unknown. The bulk of the sulfide ore bodies and the gold and silver were deposited in the intermediate and peripheral zones of the district, where the character of the solutions changed most rapidly and drastically during mineralization. In this environment the hot, high pressure ore fluids are believed (Sims and Barton, 1962) to 
have cooled rapidly, first through expansion and then by mixing .with ground waters, and as a consequence of the drastic decreases in both pressure and temperature precipitated the bulk of the metals from solution. The metals that remained in solution were deposited in small quantities as the solutions moved upward and outward, probably mainly through cooling by ground water. The nearly barren core probably indicates that the solutions that penetrated it were hot and undersaturated with respect to the base-metal sulfides.

\section{ORIGIN OF URANIUM ORES}

Several lines of evidence suggest that the uranium ores were derived directly from the magma that consolidated to form quartz bostonite porphyry, the igneous rock which is most nearly contemporaneous with the ore, rather than from the some deep-seated source as the sulfide ores.

Throughout the district a close geographic relation exists between uranium deposits and exposed bodies of quartz bostonite porphyry (pl. 1). In the two principal areas of uranium deposits-Quartz Hillupper Russell and Eureka Gulches-the uranium deposits are clustered adjacent to or within a few hundred feet of exposed dikes of quartz bostonite porphyry; most of the larger deposits are within 500 feet of a known dike. The deposits in lower Russell Gulch and on Silver Hill are farther from an exposed dike, but within a maximum distance of 2,000 feet. This close spatial relation between uranium deposits and quartz bostonite porphyry was first noted on Quartz Hill by Alsdorf (1916), and it led him to the conclusion of a genetic relation between the ores and the rock. More recently Phair (1952) stressed this spatial relation and also proposed that the uranium was derived from quartz bostonite magma.

The minor element content of pitchblende supports a presumed quartz bostonite source for the uranium. Throughout the district pitchblende, the primary oxide of uranium, contains notable quantities of zirconium, an element known to be characteristic of the quartz bostonites (Phair, 1952). Most pitchblende deposits contain more than 1 percent and some contain more than 7 percent zirconium. As zirconium is quantitatively insignificant in other ores and ore minerals at Central City (tables 14, 16) and as it probably is too abundant to be accounted for by selective absorption from the altered wallrocks by some form of diffusion, it is believed to have been introduced directly from the magma source and incorporated in pitchblende.

As might be expected if the uranium ores were derived from a different source than the sulfide ores, the uranium deposits are not directly related to the pattern of sulfide mineral zoning. Instead, they occur in clusters widely spaced geographically, and along veins of various mineralogic type. Although most deposits occur in pyrite veins containing galena, sphalerite, and copper minerals (type $C$ ), many are associated with galena-sphalerite veins and a few are associated with other types of pyrite veins.

Studies of the behavior of uranium and thorium during differentiation in the Tertiary igneous sequence in the area by Phair (1952) and Wells (1960) have shown that uranium and thorium were progressively enriched in successively younger magmatic phases and that enrichment culminated in the magma that consolidated to form quartz bostonite. To account for the localization of the ores adjacent to dikes of quartz bostonite porphyry it is inferred that late-stage uranium-bearing hydrothermal solutions were given off by the several local, shallow (?) bodies of magma, and that the fluids moved upwards along the dike channelways and deposited pitchblende in adjacent fractures. Possible mechanisms by which uranium could have been concentrated with respect to thorium in the derived aqueous solutions have been considered by Phair (1952).

\section{ORIGIN OF TELLURIDE ORES}

Because of their sequence of deposition relative to the sulfide veins, their limited geographic occurrence, and apparent lack of any direct correlation with the zonal arrangement of the sulfide ores, the telluride ores are interpreted to have formed subsequent to and from a different immediate magma source than the sulfide ores.

Without exception, the telluride-bearing ores occur under peculiar circumstances, nearly always in different fractures than the main sulfide-bearing veins, and they appear to be later paragenetically than the minerals of the sulfide-bearing veins. The tellurides generally are associated with free gold, pyrite, fluorite, and chalcedonic quartz; sulfides and sulfosalts are much less abundant than in the typical sulfide-bearing veins.

The known occurrences of tellurides are near the Dory Hill fault or its blind extension (pl. 1), a northnortheastward-trending structure that transects the concentric zonal arrangement of the sulfide-bearing veins, and we believe that this structure probably was responsible for the localization of the telluride ores. Possibly the ore-forming solutions moved up along this fracture and deposited the ores in adjacent fissures that lie transverse to the main structure. The possibility of such an origin is strengthened by the occur- 
rence of sparse telluride deposits further to the south in the Idaho Springs district.

The ultimate source of the telluride-forming ore fluids is not known. Possibly, however, it was the magma that yielded the late biotite-quartz latite porphyry, for this rock in the adjacent Idaho Springs district is later than the sulfide-bearing veins ( $R$. H. Moench, oral communication). Such an origin has been postiulated for the telluride ores in the Boulder County tungsten district, about 10 miles to the north of Central City (Iovering and Tweto, 1953, p. 63-64).

\section{SUGGESTIONS FOR PROSPECTING}

The Central City district has been intensively prospected and probably all valuable veins have been found and explored to shallow depths. The most likely source for substantial quantities of ore, therefore, is the downward projection of known ore shoots and particularly those on veins that have been proved to contain large, valuable ore bodies. Small quantities of ore doubtless will continue to be recovered at places within existing mine workings, but significant quantities cannot be expected from present backs and faces. Many suggestions for prospecting of individual veins are given in the section on the mines.

The general areas regarded as most favorable to prospecting are the Quartz Hill-Nevada Hill and lower Russell Gulch areas. A large proportion of the production has come from these areas and many ore shoots extend to a great depth. Because the ore shoots in the Quartz Fill-Nevada Hill area plunge westward, they migrate to the west as depth increases, and at the level of the Argo tunnel several are west of any existing laterals. To explore at this depth, crosscuts could be driven to the north and south from the Kansas lateral. Exploration at a higher altitude, about 8,000 feet, could be undertaken from the Lucania tunnel. An extension of the Big Five tunnel from the Idaho Springs district also would be plausible. The Pittsburg-Notaway group of mines are considered favorable prospects for deep production in the lower Russell Gulch area; the veins in the vicinity of the Powers and Silver Dollar mines also are considered favorable. In each of these areas it is probable that centrally located vertical shafts are the ideal means of access to deep levels.

The generalizations made in the section on localization of ore should be kept in mind in prospecting. Experience in the district clearly indicates that certain structures and rock types are favorable for the occurrence of ore shoots and that others are unfavorable. Also, those veins formed by composite mineral- ization (p. 41) are most likely to contain commercially valuable ore bodies.

\section{FUTURE OF DISTRICT}

If the district again is to attain prominence as a substantial source of precious metals and base metals, it probably will be necessary to integrate mining properties into large scale, carefully planned operations that can maintain large daily tonnage outputs. The history of the district shows that although some veins yielded substantial quantities of $\$ 30$ to $\$ 90$ ore, most veins yielded ores valued at $\$ 10$ or less. This type of ore, present in many of the larger veins, is susceptible to modern-day, mechanized mining methods, whereas small streaks of high-grade (smelting) ore, which were mined successfully during the early days by hand-steel mining methods, are not susceptible to modern mining methods. Beneficiation of the ores is of equal importance to profitable mining operations. Mills with flow sheets adapted to the particular type of ore are necessary for efficient recovery, and insofar as possible mill heads should be standardized.

During recent years activity in the district generally has been greatest during years of depression or economic recession, and it can be expected that this trend will continue. These times of a larger labor market and lower costs are most favorable because of the generally uniform metal prices, and particularly should initiate the reopening of small-scale operations of the type carried on in the past by small companies and leasors. A rise in the price of gold also would stimulate much new mining activity.

\section{DESCRIPTIONS OF MINES AND VEINS}

The Central City district is one of the most intensively mined areas in the West, and it is nearly completely blanketed with claims. Although most of the claims are of standard dimensions -150 by 1,500 feetthose patented during the early days of the camp are odd sized and generally smaller than the presentday claims. Accordingly, mine openings along most of the veins that were mined during the early years of the district are spaced at intervals of as little as 50 or 100 feet. Because of the generally moderate topographic relief, mining in the district has been done largely from shafts, mainly sunk on the dip of the vein. Adits, referred to locally as tunnels, were driven at places along North Clear Creek and its tributaries.

All the accessible mines and prospects were examined during this survey, and their locations are shown on plate 1 . The more important mines, which total 538, are identified on plate 1 by numbers; to 
facilitate reference to the map the numbers are also given after the mine names in the following descriptions.

The mines for which information is available are described. Geologic maps were made of the mines that were open between 1952 and 1955. The information on ore production and tenor of this ore from individual mines has been drawn from many sources, and unless the source is specifically identified in the description it is one of the following: The production statistics were compiled by the U.S. Bureau of Mines, and are published by permission. Assays and other data on ore tenor for many of the active mines have been furnished by the operators, and are published by permission; for other mines, particularly those that have not been active for many years, such data are largely from published reports, from mining engineers and geologists, informal records and reports on file in the Denver Public Library and the library at the Colorado School of Mines, Golden, Colo., and from the records of the Idaho Springs Sampling Works, which are published by permission.

As the mines that contain significant uranium deposits are described in detail in a separate report by Sims and others (1963); these mines are described only briefly in this report.

The individual mines are listed alphabetically in the index of this report, but in the following pages they are grouped according to position in the district, as this arrangement should facilitate reference to descriptions of neighboring properties. The mines are discussed under the following geographic headings:

Quartz Hill area
Nevada Hill and Prosser
Gulch areas
Upper Russell Gulch area
Willis Gulch and lower Rus-
sell Gulch areas
Central, Mammoth, Gregory,
Bobtail, and Bates hills

Chase Gulch, Maryland Mountain, and Winnebago Hill areas

Silver Hill area

Nigger Hill area

Upper Chase Gulch area

\section{QUARTZ HILL AREA}

The Quartz Hill area includes the mines on Quartz Hill and Alps Hill and in Leavenworth Gulch (pl. 1), south of Nevada Gulch and north of State Highway 279. The area contains several commercially valuable mines and has yielded a substantial proportion of the metal production from the district. Although the veins are chiefly valuable for their gold and silver content, a few contain pitchblende. The major pitchblende-bearing veins are on the south slope of Quartz Hill, near the head of Leavenworth Gulch (see Sims and others, 1963; Drake, 1957; and Moore and Butler, 1952).
The principal wallrock of the Quartz Hill area is microcline-bearing gneiss. The contact of this gneiss with overlying biotite gneisses trends northward across Alps Hill in the western part of the area (fig. 4). A continuous 250-foot layer of biotite-quartz-plagioclase gneiss (fig. 17), several small lenses of other gneisses, and abundant pegmatite occur within the layer of microcline-bearing gneiss. The Precambrian rocks are cut by many dikes of bostonite porphyry and quartz bostonite porphyry.

The northeastward-trending Central City anticline is the dominant structural feature of the area. The axis trends northeast from the Wood mine to the Patch. Dips on the northwest limb generally are less than $45^{\circ}$; dips on the southeast limb are locally steeper and more irregular.

The veins strike east, east-northeast, northeast, and west-northwest, and except for the Topeka, dip $60^{\circ}$ or more. Opposing dips are common. The eastwardtrending veins have been the most valuable, but veins of other trends are locally valuable. Most of the ore deposits are in pyrite veins that contain chalcopyrite, sphalerite, and galena (type $C$ ); these veins pass westward into galena-sphalerite veins and eastward into pyrite veins of types $B$ and $A$. One large stockwork ore body, the Patch, is on the crest of Quartz Hill. It contains the same ore minerals as the veins, but minerals are more widely diffused than in the veins.

Most of the known ore shoots plunge westward and seem to be related to vein junctions. The microclinebearing gneiss wallrock was markedly more favorable for ore localization than the biotite gneiss, and nearly all large ore bodies occur in this rock.

\section{ALPS MINE (B-V-41)}

The Alps mine is near the crest. of Quartz Hill about 420 feet S. $8^{\circ} \mathrm{W}$. from the German mine. The mine was opened in 1863, and within 4 months had produced $\$ 54,537.14 .^{3}$ It was operated nearly continuously until 1879 ; the property was closed because of litigation between 1879 and 1886 . The mine again was active from 1886 to 1915 , when it was closed. It was reopened during the 1930's and again in 1954, to explore the adjoining veins; a crosscut station was cut on level 6 , but little drifting was done. The dollar yield from the mine prior to 1898 is given in table 18. The production since 1902 is given in table 19 ; this ore if produced today would have a total value of about $\$ 1$ million.

3 Bancroft, G. J., 1914, $A$ report on the Alps and Delmonico groups, 8 p., report on file at the Denver Public Library, Denver, Colo. 
$\mathrm{T}_{\mathrm{ABL}}$ 18.-Ore produced from the Alps mine, in dollars, 1863-97 1

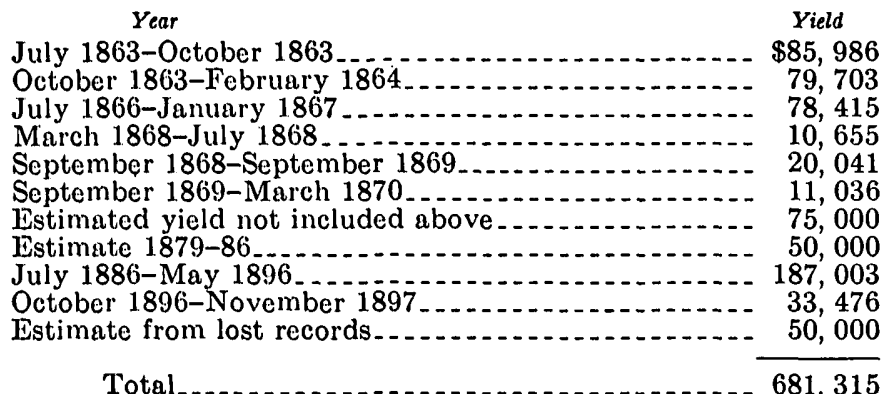

1 Modifled from Bancroft, Q. J., 1914, A report on the Alps and Delmonlco groups $8 \mathrm{p}$. report on flo at the Donver Public Library, Denver, Colo.

TABLE 19.-Ore produced from the Alps mine, 1902-54 ${ }^{1}$

\begin{tabular}{|c|c|c|c|c|c|}
\hline Year & $\begin{array}{l}\text { Crude ore } \\
\text { shlpped } \\
\text { (tons) }\end{array}$ & $\begin{array}{l}\text { Concen- } \\
\text { trates } \\
\text { shipped } \\
\text { (tons) }\end{array}$ & $\begin{array}{l}\text { Gold } \\
\text { (ounces) }\end{array}$ & $\begin{array}{c}\text { Silver } \\
\text { (ounces) }\end{array}$ & $\begin{array}{c}\text { Copper } \\
\text { (pounds) }\end{array}$ \\
\hline $\begin{array}{l}1904 \ldots \\
1005 \\
1900 \\
1007\end{array}$ & $\begin{array}{r}1,650 \\
3,870 \\
\mathbf{3}, 096 \\
\mathbf{1 7 5}\end{array}$ & \begin{tabular}{|r}
150 \\
$\ldots$ \\
\\
\end{tabular} & $\begin{array}{r}1,605.00 \\
483.75 \\
362.86 \\
993.34\end{array}$ & $\begin{array}{r}7,050 \\
852 \\
1.650\end{array}$ & $\begin{array}{r}25,500 \\
3,754\end{array}$ \\
\hline $\begin{array}{l}1908 \ldots \ldots \\
1909 \ldots \ldots \\
1910 \\
1911 . \ldots .\end{array}$ & $\begin{array}{r}450 \\
400 \\
405 \\
2\end{array}$ & $\begin{array}{l}60 \\
82 \\
44\end{array}$ & $\begin{array}{r}175.00 \\
980.17 \\
180.92 \\
5.67\end{array}$ & $\begin{array}{r}780 \\
5,143 \\
818 \\
20\end{array}$ & \begin{tabular}{r}
1,212 \\
\hdashline 1,315 \\
114
\end{tabular} \\
\hline $\begin{array}{l}1912 \ldots \ldots \\
191314 \\
1015\end{array}$ & $\begin{array}{r}404 \\
631 \\
115 \\
+\quad 1 \\
\end{array}$ & \begin{tabular}{r}
53 \\
99 \\
12 \\
\hdashline \\
\end{tabular} & $\begin{array}{r}248.78 \\
489.98 \\
90.34 \\
.64 \\
\end{array}$ & $\begin{array}{r}325 \\
889 \\
455 \\
3 \\
\end{array}$ & 18 \\
\hline Total.... & 11,198 & 500 & $5,616.45$ & 17,985 & 32,434 \\
\hline
\end{tabular}

1 Complled by U.S. Bureau of Mines. Published by permission.

The mine is opened by a 708-foot nearly vertical shaft from which 8 levels and 1 sublevel have been turned (figs. 22 and 23). Most of the workings are west of the shaft. On level 7, about 360 feet west of the shaft, a winze known as the Submarine shaft connects with level 8 and 5 additional levels (fig. 22). Levels 1, 3, 4, and 5 from the Alps shaft connect with the Mackie mine shaft (fig. 23). The location and extent of the known stopes is shown on figure 23. In 1954, only a small part of the workings was accessible.

The shaft is collared in microcline-bearing gneiss, and this rock is dominant throughout the mine. A layer of biotite-quartz-plagioclase gneiss, about 250 feet thick, which contains many small pegmatite bodies and one large enough to map, was cut above level 4 (fig. 23). The rocks dip gently west. The Precambrian rocks are cut by two dikes of quartz bostonite porphyry, which diverge as depth increases.

Two veins, the Alps and the Mackie, are developed in the mine. Most of the workings are on the Alps vein, as shown in figure 22. Probably the main vein worked on the levels driven from the Submarine shaft which dips steeply north and was named the Sub-

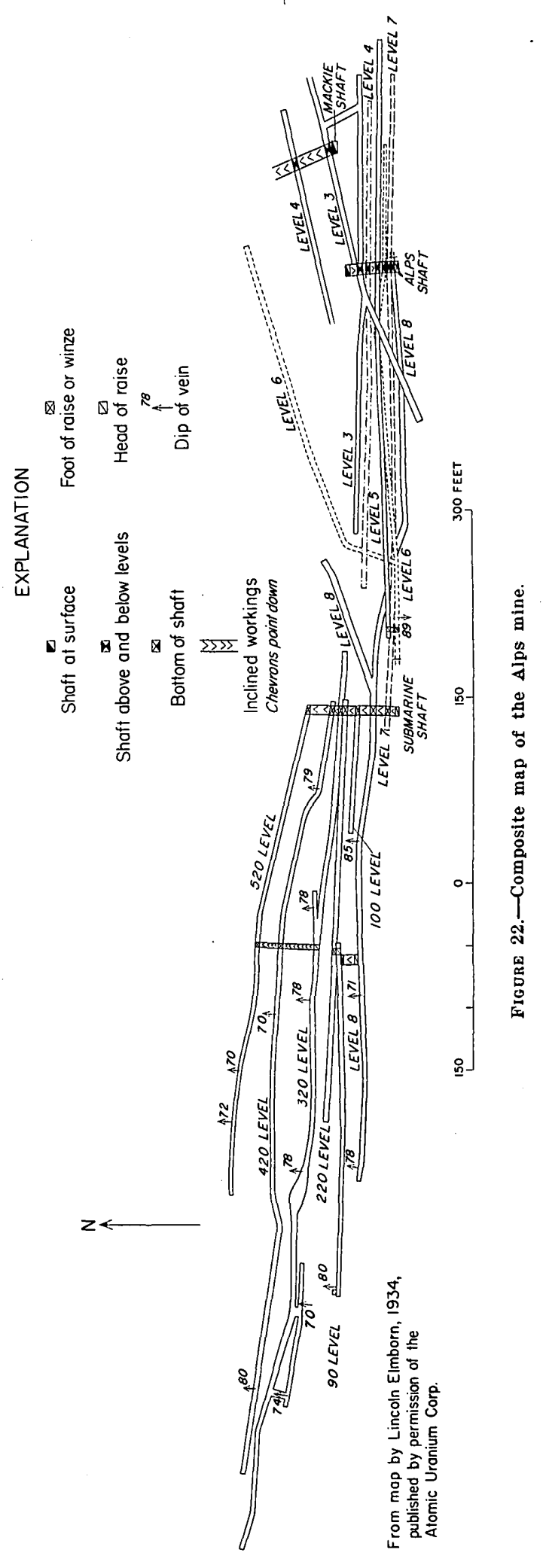



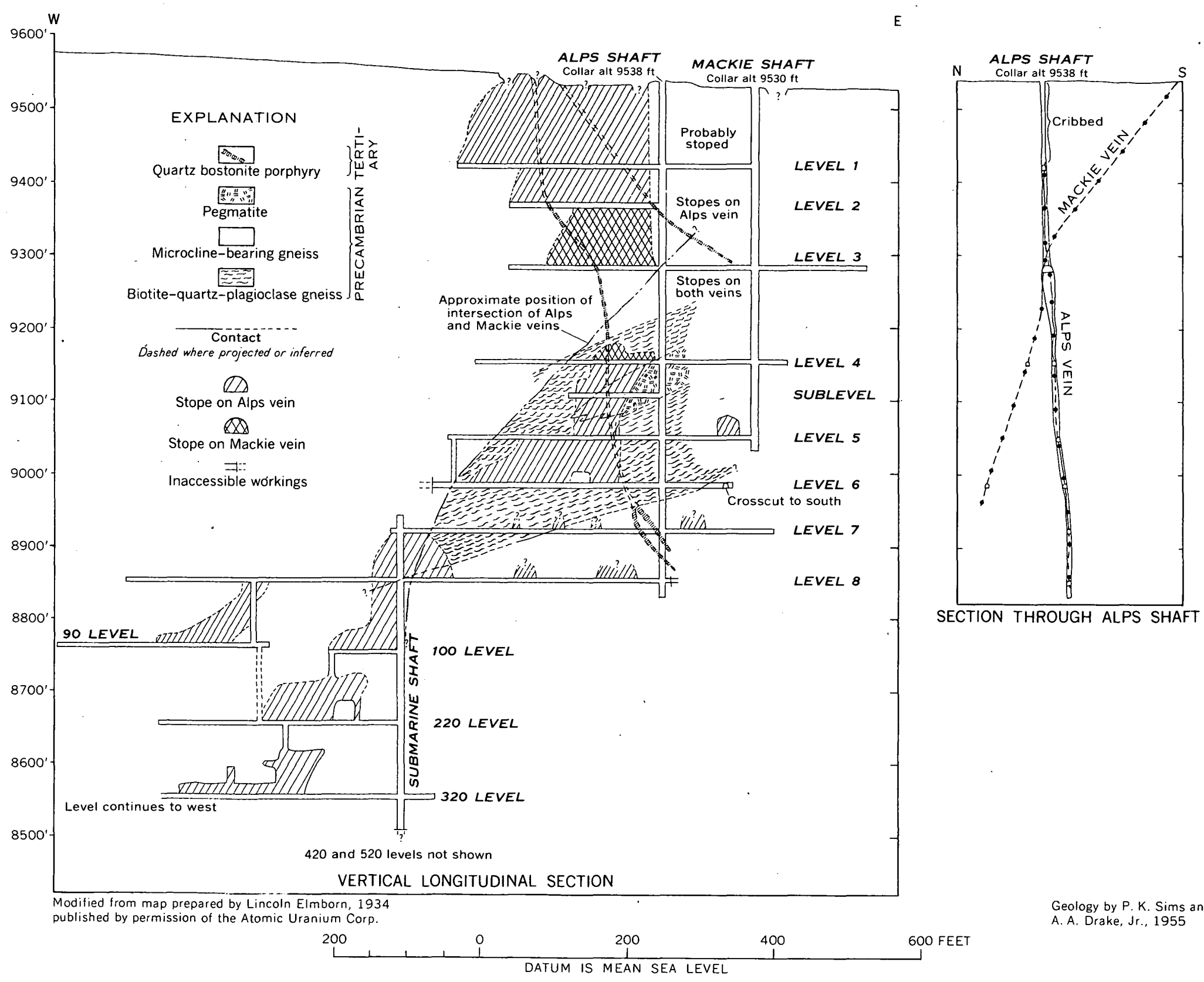

Fhaure 23.-Sections of the Alps mine. 
marine vein by Bancroft ${ }^{4}$ is also the Alps vein. The northeast, extension of the vein mined in the Delmonico mine should intersect or junction with the Alps vein in the ground west of the Submarine shaft, but this cannot be proved. Another vein is also reported to intersect the Alps vein east of the shaft on level 8 , but this ground was inaccessible at the time of our studies.

The Alps vein strikes eastward and at and near the shaft dips steeply south (fig. 23). In the western part of the mine, below level 6 , the vein dips steeply north (fig. 22). The vein averages about 12 inches in width.

The Mackie vein strikes east-northeast and, except locally, dips about $65^{\circ}-70^{\circ} \mathrm{NW}$. It averages about 1 foot in width. On level 3, west of its intersection with the Alps vein (fig. 24), the vein consists of 6 inches of gouge and sulfides. The vein cuts the Alps vein, but the intersection could not be observed. Displacement along the vein, however, is shown by displaced ends of a porphyry dike (fig. 24) which indicate that the northwest wall moved to the east with respect to the southeast wall.

Both the Alps and Mackie are pyrite veins that contain copper minerals, sphalerite, and galena (type $C)$. Both chalcopyrite and tennantite are present; sphalerite and galena are sparse. Quartz and altered wallrock constitute the gangue.

The principal ore shoot is related to the intersection of the Alps and Mackie veins (fig. 23), and the shoot was exploited from the surface to the bottom of the workings. The shoot plunges about $60^{\circ}$ west and has a known plunge-length of about 1,300 feet. Stopes are present on both veins, at and near the intersection (figs. 23 and 24 ).

The ore from the mine is chiefly valuable for its gold content (table 19). The average assay of smelting ore from the mine is reported to have been 2.13 ounces of gold, 7 ounces of silver, and 70 percent copper per ton; the mill dirt averaged about $\$ 7$ per ton."

\section{AMERICAN FLAG MINE (B-IV-6)}

Location.-On the north slope of Quartz Hill, about 1,470 feet $\mathrm{N}$. $84^{\circ} \mathrm{W}$. from the California mine.

Production.-About $\$ 200,000$ prior to 1899 (Callbreath, 1899).

Development.-Shafts 200 and 800-feet deep; 4,000 feet of drift.

Veins.-American Flag: Strike, N. $45^{\circ}$ E; dip, $80^{\circ} \mathrm{NW}$.

\footnotetext{
4 Bancroft, G. J., 1914, A report on the Alps and Delmonico groupg, on fle at the Denver Public Library, Denver, Colo.

5 Bancroft, G. J., 1914, op. cit.
}

Wallrock.-Microcline-bearing gneiss.

Ore and sulfide minerals.-Pyrite, gold, silver, chalcopyrite, galena, and sphalerite.

Gangue minerals.-Quartz.

\section{BARKER MINE (B-IV-12)}

Location.-On the north slope of Quartz Hill about 600 feet S. $48^{\circ} \mathrm{W}$. from the Hidden Treasure mine.

Production.-About $\$ 50,000$ prior to 1899 (Callbreath, 1899).

Development.-A 400-foot shaft; 500 feet of drifts. Veins.-Ivanhoe: Strike, N. $85^{\circ}$ E.; dip, $75^{\circ} \mathrm{NW}$.

Wallrock.-Microcline-bearing gneiss and bostonite porphyry.

Ore and sulfide minerals.-Galena, sphalerite, silver, chalcopyrite, pyrite, and gold.

Gangue minerals.-White quartz and dark-gray chalcedonic quartz.

Tenor.-Probably similar to Ivanhoe mine.

\section{BARNES MINE (D-IV-11)}

The Barnes mine is on the southeast slope of Quartz Hill about 880 feet S. $78^{\circ} \mathrm{W}$. from the National mine. The recorded production of individual metals for the years $1902-54$ is given in table 20 . This ore if produced today would have a value of about $\$ 131,000$. In addition to the above production, 2,035 tons of smelting ore and 595 tons of concentrates shipped between 1893 and 1902 yielded $\$ 60,807.08 .^{6}$ The mine is developed by a 636-foot shaft that connects with levels at depths of $100,150,200,250,325,400,500$, and 600 feet. The 500 level connects to the Quartz Hill tunnel (pl. 4). These workings were all inaccessible in 1954, but Bastin and Hill (1917, p. 243), Fuller, ${ }^{7}$ and $\operatorname{Rank}^{8}$ examined the mine; the following is taken from their descriptions:

TABLE 20.-Ore produced from the Barnes mine, 1902-54' ${ }^{1}$

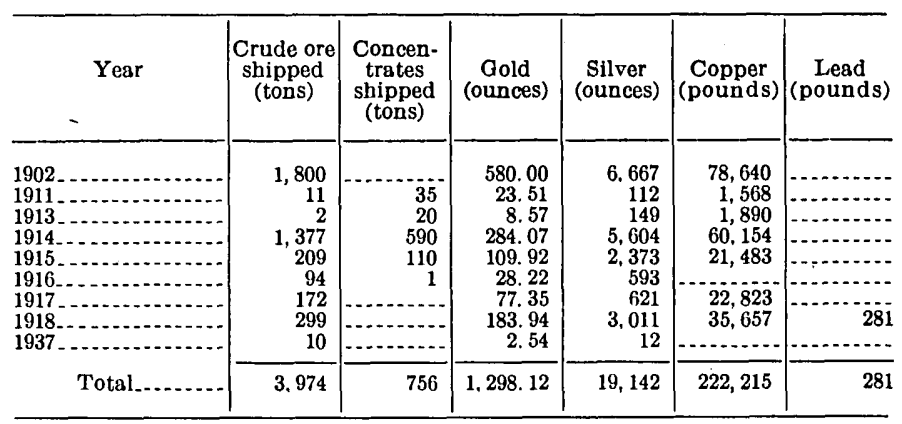

1 Compiled by U.S. Bureau of Mines. Published by permission.

6 Rank, S. A., 1932, Report on the Barnes group of mines, 7 p., report on file at the Denver Public Library, Denver, Colo.

7 Fuller, F. A., 1932, Report on the Barnes-Gauntlet group of gold mines, 4 p., report on file at the Denver Public Library, Denver, Colo. 8 Rank, S. A., 1932, op. cit. 

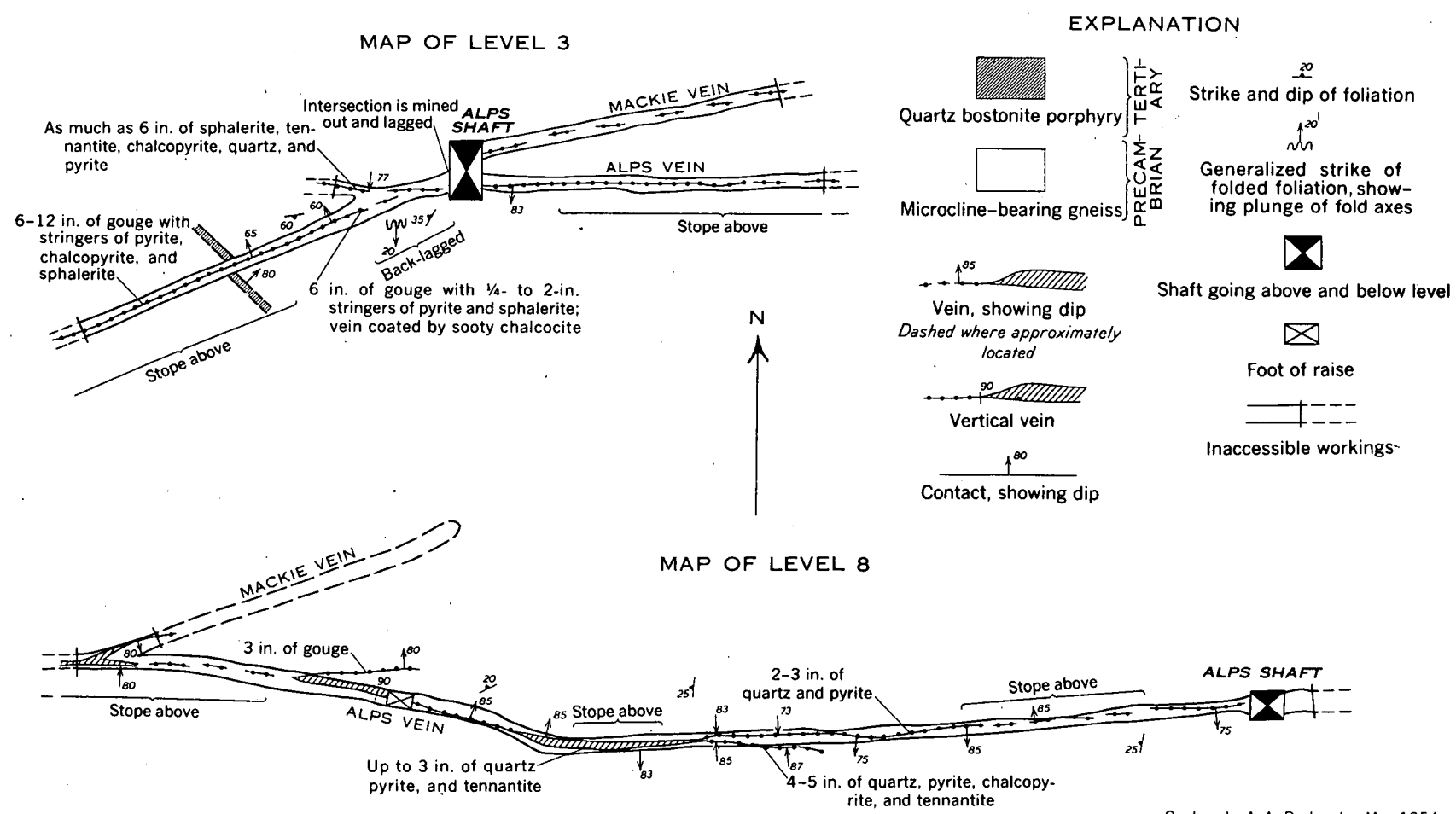

MAP OF LEVEL 8
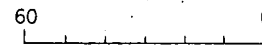

0

60120 FEET

Figure 24.-Geologic maps of parts of level 3 and level 8, Alps mine.

The mine develops the Barnes vein and an eastward-trending lode which consists of the nearly parallel Gibson and Stark County veins. These veins converge downward and unite a short distance below the surface; this united vein is known at depth as the Stark County vein, and is also developed by drifts from the Quartz Hill tunnel (pl. 4). The reader is referred to the discussion of the Quartz Hill tunnel for a description of the Stark County vein (p. 99).

The Barnes vein strikes N. $30^{\circ}-45^{\circ}$ E.', dips $65^{\circ}-80^{\circ}$ $\mathrm{SE}$., and is richest near its junction with the Stark County vein. At many places the Barnes vein consists of a network of sharp-walled pyrite-chalcopyrite veinlets, 2 inches or less wide that cut microclinebearing gneiss. In a stope about 100 feet above the 325 level, the Barnes vein is 15 inches wide; a 5-inch streak on the footwall assayed 3.66 ounces of gold, 25.4 ounces of silver, and 14 percent copper per ton. The 10 inches next to the hanging wall of the vein assayed 2.84 ounces of gold, 17.2 ounces of silver, and 3 percent copper per ton.

Both the Barnes vein and the Stark County vein contain vugs that are lined with terminated quartz crystals and cubes of pyrite. A little tennantite, galena, and sphalerite are locally present in the ore. Films of chalcocite locally coat fractures in chalcopyrite.

The principal stopes in the mine are on the ore shoot along the Barnes-Stark County vein intersection, which probably plunges steeply to the northeast. This shoot had a stope length of 90 feet on the 325 level.

Sampling-works assays (Bastin and Hill, 1917, p. 243) of 108 tons of ore shipped between 1893 and 1907 showed gold, 0.27 to 2.68 (average 1.19) ounces per ton; silver, 4 to 17.4 (average 11.81) ounces per ton; and copper 3 to 9.55 percent.

\section{BAXTFR MINE (D-IV-15)}

Location.-In Spring Gulch about 960 feet N. $40^{\circ}$ E. from the National mine.

Production.-About $\$ 120,000$ prior to $1910 ; 229$ tons of ore and 15 tons of smelting ore shipped in 1910 and 1911 contained 126.50 ounces of gold, 520 ounces of silver, and 5,069 pounds of copper; mine was owned and operated by the Chain O'Mines after 1928. (Com- 
piled by U.S. Bureau of Mines. Published by permission.)

Development.-A 300-foot shaft.

Veins.-Baxter: Strike, N. $80^{\circ}$ E.; dip, nearly vertical.

Wallrock.-Granodiorite.

Ore and sulfide minerals.-Pyrite, gold, silver, chalcopyrite, and tennantite.

Gangue minerals.-Quartz.

Tenor.-Ore shipped in 1910 showed gold, 0.29 to 4.78 (average 2.52 ) ounces per ton; silver, 2.7 to 10.4 (average 6.55) ounces per ton; copper, 1.6 to 6 percent.

\section{BEZANT (QUARTZ MILL) MINE (B-V-20)}

The Bezant mine, on the south side of Leavenworth Gulch about 410 feet southeast of the East Calhoun mine, is opened by a shaft (vertical depth $455 \mathrm{ft}$ ) inclined about $70^{\circ} \mathrm{N}$. and 7 levels (fig. 25). The workings are connected to the 5th level of the East Calhoun mine by a crosscut. The recorded production from the mine is given in table 21 , but judging from the amount of stoping, this figure is incomplete.

The Bezant shaft is in microcline-bearing gneiss above the $3 \mathrm{~d}$ level. Aside from a thin layer of microcline-bearing gneiss on the 5th level, biotite-quartzplagioclase gneiss constitutes the wallrock between the $3 \mathrm{~d}$ level and the bottom of the shaft. The Precambrian rocks are cut by dikes of quartz bostonite porphyry about 45 feet west of the shaft on the $3 \mathrm{~d}$ level and near the cave in the east drift on the 5th level (fig. 25). The Precambrian rocks, except locally, strike northeast and dip moderately to the southeast. Locally they are deformed by broad warps that plunge gently to the southeast.

TABLE 21.-Ore produced from the Bezant mine, 1902-541

\begin{tabular}{|c|c|c|c|c|c|}
\hline Yent & $\begin{array}{l}\text { Crude ore } \\
\text { shipped } \\
\text { (tons) }\end{array}$ & $\begin{array}{c}\text { Concen- } \\
\text { trates } \\
\text { shlpped } \\
\text { (tons) }\end{array}$ & $\begin{array}{c}\text { Gold } \\
\text { (ounces) }\end{array}$ & $\begin{array}{c}\text { Silver } \\
\text { (ounces) }\end{array}$ & $\begin{array}{l}\text { Copper } \\
\text { (pounds) }\end{array}$ \\
\hline $1907 \ldots . . . .$. & \multirow{5}{*}{$\begin{array}{l}130 \\
500\end{array}$} & \multirow{5}{*}{$\begin{array}{r}21 \\
29 \\
25 \\
25 \\
28 \\
19\end{array}$} & \multirow{5}{*}{$\begin{array}{l}20.12 \\
16.84 \\
58.50 \\
67.06 \\
36.73 \\
61.74 \\
33.03 \\
24.89\end{array}$} & \multirow{5}{*}{$\begin{array}{r}65 \\
28 \\
.114 \\
163 \\
39 \\
170 \\
89 \\
54\end{array}$} & 100 \\
\hline 1910................... & & & & & 190 \\
\hline 1012 & & & & & 111 \\
\hline 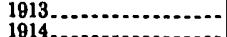 & & & & & 1,276 \\
\hline 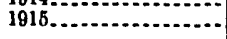 & & & & & 1,226 \\
\hline Totals... & 1,371 & 119 & 317.91 & 722 & 3,588 \\
\hline
\end{tabular}

1 Compiled by U.S. Bureau of Mines. Publlshed by permission.

The Bezant mine develops four main veins-the Quartz Mill, a nearly vertical footwall split of the Quartz Mill vein found at the 1st level, the Knowles, and a southward-dipping hanging wall split of the Quartz Mill vein found on the 5th level. The Quartz Mill vein strikes about $\mathrm{N}$. $65^{\circ} \mathrm{E}$., dips $65^{\circ}-81^{\circ} \mathrm{NW}$., and ranges in width from 3 inches to about 3 feet. As the vein has been largely stoped in the accessible workings, none of its minable parts could be studied. The unmined segments consist of thin, sparse stringers of quartz and pyrite as much as 12 inches in total width, in silicified and pyritized wallrock. The stoped material probably contained moderate chalcopyrite and some tennantite. Movement along the fault filled by the vein displaced the north wall east with respect to the south wall, as shown by the offset of a bostonite dike about 45 feet west of the shaft on the $3 d$ level. The Quartz Mill vein intersects and crosses the Calhoun vein with little or no displacement just above the 6th level of the East Calhoun mine (Drake, 1957 , p. 143), and all the mine openings below the 6th level of that mine are on the Quartz Mill vein. The metal concentrations in the Quartz Mill vein occur within an ore shoot that plunges steeply to the west. The downward extension of this shoot was stoped out on the lower levels of the East Calhoun mine (Drake, 1957, p. 143). The factors responsible for localization of the ore are not known, but the stopes seem to be on the steeper parts of the vein; Sanderson ${ }^{\theta}$ noticed that the intersection of "feeders" with the Quartz Mill vein tended to localize ore.

The Knowles vein is developed on the $3 \mathrm{~d}$ and 5 th levels of the mine (fig. 25). On the 3d level the vein strikes about N. $60^{\circ}$ E. and dips $60^{\circ}-73^{\circ} \mathrm{SE}$. The Knowles vein contains sparse sulfides where observed, and typically consists of several subparallel inch-thick pyrite-quartz-chalcopyrite-sphalerite veinlets in sericitized and pyritized wallrock.

The Quartz Mill footwall split is developed on the $3 \mathrm{~d}$ level and probably is the vein on which the shaft was originally sunk. It strikes about $\mathrm{N} .70^{\circ} \mathrm{E}$. and dips $63^{\circ} \mathrm{SE}$. to vertical. The vein typically is nearly barren, consisting only of about 6 inches of sheared sericitized rock that carried sparse disseminated pyrite.

The Quartz Mill hanging-wall split leaves the Quartz Mill vein proper on the 5th level about 35 feet east of the shaft. The vein strikes about N. $60^{\circ}$ E. to a point about 75 feet east of the crosscut, where it swings to a $\mathrm{N} .75^{\circ} \mathrm{E}$. strike; it dips $73^{\circ}-88^{\circ} \mathrm{SE}$. It is about 12 inches thick, and consists of sparse veinlets of quartz, pyrite, chalcopyrite, and sphalerite in altered rock. Judging from the extensive stoping,

9 Sanderson, H. S., 1909, Sampling report, Bezant mine, 12 p., on flle at the Denver Public Library, Denver, Colo. 


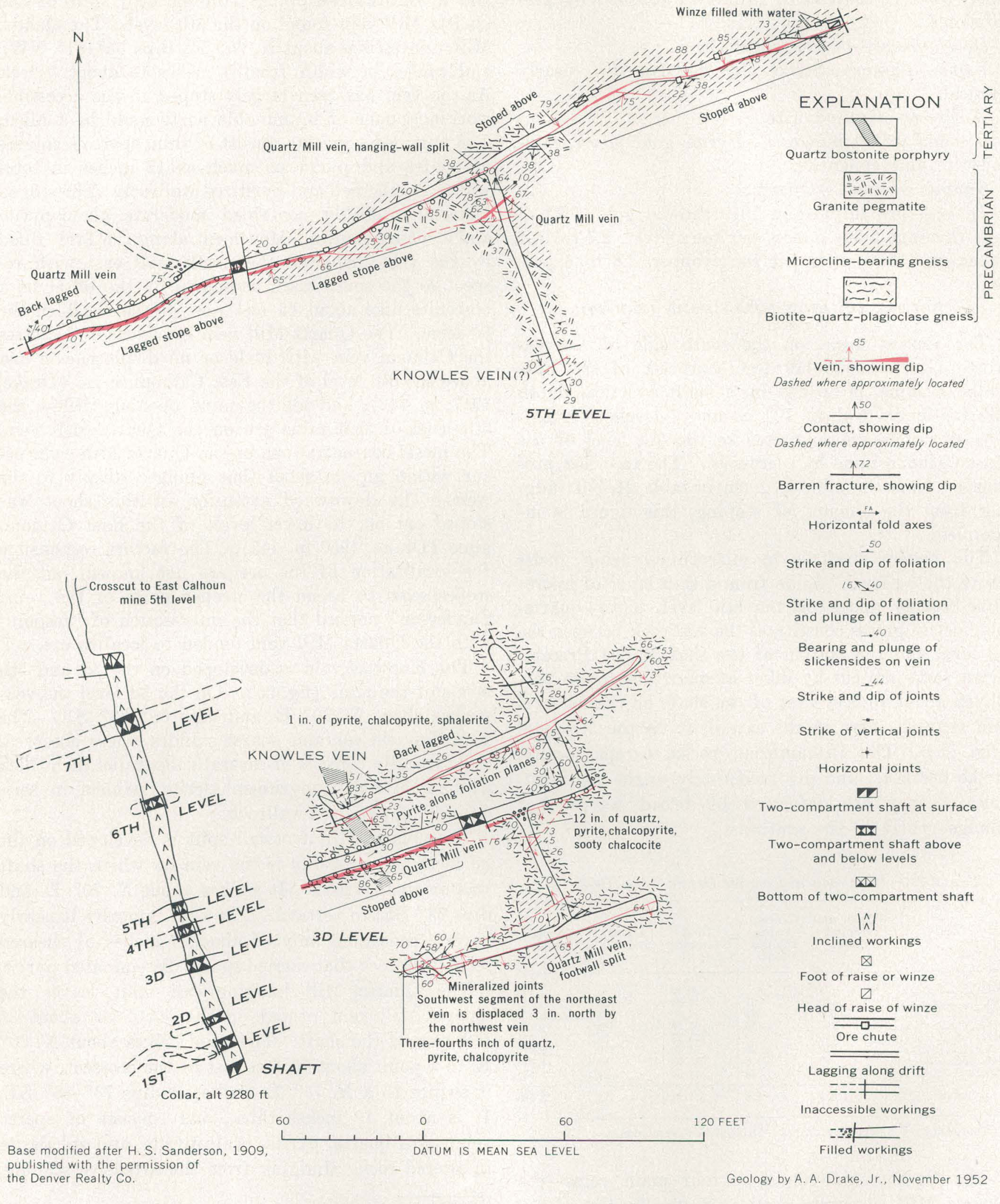

Figure 25.-Geologic map of part of the Bezant mine. 
the vein must have been wider and richer in sulfides at the east end of the 5th level.

Smelting ore shipped by leasers in 1935, aggregating 10.05 tons, had an average assay of 1.30 ounces of gold, 3.30 ounces of silver, 0.4 percent lead, 2.4 percent copper, and 5 percent zinc (R. R. Hinckley, oral communication).

\section{BLANCEE M MINE (B-V-7)}

The Blanche $\mathbf{M}$ mine, at an altitude of 9,370 feet, is 400 feet west of the Topeka mine. The shaft bears N. $30^{\circ} \mathrm{W}$., is inclined an average of $73^{\circ} \mathrm{NW}$., and is 143 feet deep; short levels are present at vertical depths of 63,94, and 137 feet. The upper part of the shaft cuts metaquartz diorite; below a depth of 95 feet the shaft is in biotite-quartz-plagioclase gneiss. At the surface along strike, the vein passes into microcline-bearing gneiss. The country rocks strike northeast and dip moderately steeply to gently northwest.

The vein mined at the Blanche $M$ shaft can be traced in surface pits less than 300 feet either side of the shaft, but may connect northeastward with the vein in the Bon Ton mine. At the Blanche $\mathbf{M}$ shaft the vein strikes $\mathrm{N} .60^{\circ}$ E. and dips $55^{\circ}$ to $80^{\circ} \mathrm{NW}$.; the average dip is $72^{\circ} \mathrm{NW}$. The vein ranges in thickness from about 1 inch to a maximum of 15 inches and averages 3 to 6 inches in thickness. Both vein walls, where seen, are frozen and somewhat irregular. The vein consists of white to milky quartz, pyrite, local scattered cubes and aggregates of galena, and discontinuous stringers and clots of sphalerite. The sphalerite and galena in part fill fractures that cut across the quartz-pyrite vein. The pyrite predominantly occurs as small, striated pyritohedrons that form vuggy aggregates. Most pyrite seems to have formed as vein fillings rather than as a replacement of quartz.

A sample cut from the face on the 137 level, 24 feet northeast of the shaft assayed : gold, trace; silver, 2.78 ounces per ton; copper, 0.16 percent; lead, 8.39 percent; and zinc, 10.57 percent. The equivalent uranium content is 0.004 percent and the total iron, as $\mathrm{Fe}_{2} \mathrm{O}_{3}$, is 20.53 percent.

Both the metaquartz diorite and the biotite-quartzplagioclase gneiss are altered adjacent to the vein. On the 137 level, the biotite-quartz-plagioclase gneiss on both walls is bleached, silicified, and sericitized for about 12 inches. Outside this zone for a few inches the gneiss is soft and crumbly; the plagioclase has been largely altered to clay minerals, but the biotite appears unchanged.

BON TON (QUARTZ HILL) MINE (B-V-6)

Location.-On Quartz Hill about 190 feet S. $50^{\circ} \mathrm{W}$. from the Taylor-Leavenworth mine.

Production.-Small.

Development.-Inclined shaft; probably only minor workings from it.

Veins.-Bon Ton: Strike, N. $45^{\circ}-65^{\circ}$ E.; dip, $65^{\circ}$ NW.; width, 12 inches.

Wallrock.-Microcline-bearing gneiss.

Ore and sulfide minerals.-Pyrite, sphalerite, chalcopyrite, azurite, gold, and silver.

Gangue minerals.-Quartz.

\section{BURRO MINE (B-V-48)}

Location.-South slope of Quartz Hill, about 140 feet S. $40^{\circ} \mathrm{E}$. from the German mine.

Development.-Shaft less than 200 feet deep.

Veins.-Last Chance-Burro: strike, N. $70^{\circ}$ E.; dip $80^{\circ} \mathrm{NW}$.; average width, 1 foot. Vein is cut in German mine.

Wallrock.-Microcline-bearing gneiss.

Ore and sulfide minerals.-Pyrite, gold, silver, chalcopyrite, galena, and sphalerite.

Gangue minerals.-Quartz.

\section{BURROUGHS LODE (C-IV)}

The Burroughs lode crops out on the north side of Quartz Hill, and has been developed along a strike length of about 2,700 feet (pl. 1). The lode, discovered by Ben Burroughs in May 1859 (Fossett, 1876, p. 277), is developed by four shafts, from east to west, the Mackey-Burroughs (C-IV-24), Phoenix-Burroughs (C-IV-23), Conley-Burroughs (C-IV-22), and Ophir-Burroughs (C-IV-21). The Ophir shaft is reported to be 1,200 feet deep (Bastin and Hill, 1917 , p. 229); the Phoenix shaft connects with 14 levels (pl. 3); the Mackey shaft is 600 feet deep (Callbreath, 1899, p. 270); the depth of the Conley shaft is not known. The 10th level of the PhoenixBurroughs mine connects with the bottom level of the Pease-Kansas mine (pl. 3). The lode is also developed by a lateral from the Argo tunnel (pl. 3) and by a drift from the LaCrosse tunnel (fig. 35). With the exception of the LaCrosse tunnel drift, all of these workings were inaccessible in 1954 .

The recorded production from the lode is given in table 22 ; this ore if produced today would have a 
TABLE 22.-Ore produced from the Burroughs lode, 1887-1954 ${ }^{1}$

\begin{tabular}{|c|c|c|c|c|c|c|c|c|}
\hline Year & $\begin{array}{c}\text { Crude ore } \\
\text { shipped (tons) }\end{array}$ & $\begin{array}{c}\text { Concentrates } \\
\text { shipped (tons) }\end{array}$ & Gold (ounces) & Silver (ounces) & $\begin{array}{l}\text { Copper } \\
\text { (pounds) }\end{array}$ & Lead (pounds) & Zinc (pounds) & Remarks \\
\hline $\begin{array}{l}1887 \ldots \\
1888 \\
1889 \\
1891\end{array}$ & $\begin{array}{l}(?) \\
(?) \\
(?) \\
(?)\end{array}$ & 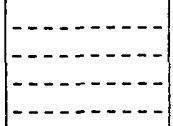 & $\begin{array}{r}3,571.00 \\
1,260.00 \\
600.00 \\
793.00\end{array}$ & $\begin{array}{r}3,134 \\
175 \\
1,503 \\
75\end{array}$ & $\begin{array}{r}15,129 \\
4,806 \\
- \\
-\end{array}$ & 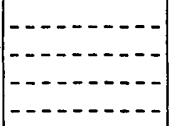 & $\mid-\cdots$ & \multirow{6}{*}{$\begin{array}{l}\text { From Mackey-Burroughs. } \\
\text { Do. } \\
\text { Do. } \\
\text { Do. } \\
\text { Do. } \\
\text { From Ophir-Burroughs. } \\
\text { Do. }\end{array}$} \\
\hline $\begin{array}{l}1892 \\
1902 \\
1904 \\
1905\end{array}$ & $\begin{array}{l}(?) \\
2,615 \\
1,250 \\
3,047\end{array}$ & $\mid$\begin{tabular}{c}
$\cdots$ \\
\hdashline \\
\hdashline
\end{tabular} & $\begin{array}{l}1,190.00 \\
1,582.97 \\
1,201.00 \\
1,774.02\end{array}$ & $\begin{array}{r}3,316 \\
2,456 \\
2,931\end{array}$ & $\begin{array}{r}75,742 \\
\cdots\end{array}$ & 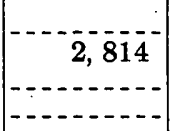 & 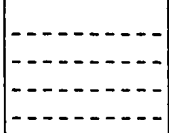 & \\
\hline $\begin{array}{l}1906 \\
1907 \\
1909 \\
1915\end{array}$ & $\begin{array}{r}1,881 \\
588 \\
5 \\
180\end{array}$ & $\begin{array}{r}28 \\
5 \\
-\ldots . .5\end{array}$ & $\begin{array}{r}945.73 \\
233.51 \\
15.60 \\
46.78\end{array}$ & $\begin{array}{r}1,567 \\
423 \\
53 \\
205\end{array}$ & $\begin{array}{r}57,940 \\
1,495 \\
186\end{array}$ & & 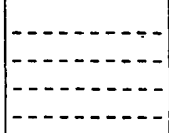 & \\
\hline $\begin{array}{l}1916 \ldots \ldots \\
1917 \\
1918 \\
1920\end{array}$ & $\begin{array}{c}262 \\
633 \\
12 \\
-0 .-1\end{array}$ & $\begin{array}{r}70 \\
\hdashline\end{array}$ & $\begin{array}{r}336.48 \\
467.59 \\
12.90 \\
7.72\end{array}$ & $\begin{array}{r}2,936 \\
4,226 \\
213 \\
63\end{array}$ & $\begin{array}{r}7,947 \\
35,954 \\
426 \\
252\end{array}$ & $\begin{array}{r}495 \\
-5,05 \overline{5} \\
204\end{array}$ & 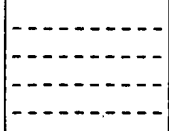 & \\
\hline $\begin{array}{l}1921 \ldots \\
1922 \\
1923 \ldots\end{array}$ & $\begin{array}{r}4 \\
815 \\
12\end{array}$ & $\begin{array}{r}56 \\
91 \\
. \quad 9\end{array}$ & $\begin{array}{r}112.74 \\
281.62 \\
48.70\end{array}$ & $\begin{array}{r}746 \\
1,355 \\
307\end{array}$ & $\begin{array}{r}2,024 \\
6,895 \\
736\end{array}$ & $\begin{array}{r}1,553 \\
191\end{array}$ & 349 & \\
\hline Total $\ldots$ & $11,304+$ & 1,050 & $14,481.36$ & 25,684 & 209,532 & 10,312 & 349 & \\
\hline
\end{tabular}

1 Complled by U.S. Bureau of Mines. Published by permission.

value of about $\$ 594,000$. The mine has probably yielded a production valued at more than $\$ 1$ million.

The Burroughs lode trends about N. $85^{\circ} \mathrm{E}$., is nearly vertical, and it intersects the Kansas vein. The intersection plunges gently to the east, and on the Argo tunnel level, the veins have reversed their relative positions, the Burroughs lode being north of the Kansas vein (pl. 3). On the 700 level of the Ophir mine, the lode splits into a north- and south-dipping segment (Fossett, 1876, p. 281). The original development followed the south-dipping vein, but little ore was found in it; the subsequent work was done on the north-dipping segment (Fossett, 1876, p. 282). The Burroughs lode, as exposed in the Ophir mine, was described by Hague (1870, p. 532-536) as follows:

The walls are usually well defined, smooth, and regular, sometimes carrying a thin gouge of clay, sometimes having the seam of ore resting directly upon it without anything intervening. The vein, however, is not wide as compared with other leading veins, varying from 8 to 10 inches to 3 or 4 feet, seldom exceeding the latter.

The vein matter and the ore, consisting usually of a solid seam of the latter from a few inches to more than 1 foot in thickness and associated with a belt of siliceous and feldspathic material highly charged with pyrites, . . . but the pyritous ore is more exclusively iron rather than copper pyrites ***

The ore on the dumps of the mines consists largely of quartz and pyrite, and contains sparse chalcopyrite and tennantite. As some lead and zinc have been produced from the lode, galena and sphalerite are also present locally.

Ore shipped between 1893 and 1899 averaged 4.3 ounces of gold and 9.97 ounces of silver to the ton; the copper content was commonly less than 3 percent (Bastin and Hill, 1917, p. 23). Ore shipped from the Ophir-Burroughs (Argo level) between 1919 and 1929 showed the following range in metal content: gold, 1.04 to 4.79 ounces per ton; silver, 11.14 to 21.63 ounces per ton; copper, 0.60 to 4.0 percent; lead, 0 to 2.8 percent; and zinc, 0 to 3.2 percent.

\section{CALIFORNIA-HIDDEN TREASURE-GARDNER LODE}

The great California-Hidden Treasure-Gardner lode crops out on the north side of Quartz Hill and is the western segment of a mineralized zone that extends east of the Patch where it is known as the National-Mammoth-Bobtail lode. The lode is developed, from east to west, by the 500-foot Gardner shaft (C-IV-7), the 763-foot Hawley-Gardner shaft (C-IV-8), the 2,250-foot California shaft (B-IV-6), and the 1,500-foot Hidden Treasure shaft (B-IV-7) (pl. 3). The California is the deepest mine in the Central City district; the bottom level of the shaft is about 500 feet deeper than the Argo tunnel. The lode also is developed by the Gardner lateral from the 
Argo tunnel. These mines have all been extensively stoped; the position and location of the stopes in the California and Hidden Treasure mines are shown on figure 26. The workings were all inaccessible in 1954, but T. A. Rickard (1897, p. 193-241), Collins (1930, p. $252-267$; 1913, p. 211-232), Bastin and Hill (1917, p. 233-234), and Lovering and Goddard (1950, p. 181) have described different features of the lode, and much of the following is taken from their work.

Most of the ore was extracted from the lode prior to 1902 . Fossett $(1876$, p. 274-276) reports that from the time of its discovery in 1860 to 1876 , the lode yielded ores valued at about $\$ 1$ million. The following yields are reported for mines on the lode prior to 1899 : California, $\$ 6$ million; Clark-Gardner, $\$ 700$,000 ; and Hawley-Gardner, $\$ 206,000$. The total production from the mines is estimated to be $\$ 10$ million. The recorded production, since 1902, is given in tables 23 and 24.

The California-Hidden Treasure-Gardner lode strikes nearly east and dips about $80^{\circ} \mathrm{S}$. Throughout most of its length it is nearly parallel to a dike of bostonite porphyry. The lode is a pyrite vein that formed by composite mineralization; the vein is copper bearing in the Gardner workings and mainly galena sphalerite bearing in the Hidden Treasure workings (Bastin and Hill, 1917, p. 233). In the Gardner lateral, about 130 feet west of the Argo tunnel, the vein consists of barren fissures in 14 inches of pyritized and silicified bostonite porphyry (Bastin and Hill, 1917 , p. 234). In the west breast of the California 2,000 level, the vein lies in the footwall of a 17-foot brecciated bostonite porphyry dike, and at the west breast of the 2,100 level of the California mine the dike forms the footwall of the vein. In the 800 level west of the Hidden Treasure mine, the vein is about 4 feet wide and consists of thin, reticulating stringers of sphalerite and a 12-inch layer of massive sphalerite and chalcopyrite in 3 feet of altered and pyritized country rock. In a stope above the 800-level of the Hidden Treasure mine, the vein is vuggy and has the appearance of an old filled stope, but the material is hard and difficult to break. Even where the brecciation is most evident, both walls are lined by a few inches of unbroken ore that grade into altered wall rock. Sphalerite is the dominant mineral; pieces of it are cemented and coated by bluish-gray, fine-grained silica. At many places the vugs prior to mining were filled with gas, probably $\mathrm{CO}_{2}$.

As shown in figure 26, two ore shoots were developed in the California and Hidden Treasure mines. The
TABLE 23.-Ore produced from the California and Hidden Treasure mines, 1890-1954'

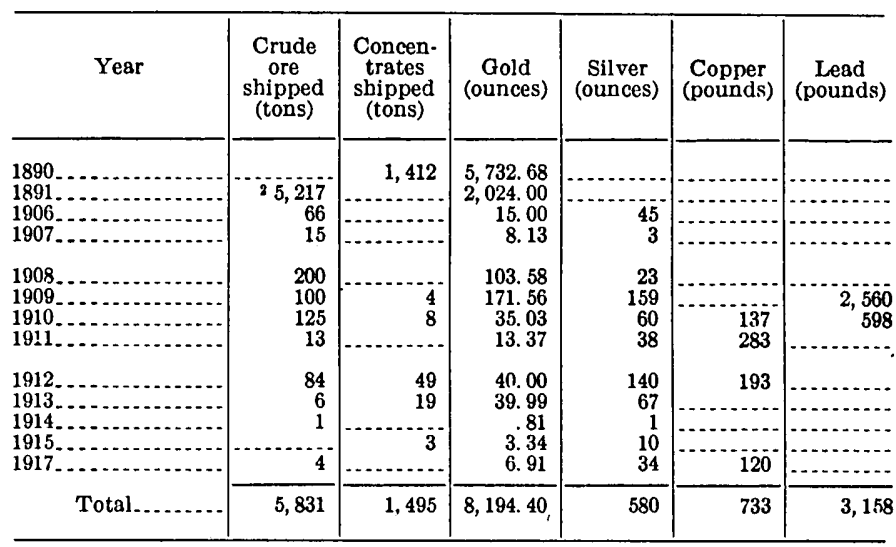

1 Compiled by U.S. Bureau of Mines. Published by permission.

2 Figure includes all rock hoisted during period, undoubtedly considerable wast is included in total. Excludes production for January, February, November, and
December.

California vein was virtually barren above the 500 level, where an ore shoot entered the workings from the east. This ore shoot was exploited down to the 2,000 level, for a plunge length of 1,800 feet. The 2,100 and 2,200 levels probably did not cut the downward extension of this shoot. The Hidden Treasure shaft cuts the center of the other ore shoot, which was mined along its plunge-length to the 1,100 level. The shoot apparently pinched at this altitude, but the favorable ground at depth along its plunge has been little explored by the lower levels of the mine. It is not known whether the ore shoots in the mine will continue to greater depths, but mining probably ceased because of economic conditions rather than because of physical impoverishment of the vein. The

$\mathrm{T}_{\mathrm{ABLE}}$ 24.-Ore produced from the Gardner vein, 1908-54

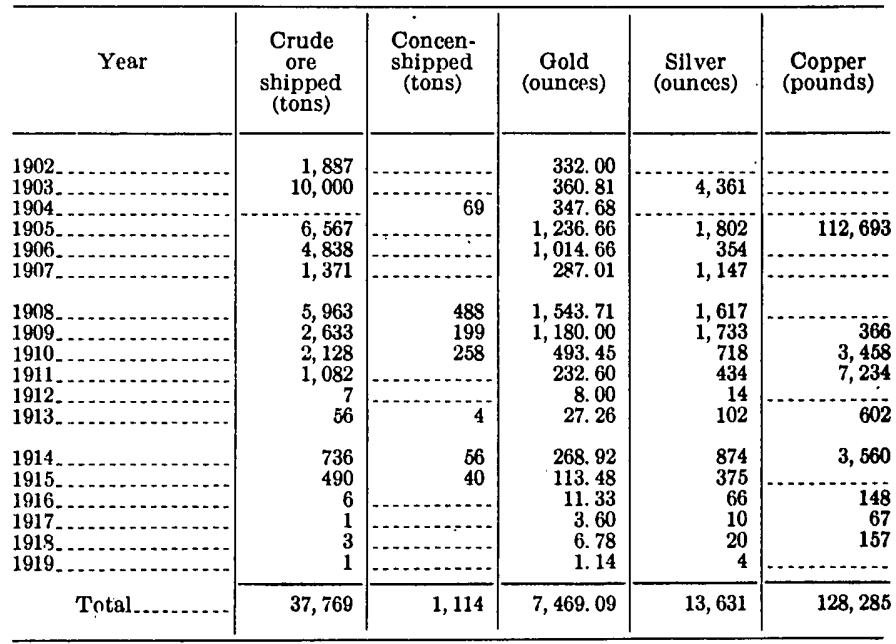

1 Compiled by U.S. Bureau of Mines. Published by permission. 


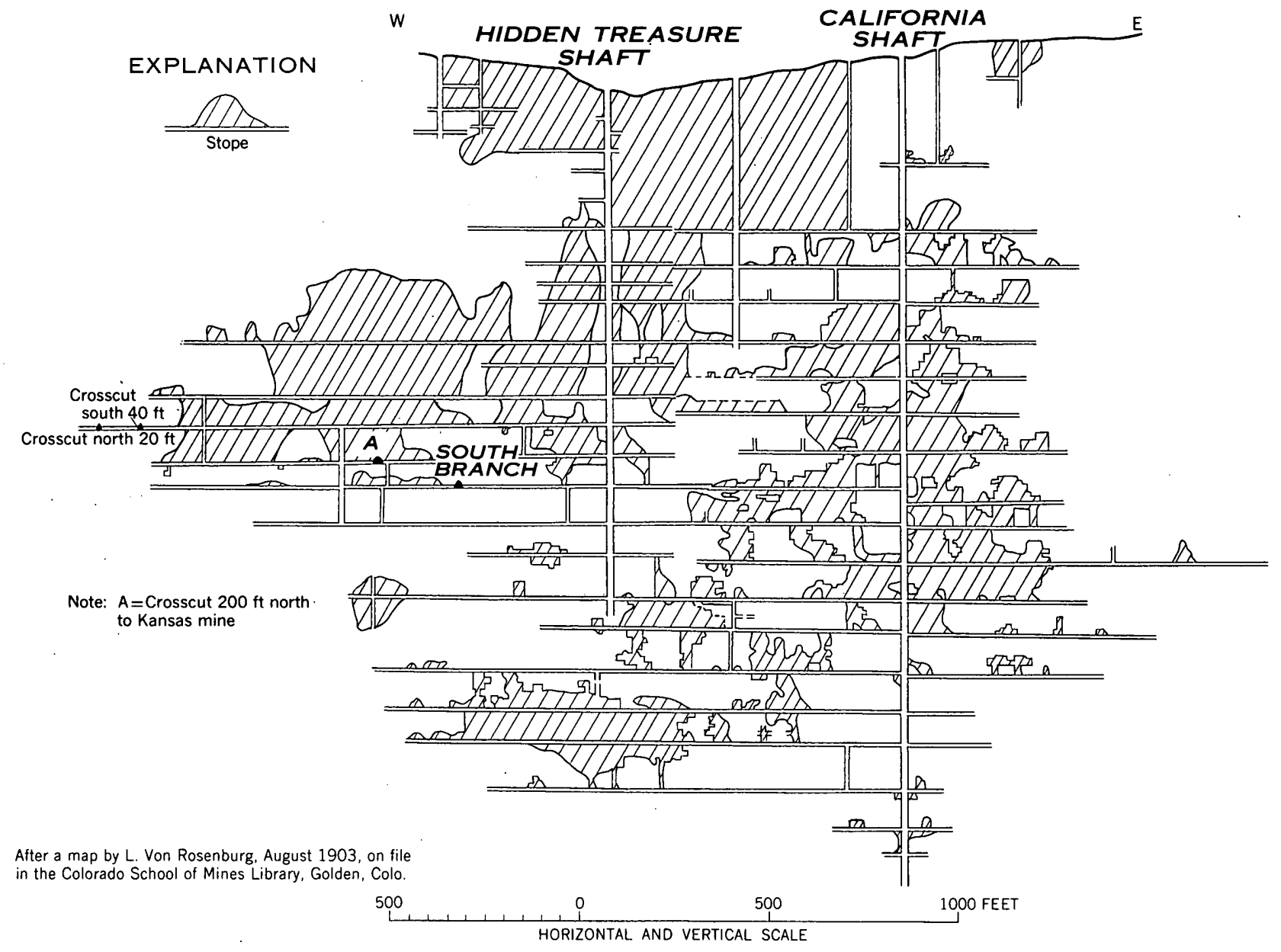

Frgorn 26.-Longitudinal section of the California and Hidden Treasure mines.

only feasible method of working the lode in the future, would be through the Argo tunnel.

The factors that caused localization of the ore shoots are not known. Collins $(1930$, p. 263) reports that the miners familiar with the California mine noted that vein crossings with the porphyry dike were especially favorable for the development of ore bodies. It is presumed that increased fracturing resulted from strike deflections at the dike crossings, and produced an increase in the width of ore.

Sufficient data are not available to calculate a satisfactory average value of the ore from the lode. Bastin and Hill (1917, p. 234) state that ore from the Gardner vein on the Argo tunnel level had a gold content of 0.05 to 0.50 ounces per ton, and a silver content of 0.50 to 3.50 ounces per ton; tennantite-rich ore from this level contained as much as 3.24 ounces of gold and 9 ounces of silver per ton. Collins (1930, p. 257) reports the following yields for development ore from the western part of the lode: California 2,200 level east, $\$ 3.75$ per ton; California 2,200 level west, $\$ 6.33$ per ton; California 2,200 level, $\$ 8.28$ per ton; and Hidden Treasure 1,600 level stope, $\$ 8.40$ per ton. None of this ore was from the important ore shoots.

\section{CAMP GROVE MINE (C-IV-30)}

Location.-On south slope of Nevada Gulch about 480 feet N. $59^{\circ}$ E. from the Gold Coin-Kansas mine. Production.-Estimated to be about $\$ 100,000$.

Development.-A 200-foot shaft and 1,000 feet of drifts.

Veins.-Camp Grove: Strike, N. $57^{\circ}$ E.; dip, nearly vertical; intersects the Kansas lode near the Gold Coin-Kansas shaft.

Wallrock-Microcline-bearing gneiss.

Ore and sulfide minerals.-Pyrite, gold, silver, chalcopyrite, galena, and sphalerite.

Gangue minerals.-Quartz. 
Charter oAK MINE (B-V-25)

Location.-The shaft is at an altitude of 9,585 feet, about 600 feet north of the Jefferson-Calhoun shaft.

Production.-From 1903 to 1917, 141 tons of smelting ore contained 310.43 ounces of gold, 2 ounces of silver, and 132 pounds of lead. (Compiled by U.S. Bureau of Mines. Published by permission.)

Development.-The mine workings consist of a shaft 430 feet deep (vertically), inclined an average of $70^{\circ} \mathrm{NW}$., with levels at depths of $155,245,355$, and 425 feet. Aside from the 425 level, drifts are short. The 425 level extends west from the shaft, then turns to cross cut into the footwall of the Charter Oak vein. Small stopes are present on the 245,355 , and 425 levels.

Vein.-The Charter Oak vein trends N. $65^{\circ} \mathrm{E}$. dips about $70^{\circ} \mathrm{NW}$. It consists of pyrite, sphalerite, galena, and copper-bearing minerals in a quartz gangue.

Wallrock.-Predominantly microcline-bearing gneiss.

Tenor.-Two shipments of smelting ore to the Idaho Springs Sampling Works in 1923 had the following average assays: 7.78 tons assayed 0.13 ounce of gold and 15.20 ounces of silver per ton and 1.26 percent lead and 3.12 percent zinc; 1.29 tons assayed 0.15 ounce of gold and 15.50 ounces of silver per ton and 7.90 percent zinc.

\section{CLIMAX MINE (C-IV-17)}

Location.-Near the crest of Quartz Hill about 300 feet S. $52^{\circ}$ E. from the Phoenix-Burroughs mine.

Production.-About $\$ 125,000$ prior to 1899 (Callbreath, 1899).

Development.-A 532-foot shaft with 11 levels aggregating about 4,000 feet of drift; the 263 level connects with the LaCrosse tunnel.

Veins.-Climax: Strike, N. $60^{\circ}$ E.; dip, $75^{\circ}$ SW.; pinches out in the Patch to the west of the shaft.

Wallrock.-Microcline-bearing gneiss.

Ore and sulfide minerals.-Pyrite, gold, silver, chalcopyrite, sphalerite, and galena.

Gangue minerals.-Quartz.

Tenor.-Ore shipped in 1934 and 1935 showed the following range: gold, 0.02 to 1.30 ounces per ton; silver, 4 to 27 ounces per ton; copper, 0 to 0.6 percent; lead, 0 to 2.1 percent; and zinc, 0 to 4.85 percent.

\section{COLUMBIA TUNNEL (D-IV-2)}

Location.-On south side of Nevada Gulch about 240 feet N. $68^{\circ}$ W. from the Quartz Hill tunnel.
Production.-From 1909 to $1923,7,463$ tons of smelting ore and 776 tons of concentrates that contained 5,415.40 ounces of gold, 14,881 ounces of silver, 144,215 pounds of copper, and 1,823 pounds of lead. (Compiled by U.S. Bureau of Mines. Published by permission.)

Development.-A 500-foot crosscut that bears S. $30^{\circ} \mathrm{W}$; drift from the breast of the crosscut extends 130 feet to the west; winze connects to sub-levels 100 and 200 feet below the tunnel.

Veins.-Columbia: Strike, N. $70^{\circ}-75^{\circ}$ E.; dip, $75^{\circ}$ SE.; splits into 2 segments to the west; 3 to 4 feet wide. Argo: Strike, N. $30^{\circ}$ E.; dip, $60^{\circ}$ SE., 3 to 6 inches wide.

Wallrock.-Microcline-bearing gneiss.

Ore and sulfide minerals.-Pyrite, gold, silver, chalcopyrite, tennantite, galena, and sphalerite.

Gangue minerals.-Quartz.

Tenor-About 193 tons of smelting ore shipped in 1910 showed gold, 0.68 to 5.52 (average 2.41) ounces per ton; silver, trace to 13.33 (average 3.93 ) ounces per ton; and copper not exceeding 4.8 percent.

\section{DELMONICO MINE (B-V-35)}

The Delmonico mine, near the crest of Quartz Hill, at an altitude of 9,616 feet, is opened by a shaft which is 1,310 feet deep. Fourteen levels have been turned from the shaft, but little drifting or stoping has been done (R. R. Hinckley, oral communication). The mine was sunk to its present depth before 1900; subsequently it has been worked sporadically but little ore has been shipped. It was worked most recently by the Chain O'Mines Inc., operators of the Patch in the early forties. Selected shipments of crude ore sent to the Idaho Springs Sampling Works during the twenties and thirties are given below:

\begin{tabular}{l} 
Sampling-works assay of selected shipments of crude ore from \\
the Delmonico mine, 1925-35 1 \\
\hline Year \\
\hline
\end{tabular}

1 Published by permission of Idaho Springs Sampling Works. 3 Ounces per ton.

The wallrock is dominantly microcline-bearing gneiss, which except locally dips gently northwestward; a layer of biotite-quartz-plagioclase gneiss occurs in the shaft between depths of about 700 feet 
and 950 feet (R. R. Hinckley, oral communication). This body of biotite gneiss correlates with the widespread layer that lies at shallow depths under Quartz Hill and which was cut in the Alps mine below level 3 (fig. 17).

The Delmonico vein strikes east-northeast, dips nearly vertical, and varies widely in thickness, ranging up to as much as 4 feet thick. The ore consists of massive chalcopyrite, sphalerite, and galena in a quartz gangue; pyrite is ubiquitous and is locally intergrown with marcasite. A specimen from level 12 shown to the writers contains free gold as a vug filling. Judging from specimens of the ore most of the chalcopyrite is later than galena. An unknown mineral (calaverite?), pyrite, and marcasite are associated with the chalcopyrite.

The known ore is reported to occur in a shoot that plunges about $80^{\circ} \mathrm{SW}$. Good ore has been found on levels $6,7,10,11$, and 12 ; the vein contains sparse sulfides where it intersects the layer of biotite gneiss.

EAST CALHOUN MINE (B-V-15)

Location.-South slope of Quartz Hill.

Production.-Drake (1957, p. 144) reports that the Calhoun vein yielded ore valued at about $\$ 11 / 2$ million. It is probable that little ore was taken from the Calhoun vein in the East Calhoun mine, for most of mining was on the Quartz Mill vein.

Development.-Shaft inclined about $70^{\circ} \mathrm{S}$. to just above 6th level and inclined steeply to north below that level to a depth of about 980 feet; 11 levels are turned from shaft (Drake, 1957, p. 142-143).

Veins.-Calhoun: Strike, N. $60^{\circ}$ E.; dip, $70^{\circ}$ SE. Quartz Mill: Strike N. $65^{\circ}$ E.; dip, $70^{\circ}-75^{\circ}$ NW.

Wallrock.-Dominantly microcline-bearing gneiss; layers and lenses of biotite-quartz-plagioclase gneiss and amphibolite.

Ore and sulfide minerals.-Pyrite, chalcopyrite, sphalerite, tennantite, galena, sparse pitchblende.

Gangue minerals.-Quartz.

Ore shoot.-Production came largely from a steeply plunging shoot on Quartz Mill vein.

Tenor.-The Quartz 'Mill vein contains a high copper content.

\section{EDINBOROUGH MINE (C-IV-42)}

Location.-Near the crest of Quartz Hill about 900 feet east of the Gardner shaft.

Production.-About 236 tons of smelting ore and 15 tons of concentrates shipped in 1912 and 1913 contained 58.49 ounces of gold, 533 ounces of silver, 4,672 pounds of copper, and 1,321 pounds of lead. Compiled by U.S. Bureau of Mines. Published by permission.
Development.-A 185-foot shaft with levels at 133 and 185 feet. The 185 level connects with the 185 level of the Murray mine and the first level of the Illinois mine.

Veins.-Illinois: Strike, N. $60^{\circ}$ E.; dip, $85^{\circ} \mathrm{SE}$.

Wallrock.-Microcline-bearing gneiss.

Ore and sulfide minerals.-Pyrite, gold, silver, chalcopyrite, tennantite, galena, and sphalerite.

Gangue minerals.-Quartz.

Tenor.-148 tons shipped in 1913 averaged 0.30 ounce of gold per ton, 3.1 ounces of silver per ton, 1.45 percent copper, and 0.44 percent lead.

\section{EGYPTIAN MINE (C-IV-3)}

The Egyptian mine, near the crest of Quartz Hill about 600 feet southwest of the Patch, is opened by an inclined shaft 780 feet deep, from which 8 principal levels and 1 intermediate level (figs. 27 and 28) have been turned. Levels 6 and 7 connect with the Ralls County mine; level 8 connects through stopes with the Scandia mine. The position of the stopes is shown on figure 28. The workings were inaccessible in 1954, and much of the following is taken from the earlier description by Bastin and Hill (1917, p. 239).

The recorded production from the property is given in table 25 ; this ore if produced today would be worth about $\$ 443,000$. The mine reportedly yielded $\$ 150,000$ prior to 1899 (Callbreath, 1899, p. 256).

TABLE 25.-Ore produced from the Egyptian mine, 1887-1954 ${ }^{1}$

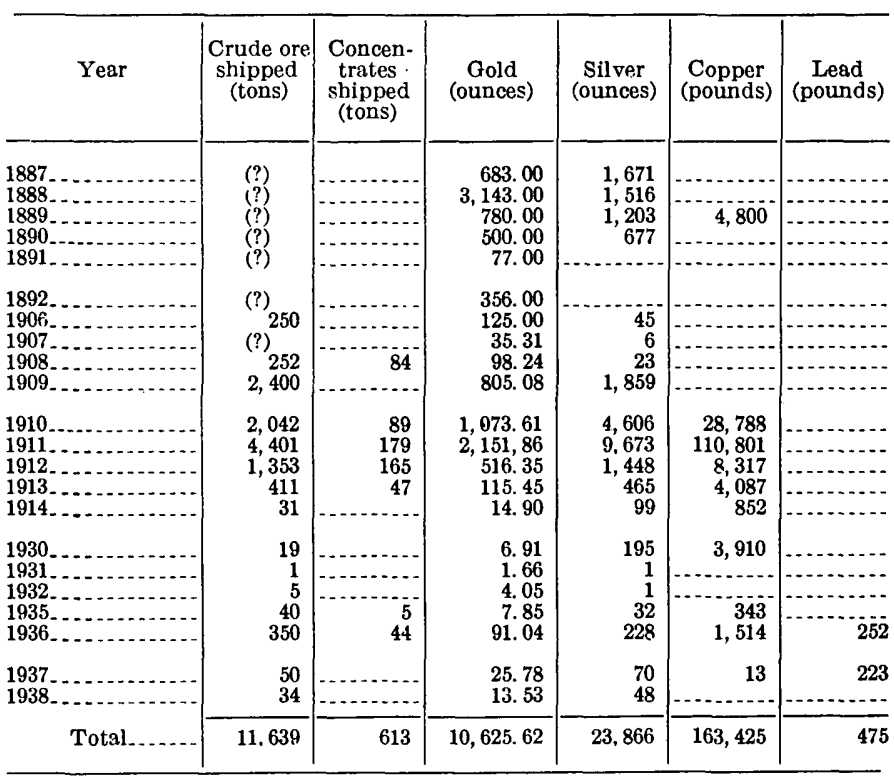

${ }^{1}$ Compiled by U.S. Bureau of Mines. Published by permission.

The Egyptian mine largely develops the Egyptian and Ralls County veins, but the so-called Cross, Watercourse, Crosscut, and Scandia veins were cut on the lower levels (fig. 27). The Egyptian vein is inter- 

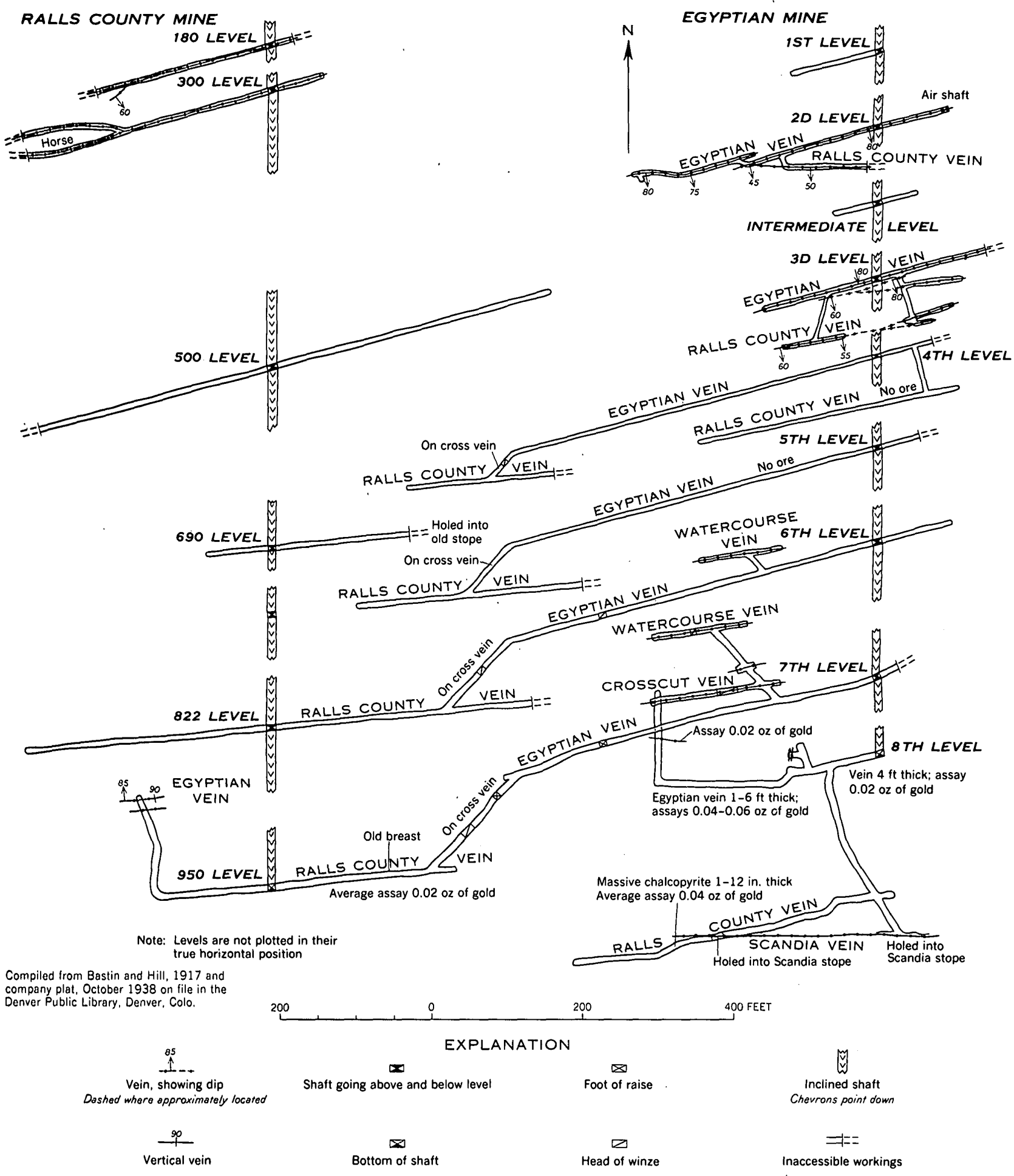

Figure 27.-Composite map of the Egyptian and Ralls County mines. 


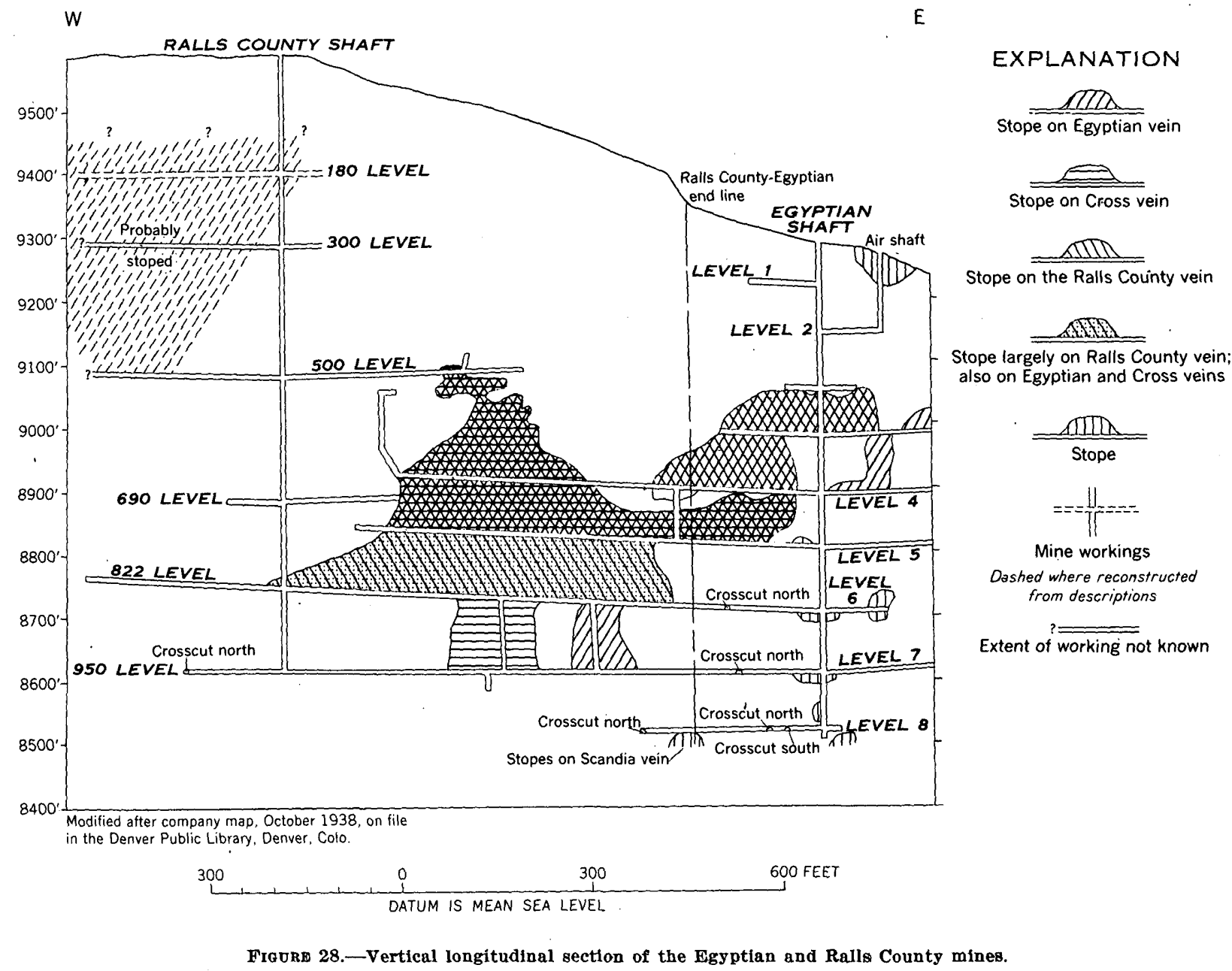

sected by the Ralls County vein on the $2 \mathrm{~d}$ level (fig. 27 ); the intersection plunges gently to the west, and therefore lies east of the shaft at the surface. It is probable that the Egyptian vein is the equivalent of the east-northeastward-trending Illinois vein exposed at the surface (pl. 1).

The Egyptian vein strikes east-northeast, dips $60^{\circ}-$ $80^{\circ} \mathrm{SE}$., and is developed on all levels of the mine. At the shaft on level 3 the vein is 8 to 14 inches wide and consists of several subparallel. veinlets of pyrite, sphalerite, and gray quartz; the widest of these veinlets is $3 \frac{1}{2}$ inches. On level 8 the vein is 4 to 6 feet wide, but contains a low gold content (fig. 27).

The Ralls County vein strikes a few degrees north of east and dips $50^{\circ}-75^{\circ} \mathrm{S}$. It is generally wider than the Egyptian vein, and in a stope above the east end of level 3 it is 5 feet wide. The primary ore minerals include galena, sphalerite, and chalcopyrite. In the more open parts of the vein supergene chalcocite occurs as thin films along fractures in chalcopyrite. Late fracturing has crushed the ore and wallrock in places, forming a breccia of angular ore fragments in a groundmass of crushed and recemented microclinebearing gneiss. On level 8 , west of the shaft, the vein contains 1 to 12 inches of massive chalcopyrite, but gold assays are low (fig. 27).

The Cross vein occurs between the Egyptian and Ralls County veins on levels 4, 5, 6, and 7 (fig. 27). This vein strikes northeast, is nearly vertical, and it connects the two main veins. The vein locally contains ore, for it was stoped on levels 4,5 , and 6 .

The Scandia vein crosses the Ralls County vein west of the shaft on level 8, apparently with little or no displacement. It trends nearly east and probably is nearly vertical. The vein has been stoped at and above level 8 , but the extent of the stoping is not known.

The so-called Crosscut vein is exposed in a short drift north of the Egyptian vein on level 7. The Crosscut vein trends nearly east, and as it is not cut in the south crosscut on level 8 , the vein apparently dips moderately steeply to the north. The Crosscut vein is possibly the Mitchell vein, which on the surface lies between the Scandia and Egyptian veins. 
The so-called Watercourse vein is exposed in short drifts north of the Egyptian vein on levels 6 and 7 . The Watercourse vein strikes nearly east and dips steeply north.

At least three ore shoots have been exploited by the mine, one each in the Egyptian, Ralls County, and Cross veins. Sufficient data are not at hand to prepare separate stope sections for each vein, but it appears that westerly plunging ore shoots are present in both the Ralls County and Egyption veins, near but not at their intersection. The shoots overlap in section, the Egyptian shoot being the farthest east. The major shoots are probably partly controlled by the increased fracturing near the Ralls County-Egyptian vein intersection.

Smelting ore shipped from the mine between 1899 and 1909 showed the following range of metal content: gold, 0.28 to 5.77 (average 2.98) ounces per ton; silver 2.7 to 22.3 (average 12.33) ounces per ton; and copper, 9.5 percent or less. (Bastin and Hill, 1917, p. 239). Similar assays of ore shipped during 1910 show gold, 0.64 to 5.48 (average 2.4) ounces per ton; silver, 2 to 23.5 (average 17.35) ounces per ton; and copper, 4.65 percent or less (Bastin and Hill, 1917, p. 239).

\section{ELDORADO (QUARTZ HILL) MINE (B-V-17)}

Location.-On the south slope of Quartz Hill about 260 feet S. $70^{\circ} \mathrm{W}$. from the Leavenworth mine.

Production.-3,349 tons of smelting ore shipped between 1902 and 1954 contained 1,347.53 ounces of gold, 2,380 ounces of silver, 6,290 pounds of copper, and 576 pounds of lead. (Compiled by U.S. Bureau of Mines. Published by permission.)

Development.-Inclined shaft about 400 feet deep.

Veins.-Eldorado: Strike, N. $70^{\circ}$ E.; dip, $80^{\circ} \mathrm{NW}$., intersects the Leavenworth vein near the 498 level of the Leavenworth shaft.

Wallrock.-Microcline-bearing gneiss, amphibolite, and biotite-quartz-plagioclase gneiss.

Ore and sulfide minerals.-Pyrite, sphalerite, galena, chalcopyrite, gold, silver, malachite, and pitchblende.

Gangue minerals.-Quartz.

Tenor.-Ore shipped between 1902 and 1940 averaged 0.40 ounce of gold and 0.71 ounce of silver per ton.

\section{ETHAN ALLEN MINE (B-V-B6)}

Location.-On the south slope of Quartz $\cdot$ Hill about 540 feet $\mathrm{S} .80^{\circ} \mathrm{W}$. from the Kirk mine.

Production.-About 878 tons of smelting ore and 124 tons of concentrates shipped between 1912 and
1914 contained 325.54 ounces of gold, 6,044 ounces of silver, 26,754 pounds of copper, 5,863 pounds of lead, and 20,026 pounds of zinc. (Compiled by U.S. Bureau of Mines. Published by permission.)

Development.-Inclined shaft, 1st level is at 107 feet; workings reportedly connect with the 6th level of the Delmonico mine.

Veins.-Ethan Allen: Strike, nearly east; dip $80^{\circ} \mathrm{S}$. Wallrock.-Microcline-bearing gneiss.

Ore and sulfide minerals.-Pyrite, sphalerite, galena, chalcopyrite, gold, silver, and pitchblende(?).

Gangue minerals.-Quartz.

Ore shoots.-Lens of high-grade steel galena mined about 100 feet east of the shaft.

Tenor--Ore shipped between 1912 and 1914 averaged 0.21 ounce of gold and 4.56 ounces of silver per ton, 1.09 percent copper, 0.29 percent lead, and 0.57 percent zinc.

\section{FAIRFIELD MINE (A-VI-1)}

The Fairfield mine is near the head of Russell Gulch, at an altitude of 9,350 feet. According to Mr. Gus Reidle (written communication, 1954) the shaft is about 500 feet deep, and levels are turned at approximate depths of about $100,250,350,400$, and 450 feet. He reports that the 400 level connects to the Belmont mine. The total production is not known, but small quantities of ore were shipped to the Idaho Springs Sampling Works between 1925 and 1934. Typical shipments of ore are listed below.

Shipments from the Fairfield mine

[Published by permission of Idaho Springs Sampling Works]

\begin{tabular}{|c|c|c|c|c|}
\hline Year & Tons & Gold 1 & Silver ${ }^{1}$ & $\begin{array}{c}\text { Copper } \\
\text { (percent) }\end{array}$ \\
\hline $1925 \ldots$ & $\begin{array}{l}1.79 \\
2.57\end{array}$ & $\begin{array}{l}\text { 4. } 28 \\
\text { 3. } 60\end{array}$ & $\begin{array}{l}\text { 8. } 40 \\
\text { 6. } 25\end{array}$ & $\begin{array}{r}\text { 1. } 20 \\
.45\end{array}$ \\
\hline $1926 \ldots$ & .69 & 1. 98 & 4. 02 & 285 \\
\hline $\begin{array}{l}1929 \\
1934\end{array}$ & $\begin{array}{l}\text { 1. } 25 \\
\text { 1. } 42\end{array}$ & $\begin{array}{l}\text { 5. } 40 \\
\text { 4. } 18\end{array}$ & $\begin{array}{l}\text { 10. } 25 \\
11.22\end{array}$ & $\begin{array}{l}2.85 \\
1.60\end{array}$ \\
\hline
\end{tabular}

1. Ounces per ton.

The Fairfield vein strikes north-northeast, more northerly than other veins in this part of the district, and dips steeply west. According to Mr. R. R. Hinckley (oral communication) the vein is narrow, and it consists of pyrite, chalcopyrite, some sphalerite, and rare galena in a quartz gangue. Native gold occurs locally as small nuggets in white quartz. Copper is the dominant base metal, as shown by the sampling-works assays, and the silver-gold ratio is low, being about 2:1. 
A substantial gold ore shoot that plunges gently to the southwest was mined on the 400 and 500 levels.

\section{FOURTH OF JULY MINE (C-IV-25)}

Location.-On northeast slope of Quartz Hill about 1,370 feet S. $80^{\circ}$ W. from the Quartz Hill tunnel.

Production.-18.68 ounces of gold and 42 ounces of silver in 1911 (compiled by U.S. Bureau of Mines. Published by permission) ; reportedly yielded $\$ 250,000$ from a stope above the 250-level.

Development.-About 600-foot shaft, known levels at 250 and 450 feet.

Veins.-Fourth of July: Strike, N. $90^{\circ}$ E.; dip, steep either side of vertical; width, 6 inches to 10 feet, average $21 / 2$ feet; consists of silicified, crushed wallrock impregnated and veined by sulfides. Cross fracture on 450 level: Strike, N. $70^{\circ}$ E.; dip, $73^{\circ}$ SE.; unites with Fourth of July vein.

Wallrock.-Microcline-bearing gneiss.

Ore and sulfide minerals.-Pyrite, gold, silver, chalcopyrite, galena, and sphalerite.

Gangue minerals.-White and dark-gray quartz and dark-gray. chalcedony; the fine-grained chalcedony coats other minerals.

Ore shoots.-Shaft is in center of main shoot that plunges to the west and has a stope length of 150 feet.

\section{GAUNTLET MINE (D-IV-10)}

Location.-On the southeast slope of Quartz Hill about 690 feet $\mathrm{S} .60^{\circ} \mathrm{W}$. from the National mine.

Production.-About $\$ 25,000$ prior to 1899 (Callbreath, 1899); 147 tons of smelting ore and 41 tons of concentrates shipped between 1902 and 1912 contained 110.97 ounces of gold, 626 ounces of silver, and 5,105 pounds of copper. (Compiled by U.S. Bureau of Mines. Published by permission.)

Development.-The 500-foot shafts about 300 feet apart that connect with about 3,000 feet of drift.

Veins.-Gauntlet: strike, N. $75^{\circ}$ E.; dip, nearly vertical.

Wallrock.-Microcline-bearing gneiss.

Ore and sulfide minerals.-Pyrite, gold, silver, chalcopyrite, and galena, and sphalerite.

Gangue minerals.-Quartz.

Tenor.-Ore shipped between 1889 and 1906 contained gold, 1.10 to 3.02 ounces per ton; silver, 2.20 to 21.70 ounces per ton; copper, 0 to 12 percent; and lead, 0 to 48.00 percent.

\section{GEM-GOLDEN DOLLAR VEYN}

The Gem-Golden Dollar vein is on Alps Hill, near the west edge of the Quartz Hill area. It has been worked principally from the Gem (B-V-24) and Golden Dollar (B-V-23) mines and to shallow depths from two intervening shafts (fig. 29), the deepest of which is the Stewart (B-V-49). The recorded production from the vein, 1902-50, is given in tables 26 , 27 , and on page 83 . Most of the metal values have been in gold and silver, but some have been obtained from lead, copper, and zinc.

The vein strikes N. $65^{\circ}-70^{\circ}$ E. and, except locally, dips steeply northwest. It has been traced at the surface for more than 2,000 feet. The vein is a pyrite vein that contains local seams and pods of galena, sphalerite and chalcopyrite at the northeast end, but it is a galena-sphalerite vein in the Golden Dollar mine.

\section{GOLDEN DOLLAR MINE (B-V-23)}

The Golden Dollar (or Gold Dollar) mine is 740 feet southwest of the Gem shaft, at an altitude of 9,431 feet. The early history of the mine is not known. Production is reported for the years 1911 and 1915 and 1936-38 (table 26). In 1955, the mine was reopened by Central Uranium Corp., and the shaft was sunk from a depth of about 160 feet to a depth of about 210 feet.

The Golden Dollar shaft is a 2-compartment opening, inclined an average of $80^{\circ} \mathrm{NW}$., which was about 175 feet deep in May 1955. Three levels, at vertical depths of 42,66 , and 128 feet, connect with the shaft; the 66 level is 128 feet long and the 128 (main) level is 675 feet long (fig. 30). Small stopes have been driven above the 128 level on both sides of the shaft; the largest of the stopes-the Stewart stope-connects to the 128 level through several manway raises and ore passes (fig. 29).

The country rock is mainly microcline-bearing gneiss, which contains small bodies of pegmatite. Migmatitic biotite gneiss occurs at the southwest end of the 128 level (fig. 30). The wallrocks strike to northeast and dip regularly $20^{\circ}-50^{\circ} \mathrm{NW}$.

TABLE 26.-Ore produced from the Golden Dollar mine, 1902-54:

\begin{tabular}{|c|c|c|c|c|c|c|c|}
\hline Year & $\begin{array}{l}\text { Crude } \\
\text { ore } \\
\text { shipped } \\
\text { (tons) }\end{array}$ & $\begin{array}{l}\text { Concen- } \\
\text { trates- } \\
\text { shipped }\end{array}$ & $\begin{array}{c}\text { Gold } \\
\text { (ounces) }\end{array}$ & $\begin{array}{c}\text { Silver } \\
\text { (ounces) }\end{array}$ & $\begin{array}{l}\text { Copper } \\
\text { (pounds) }\end{array}$ & $\begin{array}{c}\text { Lead } \\
\text { (pounds) }\end{array}$ & $\begin{array}{c}\text { Zinc } \\
\text { (pounds) }\end{array}$ \\
\hline & 61 & \multirow[b]{2}{*}{2} & \multirow{5}{*}{$\begin{array}{r}20.27 \\
.69 \\
.90 \\
14.87 \\
7.80 \\
55.54 \\
30.00 \\
111.08\end{array}$} & \multirow{5}{*}{$\begin{array}{r}102 \\
6 \\
20 \\
20 \\
116 \\
253 \\
100 \\
226\end{array}$} & & 629 & \\
\hline 15 & 2 & & & & & 858 & 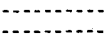 \\
\hline 936 & & ii & & & & $3,890^{\circ}$ & $2,47 \overline{6}$ \\
\hline 937. & 166 & 10 & & & $\begin{array}{l}196 \\
500\end{array}$ & $\begin{array}{l}2.759 \\
5.718\end{array}$ & \\
\hline 1938 & 291 & & & & & & \\
\hline Total.: & 558 & 23 & 241.15 & 843 & 696 & 13,854 & 2,476 \\
\hline
\end{tabular}

1 Compiled by U.S. Bureau of Mines. Published by permission. 
S. $60^{\circ} \mathrm{W}$

N. $60^{\circ} \mathrm{E}$.

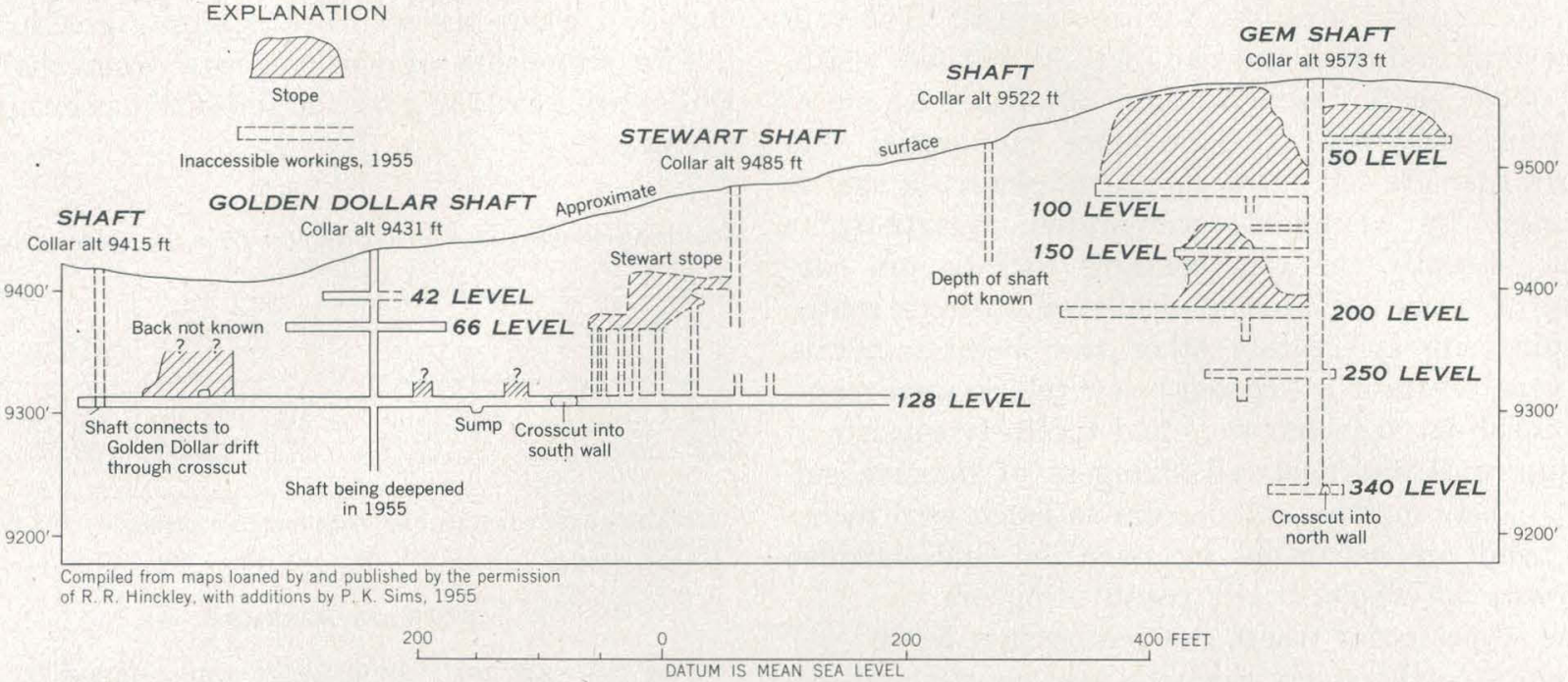

FIGURE 29.-Vertical longitudinal projection showing workings on Gem-Golden Dollar vein.

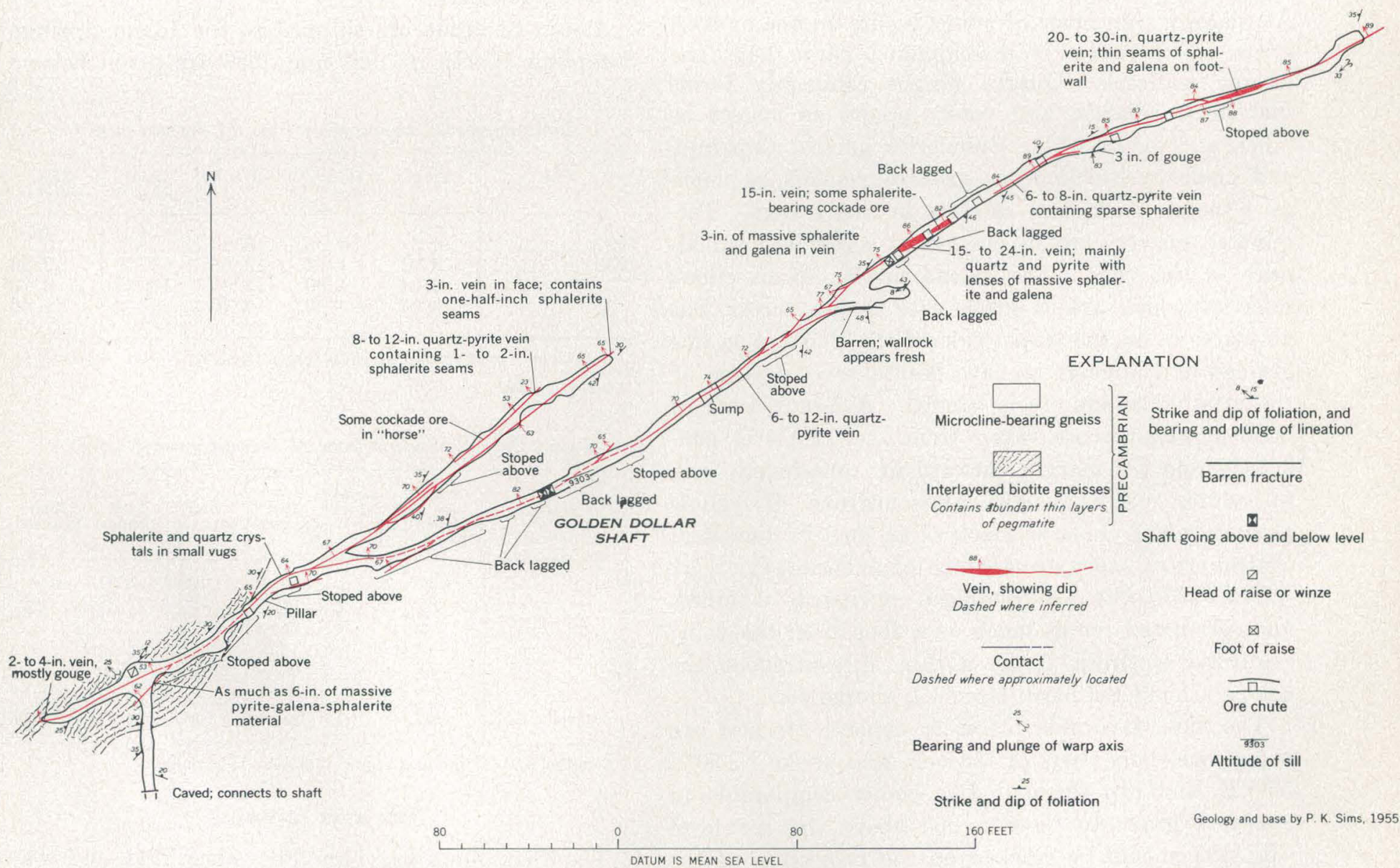

FIGURE 30.-Geologic map of the 128 level, Golden Dollar mine. 
The vein in the Golden Dollar mine strikes on the average $\mathrm{N} .60^{\circ}-65^{\circ} \mathrm{E}$., but it ranges from N. $50^{\circ} \mathrm{E}$. to N. $70^{\circ} \mathrm{E}$., and $\operatorname{dips} 55^{\circ} \mathrm{NW}$. to vertical. The vein has several branches, and one of these 100 feet southwest of the shaft was drifted for 160 feet. At places the vein consists of two or more subparallel vein fissures that are separated by altered wallrock that is traversed by abundant, subparallel, quartz-pyrite seams. Locally the vein contains cockade ore consisting of broken fragments of altered wallrock coated by sphalerite and rarely other base-metal minerals. The vein, where it is exposed below the Stewart stope, is as much as 30 inches wide and typically consists of hanging-wall and footwall stringers of massive sulfides. These massive sulfides are as much as 6 inches thick and are separated by pyritized and silicified wallrock, the whole locally constituting ore.

The stopes occur where the vein strikes N. $50^{\circ}-55^{\circ}$ E. (more northeasterly than the average strike direction) and dips steeply northwest. The stopes plunge steeply to the west.

Within the mine the exposed vein consists mainly of quartz, pyrite, and altered and broken wallrock. At places a thin layer of gouge occurs on one or both walls. The pyrite is disseminated throughout the altered wallrock. Quartz gangue commonly forms inch-thick veinlets, and rarely occurs as masses as much as 6 inches wide. Sphalerite, galena, tennanite, and chalcopyrite occur as massive veinlets as much as 4 inches thick, and as clots in small vugs. Terminated quartz crystals commonly occur with sphalerite in the vugs. The galena mostly forms cubes, some of which are as much as 2 inches across, but at places as in the stope west of the shaft, it is fine grained and appears to have been sheared. Some of the massive sulfide ore is banded. A 4-inch seam of banded, massive ore taken from the 128 level consisted from the margin outward of: one-fourth inch of white, milky quartz; pyritohedrons of yellow pyrite; galena cubes as much as an inch in diameter; chalcopyrite; one-sixteenth inch of ankerite(?).

The wallrocks are bleached, pyritized, silicified, and sericitized for as much as a foot from the vein; argillized wallrock forms a thin, discontinuous envelope around the hard, bleached, altered rock.

The most favorable places to explore for new ore bodies are those parts of the vein that strike $\mathrm{N}: 50^{\circ}$ $55^{\circ}$ E. and dip steeply. Ore bodies comparable in size and grade to those mined above the 128 level (fig. 29) should be reached on the projection of the shoots at deeper levels. It is improbable that commercial-grade ore will be found southwest of the present mine workings, for the vein is thin and weakly mineralized in the southwest face of the 128 level (fig. 30), where the wallrock is biotite gneiss.

Two shipments of smelting ore from the Golden Dollar mine in 1939 gave the following smelting-works assays:

Sampling-works assays of smelting ore from the Golden Dollar mine, $1999^{1}$

\begin{tabular}{|c|c|c|c|c|}
\hline Tons & Gold 2 & Silver ${ }^{2}$ & $\underset{\text { (percent) }}{\text { Lead }}$ & $\underset{\text { (percent) }}{\text { Zinc }}$ \\
\hline 1.68 & $\begin{array}{r}0.23 \\
.17\end{array}$ & $\begin{array}{r}\text { 5. } 35 \\
\text { 12. } 35\end{array}$ & $\begin{array}{r}6.75 \\
20.75\end{array}$ & $\begin{array}{r}5.25 \\
10.00\end{array}$ \\
\hline
\end{tabular}

1 Data on ore tenor furnished by Idaho Springs Sampling Works. Publisbed hr. permission.

2 Ounces per ton.

STEWART MINE (B-V-49)

The Stewart mine originally was opened by a shaft (fig. 29), but most of the production (Stewart stope) was taken out through the 128 level of the Golden Dollar mine. The reported production since 1902 is given in table 27.

Assays of crude ore shipped to the Idaho Springs Sampling Works in 1921 and 1939 are given belnw.

Sampling-works assays of ore from the Stewart mine ${ }^{1}$

\begin{tabular}{|c|c|c|c|c|c|}
\hline Year & Tons & Gold 2 & Silver 2 & $\begin{array}{c}\text { Lead } \\
\text { (percent) }\end{array}$ & $\begin{array}{c}\text { Zine } \\
\text { (percent) }\end{array}$ \\
\hline $1921 \ldots$ & $\begin{array}{l}0.51 \\
\text { 3. } 91 \\
\text { 2. } 34 \\
\text { 4. } 03\end{array}$ & $\begin{array}{r}0.98 \\
1.72 \\
1.80 \\
.49\end{array}$ & $\begin{array}{r}8.40 \\
10.65 \\
13.45 \\
4.40\end{array}$ & $\begin{array}{r}13.52 \\
13.25 \\
-\end{array}$ & $\begin{array}{l}\text { 2. } 90 \\
\text { 3. } 75 \\
\text { 1. } 40\end{array}$ \\
\hline
\end{tabular}

1 Data on ore tenor furnished by Idaho Springs Sampling Works. Published by permission.
2 Ounces per ton.

TABLE 27.-Production from the Stewart mine, 1902-54 ${ }^{1}$

\begin{tabular}{|c|c|c|c|c|c|c|}
\hline Year & $\begin{array}{l}\text { Crude } \\
\text { ore } \\
\text { shipped } \\
\text { (tons) }\end{array}$ & $\begin{array}{l}\text { Concen- } \\
\text { trates } \\
\text { shipped } \\
\text { (tons) }\end{array}$ & $\begin{array}{c}\text { Gold } \\
\text { (ounces) }\end{array}$ & $\begin{array}{c}\text { Silver } \\
\text { (ounces) }\end{array}$ & $\begin{array}{c}\text { Lead } \\
\text { (pounds) }\end{array}$ & $\begin{array}{c}\text { Zinc } \\
\text { (pounds) }\end{array}$ \\
\hline 1902 & & & $\begin{array}{r}534.03 \\
47.34\end{array}$ & $\begin{array}{l}114 \\
154\end{array}$ & $\begin{array}{l}3,611 \\
5,638\end{array}$ & \\
\hline $\begin{array}{l}1910 . \\
1911 .\end{array}$ & $\begin{array}{r}108 \\
77\end{array}$ & $\begin{array}{l}4 \\
4\end{array}$ & $\begin{array}{l}47.24 \\
19.23\end{array}$ & $\begin{array}{l}154 \\
170\end{array}$ & $\begin{array}{l}4.946 \\
4.040\end{array}$ & 2,105 \\
\hline 1912. & 73 & 5 & 28.42 & 1 & 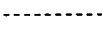 & $\cdots$ \\
\hline $1932-$ & $6^{6}$ & $\cdots$ & $\begin{array}{l}3.34 \\
2.35 \\
3\end{array}$ & 267 & 5,222 & \\
\hline 1938 & 235 & -............. & 61.12 & 354 & 4,754 & 1,812 \\
\hline & & & 84.28 & & & \\
\hline Total. & 1,611 & 13 & 780.11 & 1.062 & 24,171 & 5.145 \\
\hline
\end{tabular}

${ }_{1}$ Compiled by U.S. Bureau of Mines. Published by permission.

GEM MINE (B-V-24)

The Gem mine has been idle since 1914 and was inaccessible in 1955. The known production, 1902-54, is given in the following tabulation. 
Ore produced from the Gem mine (Alps Hill), 1902-54'

\begin{tabular}{|c|c|c|c|c|c|}
\hline Yenr & $\begin{array}{c}\text { Crude ore } \\
\text { shipped } \\
\text { (tons) }\end{array}$ & $\begin{array}{l}\text { Concen- } \\
\text { trates } \\
\text { shipped } \\
\text { (tons) }\end{array}$ & $\begin{array}{c}\text { Gold } \\
\text { (ounces) }\end{array}$ & $\begin{array}{c}\text { Silver } \\
\text { (ounces) }\end{array}$ & $\begin{array}{l}\text { Copper } \\
\text { (pounds) }\end{array}$ \\
\hline $\begin{array}{l}1902 \ldots \ldots \ldots \\
1903 \ldots \ldots \ldots \\
1005 \ldots \ldots . . \\
1906 \ldots . . .\end{array}$ & $\begin{array}{r}150 \\
50 \\
8.400 \\
450\end{array}$ & & $\begin{array}{r}46.50 \\
75.00 \\
350.00 \\
580.50\end{array}$ & $\begin{array}{r}2.000 \\
4.476\end{array}$ & 4.500 \\
\hline $\begin{array}{l}1907 \ldots \ldots \\
1911 \ldots \ldots \\
1911 \ldots \ldots \\
1912 \ldots \ldots\end{array}$ & $\begin{array}{r}225 \\
52 \\
124\end{array}$ & 2 & $\begin{array}{r}272.50 \\
56.45 \\
1.26 \\
94.20\end{array}$ & $\begin{array}{r}2.247 \\
320 \\
6 \\
173\end{array}$ & $\begin{array}{l}1,500 \\
\cdots\end{array}$ \\
\hline $\begin{array}{l}1912 \\
1913 \\
1913 \\
1914 \\
1914 \ldots\end{array}$ & 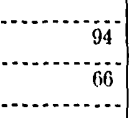 & 6 & $\begin{array}{r}3.38 \\
27.84 \\
3.25 \\
21.63 \\
3.84\end{array}$ & $\begin{array}{l}12 \\
23 \\
12 \\
37 \\
12\end{array}$ & $\cdots$ \\
\hline 'Toto & 0.611 & 18 & $1,536.35$ & 9,318 & 6.000 \\
\hline
\end{tabular}

1 Compiled by U.S. Bureau of Mines. Published by permission.

$$
\begin{array}{r}
\text { GERMAN (QUARTZ HILL) } \\
\text { (B-V-4-45) MINES }
\end{array}
$$

The German and Belcher mines, on the summit of Quartz Fill, are connected underground and accordingly are described together. The mines have produced moderate quantities of gold, silver, copper (table 28), and 16,160 pounds of pitchblende ore containing 1,622 pounds of $\mathrm{U}_{3} \mathrm{O}_{8}$. (Data on production and ore tenor furnished by the owners of the German and Belcher mines, and published by permission.)

The German shaft, inclined an average of $77^{\circ} \mathrm{S}$., is reported (Bastin and Fill, 1917, p. 240) to be 600 feet deep, but in 1954 it was accessible only to a vertical depth of 440 . Levels are present at vertical depths of $130,195,256,347,378$, and 435 feet.

The Belcher shaft was inaccessible in 1954, but it is more than 280 feet deep. A level at a depth of 280 feet connects with the 256 level of the German mine.

TABLE 28.-Ore produced from the German and Belcher mines,

\begin{tabular}{|c|c|c|c|c|c|c|c|}
\hline Year & $\begin{array}{c}\text { Crude } \\
\text { ore } \\
\text { shlpped } \\
\text { (tons) }\end{array}$ & $\begin{array}{l}\text { Concen- } \\
\text { trates } \\
\text { shipped } \\
\text { (tons) }\end{array}$ & $\begin{array}{l}\text { Clold } \\
\text { (ounces) }\end{array}$ & $\begin{array}{c}\text { Silver } \\
\text { (ounces) }\end{array}$ & $\begin{array}{c}\text { Copper } \\
\text { (pounds) }\end{array}$ & $\begin{array}{c}\text { Lead } \\
\text { (pounds) }\end{array}$ & $\begin{array}{c}\text { Zinc } \\
\text { (pounds) }\end{array}$ \\
\hline $\begin{array}{l}1891 . \\
1892\end{array}$ & & & & & & & \\
\hline 1003 & 10 & $\ldots$ & 120.95 & & & & \\
\hline $1909 \ldots . .$. & 134 & .............. & 128. 29 & 388 & 368 & & \\
\hline $1000^{3}$ & & 17 & 12.01 & 51 & & & \\
\hline $\begin{array}{l}1013 \\
1914\end{array}$ & 687 & 85 & 182.03 & 309 & 711 & & \\
\hline 1915. & 20 & $\cdots \cdot$ & $\begin{array}{l}6.45 \\
6.31\end{array}$ & $\begin{array}{l}44 \\
36\end{array}$ & 310 & $\cdots$ & \\
\hline 1010 & 43 & 6 & 12.66 & 23 & & & \\
\hline 1918. & 115 & & 73. & 364 & 10.579 & & \\
\hline $\begin{array}{l}1025 \ldots \ldots . . . . . \\
1930 \ldots .\end{array}$ & $\begin{array}{l}12 \\
15\end{array}$ & 3 & $\begin{array}{l}22.04 \\
17.74\end{array}$ & $\begin{array}{r}106 \\
12\end{array}$ & $\begin{array}{l}\text { 1. } 300 \\
133\end{array}$ & . & $-\cdots$ \\
\hline 1031. & 10 & & 10.63 & 9 & - & & \\
\hline $\begin{array}{l}193: \\
193:\end{array}$ & (1) ${ }_{20}$ & & & & 970 & & \\
\hline 1034 & 34 & $i$ & $\begin{array}{l}18.87 \\
11.87\end{array}$ & $\begin{array}{r}142 \\
46\end{array}$ & 970 & $\begin{array}{r}25 \\
157\end{array}$ & \\
\hline 1935 & 24 & ............. & 3.95 & & . & & \\
\hline 'Total.. & $\ldots$ & $\ldots$ & $1,055.07$ & 1.530 & 14,371 & 182 & 91 \\
\hline
\end{tabular}
exclusive of uranium, 1891-1954.1
The principal wallrocks are microcline-bearing gneiss and biotite-quartz-plagioclase gneiss. As shown in figure 17 , microcline-bearing gneiss forms the wallrock above the 256 level, and biotite-quartz-plagioclase gneiss forms the walls in the lower workings. The rocks strike northeast and except locally dip gently northwest. Two small dikes of quartz bostonite porphyry, which strike northwest and dip about $60^{\circ} \mathrm{NE}$, are present on the 435 level west of the German shaft.

Two veins of opposing dip, the German-Belcher and the Last Chance-Burro, are developed in the mines. The veins intersect in the 256 level just west of the Belcher shaft, and the intersection plunges about $17^{\circ}$ west.

The German vein strikes N. $75^{\circ}-80^{\circ}$ E., dips an average of $80^{\circ} \mathrm{S}$., and is irregular and characterized by many complex branching vein fissures. At places it is a single well-defined structure as much as 20 inches wide, but more commonly it consists of subparallel or acutely diverging vein fissures that constitute a wide mineralized zone. "Horses" between splits in the vein are altered and contain disseminated pyrite. Postmineralization shearing along the vein is slight. The wallrocks generally are intensely altered, and at many places immediately adjacent to the vein it is difficult to distinguish between microcline-bearing gneiss and biotite-quartz-plagioclase gneiss wallrocks. Near the face on the 130 level-east the vein, 12 inches wide, is surrounded by an 18-inch silicified and sericitized zone in which the mafic rock minerals are gone, and this zone in turn is surrounded by a 12-inch or more zone of argillic alteration which grades outward into unaltered wallrock. The contact between the silicified and argillic zones appears transitional.

The Last Chance-Burro vein strikes more northeasterly than the German vein and dips steeply north. At the surface (pl. 1) it trends N. $65^{\circ}-70^{\circ}$ E. and dips $75^{\circ}-85^{\circ} \mathrm{NW}$. The calculated dip of the Burro vein from the surface to its intersection with the German vein in the German shaft is $80^{\circ} \mathrm{NW}$. Observations in the German-Belcher mine show that the Burro vein is steeper near the intersection, and at places below the intersection it reverses dip to dip steeply southeast.

Both veins (pyrite, type $C$ ) contain sphalerite, galena, and chalcopyrite stringers that cut across the original pyrite vein material. Vugs that contain terminated quartz crystals are common, and stringers of white to tan chalcedonic quartz cut the sulfides. Pitchblende occurs locally in the German vein above the 130 level.

The ore that was shipped from the German and Belcher mines came entirely from stopes above the 
256 level and most of it probably was taken from a large stope above the 130 level between the German and Belcher shafts. Sampling-works assays of smelting ore shipped in 1909 , which is thought to be representative of the ore, are given in the table below.

Sampling-works assays of smelting ores from German and Belcher mines, 1909

[Source: Bastin and Hill (1917, p. 242)]

\begin{tabular}{|c|c|c|c|c|}
\hline Ore (net tons) & Gold ${ }^{1}$ & Silver ${ }^{1}$ & $\begin{array}{l}\text { Copper } \\
\text { (percent) }\end{array}$ & $\begin{array}{c}\text { Lead } \\
\text { (percent) }\end{array}$ \\
\hline $\begin{array}{l}3.122 \ldots \\
1.596 \\
1.305 \\
3.337 \\
1.286\end{array}$ & $\begin{array}{r}\text { 2. } 09 \\
2.86 \\
.46 \\
.31 \\
\text { 3. } 40\end{array}$ & $\begin{array}{l}7.44 \\
9.60 \\
6.90 \\
4.00 \\
9.00\end{array}$ & 0.20 & 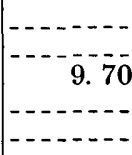 \\
\hline $\begin{array}{l}2.413 \\
3.580 \\
6.205 \\
0.907 \\
1.443 \\
3.270\end{array}$ & $\begin{array}{l}\text { 5. } 99 \\
\text { 2. } 00 \\
\text { 1. } 30 \\
\text { 4. } 00 \\
\text { 3. } 46 \\
.76\end{array}$ & $\begin{array}{r}13.64 \\
12.00 \\
2.30 \\
21.60 \\
11.30 \\
2.00\end{array}$ & $\begin{array}{r}.95 \\
1.80 \\
-1.90 \\
1.50\end{array}$ & 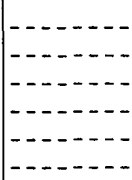 \\
\hline
\end{tabular}

1 Ounces per ton.

Most of the stoped ground is between walls of microcline-bearing gneiss or pegmatite, and it can be interpreted that the competence of these wallrocks was the principal factor in localizing the ore shoots. In the lower part of the mine, where the vein occurs between biotite-quartz-plagioclase gneiss walls, the vein is narrow and weakly mineralized.

The pitchblende produced from the German mine, so far as known, came entirely from the 130 level. Most of it probably came from the stope east of the shaft, but a piece of high-grade ore weighing 240 pounds that assayed 88 percent uranium oxide came from the 130 level-west (Bastin and Hill, 1917, p. 241). Probably the uranium ore taken from the Belcher mine similarly came from the upper levels. The pitchblende occurs as small lenses, weighing from a few pounds to a few hundred pounds, that are erratically distributed along the vein. The pitchblende also occurs as discontinuous veinlets from a fraction of an inch to 3 or 4 inches wide. Many veinlets branch from the main vein into the wall, particularly the footwall; these veinlets contain white quartz: and sparse sulfides in addition to pitchblende. The veinlets and lenses generally are high in grade, but the grade of the ore produced from them has depended on the size and spacing of individual occurrences and on the care with which they were mined and subsequently hand sorted.

\section{GOLD PATCH MINE (D-IV-14)}

The Gold Patch mine is on the northeast part of the Great Mammoth (351) claim, at an altitude of about 8,990 feet. All the workings were inaccessible in 1952. The recorded production from the Great Mammoth claim is 153 ounces of gold, 774 ounces of silver, 2,077 pounds of copper, 31,282 pounds of zinc, and 737 pounds of lead. (Compiled by U.S. Bureau of Mines. Published by permission.)

The Gold Patch mine was last worked in 1935. At that time the mine was about 140 feet deep. All the stoping was done northeast of the shaft, on the 90 and 140 levels.

The principal wallrock, microcline-bearing gneiss, strikes northeast and is folded into tight, asymmetric anticlines and synclines. A bostonite porphyry dike that trends east-northeast lies a short distance north of the Gold Patch shaft.

The vein worked in the Gold Patch mine strikes N. $50^{\circ}-60^{\circ}$ E. and dips nearly vertical; to the southwest it strikes more easterly and dips about $80^{\circ}$ southeast. The vein consists of a wide altered zone with abundant pyrite, white crystalline quartz, and dark gray cryptocrystalline quartz. Ore specimens on the dump indicate that the pyrite is predominantly cubic; it is abundantly disseminated through the vein and at places forms veinlets.

\section{HARSH MINE (C-V-6)}

Location.-On the south slope of Quartz Hill, about 1,290 feet S. $83^{\circ}$ E. from the East Calhoun mine.

Production.-About $\$ 20,000$ prior to 1899 (Callbreath, 1899); 141 tons of smelting ore and 102 tons of concentrates shipped between 1909 and 1912 contained 83.62 ounces of gold, 527 ounces of silver, and 11,677 pounds of copper. (Compiled by U.S. Bureau of Mines. Published by permission.)

Development.-80-foot shaft with drifts 50 feet west and 10 feet east at the bottom.

Veins.-Harsh: Strike, N. $60^{\circ}$ E.; dip, nearly vertical; 4-6 feet wide; post-mineral movement has crushed the filling and formed slickensides on the walls.

Wallrock.-Microcline-bearing gneiss.

Ore and sulfide minerals.-Pyrite, gold, silver, chalcopyrite, galena, and sphalerite. Sparse pitchblende is found on dump.

Gangue minerals.-Quartz and gray fine-grained quartz.

Tenor.-3 tons shipped in 1910 averaged 0.48 ounce of gold and 2.1 ounces of silver per ton.

\section{HAYES AND WHEELER TUNNEL (D-IV-9)}

The Hayes and Wheeler tunnel is at the head of Spring Gulch, about 250 feet, S. $50^{\circ}$ E. from the National mine. The tunnel, a drift, extends south- 
west for 420 feet; two branch drifts and a branch crosscut are turned from the main drift (fig. 31). The only stope in the accessible part of the mine is just northeast of the crosscut; other caved stopes appear to be present on veins $A$ and $C$.

The predominant wallrock of the mine is quartz diorite, a mafic border phase of the granodiorite body exposed east of the mine (fig. 4). This rock is cut by several small dikes of pegmatite, but only one of these is large enough to map (fig. 31). A dike of bostonite porphyry, which has an irregular trend and dips $75^{\circ} \mathrm{N}$. to vertical, is intersected by the tunnel about 262 feet from the portal and is exposed in the crosscut.

Near the portal, the tunnel follows vein $A$ (fig. 31), which trends about N. $53^{\circ}$ E. and dips $50^{\circ}-80^{\circ} \mathrm{SE}$. The vein ranges from 3 to 12 inches in width and in general is poorly mineralized. Just southwest of the portal lagging the vein is 12 inches wide and consists of breccia fragments of gray fine-grained quartz that are cemented by dense white honeycomb quartz and clear comb-quartz crystals. The openings in the

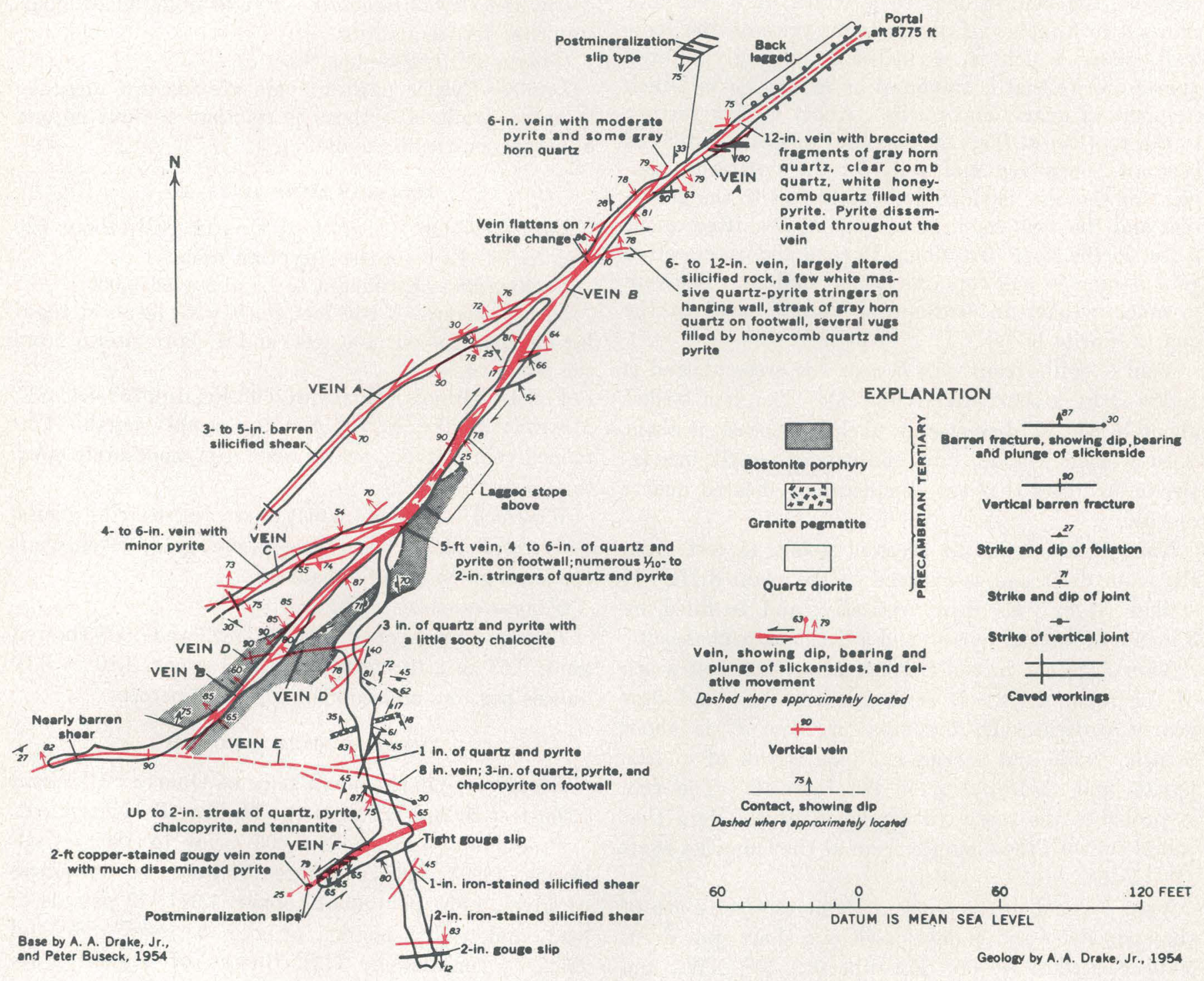

Frgure 31.-Geologic map of the Hayes and Wheeler tunnel. 
honeycomb are filled by pyrite crystals, and pyrite is liberally sprinkled throughout the vein. Several branch veins pass into both walls.

Vein $B$, which enters the main drift from the north about 105 feet from the portal, cuts and offsets vein $A$; the east segment of vein $A$ is shifted about 9 feet to the south along vein $B$ (fig. 31 ). Vein $B$ strikes about N. $40^{\circ}$ E., dips steeply northwest to vertical, and ranges in width from 6 inches to as much as 5 feet. Where vein $B$ enters the main drift, it consists of 6 inches of dense white quartz, pyrite, and some fragments of gray fine-grained quartz. About 145 feet from the portal the vein is joined from the east by a 6- to 12-inch "feeder vein," and southwest of this junction vein $B$ is markedly wider. Near the 205 crosscut, the vein widens to a width of 5 feet and shows 4 to 6 inches of quartz and pyrite on the footwall, above which is 54 inches of strongly altered quartz diorite that is traversed by many $1 / 10^{-}$to 2 -inch stringers of quartz and pyrite. About 60 feet farther to the southwest, the vein cuts and offsets the dike of bostonite porphyry and vein $D$; the northwest segment of the dike is shifted about 10 feet to the northeast and the west segment of vein $D$ is shifted about 5 feet in the same direction. Beyond this intersection vein $B$ pinches and contains sparse sulfides. The vein is much weaker in bostonite porphyry than in the quartz diorite body.

Vein $C$ splits from vein $B$ near the crosscut, and is followed by a short drift (fig. 31). The vein strikes about $\mathrm{N} .63^{\circ}$ E., dips steeply to the southeast, is about 4 to 6 inches wide, and consists of small quartzpyrite stringers that cut silicified and sheared quartz diorite.

Vein $D$ is cut in the crosscut about 45 feet from the main drift and is exposed in the main drift. It strikes N. $82^{\circ}$ E., dips vertically, and is filled by 3 inches of quartz, pyrite, and a little sooty chalcocite.

Vein $E$ is cut in the crosscut about 105 feet south of the main drift. It strikes nearly east and dips nearly vertical. In the crosscut, vein $E$ is about 8 inches wide and carries a 3 -inch streak of quartz, pyrite, and chalcopyrite on the footwall. The vein is probably the eastward extension of the vein that junctions with the Gauntlet vein at the Gauntlet shaft (D-IV-10).

Vein $F$ is cut in the crosscut about 130 feet south of the main drift and is developed by a short spur drift. Vein $F$ strikes N. $60^{\circ}$ E., dips $65^{\circ}-79^{\circ}$ NW., and ranges from 12 to 18 inches in width. It consists of a 2-inch streak of quartz, pyrite, chalcopyrite, and tennantite on the footwall.

\section{HECLA MINE (D-IV-6)}

Location.-On the south slope of Quartz Hill, about 600 feet west of the National mine.

Production.-About $\$ 25,000$ prior to 1899 (Callbreath, 1899); 4 tons of smelting ore and 16 tons of concentrates shipped between 1911 and 1914 contained 13.44 ounces of gold, 56 ounces of silver, and 282 pounds of copper. (Compiled by U.S. Bureau of Mines. Published by permission.)

Development.-A 500-foot shaft with 5,000 feet of drift.

Veins.-Hecla, a member of the Mammoth-National lode: strike, N. $82^{\circ}$ E.; $\operatorname{dip}, 85^{\circ} \mathrm{NW}$.

Wallrock.-Microcline-bearing gneiss and biotitequartz-plagioclase gneiss.

Ore and sulfide minerals.-Pyrite, gold, silver, chalcopyrite, and tennantite.

Gangue minerals.-Quartz.

Tenor.-Pyritic parts of vein are too low in grade to mine profitably; those parts that contain copper minerals constitute the ore.

\section{ILLINOIS MINE (C-IV-4)}

Location.-On the crest of Quartz Hill, about 620 feet N. $70^{\circ}$ E. from the Egyptian mine.

Production.-Estimated to be about $\$ 350,000$.

Development.-A 635-foot shaft with levels at regular depths of about 100 feet, and a short lateral from the Argo tunnel.

Veins.-Illinois: Strike, N. $60^{\circ}$ E.; dip, $75^{\circ}-85^{\circ} \mathrm{SE}$. Murray: Strike, N. $70^{\circ}$ E.; dip, steeply north. Unnamed vein: Strike, nearly east; dip, moderately steep to the south.

Wallrock.-Predominantly microcline-bearing gneiss.

Ore and sulfide minerals.-Pyrite, gold, silver, chalcopyrite, galena, and sphalerite.

Gangue minerals.-Quartz.

Tenor.-Ore shipped between 1893 and 1908 showed gold, 0.68 to 2.12 ounces per ton; silver, 4.80 to 8.10 ounces per ton, and copper, 0 to 3.90 percent.

\section{IVA'NHOE MINE (B-IV-15)}

Location.-On the north slope of Quartz Hill, about 1,500 feet S. $70^{\circ} \mathrm{W}$. from the Hidden Treasure shaft. Production.-About $\$ 100,000$ prior to 1899 (Callbreath, 1899) ; 3,682.69 ounces of gold, 64,766 ounces of silver, 1,893 pounds of copper, 1,917,319 pounds of lead, and 54,162 pounds of zinc between 1887 and 1952. (Compiled by U.S. Bureau of Mines. Published by permission.')

Development.-A 1,100 foot shaft; 2,000 feet of drift. 
Veins.-Ivanhoe: Strike, N. $75^{\circ}$ E.; dip, $75^{\circ} \mathrm{NW}$; some of the ore has been brecciated so that angular sulfide fragments are embedded in a matrix of altered country rock.

Wallrock.-Microcline-bearing gneiss, biotite-quartzplagioclase gneiss, and quartz bostonite porphyry.

Ore and sulfide minerals.-Galena, sphalerite, silver, chalcopyrite, pyrite, and gold.

Gangue minerals.-White quartz and dark-gray cherty quartz.

Tenor.-10 tons of ore shipped between 1898 and 1902 showed gold, 0.1 to 0.9 (average 0.59 ) ounce per ton; silver, 7.62 to 21.4 (average 13.95) ounces per ton; lead, 10.9 to 54.1 percent; and zinc, 8 to 18 percent.

\section{KANSAS LODE (C-IV-20)}

The Kansas, one of the richest lodes in the Central City district, crops out on the north slope of Quartz Hill (pl. 1) and has been developed for a distance of about 5,000 feet from Nevada Gulch on the northeast to a point just north of the Hidden Treasure shaft. The lode was discovered in 1859 , and it was claimed by many individuals. In 1864, several companies purchased parts of the lode, and systematic mining was begun. By 1877 the lode had been developed to a depth of 800 feet from the MonmouthKansas shaft (C-IV-20). ${ }^{10}$ Mining had largely ceased at the time of the study by Bastin and Hill (1917, p. 228-229), but subsequently a lateral was driven on the lode from the Argo tunnel and considerable mining was done from the lateral in the twenties, thirties, and early forties. In 1942, while driving a raise above the lateral, the workings of one of the shafts were accidentally reached, and as a consequence the water that had filled the old stopes of this and connecting veins on Quartz Hill entered the tunnel workings, drowning the miners and partly filling the Argo tunnel with old stope fill, necessitating its closing. Only minor work has been done on the lode since that date, and it was inaccessible in 1954 .

The lode reportedly yielded $\$ 4$ million before 1899 (Callbreath, 1899, p. 270). The recorded production from the Kansas lode 1902-54 is given in table 29; this ore if produced today would have a value of about $\$ 1,207,000$.

The lode is developed by 7 principal shafts, from east to west, the Alger-Kansas (D-IV-4), EnglishKansas (V-IV-26), University-Kansas (C-IV-28), First National-Kansas (C-IV-29), Monmouth-Kansas (C-IV-20), and Gold Coin-Kansas (B-IV-4). The Alger-Kansas mine is opened by a 390 -foot shaft

10 Collins, G. E., undated, Early mining history of Gilpin County, 12 p., report on flle in the Denver Public Library, Denver, Colo. $6548270-63 \longrightarrow 7$ from which levels have been turned at 80,135 , and 300 feet (Bastin and Hill, 1917, p. 229). The PeaseKansas shaft (C-IV-27) is more than 700 feet deep and connects to eight levels; the University-Kansas shaft is 683 feet deep and connects to nine levels; and the Gold Coin-Kansas shaft is 1,350 feet deep, and connects to 22 levels (pl. 3). The bottom level of the Pease-Kansas shaft connects with the 10th level of the Phoenix-Burroughs mine, and the 900 level of the Gold Coin-Kansas shaft connects with the 1,000 level of the Hidden Treasure mine (pl. 3). The amount of development from the other shafts is not known. The Kansas lode is also developed by the LaCrosse tunnel (fig. 35) and by a lateral from the Argo tunnel (pl. 3). The location and extent of the stoping in the Gold Coin-Kansas mine are shown on figure 32 .

The Alger-Kansas mine has stopes for 100 feet east of the shaft between the surface and the 300 level, and between the surface and the 135 level west of the shaft (Bastin and Hill, 1917, p. 229).

The Kansas lode trends about N. $77^{\circ}$ E., dips $80^{\circ} \mathrm{S}$. to vertical, and ranges in thickness from 2 to 4 feet. Near the Pease-Kansas shaft, the lode deflects to a strike of about N. $60^{\circ}$ E. and splits into several segments (pl. 1). The northernmost of these segments is developed by the English-Kansas mine, and farther to the east, is known as the Mlinois-Kansas vein. The Alger-Kansas vein lies a few feet south of the IllinoisKansas vein. It strikes about N. $60^{\circ}$ E., dips $80^{\circ}$ S., and ranges in width from 18 inches to 4 feet. The vein consists of pyrite-impregnated microcline-bearing gneiss cut by stringers of almost solid pyrite 1 inch or less in width, and by a series of dark quartzgalena-sphalerite-chalcopyrite veinlets, which are younger than the pyrite filling (Bastin and Hill, 1917, p. 229). Endlich (1874, p. 288) describes the main lode as follows:

The thickness of the vein is between 3 and 4 feet with a good body of ore, which receives and sends out quite a num. ber of shoots from and into either wall, while some cross the main vein; and in this case the intersections prove, as a rule, to be richer than the other portions *** Minerals found in the Kansas are identical with those from the lodes previously spoken of, the only difference being the cubical form is almost exclusively the only one for pyrite. Sphalerite begins to grow a little more abundant than it was in the central portion of the mining region. The ore of this lode is said to yield good pay, containing an appreciable quantity of gold.

The Kansas lode is intersected by the Camp Grove vein at about the Gold Coin shaft, and according to Fossett $(1876$, p. 266$)$ unites with the Burroughs lode at a depth of 400 feet in this mine. The map of the 
EOONOMIC GEOLOGY, CENTRAL CITY DISTRICT

TABLE 29.-Ore produced from the Kansas lode, 1902-54 ${ }^{1}$

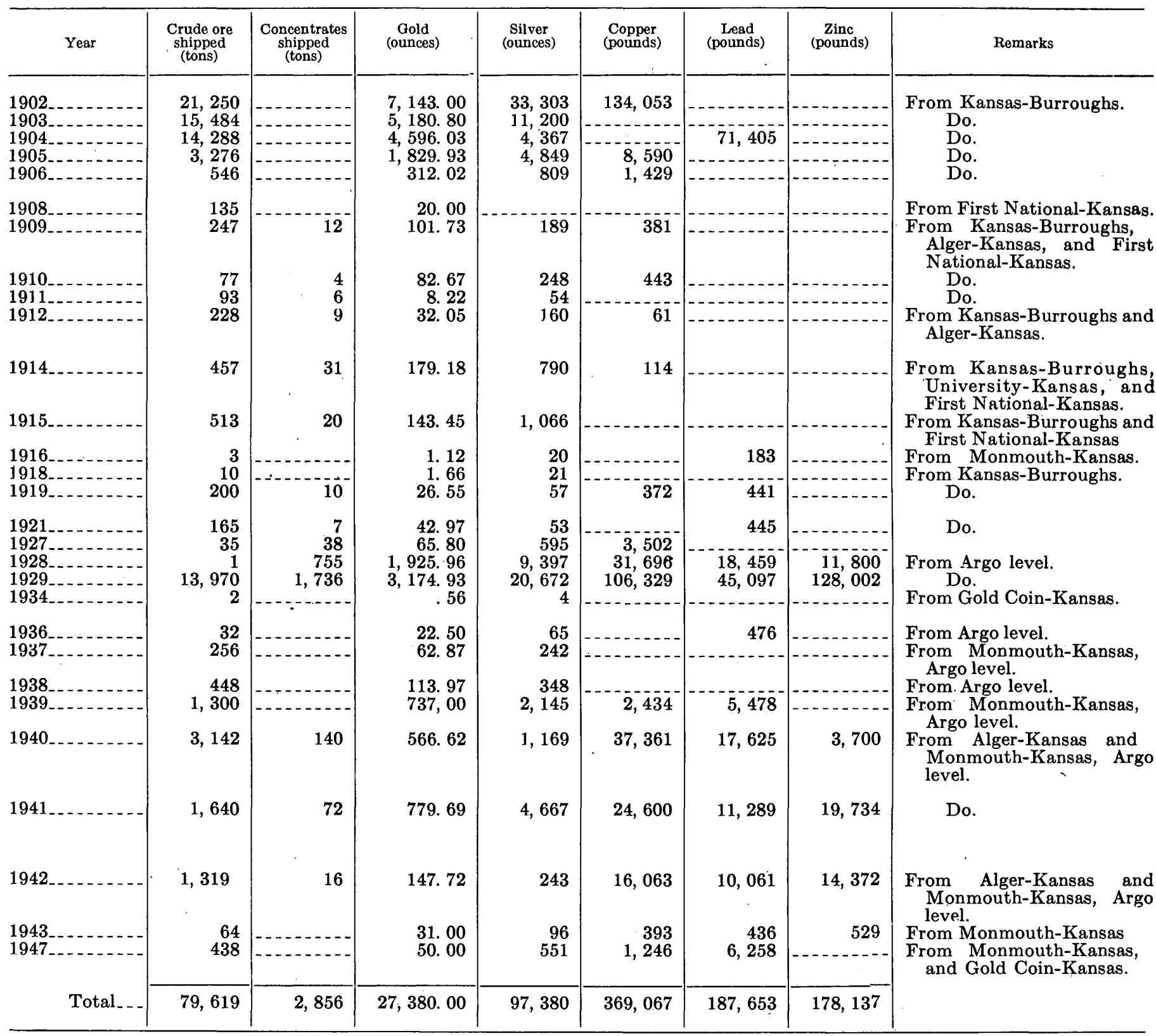

1 Compiled by U.S. Bureau of Mines. Published by permission.

western part of the mine suggests that part of the development is on the Burroughs lode (pl. 3). The intersection of the Kansas and Burroughs lodes plunges flatly to the east; the lodes are about 300 feet apart on the Argo level.

The location and attitude of the ore shoots in the Kansas lode are not fully known; the stopes shown on figure 32 are on more than one vein and cannot be distinguished separately. It is probable, however, that the ore shoots plunge to the west, probably at a moderately steep angle as do the others in this area. Ore certainly extends at depth at least to the Argo innel level, as much stoping was done on the lode at this altitude before the flooding disaster.

Representative metal contents of the ore from the lode are shown by the 348 tons shipped between 1894 and 1905; this contained gold, 0.35 to 5.56 (average 1.62) ounces per ton; silver, 2.25 to 14.7 (average 6.50 ) ounces per ton; and copper 5.5 percent or less. Concentrating ore shipped from the Phoenix-Kansas (Pease(?)) vein at and just above the Argo tunnel level averaged 0.59 ounces of gold, 2.52 ounces of silver, 0.78 percent copper, and 0.39 percent lead. ${ }^{11}$

11 Collins, G. E., op. cit. 
W

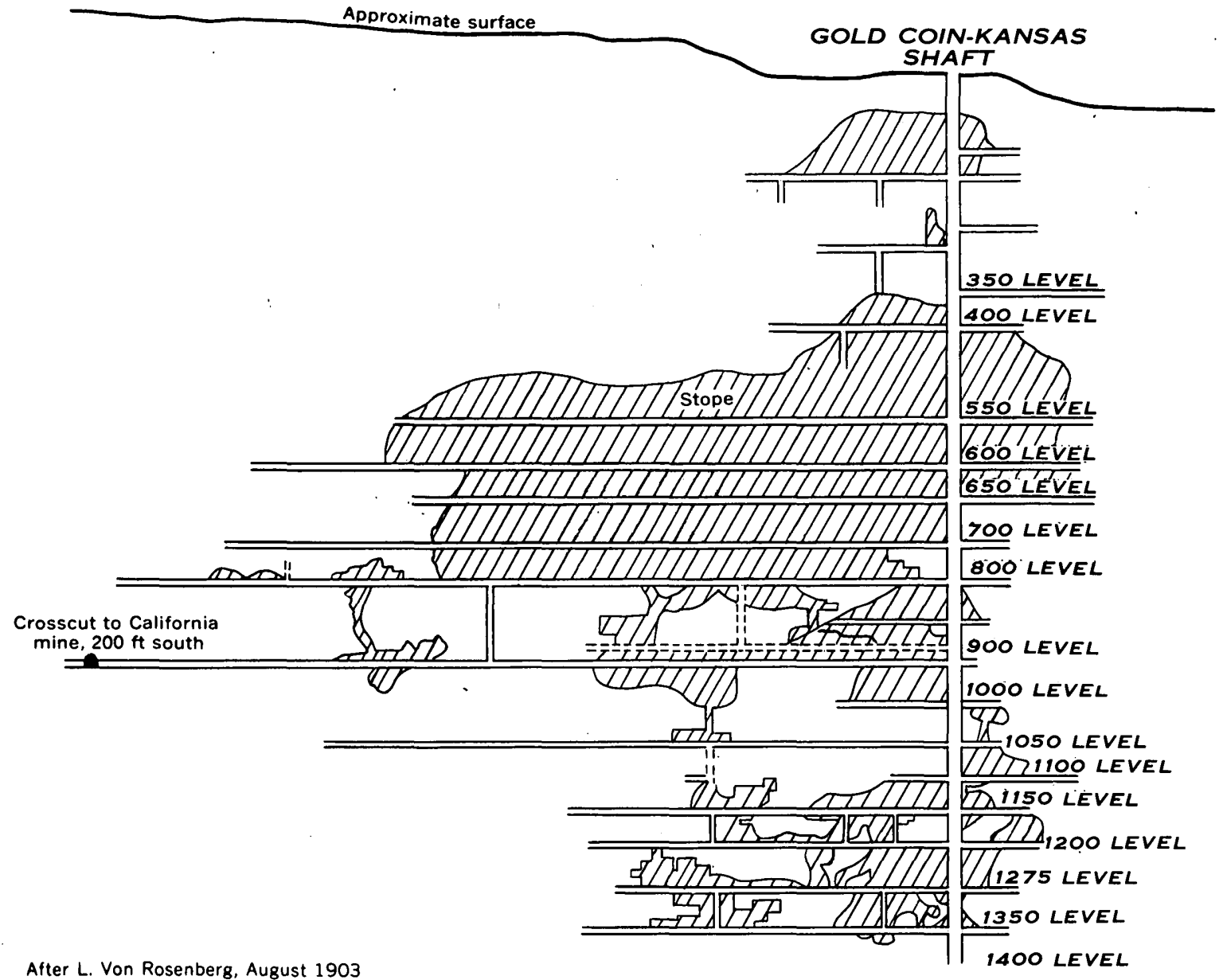

After L. Von Rosenberg, August 1903

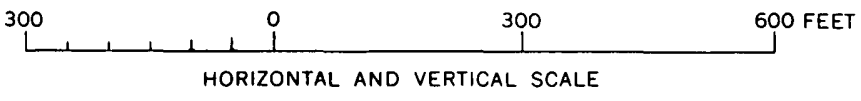

Figure 32.-Longitudinal section of the Gold Coln-Kansas mine

Smelting ore shipped to the Idaho Springs Sampling Works from the lode at and above the Argo level in the twenties and thirties showed the following range of metal content: gold, 1.23 to 3.15 (average about 2) ounces per ton; silver, 10.95 to 23.25 ounces per ton; copper, 0 to 3.29 percent; lead, 0 to 2.30 percent; and zinc, 0 to 3.12 percent.

\section{KENT COUNTY MINE (B-IV-16)}

The Kent County mine is on the north slope of Quartz Hill, about 1,000 feet S. $52^{\circ}$ W. from the California mine. The property is opened by an inclined shaft, 1,175 feet deep on the dip of the vein, and 12 levels and 2 sublevels (fig. 33). The longest of these levels, the 500 level, extends about 1,200 feet west of the shaft. These workings were inaccessible in 1954 .

The collar of the shaft is in microcline-bearing gneiss. Bostonite porphyry is reported on the hanging wall of the 5th level (Bastin and Hill, 1917, p. 238).

The gross output of the mine is estimated to have been about $\$ 800,000$ (Bastin and Hill, 1917, p. 238).

The Kent County vein strikes nearly east and dips $65^{\circ}-80^{\circ} \mathrm{S}$. It also is developed to the east by the Aetna (B-IV-17) and East Kent (C-IV-2) mines and to the west by several small shafts. Bastin and Hill (1917, p. 238) report that the vein ranges from 2 to 20 feet in width and consists of altered wallrock containing disseminated pyrite that is traversed by veinlets of galena, sphalerite, and chalcopyrite. They also report that the vein branches into both the hanging wall and footwall; the branches are almost parallel to the Kent County vein but dip more steeply.

The map of the western parts of the 700,800 , and 


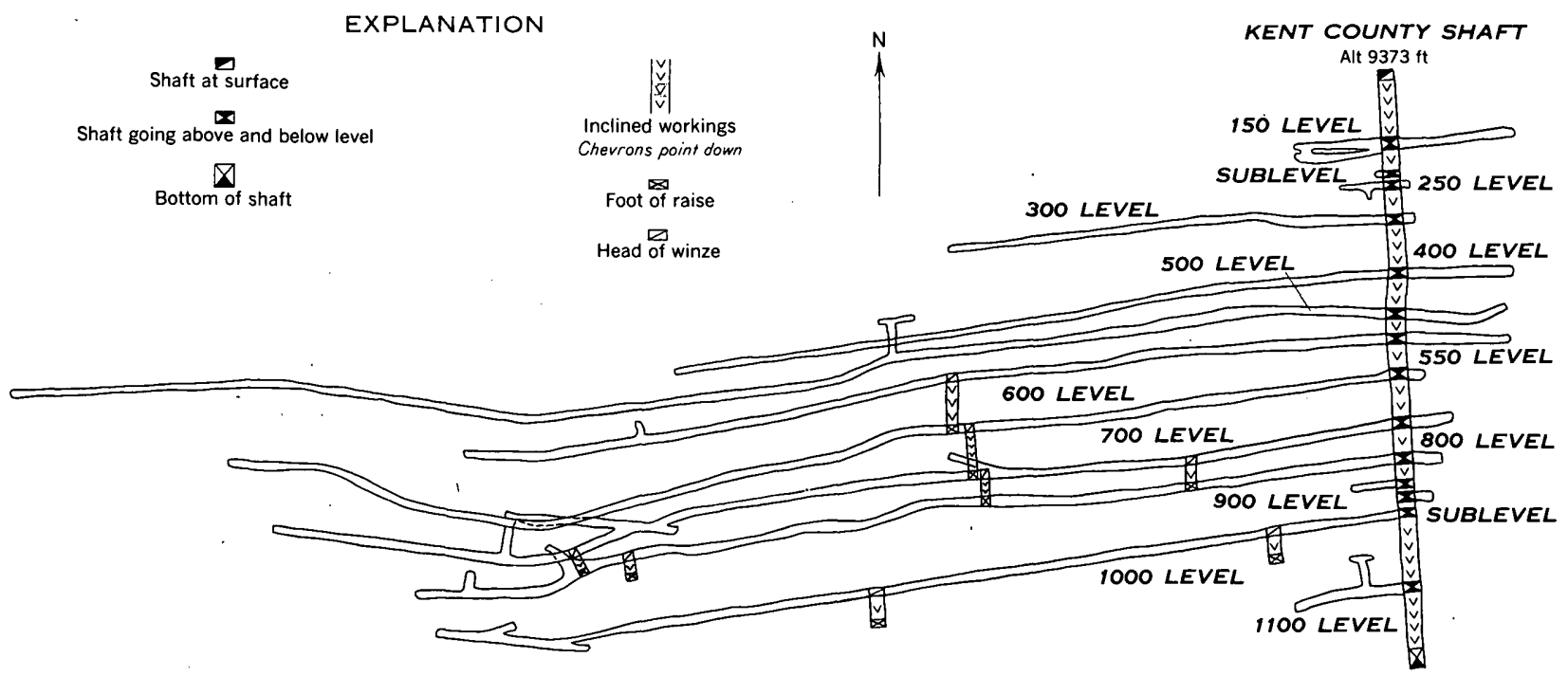

After company plat, 1910

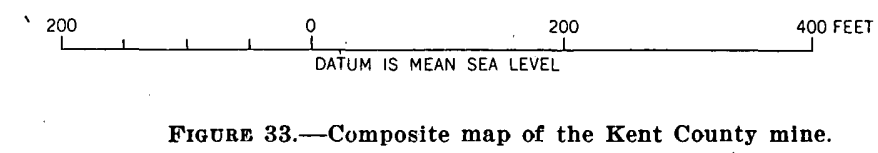

1,000 levels (fig. 33) suggests that the Kent County vein is intersected by another vein that trends a few degrees north of west and dips moderately to the southwest. The east segment of the Kent County vein apparently is displaced a few feet to the southeast along this vein.

The main ore shoot in the Kent County vein was found on the $2 \mathrm{~d}$ level-probably the 300 level (fig. 33 ), and was mined down plunge to just above the 800 level (Bastin and Hill, 1917, p. 238). The dimension, plunge angle, and structural control of this ore body are not known, but it obviously plunged to the west. It is inferred that the plunge was moderately steep, almost parallel to the trace of the intersection of the vein fissure and the foliation of the wallrock.

Ore shipped in 1904, the last year the mine operated, averaged 0.17 ounces of gold and 2.62 ounces of silver to the ton; this ore may not be representative of the run-of-the-mine, as the property closed the year it was shipped.

\section{KIRK MINE (B-V-37)}

The Kirk mine, on the upper part of Quartz Hill, has produced moderate quantities of gold, silver, copper, and uranium (table 30). It is one of the two principal sources of pitchblende in the district, having

TABLE 30.-Ore produced from the Kirk mine, 1897-1954 ${ }^{1}$

\begin{tabular}{|c|c|c|c|c|c|c|c|c|}
\hline Year & $\begin{array}{l}\text { Crude ore } \\
\text { shir fed } \\
\text { (tons) }\end{array}$ & $\begin{array}{c}\text { Concentrates } \\
\text { shirfed } \\
\text { (tons) }\end{array}$ & $\begin{array}{c}\text { Gold } \\
\text { (ounces) }\end{array}$ & $\begin{array}{c}\text { Silver } \\
\text { (ounces) }\end{array}$ & $\begin{array}{l}\text { Coprer } \\
\text { (pounds) }\end{array}$ & $\begin{array}{c}\text { Lead } \\
\text { (pounds) }\end{array}$ & $\begin{array}{c}\text { Zinc } \\
\text { (pounds) }\end{array}$ & $\begin{array}{c}\mathrm{U}_{3} \mathrm{O}_{8} \\
\text { (pounds) }\end{array}$ \\
\hline $\begin{array}{l}1897,10 \\
1898 \\
1905 \\
1906 \\
1907\end{array}$ & $\begin{array}{l}2.25 \\
8 \\
320 \\
123 \\
950\end{array}$ & $\begin{array}{r}100 \\
\hdashline\end{array} \quad 18$ & $\begin{array}{r}193.50 \\
129.12 \\
37.83\end{array}$ & $\begin{array}{r}1,656 \\
536 \\
77\end{array}$ & $\begin{array}{r}2,506 \\
810\end{array}$ & 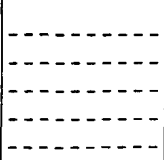 & 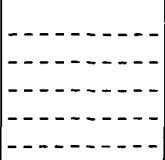 & $\begin{array}{r}2,250 \\
8,000 \\
14,000 \\
7,000\end{array}$ \\
\hline 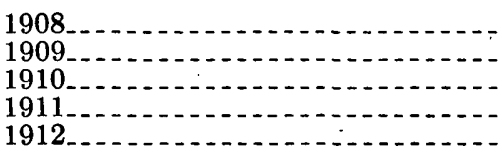 & $\begin{array}{r}870 \\
67 \\
44 \\
247 \\
48.5\end{array}$ & $\begin{array}{r}120 \\
17 \\
5 \\
24 \\
-\end{array}$ & $\begin{array}{r}\text { 297. } 00 \\
19,55 \\
\text { 7. } 20 \\
\text { 23. } 86 \\
\text { 1. } 14\end{array}$ & $\begin{array}{r}1,290 \\
72 \\
67 \\
153 \\
3\end{array}$ & $\begin{array}{r}10,800 \\
1, \begin{array}{r}155 \\
25\end{array}\end{array}$ & 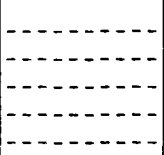 & 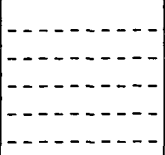 & $(1,490$ \\
\hline $\begin{array}{l}1914, \ldots 1 \\
1931 \\
1937 \\
1938 \\
1939\end{array}$ & $\begin{array}{r}50 \\
2 \\
315 \\
111 \\
55\end{array}$ & 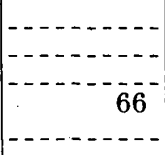 & $\begin{array}{l}49.12 \\
84.70 \\
20\end{array}$ & $\begin{array}{r}4 \\
182 \\
447 \\
93\end{array}$ & $\begin{array}{r}540 \\
541\end{array}$ & (2- & (2- & 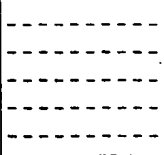 \\
\hline Total $\ldots \ldots$ & $3,212.75$ & 350 & 863. 44 & 4,580 & 16,659 & 541 & 525 & 32,740 \\
\hline
\end{tabular}

1 Compiled by U. S. Bureau of Mines. Published by permission. 
produced 180.25 tons of ore that contained 32,740 pounds of $\mathrm{U}_{3} \mathrm{O}_{8}$ (Sims and others, 1963).

The mine is opened by three shafts, the Main shaft, Discovery shaft, and Outer (East) shaft (fig. 34); short levels are turned from the Main shaft at vertical depths of $88,141,203,239,301$, and 381 feet. With the exception of the workings from the Discovery shaft, which were caved, the mine was examined and sampled in 1944 by Guillotte and Hill (written communication, 1944). As this survey was primarily to evaluate the mine as a potential source of uranium ore, they obtained much information concerning grade but made few observations concerning geologic relations of the pitchblende-bearing ore.

The Kirk vein strikes N. $70^{\circ}-75^{\circ}$ E., dips an average of about $75^{\circ} \mathrm{SE}$. and can be traced at the surface for a distance of at least 1,400 feet (pl. 1). The vein cuts microcline-bearing gneiss and biotite-quartz-plagioclase gneiss, which strike northeast and dip gently northwest (fig. 17). The mine workings are bottomed in biotite-quartz-plagioclase gneiss. Two northwestward-trending quartz bostonite dikes crop out sporadically at the surface west of the main shaft, and several dikes were cut underground.

The Kirk vein occupies a strong zone of fracturing that ranges in width from less than a foot to about 6 feet. It consists of gray quartz, abundant pyrite, some chalcopyrite and tennantite, and scattered sphalerite and galena; chalcocite is reported in the ore to depths of at least 141 feet. The wallrocks are serici-

W

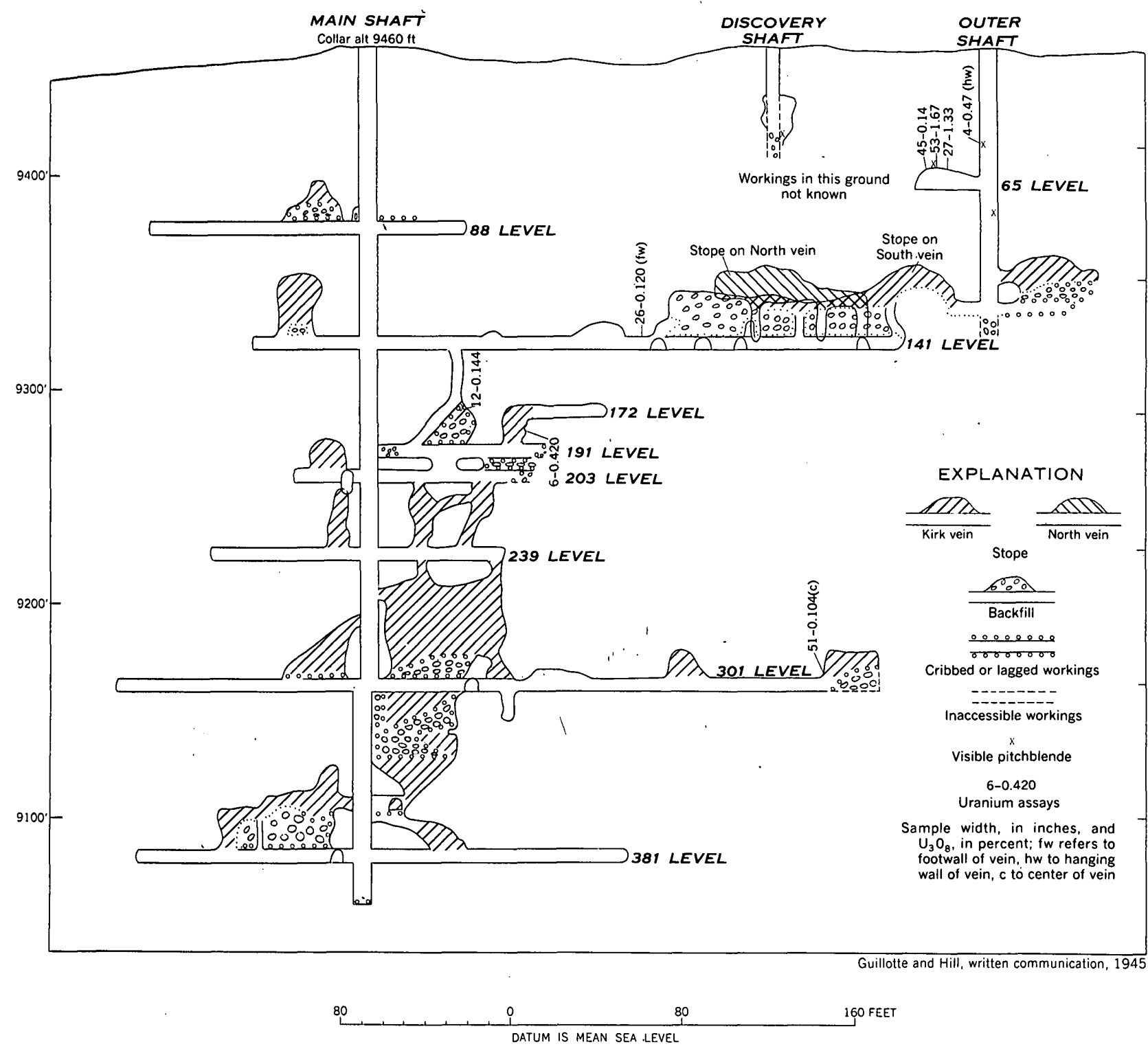

Figurn 34.-Longitudinal projection in plane of Kirk veln, Kirk mine. 
tized, silicified, and impregnated with small cubes of pyrite. The metallic minerals form erratic stringers from half an inch to about a foot wide, which at places are frozen to the walls and at other places occur in the altered wallrock which fills much of the vein zone. Gouge-filled postmineralization fractures occur on the walls or cross from one wall to the other. Guillotte and Hill (written communication, 1944) state that the vein is strongly mineralized in microcline-bearing gneiss but is weakly mineralized in "schist." On the 141 level, 100 feet east of the main shaft, the Kirk vein is crossed by a vein that strikes N. $78^{\circ}$ E. and dips $80^{\circ} \mathrm{S}$; ; possibly the same intersection was reached on the 381 level east.

Detailed sampling of the mine by Guillotte and Hill shows that the exposed parts of the vein generally contain sparse gold. Most samples that were taken contained less than 0.2 ounces of gold per ton, and only 2 samples assayed more than 1 ounce of gold per ton. In general, the gold content of the exposed vein is slightly higher in the ground adjacent to the Outer (East) shaft.

Judging from the distribution of stopes in the mine (fig. 34), three separate gold-bearing ore shoots, which locally contain pitchblende ore, were mined. The largest ore shoot extends from just below the 141 level to the 381 level and probably below, and plunges steeply west. The stopes on this ore shoot are rarely as much as 3 feet wide and at places are only a foot wide (Guillotte and Hill, written communication, 1944). Another large stope is on the south vein above the 141 level, beginning 50 feet east of the main shaft and extending 50 feet beyond the east shaft. A third stope is above the 141 level on the North vein. This stope is 6 to 8 feet wide, but according to Guillotte and Hill the vein is only 4 to 6 inches wide; the rest of the stoped ground consists largely of soft altered microcline-bearing gneiss. The small stopes west of the main shaft on the levels above the 381 level are on small lenses of sulfide-bearing ore in silicified microcline-bearing gneiss. The stope walls range from 1 to 4 feet apart; the sulfide ore pinches to the west. The extent of mining from the Discovery shaft is not known, nor is it known which of the two veins in this area was mined.

The detailed sampling by Guillotte and Hill shows that the uranium-bearing parts of the vein occur predominantly in the upper workings. The locations of the samples that assayed more than 0.1 percent $\mathrm{U}_{3} \mathrm{O}_{8}$ are shown on figure 34 , together with the locations where pitchblende was observed in place. On the 65 level of the East shaft a segment of vein more than 10 feet long, having an average width of 3.6 feet, con- tains an average of 1.05 percent $\mathrm{U}_{3} \mathrm{O}_{8}$. Pitchblende was observed nearby in the shaft both above and below the level. Pitchblende also was seen above the cave in the Discovery shaft, and at one place in the stope between the 141 and 203 levels.

\section{LA CROSSE TUNNEL AND THE PATCH}

The portal of the LaCrosse tunnel (C-IV-40) is on the north slope of Quartz Hill, at an altitude of $8,997 \mathrm{ft}$ (pl. 1). The tunnel was driven in 1867 to drain the mines on the north slope of Quartz Hill to the level of Nevada Gulch, and in recent years it served as a haulageway for the Chain O'Mines glory hole operations at the Patch.

The tunnel extends for about 1,400 feet on a general southerly direction. Many crosscuts and drifts have been turned from the principal tunnel, forming a complex maze of workings, some of which are shown on plate 3 ; a more complete map of the workings is given by Lovering and Goddard (1950, fig. 61). The tunnel connects with the 4th level of the San Juan mine to the west, with the Climax shaft to the east, and with the Protection shaft of the Rhoderick Dhu mine (C-IV-44) to the south. In recent years, the ground above the northern part of the tunnel was stoped by glory-hole methods, and the resultant open space extends several feet below the tunnel level. The Patch is also developed by the Quartz Hill tunnel (Lovering and Goddard, 1950, fig. 61) and the Argo tunnel (pl. 3), the Rome-Gardner mine 900 feet below the surface, the Mackey-Burroughs mine 1,000 feet below the surface, and a short crosscut from the 1,300 level of the Phoenix-Burroughs mine. ${ }^{12}$ In 1954 most of the LaCrosse tunnel workings were accessible, but only a small part of the workings were mapped in order to study the geologic relations of the Patch (fig. 35).

The total production from the LaCrosse tunnel is not known. It is reported ${ }^{13}$ that prior to 1929 the San Juan stopes above the LaCrosse tunnel yielded $\$ 400,000$, the Protection stopes yielded $\$ 85,000$, and the Modoc stopes yielded $\$ 20,000$. From 1929 to 1950 , $1,428,135$ tons of rock that yielded 20,239 tons of concentrates were milled, and 48 tons of smelting ore was shipped from the LaCrosse tunnel workings. The concentrates and crude ore contained $61,080.49$ ounces of gold, 124,421 ounces of silver, 335,914 pounds of copper, 496,591 pounds of lead, and 2,322,429 pounds of zinc; this ore, if produced today would have a

12 Collins, G. E., 1907, Report on the Patch area, Gilpin County, Colorado, 19 p. Report on file in the Denver Public Library, Denver, Colo.

13 Collins, G. E., 1907, op. cit. 


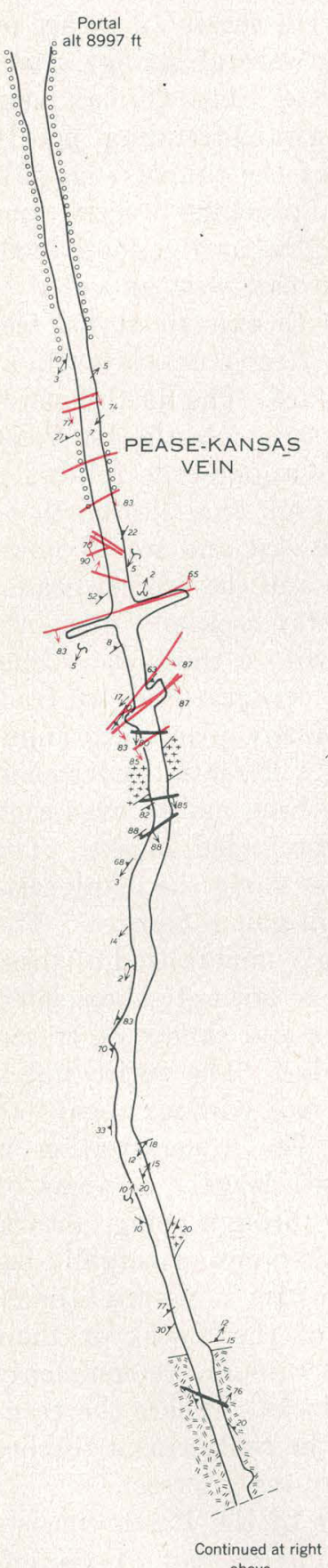

Base by A. E. Dearth
and A. R. Krueger, 1953

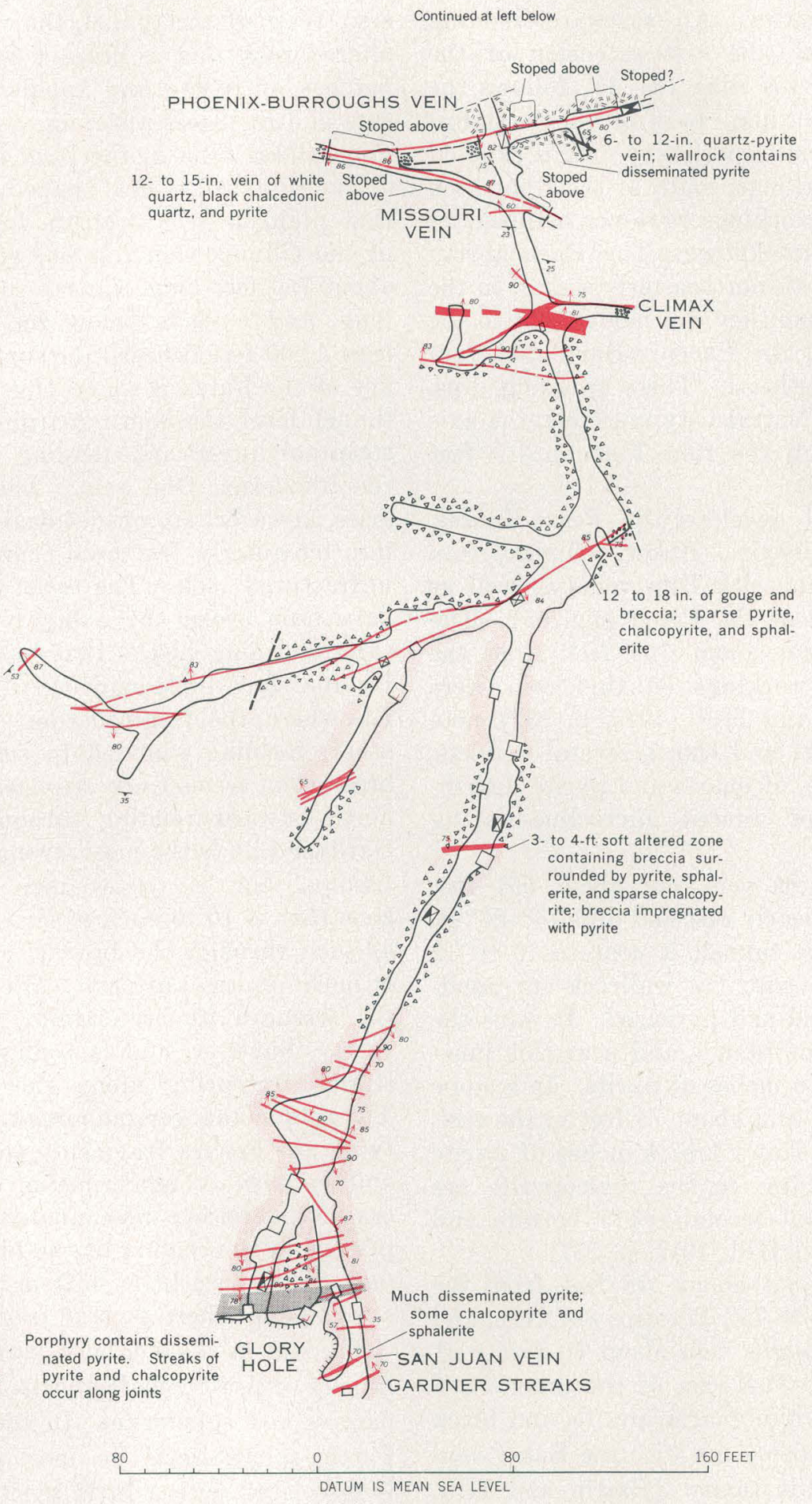

Bearing and plunge of lineation

Strike of

Strike of vertical foliation and plunge of lineation

Strike and dip of foliation

Strike and dip of foliation and bearing and plunge of lineation

Shaft going above and below level

Bottom of shaft

Foot of raise

Head of winze

Ore chute

200000

Lagging

그

Caved working

괄

Filled working

Geology by A. A. Drake, Jr and P. K. Sims, 1954

FIgURE 35.-Geologic map of part of the LaCrosse tunnel. 
value of about $\$ 2,706,500$. (Compiled by U.S. Bureau of Mines. Published by permission of the owners.)

Microcline-bearing gneiss is the prevailing wallrock in the mine; it contains thin interlayers of amphibolite and granite pegmatite. An eastward-trending bostonite porphyry dike, the east extension of the long, continuous California dike ( $\mathrm{pl} .1$ ), follows the Gardner vein in the southern part of the workings (fig. 35). Another bostonite porphyry dike is exposed in the southernmost workings, south of the Rhoderick Dhu vein, but as these workings were not mapped, its geologic relations are not known. The Precambrian rocks have a general north-northeasterly strike; in the northern part of the mine they dip moderately to the northwest, and south of the Phoenix-Burroughs vein they dip moderately southeast. These opposing dips, in general, outline the Central City anticline, the axis of which passes through the tunnel about 410 feet from the portal (fig. 35).

The LaCrosse tunnel develops the Pease-Kansas, Phoenix-Burroughs, Missouri, Baker, Climax, San Juan, Gardner, and Rhoderick Dhu veins as well as the stockwork ore body of the Patch (fig. 35). The Pease-Kansas vein is cut about 150 feet from the portal. In 1954, the workings on this vein were lagged off, but Bastin and Hill (1917, p. 237) note that it is nearly vertical and shows several veinlets, 2 inches or less in width, of quartz and pyrite distributed through 2 feet of altered microcline-bearing gneiss.

The Phoenix-Burroughs vein, cut about 554 feet from the portal, trends nearly east and dips $75^{\circ}-86^{\circ} \mathrm{S}$. In the drift east of the tunnel, it contains 6 to 12 inches of quartz and pyrite; the wallrock surrounding the vein is sericitized and pyritized. It joins the Missouri vein west of the tunnel, and near this junction has a maximum of 6 inches of pyrite. In a stope 30 feet above the tunnel and about 75 feet to the east, one branch of the vein shows 1 to 4 inches of pyrite and chalcopyrite; fractures in the chalcopyrite are coated with thin films of secondary(?) bornite and chalcopyrite (Bastin and Hill, 1917, p. 237).

The Missouri vein is cut about 578 feet from the portal. It strikes about $\mathrm{N}$. $75^{\circ} \mathrm{W}$., dips $86^{\circ} \mathrm{NE}$., and joins the Phoenix-Burroughs vein about 80 feet west of the tunnel (fig. 35). Just east of the junction, it has 12 to 15 inches of white quartz, pyrite, and black fine-grained quartz. It also joins with the Baker vein about 50 feet east of the tunnel (Bastin and Hill, 1917, p. 237).

The Climax vein is intersected about 626 feet from the portal. It appears as a flat $S$ in outline, with the legs striking about east and the center limb about
N. $60^{\circ}$ E.; it dips $75^{\circ}-83^{\circ}$ N. (fig. 35). Just east of the tunnel, the vein is an 18- to 24 -inch "silicified" zone that contains sparsely disseminated pyrite, and is cut by several $1 / 6$ - to $1 / 2$-inch pyrite-sphalerite stringers. West of the tunnel, the vein shows 12 inches of altered rock that is crossed by several stringers and patches of pyrite and sphalerite. The Climax vein cuts and displaces a strong eastward-trending, poorly mineralized zone in the back of the tunnel (fig. 35).

The Patch, an oval-shaped, pipelike breccia zone that plunges steeply north, begins at the south wall of the Climax vein. It has an east-west axis that is about 750 feet long, a north-south axis about 450 feet long, and extends below the Argo tunnel level, at least 1,600 feet beneath the surface. The north boundary of the Patch is sharp (fig. 35). On the LaCrosse tunnel level the south margin apparently follows a steep northwestward-trending fault that lies north of the Rhoderick Dhu vein. The east and west boundaries, however, are gradational and the breccia grades into irregularly fractured country rock and then into unfractured rock. The rocks within the breccia zone have been broken by a highly irregular net of fractures, forming blocks that in many places are angular and show little evidence of differential movement. Elsewhere, the fragments have been moved over each other, forming rounded to subrounded blocks. The brecciation seems to be strongest along the many eastnortheastward-trending through-going fissures. The Gardner vein is the most strongly mineralized of these fissures, but it passes into a strongly brecciated zone that is 10 to 20 feet across and cannot be traced as such through the breccia pipe. The entire Patch is more or less uniformly altered, without regard to the strength of brecciation. The mineralization is spotty, however, and is confined largely to areas of strong fracturing along the through-going shears. The sulfide and gangue minerals occur principally between the breccia fragments, in part as fissure fillings, and in part as replacements of the blocks or their crushed matrices; disseminated sulfides are commonly present in the centers of the blocks. Where the fragments have been little shifted, the replacement reaches a maximum where several fractures intersect.

The ore in the southern part of the Patch consists largely of pyrite, chalcopyrite, quartz, and a little tennantite and sphalerite. In the northern part of the Patch, sphalerite is the most abundant mineral, and is associated with a little pyrite, galena, chalcopyrite, quartz, and ankerite(?). Vugs 2 to 3 inches across are common; they are generally filled with terminated quartz crystals, and more rarely by a sphaleritechalcopyrite assemblage. 
The Patch is exposed in the Argo tunnel from 18,867 to 19,412 feet from the portal. These workings were inaccessible at the time of our study, but are described by Bastin and Hill (1917, p. 236) as follows. The south border of the Patch at this altitude is a nearly vertical northwestward-trending fault zone about a foot wide, which consists of soft, crushed biotite-quartz-plagioclase gneiss that contains boulderlike masses of pegmatite and microcline-bearing gneiss. This fault zone cuts sharply across the foliation of the undisturbed biotite-quartz-plagioclase gneiss that forms its south wall. In places along the tunnel the rock fragments in the Patch are generally less than 4 feet in diameter and are set in an arkoselike matrix. The fragments are heterogeneous in size, in lithology, and in degree of rounding. The Patch, as exposed in the Argo tunnel, is practically barren as compared with the LaCrosse workings; sulfides are present in only a few small areas.

Ore shipped from the San Juan workings in the Patch (see p. 100) between 1888 and 1909 showed gold, a trace to 12.2 (average 2.09) ounces; silver, 2.15 to 34 (average 6.81) ounces; and copper from less than 1.5 to 9 percent. These figures represent only the richer ore. The average value of concentrates for the above period was about $\$ 26$ per ton. A test mill run of 576.86 tons of run of the mine material from the Patch returned $\$ 1.58$ (at $\$ 20$ gold) per ton in gold. The weighted average of many samples cut along the south wall of the Argo tunnel in the Patch was 0.071 ounce of gold and 0.489 ounce of silver per ton.

\section{LAST CHANCE MINE (B-V-44)}

Location.-On the south slope of Quartz Hill about 140 feet S. $75^{\circ} \mathrm{E}$. from the Belcher mine.

Production.-About $\$ 5,000$ prior to 1899 (Callbreath, 1899).

Development.-A 125-foot shaft and 250 feet of drift; crosscut from shaft bottom connects with the 20 level of the Belcher mine.

Veins.-Last Chance-Burro: Strike, N. $70^{\circ}$ E., dip $80^{\circ} \mathrm{NW}$; average width, 1 foot.

Wallrock.-Microcline-bearing gneiss, biotite-quartzplagioclase gneiss, and minor amphibolite.

Ore and sulfide minerals.-Pyrite, gold, silver, chalcopyrite, galena, and sphalerite.

Gangue minerals.-Quartz.

\section{MAMMOTH MINE (D-IV-8)}

The Mammoth mine, at the west end of the Mammoth 114 patented claim, is one-third of a mile south of Central City. The shaft collar, at an altitude of 8,695 feet, is on the west side of State Highway 279 (pl. 1). The workings consist of a shaft, 125 feet deep, that is inclined steeply to the south, a short level at a depth of about 90 feet, and a level at a depth of 125 feet (fig. 36).

The microcline-bearing gneiss wallrock in the mine dips gently to the northwest, and constitutes the southeast limb of a small syncline. The gneiss is cut by an eastward-striking bostonite porphyry dike, 11 to 14 feet wide, that dips steeply south (fig. 36).

The vein worked in the mine is part of the Mammoth lode system but is about 100 feet southeast of the main Mammoth vein which was mined on Bobtail hill (pl. 1). The vein was worked by shallow shafts and pits for about 600 . feet each side of the Mammoth shaft. On the 125 level the vein consists of two or more echelon fractures that "horsetail" (fig. 36). The main veins strike $\mathrm{N}$. $70^{\circ}-75^{\circ} \mathrm{E}$; ; laterally, to the east, each passes into "horsetailing" veins that strike more northeasterly. Probably the horsetailing-filled fracture die out within a short distance from the main veins.

The vein is made up predominantly of quartz and pyrite; veinlets and pods composed largely of copper-bearing minerals are present throughout the mine, but are not abundant. The east-northeastward-striking veins commonly are a foot or more thick; northeast of the winze there are two principal veins, each from 3 to 18 inches wide, which are separated by altered wallrock containing abundant veinlets and disseminations of pyrite. The wallrock on the north side of the drift nearly everywhere is altered and veined by quartz and pyrite or contains moderate to abundant disseminated pyrite; the wallrock on the south wall is much fresher and commonly barren, except immediately adjacent to the vein. Vugs, as much as a few inches long, occur here and there in the veins; they contain small, terminated quartz crystals, and at many places sooty chalcocite.

From the winze northeast to the face and also in the raise above the level, a black lenticular seam as much as 4 inches wide consisting largely of tennantite, chalcopyrite, chalcocite, occurs near the center of the main quartz-pyrite vein. In the raise the copper-bearing vein cuts across the strike of the quartz-pyrite vein; elsewhere it is almost parallel. On the 125 level, and on the level above, chalcocite is the principal copper-bearing mineral; in the winze, however, chalcocite is less abundant, and concomitantly, tennantite and chalcopyrite are more conspicuous.

Polished sections examined under the microscope show that the copper-bearing minerals occur in openings in the pyrite-quartz vein formed by fracturing 

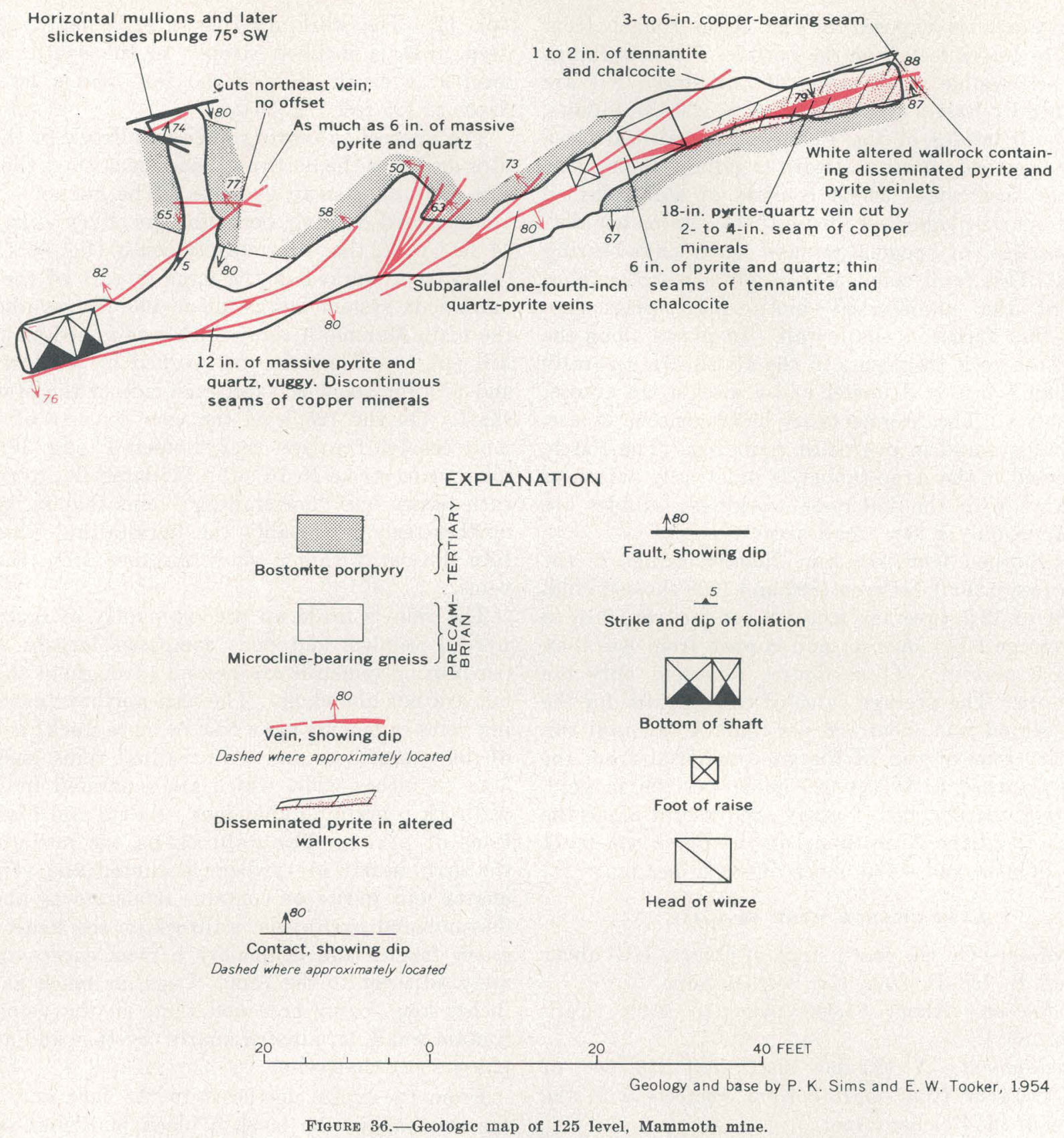

and brecciation of pyrite. The copper-bearing minerals - chalcostibite(?), chalcopyrite, and tennantiteare intergrown; some sphalerite locally occurs with these minerals. Alteration to chalcocite took place outward from vugs in the ore. Most of the chalcocite is coarse grained and crystalline, but some is very fine grained, black, and sooty.

Most of the gold values are associated with the copper-bearing minerals. Smaller quantities, generally not more than 0.5 ounce per ton, occur in the quartz-pyrite veinlets. The altered wallrock containing disseminated pyrite is virtually barren.
MERCER COUNTY MINE (C-IV-43)

Location.-250 feet southeast of California mine. Production.-The total recorded production from the Mercer County 139 and 732 claims is 137.1 ounces of gold, 155 ounces of silver, 713 pounds of copper, 790 pounds of lead, and 898 pounds of zinc. (Compiled by U.S. Bureau of Mines. Published by permission.)

Development. - Shaft is about 200 feet deep and is inclined $80^{\circ} \mathrm{S}$.; short levels are present at depths of 55,115 , and 159 feet. Three small stopes are present above the 159 level. 
Vein.-Flack vein: Strike N. $85^{\circ}$ E.; dip, $80^{\circ} \mathrm{S}$.

Wallrocks.-Dominantly microcline bearing gneiss.

Ore and sulfide minerals.-Gold, silver, pyrite, sphalerite, sparse chalcopyrite, and sparse galena. Analyses indicate a maximum of 0.007 percent uranium in vein.

Gangue.-Sparse amount of quartz.

\section{MISSOURI MINE (C-IV-18)}

Location.-On the north slope of Quartz Hill, about 180 feet south of the Phoenix-Burroughs mine.

Production.-About $\$ 10,000$ prior to $1899 ; 1,156$ tons of smelting ore and 94 tons of concentrates shipped between 1909 and 1917 contained 565.07 ounces of gold, 1,203 ounces of silver, and 1,341 pounds of copper. (Compiled by U.S. Bureau of Mines. Published by permission.)

Development.-A 300-foot shaft and 5,000 feet of drift. Also developed by a drift and stopes from the LaCrosse tunnel (pl. 3).

Veins.-Missouri: Strike, N. $75^{\circ}$ E.; dip, $70^{\circ}-75^{\circ}$ NW.; junctions with the Baker vein about 50 feet east of the LaCrosse tunnel, and with the PhoenixBurroughs vein about 70 feet west of the LaCrosse tunnel.

Wallrock.-Microcline-bearing gneiss.

Ore and sulfide minenals.-Pyrite, gold, silver, chalcopyrite, galena, sphalerite, and tennantite.

Gangue minerals.-Quartz.

Ore shoots.-Stopes are on the Missouri-Baker vein intersection.

Tenor.-Smelting ore shipped between 1919 and 1935 showed gold, 0.54 to 2.04 ounces per ton; silver, 1.80 to 3.10 ounces per ton; copper, 0 to 1 percent; and zinc, 0 to 3.67 percent.

\section{POZO MINE (C-IV-82)}

The Pozo mine is in Nevada Gulch, about 450 feet N. $45^{\circ}$ E. from the Gold Coin-Kansas shaft. Three shafts were sunk on the claim, all of which were inaccessible in 1954. The collar of the main shaft is at an altitude of 9,050 .feet; it is reported to be 290 feet deep (W. C. Russell, Jr., oral communication). The production from the Pozo mine is given in table 31. The metal concentrations are mainly in gold, but also include silver and copper and minor lead and zinc.

The Pozo vein trends N. $73^{\circ}$ E. and dips about $45^{\circ}$ SE., but it varies greatly in dip (W. C. Russell, Jr., oral communication). As the vein is in Nevada Gulch, it is covered with stream gravels, and nowhere is exposed. It is a pyrite vein that contains galena, sphalerite, and copper minerals. The wallrocks are mainly microcline-bearing gneiss.
TABle 31.-Ore produced from the Pozo mine, 1904-54'

\begin{tabular}{|c|c|c|c|c|c|c|c|}
\hline Year & $\begin{array}{c}\text { Crude } \\
\text { ore } \\
\text { shipped } \\
\text { (tons) }\end{array}$ & $\begin{array}{l}\text { Concen- } \\
\text { trates } \\
\text { shipped } \\
\text { (tons) }\end{array}$ & $\underset{\text { (ounces) }}{\text { Gold }}$ & $\begin{array}{c}\text { Silver } \\
\text { (ounces) }\end{array}$ & $\begin{array}{l}\text { Copper } \\
\text { (pounds, }\end{array}$ & $\begin{array}{l}\text { Lead } \\
\text { (pounds) }\end{array}$ & $\underset{\text { (pounds) }}{\text { Zinc }}$ \\
\hline $\begin{array}{l}1904 \ldots \\
1906 \\
1910 \\
1911\end{array}$ & $\begin{array}{r}20 \\
289 \\
483\end{array}$ & $\begin{array}{r}132 \\
-35 \\
89\end{array}$ & $\begin{array}{r}56.40 \\
4.02 \\
147.00 \\
254.17\end{array}$ & $\begin{array}{r}2,295 \\
12 \\
577 \\
892\end{array}$ & $\begin{array}{r}800 \\
\cdots 627 \\
6,341\end{array}$ & 41,600 & \begin{tabular}{r}
88,000 \\
\hdashline$\quad .6$ \\
\end{tabular} \\
\hline $\begin{array}{l}1912 \\
1913 \\
1914 \\
1915\end{array}$ & $\begin{array}{l}2,483 \\
3,772 \\
1,849 \\
2,019\end{array}$ & $\begin{array}{l}12 \\
14 \\
40\end{array}$ & $\begin{array}{l}1,920.55 \\
5,116.66 \\
1,322.32 \\
1,216.15\end{array}$ & $\begin{array}{r}7,428 \\
12,908 \\
6,456 \\
5,556\end{array}$ & $\begin{array}{l}62,459 \\
65,395 \\
41,621 \\
26,222\end{array}$ & $\begin{array}{r}20,063 \\
0 .\end{array}$ & \\
\hline $\begin{array}{l}1916 \ldots \\
1917 \\
1913 \\
1919\end{array}$ & $\begin{array}{l}427 \\
864 \\
822 \\
119\end{array}$ & $\cdots$ & $\begin{array}{r}566.35 \\
593.96 \\
610.04 \\
96.05\end{array}$ & $\begin{array}{r}2,447 \\
2,599 \\
2,432 \\
288\end{array}$ & $\begin{array}{r}22,907 \\
39,398 \\
31,236 \\
5,879\end{array}$ & $\ldots \ldots$ & $\cdots$ \\
\hline Total.. & 13,157 & 322 & $11 ; 903.67$ & 43,890 & 302,885 & 70,663 & 88,000 \\
\hline
\end{tabular}

1 Compiled by U.S. Bureau of Mines. Published by permission.

\section{PROMPT PAY MINE (B-V-30)}

The Prompt Pay mine is southwest of the JeffersonCalhoun shaft at an altitude of about 9,315 feet. The mine was operated during the late 1800's and it has been worked sporadically in recent years. The recorded production (compiled by U.S. Bureau of Mines, published by permission) from 1902-36 is 196 ounces of gold, 324 ounces of . silver, 19 pounds of copper, 2,494 pounds of lead, and 5,449 pounds of zinc. In 1916, George J. Bancroft prepared a private company report on the mine, and some of his data are incorporated in this summary. ${ }^{14}$ The mine was inaccessible in 1953. According to the report by George J. Bancroft, the total production from the mine is about $\$ 50,000$. The metal value of the ore is principally in gold. The following are samplingworks assays of a few shipments of smelting ore:

Sampling-works assays of smelting ore from the Prompt Pay mine

\begin{tabular}{|c|c|c|c|c|c|c|c|}
\hline Year & $\begin{array}{l}\text { Ore (net } \\
\text { pounds) }\end{array}$ & Gold I & Silver 1 & $\begin{array}{c}\text { Copper } \\
\text { (percent) }\end{array}$ & $\underset{\text { (percent) }}{\text { Lead }}$ & $\underset{\text { (percent) }}{\text { Zinc }}$ & Value \\
\hline $\begin{array}{l}1895 \\
1895 \\
1895 \\
1895 \\
1924 \ldots\end{array}$ & $\begin{array}{l}1,812 \\
2,069 \\
4,240 \\
3,560 \\
1,540\end{array}$ & $\begin{array}{r}10.80 \\
5.14 \\
4.28 \\
10.40 \\
.82\end{array}$ & $\begin{array}{l}36.00 \\
16.00 \\
21.00 \\
19.00 \\
10.16\end{array}$ & $\begin{array}{r}2.50 \\
24\end{array}$ & $\begin{array}{r}18.02 \\
16.00 \\
14.00 \\
8.00 \\
20.10\end{array}$ & 15.00 & $\begin{array}{r}\$ 203.29 \\
110.70 \\
183.36 \\
359.70\end{array}$ \\
\hline
\end{tabular}

1 Ounces per ton.

The mine workings in 1916 consisted mainly of a nearly vertical shaft, 188 feet deep, and principal levels at depths of 60,120 , and 170 feet. Most of the stoping was done above the 60 level, east of the shaft, and above the 120 level, west of the shaft, from a westward plunging ore shoot.

The wallrock at the Prompt Pay shaft collar is microcline-bearing gneiss, but amphibolite generally

14 Bancroft, G. J., 1916, Report on the Prompt Pay mine, Gilpin County, Colo., report on file in the Denver Public Library, Denver, Colo. 
an unfavorable wallrock on Quartz Hill, possibly constitutes the wallrocks on the 120 level, east of the shaft, and in the lower part of the shaft.

The Prompt Pay vein trends N. $55^{\circ}$ E. and is nearly vertical. The vein is the southwest extension of, or a branch vein from, the Jefferson-Calhoun vein. About 150 feet southwest of the JeffersonCalhoun shaft the Prompt Pay vein joins(?) the vein that is worked in the Delaware mine.

The ore in the Prompt Pay vein consists chiefly of pyrite, sphalerite, and galena in gangue quartz. A galena separate concentrated on a Wilfley-type table after grinding to 30 mesh contained 53.3 percent lead, 13.3 ounces silver, and 4.62 ounces gold. ${ }^{15}$ Although most of the gold was in the galena concentrate, some was in a pyrite concentrate.

\section{QUARTZ HILL TUNNEL (D-IV-1)}

The portal of the Quartz Hill tunnel is on the south side of Nevada Gulch, at an altitude of 8,600 feet. The tunnel was started in the late 1860's to mine some of the large veins in the eastern part of Quartz Hill -and the Patch, and it was last worked in '1935. The recorded production from the mine, given in table 32 , probably is only a fraction of the total yield from the property.

TABLE 32.-Ore produced from the Quartz Hill tunnel, 1902-5/ ${ }^{1}$

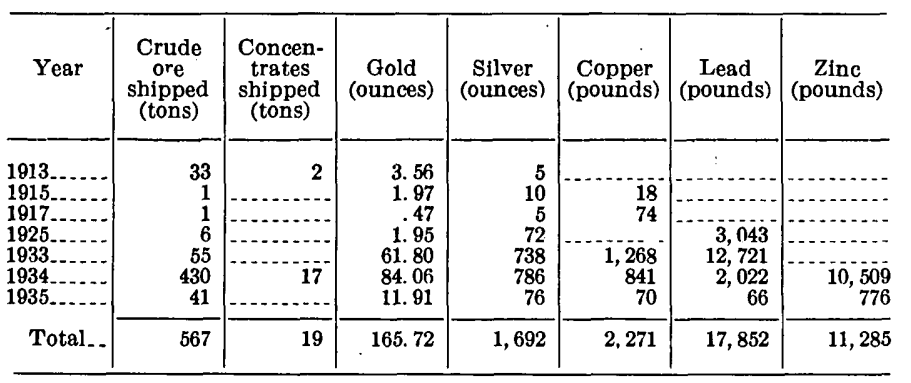

1 Production for 1933-35 contains some from Delmonico mine, much of the lead and zine was probably contained in that ore. Compiled by U.S. Bureau of Mines. Pubzinc was probabiy con
lished by permission.

The tunnel is a crosscut adit that bears S. $25^{\circ} \mathrm{W}$. (pl. 4). At 1,310 feet, a drift is turned to the east and west on the Hecla vein. The Hecla east drift possibly connects to the National mine, and the Hecla west drift extends into the Patch (Lovering and Goddard, 1950, fig. 60), but it was caved about 1,130 feet from the crosscut. The 503 Barnes crosscut and drift are turned from the Hecla west drift about 100 feet from the crosscut. Two crosscuts extend south from the Hecla west drift and connect to drifts on the Barnes and Stark County veins.

The predominant wallrock of the mine is microclinebearing gneiss, which contains several small layers

${ }^{15}$ Bancroft, G. J., 1916, op. cit. of biotite-quartz-plagioclase gneiss. The foliation of these rocks strikes generally north-northeast and dips moderately to steeply to the southeast. The rocks are locally deformed by small isoclinal to overturned drag folds that plunge gently to the north-northeast or the south-southwest; in general, the synclinal axes plunge to the south-southwest and the anticlinal axes to the north-northeast. The axial planes of these drag folds dip to the southeast.

The first 1,310 feet of the tunnel cuts several unimportant veins.

The Hecla vein, a member of the great BobtailMammoth-Gardner-California-Hidden Treasure lode, is cut at 1,310 feet. It strikes generally eastward and dips steeply either side of vertical. The vein has an average width of $31 / 2$ feet, and consists of narrow subparallel stringers of quartz and pyrite in pyriteimpregnated microcline-bearing gneiss. At the western extremity of the accessible workings, the vein loses its continuity as a true fissure-the rock is intensely broken by a network of randomly oriented fractures, is strongly altered, and contains some disseminated pyrite over the width of the drift. It is probable that this part of the mine is approaching the Patch. The occurrence of the stopes on that part of the vein that strikes east-northeastward suggests that the ore was deposited in open spaces on strike changes to the left. Most of the ore produced from the vein is said to have been mill dirt, and to have averaged about 0.20 ounce of gold per ton (Bastin and Hill, 1917, p. 232).

An eastward-trending vein, 6 inches to $31 / 2$ feet wide, is exposed in 3 crosscuts south of the Hecla vein and joins the Hecla vein about 420 feet west of the main crosscut adit (pl. 4). It generally consists of thin quartz-pyrite stringers in pyritized and altered wallrock.

The Barnes vein, as exposed in the Barnes drift (pl. 4), strikes about N. $60^{\circ}$ E. and dips $70^{\circ}-80^{\circ} \mathrm{SE}$. The vein is about 12 inches wide on the average and consists of several subparallel pyrite stringers in strongly silicified and pyritized microcline-bearing gneiss. The relation of the Barnes vein to the Hecla vein is not known. It is possible, however, that the split that leaves the Hecla vein 40 feet west of the crosscut (pl.4) is the Barnes vein.

The Stark County vein is exposed in the drift at the end of the crosscut and in drift at the breast of the 730 crosscut (pl. 4). It strikes east and dips steeply either side of vertical, the hinge point is somewhere between the two exposures. In the main crosscut, the vein is about $21 / 2$ feet wide and consists of subparallel veinlets in silicified microcline-bearing 
gneiss heavily impregnated with pyrite. In the 730 crosscut and drift, the vein is about 3 feet(?) wide, and has a 3-inch streak of massive pyrite on the south wall and $1 \frac{1}{2}$ inches of solid pyrite on the north wall. The horse of rock between these streaks is strongly silicified and is heavily impregnated with pyrite. To the west, the vein splits into several branches that pass into both walls. Considerable stoping has been done on this vein, but the metal content of the ore is not known; Bastin and Hill (1917, p. 240), however, report that ore from the vein in the Barnes mine averaged about $\$ 10$ per ton.

\section{RALLS COUNTY MINE (C-IV-39)}

The Ralls County mine is on the north slope of Quartz Hill, about 840 feet west of the Egyptian mine. The mine is opened by an inclined shaft (vertical depth 950 feet) from which levels have been turned at 180, 300,500,690, 822, and 950 feet (figs. $27,28)$. The 950 level is level 7 of the Egyptian mine, and the 822 level is level 6 of the Egyptian mine. The 690 level cuts a stope in the Egyptian mine. The position of the stopes is shown on figure 28. These workings were all inaccessible in 1954, and much of the following is taken from the description by Bastin and Hill (1917, p. 238-239).

The known production from the Ralls County mine is given in table 33. Bastin and Hill (1917, p. 238) report that the mine yielded about $\$ 225,000$ prior to 1912.

TABLE 33.-Ore produced from the Ralls County mine, 1902-54 ${ }^{1}$

\begin{tabular}{|c|c|c|c|c|c|}
\hline Year & $\begin{array}{l}\text { Crude ore } \\
\text { shipped } \\
\text { (tons) }\end{array}$ & $\begin{array}{l}\text { Concen- } \\
\text { trates } \\
\text { shipped } \\
\text { (tons) }\end{array}$ & $\begin{array}{c}\text { Gold } \\
\text { (ounces) }\end{array}$ & $\begin{array}{c}\text { Silver } \\
\text { (ounces) }\end{array}$ & $\begin{array}{c}\text { Copper } \\
\text { (pounds) }\end{array}$ \\
\hline $\begin{array}{l}1906 \\
1907 \\
1008 \\
1911 \\
1912 \\
1913 \\
1939\end{array}$ & $\begin{array}{r}500 \\
25 \\
162 \\
240 \\
182 \\
354 \\
19\end{array}$ & \begin{tabular}{r|r|}
40 \\
11 \\
26 \\
\end{tabular} & $\begin{array}{r}250.00 \\
37.49 \\
15.20 \\
66.63 \\
185.80 \\
233.07 \\
1.78\end{array}$ & $\begin{array}{r}1.500 \\
200 \\
4 \\
173 \\
545 \\
519\end{array}$ & $\begin{array}{r}30,000 \\
2,000 \\
2.065 \\
2,070 \\
1,890 \\
\end{array}$ \\
\hline Total & 1,482 & 77 & 789.97 & 2,941 & 38.025 \\
\hline
\end{tabular}

1 Complled by U.S. Bureau of Mines. Published by permission.

The Ralls County vein strikes nearly east and dips $62^{\circ}-72^{\circ} \mathrm{S}$. The vein is developed also by the Egyptian mine to the east (fig. 27) and possibly by the Kent County mine to the west. The vein ranges from 1 to 6 feet in width and averages 3 feet. The vein consists of stringers of pyrite, chalcopyrite, and tennantite in a zone of crushed, altered microcline-bearing gneiss that is impregnated with pyrite. West of the shaft, the pyrite filling is cut by veinlets of darkgray quartz, galena, sphalerite, and chalcopyrite. Recurrent movements along the vein subsequent to the period of galena-sphalerite deposition brecciated the ore minerals.

The principal ore shoot in the mine occurs where the pyrite vein filling was cut by later sulfides. The ore shoot was reached in the shaft at the 180 level, and was mined at least as deep as the 500 level (fig. $28)$; it plunges about $65^{\circ}$ to the west. The structural controls of the ore shoot are not known. As is common in the area, the ore shoot plunges nearly parallel to the intersection of the vein and the rock foliation.

Many shipments of smelting ore from the mine in 1905 and 1907 showed gold, 0.54 to 2.08 ounces per ton; silver, 9.1 to 16 ounces per ton; and copper, 2.5 to 10.3 percent. The mill dirt which consisted largely of pyrite-impregnated microcline-bearing gneiss contained about 0.37 ounces of gold per ton.

\section{RHODERICK DHU MINE (O-IV-44)}

Location.-On the crest of Quartz Hill, about 590 feet east of the Gardner mine.' The main shaft is in the Patch and has been destroyed; the Protection shaft $(\mathrm{C}-\mathrm{IV}-44)$ is at the south edge of glory hole.

Production.-About $\$ 200,000$ prior to 1899 (Callbreath, 1899); 364 tons of smelting ore, and 1,526 tons of concentrates shipped between 1904 and 1918 contained 3,095.65 ounces of gold, 1,188 ounces of silver, and 6,406 pounds of copper. ( Compiled by U.S. Bureau of Mines. Published by permission.)

Development.-An 800-foot shaft with 5,000 feet of drift. Shaft collar and upper levels have been mined out by the glory hole.

Veins.-Rhoderick Dhu: Strike, N. $80^{\circ}$ E.; dip, nearly vertical; is probably a branch of the Mammoth lode. Much of the mining was done on the stockwork of the Patch.

Wallrock.-Microcline-bearing gneiss.

Ore and sulfide minerals.-Pyrite, gold, silver, chalcopyrite, tennantite.

Gangue minerals.-Quartz.

Tenor.-About $\$ 4$ to $\$ 20$ per ton.

\section{SAN JUAN MINE}

Location.-In Patch; shaft has been mined out in glory hole.

Production.-About $\$ 600,000$.

Development.-A 916-foot shaft and 11 levels; 4 th level connects with the LaCrosse tunnel (pl. 3) ; shaft collar and part of the upper levels have been mined out by the Patch glory hole.

Veins.-San Juan: Strike, N. $70^{\circ}$ E.; dip, nearly vertical; is probably a branch of the Mammoth lode. Most of the mining was done on the stockwork ore of the Patch. 
Wallrock.-Microcline-bearing gneiss.

Ore and sulfide minerals.-Pyrite, gold, silver, chalcopyrite, sphalerite, tennantite, and galena.

Gangue minerals.-Quartz.

Tenor.-Ore shipped between 1888 and 1909 contained a trace to 12.2 ounces of gold and 2.15 to 34 ounces of silver per ton and as much as 9 percent copper. The gold content of the large stopes ranged from 0.44 to 1.78 ounces to the ton. Concentrating ore contained 0.22 ounce of gold and 0.3 ounce of silver per ton.

Ore shoots.-Large chamber stopes on the stockwork mineralization of the Patch. Highest metal content seems to be in the strongly brecciated areas near through-going veins.

\section{SYMONDS FORK (FORKS) MINE (B-IV-18)}

Location.-On the north slope of Quartz Hill, about 340 feet S. $57^{\circ} \mathrm{W}$. from the Hidden Treasure mine.

Production.-Smelting ore and concentrates shipped between 1904 and 1936 contained 864.90 ounces of gold, 5,657 ounces of silver, 95,522 pounds of lead, and 1,209 pounds of zinc; yield prior to 1899 was reportedly \$1 million (Callbreath, 1899). (Compiled by U.S. Bureau of Mines. Published by permission.)

Development.-A thousand-foot shaft and 5,000 feet of drift.

Veins.-Forks: Strike, N. $70^{\circ}$ E.; dip, $65^{\circ}$ NW.; 1 to 5 feet wide. Helos: Strike, N. $90^{\circ}$ E.; dip, $70^{\circ}$ N. Veins intersect underground.

Wallrock.-Microcline-bearing gneiss and biotitequartz-plagioclase gneiss.

Ore and sulfide minerals.-Silver, galena, sphalerite, and some pyrite, chalcopyrite, and gold. Argentite was contained in the near-surface ores.

Gangue minerals.-Quartz.

Tenor.-About 1,536 tons of smelting ore shipped between 1904 and 1936 averaged 0.33 ounce of gold, 0.95 ounce of silver, and 3.04 percent lead.

\section{TAYLOR-LEA VENWORTH MINE (B-V-18)}

Location.-On the south slope of Quartz Hill, about 390 feet S. $47^{\circ} \mathrm{W}$. from the Bezant mine.

Production.-About $\$ 11 / 2$ million prior to 1899 (Callbreath, 1899).

Development.-A 700-foot shaft and 2,000 feet of drift.

Veins.-Leavenworth: Strike, N. $80^{\circ}$ W.; dip, vertical.

Wallrock.-Predominantly microcline bearing gneiss.

Ore and sulfide minerals.-Pyrite, chalcopyrite, gold, silver, and pitchblende.

Gangue minerals.-Quartz.
TELEGRAPH MINE (C-V-20)

Location.-On Quartz Hill, 1,600 feet south of the Patch. The shaft collar is at an altitude of 9,090 feet.

Production.-Small.

Development.-A 170 -foot shaft inclined $80^{\circ}-85^{\circ}$ SE., a short level at a vertical depth of 170 feet, and a small stope west of shaft.

Veins.-Telegraph vein: strike, N. $65^{\circ}$ E.; dip, $80^{\circ}-85^{\circ} \mathrm{SE}$.

Wallrock.-Dominantly microcline bearing gneiss.

Ore and sulfide minerals.-Dominantly pyrite with sparse amounts of chalcopyrite and pitchblende. Chalcopyrite partly altered to chalcocite to depth of 170 feet.

Gangue minerals.-Quartz and altered wallrock.

\section{TOPEKA MINE (B-V-4)}

The Topeka mine is on the south slope of Quartz Hill, about 920 feet S. $57^{\circ}$ E. from the Jefferson shaft. The mine is opened by an inclined shaft, vertical depth of 969 feet, that connects with 15 levels; and by the Topeka west shaft $(\mathrm{B}-\mathrm{V}-3)$ that connects to the 7th level of the main shaft workings (fig. 37). The 500 level connects to the 360 level of the Wyandotte mine through a winze, and the 11th level connects with the bottom(?) level of the Ayres-Leavenworth mine (fig. 37). These workings, were all inaccessible in 1954. Bastin (Bastin and Hill, 1917, p. 248-250) examined the mine, however, and much of the following is taken from his description and from his unpublished field notes. Stopes which he describes in his notes are shown on figure 37.

The known production from the Topeka mine, since 1902 , is given in table 34 ; this ore if produced today would have a value of about $\$ 236,000$. Bastin and Hill (1917, p. 250) report that the mine had yielded $\$ 1,850,000$ prior to their study. The total yield from the property probably approaches $\$ 2$ million.

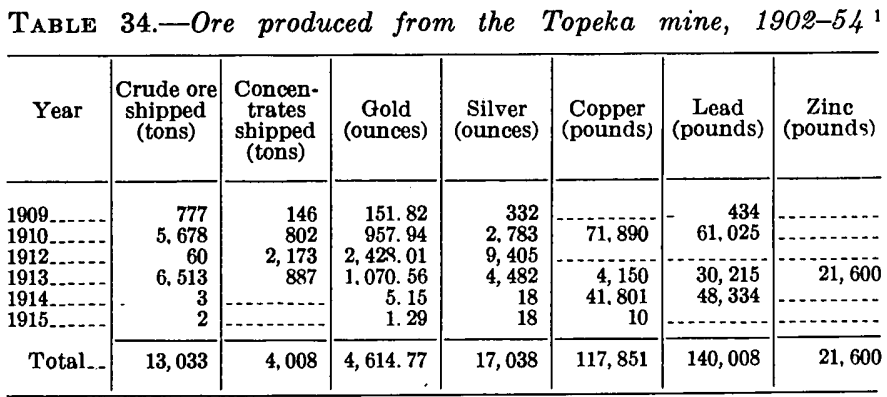

1 Compiled by U.S. Bureau of Mines. Published by permission. 


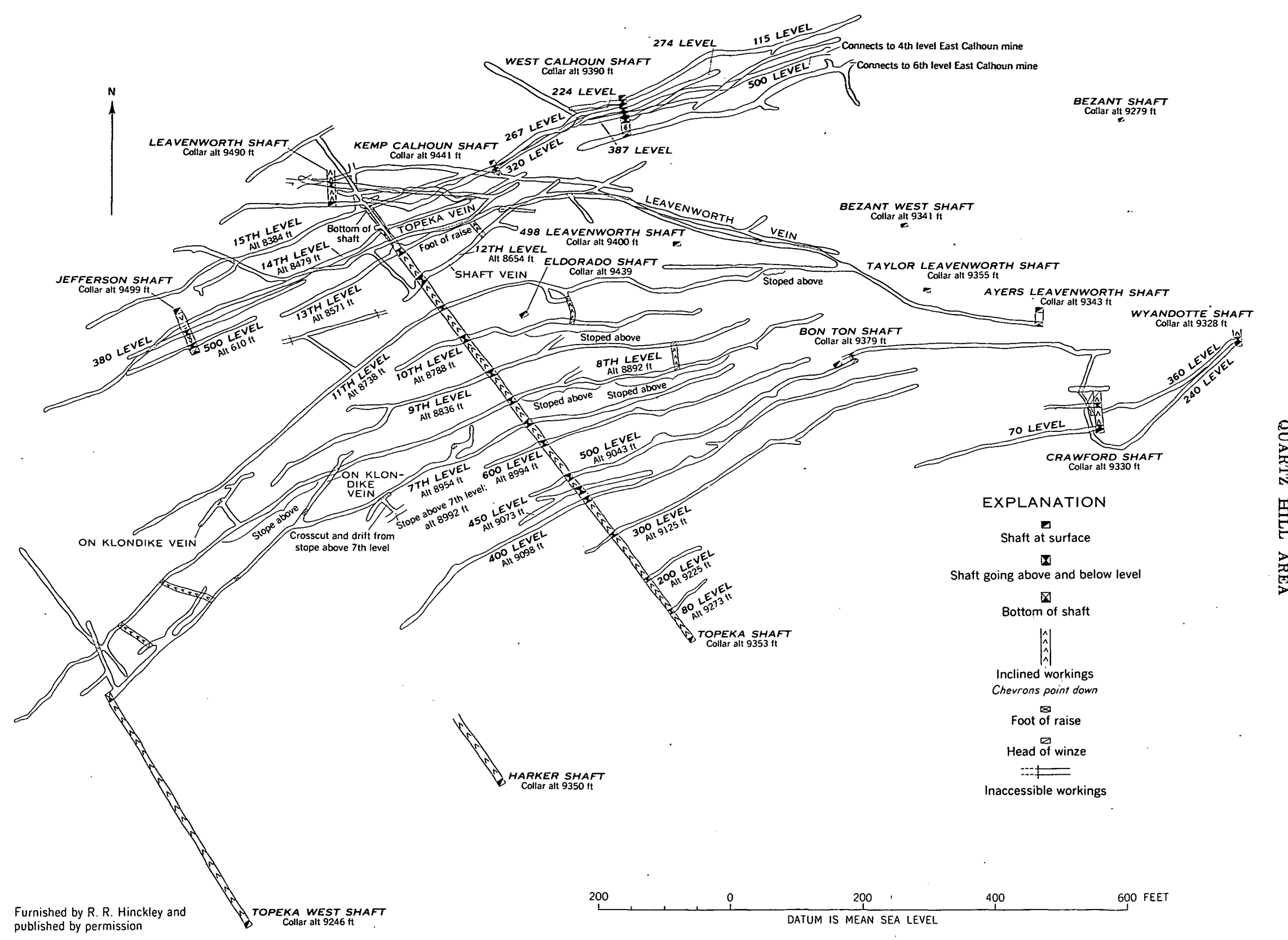


The collar of the Topeka shaft is in microclinebearing gneiss, and this rock is dominant throughout the mine. In some places, however, according to Bastin and Hill, amphibolite is present, and this rock is prevalent on the 12 th level. Some granite pegmatite is interlayered with the amphibolite. It is probable that some of the hornblende rocks described by Bastin and Hill are quartz diorite, for a large lens of this rock crops out west of the shaft collar.

Several veins were developed in the mine, but the complex vein pattern is little known. Most of the workings above the 11th level (fig. 37) are on the Topeka vein, but the fabulously rich Klondike vein was mined on the 7th and 8th levels and in stopes between these levels. The workings below the 11th level also develop the Shaft vein, considered a footwall split of the Topeka vein, the Leavenworth vein, and a vein herein referred to as the North vein. As shown in figure 38, several veins which have been worked near the surface and which should have been found in the mine have not been recognized, so far as known.

The Topeka vein strikes about N. $50^{\circ}$ E. and dips $35^{\circ}-60^{\circ} \mathrm{NW}$. (average $40^{\circ}$ ). At the surface it can be traced for about 1,400 feet; the surface trace of the vein is remarkably similar to the strike of the vein shown by the drifts and shows a change to a more easterly strike northeast of the Topeka shaft. The Topeka vein, judging from the map (fig. 37) and Bastin's descriptions, has several branch veins that pass into both the hanging wall and footwall. The most important branch veins are the Shaft vein and the Klondike vein, which are described later. The Topeka vein ranges in width from a few inches to about 7 feet. For the most part the vein consists of disseminated pyrite or stringers of pyrite and sparse sphalerite, but locally it contains as much as 15 inches of solid base-metal sulfides bordered by disseminated sulfides, principally pyrite. At places the vein walls are frozen. Galena and chalcopyrite occur locally but generally are sparse. Gouge produced by movements after mineralization is visible at places. Because the ore minerals in the vein are intimately mixed, most of the ore has been concentrated. A zinc concentrate produced in 1912 contained 0.3 to 0.4 ounce of gold, 2 to 4 ounces of silver, and 20 to 30 percent zinc to the ton.

The Shaft vein (fig. 38) is similar to the Topeka vein. On the 13th level 20 feet east of the shaft 2 veins of solid sulfides are exposed, 12 and 14 inches wide, which cross a 5 -foot zone of altered rock. The 2 veins contain 50 to 75 percent pyrite and 25 to 50 percent sphalerite. The altered rock consists of dis- seminated pyrite and is crossed by pyrite or pyritesphalerite veinlets less than one-fourth inch wide. Postmineralization slip planes occur on both walls. Pyrite and sphalerite are the most abundant sulfide minerals; chalcopyrite and galena are subordinate. Quartz and calcite are the principal gangue minerals; siderite is locally present. Native bismuth is reported from the 14th level. At most places the vein minerals are irregularly mixed, but at some places sphalerite and calcite tend to occupy the center of the veinlets with pyrite next to the wall. Vugs are sparse and small. Most of them are lined with crystals of quartz, pyrite, and sphalerite; one on the 14th level was lined with calcite.

The richest ore produced from the mine came from the Klondike vein. This vein joins the Topeka vein on the 7th level, about 380 feet west of the shaft, and is also exposed in a drift reached by a short crosscut north of the 8th level and in extensive stopes between these levels (fig. 37). The Klondike vein strikes about N. $35^{\circ}$ E. and dips $25^{\circ}-40^{\circ} \mathrm{NW}$. Where exposed on the 7th level it is 4 inches wide and poorly mineralized. In the stopes between the 7th and 8th levels the vein ranges from 6 to 24 inches in width, and near its junction with the Topeka vein, it is 10 to 15 feet wide and contains bonanza ore. A raise above the 7th level and a winze below the 8th level failed to find a continuation of this ore. The sulfides of the Klondike vein contain commercial amounts of precious metals, but its bonanza character is due to free gold. This gold occurred in places with white quartz, but elsewhere was associated with sphalerite, chalcopyrite, galena, and pyrite. 'Polished surface examination of gold-quartz ore showed that the gold is not related to fracture planes in the quartz, but occurs in highly irregular masses. Sphalerite and galena are intercrystallized with the gold. Bastin and Hill (1917, p. 250) found that the Klondike was almost certainly a branch of the Topeka vein and not a cross vein. The relations suggest that the Topeka-Klondike intersection plunges flatly to the west. The stope on the Klondike vein, 280 feet long, 44 feet high, and 16 feet in maximum width, yielded about $\$ 480,000$. One rich piece of ore that weighed 88 pounds yielded $\$ 5,449$; a rough calculation shows that the specimen must have been 25 percent gold.

A vein found on the 13th level, at the end of the crosscut (fig. 37), is herein referred to as the North vein. Miners have considered this vein a faulted segment of the Topeka vein, but the writers believe that the North vein probably is a separate vein, for the North and Topeka veins differ greatly in strike on the 13th level (fig. 37). 


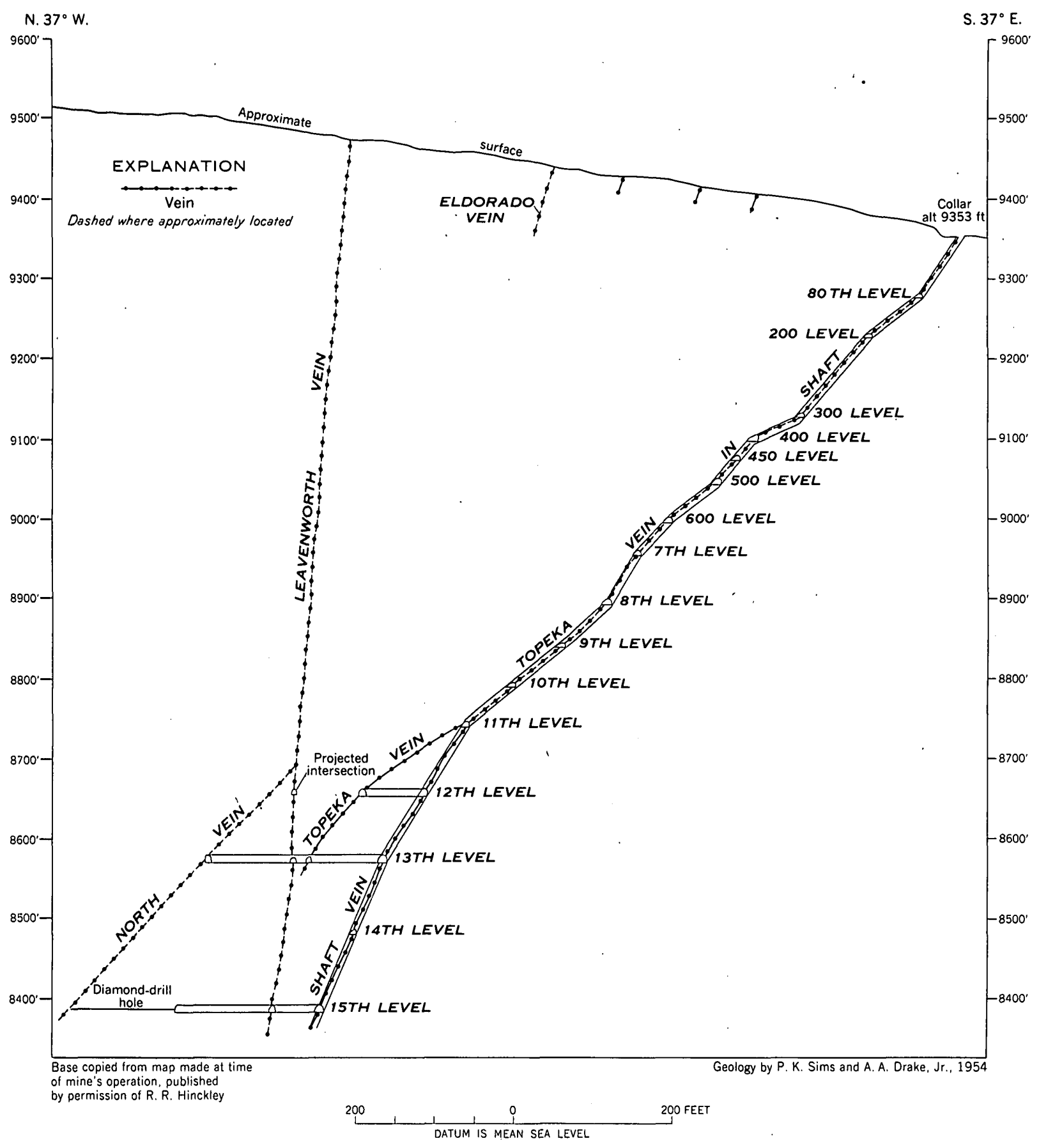

Figure 38.-Vertical section through the Topeka shaft.

The Leavenworth vein is first reached in the mine about 600 feet east of the shaft on the 11th level; it is also developed on the 12th, 13th, and 15th levels (fig. 37). The vein has a general west-northwesterly trend and dips steeply either side of vertical. It joins the Topeka vein a short distance below the 13th level, about 150 feet north of the shaft (fig. 38).
Judging from the amount of drifting on the Leavenworth vein, it must have been stoped at least locally in the Topeka mine.

\section{WEST FLACK MINE (B-IV-11)}

Location.-1,300 feet west-southwest of California shaft, at altitude of 9,400 feet.

$6548270-63-8$ 
Production.-The production figures have been combined with those from the Flack (B-IV-19) and East Flack (B-IV-18) mines. The total recorded production from these mines is: 7,194.6 ounces of gold, 4,482 ounces of silver, 72,995 pounds of copper, and 902 pounds of lead. (Compiled by U.S. Bureau of Mines. Published by permission.)

Development.-A 475-foot shaft and short levels at vertical depths of $100,160,320,410$, and 475 feet. A 15-foot winze 80 feet west of the shaft on the 475 level, connects with a drift from the East Flack mine. All stopes are above the 320 level.

Vein.-Flack vein: strike, N. $85^{\circ} \mathrm{E}, \operatorname{dip} 80^{\circ} \mathrm{S}$.

Wallrock.-Interlayered microcline-bearing gneiss, biotite-quartz-plagioclase gneiss, granite pegmatite, and amphibolite.

Ore and sulfide minerals.-Gold, silver, galena, sphalerite, pyrite, chalcopyrite, marcasite, and pitchblende.

Gangue.-Quartz, sparse calcite, silicified and pyritized wallrock.

\section{WOOD MINE (B-V-27)}

Location.-South slope of Quartz Hill.

Production.-According to Drake (1957, p. 144, $146)$.the Wood vein had yielded ore valued at about $\$ 600,000$. From 1871 to $1940,46,749$ pounds of $\mathrm{U}_{3} \mathrm{O}_{8}$ were recovered from 69.6 tons of crude ore and 35 tons of concentrates.

Development.-See Moore and Butler (1952); Drake (1957, p. 144-145).

Veins.-Wood: Strike, approximately east-west; dip, steep to north or south. Willowdale: Strike, N. $45^{\circ}$ E.; dip, steep northwest or southeast.

Wallrock.-Microcline-bearing gneiss dominant.

Ore and sulfide minerals.-Pyrite, chalcopyrite, tennantite, sphalerite, sparse galena, sparse pitchblende.

Gangue minerals.-Quartz.

Ore shoot.-The pitchblende is in a small ore shoot that extends from near the surface to the 583 level and plunges steeply west (Drake, 1957, fig. 34).

Tenor.-The pitchblende is in small, massive, highgrade pods and lenses.

\section{WYANDOTTE MINE (B-V-50)}

Location.-On the south slope of Quartz Hill, about 300 feet S. $80^{\circ}$ E. from the Ayres-Leavenworth mine.

Production.-About $\$ 225,000$ prior to 1899 (Callbreath, 1899).

Development.-A 915 -foot shaft with levels at 240 , $360,550,600,650,825$, and 900 feet; totaling about 3,000 feet of drift.

Veins.-Wyandotte: Strike, N. $53^{\circ}$ E.; dip, $80^{\circ}$ NW. Wallrock.-Microcline-bearing gneiss.
Ore and sulfide minerals.-Pyrite, gold, silver, and pitchblende.

Gangue minerals.-Quartz.

\section{NEVADA HILL AND PROSSER GULCH AREAS}

The Nevada Hill and Prosser Gulch areas are west of Central City and include the ground between Nevada Gulch on the south and Eureka Gulch on the north. The areas contain some of the richest ore bodies in the district, including those on the Eureka, Gunnell, Prize, and Hubert veins; and the downward extensions of these deposits are promising for future production.

The principal wallrock of the deposits is microclinebearing gneiss, which dips gently westward. The contact of the gneiss with biotite gneisses in the western part of the area virtually defines the western limit of the valuable ore deposits.

The larger ore shoots in this part of the district occur at vein junctions or intersections and generally plunge $45^{\circ}$ or less westward, nearly parallel to the prevailing dip of the country rock. The ore shoots are mainly gold-bearing base-metal ores that formed by composite mineralization.

Uranium occurs along the Rara Avis and Bullion veins and in the Buckley mine; these occurrences have been described previously (Sims, Osterwald, and Tooker, 1955).

\section{ASHTABULA MINE (C-IV-45)}

Location.-On the south slope of Nevada Hill about 560 feet N. $10^{\circ}$ E. from the LaCrosse tunnel.

Production.-About 75 tons of smelting ore and 4 tons of concentrates shipped in 1909 and 1911 contained 29.96 ounces of gold, 57 ounces of silver, and 333 pounds of copper. (Compiled by U.S. Bureau of Mines. Published by permission.)

Development.-A 200-foot shaft and 400 feet of drift.

Veins.-Ashtabula: Strike, N. $65^{\circ}$ E.; dip, $80^{\circ}$ NW. Wallrock.-Microcline-bearing gneiss.

Ore and sulfide minerals.-Pyrite, chalcopyrite, sphalerite, galena, gold, and silver.

Gangue minerals.-Quartz.

Tenor.-About 8 tons of smelting ore shipped in 1911 averaged 1.92 ounces of gold, 5 ounces of silver, and 2.08 percent copper per ton.

\section{COEUR D'ALENE MINE (D-III-6)}

Location.-On the south slope of Nevada hill, about 1,210 feet $\mathrm{N} .30^{\circ} \mathrm{E}$. from the Quartz Hill tunnel.

Production.-1908-54, 328 tons of smelting ore and 131 tons of concentrates that contained 271.03 ounces 
of gold, 549 ounces of silver, 8,017 pounds of copper, and 260 p.ounds of lead. (Compiled by U.S. Bureau of Mines. Published by permission.)

Development.-A 700-foot shaft with levels at depths of $200,400,450,550,600$, and 700 feet.

Wallrock.-Microcline-bearing gneiss with thin layers of biotite-quartz-plagioclase gneiss.

Veins.-Coeur d'Alene, a zone of fracturing that is only locally mineralized. Strike, N. $70^{\circ}$ E. to N. $70^{\circ}$ W.; dip, nearly vertical; in microcline-bearing gneiss the vein consists of one or more sharp-walled sulfide veinlets 2 inches or less in width distributed through several feet of pyritized wallrock; in biotite-quartzplagioclase gneiss the vein is barren or consists of irregular sulfide disseminations for a width of 10 to 20 feet.

Ore and sulfide minerals.-Pyrite, chalcopyrite, galena, sphalerite, gold, and silver.

Gangue minerals.-White and dark-gray quartz.

Ore shoot.-A steeply. plunging ore shoot about 20 feet long (stope length) was. mined just west of the shaft to a depth of about 500 feet (H. G. Berky, oral communication).

Tenor.-The disseminated ore reportedly averaged 2 ounces of gold per ton.

\section{CORYDON MINE (D-IV-8)}

Location.-On the east side of Nevada Gulch about 360 feet N. $9^{\circ} \mathrm{W}$. from the Quartz Hill tunnel.

Production. -4,974 tons of smelting ore and 548 tons of concentrates shipped between 1892 and 1938 contained 2,771.21 ounces of gold, 5,127 ounces of silver, 24,408 pounds of copper, 5,415 pounds of lead, and 333 pounds of zinc. (Compiled by U.S. Bureau of Mines. Published by permission.)

Development.-A 700 -foot shaft with levels at 100 , 200,260 , and 320 feet; the position of the lower levels is not known.

Veins.-Corydon: Strike N. $60^{\circ}$ E., dip, $70^{\circ}$ SE.; width, 18 inches to 8 feet. Branch vein: strike, N. $45^{\circ}$ W.; dip, nearly vertical; width 18 inches. The veins join on the 260 and 320 levels, the horse between them is more or less mineralized and is traversed by a number of crossveinlets.

Wallrock.-Microcline-bearing gneiss.

Ore and sulfide minerals.-Pyrite, chalcopyrite, chalcocite, galena, sphalerite, gold, and silver.

Gangue minerals.-Quartz.

Ore shoots.-Most of the ground above the 320 level has been stoped; largest stope is east of the shaft between the 200 and 260 levels.

Tenor.-51 tons shipped between 1892 and 1897 contained 1.08 to 2.62 ounces of gold per ton, 2 to 15 ounces of silver per ton, and 8 percent or less copper; the average content being 1.74 ounces of gold and 5.63 ounces of silver. The ore from the large stope between the 200 and 260 levels averaged 2 to 3 ounces of gold per ton and only a little silver.

\section{DYKE MINE (C-IV-84)}

Location.-On the north side of Nevada Gulch about 480 feet N. $15^{\circ}$ E. from the LaCrosse tunnel.

Production.-About $\$ 10,000$ prior to 1899 (Callbreath, 1899).

Development.-A 300-foot shaft with 1,000 feet of drift; a lateral from the Argo tunnel, about 20,370 feet from the portal, extends about 800 feet to the west.

Veins.-Dyke: Strike, N. $85^{\circ}$ E., dip, $80^{\circ}$ SE. On the Argo level the vein ranges in width from 1 to $21 / 2$ feet and ranges in mineralization from a zone of fractured rock containing disseminated sulfides to a vein having as much as 10 inches of solid sulfides.

Wallrock.-Microcline-bearing gneiss and sparse biotite-quartz-plagioclase gneiss.

Ore and sulfide minerals.-Pyrite, chalcopyrite, gold, and silver.

Gangue minerals.-White and gray quartz.

Tenor.-On the Argo level, a large number of assays showed gold, 0.3 to 2 (maximum 9.8 ) ounces per ton and silver, 3 to 15 (maximum 36 ) ounces per ton. The copper content is usually negligible.

\section{ESSEX MINE (B-III-4)}

The Essex mine is near the head of Prosser Gulch, a mile west of Central City and 1,025 feet southwest of the Gilpin-Eureka shaft. The mine works the Essex vein, the southwest extension of the vein mined from the Gilpin-Eureka shaft.

The claim was located prior to 1900 . Later a shaft was sunk to a depth of about 100 feet and a drift was driven at the 80 level. Good ore was found west of the shaft, which, according to Van McKay (oral communication), was stoped nearly to the surface. The metal concentration of the lead-zinc ore extracted during this period of operation is not known.

A shipment of concentrates to the sampling-works at Idaho Springs gave the following results:

Sample-works assays of concentrates from Essex mine, $1995^{1}$

\begin{tabular}{r|r|r|r|r}
\hline \multicolumn{1}{c|}{ Tons } & \multicolumn{1}{c|}{ Gold ${ }^{2}$} & Silver 2 & $\begin{array}{r}\text { Lead } \\
\text { (percent) }\end{array}$ & $\begin{array}{r}\text { Zinc } \\
\text { (percent) }\end{array}$ \\
\hline 1.51 & 0.74 & 7.00 & 36.80 & 12.50 \\
\hline
\end{tabular}

. 2 Data on ore tenor furnished by the Idaho Springs Sampling Works. Published by permission. 
In August 1951, United Mining and Leasing Corp. was granted an exploration loan by the Defense Minerals Exploration Administration. The Patterson shaft was rehabilitated and deepened 81 feet, 85 feet of drift was driven on the 80 level, and 628 feet of drift and crosscut was driven on the 150 level; although good ore was found, no shipments were made. Since August 1953, the mine has been idle.

The mine workings are shown in plate 5. They consist principally of the Patterson shaft, the McKay shaft, primarily a ventilation shaft, and levels at vertical depths of about 80 and 150 feet. Except for the mining done west of the Patterson shaft on the 80 level, there has been little stoping.

The country rock consists largely of interlayered microcline-bearing gneiss, biotite-quartz-plagioclase gneiss, and migmatite. Granite pegmatite occurs as small, discrete lenticular layers. Although dips generally are gentle, at places, because of intricate folding, they are steep.

Two principal veins have been found in the mine, the hanging-wall (or main) vein and the footwall vein (pl. 5). A minor, eastward-trending vein was cut in the crosscut on the 80 level. On the 150 level, west of the shaft, the principal veins are about 50 feet apart. The footwall vein probably connects with the main vein about 50 feet east of the Patterson shaft, at ore shoot $A$. The veins appear to join on the 80 level about 40 feet east of the shaft.

The main (Essex) vein trends on the average $\mathrm{N}$. $65^{\circ} \mathrm{E}$., but, as can be seen in plate 5 , it makes an S-shaped (cymoid) bend southwest of the shaft; it dips an average of $55^{\circ} \mathrm{NNW}$., but at places it is either somewhat flatter or steeper. Splits and branches from the main vein are common, particularly at the deflection in strike; and throughout most of the mine the vein is characterized by two conspicuous filled-fractures-a footwall and hanging-wall seam-which are separated by broken, sheared, and mineralized ground.

The ore consists predominantly of sphalerite with lesser amounts of galena, pyrite, and chalcopyrite. At places a trace of tetrahedrite-tennantite is present. The sphalerite contains variable but locally abundant blebs of chalcopyrite that cannot be distinguished except under high magnification ( $\times 100$ or greater). Galena oceurs in vuggy openings as fillings, and to lesser extent as replacements of sphalerite. Pyrite, the latest metallic mineral to crystallize, replaces quartz gangue, and to a minor extent sphalerite and galena.

The main vein is highly variable in structure and mineralogy. At most places it consists largely of altered and fractured country rock containing dissemi- nated pyrite and $1 / 16^{-}$to $1 / 4^{-i n c h}$ seams of white quartz, which is veined by discontinuous streaks of sphalerite generally less than an inch thick. Seams of white gouge, ranging in width from an inch or less to as much as 2 feet, occur along one or both vein walls. The sulfide seams are particularly abundant in the wedge of rock between two or more closely spaced, converging fractures. At places the vein is composed almost entirely of breccia-type ore which consists of subangular fragments of altered and sparsely pyritized country rock, generally less than 3 inches in greatest dimension, that are surrounded by darkbrown sphalerite (marmatite) and galena, which in turn are enclosed by gray to black chalcedonic quartz. Terminated white quartz crystals locally coat the sulfides where the ore is vuggy. The breccia-type ore constitutes the ore shoot east of the Patterson shaft. The ore bodies west of the shaft, however; so far as known, consist largely of gouge that contain abundant, closely spaced veinlets of sphalerite and galena. Possibly, however, parts of these shoots contain some ore of the breccia type. Postmineralization slickensides are conspicuous along the vein. The first movements, judging from grooves on the vein walls, were almost horizontal. The latest movements were dip slip in character and on the average plunge about $50^{\circ} \mathrm{N} .25^{\circ} \mathrm{E}$; t the hanging wall apparently was displaced down in relation to the footwall. Most of the movement was taken up along the hanging wall after mineralization. Where the slips crossed sulfide ore, they consist in part of a thin film of black, sheared sulfides.

Ore shoot $A$ appears to occur at, and east of, the junction of the hanging wall (Essex) and footwall veins; ore shoots $B$ and $C$ appear to be related to openings formed by deflections in strike of the hanging wall vein. The ore shoots plunge steeply northeast, and as outlined in plate 5 have a stope length of as much as 50 feet, but for the most part probably are smaller, and average 2 feet or less in thickness. The plunge length of the ore shoots is not known. The average grade of the ore in the shoots, as determined by samples taken during the Defense Minerals Exploration Administration exploration work, is given on plate 5 . These data indicate that there is no apparent change in the lead-zinc ratio within the mine workings.

\section{EUREKA MINE (C-III-17)}

The Eureka mine is on the north side of Prosser Gulch, 1,025 feet northeast of the Essex mine and on the same vein. The mine is worked through the 
Gilpin-Eureka shaft (fig. 16), which is inclined an average of $60^{\circ} \mathrm{NW}$. and is about 650 feet deep vertically. Eight levels have been driven; the lowerwinze level-is opened by a winze; all other levels connect to the shaft.

The Eureka mine was discovered in 1859 or 1860 , at which time several 100 -foot claims were established. Later these claims were consolidated into the Sierra Madre and Eureka mines. In 1877 the Eureka mine was closed by litigation, but title to the property soon was cleared and production was resumed. Except for a few years, the mine was worked from 1905 to 1927 ; since that time it has been little worked. The mine was inactive in 1954, and the description that follows is taken largely from Bastin and Hill (1917, p. 213-214).

Prior to 1909 the Eureka mine yielded at least $\$ 400,000$; the most valuable metal was gold. Most of this production was made before 1900 , and it came from workings above a depth of 90 feet and along a length of about 400 feet. Presumably this ore was mechanically enriched by weathering. The production since 1905 (table 35) is mostly, if not entirely, primary ore.

The wallrock is mainly Precambrian microclinebearing gneiss. A large lens of pegmatite crops out north of the shaft collar, and according to Bastin and Hill (1917, p. 213), a small lens of biotite gneiss is on the 350 level west. The wallrocks trend northeast and dip moderately northwest.

Four veins-Eureka, North, South, and Spur-are present in the mine (fig. 39). The Eureka vein, exposed on all levels, strikes on the average N. $70^{\circ} \mathrm{E}$. and dips $45^{\circ}-70^{\circ} \mathrm{NW}$.; probably it correlates with the Essex vein. It ranges from about 1 to 6 feet in width, and averages about $21 / 2$ feet. The North vein strikes about N. $85^{\circ}$ E. and dips steeply north. It joins the Eureka vein near the Gilpin-Eureka shaft, but is not present east of the shaft. Except for a lens of ore 80 feet long between the 200 and 600 levels, west of the shaft, the North vein is about 10 inches wide and sparsely mineralized. At the 600 level near the shaft, the North and Eureka veins are about 12 feet apart; the country rock between the veins contains sparse sulfides. The South vein strikes about N. $85^{\circ}$ E. and dips $65^{\circ}-70^{\circ}$ NW. On the 350 level, it joins the Eureka vein 200 feet west of the shaft, follows that vein westward for about 50 feet, and then resumes its independent course. On the 400 level, it intersects the Eureka vein about 280 feet west of the shaft; and on the 500 level, it joins this vein about 300 feet west of the shaft (Bastin and Hill, 1917, p. 213). The South vein generally is 12 to 18 inches wide, but is as much as 24 inches wide near the junction. The Spur vein, worked at the surface (pl. 1) and cut on the 350 level (fig. 39 ), strikes N. $68^{\circ} \mathrm{W}$. and dips $80^{\circ} \mathrm{SW}$. At most places, it is narrow, but near the junction with the Eureka vein it is as much as 2 feet wide and is stoped.

TABLE 35.-Ore produced from the Eureka mine, 1905-54

\begin{tabular}{|c|c|c|c|c|c|c|c|}
\hline Year & $\begin{array}{c}\text { Crude ore } \\
\text { shipped } \\
\text { (tons) }\end{array}$ & $\begin{array}{l}\text { Concen- } \\
\text { trates } \\
\text { shipped } \\
\text { (tons) }\end{array}$ & $\begin{array}{c}\text { Gold } \\
\text { (ounces) }\end{array}$ & $\begin{array}{c}\text { Silver } \\
\text { (ounces) }\end{array}$ & $\begin{array}{l}\text { Copper } \\
\text { (pounds) }\end{array}$ & $\begin{array}{c}\text { Lead } \\
\text { (pounds) }\end{array}$ & $\begin{array}{c}\text { Zinc } \\
\text { (pounds) }\end{array}$ \\
\hline & $\begin{array}{l}300 \\
459\end{array}$ & & $\begin{array}{l}485.00 \\
248.21 \\
278.21\end{array}$ & $\begin{array}{r}1,657 \\
552\end{array}$ & & 81,250 & \\
\hline & & 63 & $\begin{array}{r}372.24 \\
24.44\end{array}$ & $\begin{array}{r}487 \\
97\end{array}$ & & & \\
\hline & 574 & 33 & $\begin{array}{r}118.85 \\
0.06\end{array}$ & 32 & & & \\
\hline 9 & 3.665 & & 907.90 & 291 & & & \\
\hline & & 43 & & 71 & & & \\
\hline & 597 & 74 & & $\begin{array}{l}130 \\
196\end{array}$ & 237 & $\begin{array}{l}6,794 \\
6,555\end{array}$ & $\cdots$ \\
\hline & 1.908 & 1. & & 159 & & 52 & \\
\hline & & 146 & 10 & 776 & & 17.706 & 2,951 \\
\hline & 641 & & 476.47 & 273 & ...... & 4., 694 & \\
\hline & 1,590 & 177 & & $\begin{array}{r}4.134 \\
2,\end{array}$ & 3.736 & $\begin{array}{r}8.797 \\
19779\end{array}$ & 19,847 \\
\hline & & 153 & & 1,305 & & 16.225 & 17.758 \\
\hline to. &.$\quad 226$ & 254 & & $\begin{array}{l}1.485 \\
1,573\end{array}$ & $\begin{array}{l}2,666 \\
2,685\end{array}$ & $\begin{array}{l}26,983 \\
36,775\end{array}$ & 2,905 \\
\hline 6 & 72 & & 543. & 787 & 1.040 & 6,275 & \\
\hline & 3,580 & 163 & & 1,294 & 1.165 & 34 & 4,903 \\
\hline & & 195 & & 1.705 & $1,579^{\circ}$ & $29.170^{-1}$ & 12,995 \\
\hline & & 170 & $\begin{array}{l}583.69 \\
107.40\end{array}$ & 1,369 & 1,523 & 3.704 & 12,08 \\
\hline & 5,140 & & 513.75 & 4 & & & \\
\hline & 016 & 486 & & 3,236 & 4,337 & 81,541 & \\
\hline & 5.016 & 564 & & $\begin{array}{l}243 \\
\text { 3.716 }\end{array}$ & $\begin{array}{r}139 \\
0,479\end{array}$ & $\begin{array}{r}6.141 \\
143.864\end{array}$ & $\ldots$ \\
\hline & 223 & & & 138 & & 4,069 & \\
\hline & & 30 & & 157 & 324 & 2,753 & 2,601 \\
\hline & 2,000 & & 745 & 275 & & & \\
\hline & 2,024 & 114 & & $\begin{array}{l}1,005 \\
705\end{array}$ & 1,323 & $\begin{array}{l}47,735 \\
11.641\end{array}$ & $\cdots$ \\
\hline & & 203 & & 1,158 & 1,967 & 44 & \\
\hline & 1,226 & 119 & $\begin{array}{r}410.25 \\
98.10\end{array}$ & $\begin{array}{l}400 \\
517\end{array}$ & $\begin{array}{l}924 \\
151\end{array}$ & $\begin{array}{l}17,201 \\
31,066\end{array}$ & \\
\hline & 13 & & 10.7 & 38 & & & \\
\hline & & $\overline{2}$ & $\begin{array}{l}. .56 \\
13.70\end{array}$ & $\begin{array}{r}7 \\
144\end{array}$ & 17 & $\begin{array}{r}146 \\
66\end{array}$ & \\
\hline & & 78 & & 402 & 340 & 4,084 & 27,044 \\
\hline 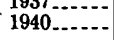 & & 2 & 17 & 11 & (1) & $152^{-1}$ & $\cdots$ \\
\hline Total. & $35,718.5$ & 3,089 & $11,942.37$ & 30,046 & 35,356 & 729,456 & 103,1 \\
\hline
\end{tabular}

I Compiled by U.S. Bureau of Mines. Published by permission.

Aside from the near-surface ore, all the ore bodies in the mine occur at vein intersections. As shown on the longitudinal section (fig. 16), 2 ore shoots plunging about $60^{\circ} \mathrm{W}$., were mined west of the shaft. The shoot nearest the shaft is at the junction of the North and Eureka veins,' and the shoot farther out from the shaft is at the junction of the South and Eureka veins. The latter has been most productive and provided the good ore extracted from the winze level. A smaller ore shoot, little mined, was worked on the 350-level at the junction of the Spur and Eureka veins.

All the veins are pyrite veins that contain sphalerite, galena, and copper minerals (type $C$ ), and according to Bastin and Hill (1917, p. 213), they were 


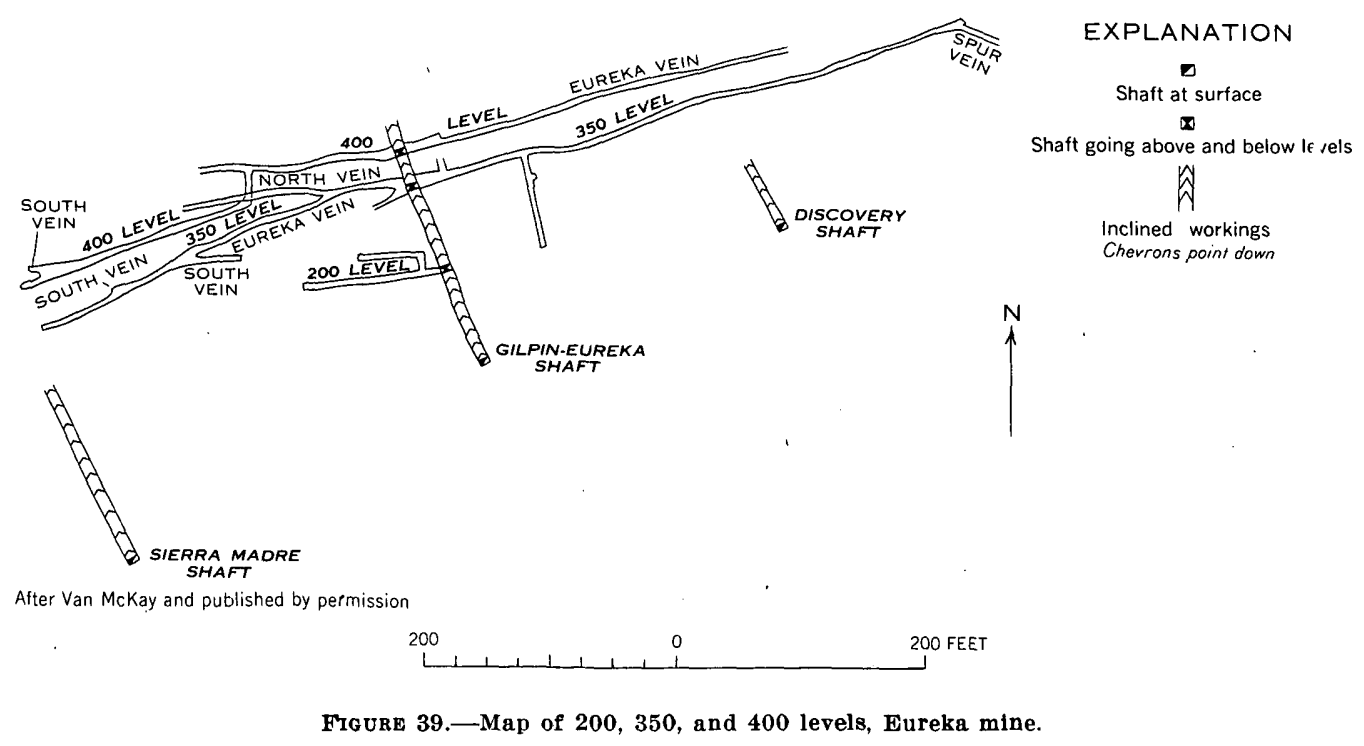

formed by composite mineralization. Pyrite, the most abundant mineral, is disseminated through quartz and altered wallrock, and this material is cut by stringers and lenses containing dark-gray, fine-grained quartz, dark sphalerite, galena, and chalcopyrite. Nearly all of the gold and silver is associated with these lenses. Sphalerite is the most abundant base metal.

Movement along the veins after mineralization is shown by heavy gouge along the vein walls and locally within the vein. The Spur vein, where cut by the Eureka vein, has been displaced about 2 feet, the northwest side having been moved southwest. On the 350 level, broken fragments of both pyrite and galenasphalerite ore are partly cemented by bluish-gray, fine-grained quartz.

In the ore shoots, the galena-sphalerite-chalcopyrite lenses are locally 8 to 10 inches wide. This type of ore has been hand sorted and shipped directly to the smelter. Other parts of the vein contain mill ore consisting of sparse narrow seams of base metals.

From 1897 to 1908,14 lots of smelting ore aggregating 30 tons averaged 1.91 ounces of gold and 12.37 ounces of silver per ton. Most of this ore contained about 16 percent lead and from 8 to 12 percent zinc. Assays of some shipments of crude ore are given below :

Sampling-works assays of crude ore shipped from the Eureka mine, $1910-24^{1}$

\begin{tabular}{|c|c|c|c|c|c|c|}
\hline Year & Tons & Gold 2 & Silver 2 & $\begin{array}{l}\text { Copper } \\
\text { (percent) }\end{array}$ & $\underset{\text { (percent) }}{\text { Lead }}$ & $\underset{\text { (percont) }}{\text { Zinc }}$ \\
\hline $1910 \ldots$ & $\begin{array}{r}22.3 \\
6.6 \\
9.3 \\
12.8\end{array}$ & $\begin{array}{l}1.58 \\
.28 \\
2.01 \\
1.50 \\
1.54\end{array}$ & $\begin{array}{r}10.6 \\
.92 \\
11.22 \\
8.05 \\
8.15\end{array}$ & $\begin{array}{r}0.77 \\
.90\end{array}$ & $\begin{array}{r}49.2 \\
3.2 \\
33.60 \\
9.22 \\
16.85\end{array}$ & $\begin{array}{r}7.20 \\
8.07 \\
6.87\end{array}$ \\
\hline
\end{tabular}

1 Complled by U.S. Bureau of Mines. Published by permission. 2 Ounces per ton.
The known ore reserves in the mine occur in the downward projection of the two ore shoots that were mined west of the shaft (fig. 16). The mining of these ore bodies will require deepening of the shaft, for it is not economically feasible to hoist ore through the winze and then transfer it for hoisting through the shaft. Possibly the Eureka mine could be worked in conjunction with the Essex mine, which exploits the same vein system.

\section{GOLD COLLAR MINE (HYDRANT CLAIM) (C-III-14)}

The Gold Collar mine (Hydrant claim) is on the north side of Prosser Gulch, about 400 feet N. $50^{\circ} \mathrm{W}$. from the Grand Army mine. The mine was inaccessible in 1954. According to Bastin and Hill (1917, p. 214), the mine is opened by a 712-foot inclined shaft with levels accessible at that time (September 1911) at 200,257 , and 332 feet. The known production from the Gold Collar mine is given in table 36 . Bastin and Hill (1917, p. 214) report that the mine yielded about $\$ 250,000$ prior to 1911 .

TABLE 36.-Ore produced from the Gold Collar mine, 1902-54 ${ }^{1}$

\begin{tabular}{|c|c|c|c|c|c|c|c|}
\hline Year. & $\begin{array}{l}\text { Crude } \\
\text { ore } \\
\text { shinped } \\
\text { (tons) }\end{array}$ & $\begin{array}{l}\text { Concen- } \\
\text { trates } \\
\text { shipped } \\
\text { (tons) }\end{array}$ & $\begin{array}{c}\text { Gold } \\
\text { (ounces) }\end{array}$ & $\begin{array}{c}\text { Silver } \\
\text { (ounces) }\end{array}$ & $\begin{array}{c}\text { Copper } \\
\text { (pounds) }\end{array}$ & $\begin{array}{c}\text { Lead } \\
\text { (pounds) }\end{array}$ & $\begin{array}{c}\text { Zinc } \\
\text { (pounds) }\end{array}$ \\
\hline 1904. & & 50 & 170.00 & 454 & & & \\
\hline 1905 & $\begin{array}{r}60 \\
700\end{array}$ & 70 & $\begin{array}{r}96.02 \\
\end{array}$ & & 18000 & ( & ....... \\
\hline $\begin{array}{l}1908 \\
1809\end{array}$ & $\begin{array}{r}700 \\
5\end{array}$ & $\begin{array}{r}70 \\
3\end{array}$ & $\begin{array}{r}530.30 \\
10.33\end{array}$ & $\begin{array}{l}1, \text { rij1 } \\
38\end{array}$ & 18,000 & & \\
\hline & 454 & 25 & 177.29 & 492 & 233 & & \\
\hline 1911 & $\begin{array}{r}70 \\
1\end{array}$ & & $\begin{array}{r}30.76 \\
36\end{array}$ & 84 & - & 104 & \\
\hline 1913 & 29 & 2 & 8. 31 & 20 & & 102 & \\
\hline 1914 & & $\overline{3}$ & 2. 98 & 19 & -1 & & \\
\hline 1915 & 5 & 2 & 8. 21 & 71 & - & 2,168 & $-\cdots$ \\
\hline Total & 1,324 & 160 & $1,034.26$ & 3,212 & 18,233 & 2,424 & 371 \\
\hline
\end{tabular}

1 Compiled by U.S. Bureau of Mines. Published by permission. 
The mine develops the Hydrant vein, probably a branch of the Eureka vein system, which trends about N. $76^{\circ}$ E. and $\operatorname{dips} 65^{\circ}-85^{\circ}$ (average $80^{\circ}$ ) SE. The vein cuts both microcline-bearing gneiss and biotitequartz-plagioclase gneiss; in the microcline-bearing gneiss the vein ranges from a few inches to 2 feet in width, but in the biotite-quartz-plagioclase gneiss it dissipates into a series of small branching fractures that almost parallel the rock foliation. The vein consists of altered wallrock, usually barren, that is cut at places by 1- to 6-inch stringers of dark sphalerite, chalcopyrite, pyrite, galena, quartz, and siderite. Sphalerite is the most abundant sulfide. The wallrock is pyritized and altered.

The principal ore shoot is bisected by the shaft and extends from the surface to a point somewhat between the 251 and 332 levels. On the 200 level the shoot extends for an unknown distance west of the shaft, and 250 feet east of the shaft. The shoot has been extracted for the entire length of the 257 level; the ore pinched out in the back of the stope about 200 feet west of the shaft. This shoot probably plunges to the west, as do most others in this area.

The smelting ore constituted about 2 to 4 percent of the vein material broken, and averaged about $\$ 70$ per ton in gold and silver in shipments for 12 to 14 years prior to 1911 . It contained about $21 / 2$ ounces of silver for each ounce of gold.

\section{GUNNELL LODE}

The Gunnell lode, one of the most persistent and productive lodes in the district, crops out on the south side of Prosser Gulch. It was discovered in 1859 by Harry Gunnell; shortly afterwards many other claims were taken up along it. Almost the whole lode was sold to eastern companies between 1863 and 1865 for a total price of about $\$ 800,000$. The lode was worked intermittently in the following years, but serious development was not begun until 1874 (Bastin and Hill, 1917 , p. 216). In that year the shaft was sunk to a depth of 700 feet and a bonanza ore body was cut. This ore body was fully exploited at depth, but eventually because of its westward plunge, mining reached the boundary between the Gunnell and Concrete claims. ${ }^{16}$ The owners of the Concrete claim, realizing that the Gunnell ore body entered their ground, started a shaft near their east endline. At the time they expected the shaft to enter ore, they broke into old workings that extended onto their property from the east; every effort was made-by burning sulfur

\footnotetext{
10 Collins, G. E., undated, Early mining history of Gilpin County. Colo., 12 p., report on fle in the Denver Public Library, Denver, Colo.
}

and exploding dynamite charges-to prevent the owners from obtaining proof that these workings were connected to the Gunnell shaft. . Finally, the proof of trespass was obtained; the Concrete owners were adjudged owner of the vein and the remaining ore. Later the western part of the Concrete claim was developed by an inclined winze; this time workings that connected with the Golden Treasure shaft were reached. Work ceased on the lode in 1904, when the Gunnell pump shaft burned and all the mines on the vein were flooded (Bastin and Hill, 1917, p. 216). Work was resumed in 1910, when the lode was drained by the Argo tunnel (Bastin and Hill, 1917, p. 216), and was continued intermittently until the disaster in the Argo tunnel in 1942.

The Gunnell lode is developed from east to west by the Gunnell pump shaft (C-III-23), the Grand Army shaft (C-III-22), the Fagan shaft (C-III-21), the Slaughter House shaft (C-III-29), the Josephine shaft (C-III-31), the Concrete shaft (C-III-20), and the Golden Treasure shaft (C-III-30). These workings are all interconnecting ( $\mathrm{pl}$. 6). The Gunnell shaft is 1,100 feet deep with levels at 100 -foot intervals; the Grand Army shaft is 1,200 feet deep with levels at 100-foot intervals; the Fagan shaft is 300 feet deep, the Josephine shaft is 800 feet deep, the Slaughter House shaft is 835 feet deep, the Concrete shaft is 1,285 feet deep, and the Golden Treasure shaft is more than 1,300 feet deep. The lodge is also developed by 3 laterals from the Argo tunnel and by sublevels 100 and 200 feet beneath the tunnel; raises from the laterals connect with the Grand Army and Concrete workings. These workings were all inaccessible in 1954, but Bastin and Hill (1917, p. 214-218), J. W. Finch, ${ }^{17}$ George Collins, ${ }^{18}$ and Lovering and Goddard. (1950, p. 178-180) examined the mines on the lode and the following is taken from their description.

The known production from the Gunnell-Grand Army part of the lode is given in table 37 ; this ore if produced today would have a value of about $\$ 2,812$,000. The known production from the Concrete mine is given in table 38 ; this ore would have a value of about $\$ 230,000$ at today's prices. It is reported that the Gunnell-Grand Army mine yielded $\$ 3$ million prior to 1899 (Callbreath, 1899, p. 257) and that the Concrete mine yielded $\$ 800,000$ to 1912 (Bastin and Hill, 1917, p. 216).

\footnotetext{
1i Finch. J. W, 1929, Report on the properties and operations of the Quartz Hill Holding Co., 12 p., report on fle in the Denver Public Library, Denver, Colo.

${ }_{18}$ Collins. G. E., undated, Early mining history of Gilpin County, Colo., 9 p., report on file in the Denver Public Library, Denver, Colo. Collins, G. E., 1944, Report on the Argo tunnel, 9 p., report on file in the Denver Public Library.
} 
TABLE 37.-Ore produced from the Gunnell mine, 1887-1954 '

\begin{tabular}{|c|c|c|c|c|c|c|c|}
\hline Year & $\begin{array}{l}\text { Crude } \\
\text { ore } \\
\text { shinped } \\
\text { (tons) }\end{array}$ & $\begin{array}{c}\text { Concen- } \\
\text { trates } \\
\text { shi'oned } \\
\text { (tons) }\end{array}$ & $\begin{array}{c}\text { Gold } \\
\text { (ounces) }\end{array}$ & $\begin{array}{c}\begin{array}{c}\text { Silver } \\
\text { (ounces) }\end{array}\end{array}$ & $\begin{array}{l}\text { Copper } \\
\text { (pounds) }\end{array}$ & $\begin{array}{l}\text { Lead } \\
\text { (pounds) }\end{array}$ & $\begin{array}{c}\text { Zinc } \\
\text { (pounds) }\end{array}$ \\
\hline $\begin{array}{l}1887 . . . \\
1888 \ldots \\
1889 \ldots \\
1902 \ldots \\
1903 \ldots\end{array}$ & $\begin{array}{c}(?) \\
(?) \\
(?) \\
13,000 \\
8,256\end{array}$ & & $\begin{array}{r}18,711.00 \\
11,279.00 \\
7,129.00 \\
5,431.00 \\
4,237.42\end{array}$ & $\begin{array}{r}1,947 \\
25,693 \\
8,759\end{array}$ & 46,000 & & $\begin{array}{l}\cdots \\
\cdots \\
\cdots\end{array}$ \\
\hline $\begin{array}{l}1904 .- \\
1905 . .- \\
1906-- \\
1907- \\
1908 . .\end{array}$ & $\begin{array}{r}3,044 \\
2,7720 \\
698 \\
658 \\
513\end{array}$ & 71 & $\begin{array}{r}1,750.50 \\
1,863.00 \\
425.60 \\
313.18 \\
399.78 \\
\end{array}$ & $\begin{array}{r}11,151 \\
329 \\
106 \\
30 \\
26\end{array}$ & & & $\begin{array}{l}-- \\
-- \\
-- \\
--\end{array}$ \\
\hline $\begin{array}{l}1909 \ldots . . \\
1910 \ldots \\
1911 \ldots \\
1912 \ldots \\
1013 \ldots\end{array}$ & $\begin{array}{r}212 \\
1,523 \\
2,711 \\
1,620 \\
339\end{array}$ & $\begin{array}{r}52 \\
113 \\
217 \\
100 \\
16\end{array}$ & $\begin{array}{r}177.75 \\
450.48 \\
1,246.65 \\
744.83 \\
304.24\end{array}$ & $\begin{array}{r}1,212 \\
658 \\
3,393 \\
2,630 \\
903\end{array}$ & $\begin{array}{r}34,649 \\
440\end{array}$ & 3,872 & 1, 255 \\
\hline $\begin{array}{l}1914 \ldots \\
1915 \\
1917 \\
1918 \ldots \\
1919 \\
1938 \ldots\end{array}$ & $\begin{array}{r}11,788 \\
8,809 \\
7,360 \\
5,838 \\
1,315 \\
135\end{array}$ & $\begin{array}{l}11 \\
11 \\
19 \\
19 \\
-7\end{array}$ & $\begin{array}{r}5,898.38 \\
4,198.55 \\
5,961.64 \\
3,522.71 \\
733.52 \\
39.94\end{array}$ & $\begin{array}{r}16,243 \\
11,710 \\
14,720 \\
9,601 \\
2,017 \\
58\end{array}$ & $\begin{array}{r}223,744 \\
1,064 \\
139\end{array}$ & $\begin{array}{r}\quad 1,783 \\
\hdashline\end{array}$ & 73 \\
\hline Total_. & $70,539+$ & $617+$ & $74,818.17$ & 111,196 & 306,036 & 5,761 & 1,328 \\
\hline
\end{tabular}

I Compiled by U.S. Bureau of Mines. Published by permission.

TABLE 38.-Ore produced from the Concrete mine, 1902-54 ${ }^{1}$

\begin{tabular}{|c|c|c|c|c|c|c|c|}
\hline Year & $\begin{array}{l}\text { Crude } \\
\text { ore } \\
\text { shipped } \\
\text { (tons) }\end{array}$ & $\begin{array}{c}\text { Concen- } \\
\text { trates } \\
\text { shipped } \\
\text { (tons) }\end{array}$ & \begin{tabular}{|c} 
Gold \\
(ounces)
\end{tabular} & $\begin{array}{c}\text { Silver } \\
\text { (ounces) }\end{array}$ & $\begin{array}{c}\text { Copper } \\
\text { (pounds) }\end{array}$ & $\begin{array}{l}\text { Lead } \\
\text { (pounds) }\end{array}$ & $\begin{array}{l}\text { Zinc } \\
\text { (pounds) }\end{array}$ \\
\hline $\begin{array}{l}1902 \ldots \\
1903 \ldots\end{array}$ & $\begin{array}{l}2,796 \\
1,441\end{array}$ & & $\begin{array}{l}747.00 \\
448.33\end{array}$ & & & & \\
\hline $\begin{array}{l}1804 \ldots \\
1905 \ldots\end{array}$ & $\begin{array}{l}1,400 \\
1,324\end{array}$ & & $\begin{array}{l}445.15 \\
145.15 \\
375.44\end{array}$ & $\begin{array}{r}15,720 \\
1,861\end{array}$ & & & 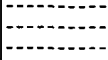 \\
\hline $\begin{array}{l}806 \ldots \ldots \\
308\end{array}$ & $\begin{array}{l}135 \\
343\end{array}$ & 114 & $\begin{array}{r}73.82 \\
154.79\end{array}$ & $\begin{array}{l}24 \\
46\end{array}$ & & & \\
\hline $\begin{array}{l}1909 . \\
1910 .\end{array}$ & $\begin{array}{r}1,013 \\
608\end{array}$ & $\begin{array}{r}112 \\
76\end{array}$ & $\begin{array}{r}419.35 \\
266.02\end{array}$ & $\begin{array}{r}2,5911 \\
239\end{array}$ & $\begin{array}{r}4,187 \\
917\end{array}$ & $\begin{array}{r}111,038 \\
24,084\end{array}$ & \\
\hline $1911 \ldots$ & $\begin{array}{r}438 \\
79\end{array}$ & 101 & $\begin{array}{l}47.62 \\
10.45\end{array}$ & $\begin{array}{r}118 \\
23\end{array}$ & 197 & $\begin{array}{l}3,881 \\
1,615\end{array}$ & - \\
\hline 915 & & & $\begin{array}{l}2.76 \\
7.91\end{array}$ & $\begin{array}{r}6 \\
22\end{array}$ & & $960^{-}$ & \\
\hline 1917 & 1,317 & & $1,199.48$ & 2,353 & 4,004 & & \\
\hline $\begin{array}{l}1919 \ldots \\
1927 \ldots \ldots\end{array}$ & $\begin{array}{r}r, 04 \\
821 \\
34\end{array}$ & 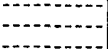 & $\begin{array}{r}491.80 \\
19.55\end{array}$ & $\begin{array}{l}1,160 \\
1,611 \\
132\end{array}$ & 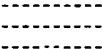 & 5,032 & 2,375 \\
\hline Total.. & 12,345 & 412 & $5,133.81$ & 26,264 & 9,305 & 146,610 & 2,375 \\
\hline
\end{tabular}

1 Compiled by U.S. Bureau of Mines. Published by permission.

The mine workings developed the Gunnell North, Gunnell Middle, Gunnell South, Hattie, Wheeler, Elizabeth, and Slaughter House-Golden Treasure veins; the Concrete vein is the westward continuation of one of the Gunnell veins, probably the Gunnell North. These veins range in strike from N. $70^{\circ}$ E. to N. $80^{\circ}$ E. and in dip from about $60^{\circ} \mathrm{N}$. to $70^{\circ}$ S.; the Slaughter House-Golden Treasure and Elizabeth are the principal north-dipping veins. The Gunnell, Grand Army, and Concrete shafts are collared on the Gunnell North vein; the Fagan shaft on the Gunnell Middle vein, and the Josephine shaft on the Gunnell South vein. The Slaughter House and Golden Treasure shafts are collared on the Slaughter House-Golden Treasure vein; this vein intersects the Concrete vein at depth. The Golden Treasure shaft follows the Concrete vein below the 673 level. The Elizabeth vein intersects the Gunnell North vein on the Argo tunnel level, and the other Gunnell veins at other levels. According to Lovering and Goddard $(1950$, p. 179$)$ the Concrete vein (in this case probably the Gunnell South vein) is faulted out in the western part of the Argo workings by movement along north-dipping splits of the Gunnell Middle vein.

This group of veins presents one of the best examples of composite mineralization in the district. The Gunnell-Grand Army part is dominantly pyritic, but some of the smaller ones are of the galena-sphalerite veins, and the larger veins have locally been reopened and mineralized with this type of ore. In the Concrete mine to the west, the ore is almost entirely galena-sphalerite.

The most important ore shoot exploited in the lode occurs along the Gunnell South-Slaughter House vein intersection, which in section has the form of an inverted $Y$. Ore occurs in the shank of the $Y$, and also to a varying depth in both legs, especially in the northern leg. The shoot plunges to the west at an average angle of $30^{\circ}$. It has been followed down plunge for 3,000 feet; it has a stope length of 300 feet (in the Concrete mine) and a vertical height of 310 feet. The shoot apexes a considerable distance east of the Gunnell pump shaft and was mined between the 450 and 760 levels of the Concrete mine; the farthest point that it has been worked is about 500 feet west of the Concrete shaft, about 200 feet above the Argo level. A second large ore shoot occurs between the 937 and 1,127 levels of the Concrete mine, west of the shaft. It probably joins the ore shoot extracted from the Gunnell-Grand Army mine between the 608 and 961 levels. This ore shoot seems to lie along the Concrete-Elizabeth vein intersection, which also plunges flatly to the west. Similar ore shoots probably occur along the intersections of the Elizabeth vein with the other veins of the lode system. Other factors also have probably influenced the occurrence of ore in the mine; the presence of competent wallrock, especially at depth, would account for stronger fracturing and consequently wider mineralization. The Gunnell North vein possibly fills a reverse fault and accordingly ore should be stronger on the "flats." The miners report that at least some of the ore in this lode occurs on the flats.

The average value of the smelting ore shipped from the Gunnell-Grand Army mine between 1874 and 1889 was $\$ 56.59$ per ton; the concentrating ore averaged about $\$ 14.02$ per ton. The average assay of 307 tons of smelting ore shipped from the Concrete mine was 1.03 ounces of gold per ton, 8 ounces of silver per 
ton, 23.80 percent lead, and 10.60 percent zinc. Some ore from the Concrete mine contained sufficient copper to be separated from the dominant lead-zinc ore. This zinc-copper-lead ore showed about as many ounces of gold as units of copper, and a gold content three times as great as the lead-zinc ore. There is apparently no decrease in metal concentration of the ore at depth, as the last ore mined from the lode at or just below the Argo tunnel level was almost exactly the same as that produced between 1876 and 1902 .

The future of the lode largely depends on development from the Argo tunnel, as it is almost impossible to gain access to it by other means. The ore shoots evidently persist to this level, and the major ore shoots should appear to the west of the present workings. Lovering and Goddard (1950, p. 179) note that the lode appears to be fraying-out beneath the tunnel, but they also suggest that a blind vein, that might persist to greater depth, may be present to one side or the other. Another factor to be considered in future work along the lode is the large tonnage of mill dirt on the Argo level. Collins ${ }^{10}$ notes that a belt of veined rock, 50 feet wide, surrounds the lode, and averages about 0.18 ounce of gold per ton; he also notes that a shipment of some 135 tons of stope fill contained 0.186 ounces of gold and just less than an ounce of silver per ton. Such material certainly would help defray the cost of future development.

\section{HUBERT MINE (C-IV-85)}

The Hubert mine is on the south slope of Nevada Hill about 1,240 feet $\mathrm{S}$. $71^{\circ} \mathrm{W}$. from the Prize mine. The mine is opened by a 1,250-foot inclined shaft (C-IV-35) that connects with 15 levels (fig. 40). The shaft dips to the north from the surface to the 400 level, and then reverses dip to the south. The shaft branches at the 600 level; the southward-dipping south branch continues to the 1,250 level. The north branch dips north to the 875 level and then reverses and dips south; this shaft bottoms on the 975 level. The 370 level of the mine connects with the Shafts mine (C-IV-41) which is developed by a southward-dipping shaft that connects with levels at 215,270 , and 370 feet (fig. 39). The 700 level connects with the 650 level of the Prize mine through a winze. The lode also is developed by the Jones mine (C-IV-36) that consists of a 500-foot shaft and 5,000 feet of drift (Callbreath, 1899, p. 269). The positions of the stopes on the three veins worked on the properties are shown on figure 41 . These workings were all inaccessible in 1954, but Schwarz (written communica-

${ }^{10}$ Collins, G. E., 1944, Notes on the Argo tunnel, 9 p., report on fle In the Denver Public Library, Denver, Colo. tion), and Bastin and Hill (1917, p. 218-221), examined the mine; the following is taken from their descriptions.

The known production from the Hubert mine is given in table 39 ; this ore if produced today would have a value of about $\$ 794,000$. The mine reportedly yielded $\$ 1$ million prior to 1899 (Callbreath, 1899, p. 257 ); the Jones mine reportedly yielded $\$ 100,000$ prior to 1899 (Callbreath, 1899, p. 269).

The Hubert mine develops two principal veins, the Hubert and the Shafts, and several branch veins, the principal one of which is the so-called Middle vein.

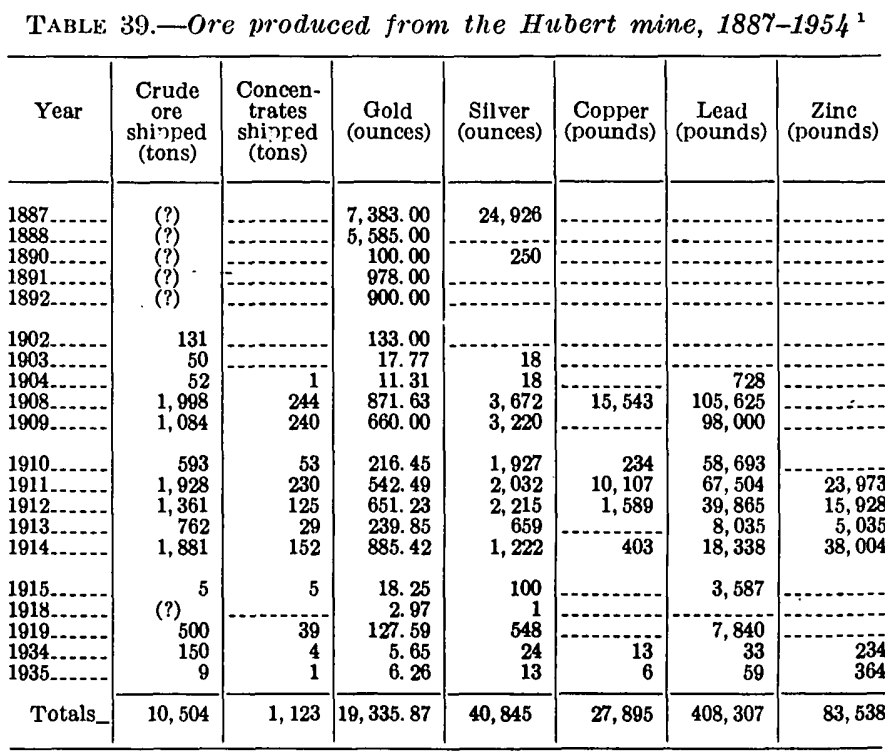

1 Compiled by U.S. Bureau of Mines. Published by permission.

Most of the development on the upper levels is on the Shafts vein, and most of that between the 400 and 900 levels is on the Hubert vein; both veins are developed on the lower levels of the mine. The Hubert vein trends about $\mathrm{N}$. $75^{\circ} \mathrm{E}$. and dips about $65^{\circ} \mathrm{N}$. from the surface to the 370 level; below that point it dips steeply southward. One of the richest ore bodies is on the 950 level about 185 feet west of the shaft. At this point, the ore body shows 1 inch of white quartz on the hanging wall, below which is 3 inches of sphalerite with chalcopyrite, 2 inches of white quartz that contains some sulfide, 3 inches of sphalerite and chalcopyrite, and 18 inches of altered microcline-bearing gneiss that contains disseminated pyrite and is traversed by $1 / 16^{-}$to $1 / 8^{-i n c h}$ stringers of sphalerite.

One of the most interesting parts of the mine is the large stope near the west end of the 850 level (fig. $40 A$ ). Near this stope the vein begins to fray out, and eventually forms a network of sulfide stringers traversing the wallrock in all directions; this locally 


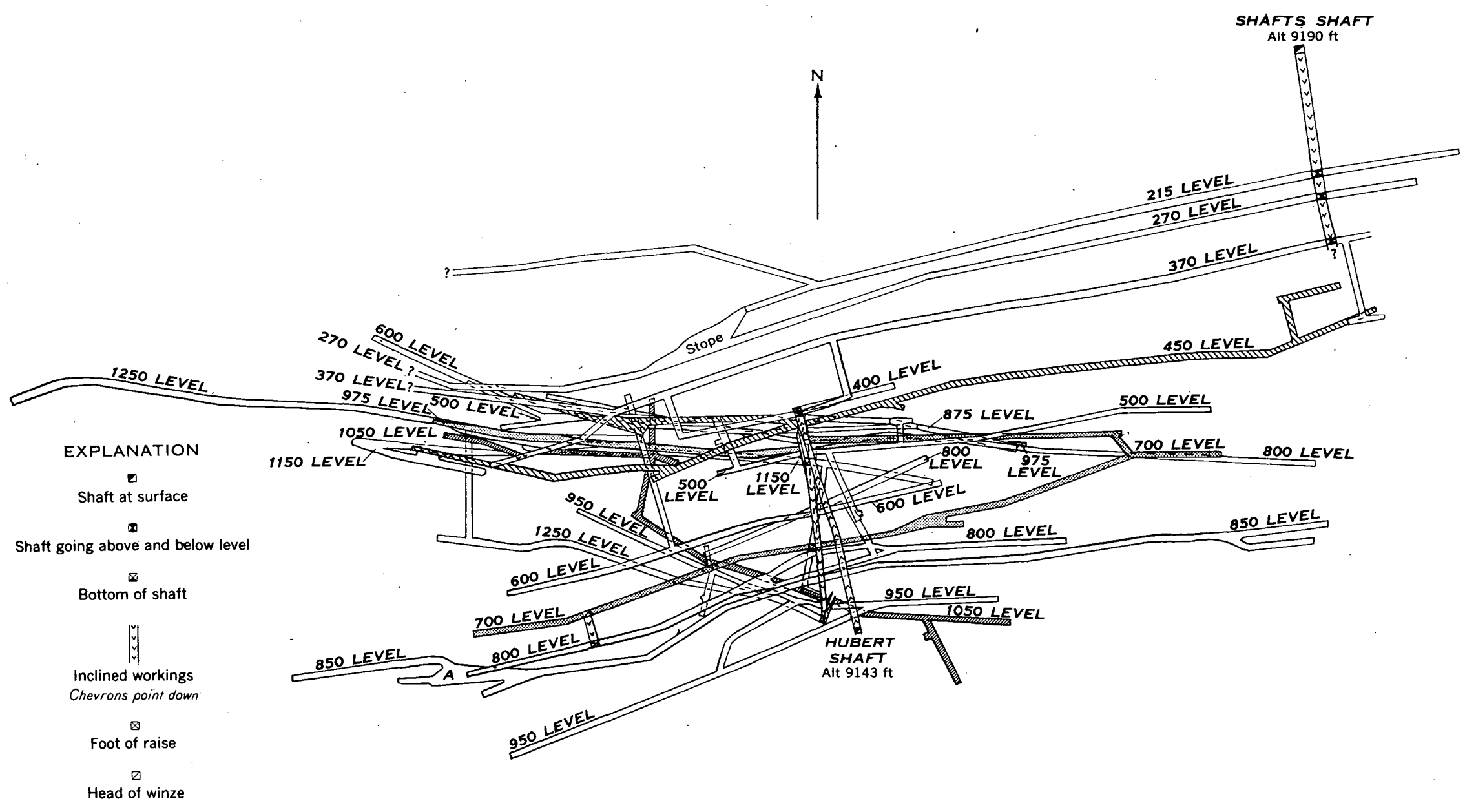

Extent of workings not known 


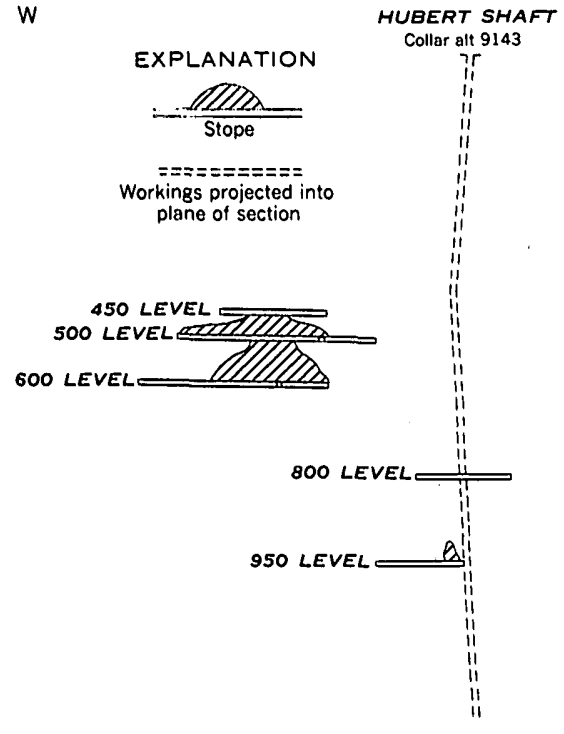

SECTION IN THE PLANE
OF THE MIDDLE VEIN

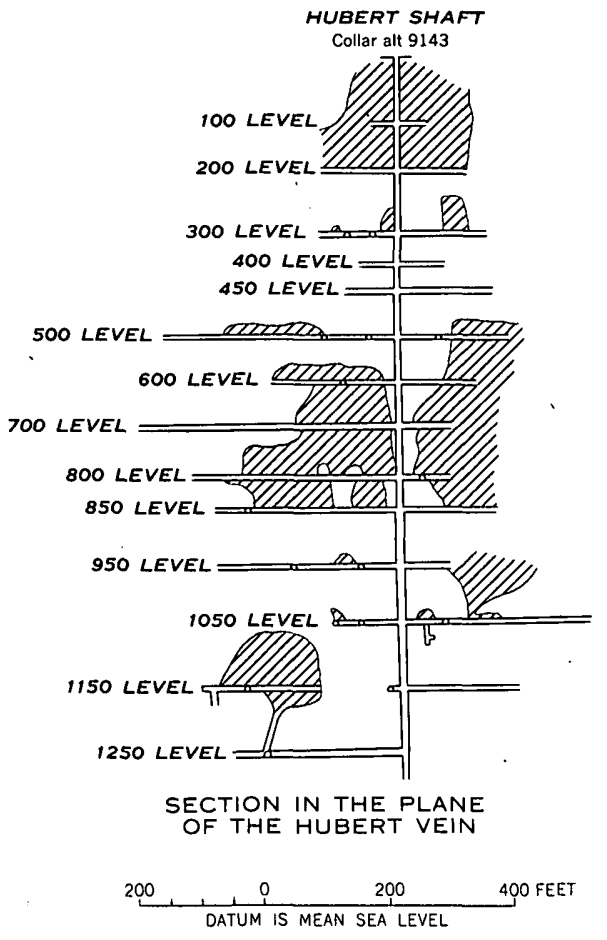

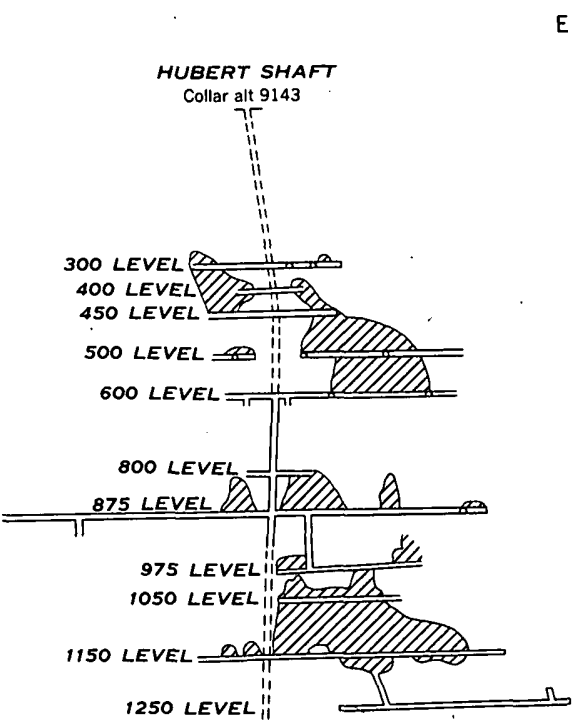

SECTION IN THE PLANE

After A. M. Wells, 1913

Figure 41.-Iongitudinal sections in the plane of the Middle, Hubert, and Shafts veins, Hubert mine.

passes into a true filled breccia. The fragments, not more than 3 inches in diameter, show sharp angular outlines and have plainly been moved from their original positions. Many sulfide aggregates between fragments show roughly triangular cross sections and a central vug lined with quartz, galena, and sphalerite crystals. The ore breccia is about 35 feet wide and extends upward to the 700 level; it does not, however, extend downward to the 950 level, where the vein branches in a normal manner without notable brecciation. This ore breccia is similar in appearance to certain parts of the Patch. The main ore body in this vein occurred between the 500 and 850 levels and had a stope length of at least 400 feet (fig. 41). Ore controls are not known, but it seems that most of the stopes are on those parts of the vein that dip steeply south.

The Shafts vein, probably the western continuation of the Seuderberg vein, was little observed by Bastin and Hill (1917, p. 219), so data concerning it are sparse. It trends about N. $80^{\circ}$ E. and from the surface to above the 800 level dips steeply south. From that point to the 875 level it dips steeply north, and then reverses to a south dip. Where exposed on the 600 level it is a nearly barren fracture zone a few inches to 3 feet wide. On the 975 level, about 160 feet west of the north shaft, it is well mineralized over a 5 -foot width for 40 feet. Three ore bodies were apparently present in the mine, one between the
370 and 600 levels, another above the 875 level, and another between the 975 and 1150 levels (fig. 41). The ore appears to occur in those parts of the vein that dip steeply south, similar to the Hubert vein.

The Middle vein, possibly the Parole vein, is developed on the $450,500,600,800$, and 950 levels of the mine (figs. 40,41 ). It trends N. $65^{\circ}-80^{\circ}$ E. and dips steeply south. Where exposed on the 800 level, it is only weakly mineralized, showing at the east breast a one-half inch veinlet of white quartz, sphalerite, and chalcopyrite. The major ore body in the vein occurs between the 450 and 600 levels; a small stope is on the 950 level (fig. 41). Too little is known of the vein to infer the ore controls.

Sampling-works assays of 131 tons of smelting ore shipped from the mine between 1888 and 1909 show gold, 0.74 to 5.8 (average 2.39) ounces per ton; silver, 2 to 17.6 (average 13.16) ounces per ton; copper, less than 6.5 and generally less than 1.5 percent; lead, less than 5 to 37 percent; and zinc, less than 32 percent. Similar assays of 72 tons of smelting ore shipped in 1910 show gold, 1.04 to 1.7 (average 1.38) ounces per ton; silver, 8 to 15.9 (average 14) ounces per ton; and lead, less than 5 to 30 percent. The average content of concentrates shipped in 1910 was gold, 0.21 ounce per ton; silver, 1.8 ounces per ton; and lead, 1.3 percent. Table 40 gives the metal content of the ore from the breccia on the 850 level. 
TABLE 40.-Some assays of breccia ore, 850 level, Hubert mine

\begin{tabular}{|c|c|c|c|c|c|}
\hline Width (feet) & Gold 1 & Silver 1 & $\begin{array}{c}\text { Copper } \\
\text { (percent). }\end{array}$ & $\underset{\text { (percent) }}{\text { Lead }}$ & $\underset{\text { (percent) }}{\text { Zinc }}$ \\
\hline $\begin{array}{l}14.80 \\
14.50 \\
4.59 \\
9.25\end{array}$ & $\begin{array}{r}0.08 \\
.10 \\
.30 \\
.08\end{array}$ & $\begin{array}{r}1.10 \\
.90 \\
3.70 \\
.82\end{array}$ & & $\begin{array}{r}10.2 \\
.3\end{array}$ & $\begin{array}{r}10.0 \\
7.6\end{array}$ \\
\hline
\end{tabular}

1 Ounces per ton.

\section{KING MINE (B-IV-1)}

The King mine, on the Skeleton claim, is on Kings Flat, west of the Nevadaville townsite. The workings were inaccessible in 1953 , and the data below were obtained largely from private company reports held by W. C. Russell, Jr. The mine is reported to have been opened in the 1860's; it was worked extensively in the eighties and again from 1901 to 1904 and 1913 to 1914 , but since that time it has been closed. The production prior to 1902 is not known. During 1913 and 1914, 2 tons of crude ore containing 0.29 ounces of gold, 35 ounces of silver, and 306 pounds of lead were shipped.

The mine workings consist of a shaft 600 feet deep and principal levels at vertical depths of 160,288 , and 600 feet. On the 288 (or 3d) level a crosscut connects the King workings with those from the Lamberson and Warren mine. At least 400 feet of drift extends east from the King shaft on the 600 level.

The vein does not crop out at the surface, but judging from the location of surface openings it trends about N. $80^{\circ}$ E. and probably dips steeply southeast. The shaft was sunk in sillimanitic biotitequartz gneiss, but microcline-bearing gneiss should be found in the lower workings. According to company reports the ore in the mine consists largely of galena, but some copper-bearing ore is found at places. The dump contains considerable sphalerite and pyrite is disseminated through altered wallrock. The gangue is quartz and altered wallrock.

\section{LAMBERSON AND WARREN MINE (B-IV-2)}

The Lamberson and Warren mine, on Kings Flat, west of the Nevadaville townsite, was inaccessible in 1953, and the following information was taken largely from private company reports held by W. C. Russell, Jr. The mine was first worked in the 1860 's; it was worked intermittently during subsequent years, and particularly from 1901 to 1904, when the Nevada Consolidated Gold Mining and Milling Co. operated it and the nearby King mine. Except for the sinking of a 70-foot shaft on the east end of the property in 1948-49, the mine has been closed since about 1904 . According to company reports the production is in excess of $\$ 50,000$.
The main workings consist of a shaft, probably at least 300 feet deep, and levels at 56, 90, and 200 feet; there must also be a level. at 300 feet, for company maps indicate that the workings are connected on this level to the King mine workings by a crosscut. Small stopes were driven above the :)0 level west of the shaft.

Sampler returns from cobbed ore taken from the old workings in 1901 and 1902 gave the following ranges: gold, $0.2-0.8$ ounce per ton; silver, $6-13$ ounces per ton; lead, 12-42 percent; and zinc, 5-14 percent. Assays from the 70-foot shaft at the east end of the property indicate that this ore is of milling grade. A sample from a depth of 44 feet gave: gold, 0.30 ounce per ton; -silver, 5.60 ounces per ton; and lead, 3.15 percent. Another sample from a depth of 46 feet assayed: gold, 0.02 ounce per ton; silver, 8.44 ounces per ton; lead, 12.20 percent; and zinc, 8.40 percent.

The vein mined in the main Lamberson and Warren shaft strikes N. $70^{\circ}$ E.; its dip is not known. Southwest of the shaft the vein appears to split. At the shaft on the east end of the claim the vein trends easterly, judging from the surface workings. It is not known whether this vein correlates with the vein worked in the main shaft. Ore specimens on the main dump consist predominantly of dark sphalerite, galena, and pyrite in a white quartz gangue. Rarely tan siderite(?) veinlets crosscut the ore assemblage. The sphalerite has moderate to sparse microscopic blebs of chalcopyrite. The pyrite is later than the galena and was the last metallic mineral to form. After deposition of the siderite, the rocks were sheared at places and veined by white cryptocrystalline quartz.

\section{NEWFOUNDLAND MINE (D-III-22)}

Location.-On the north side of Nevada Gulch about 550 feet N. $21^{\circ} \mathrm{E}$. from the Alger-Kansas mine.

Production.-About $\$ 275,000$ prior to $1911 ; 506$ tons of smelting ore and 9 tons of concentrates shipped between 1904 and 1911 contained 293.30 ounces of gold and 205 ounces of silver. (Compiled by U.S. Bureau of Mines. Published by permission.)

Development.-Inclined shaft, 1,500 feet deep.

Veins.-Newfoundland: Strike, N. $73^{\circ}$ E.; dip, $63^{\circ}$ SE. at the surface.

Wallrock.-Microcline-bearing gneiss.

Ore and sulfide minerals.-Pyrite, chalcopyrite, gold, and silver.

Gangue minerals.-Quartz.

Tenor.-Ore shipped between 1898 and 1906 showed gold, 2.01 to 10.04 ounces and silver, 1.50 to 5.25 ounces per ton; the gold value in-some picked smelting ore was $\$ 150$ to $\$ 200$. 


\section{ORANOAKE MINE (B-IV-8)}

The Oranoake mine is on Kings Flai, west of the Nevadaville townsite. The mine has long been closed and was inaccessible in 1953 . In 1896 the shaft was 135 feet deep (W. C. Russell, Jr., oral communication), but probably it has been deepened since that time. According to Russell, ore taken out in 1884 contained 5 to 6 ounces of gold per cord.

The mine workings are in Precambrian sillimaniticbiotite-quartz gneiss and pegmatite. Two northwestward-trending Tertiary quartz bostonite dikes lie within 400 feet of the shaft. The Precambrian rocks have a prevailing northwest dip, but near the mine they are deformed into gently plunging folds whose axes trend northeast.

The vein is not exposed, but it probably strikes about N. $85^{\circ} \mathrm{E}$. The upper part of the vein in the shaft is vertical. The vein material on the dump differs from other ore on Kings Flat, for it contains a large amount of manganiferous siderite, which weathers black. The ore minerals in dump specimens are sphalerite, tetrahedrite-tennantite, galena, chalcopyrite, and pyrite. The gangue is principally quartz; the carbonate is younger than the quartz and is in veinlets that cut quartz and pyrite. The ore minerals seem to have been deposited during a single period of mineralization. An unusual feature of the ore is a graphic texture produced by the replacement of tetrahedrite by galena.

\section{POST HOLE MINE (C-III-27)}

Location.-On the south slope of Nevada Hill, about 600 feet east of the Prize mine.

Production.-About $\$ 10,000$ prior to 1899 (Callbreath, 1899).

Development.-A 350 -foot shaft; 3 levels aggregating about 380 feet of drift.

Veins.-Prize(?): Strike, N. $67^{\circ}$ E.; dip, $70^{\circ}$ SE. at surface, reverses dip to northwest below the first level.

Wallrack.-Microcline-bearing gneiss.

Ore and sulfide minerals.-Pyrite, sphalerite, chalcopyrite, galena, gold, and silver.

Gangue minerals.-Quartz.

\section{PRIZE MINE (C-III-25)}

The Prize mine is on the south slope of Nevada Hill about 1,240 feet $\mathrm{N}$. $70^{\circ} \mathrm{E}$. from the Hubert mine. The mine develops two principal veins, the Prize and the Seuderberg, both of which were located about 1862. The veins are almost parallel in strike but converge at depth. Both veins were mined by the "old timers," and rich ore was found along their intersec- tion at depth. Eight years of apex litigation followed, which finally was settled when both properties were bought by one company. The mine was connected to the Argo tunnel in 1914, and active development work was begun in 1928. Unfortunately, the owners were caught in the stock-market crash in 1929, and the mine was ordered closed before active stoping could begin. The known production from the Prize mine is given in table 41. Before 1887, when the last dividends were paid, the mine is reported to have produced $\$ 2,305,000$. (D. L. Russell, oral communication.) Callbreath $(1899$, p. 286$)$ reports that the mine yielded \$3 million prior to 1899.

TABLE 41.-Ore produced from the Prize mine, 1902-54 1

\begin{tabular}{|c|c|c|c|c|c|c|}
\hline Year & $\begin{array}{l}\text { Crude ore } \\
\text { shipped } \\
\text { (tons) }\end{array}$ & $\begin{array}{c}\text { Concen- } \\
\text { trates } \\
\text { shipped } \\
\text { (tons) }\end{array}$ & $\begin{array}{c}\text { Gold } \\
\text { (ounces) }\end{array}$ & $\begin{array}{c}\text { Silver } \\
\text { (ounces) }\end{array}$ & $\begin{array}{l}\text { Copper } \\
\text { (pounds) }\end{array}$ & $\underset{\text { (pounds) }}{\text { Zinc }}$ \\
\hline $\begin{array}{l}1911 \\
1915 \\
1929 \\
1939\end{array}$ & $\begin{array}{r}676 \\
192 \\
20 \\
36 \\
8\end{array}$ & $\begin{array}{r}0.94 \\
\\
\\
\end{array}$ & $\begin{array}{r}380.10 \\
111.58 \\
1.80 \\
18.50 \\
7.00\end{array}$ & $\begin{array}{r}823 \\
329 \\
5 \\
57 \\
20\end{array}$ & $\begin{array}{r}1,044 \\
67 \\
\end{array}$ & 11, 183 \\
\hline Total & 932 & 94 & 518. 98 & 1,234 & 1,111 & 11,183 \\
\hline
\end{tabular}

1 Compiled by U.S. Bureau of Mines. Published by permission.

The mine is opened by an inclined shaft, vertical depth 700 feet, with levels at 350, 400, 450, 550, 650, and 700 feet; below the 550 level, both a hanging-wall shaft and a footwall shaft are present (pl. 6 and fig. 42). The 450 and 550 levels connect to the Seuderberg shaft (figs. 38 and 43 ) and the 650 level connects to the Hubert 700 level. The Prize vein also is developed by a lateral from the Argo tunnel, about 20,990 feet from the portal (pl.6); a raise from this lateral connects with the shaft workings at the 700 level. The position of the stopes is shown on figure 42 . These workings were all inaccessible to the writers in 1954.

The mine develops the Prize and Seuderberg veins, which apex only a few feet apart; only one vein is shown on plate 1 . The Prize vein strikes about N. $80^{\circ}$ W. and dips steeply south above the 700 level but steeply north below this level (fig. 42). The vein splits into 2 segments above the 550 level (fig. 42), which are reported to reunite on the 800 level (D. L. Russell, oral communication). The Seuderberg vein is almost parallel to the Prize vein, but it dips steeply north. It unites with the Prize vein about 450 feet below the Seuderberg shaft collar (Fossett, 1876, p. 290). The Ashtabula (?) vein, cut in the mine between the 700 and 800 levels (fig. 42), cuts and offsets the Prize vein with the hanging wall having been displaced upward with respect to the footwall.

The veins are all cumposite veins, and sphalerite and pyrite are the most abundant ore minerals. In 


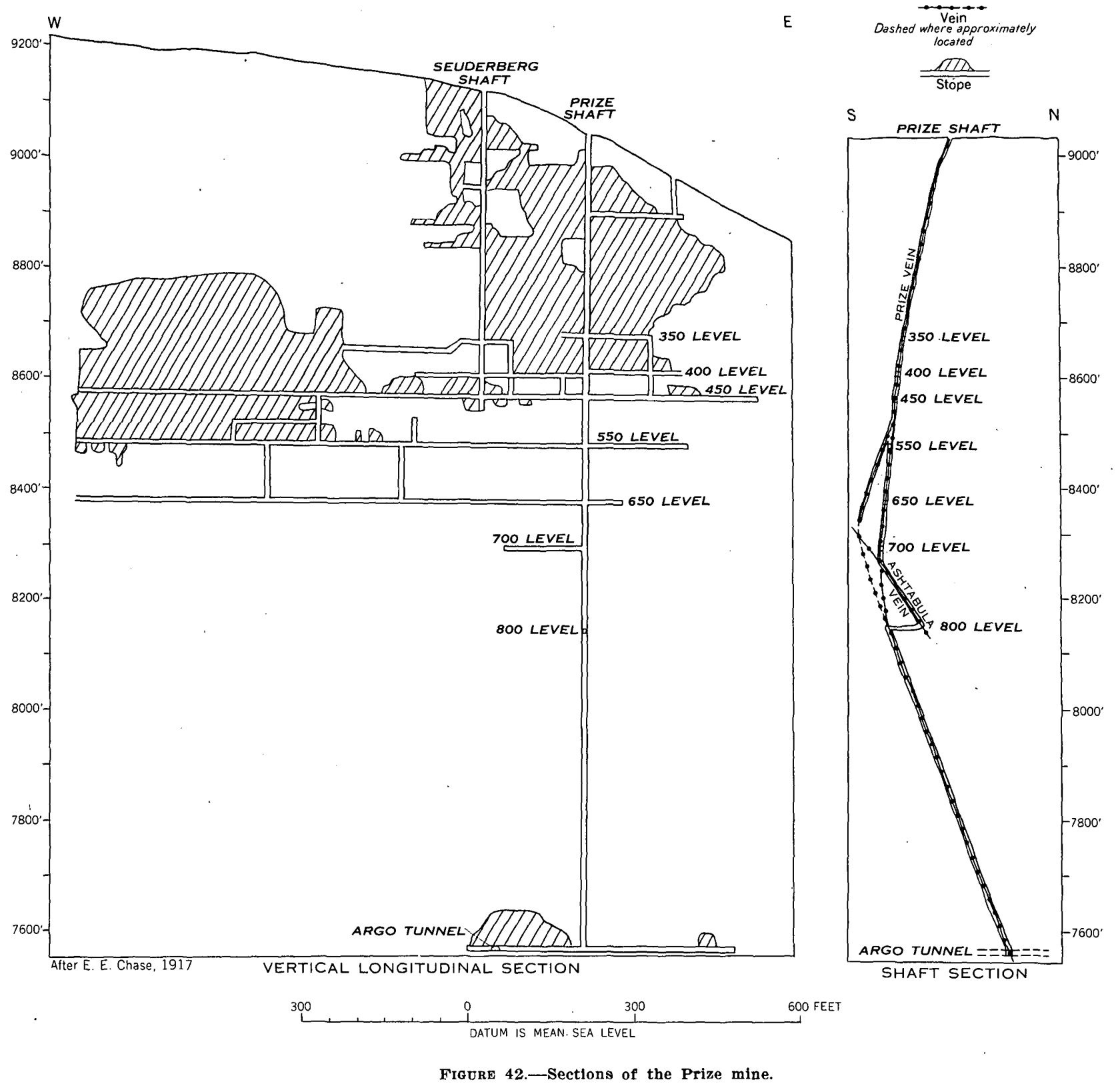

the Prize lateral from the Argo tunnel, the Prize vein consists of stringers of pyrite as much as $31 / 2$ inches wide within 1 to 4 feet of crushed and altered microcline-bearing gneiss containing disseminated pyrite. This ore contains 0.5 to 2 ounces of gold and from 3 to 16 ounces of silver per ton; some assays show as much as 4.5 percent copper (Bastin and Hill, 1917, p. 221). On the 800 level of the shaft workings, the vein is 54 inches wide and assays 0.5 ounce of gold per ton, 2.4 ounces of silver per ton, 14.5 percent zinc, 3 percent copper, and 1.3 percent lead per ton (D. L. Russell, oral communication).
As shown on figure 42 , two ore shoots have been developed in the mine. The larger one is developed from the surface to the 550 level west, and according to old sections is developed along the Shafts vein in the Hubert mine (fig. 41). This ore shoot plunges flatly to the west, and has been traced along its plunge for more than 2,000 feet. This ore shoot may be along the Prize-Seuderberg vein junction, which plunges flatly west. The vein is weakly mineralized below the split at the 550 level, but according to D. L. Russell (oral communication), it is ore-bearing where the segments reunite. Nothing is known about the small shoot 
developed above the Argo tunnel, but it may be part of a new ore shoot entering the workings from the east.

\section{READY CASH (B-III-2) AND INDEPENDENCE MINES} (B-III-8)

The Ready Cash mine (B-III-2) is on Prosser Hill, 470 feet $N .15^{\circ}$ W. from the Essex mine. The mine is opened by a small shaft inclined $80^{\circ} \mathrm{N}$. The extent of the mine workings are not known. The Independence mine (B-III-3) is 450 feet N. $83^{\circ} \mathrm{W}$. from the Ready Cash mine. Both mines were inaccessible in 1954.

The Ready Cash vein strikes easterly and dips at least $80^{\circ} \mathrm{N}$. It cuts microcline-bearing gneiss near the shaft, but passes into interlayered biotite gneisses and pegmatite west of the Independence shaft. Near the Ready Cash shaft, a northeastward-trending quartz bostonite dike is cut and offset by the Ready Cash vein, the north side having moved 20 feet west relative to the south segment. Abundant altered quartz monzonite(?) porphyry is on the dump of the shaft west of the Ready Cash shaft.

The Ready Cash vein is a galena-sphalerite vein. Dump specimens consist of white quartz with sparse disseminated pyrite cut by seams of galena and lightyellow sphalerite.

In 1910 and 1911, 51 tons of crude and 5 tons of concentrates that contained 10.47 ounces of gold, 133 ounces of silver, and 3,439 pounds of lead were shipped from the Ready Cash mine. From 1919 to 1925.15 tons of smelting ore valued at $\$ 1,924$ were shipped to the Idaho Springs Sampling Works. Assays of selected lots of this ore are given below:

Sampling-works assays of smelting ore from the Ready Cash mine, 1919-25 ${ }^{1}$

\begin{tabular}{|c|c|c|c|c|c|}
\hline Yoar & Tons & Gold 2 & Silver 3 & $\underset{\text { (percent) }}{\text { Lead }}$ & $\underset{\text { (percent) }}{\text { Zinc }}$ \\
\hline $\begin{array}{l}1919 \ldots \\
1920 \\
1923 \\
1925\end{array}$ & $\begin{array}{l}\text { 2. } 97 \\
\text { 3. } 08 \\
\text { 1. } 90 \\
\text { 7. } 08\end{array}$ & $\begin{array}{c}0.015 \\
.03 \\
.02\end{array}$ & $\begin{array}{l}171.97 \\
276.70 \\
169.83 \\
109.88\end{array}$ & $\begin{array}{l}\text { 7. } 77 \\
\text { 8. } 56 \\
\text { 6. } 70 \\
\text { 5. } 01\end{array}$ & $\begin{array}{r}6.12 \\
15.70 \\
14.30 \\
9.64\end{array}$ \\
\hline
\end{tabular}

1 Production deta furnished by the Idaho Springs Sampling Works. Published hy permission.

The Independence mine (B-III-3), from 1932 to 1952, shipped 280.5 tons of smelting ore and 20 tons of cencentrates that contained 78.83 ounces of gold, 566 ounces of silver, 164 pounds of copper, 11,077 pounds of lead, and 482 pounds of zinc.

\section{WHITING VEIN}

The Whiting vein is on Nevada hill, on the south side of Prosser Gulch, and about 250 feet south of the Gunnell lode. The vein has been mined principally from the Whiting mine (C-III-24) and the Grand Central (East Whiting) mine (D-III-25). None of the mine workings were accessible in 1954.

The Whiting mine consists of a shaft, inclined $67^{\circ}$ S. at the surface, and levels at depths of $200,300,400$, and 500 feet (Bastin and Hill, 1917, p. 218). The mine was worked almost entirely before 1900 . In 1887 ore that contained 4,590 ounces of gold, 19,283 ounces of silver, and 53,031 pounds of copper was taken from the mine. The size of the dump indicates that the Grand Central mine is large, but its workings are not known. The recorded production from the mine is given in table 42 .

TABLE 42.-Ore produced from the Grand Central (East Whiting) mine, 1902-54 1

\begin{tabular}{|c|c|c|c|c|c|}
\hline . Year & $\begin{array}{l}\text { Crude ore } \\
\text { shipped } \\
\text { (tons) }\end{array}$ & $\begin{array}{l}\text { Concen- } \\
\text { trates } \\
\text { shipped } \\
\text { (tons) }\end{array}$ & $\begin{array}{c}\text { Gold } \\
\text { (ounces) }\end{array}$ & $\begin{array}{c}\text { Silver } \\
\text { (ounces) }\end{array}$ & $\begin{array}{l}\text { Copper } \\
\text { (pounds) }\end{array}$ \\
\hline $\begin{array}{l}1902 \\
1904 \\
1905 \\
1906\end{array}$ & $\begin{array}{r}666 \\
48 \\
500 \\
50\end{array}$ & \begin{tabular}{|}
$-\ldots$ \\
\hdashline$\cdots$ \\
\hdashline
\end{tabular} & $\begin{array}{r}314.40 \\
123.00 \\
230.02 \\
22.98\end{array}$ & $\begin{array}{r}2,876 \\
216 \\
404 \\
36\end{array}$ & \begin{tabular}{|l|}
$\mid$ \\
\hdashline
\end{tabular} \\
\hline $\begin{array}{l}1907 \ldots \\
1909 \ldots \\
1909 \\
1910 \ldots\end{array}$ & $\begin{array}{r}300 \\
204 \\
14\end{array}$ & 24 & $\begin{array}{r}15.72 \\
28.00 \\
4.00 \\
1.65\end{array}$ & $\begin{array}{r}3 \\
7 \\
62\end{array}$ & \begin{tabular}{|l}
-1 \\
\hdashline
\end{tabular} \\
\hline $\begin{array}{l}1911 \ldots \\
1911 . \ldots \\
1915 \ldots \\
1916 \ldots \\
1917 \ldots\end{array}$ & $\begin{array}{r}30 \\
30 \\
\\
\end{array}$ & $\begin{array}{r}2 \\
12 \\
6 \\
14\end{array}$ & $\begin{array}{r}5.15 \\
1.25 \\
15.71 \\
8.93 \\
12.36\end{array}$ & $\begin{array}{r}77 \\
4 \\
64 \\
20 \\
33\end{array}$ & $\begin{array}{r}258 \\
-280 \\
-\cdots\end{array}$ \\
\hline Total & 1,812 & 58 & 783.17 & 3,802 & 538 \\
\hline
\end{tabular}

1 Compiled by U.S. Bureau of Mines. Published by permission.

The Whiting vein trends about N. $88^{\circ} \mathrm{W}$. and dips steeply south. Two hundred feet east of the Whiting shaft the vein is joined from the north by a vein that strikes about $\mathrm{N} .70^{\circ} \mathrm{E}$. and dips $70^{\circ} \mathrm{SE}$., which may be the Mount Lincoln vein. East of the Grand Central shaft several northeastward-trending veins, including the Butler and Grand Old Man(?), seem to join with the Whiting vein (pl. 1).

\section{UPPER RUSSELL GULCH AREA}

The upper Russell Gulch area includes the mines in or near the village of Russell Gulch, south of State Highway 279 and west of the head of Willis Gulch. Several mines are large and have been substantial producers; the Old Town, Iron, and Pewabic have each produced more than $\$ 1$ million.

Most of the area is on the southeast limb of the Central City anticline (fig. 4). The axis of a minor open syncline, the Russell Gulch syncline, is east of the Pewabic mine. The contact between microclinebearing gneiss, which crops out along the axis of the Central City anticline, and overlying interlayered biotite gneisses trends east-northeast through the area, 
generally following the south side of Russell Gulch. At least one layer of biotite-quartz-plagioclase gneiss, an estimated 250 feet thick, occurs within the microcline-bearing gneiss layer; this layer of biotite gneiss probably is the equivalent of the layer that occurs in the microcline-bearing gneiss under Quartz Hill (fig. 17).

The veins are mainly pyrite veins, most of which contain moderate quantities of copper minerals (type $B)$. Sparse amounts of pitchblende occurs locally along a few veins. In the mines south of Russell Gulch much of the gold ore, particularly the higher grade material, occurs as so-called talc ore, an argillized rock probably of supergene origin, which is enriched in gold.

Most of the ore shoots plunge nearly vertical or steeply to the west. They are localized by deflections in strike of the veins on the steep parts of the veins, and on or near vein junctions or intersections. The veins are markedly stronger in the microcline-bearing gneiss than in the biotite gneisses, and ore shoots are rarely found in the latter.

\section{BANGOR MINE (B-VI-80)}

Location.-On south side of upper Russell Gulch, about 730 feet southwest of the Old Town mine.

Development.-Shaft is inclined $50^{\circ} \mathrm{NW}$. (vertical depth 163 feet), with levels at vertical depths of 74, 105, 149, and 163 feet. Crosscut north from 163 level breaks into a stope in Becky Sharp mine.

Veins.-Bangor (a hanging-wall branch of the Iron vein) : Strike, N. $40^{\circ}$ E., dip, $50^{\circ} \mathrm{NW}$.

Wallrock.-Biotite-quartz-plagioclase-gneiss and microcline-bearing gneiss.

Ore and sulfide minerals.-Pyrite, gold, and silver with some chalcopyrite, galena, and sphalerite.

Gangue minerals.-Quartz.

Ore shoots.-One ore shoot occurs along the BangorIron vein intersection; it probably plunges west at a moderate angle beneath the Federal mine.

\section{BECKY SHARP MINE (B-VI-26)}

The Becky Sharp mine, on the south side of upper Russell Gulch about 800 feet west of the Iron mine, was inaccessible in 1954 . The mine reportedly produced ${ }^{20} 3,142,000$ ounces of gold, 7,928 ounces of silver, 76,795 pounds of copper, 877 pounds of lead, and 1,667 pounds of zinc between 1919 and 1954; much of the production from the mine has been combined with other more prominent mines in the area (especially the Old Town and Lillian).

\footnotetext{
${ }^{20}$ Billingsley, Paul, 1927, Report on Pewabic mine and associated properties, 25 p., report in the Library of the Colorado School of Mines, Golden, Colo.
}

The collar of the Becky Sharp shaft is on a vein, probably the Pewabic, that strikes east-northeast and dips north. This vein is followed to a depth of 125 feet, and a drift is turned into the east wall. The original vein is followed for about 70 feet, at which point the drift is turned onto an eastward-trending vein, probably the Iron. The structural relations of these two veins are not known, but probably the Pewabic vein is a branch from the Iron vein. A large stope has been extracted to the west of the shaft and beneath this level (fig. 47) apparently on the Pewabic vein; Billingsley notes that a stope on the Pewabic vein is in this area. A crosscut from the Bangor mine breaks into this stope.

An underground shaft with 2 branches has been sunk about 15 feet east of the Becky Sharp shaft. The southern branch connects to the 300 level of the Iron mine, and, at least at the Iron level, is on the Pewabic vein. These workings, as shown on figure 46, are only approximately correct, because several maps used in the compilation did not tie together accurately. The north branch of the shaft is a crosscut, and cuts a northeastward-trending vein at a depth of 246 feet. This vein, probably the Old Town, is followed for a considerable distance to the northeast and a short distance to the southwest. A west-northwestward trending vein is developed by a cross drift from the southwest breast of the Old Town (?) drift. The best ore in the mine was found on this level about 75 feet east of the shaft. The ore was the type referred to by the miners as "talc," 3 to 6 feet wide, that averaged 4 ounces of gold to the ton, 8 ounces of silver to the ton, and 2.85 percent copper. One other stope along the Bangor-Iron vein intersection, between the 300 and 400 levels of the Iron-Becky Sharp mine, is present in the mine.

\section{EAST PEWABIC MINE (C-VI-16)}

Location.-South side of Russell Gulch, about 790 feet S. $83^{\circ}$ E. from the Old Town mine.

Production.-Paul Billingsley ${ }^{21}$ reports that the mine yielded ores valued at about $\$ 35,000$ prior to 1927 .

Development.-A 730-foot shaft, inclined to north; levels at inclined distances of about 200,300, 400, 500, $600,700,800$, and 900 feet. The 200 level connects to the $2 \mathrm{~d}$ level of the Pewabic mine and the 200 level of the Richardson mine. Stopes are shown on figure 52.

Veins.-Pewabic: Strike, about east-west; dip, steep. A vein that strikes about N. $80^{\circ}$ W. was cut on the 200 level, 80 feet north of the Pewabic vein.

${ }^{21}$ Billingsley, Paul, 1927, Report on Pewabic mine and related properties. Report in the library of the Colorado School of Mines. Golden, Colo. 
Wallrock. - Microcline-bearing gneiss; biotite quartz-plagioclase gneiss.

Ore and sulfide minerals.-Pyrite, chalcopyrite, sparse amount of tennantite.

Gangue minerals.-Quartz.

\section{FEDERAL MINE (B-VI-24)}

The Federal mine is on the south side of upper Russell Gulch, about 780 feet S: $70^{\circ} \mathrm{W}$. from the Old Town mine. The known production from the mine is given in table 43 ; this ore if produced today would have a value of about $\$ 180,000$. This mine is opened by a shaft inclined to the north that connects to four levels (figs. 59 and 66). A crosscut south from the 4.th level of the Old Town mine connects with the Federal shaft a short distance above the Federal 4th level. As the workings were all inaccessible in 1954, the following data are largely taken from the description by Bastin and Hill (1917, p. 251).

The Federal vein strikes nearly east, dips $35^{\circ}-65^{\circ}$ N., and probably is a hanging-wall branch of the Pewabic vein. The Federal vein consists of 3 inches to 2 feet of altered microcline-bearing gneiss that contains disseminated pyrite and is traversed by irregular thin veinlets of pyrite; chalcopyrite, and tennantite (Bastin and Fill, 1917, p. 251). It is probable that much of this ore is talc ore (R. R. Hinckley, oral communication). Some galena and sphalerite must also

\begin{tabular}{|c|c|c|c|c|c|c|c|}
\hline Year & $\begin{array}{l}\text { Crude } \\
\text { ore } \\
\text { shinped } \\
\text { (tons) }\end{array}$ & $\begin{array}{l}\text { Concen- } \\
\text { trates } \\
\text { shinped } \\
\text { (tons) }\end{array}$ & $\begin{array}{c}\text { Cold } \\
\text { (ounces) }\end{array}$ & $\begin{array}{c}\text { Silver } \\
\text { (ounces) }\end{array}$ & $\begin{array}{c}\text { Copper } \\
\text { (pounds) }\end{array}$ & $\begin{array}{c}\text { Lead } \\
\text { (pounds) }\end{array}$ & $\begin{array}{c}\text { Zinc } \\
\text { (pounds) }\end{array}$ \\
\hline & 10 & & $\begin{array}{r}\text { 5. } 27 \\
279.64\end{array}$ & 453 & & & \\
\hline & $\begin{array}{r}59 \\
189 \\
138\end{array}$ & $\begin{array}{r}17 \\
77 \\
250\end{array}$ & $\begin{array}{r}56.05 \\
286.19 \\
541.65\end{array}$ & $\begin{array}{r}225 \\
1,088 \\
2,060\end{array}$ & $\begin{array}{r}1,514 \\
13,777 \\
25,970\end{array}$ & & \\
\hline & 13 & $\begin{array}{l}69 \\
57\end{array}$ & $\begin{array}{l}89.73 \\
20,55\end{array}$ & $\begin{array}{r}1,283 \\
812\end{array}$ & $\begin{array}{l}5,036 \\
4,028\end{array}$ & $\begin{array}{l}2,578 \\
6,040\end{array}$ & \\
\hline 4. & $\begin{array}{r}54 \\
1\end{array}$ & 10 & $\begin{array}{r}16.29 \\
.85\end{array}$ & $\begin{array}{r}80 \\
5\end{array}$ & 288 & & \\
\hline ). & 11 & $\cdots$ & 4. 24 & 317 & 830 & $\cdots$ & $\cdots$ \\
\hline & 18 & & 4. 49 & 288 & 761 & & \\
\hline 7. & $\begin{array}{r}2,090^{\circ} \\
795 \\
18\end{array}$ & 2 & $\begin{array}{r}1,764.01 \\
708.22 \\
17.82\end{array}$ & $\begin{array}{r}2,975 \\
1,266 \\
35\end{array}$ & 348 & & 87 \\
\hline & $\begin{array}{r}214 \\
92\end{array}$ & 7 & 217.75 & 656 & 204 & 23 & 250 \\
\hline & 73 & 28 & 185.00 & 265 & 3,039 & & 256 \\
\hline & & & & & & & \\
\hline & 3,775 & 555 & $4,308.82$ & 11,987 & 55.897 & 10,836 & 593 \\
\hline
\end{tabular}

1 Complled by U.S. Bureau of Mines. Published by permission.

be present in the ore. The best ore contained abundant copper minerals. The metal content of smelting ore, shipped between 1907 and 1910, averaged about 0.80 ounce of gold per ton and 4.7 ounces of silver per ton; the maximum copper assay was 2.65 percent.

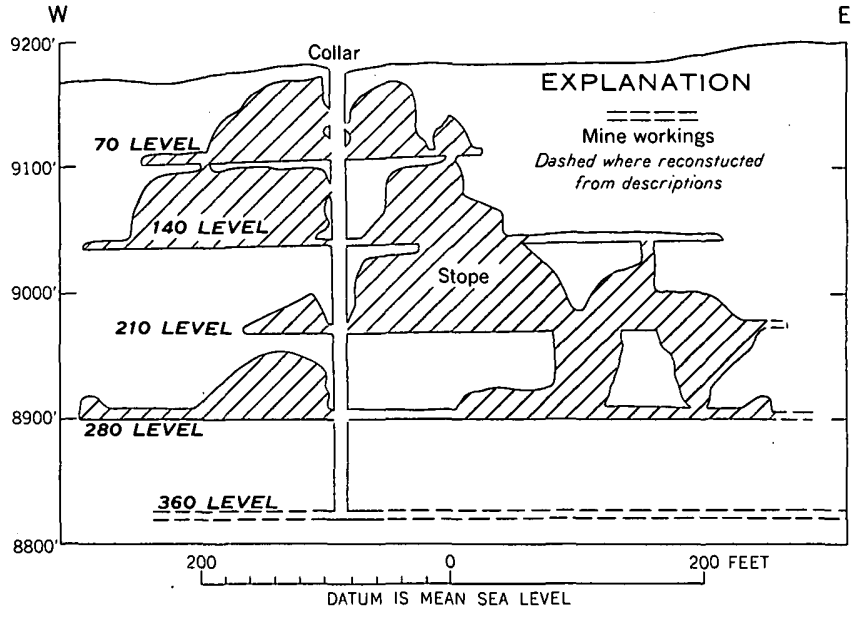

Figure 43.-Longitudinal projection in plane of vein, Forfar mine.

\section{FORFAR MINE (C-VI-17)}

The Forfar mine, on the south side of upper Russell Gulch, is opened by a 360 -foot inclined shaft that connects to levels at depths of 70,140,210,280, and 360 feet (fig. 43). Stopes are on the upper four levels (fig. 43); some stoping has probably been done also on the 360 level, but the extent is not known. The workings were inaccessible in 1954. The known production from the Forfar mine is given below. The mine is reported to have produced about $\$ 30,000$ prior to 1899 (Callbreath, 1899).

\begin{tabular}{|c|c|c|c|c|c|c|c|}
\hline Year & $\begin{array}{l}\text { Crude } \\
\text { ore } \\
\text { shipped } \\
\text { (tons) }\end{array}$ & $\begin{array}{c}\text { Concen- } \\
\text { trates } \\
\text { shipped } \\
\text { (tons) }\end{array}$ & $\begin{array}{c}\text { Gold } \\
\text { (ounces) }\end{array}$ & $\begin{array}{l}\text { Silver } \\
\text { (ounces) }\end{array}$ & $\begin{array}{l}\text { Copper } \\
\text { (pounds) }\end{array}$ & $\begin{array}{c}\text { Lead } \\
\text { (pounds) }\end{array}$ & $\begin{array}{c}\text { Zinc } \\
\text { (pounds) }\end{array}$ \\
\hline & 243 & 15 & \multirow{5}{*}{$\begin{array}{r}70.40 \\
6.54 \\
51.42 \\
13.33 \\
10.60 \\
16.62 \\
61.47 \\
3.92\end{array}$} & \multirow{5}{*}{$\begin{array}{r}384 \\
46 \\
302 \\
85 \\
155 \\
121 \\
449 \\
22\end{array}$} & \multirow{2}{*}{$\begin{array}{l}385 \\
314 \\
430\end{array}$} & & \multirow{2}{*}{$\cdots$} \\
\hline$\cdots$ & $\begin{array}{l}19 \\
52\end{array}$ & & & & & $\ldots$ & \\
\hline & 13 & 3 & & & & & (n........... \\
\hline$\ldots$ & 33 & 7 & & & 460 & 323 & $\cdots 5$ \\
\hline $6 \ldots$ & $\begin{array}{r}280 \\
37\end{array}$ & 1 & & & - & | & $\mid$ \\
\hline Total.. & 709 & 25 & 234. 30 & 1,564 & 1,776 & 1,154 & 552 \\
\hline
\end{tabular}

The Forfar vein, which has been developed underground along strike for about 700 feet, probably is the eastward extension of the Pewabic vein. The western part of the vein strikes east, whereas the eastern part strikes about $\mathrm{N} .75^{\circ} \mathrm{E}$. The vein dips steeply north, averages about 2 feet in width, and consists largely of quartz and pyrite, but it also contains chalcopyrite, galena, and sphalerite. Reportedly, 709 tons of smelting ore shipped between 1909 and 1936 averaged 0.45 ounce of gold and 2 ounces of silver per ton. The average value of 5,000 tons of ore from the stopes between the 210 and 70 levels was $\$ 33.50$ per ton. ${ }^{22}$

\footnotetext{
${ }^{22}$ Huntington, F. I., 1934. The Forfar mine patent survey No. 860 3 p., report on file in the Denver Public Library, Denver, Colo.
} 


\section{GOLDEN OPPORTUNITY TUNNEL (B-VI-82)}

The Golden Opportunity tunnel, south of Russell Gulch, is a 1,034-foot crosscut adit that bears southward (fig. 44). It cuts several minor veins, but so far as known has not yielded appreciable quantities of ore.

The tunnel intersects interlayered biotite gneisses that contain a few small bodies of pegmatite and which are cut by a 10 -foot quartz bostonite dike. The Precambrian gneisses are folded into several small upright anticlines and synclines that plunge northeastward. A major synclinal axis probably is present near the face of the adit.

Several steep veins that trend west-northwest, east, and northeast are cut on the tunnel, but aside from the Mars and Bloomfield(?) veins, none of the veins appear to have any economic significance.

The Mars vein and a footwall split thought to be the Bloomfield vein is cut at 330 feet in the tunnel. The Mars vein strikes N. $40^{\circ}-50^{\circ}$ E., dips $76^{\circ} \mathrm{NW}$., and consists of 18 inches of quartz, pyrite, and sparse sphalerite, galena, and chalcopyrite. The Bloomfield(?) vein splits from the footwall of the Mars vein. It strikes $\mathrm{N} .70^{\circ}-80^{\circ} \mathrm{E}$., dips $43^{\circ} \mathrm{NW}$., and like the Mars vein consists largely of quartz and pyrite. A wide zone of highly silicified wallrock occurs on the footwall of the vein.

The Mars vein is stoped west of the crosscut adit, where it is deflected from a strike of N. $40^{\circ}$ E. to N. $50^{\circ}$ E. and junction with the Bloomfield(?) vein.

\section{GOPHER VEIN}

The Gopher vein, east of Russell Gulch village, has been developed by the Gopher (C-V-12) mine. The Holland (C-V-11) mine, 1,200 feet east of the Gopher shaft, is located at the junction of the Gopher vein and an eastward-trending vein (pl. 1).

The Gopher vein can be traced on the surface for about 2,000 feet. It dips nearly vertical and trends eastward; near the Gopher shaft the vein strikes N. $70^{\circ}$ E., but near the Holland shaft it strikes N. $80^{\circ} \mathrm{W}$. Production from the vein is not known but is probably small.

The Gopher mine workings consist of a 120-foot shaft and a short drift to the east at a depth of 100 feet. The Holland mine consists of a nearly vertical 210 -foot shaft and short levels.

Two shipments of smelting ore from the Holland mine, sent to the Idaho Springs Sampling Works in 1934 gave the following results:
Sampling-uvorks assays of smelting ore from Holland mine, 1994

\begin{tabular}{r|r|r}
\hline Tons & \multicolumn{1}{|c|}{ Gold $^{2}$} & \multicolumn{1}{|c|}{ Silver $^{2}$} \\
\hline 2. 59 & $\begin{array}{r}0.84 \\
.72\end{array}$ & $\begin{array}{r}0.96 \\
1.48\end{array}$ \\
\hline 1 99 &
\end{tabular}

1 Data on production and ore tenor furnished by the Id
Works. Published by permission.

HALL MINE (C-VI-6)

The Hall mine, on the north side of upper Russell Gulch, is opened by an inclined shaft, 260 feet deep (Bastin and Hill, 1917, p. 258), that connects with levels at inclined depths of 50, 100, and 200 feet. These workings were inaccessible in 1954. The known production from the Hall mine is given in table 45; this ore if produced today would be worth about $\$ 42,00 \mathrm{C}$

The Hall vein strikes about N. $55^{\circ}$ E., dips steeply northwest, and possibly is the northeastward extension of the Incidental vein. A vein that strikes farther eastward than the Hall vein was developed on the 200 level of the mine. The ore on the dump of the mine consists entirely of quartz and pyrite, but moderate quantities of copper minerals occur in some of the ore. The smelting ore that was shipped was high in grade and probably was hand cobbed before shipment. The 503 tons of smelting ore shipped from the mine between 1902 and 1932 averaged 1.84 ounces of gold per ton, 6.27 ounces of silver per ton, and 2.4 percent copper.

TABLE 45.-Ore produced from the Hall mine, 1902-54 ${ }^{1}$

\begin{tabular}{|c|c|c|c|c|c|}
\hline Year & $\begin{array}{c}\text { Crude ore } \\
\text { shipped } \\
\text { (tons) }\end{array}$ & $\begin{array}{l}\text { Concen- } \\
\text { trates } \\
\text { shipped } \\
\text { (tons) }\end{array}$ & $\begin{array}{c}\text { Gold } \\
\text { (ounces) }\end{array}$ & $\begin{array}{c}\text { Silver } \\
\text { (ounces) }\end{array}$ & $\begin{array}{l}\text { Copper } \\
\text { (pounds) }\end{array}$ \\
\hline $\begin{array}{l}1902 \\
1904 \\
1906 \\
1907\end{array}$ & $\begin{array}{r}300 \\
50 \\
40 \\
5\end{array}$ & - & $\begin{array}{r}610.90 \\
150.00 \\
80.01 \\
10.01\end{array}$ & $\begin{array}{r}2,127 \\
400 \\
161 \\
21\end{array}$ & $\begin{array}{r}12,000 \\
4,500 \\
2,401\end{array}$ \\
\hline $\begin{array}{l}1908 \\
1909 \\
1910\end{array}$ & $\begin{array}{r}4 \\
41 \\
47 \\
8\end{array}$ & $\begin{array}{r}8 \\
21 \\
4 \\
1\end{array}$ & $\begin{array}{r}12.30 \\
53.18 \\
17.59 \\
2.88\end{array}$ & $\begin{array}{r}104 \\
265 \\
89 \\
9\end{array}$ & $\begin{array}{r}773 \\
1,223 \\
363\end{array}$ \\
\hline $\begin{array}{l}1912 \\
1914 \\
1916 \\
1932\end{array}$ & $\begin{array}{l}1 \\
1 \\
4 \\
1 \\
1\end{array}$ & 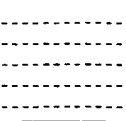 & $\begin{array}{r}.26 \\
.45 \\
4.56 \\
.09 \\
2.94\end{array}$ & $\begin{array}{r}5 \\
4 \\
18 \\
73 \\
4\end{array}$ & $\begin{array}{r}\mathbf{3 9} \\
211 \\
\end{array}$ \\
\hline Total & 503 & 34 & 945.17 & $\overline{3,280}$ & 21,510 \\
\hline
\end{tabular}

Sampling-works assays of some ore shipped in 1910 are given below :

Sampling-works assays of some ore from the Hall mine ${ }^{1}$

\begin{tabular}{|c|c|c|c|}
\hline Ore (pounds) & Gold ${ }^{2}$ & Silver ${ }^{2}$ & $\begin{array}{c}\text { Copper } \\
\text { (percent) }\end{array}$ \\
\hline $\begin{array}{l}7,223 \ldots \\
463 \\
6,441 \\
3,674 \\
591 \\
462\end{array}$ & $\begin{array}{r}1.69 \\
1.16 \\
1.66 \\
.44 \\
1.14 \\
.76\end{array}$ & $\begin{array}{r}\text { 11. } 56 \\
6.80 \\
\text { 8. } 60 \\
\text { 2. } 90 \\
\text { 2. } 60 \\
\text { 7. } 30\end{array}$ & $\begin{array}{r}9.20 \\
3 . \overline{55} \\
\begin{array}{r}2.00 \\
4.00\end{array}\end{array}$ \\
\hline
\end{tabular}




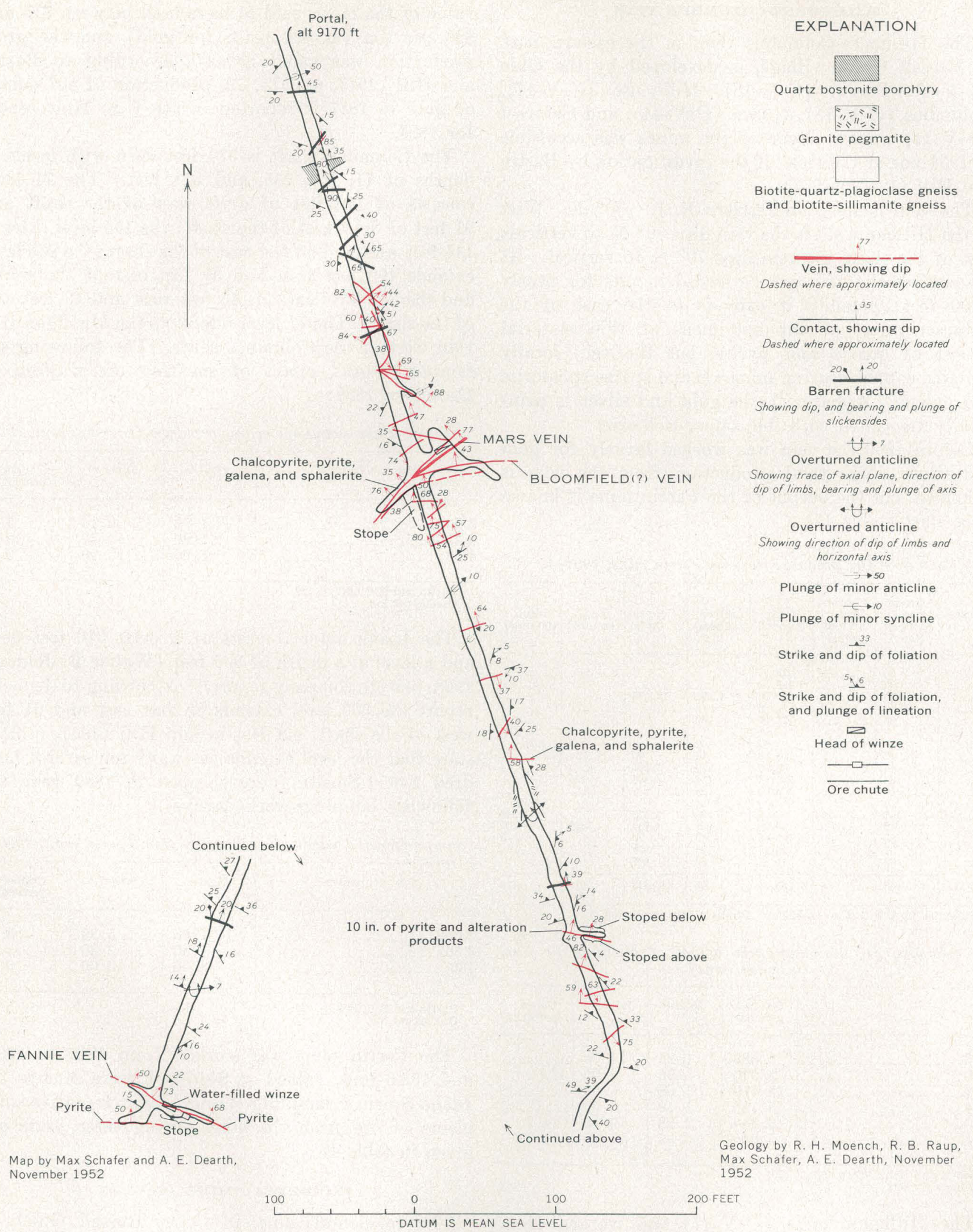

FIguRe 44.-Geologic map of the Golden Opportunity tunnel. 


\section{HILLFOU SE-COLUMBUS VEIN}

The Hillhouse-Columbus vein, in the eastern part of Russell Gulch village, is developed by the Ohio (B-V-1), Perrin (C-V-18), Hillhouse (C-V-17), Columbus (C-V-15), Ipavia (C-V-14), and Cataract $(\mathrm{D}-\mathrm{V}-11)$ mines. None of the mines was accessible in 1954 nor at the time of the investigation by Bastin and Hill (1917, p. 257).

The vein is steep and strikes $\mathrm{N} .70^{\circ}-80^{\circ} \mathrm{E}$. West of the Hillhouse shaft the vein dips $80^{\circ} \mathrm{N}$. to vertical; east of the shaft the vein dips $70^{\circ} \mathrm{S}$. to vertical. At the surface the vein can be traced in pits for nearly 4,000 feet; possibly it extends to the east of the Cataract mine. Dump specimens of vein material consist of quartz and pyrite, but the vein locally contains copper-bearing minerals and sparse sphalerite and galena. Apparently the gold and silver is principally associated with the copper-rich ores.

Before 1900 the vein was worked largely for gold and silver. The total production from the vein is unknown, but the output of the Perrin mine is known since 1902 (table 46).

TABLE 46.-Ore produced from the Perrin mine, 1902-54.1

\begin{tabular}{|c|c|c|c|c|c|c|c|}
\hline Year & $\begin{array}{c}\text { Crude } \\
\text { ore } \\
\text { shipped } \\
\text { (tons) }\end{array}$ & $\begin{array}{l}\text { Concen- } \\
\text { trates } \\
\text { shipped } \\
\text { (tons) }\end{array}$ & $\begin{array}{c}\text { Gold } \\
\text { (ounces) }\end{array}$ & $\begin{array}{c}\text { Silver } \\
\text { (ounces) }\end{array}$ & $\begin{array}{c}\text { Copper } \\
\text { (pounds) }\end{array}$ & $\begin{array}{l}\text { Lead } \\
\text { (pounds) }\end{array}$ & $\begin{array}{c}\text { Zinc } \\
\text { (pounds) }\end{array}$ \\
\hline $\begin{array}{l}1904 \\
1905\end{array}$ & 60 & & $\begin{array}{r}\text { 18. } 77 \\
\text {.33 }\end{array}$ & & & & \\
\hline 1906 & $\begin{array}{r}02 \\
400\end{array}$ & & $\begin{array}{r}429.90 \\
4296\end{array}$ & 1,491 & 16,500 & & \\
\hline 1900 & 24 & & $\begin{array}{l}1.00 \\
11.06\end{array}$ & 260 & 657 & & \\
\hline 1910. & $\frac{1}{2}$ & & $\begin{array}{r}.52 \\
8.89\end{array}$ & $\underset{14}{2}$ & 90 & & \\
\hline & $\begin{array}{r}39 \\
123 .\end{array}$ & & $\begin{array}{r}36.09 \\
231.09\end{array}$ & $\begin{array}{l}179 \\
456\end{array}$ & $\begin{array}{r}7,551 \\
4,403\end{array}$ & 195 & \\
\hline 1833 & $\begin{array}{l}1250 \\
150\end{array}$ & & 105.99 & . & & & \\
\hline $1934 \ldots \ldots$ & $\begin{array}{r}147 \\
42\end{array}$ & $\begin{array}{r}27 \\
9\end{array}$ & $\begin{array}{l}99.78 \\
60.96\end{array}$ & $\begin{array}{l}258 \\
222\end{array}$ & $\begin{array}{l}5,573 \\
4,184\end{array}$ & 332 & $\begin{array}{l}243 \\
170\end{array}$ \\
\hline & 23 & & 9.08 & 32 & $\begin{array}{l}4,104 \\
70\end{array}$ & & \\
\hline 1938. & $\begin{array}{l}37 \\
33\end{array}$ & $\ldots$ & $\begin{array}{l}26.47 \\
11.87\end{array}$ & $\begin{array}{l}96 \\
96\end{array}$ & $\begin{array}{l}978 \\
407\end{array}$ & & \\
\hline Total_. & 1,143 & 36 & $1,236.04$ & 3,096 & 40,413 & $\overline{527}$ & 418 \\
\hline
\end{tabular}

1 Complled by U.S. Bureau of Mines. Published by permission.

The following are sampling-works assays of smelting ore from Hillhouse vein:

\begin{tabular}{|c|c|c|c|c|}
\hline Year & $\begin{array}{l}\text { Ore (net } \\
\text { pounds) }\end{array}$ & Gold 2 & Silver ${ }^{2}$ & $\begin{array}{c}\text { Copper } \\
\text { (percent) }\end{array}$ \\
\hline $\begin{array}{l}1903 \\
1903 \\
1903 \\
1906 \\
1907\end{array}$ & $\begin{array}{r}5,588 \\
5,910 \\
16,110 \\
5,180 \\
6,944 \\
5,645\end{array}$ & $\begin{array}{l}\text { 1. } 25 \\
.95 \\
\text { 1. } 08 \\
\text { 1. } 10 \\
\text { 2. } 28 \\
\text { 5. } 35\end{array}$ & $\begin{array}{r}14.70 \\
9.05 \\
5.00 \\
\text { 8. } 00 \\
19.40 \\
17.80\end{array}$ & $\begin{array}{r}4.25 \\
13.00\end{array}$ \\
\hline
\end{tabular}

I Bastin and Hill, 1917, p. 257

The Hillhouse mine (C-V-17) was worked from 2 shafts, 200 and 600 feet deep, with levels every 100 feet (Bastin and Hill, 1917, p. 257). The average value of the ore is said to have been between $\$ 15$ and $\$ 20$ per ton (at $\$ 20$ price for gold) and the gross production was about $\$ 50,000$, according to Bastin and Hill (1917, p. 257). A production of 507 ounces of gold in 1887 is reported in the U.S. Mint report for 1888 .

The Columbus shaft is 370 feet deep with levels at depths of $71,155,235$, and 311 feet. The 71 level consists of 110 feet of drift west of the shaft and 81 feet of drift east of the shaft; the 155 level extends 144 feet west and 50 feet east of the shaft; the 235 level extends 192 feet west and 39 feet east of the shaft; and the 311 level extends 43 feet west and 18 feet east of the shaft. The 71 level intersects the Michigan Boy vein west of the Columbus shaft. The following are sampling-works assays of smelting ore shipped in December, 1888:

Sampling-works assays of smelting ores from Columbus vein, $1888^{1}$

\begin{tabular}{|c|c|c|c|}
\hline Ore (net pounds) & Gold 2 & Silver 2 & $\begin{array}{c}\text { Copper } \\
\text { (percent) }\end{array}$ \\
\hline $\begin{array}{l}5,603 \\
3,455 \\
4,535\end{array}$ & $\begin{array}{l}\text { 1. } 70 \\
\text { 1. } 90 \\
1.60\end{array}$ & $\begin{array}{r}9.10 \\
10.30 \\
10.90\end{array}$ & $\begin{array}{l}\text { 5. } 30 \\
9.50 \\
6.00\end{array}$ \\
\hline
\end{tabular}

${ }^{1}$ Bastin and Hill, 1917, p. 257.

Ounces per ton.

The Ipavia mine consists of a shaft 316 feet deep and a level at a depth of 300 feet (Walter B. Jenners, 1908 , private company report). According to Jenners' report the 300 level extends 85 feet east and 91 feet west of the shaft, but Bastin and Hill (1917, p. 257) state that the level extends eastward for several hundred feet. Smelting ore shipped in 1889 gave the following sampling-works assays:

Sampling-works assays of smelting ore from Ipavia shaft, 1889

\begin{tabular}{r|r|r|r}
\hline Ore (net pounds) & \multicolumn{1}{|c|}{ Gold 2} & \multicolumn{1}{|c|}{ Silver 2 } & \multicolumn{1}{c}{$\begin{array}{c}\text { Copper } \\
\text { (percent) }\end{array}$} \\
\hline 2,058 & 1.05 & $\begin{array}{r}5.30 \\
2.20\end{array}$ & 3.00 \\
3367 & $\begin{array}{r}.80 \\
13.00\end{array}$ & $\mathbf{9 . 5 0}$ \\
\hline
\end{tabular}

1 Bastin and Hill, 1917, p. 257. ${ }_{2}$ Ounces per ton.

The Perrin mine was worked from 1929 to 1936 , and 135.6 tons, valued at $\$ 4,073.00$, were sent to the Idaho Spirngs Sampling Works. Representative shipments of ore from the mine during these years are given in table 47 .

\section{INCIDENTAL MINE (C-VI-9)}

The Incidental mine, in upper Russell Gulch, is opened by an inclined shaft having a vertical depth of 230 feet, which connects with levels at depths of 
TABLE 47.-Sampling-works assays of crude ore and concentrates from Perrin mine, $1929-96{ }^{1}$,

\begin{tabular}{|c|c|c|c|c|c|c|}
\hline Year & Tons & Gold 2 & S!lver 2 & $\underset{\text { (percent) }}{\text { Lead }}$ & $\begin{array}{c}\text { Copper } \\
\text { (percent) }\end{array}$ & $\begin{array}{c}\text { Zinc } \\
\text { (percent) }\end{array}$ \\
\hline 20. & 1. & ก & 35 & & 32 & \\
\hline 1030 & $\begin{array}{r}.84 \\
7.24 \\
13.06\end{array}$ & $\begin{array}{l}2.70 \\
.64 \\
.94\end{array}$ & $\begin{array}{l}8.42 \\
6.55 \\
4.85\end{array}$ & & $\begin{array}{l}1.30 \\
3.25 \\
1.75\end{array}$ & - \\
\hline 34. & $\begin{array}{r}1.82 \\
86.85\end{array}$ & $\begin{array}{l}3.26 \\
2.21\end{array}$ & $\begin{array}{r}15.78 \\
6.25\end{array}$ & & $\begin{array}{r}12.62 \\
6.40\end{array}$ & 1.65 \\
\hline 35. & $\begin{array}{r}8.99 \\
87.92 \\
2.34\end{array}$ & $\begin{array}{l}2.42 \\
2.26 \\
2.95\end{array}$ & $\begin{array}{r}11.00 \\
9.15 \\
9.85\end{array}$ & $\begin{array}{l}0.25 \\
20\end{array}$ & $\begin{array}{r}9.50 \\
11.00 \\
7.60\end{array}$ & \\
\hline 1836 & $\begin{array}{r}.50 \\
10.05\end{array}$ & 2.3 & $\begin{array}{l}8.97 \\
1.30\end{array}$ & - & 7.00 & \\
\hline
\end{tabular}

1 Furnished by the Idaho Springs Sampllng Works. Publlshed by permisston. :Ounces por ton.

96, 173, and 230 feet (fig. 45). All these workings were inaccessible in 1954. The known production from the Incidental mine is given in table 48 .

The mine develops two main veins, the Incidental and the Old Town(?). A footwall split from the Incidental vein also is developed by a short drift on the 230 level. The Incidental yein trends about N. $45^{\circ}$ E. and dips $70^{\circ} \mathrm{NW}$. It is principally worked on the 96 and 173 levels. The Old Town (?) vein is developed by crosscuts and drifts that are north of the Incidental workings.

Ore-bearing material on the dump of the mine in 1952 consisted of quartz, pyrite, and some chalcopyrite. The production record of the mine (table 48) shows that small quantities of galena were shipped. The metal content of 26 tons of ore shipped from the mine between 1922 and 1925 was gold, 0.63 to 1.37 (average 1.20 ) ounces per ton; silver, 5 to 6.20 (average 6) ounces per ton; and copper, 1.23 to 4.20 percent. (Data on tenor furnished by the Idaho Springs Sampling Works. Published by permission.)

TABLE 48.-Ore produced from the Incidental mine, 1902-54 ${ }^{1}$

\begin{tabular}{|c|c|c|c|c|c|c|}
\hline Year & $\begin{array}{c}\text { Crude ore } \\
\text { shlpped } \\
\text { (tons) }\end{array}$ & $\begin{array}{l}\text { Concen- } \\
\text { trates } \\
\text { shipped } \\
\text { (tons) }\end{array}$ & $\begin{array}{c}\text { Gold } \\
\text { (ounces) }\end{array}$ & $\begin{array}{c}\text { Silver } \\
\text { (ounces) }\end{array}$ & $\mid \begin{array}{c}\text { Copper } \\
\text { (pounds) }\end{array}$ & $\underset{\text { (pounds) }}{\text { Lead }}$ \\
\hline $\begin{array}{l}1915 \ldots \\
1916 \ldots \\
1917 . \\
1919 \ldots \\
1020 \ldots\end{array}$ & \begin{tabular}{c}
3 \\
$\cdots 42$ \\
\hdashline
\end{tabular} & $\begin{array}{c}5 \\
7\end{array}$ & $\begin{array}{r}10.21 \\
8.14 \\
.98 \\
2.70 \\
26.20\end{array}$ & $\begin{array}{r}3 \\
26 \\
8 \\
18 \\
152\end{array}$ & $\begin{array}{l}185 \\
144 \\
131 \\
880\end{array}$ & $\mid$\begin{tabular}{cc}
-1 \\
\hdashline $\mathbf{3 6 3}$
\end{tabular} \\
\hline $\begin{array}{l}1822 \\
1824 \\
1925 \\
1027 \\
1033 \\
1036\end{array}$ & $\begin{array}{r}30 \\
22 \\
1 \\
404 \\
5 \\
70\end{array}$ & (1) & $\begin{array}{r}44.42 \\
28.52 \\
.65 \\
184.00 \\
4.20 \\
23.34\end{array}$ & $\begin{array}{r}101 \\
134 \\
6 \\
548 \\
\hdashline 24\end{array}$ & $\begin{array}{r}1,173 \\
994 \\
107 \\
1,286\end{array}$ & 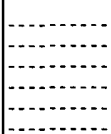 \\
\hline Total & $577+$ & 83 & 333. 36 & 1,020 & 4,900 & 363 \\
\hline
\end{tabular}

1 Complled by U.S. Bureau of Mines. Published by permission.

IRON MINE (C-VI-19)

The Iron mine, on the south side of Russell Gulch, about 430 feet southeast of the Old Town mine, is one of the most valuable properties in the Central

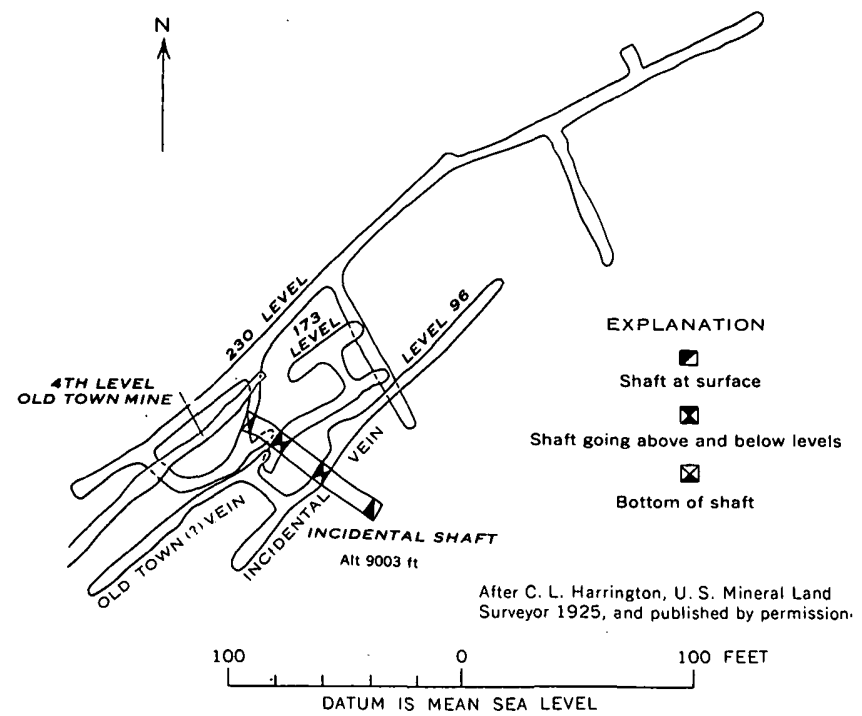

FrgURE 45.-Composite map of the Incidental mine.

City district. It is reported to have yielded about $\$ 1$ million worth of ore prior to 1904 . The known production from the Iron mine since 1902 is given in table 49 ; this ore if produced today would have a value of about $\$ 1,191,500$.

The property is opened by a nearly vertical shaft with levels at inclined depths of $120, .250,300,400,500$, 600 , and 700 feet (figs. 46, 47). The 300 and 400 levels connect with the Richardson shaft, and the

TABLE 49.-Ore produced from the Iron mine, 1902-54 ${ }^{1}$

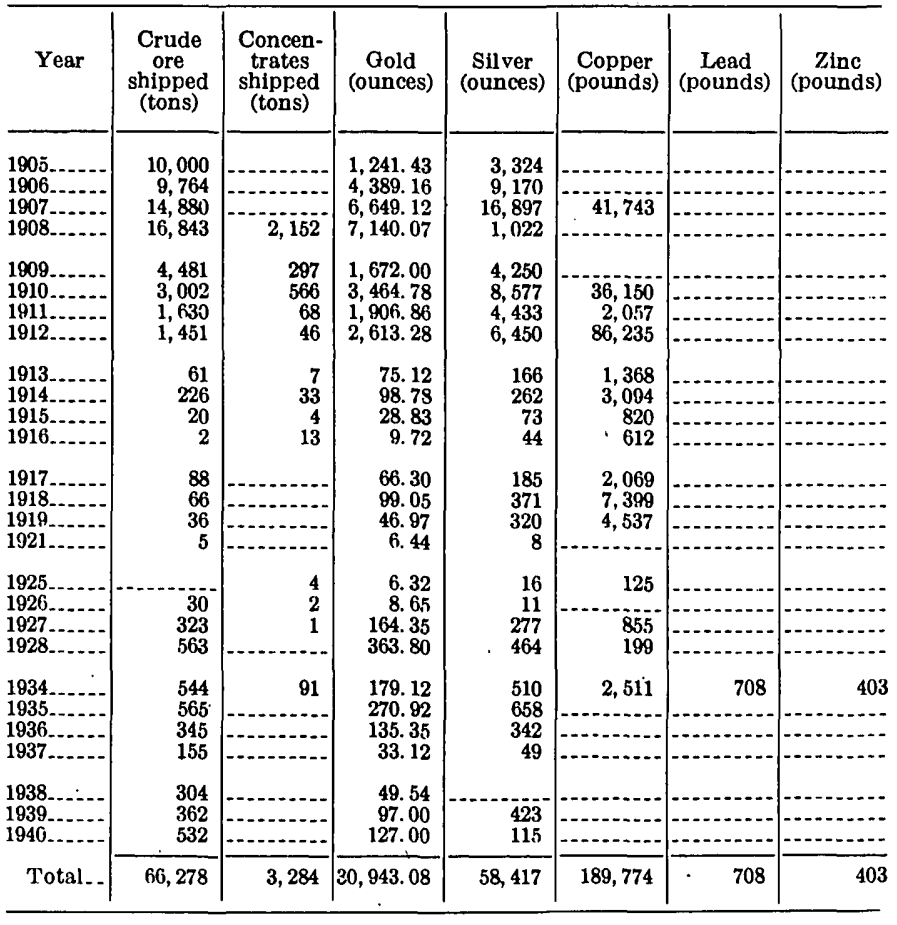

1 Probably includes a small amount of production from the Pewablc mine. Compiled by U.S. Bureau of Mines. Published by permission. 


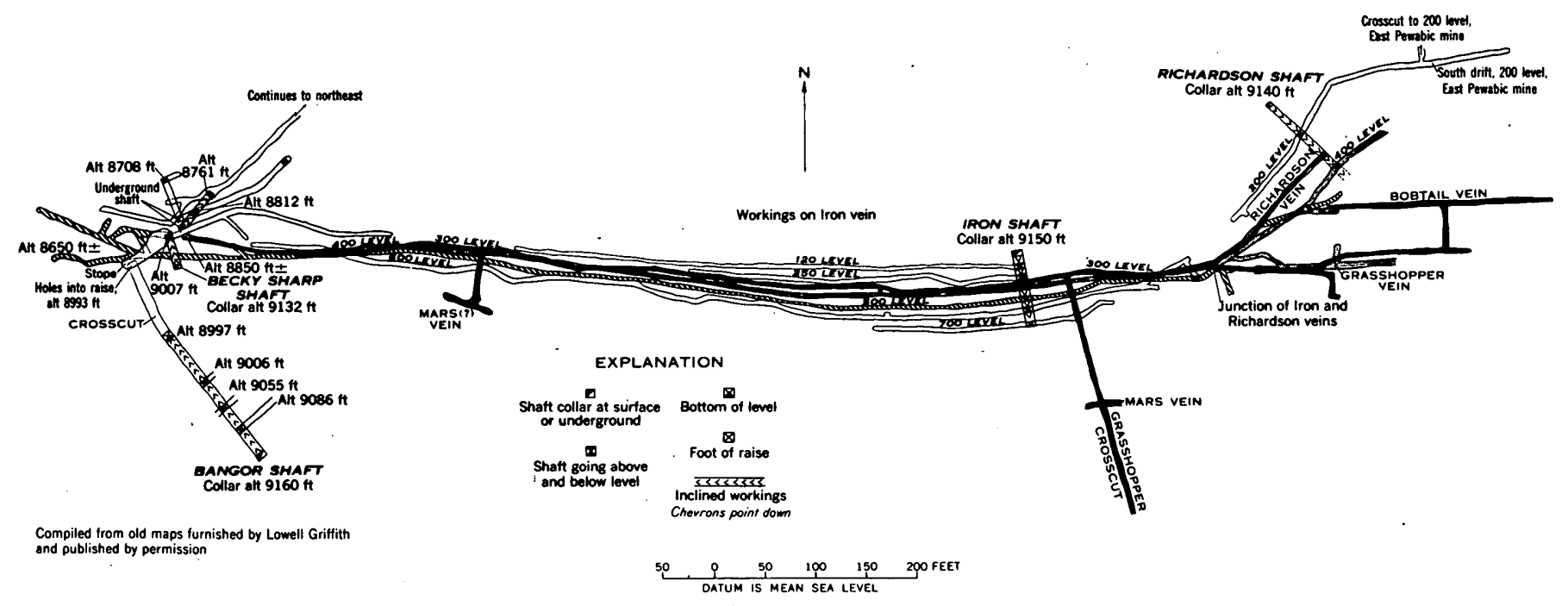

Figure 46.-Composite underground map of the Iron, Richardson, Bangor, and Becky Sharp mines.

300 level connects with the Becky Sharp mine (figs. 46, 47). Extensive stopes are present in the mine. The location of known stopes is shown on figure 47 ; other stopes are on the lower levels of the mine, west of the shaft, but their exact location and size are not known. In 1954, only the 300 level was accessible; the upper levels were caved and the lower levels were flooded.

The collar of the Iron shaft is in a sequence of interlayered biotite gneisses. The wallrock of the 300 level and probably also the lower levels is microclinebearing gneiss. A west-northwestward trending dike of trachytic granite porphyry is exposed in the Grass- hopper crosscut on the 300 level (pl. 7). The same dike probably is exposed on the 400 level east of the shaft (Bastin and Hill, 1917, p. 254).

The Iron vein is the most persistent vein in upper Russell Gulch, and on the average it trends eastward and dips vertically to $75^{\circ} \mathrm{S}$. (average $85^{\circ} \mathrm{S}$.). It appears to split into several branch veins, the most important of which are the Richardson, Bobtail, Grasshopper, Bangor, and Rocky Mountain Terror. The Iron vein proper has been developed along strike for about 1,200 feet and to a maximum depth of 650 feet. It ranges from a few inches to several feet in thickness; the stopes on the 400 level near the shaft

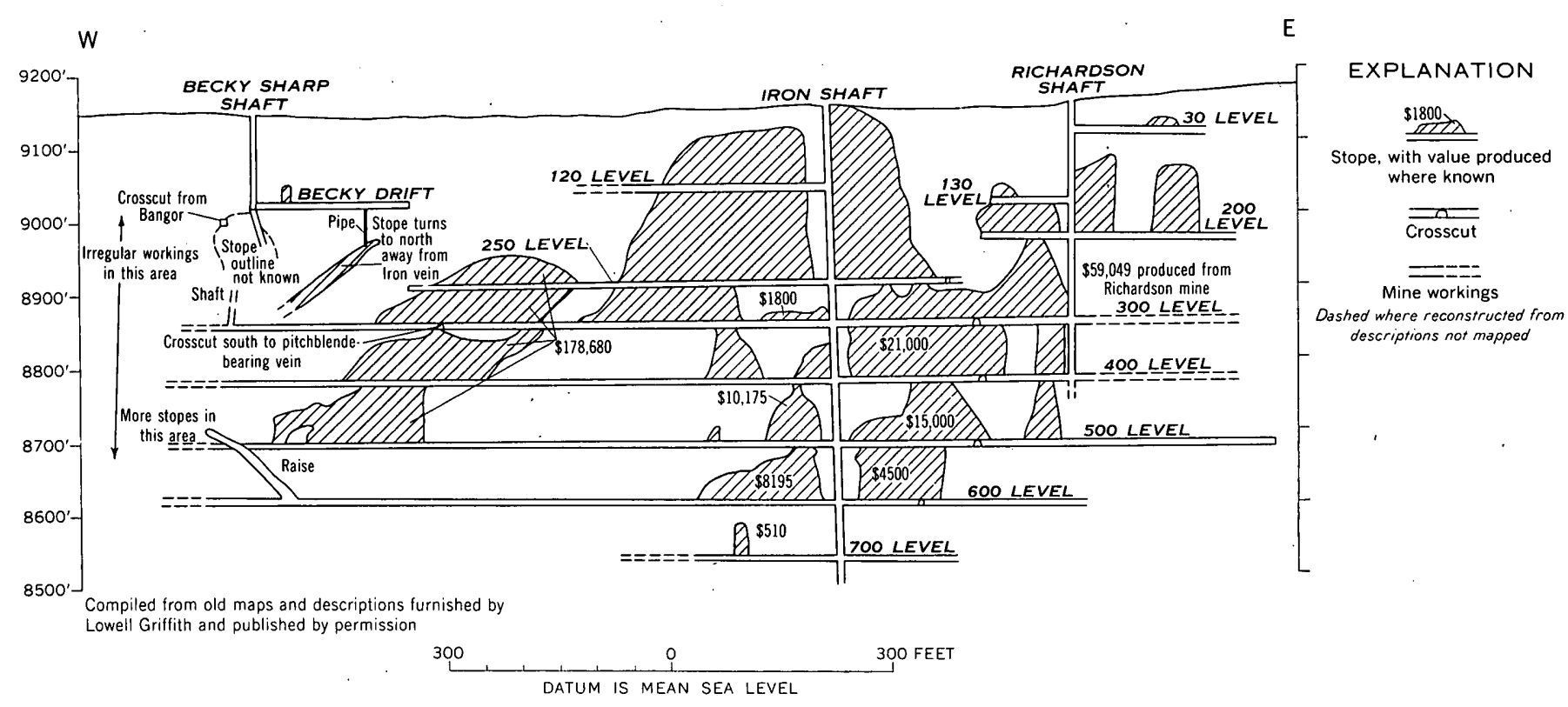

Figdro 47.-Longitudinal projection in the plane of the Iron veln of parts of the Iron, Richardson, and Becky Sharp mines. 
are reported to be 12 feet wide (Bastin and Hill, 1917, p. 254-255). The vein typically consists of a wide zone of fractured and altered country rock containing abundant disseminated pyrite. Locally the altered rock is traversed by a network of tiny pyritechalcopyrite veinlets and less commonly by several inch-thick seams of nearly solid pyrite.

The branching pattern of the Iron vein is complex and not well known, but judging from the composite underground map of the mine, the writers infer that the Iron vein splits into three and perhaps four segments. In general, both the hanging-wall and footwall branches diverge upwards from the Iron vein.

The Richardson vein, which strikes about N. $40^{\circ} \mathrm{E}$. and dips $65^{\circ}-80^{\circ} \mathrm{SE}$., branches from the Iron vein about 190 feet east of the shaft on the 500 level (fig. 46). In a stope 20 feet east of the Richardson shaft, the vein consists of 6 feet of altered microcline-bearing gneiss that is traversed by a network of irregular pyrite veinlets as much as 5 inches wide (Bastin and Hill, 1917, p. 255). The pyrite crystals in the vein are coarse-as much as $1 \frac{1}{2}$ inches in diameter-and contain low concentrations of gold. The Iron-Richardson junction plunges about $78^{\circ} \mathrm{E}$.

On the 300 level, about 100 feet east of the location where the Richardson vein splits from the Iron vein, the Iron vein again splits into two segments, the northernmost of which is thought to be the Iron vein proper (fig. 46). The southernmost branch is the Grasshopper vein. The Grasshopper-Iron junction also is exposed on the 400 level, about 200 feet east of the shaft. On this level the Grasshopper vein strikes east, is nearly vertical, and is weakly mineralized. The Iron-Grasshopper junction plunges moderately to the east (fig. 46).

Near the east end of the 300 level, a 42 -foot crosscut north from the Iron drift intersects the Bobtail vein (fig. 46). The Bobtail vein strikes east and dips nearly vertical. It is inferred to be a branch from the Richardson vein.

The Iron vein shows the same tendency to split on the 300 level west of the shaft (pl. 7). About 47 feet west of the shaft it splits into a hanging-wall and a footwall segment. At 344 feet west of the shaft, the Iron vein splits into three segments, one of which dips south; the others dip north. The south-dipping segment, thought to be the Iron vein proper, enters the north wall. The middle segment is developed by the 300 level to a point about 140 feet west of the 524 crosscut; at this point it enters the south wall of the drift and a south-dipping vein, probably the Iron vein proper, enters the drift from the north wall and extends to the Becky Sharp shaft, about 150 feet far- ther to the west. This north-dipping vein is probably the Rocky Mountain Terror vein. The westernmost branch vein, at 344 feet, is developed by a short spur drift (pl: 7) ; it strikes about N. $63^{\circ}$ E., dips $76^{\circ} \mathrm{NW}$. A projection of this vein to the surface correlates with the vein developed in the Santiago mine.

The Becky Sharp shaft is caved, but it appears that the shaft was sunk on a vein that strikes east-northeast and dips steeply northwest (fig. 46). This probably is the Pewabic vein, for Billingsley ${ }^{23}$ states that an ore shoot occurs on the Pewabic vein in the Becky Sharp mine. The relation of the Pewabic vein to the Iron vein is not known, but it is possible that the Pewabic is a major branch vein from the Iron.

The Mars vein is exposed in the Grasshopper crosscut on the 300 level, about 125 feet south of the Iron vein (pl. 7). The vein strikes nearly east, dips $50^{\circ}-$ $67^{\circ} \mathrm{N}$., and consists of 12 to 18 inches of altered microcline-bearing gneiss with disseminated pyrite which is cut by 3 - to 6 -inch quartz-pyrite veinlets. The same vein probably is exposed by the short drift at the breast of the 524 crosscut (pl. 7), where it contains pitchblende. The pitchblende is in discontinuous patchy veinlets as much as half an inch wide on the hanging wall of the major vein.

Two principal ore shoots have been stoped in the Iron mine, one near the shaft and the other at the west end of the mine. The ore shoot near the shaft plunges vertically, has an average stope length of 300 feet, and appears to pinch out about the 700 level (fig. 47). The west ore shoot plunges about $44^{\circ} \mathrm{W}$., has a stope length of about 150 feet, and has been mined over a plunge length of 700 feet. The ore shoot near the shaft is on the main Iron vein, and the west ore shoot probably occurs along both the Iron and Rocky Mountain Terror branch veins. Two other ore shoots in the Iron vein in the Becky Sharp mine are reported by Billingsley, ${ }^{24}$ one below the Becky Sharp shaft, and the other along the Bangor-Iron vein intersection. The stopes shown in the eastern part of figure 47 are probably on the Richardson vein; this ore probably is the downward continuation of the vertical-plunging Richardson ore shoot.

The ore controls in the Iron mine are not fully known. The vein is strongly mineralized in the central part of the mine workings and is relatively weakly mineralized both to the east and west, where it splits into many branches. Judging from the location of the stopes, the major ore shoots occur where the vein is steeper than normal. The west ore shoot

${ }^{23}$ Billingsley, Paul, 1927, Report on Pewabic mine and associated properties, $25 \mathrm{p}$., report on file in the Library of the Colorado School of Mines, Golden, Colo.

${ }^{24}$ Billingsley, Paul, 1927, op. cit. 
(fig. 47) seems to plunge almost parallel to the intersection of the Iron vein with the average foliation of the wallrock. Acute vein intersections that increase the width of fracturing and concomitantly the width of mineralization are responsible for several small ore bodies in the mine.

\section{IRON DUKE MINE (C-VI-20)}

Location.-On south side of upper Russell Gulch. Development.-A 510-foot shaft; 3 levels aggregating about 2,664 feet of drift; crosscut southeast from 500 level east.

Veins.-Iron Duke (probably the eastward extension of the Bobtail vein): Strike, nearly east; dip, $70^{\circ} \mathrm{N}$. A south-dipping vein is cut between the 400 and 500 levels. 500 level crosscut cuts the $G$ and Spur veins and was being extended in 1910 to cut the Two-Forty vein.

Wallrock.-Biotite-quartz-plagioclase gneiss and microcline-bearing gneiss.

Ore and sulfide minerals.-Pyrite, gold, silver, and a little chacopyrite.

Gangue minerals.-White, massive and gray finegrained quartz.

Tenor.-Ore shipped ranged from $\$ 3$ to $\$ 64$ per ton.

KNICKERBOCKER TUNNEL (A-VI-9)

Location.-About 1,700 feet west-southwest of the Springdale mine.

Production.-Not known; probably small.

Development.-A crosscut tunnel to J. L. Emerson vein; drift to southeast follows vein for more than 2,200 feet.

Veins.-J. L. Emerson vein, a wide pyrite vein; several northeastward-trending veins should be intersected by tunnel.

Ore shoots.-Two ore bodies are reported to have been mined, one 950 feet from the portal and the other 2,200 feet from the portal (Henry de Linde, 1955, oral communication).

\section{LILLIAN MINE (C-VI-13)}

Location.-On south side of upper Russell Gulch, about 740 feet $N$. $76^{\circ}$ E. from the Old Town mine.

Production.-From 1902 to 1917, 841 tons of smelting ore and 402 tons of concentrates that contained $1,527.20$ ounces of gold, 3,264 ounces of silver, 35,416 pounds of copper, and 3,904 pounds of lead. (Compiled by U.S. Bureau of Mines. Published by permission.)

Development.-A 550-foot shaft with 6 levels aggregating 1,200 feet of drift.

Veins.-Lillian (probably the Pewabic hanging- wall vein) : Strike, N. $65^{\circ} \mathrm{E}$; dip, steep to the northwest.

Wallrock.-Biotite-quartz-plagioclase gneiss, pegmatite, and microcline-bearing gneiss.

Ore and sulfide minerals.-Pyrite, gold, silver, chalcopyrite, tennantite; some galena and sphalerite.

Gangue minerals.-Quartz.

Tenor.-841 tons of smelting ore shipped between 1902 and 1917 averaged 1.54 ounces of gold and 3.24 ounces of silver per ton.

\section{LOTUS MINE (C-VI-8)}

The Lotus mine is in Russell Gulch, just above the lower road between Russell Gulch and Central City. Bastin was able to examine the mine by entering through the tunnel (or first) level (Bastin and Hill, 1917, p. 256-257) and much of the description that follows is taken from his report.

The production for the years 1902 to 1940, when the Lotus mine was closed, is given in the following table (table 50):

TABLE 50.-Ore produced from Lotus mine, 1902-54 ${ }^{\mathrm{t}}$

\begin{tabular}{|c|c|c|c|c|c|c|c|}
\hline Year & $\begin{array}{c}\text { Crude } \\
\text { ore } \\
\text { shinred } \\
\text { (tons) }\end{array}$ & $\begin{array}{l}\text { Concen- } \\
\text { trates } \\
\text { shipred } \\
\text { (tons) }\end{array}$ & $\begin{array}{c}\text { Gold } \\
\text { (ounces) }\end{array}$ & $\begin{array}{c}\text { Silver } \\
\text { (ounces) }\end{array}$ & $\begin{array}{c}\text { Copper } \\
\text { (pounds) }\end{array}$ & $\underset{\text { (pounds) }}{\text { Lead }}$ & $\begin{array}{c}\text { Zinc } \\
\text { (pounds) }\end{array}$ \\
\hline $\begin{array}{l}1907 \ldots \\
1908 \\
1911 \\
1911\end{array}$ & $\begin{array}{r}100 \\
51 \\
142\end{array}$ & $\cdots$ & $\begin{array}{r}120.02 \\
54.28 \\
126.37 \\
19.44\end{array}$ & $\begin{array}{r}450 \\
234 \\
281 \\
78\end{array}$ & & $\begin{array}{l}7,995 \\
3.804 \\
3,361 \\
1,721\end{array}$ & \\
\hline $\begin{array}{l}1912 \\
1913 . \\
1913 \\
1915\end{array}$ & $\begin{array}{r}19 \\
64 \\
-7\end{array}$ & 19 & $\begin{array}{r}15.03 \\
39.73 \\
7.22 \\
4.18\end{array}$ & $\begin{array}{r}42 \\
172 \\
21 \\
44\end{array}$ & & $\begin{array}{r}436 \\
2,263\end{array}$ & \\
\hline $\begin{array}{l}1933 \ldots \\
1934 \\
1934 \\
1935\end{array}$ & $\begin{array}{r}23 \\
115 \\
-129\end{array}$ & & $\begin{array}{r}13.27 \\
2.00 \\
17.82 \\
32.64\end{array}$ & $\begin{array}{l}96 \\
106 \\
112\end{array}$ & & 125 & 54 \\
\hline $\begin{array}{l}1936 \\
1937 \\
1938 \\
1939 \\
1940\end{array}$ & $\begin{array}{r}59 \\
56 \\
181 \\
81 \\
\end{array}$ & 48 & $\begin{array}{l}24.93 \\
16.09 \\
45.00 \\
67.60 \\
62.00\end{array}$ & $\begin{array}{r}120 \\
22 \\
59 \\
97 \\
151\end{array}$ & $\begin{array}{l}158 \\
683\end{array}$ & 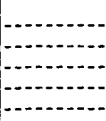 & \\
\hline Total_. & 1,027 & 112 & 667.62 & 2,085 & 841 & 19,705 & 54 \\
\hline
\end{tabular}

1 Compiled by U.S. Bureau of Mines. Published by permission.

A map of the mine workings, as known in 1900, and sections of the workings are shown in figure 48 . The Lotus shaft, 810 feet deep, is connected to 7 levels about 100 feet apart vertically. An air shaft connects the tunnel level to the surface. A winze, about 300 feet east of the Lotus shaft, connects the tunnel level and the 450 feet. The outline of stopes, as known in 1900, is given in figure 48. Subsequently, however, additional stoping has been done, but the location of this work is not known.

The wallrock in the workings is largely microcline-bearing gneiss which contains thin layers of biotite-quartz-plagioclase gneiss. 

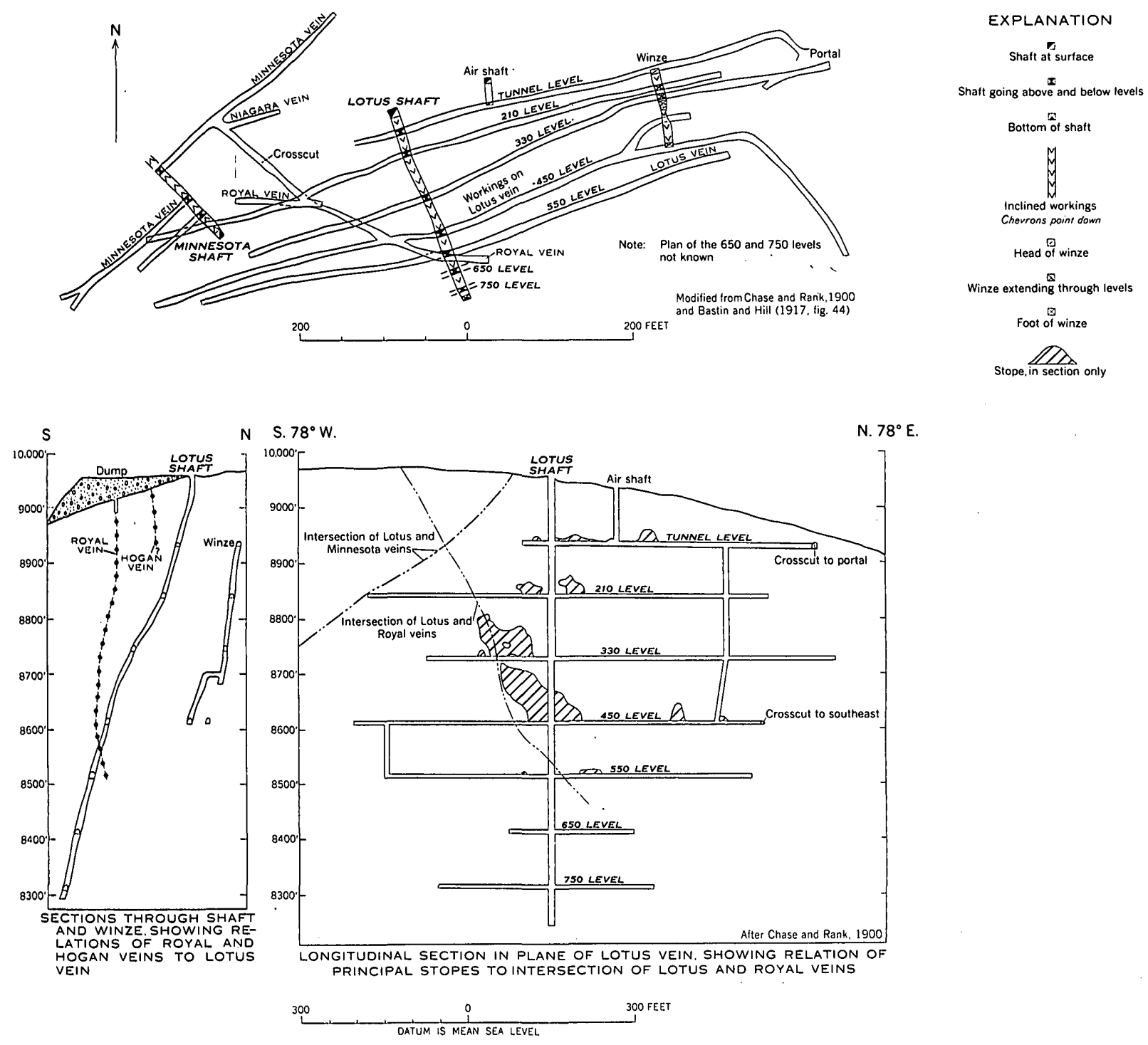

Figure 48.-Map and sections of the Lotus mine and part of the Minnesota mine.

Although the Lotus vein was the principal vein worked in the mine, the Minnesota, Royal, and $\mathrm{Ni}$ agara veins were developed on the 450 level (Bastin and Hill, 1917, fig. 44). Another vein, the Hogan, was prospected at the surface, but so far as known, was not explored underground. All the veins are pyritic. Bastin and Hill (1917, p. 257) state that subordinate chalcopyrite and tetrahedrite-tennantite occur in the veins. Galena and sphalerite also are abundant locally, for 19,705 pounds of lead and 54 pounds of zinc ore were shipped after 1907. Polished sections of dump specimens, collected in 1952, examined under a reflecting microscope, show that the pyrite and quartz-the predominant vein minerals-are brecciated. Subsequently some galena and a platy darkgray microcrystalline quartz veined and embayed the early brecciated minerals.

The Lotus vein strikes N. $75^{\circ}-80^{\circ}$ E. and dips southeast. In the shaft, which follows the vein (Bastin and Hill, 1917, p. 256), the vein dips $75^{\circ}$ SE., except between the 210 and 450 levels where it flattens to $60^{\circ}$ SE. The vein car be traced on the surface for about 1,500 feet. It crosses the Minnesota vein apparently without appreciable displacement west of the Lotus shaft, and at depth intersects the Royal vein and perhaps also the Hogan vein. Probably a short distance 
east of the Niagara shaft $(\mathrm{C}-\mathrm{V}-21, \mathrm{pl} .1)$, the Lotus vein joins(?) the Niagara vein. According to Bastin and Hill (1917, p. 257):

The Lotus vein as exposed on the tunnel level is in a few places a barren fracture seam; in other places it consists of 2 feet or so of fractured granite gneiss carrying disseminated pyrite; where most heavily mineralized it may show as much as 7 feet of pyrite-impregnated granite gneiss traversed by numerous sub-parallel veinlets of pyrite and quartz whose maximum width is about 1 inch. In places both the veinlets and the impregnated gneiss contain abundant tennantite associated with the pyrite. On the 210 -foot level east the vein in places contains large amounts of coarse pyrite, evidently of low grade. About 250 feet east of the shaft on this level the vein, which is over 3 feet wide, shows 3 to 4 inches of gouge next the hanging wall, then $1 \frac{1}{2}$ feet of granite gneiss containing more or less disseminated pyrite, then a $1 \frac{1}{2}$-foot vein about one-third quartz and two-thirds pyrite, the latter in very coarse crystals exceptionally 2 inches across.

The Royal vein strikes about N. $70^{\circ} \mathrm{W}$. and dips steeply either side of vertical. It can be traced on the surface for a distance of about 1200 feet. The principal workings on the vein were from Royal shaft (6-C-VI, pl. 1) about 500 feet northwest of Lotus shaft. In the Lotus mine (Bastin and Hill, 1917, p. 257) :

The Royal vein, as exposed on the 450-level about 100 feet east of its junction with the Lotus vein, is about 4 inches wide and is composed of nearly solid pyrite. The granite gneiss [microcline-bearing gneiss of this report] walls carry disseminated pyrite in amounts that gradually decrease from the vein outward. Locally some chalcopyrite occurs with the pyrite.

The Niagara vein, worked principally from the Niagara shaft (C-V-21, pl. 1), now inaccessible, was reached on the 459 level of the Lotus mine. According to Bastin and Hill (1917, p. 257), the vein

shows in places 3 feet of altered granite gneiss carrying disseminated pyrite and is cut by a number of indefinitely bounded pyrite stringers. In one place a single sharp veinlet of solid pyrite is $1 \frac{1}{2}$ inches wide. Near its junction with the Minnesota vein the rock between the two veins is mineralized in a similar manner for a width of 4 feet, some of the solid pyrite veinlets being 5 inches wide.

According to Bastin and Hill (1917, p. 257), The Minnesota vein, as exposed on the 450-foot level, consists at one point of 5 feet of granite gneiss carrying varying amounts of disseminated pyrite. At another place a $1 \frac{1}{2}$-foot band of gray quartz carries rather fine pyrite. There has been movement along the vein subsequent to mineralization.

The principal ore shoots within the Lotus mine, at and near the intersection between the Lotus and Royal veins, plunge moderately eastward. as shown on figure 48 .

\section{LUTZ-I.X.L。 VEIN}

The Lutz-I.X.L. vein crops out on the south side of upper Russell Gulch, and is developed by the Lutz (C-VI-10) and the I.X.L. (C-VI-11) mines. The Lutz shaft is inclined steeply north and connects to
$E$

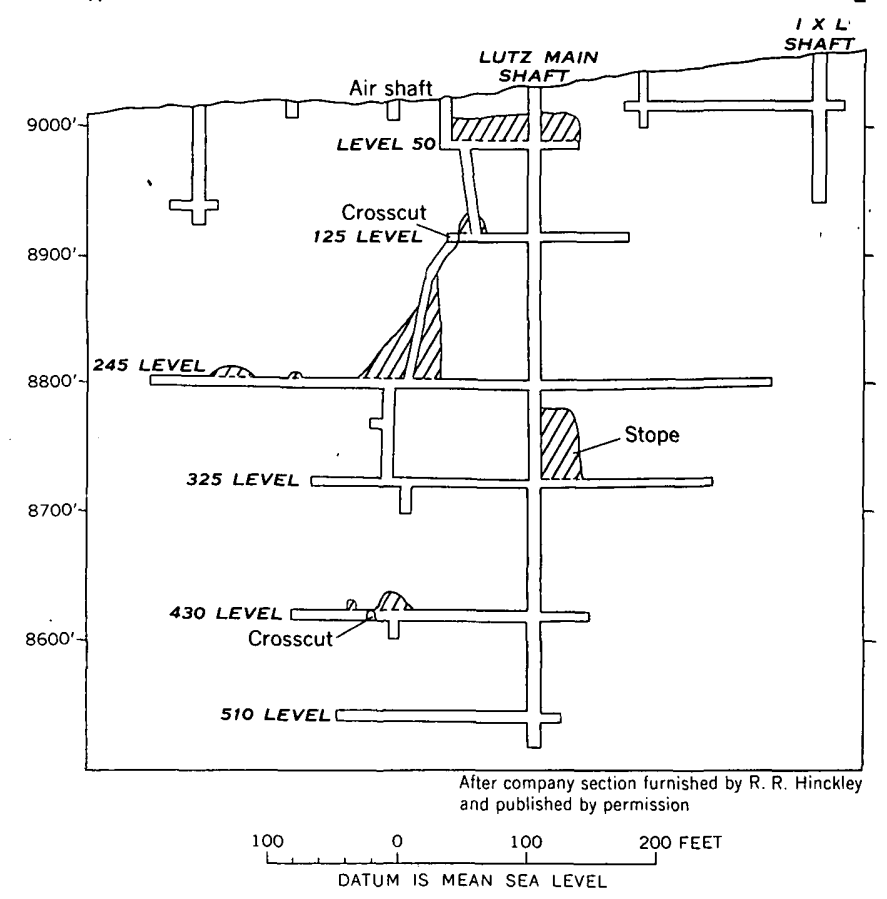

FigURe 49.--Vertical longitudinál section of the Lutz-I.X.L. veln.

levels at depths of $50,125,245,325,430$, and 510 feet (fig. 49). The I.X.L. shaft is about 100 feet deep and has 1 level at a depth of 30 feet. The location of the stopes is shown on figure 49. These workings were inaccessible in 1954.

The Lutz-I.X.L. vein strikes approximately eastwest. From the surface to just above the 245 level of the Lutz shaft, the vein dips steeply either side of vertical; from that point to the 325 level it dips about $70^{\circ} \mathrm{N}$.; below the 325 level it again dips steeply either side of vertical. The Lutz-I.X.L. vein probably joins with a cross vein that strikes about $\mathbf{N}$. $50^{\circ}$ E. approximately 40 feet west of the I.X.L. shaft. The vein material noted on the mine dumps consists wholly of quartz and pyrite, some of which was brecciated and recemented by fine-grained gray quartz. The stope outlines on figure 49 show no persistent ore shoot. The larger stopes occur west of the shaft near, but not on, the vein junctions.

\section{MINNESOTA-MICHIGAN BOY-GETTYSBURG VEIN}

The Minnesota-Michigan Boy-Gettysburg vein can be traced from the lower road in Russell Gulch northeastward for 3,000 feet and perhaps farther; probably it is equivalent to one of the veins developed in the Hayes and Wheeler tunnel (D-IV-9, pl. 1). The vein strikes on the average $\mathrm{N}$. $35^{\circ} \mathrm{E}$. and dips steeply northwest. It was developed principally in the Minnesota and Gettysburg mines, both of which were inaccessible at the time of this survey. The total pro- 
duction from the vein is not known. The production from the Gettysburg mine (C-V-9) from 1902 to 1954 is given in table 51, and the recorded production from the Minnesota mine for the same years is given in table 52 .

$\mathrm{T}_{\Lambda \mathrm{BLE}}$ 51.-Ore produced from the Gettysburg mine, 1902-54 ${ }^{1}$

\begin{tabular}{|c|c|c|c|c|}
\hline Year & $\begin{array}{c}\text { Crude oro } \\
\text { shipped } \\
\text { (tons) }\end{array}$ & $\begin{array}{c}\text { Concentrates } \\
\text { shipped } \\
\text { (tons) }\end{array}$ & $\begin{array}{c}\text { Gold } \\
\text { (ounces) }\end{array}$ & $\begin{array}{c}\text { Silver } \\
\text { (ounces) }\end{array}$ \\
\hline $\begin{array}{l}1908 \\
1910 \\
1911 \\
1912 \\
1914 \\
1914 \\
1933 \\
1935\end{array}$ & $\begin{array}{r}2 \\
1 \\
1 \\
1 \\
26 \\
-45 \\
-2-\end{array}$ & $\begin{array}{r}-1 \\
\hdashline\end{array}$ & $\begin{array}{l}\text { 1. } 19 \\
\text { 1. } 49 \\
.34 \\
\text { 1. } 26 \\
\text { 3. } 74 \\
.80 \\
\text { 6. } 66 \\
\text { 1. } 45\end{array}$ & $\begin{array}{r}6 \\
1 \\
2 \\
5 \\
25 \\
4 \\
2 \\
25\end{array}$ \\
\hline Total... & 76 & 7 & 16. 93 & 70 \\
\hline
\end{tabular}

I Compllod by U.S. Bureau of Mines. Published by permission.

The Minnesota mine (C-VI- 4 ), just above the lower Russell Gulch-Central City road, in Russell Gulch, consists of a 356 -foot shaft, inclined northwest, and at least 3 levels (fig. 48). The mine is connected to the Lotus mine on the 450 level by a crosscut.

Little is known of the workings at the Gettysburg mine (C-V-9), but judging from the size of the dump, they are large. The mine is known to have been open as recently as 1935 .

TABLE 52.-Ore produced from the Minnesota mine, 1902-54

\begin{tabular}{|c|c|c|c|c|c|c|c|}
\hline Year & $\begin{array}{l}\text { Crude } \\
\text { ore } \\
\text { shlpred } \\
\text { (tons) }\end{array}$ & $\begin{array}{l}\text { Concen- } \\
\text { trates } \\
\text { shifred } \\
\text { (tons) }\end{array}$ & $\begin{array}{c}\text { Gold } \\
\text { (ounces) }\end{array}$ & $\begin{array}{c}\text { Silver } \\
\text { (ounces) }\end{array}$ & $\begin{array}{c}\text { Copper } \\
\text { (pounds) }\end{array}$ & $\begin{array}{c}\text { Lead } \\
\text { (pounds) }\end{array}$ & $\begin{array}{c}\text { Zinc } \\
\text { (pounds) }\end{array}$ \\
\hline & $\begin{array}{r}9 \\
16\end{array}$ & & 1.84 & 7 & & 515 & \\
\hline & 1 & $\cdots$ & 1.01 & $\ddot{\theta}$ & $\cdots$ & 695 & 29 \\
\hline & $\begin{array}{r}6 \\
83\end{array}$ & $10^{\circ}$ & $\begin{array}{r}5.99 \\
5.99 \\
27.89\end{array}$ & 19 & $\begin{array}{l}1150 \\
578\end{array}$ & 8 & 324 \\
\hline & 111 & & 11.48 & 53 & $\mid-\ldots . .$. & 19 & 19 \\
\hline Total. & 227 & $\overline{17}$ & 50.89 & 190 & 693 & 1,944 & 372 \\
\hline
\end{tabular}

I Complled by U.S. Bureau of Mines. Published by permission.

The Minnesota-Michigan Boy-Gettysburg vein is a pyrite vein (type $B$ ). Specimens found on the dumps in 1952 consisted of crystalline pyrite in a gray to white quartz gangue. The production from the Minnesota mine indicates, however, the presence of substantial quantities of copper-bearing minerals, sphalerite, and galena. According to Bastin and Hill (1917, p. 258) the ore at the Gettysburg contains a considerable amount of chalcopyrite, in addition to pyrite, and subordinate tetrahedrite-tennantite. Vugs in the ore are common.

Sampling-works assays of 2 shipments of 436 and 1,941 pounds from the Gettysburg mine show, re- spectively, gold 0.55 ource and silver 3.5 ounces per ton, and gold 2 ounces per ton, silver 7.5 ounces per ton, and copper 3 percent.

Shipments of smelting ore from the Minnesota mine gave the following sampling-works assays:

Sampling-works assays of smelting ore from the Minnesota mine, $1923-35^{1}$

\begin{tabular}{|c|c|c|c|c|c|c|}
\hline Year & Tons & Gold 2 & Silver ${ }^{2}$ & $\begin{array}{c}\text { Copper } \\
\text { (percent) }\end{array}$ & $\begin{array}{c}\text { Lead } \\
\text { (percent) }\end{array}$ & $\underset{\text { (percent) }}{\text { Zinc }}$ \\
\hline 1923 & $\begin{array}{r}1.43 \\
2.31 \\
4.63 \\
15.97\end{array}$ & $\begin{array}{r}0.70 \\
1.70 \\
.80\end{array}$ & $\begin{array}{l}6.00 \\
8.00 \\
5.00 \\
62\end{array}$ & $\begin{array}{l}2.50 \\
3.50\end{array}$ & 19.20 & $\begin{array}{l}1.00 \\
2.20 \\
2.35\end{array}$ \\
\hline 1935. & 2.43 & .14 & .82 & . & .40 & .40 \\
\hline
\end{tabular}

1 Data on ore tenor furnished by the Idaho Springs Sampling Works. Published by permission.

\section{MISSOURI MINE (C-VI-1)}

Location.-On the north slope of upper Russell Gulch, about 2,470 feet S. $80^{\circ} \mathrm{W}$. from the Saratoga mine.

Production.-From 1908 to 1939473 tons of smelting ore and 146 tons of concentrates were shipped that contained 413.64 ounces of gold, 1,149 ounces of silver, 1,323 pounds of copper, 279 pounds of lead, and 7 pounds of zinc. (Compiled by U.S. Bureau of Mines. Published by permission.) Mine yielded $\$ 200,000$ worth of ore prior to 1899 (Callbreath, 1899).

Development.-Missouri shaft which connects with 4 levels, and the East Missouri shaft which is 250 feet deep.

Veins.-North Missouri: Strike, N. $80^{\circ}$ E., dip $65^{\circ}$ NW.; consists of 3 feet of altered wallrock cut by sharp-walled sulfide veinlets; movement that occurred after mineralization has crushed the sulfides in places. South Missouri: Strike, N. $75^{\circ}-80^{\circ}$ E.; dip, $55^{\circ}$ NW.; vein is tight and ranges from 2 inches to 2 feet in width.

Wallrock.-Biotite-quartz-plagioclase gneiss and microcline-bearing gneiss.

Ore and sulfide minerals.-Pyrite, gold, silver, and some chalcopyrite, tennantite, galena, and sphalerite.

Gangue minerals.-Quartz.

Tenor.-Smelting ore from the North Missouri vein shipped in 1910 averaged 2.91 ounces of gold and 6 ounces of silver per ton. Ore from the South Missouri vein contained 1 to 3 ounces of gold and 2 to 3 ounces of silver to the ton.

\section{OLD TOWN MINE (B-VI-21)}

The Old Town mine, on the south side of upper Russell Gulch, was opened in the late 1800's, but little work was done until rich gold ore was discovered in the adjacent Wautauga mine at the junction of the Wautauga and Old Town veins. After a period 


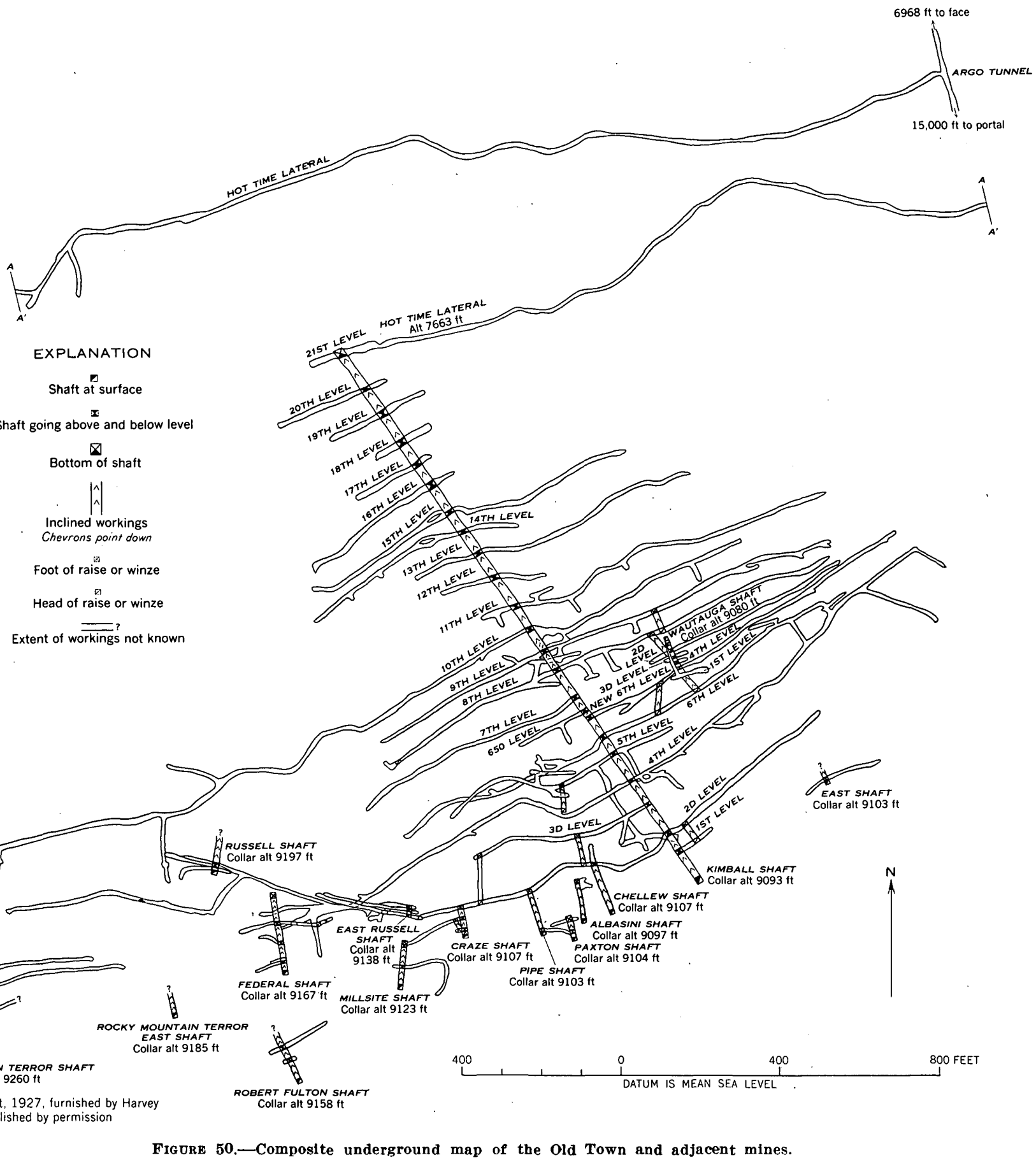

of apex litigation, the Old Town and Wautauga interests were consolidated and all subsequent work was done through the Old Town shaft. The mine was last open in 1952 to evaluate pitchblende discoveries made underground by J. D. Wells and A. E. Dearth of the Geological Survey. At that time, the shaft was rehabilitated to the 8 th level.

The Old Town mine is opened by a 2,205-foot inclined shaft from which 21 principal and 2 sublevels have been turned (fig. 50). The 4th level west con- nects to the Russell, East Russell, and Federal mines (fig. 50). The 4th level east extends to the Incidental mine (see fig. 45); it continues at least 200 feet farther east than shown on figure 50. The new 6 th level connects to the Wautauga mine, and the $22 \mathrm{~d}$ level (Hot Time lateral) connects to the Argo tunnel (fig. 50). Stopes, though present on all levels, are more extensive above the 11th level (fig. 51). In 1954, only parts of the 4th, 5th, 6th, new 6th, 650, and 7th levels were accessible (pl. 8). 
The mine is reported to have had a gross yield of about $\$ 2,700,000$ prior to 1912 (Bastin and Hill, 1917, p. 254). The production from the Old Town mine since 1902 is given in table 53; this ore if produced today would have a value of about $\$ 4,620,000$.

The collar of the shaft is in sillimanitic biotitequartz gneiss, but the shaft enters microcline-bearing gneiss a short distance below the $2 \mathrm{~d}$ level (pl. 8). Biotite-quartz-plagioclase gneiss is intersected by the shaft below the 6th level, and it is reported to constitute the wallrock to a point just above the 9th level, where microcline-bearing gneiss again is intersected (John Anderly, oral communication). Microclinebearing gneiss, with a few small layers of biotite gneiss, is the prevailing wallrock below the 9th level (Bastin and Hill, 1917, p. 253).

The mine is on the northwest flank of the Russell Gulch syncline, a short distance from the axis; consequently the rocks trend northeastward and dip moderately to the southeast. Locally, the rocks are deformed by 1 - to 20-foot zigzag isoclinal folds, that plunge gently to the north-northeast, and by many broad cross warps that plunge gently to the northwest.

The principal workings of the Old Town mine are on the Old Town vein and veins that branch from it. The Federal, Russell, and Rocky Mountain Terror veins are developed by the 4th and 10th levels west (fig. 50,51) and the Incidental and probably also the Lutz vein by the 4 th level east (R. R. Hinckley, oral communication). The Pewabic hanging wall vein is developed by a long crosscut and drift south of the 5 th level (figs. 50, 52); the Wautauga vein was worked from the new 6th level (fig. 50); and the Columbus vein was intersected by the Hot Time lateral (Bastin and Hill, 1917, p. 252-253).

The Old Town vein, one of the largest and most persistent in the Central City district, strikes about N. $60^{\circ}$ E. and $\operatorname{dips} 35^{\circ}-50^{\circ}$. NW. Billingsley ${ }^{25}$ reports that the Old Town vein splits from the Iron vein, but the present writers could not verify this statement.

The Old Town vein is characterized on the upper levels by many branches. West of the Kimball shaft on the 4th, 5th, and 6th levels (pl. 8), several branches that strike near east-west split from the vein and enter the hanging wall; these branches, if followed sufficiently far, are joined by other northeastward-trending veins or they swing to a northeastward course, forming a vein structure similar to that described in the Pewabic mine. East of the Kimball shaft,

${ }^{25}$ Billingsley, Paul, 1927, Report on Pewabic mine and associated propertles, 25 p., report on file in the Library of the Colorado School of Mines, Golden, Colo. branches from the main vein that strike about eastwest enter the footwall. These branch veins appear to leave the Old Town vein at places where the vein strikes more easterly than normal.

$\mathrm{T}_{\mathrm{ABLE}}$ 53.-Ore produced from the Old Town mine, 1902-54 ${ }^{1}$

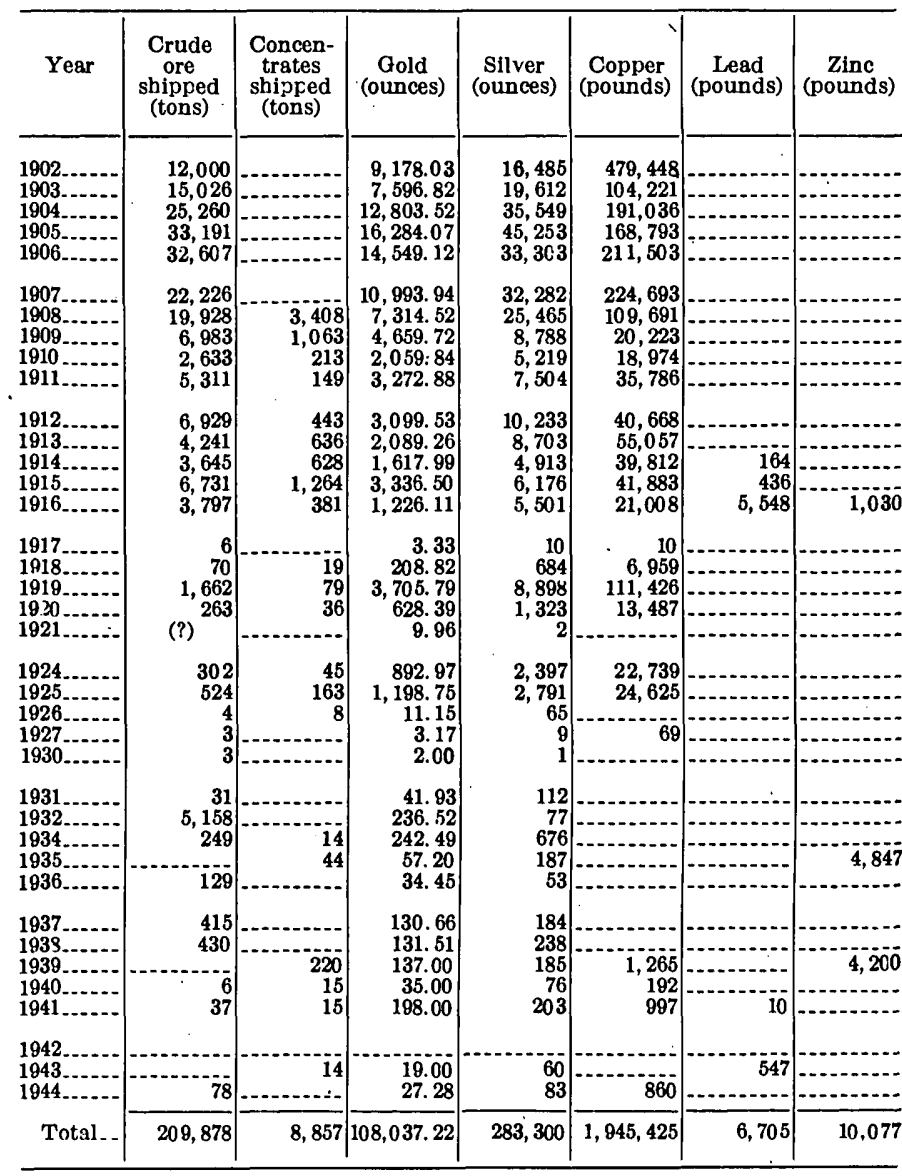

1 Compiled by U.S. Bureau of Mines. Published by permission.

Most of the vein filling observed by the writers in the accessible parts of the mine was talc ore, that is, argillized country rock containing disseminated pyrite with soft chalcocite. Probably the clay-type material is secondary and formed by weathering; hence it is possible that the gold in this environment was secondarily enriched. Similar ore was present in the adjoining Pewabic mine to the altitude of the 6th level (altitude 8,675 feet), suggesting that the zone of oxidation in the Old Town mine possibly extends approximately to the 7th level. "Hard ore" also is present in the mine, and at places it is 6 to 8 feet wide. It characteristically consists of altered gneiss heavily impregnated with pyrite and traversed by numerous pyrite-chalcopyrite veinlets as much as one-fourth inch wide. The highest gold concentrations are associated with chalcopyrite; copper constitutes about 3 percent of the better parts of the vein. 
W

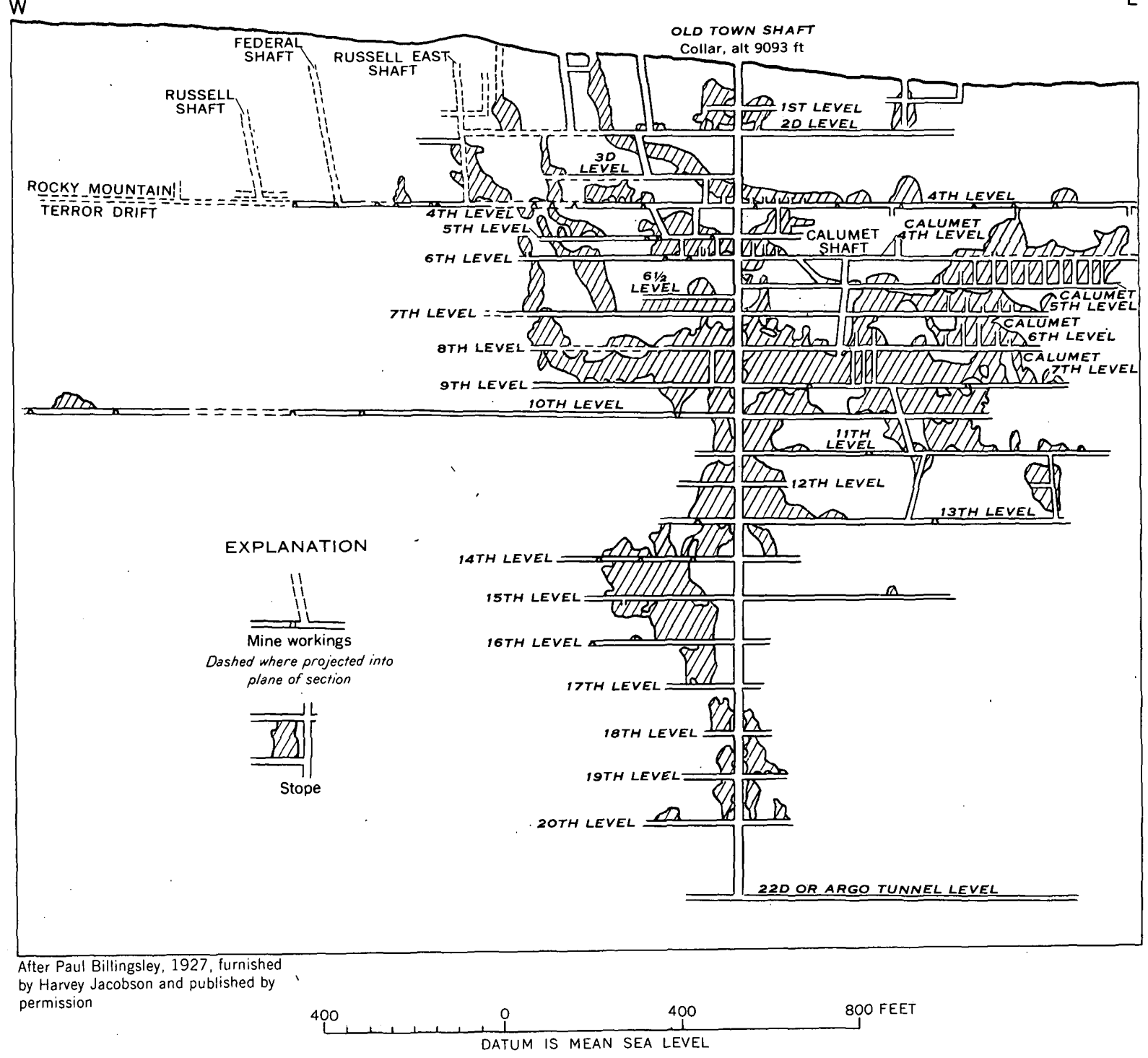

FigurE 51.-Longitudinal section in the plane of the Old Town vein, Old Town mlne.

According to long-time district residents, the richest ore was taken from the mine's upper levels. Ore in one shoot between the surface and the $3 \mathrm{~d}$ level averaged about $\$ 59$ per ton (Bastin and Hill, 1917, p. 254). Good ore was found on the intermediate levels, but in general the grade decreased somewhat with depth. Ore blocked out on the 14th and 15th levels averaged $\$ 32.01$ to $\$ 40.58$ per ton, and ore on the Hot Time lateral averaged only $\$ 0.80$ to $\$ 1.00$ per ton (Bastin and Hill, 1917, p. 254).

Pitchblende is present on the 6th, new 6th, and 7th levels of the mine, and in the shaft 20 feet above the 7th level (pl. 8). Harvey Jacobson (oral communication) reports that anomalously high radioactivity also is present on the 11th level. The pitchblende occurs in tiny veinlets as much as one-fourth inch thick, that fill gash fractures in silicified rock in the walls of the Old Town vein. The pitchblende is soft and sooty. It has been leached and is far out of equilibrium.

The Pewabic hanging wall vein is exposed in a crosscut and drift 210 feet south of the Old Town vein on the 5th level (pl. 8). It strikes nearly east and dips steeply north. At the crosscut the Pewabic vein consists of 26 inches of talc ore, and contains one-half-inch veinlet of quartz and pyrite near the hanging wall. So far as is known, the vein is not developed elsewhere in the mine.

The Wautauga vein joins the Old Town vein just above the new 6th level about 20 feet east of the Wautauga shaft. According to Bastin and Hill $(1917$, p. 252) the Wautauga vein descends with a 
dip of about $78^{\circ} \mathrm{S}$. within 5 or 6 feet of the Old Town vein and then swings into it. The best "hard ore" in the mine was found along and especially below this intersection.

The Columbus vein is cut by the Hot Time lateral from the Argo tunnel about 1,750 feet east of the Old Town shaft, and is followed for about 1,100 feet (fig. 50; Bastin and Hill, 1917, p. 252-253). It nearly parallels the Old Town vein, and is weakly mineralized. The Columbus vein follows a fracture zone from a few inches to 2 feet in width consisting of local, small streaks of pyrite and sparse disseminated pyrite (Bastin and Hill, 1917, p. 254).

For a discussion of the Federal, Russell, Rocky Mountain Terror, Incidental, and Lutz veins, the reader is referred to the descriptions of those mines.

The Old Town vein is largely stoped out over a length of 1,300 feet between the $2 d$ and 10th levels (fig. 51). Below the 10th level, the stoped ground forms a single chimney that has a stope length of about 200 feet. Much of the ore from the upper workings was probably talc. In the accessible workings the larger stopes are located on those parts of the vein that strike more easterly and dip steeper than normal. The junctions of the northwestwardtrending branch veins with the Old Town vein also appear to form favorable loci for ore; several stopes appear to be driven up the plunge of such intersections.

\section{PEWABIC MINe (C-VI-15)}

The Pewabic mine is on the south side of upper Russell Gulch, about 380 feet southeast of the Old Town mine. The mine is opened by an inclined shaft that connects with 9 levels; the Griffith winze sunk from the 9th level connects to 2 other levels (pl. 9; fig. 52). The $2 \mathrm{~d}$ level connects to the East Pewabic mine. Extensive stopes are present in the mine above the 9th level; their positions are shown on figure 52 . All the workings were inaccessible in 1954; the following description is taken mainly from an unpublished report prepared by Paul Billingsley, ${ }^{26}$ who made a geologic study of the mine in 1927.

The production from the Pewabic mine is not accurately known as shipments were combined with the Iron mine, but it is estimated to be about $\$ 1,500,000$.

The mine workings are dominantly in Precambrian microcline-bearing gneiss and interlayered biotite gneisses. Interlayered biotite gneisses constitute the wallrocks of the shaft from the surface to the $2 d$ level and from the 9th level to the 11th level; and microcline-bearing gneiss forms the walls of other parts of the shaft (fig. 52). Pegmatite and migmatite are

26 Blllingsley, Paul, 1927, op. cit. locally intercalated with the gneisses, but only a few of these bodies are sufficiently large to be mapped (pl. 9). In general, the wallrocks trend northeastward and dip gently southeastward, toward the axis of the Russell Gulch syncline.

The Pewabic vein strikes nearly east-west and dips steeply to moderately north. Deflections of a few degrees in both strike and dip are common, however, as shown in plate 9 and figure 52 , and are accompanied by many splits and branches. In general, any curvature of the vein toward the south (pl. 9) tends to be accompanied by a series of westward-trending fissures that split out into the hanging wall, and a flattening of the vein (fig. 52) tends to be accompanied by a series of fractures that split out into the footwall.

The vein material is notably different on the upper and lower levels. Above the 4th level, the vein contained much soft clayey material referred to by the miners as talc ore, and below this level the vein consisted of the more common hard ore. The typical talc ore consists of argillized wallrock that contains abundant disseminated pyrite and considerable chalcocite. It is soft and locally can be gouged out with a pick. Typical hard ore, on the other hand, consists of breccia fragments of quartz and pyrite vein material cemented by dark-gray, fine-grained quartz containing considerable chalcopyrite, or of intergrown quartz, pyrite, and chalcopyrite.

Judging from assays given in the report by Billingsley, gold and silver concentrations were notably higher in the talc ore than in the hard ore. Assays of talc ore indicate that this material commonly contained 2 to 3 ounces of gold to the ton and 7 to 10 ounces of silver to the ton, whereas the hard ore contained less than half an ounce of gold per ton and low silver values. Records of ore shipments further indicate that the talc ore was the principal source of gold and silver, for $\$ 1,100,000$ of the $\$ 1,500,000$ production from the mine came from the workings above the 4 th level.

The principal ore shoot in the mine extends from the $2 \mathrm{~d}$ to the 9 th levels, and has an average stope length of 500 feet and a plunge length of about 550 feet (fig. 52). As the ore shoot occurs between walls of microcline-bearing gneiss, it is inferred that this competent wallrock was principally responsible for localizing the ore. Deflections in strike and dip may also have been partly responsible for localizing the ore, however. The vein occupies a left lateral fault and is widest where it strikes more northerly than normal (pl. 9) and is steeper than its average dip (fig. 52).

The following suggestions for prospecting were made by Billingsley in 1927. As the writers do not 

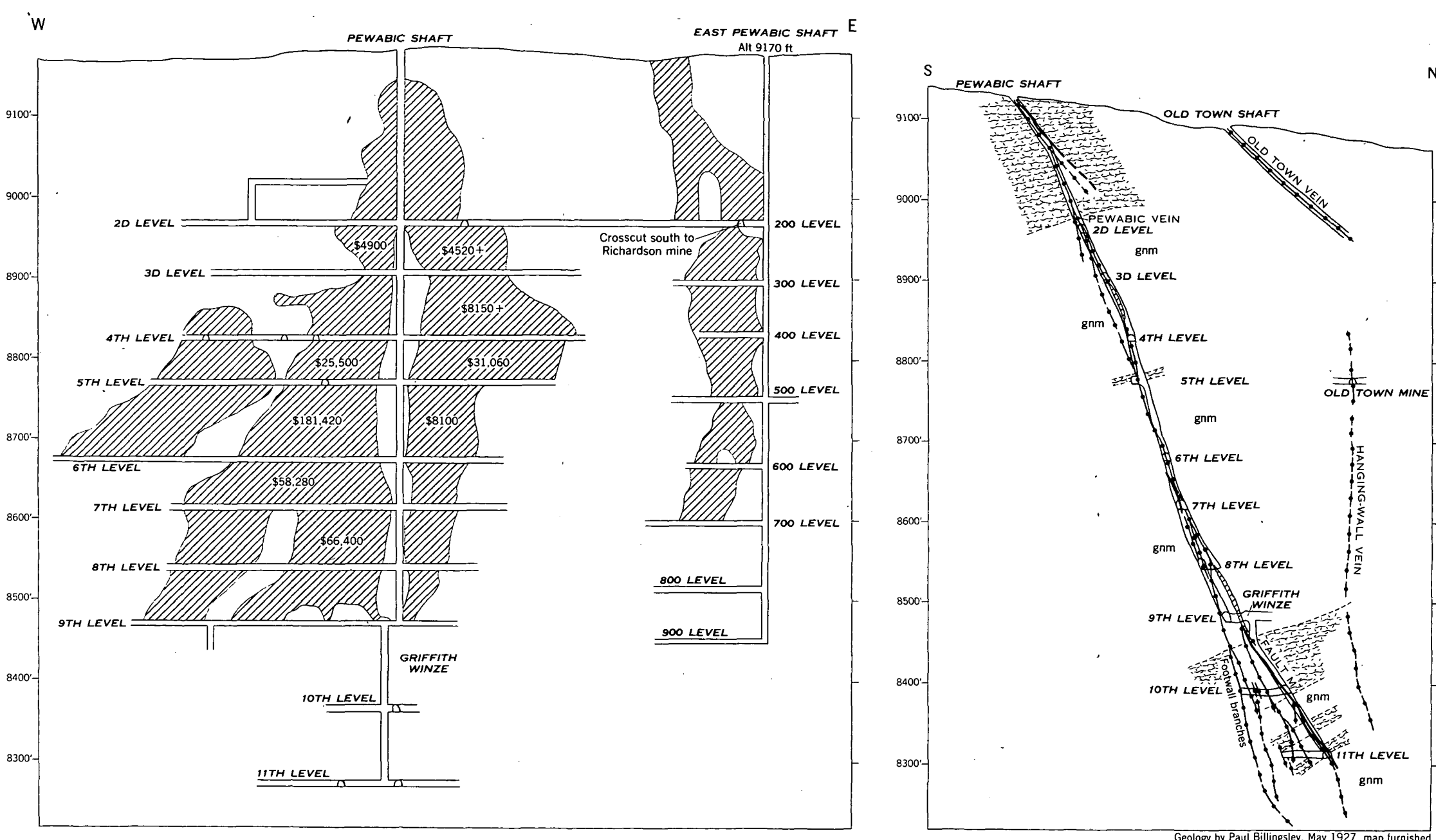
DATUM IS MEAN SEA LEVEL

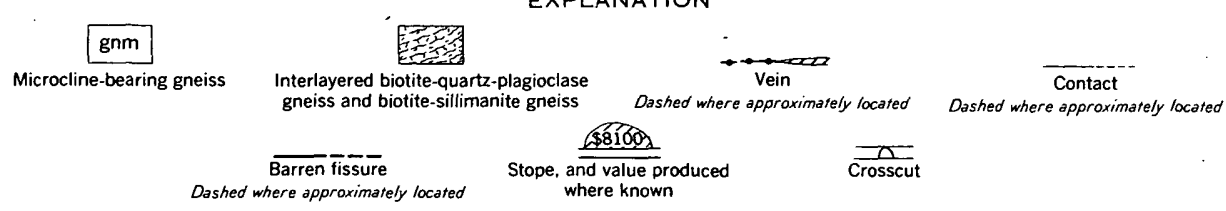

FIodrn 52.-Geologic section of the Pewabic shaft and tongitudinal section in the plane of the Pewabic vein, Pewabic and East Pewabic mines. 
know whether the mine owners carried out the recommendations, they are included in this report. It was suggested that part of the Pewabic vein that lies between the west breast of the 9th level and the Becky Sharp mine be tested. The vein in this area is between microcline-bearing gneiss walls, and it should be joined near the Becky Sharp mine by a flat northeastwardtrending branch vein coming in from the hanging wall. The 11th level should be extended to the west to cut the downward projection of the Pewabic ore shoot. The block of ground east of the Pewabic shaft should also be tested, perhaps by an extension of the 7th level. Only the $2 d$ level is driven east of the shaft for any distance, and it is largely in unfavorable biotite gneiss.

In addition to Billingsley's recommendations, the writers suggest that both the footwall and hanging wall of the tight parts of the vein be prospected by crosscuts as branch veins can be expected in these parts of the vein. Two such parallel veins were developed and stoped on the $3 \mathrm{~d}$ level of the mine (pl. 9), but little footwall exploration was done in other parts of the mine.

\section{RICHARDSON MINE (C-VI-18)}

The Richardson mine is on the south side of upper Russell Gulch, about 590 feet S. $76^{\circ}$ E. from the Old Town mine. The mine is opened by an inclined shaft, at least 400 feet deep, from which levels have been turned at depths of $30,130,200,300$, and 400 feet (figs. 46, 47). The 200 level connects with the 200 level of the East Pewabic mine; the 300 and 400 levels connect with the Iron mine. The extent and location of the stoping are shown on figure 47. The workings were all inaccessible in 1954 . The known production from the Richardson mine is given in table 54 ; this ore if produced today. would have a value of about $\$ 73,470$. Billingsley ${ }^{27}$ reports that the mine yielded ore worth $\$ 59,049$ prior to 1927 .

The Richardson vein strikes about N. $40^{\circ}$ E. and dips $65^{\circ}-80^{\circ} \mathrm{SE}$. It is a footwall branch of the Iron vein, and probably joins with the south vein developed in the East Pewabic mine. As exposed in a stope 20 feet east of the shaft on the 400 level, the vein consists of altered gneiss traversed by a network of irregular sulfide veinlets as much as 5 inches in width; these veinlets consist almost entirely of pyrite in crystals whose maximum dimension is $11 / 2$ inches (Bastin and Hill, 1917, p. 255). According to Bastin and Hill, the vein at this place assays about $\$ 7$ per ton, the coarse pyrite being characteristically of low grade. In other places, the vein must have contained chalcopyrite and (or) tennantite and some galena

\footnotetext{
" Blllingsley, Paul, 1927, op cit. $6548270-63-10$
}

TABLE 54.-Ore produced from the Richardson mine, 1902-54 ${ }^{1}$

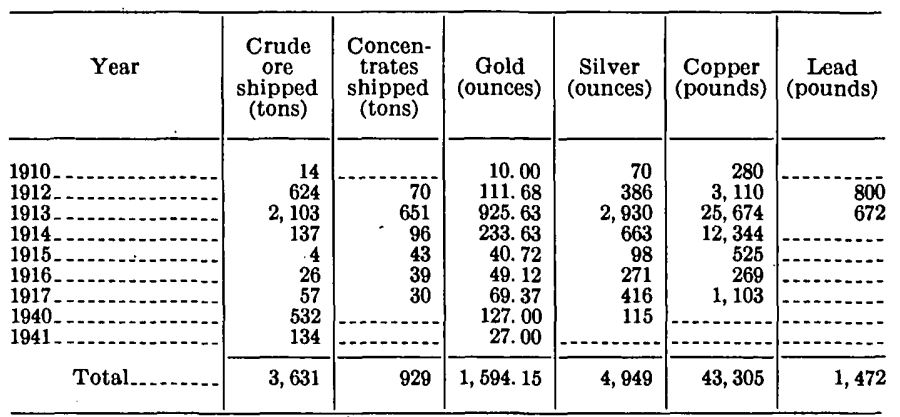

1 Compiled by U.S. Bureau of Mines. Published by permission.

(see table 54). It is inferred that the higher concentrations in gold and silver are in those parts of the vein that contain base-metal sulfides.

\section{ROCKY MOUNTAIN TERROR MINE (B-VI-28)}

Location.-On south side of upper Russell Gulch, about 1,850 feet S. $76^{\circ}$ E. from the Old Town mine.

Development.-Inclined shaft with 6 levels (fig. 50). Vein also developed by drifts at west ends of Old Town 4th and 10th levels (fig. 51).

Veins.-Rocky Mountain Terror (probably a branch of the Iron vein): Strike, nearly east; dip, moderate to the north.

Ore and sulfide minerals.-Pyrite, gold, silver, chalcopyrite, galena, sphalerite.

Gangue minerals.-Quartz.

Tenor--Shipments of 8,304 and 5,122 pounds of ore in 1898 showed respectively 1.74 ounces of gold and 8 ounces of silver per ton; and 1.9 ounces of gold and 8 ounces of silver per ton.

\section{RUSSELL VEIN}

The Russell vein, which crops out on the south side of upper Russell Gulch, is developed by 2 shafts, the Russell (B-VI-15) and the East Russell (B-VI-16). The East Russell shaft is about 730 feet. west of the Old Town mine. The Russell shaft is about 475 feet deep on the dip of the vein, and connects to 4 levels (fig. 53). The East Russell shaft connects to 2 levels; below the $2 \mathrm{~d}$ level the workings are on the Old Town vein, and connect to the Old Town 4th level (fig. 53). A 20-foot crosscut south from the Old Town 4 th level connects to a short drift on the Russell vein (fig. 53). These workings were all inaccessible in 1954, but Bastin and Hill (1917, p. 251) examined the mines; the following is largely taken from their description. The production from the Russell vein is given table 55. Most of the ore shipped in 1932 was sent to the Chain O'Mines mill, and the amount of metal recovered is not known.

The Russell vein trends about N. $70^{\circ} \mathrm{W}$. and dips steeply to the northeast. Vein material noted on the 


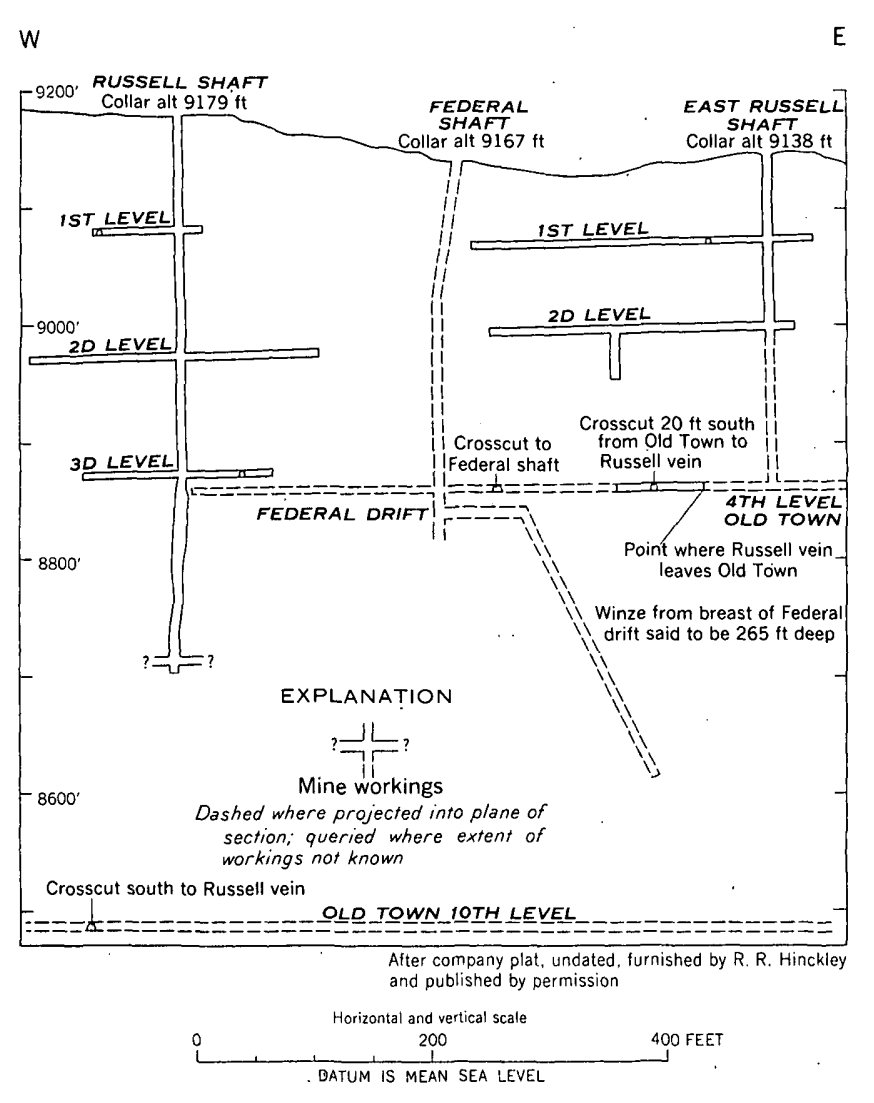

FrguRv 53.-Longitudinal section in the plane of the Russell vein, showing parts of the Old Town and Federal workings.

TABLE 55.-Ore produced from the Russell vein, 1902-54 ${ }^{\mathrm{t}}$

\begin{tabular}{|c|c|c|c|c|c|c|}
\hline Year & $\begin{array}{c}\text { Crude } \\
\text { ore } \\
\text { shipped } \\
\text { (tons) }\end{array}$ & $\begin{array}{c}\text { Concen- } \\
\text { trates } \\
\text { shipped } \\
\text { (tons) }\end{array}$ & $\begin{array}{c}\text { Gold } \\
\text { (ounces) }\end{array}$ & $\begin{array}{c}\text { Silver } \\
\text { (ounces) }\end{array}$ & $\begin{array}{c}\text { Copper } \\
\text { (pounds) }\end{array}$ & $\begin{array}{c}\text { Zinc } \\
\text { (pounds) }\end{array}$ \\
\hline 1904 1906 1908 & $\begin{array}{r}50 \\
100 \\
100 \\
21\end{array}$ & $\cdots$ & $\begin{array}{r}150.00 \\
18.77 \\
150.01 \\
2.00\end{array}$ & $\begin{array}{l}500 \\
188 \\
600\end{array}$ & 5,714 & \\
\hline $\begin{array}{l}1909 \\
1910 \\
19114 \\
1914\end{array}$ & $\begin{array}{r}680 \\
181 \\
184 \\
10\end{array}$ & $\begin{array}{c}150 \\
-1\end{array}$ & $\begin{array}{r}138.60 \\
78.13 \\
54.40 \\
1.28\end{array}$ & $\begin{array}{r}982 \\
880 \\
369 \\
6\end{array}$ & $\begin{array}{l}4,271 \\
1,946\end{array}$ & \\
\hline $\begin{array}{l}1915 \\
1923 \\
1924 \\
1925\end{array}$ & $\begin{array}{r}10 \\
80 \\
3 \\
1,200\end{array}$ & ( & $\begin{array}{r}9.37 \\
38.88 \\
2.03 \\
413.92\end{array}$ & $\begin{array}{r}35 \\
19 \\
11 \\
190\end{array}$ & $\begin{array}{c}362 \\
137\end{array}$ & $\begin{array}{l}-- \\
-- \\
--\end{array}$ \\
\hline $\begin{array}{l}1932 \\
1933 \\
1934\end{array}$ & $\begin{array}{r}3 \\
20 \\
\end{array}$ & $\begin{array}{r}11 \\
3 \\
\hdashline\end{array}$ & $\begin{array}{l}.89 \\
8.20 \\
4.19 \\
3.17\end{array}$ & $\begin{array}{r}6 \\
29 \\
12\end{array}$ & $\mid-\ldots+\cdots$ & 77 \\
\hline Total & 2,642 & 165 & $1,073.84$ & 3,827 & 12,430 & 77 \\
\hline
\end{tabular}

1 Compiled by U.S. Bureau of Mines. Published by permission.

dump is chiefly quartz and pyrite, but some chalcopyrite is present. As a little zinc was recovered from the ore (table 56), sphalerite must also be present locally in the vein. Abnormally radioactive vein material was noted on the Russell dump. Two samples of silicified, pyritized microcline-bearing gneiss analysed 0.007 and 0.014 percent equivalent uranium, and 0.001 and 0.000 percent $\mathrm{U}_{3} \mathrm{O}_{8}$ respectively. The uranium in these samples probably was leached by concentrated sulfate surface waters.

Smelting ore shipped from the vein in 1910 averaged 0.51 ounce of gold per ton, 6.23 ounces of silver per ton, and 1.41 percent copper. The metal content of ore shipped between 1907 and 1909 showed the following: gold, 0.32 to 3.22 ounces per ton; silver 2.00 to 10.75 ounces per ton, and copper 0 to 7.65 percent.

\section{SLIDE MINE (C-VI-12)}

Location.-On south side of upper Russell Gulch, about 1,900 feet east-northeast of the Old Town mine.

Production.-One shipment of 17 tons in 1912 contained 10.96 ounces of gold; 40 ounces of silver, and 510 pounds of copper.

Development.-Shaft more than 200 feet deep; 2 levels.

$V$ eins.-Slide, possibly the northeastward extension of the Lillian: Strike, N. $75^{\circ}$ E.; dip, $75^{\circ}$ NE. to $75^{\circ} \mathrm{SW}$.; 3 to 8 inches wide.

Wallrock.-Biotite-quartz-plagioclase gneiss and microcline-bearing gneiss.

Ore and sulfide minerals.-Pyrite, chalcopyrite, tennantite, gold, and silver.

Gangue minerals.-Quartz.

Tenor.-About 17 tons shipped in 1912 averaged 0.64 ounce of gold to the ton, 2.35 ounces of silver to the ton, and 1.5 percent copper. Richest ore may reach a value of $\$ 60$ per ton and contain up to 14 percent copper.

\section{SPRINGDALE (GOLD ROCK) MINE (A-VI-4)}

The Springdale mine is near the head of upper Russell Gulch, about 3,600 feet N. $83^{\circ}$ W. from the Old Town mine. The mine was opened in the early 1860 's, ${ }^{28}$ and was worked until sulfide ores were found. It was reopened in 1890 ; most of the present development dates from that time. Pitchblende was found on the dump in 1949, and the mine was reopened and partly rehabilitated in 1952 .

The known production from the mine is given in table 56. The mine is reported to have yielded ore that sold for $\$ 150,000$ prior to 1899 (Callbreath, 1899, p. 299). Some pitchblende was mined, but probably was discarded.

The property is opened by a nearly vertical, 685-foot shaft from which 7 levels and 4 sublevels have been turned (fig. 54). The extent and location of the stoping are shown on figure 54. In 1953, only parts

28 Farish, W A, 1S97, Report on the Springdale or Gold Rock mine, 4 p., report on file in the Denver Public Library, Denver, Colo. 
TABLE 56.-Ore produced from the Springdale mine, 1902-54'

\begin{tabular}{|c|c|c|c|c|c|c|c|}
\hline Yrar & $\begin{array}{l}\text { Crude } \\
\text { ore } \\
\text { shinped } \\
\text { (tons) }\end{array}$ & $\begin{array}{c}\text { Concen- } \\
\text { trates } \\
\text { shipped } \\
\text { (tons) }\end{array}$ & $\begin{array}{c}\text { Cold } \\
\text { (ounces) }\end{array}$ & $\begin{array}{c}\text { Silver } \\
\text { (ounces) }\end{array}$ & $\begin{array}{l}\text { Copper } \\
\text { (pounds) }\end{array}$ & $\begin{array}{l}\text { Lead } \\
\text { (pounds) }\end{array}$ & $\begin{array}{c}\text { Zinc } \\
\text { (pounds) }\end{array}$ \\
\hline $1907 \ldots . .$. & & & $\begin{array}{l}5.78 \\
1.31\end{array}$ & $\frac{1}{5}$ & & & \\
\hline $\begin{array}{l}1912 \ldots . \\
1012 \ldots\end{array}$ & 156 & $x_{0}$ & $\begin{array}{r}1.31 \\
26.65 \\
3.62\end{array}$ & $\begin{array}{l}55 \\
18\end{array}$ & & & \\
\hline $1913 \ldots$ & 88 & & 4.50 & & & & \\
\hline $\begin{array}{l}1914 \ldots \ldots . \\
1915\end{array}$ & $34^{7}$ & & $\begin{array}{r}7.54 \\
27.80\end{array}$ & $\begin{array}{l}20 \\
94\end{array}$ & & & \\
\hline 1917. & 59 & ....... & 65.70 & 510 & 2,091 & & \\
\hline $\begin{array}{l}1920 \ldots \\
1020 \ldots\end{array}$ & & 45 & $\begin{array}{l}65.97 \\
42.82\end{array}$ & $\begin{array}{l}494 \\
310\end{array}$ & $\begin{array}{r}2,727 \\
696\end{array}$ & 584 & 200 \\
\hline 1021 & 78 & & 71. 38 & 362 & 1,298 & & \\
\hline & 1 & 7 & $\begin{array}{l}6.75 \\
.84\end{array}$ & $\begin{array}{l}43 \\
14\end{array}$ & 286 & & \\
\hline & 10 & $\cdots$ & 6. 94 & 117 & 460 & $\ldots$ & 651 \\
\hline & & & & & & & \\
\hline Total.. & 725 & 50 & 339.30 & 2,057 & 7,558 & 584 & 1,375 \\
\hline
\end{tabular}

I Compiled by U.S. Bureau of Mines. Published by permission.

of the $2 \mathrm{~d}, 3 \mathrm{~d}, 4 \mathrm{th}, 5$ th, and 6 th levels were accessible for study by the writers.

The collar of the shaft is in biotite-quartz-plagioclase gneiss. Microcline-bearing gneiss is cut about 20 feet below the $2 \mathrm{~d}$ level (fig. 55) and is the dominant wallrock below this point (pl. 10). These Precambrian rocks are intruded by a dike of bostonite porphyry.

The Springdale mine is on the northwest flank of the Central City anticline, about 100 feet from the axis. The rocks, in general, dip moderately to the northwest, but locally they are deformed by northward-trending cross warps. The bostonite porphyry

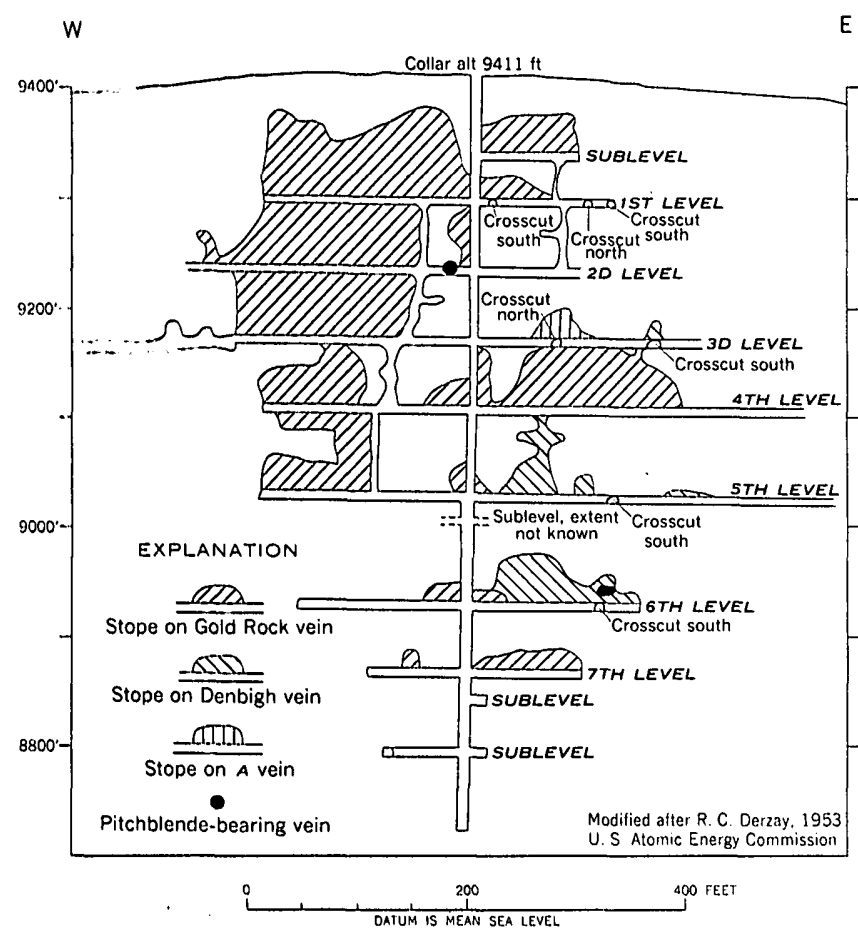

Froure 54,-Vertical longltudinal section of the Springdale mine.

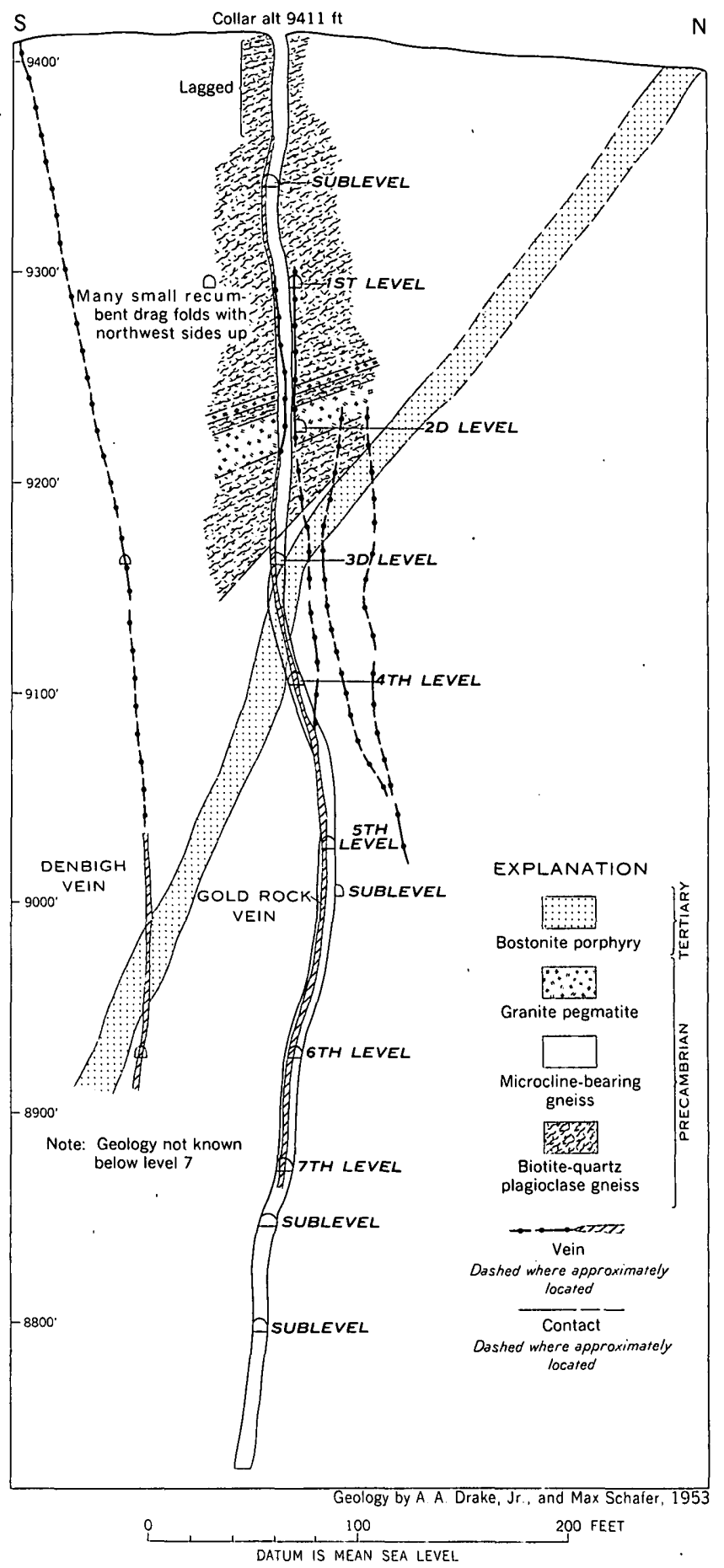

FIGURE 55.-Geologic section of the Springdale shaft.

dike has an average trend of $N$. $70^{\circ}$ E., and above the microcline-bearing gneiss-biotite-quartz-plagioclase gneiss contact the dike dips steeply south. As the dike approaches the contact, however, it flattens in dip and tends to be parallel to the contact. 
The Springdale mine develops the Gold Rock and the Denbigh veins, and a hanging-wall vein named in this report vein $A$.

The Gold Rock vein in the western part of the mine varies in strike from eastward to N. $60^{\circ}$ E. It dips steeply either side of vertical; major reversals in dip occur on the $3 \mathrm{~d}$ and 5 th levels (fig. 55). On the 5th level (pl. 10) the Gold Rock vein cuts and offsets the Denbigh vein, the apparent displacement of the north segment being 23 feet to the west. On the 4th level the north segment of the bostonite porphyry dike has been shifted a few feet to the west along the vein. The Gold Rock vein is largely filled with gouge that contains disseminated pyrite and sparse chalcopyrite. The richer parts of the vein show 2 to 3 feet of strongly altered wallrock containing disseminated pyrite and cut by several $1 / 2$ - to 4 -inch stringers of quartz and pyrite; the quartz-pyrite stringers are in turn cut by $1 / 8$ - to 2 -inch stringers of galena, sphalerite, and chalcopyrite. One uranium-bearing pod was found in the vein on the $2 \mathrm{~d}$ level, about 12 feet west of the shaft (fig. 54). The uranium mineral (pitchblende?) in this pod is black and occurs as sooty encrustations on fractures in the vein.

Judging from figure 54, the principal ore shoot in the Gold Rock vein is west of the shaft. It plunges nearly vertically and has been exploited over a plunge length of 350 feet. Some stopes are on the vein east of the shaft (fig. 54), but no definite ore shoot is suggested by their outline.

The Gold Rock vein is a pyrite vein, type $C$. Copper is more abundant, however, than in many veins of this type. Chalcopyrite is the main copper mineral, but sparse tennantite also is present. At least some chalcopyrite is earlier in the paragenetic sequence than sphalerite; it is both veined and corroded by the sphalerite.

The Denbigh vein strikes N. $60^{\circ}$ E., dips steeply either side of vertical; and ranges in width from 2 inches to about 4 feet. It has been developed from the Denbigh shaft (A-VI-5) westward to the Pendleton shaft (B-VI-7) and eastward for about 2,500 feet. On the 5th level in the Springdale mine, the vein follows the hanging-wall contact of the bostonite porphyry dike for some distance. Here, the vein consists largely of milky-white to gray, fine-grained quartz that is cut by $1 / 16^{-}$to 4 -inch stringers of pyrite. The quartz-pyrite vein is crosscut by $1 / 8$ - to 4 -inch stringers of galena, sphalerite, chalcopyrite, and tennantite. Pitchblende, found 15 feet up in a stope above the 6th level (fig. 54), occurs in a pod that has a stope length of 10 to 12 feet. Within the pod, the pitchblende fills $1 / 2$ - to 4 -inch discontinuous veinlets on the southeast wall of the vein. The pitchblende veinlets are cut by base-metal veinlets.

Stopes on the Denbigh vein are known to be present on the $3 \mathrm{~d}$, 5th, and 6th levels (fig. 54).

Vein $A$, parallel to and north of the Gold Rock vein, consists of a series of imbricating, subparallel, mineralized fractures that contain the same ore minerals as the Gold Rock vein. It is exposed on the $2 \mathrm{~d}, 3 \mathrm{~d}$, and 4 th levels of the mine (pl. 10). One stope is present on the vein above the $3 \mathrm{~d}$ level, in the accessible workings. Farish ${ }^{29}$ reports that much of the work done before 1890 was done on the oxidized ores of this vein, principally near the west end line of the claims. This work was probably done through 2 small shafts that are 170 and 250 feet west of the Springdale shaft.

Sampling-works assay of small lots of ore shipped from the mine between 1920 and 1934 show gold, 0.25 to 3.34 (average about 1.00 ) ounces per ton; silver, 2.28 to 20.77 (average about 10.00) ounces per ton; copper, 0 to 4.37 percent; lead, 0 to 7.03 percent; and zinc, 0 to 15 percent. The source of the ore shipments is not known.

\section{WILLIS GULCH AND LOWER RUSSELL GULCH AREAS}

The Willis Gulch and lower Russell Gulch areas include the mines in and adjacent to Willis, lower Russell, South Willis, and Hangman Gulches. Several of the mines are large and many have been substantial ore producers; nearly all were inaccessible in 1954.

Although most of the veins are pyrite veins, several contain enargite and the unusual gold tellurides. (See p. 37-38). Sparse molybdenite and wolframite have been noted at two localities. The silver-gold ratio is exceptionally high in the ores from many veins, particularly the Powers, Silver Dollar, and Kokomo; and copper is more abundant in some veins than in other parts of the district. Pitchblende is present in the Bonanza mine, on Justice Hill, and in the Cherokee and Little Annie mines, on Banta Hill (Sims and others, 1963). Quartz is the chief gangue mineral, but rhombohedral carbonate minerals and colorless, purple, and green fluorite occur in some veins.

Biotite gneiss and granite pegmatite, and locally migmatite, are the major rock types of the area. The Precambrian rocks are cut by many dikes and small plutons of quartz monzonite porphyry, granodiorite porphyry, and bostonite porphyry.

The Precambrian rocks throughout most of the area have a prevailing southeastward dip, but they

${ }^{29}$ Farish, W. A., 1897, op. cit. 
are folded into many small, open anticlines and synclines. Southeast of Justice Hill the rocks are tightly folded along northeastward-trending axes, and the dips are nearly vertical.

\section{ACE IN THE HOLE MINE (F-V-21)}

Location.-About 500 feet north-northeast of the Bonanza tunnel.

Production.-About 41/2 tons of crude ore shipped from 1931 to 1933 contained a total of 5.1 ounces of gold and 14 ounces of silver. (Compiled by U.S. Bureau of Mines. Published by permission.)

Development.-Shaft, nearly vertical; reported to be at least 100 feet deep with 100-foot drifts to the northeast and southwest at the 100 level.

Vein.-Strike, N. $70^{\circ}$ E.; dip, $60^{\circ} \mathrm{NW}$. to vertical.

Ore and sulfide minerals.-Pyrite and sparse galena on dump.

\section{ALVA ADAMS MINE (E-V-10)}

Location.-On south side of lower Russell Gulch, about 1,830 feet S. $64^{\circ} \mathrm{W}$. from the Pittsburg mine.

Development.-A 375-foot shaft and 1,800 feet of drifts.

Production.-About $\$ 50,000$ prior to 1899 (Callbreath, 1899); 3 tons of smelting ore and 14 tons of concentrates that contained 13.86 ounces of gold, 39 ounces of silver, and 55 pounds of copper were shipped from 1902 to 1954. (Compiled by U.S. Bureau of Mines. Published by permission.)

Veins.-Alva Adams: Strike, N. $60^{\circ}$ E.; dip $60^{\circ}$ $70^{\circ} \mathrm{NW}$; apparently is the southwest continuation or a branch of the Argo vein.

Wallrock.-Biotite-quartz-plagioclase gneiss and granite pegmatite.

Ore and sulfide minerals.-Pyrite, gold, silver, chalcopyrite, tennantite, and enargite.

Gangue minerals.-Quartz.

Tenor.-Average grade shipped prior to 1902 was about 0.5 ounce of gold and 3 ounces of silver per ton.

\section{ANCHOR MINE (E-VI-1)}

The Anchor mine is on the south side of Willis Gulch, near its intersection with South Willis Gulch, about 1,470 feet $\mathrm{S} .52^{\circ} \mathrm{W}$. from the War Dance mine (E-V-23). The property was opened about 1890 but was closed prior to 1902 ; it was again open from 1907 to 1911 . Since 1911 leasers have shipped small quantities of ore intermittently from the mine. It was last operated in 1945. The known production from the property since 1902 is given in table 57 ; this ore if produced today would have a value of about $\$ 285,500$. The mine is opened by a shaft that was 500 feet deep on the incline in 1912; the extent of the other work- ings is not known as the mine was inaccessible in 1954. Bastin and Hill (1917, p. 274-275) did not gain access to the property, but they give a good description of the ore; the following is largely taken from their description.

The Anchor vein strikes about N. $80^{\circ}$ E. and dips $45^{\circ}-65^{\circ}$. (average $50^{\circ}$ ) N. The eastward extension of the vein appears to swing toward a northeastward trend, and may be the same vein developed by the Silver Dollar or possibly the Powers mine on the north side of Willis Gulch. The most abundant type of ore on the dump consists of white to dark-gray quartz and pyrite. Another common type consists of white quartz, white to pale-purple fluorite, and pyrite. Some specimens show abundant finely divided molybdenite associated with quartz, fluorite, and pyrite. Other specimens show abundant enargite intergrown with pyrite and fluorite. Significant galena and sphalerite were present in the ore shipped (table 57), but their relation to other minerals was not seen in specimens. The average metal content of the smelting ore shipped in 1910 was gold, 0.44 ounce per ton; silver, 12.8 ounces per ton; copper, 0.2 percent; and lead, 3.2 percent.

\begin{tabular}{|c|c|c|c|c|c|c|c|}
\hline Year & $\begin{array}{c}\text { Crude } \\
\text { ore } \\
\text { shipped } \\
\text { (tons) }\end{array}$ & $\begin{array}{c}\text { Concen- } \\
\text { trates } \\
\text { shipped } \\
\text { (tons) }\end{array}$ & $\begin{array}{c}\text { Gold } \\
\text { (ounces) }\end{array}$ & $\begin{array}{c}\text { Silver } \\
\text { (ounces) }\end{array}$ & $\begin{array}{c}\text { Copper } \\
\text { (pounds) }\end{array}$ & $\begin{array}{c}\text { Lead } \\
\text { (pounds) }\end{array}$ & $\begin{array}{c}\text { Zinc } \\
\text { (pounds) }\end{array}$ \\
\hline $\begin{array}{l}1907 \ldots \\
1908 . \\
1909 \\
1910 \ldots \\
1911 . .\end{array}$ & $\begin{array}{r}150 \\
1,500 \\
2,925 \\
1,148 \\
1,146\end{array}$ & $\begin{array}{r}240 \\
450 \\
45\end{array}$ & $\begin{array}{r}55.00 \\
339.98 \\
772.00 \\
405.43 \\
200.20\end{array}$ & $\begin{array}{r}2,500 \\
29,400 \\
17,650 \\
11,051 \\
6,931\end{array}$ & $\begin{array}{r}4,800 \\
6,000 \\
9,600 \\
4,800 \\
53,274\end{array}$ & $\begin{array}{r}33,000 \\
150,000 \\
126,000 \\
10,923\end{array}$ & \\
\hline $\begin{array}{l}1916 \ldots . . \\
1917 \ldots \ldots \\
1926 . \\
1933 \ldots \\
1934 \ldots \\
\end{array}$ & $\begin{array}{r}4 \\
19 \\
21 \\
363\end{array}$ & $\begin{array}{l}5 \\
9\end{array}$ & $\begin{array}{r}2.48 \\
21.48 \\
1.02 \\
10.58 \\
107.52\end{array}$ & $\begin{array}{r}23 \\
112 \\
147 \\
172 \\
3,290\end{array}$ & 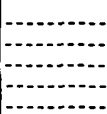 & $\begin{array}{l}1,223 \\
7,814 \\
3,190\end{array}$ & 3,298 \\
\hline $\begin{array}{l}1935 \ldots \ldots \\
1936 \ldots \\
1940 \\
1941 \ldots \\
1942 . \\
\end{array}$ & $\begin{array}{r}719 \\
45 \\
2 \\
29 \\
411\end{array}$ & \begin{tabular}{r}
138 \\
474 \\
\hdashline 4 \\
55
\end{tabular} & $\begin{array}{r}325.95 \\
295.81 \\
1.60 \\
9.21 \\
73.73\end{array}$ & $\begin{array}{r}9,680 \\
11,119 \\
146 \\
239 \\
2,003\end{array}$ & $\begin{array}{r}3,377 \\
14,905 \\
206 \\
137 \\
2,050\end{array}$ & $\begin{array}{r}33,084 \\
66,218 \\
889 \\
1,715 \\
18,259\end{array}$ & $\begin{array}{r}13,563 \\
1,071\end{array}$ \\
\hline $\begin{array}{l}1943 \\
1945\end{array}$ & $\begin{array}{r}421 \\
50\end{array}$ & $\begin{array}{r}67 \\
9\end{array}$ & $\begin{array}{l}67.28 \\
11.00\end{array}$ & $\begin{array}{r}2,620 \\
80\end{array}$ & $\begin{array}{r}1,936 \\
223\end{array}$ & $\begin{array}{r}17,313 \\
5,098 \\
\end{array}$ & 10,619 \\
\hline Total. & 8,953 & 1,507 & $2,700.27$ & 97,163 & 101,308 & 474,726 & 23,968 \\
\hline
\end{tabular}

1 Compiled by U.S. Bureau of Mines. Published by permission.

ARGO MINE (E-V-1)

The Argo mine is on the south side of lower Russell Gulch, about 1,020 feet, S. $59^{\circ} \mathrm{W}$. from the Pittsburg mine. The property was probably opened about 1880 , and was last worked in 1933 . The known production from the Argo mine is given in table 58; this ore if produced today would have a value of about $\$ 25,000$.

The mine is opened by a 340-foot shaft with short levels at depths of $150,200,265$, and 340 feet. These workings were inaccessible in 1954, but Bastin and 
TABLE 58.-Ore produced from the Argo mine, 1902-54 ${ }^{1}$

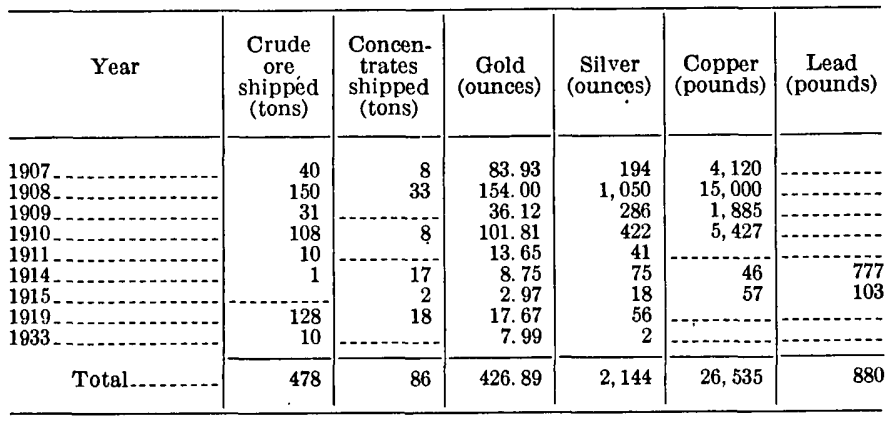

1 Compiled by U.S. Bureau of Mines. Published by permission.

Hill (1917, p. 260-261) examined the property; the following is taken from their description.

The Argo vein strikes about N. $87^{\circ}$ E. and dips $55^{\circ}-70^{\circ} \mathrm{NW}$. It ranges from a single, tight, barren fracture to a well-mineralized fracture zone 2 feet in width. The richer parts of the vein commonly consist of solid veinlets and lenses of pyrite as much as 6 inches wide in altered and pyritized wallrock. On the 200 level west the vein splits into nearly parallel hanging wall and footwall branches.

Pyrite, coarsely crystalline in places, is the principal vein mineral; it is locally associated with chalcopyrite, enargite, tennantite, and a little galena. The richest ore consists of tennantite, chalcopyrite, and enargite. The pyrite ore seldom contains more than 0.12 ounce of gold per ton.

Shipments of 30 tons of smelting ore between 1889 and 1908 contained gold, 0.50 to 5 (average 2.39) ounces per ton; silver, 2.5 to 12.13 (average 7.31) ounces per ton; and copper, 2.1 to 16 percent. The average value of the smelting ore shipped in 1910 was gold, 1.18 ounces per ton; silver, 5 ounces per ton; and copper, 6.1 percent.

\section{AURORA MINE (D-V-7)}

The Aurora mine, on the north side of Russell Gulch, about 2,550 feet $\mathrm{S}$. $75^{\circ} \mathrm{W}$. from the Pittsburg mine, was probably opened about 1880 and was worked until 1912. The property was reopened and worked for a short period in 1941 . The known production from the mine is given in table 59; this ore if produced today would be worth about $\$ 89,000$, gold and copper accounting for all but $\$ 4,000$. The property probably had a sizable production prior to 1909, but the amount is not known; the $1902-09$ production is combined with that from the East Notaway mine.

The mine is opened by a 578-foot, nearly vertical shaft from which levels have been turned at depths of $85,183,258,316,392$, and 501 feet. All these workings were inacessible in 1954 , but the mine was examined by Bastin and Hill (1917, p. 259-260); the
TABLE 59.-Ore produced from the Aurora mine, 1909-541

\begin{tabular}{|c|c|c|c|c|c|}
\hline Year & $\begin{array}{l}\text { Crude ore } \\
\text { shipped } \\
\text { (tons) }\end{array}$ & $\begin{array}{l}\text { Concen- } \\
\text { trates } \\
\text { shipped } \\
\text { (tons) }\end{array}$ & $\begin{array}{c}\text { Gold } \\
\text { (ounces) }\end{array}$ & $\begin{array}{c}\text { Silver } \\
\text { (ounces) }\end{array}$ & $\begin{array}{c}\text { Copper } \\
\text { (pounds) }\end{array}$ \\
\hline $\begin{array}{l}1909 \\
1910 \\
1911 \\
1912\end{array}$ & $\begin{array}{r}184 \\
313 \\
1,296 \\
280 \\
\end{array}$ & $\begin{array}{r}24 \\
27 \\
116 \\
20 \\
4\end{array}$ & $\begin{array}{r}110.55 \\
235.17 \\
756.35 \\
153.96 \\
11.00\end{array}$ & $\begin{array}{r}202 \\
565 \\
2,913 \\
398 \\
5\end{array}$ & $\begin{array}{r}4,740 \\
20,540 \\
103,429 \\
4,770 \\
285\end{array}$ \\
\hline Total & 2,073 & 191 & $1,267.03$ & 4,083 & 133,764 \\
\hline
\end{tabular}

1 Production prior to-1909 combined with East Notaway mine. Compiled by U.S. Bureau of Mines. Published by permission.

following discussion is taken largely from their description.

The mine develops a part of two nearly parallel veins, the North or Aurora vein and the South vein. These veins have near easterly strikes and dip steeply either side of vertical. They appear to converge from the surface to the 258 level, where they are 10 feet apart, and thence to diverge. The shaft follows the North vein down to the 258-level; below this depth there are two shafts, one which follows the North vein and the other the South vein.

The North vein, which was discovered by placer miners working in Russell Gulch, is possibly the west extension of the Pittsburg vein. For about 100 feet below the surface it dips steeply south, and below that point it dips about $70^{\circ} \mathrm{N}$. The vein is well exposed on the 180 level where it has been followed 280 feet east and 300 feet west, of the shaft. It is a true fissure vein showing one or more stringers of pyrite and white quartz in a width of several feet of altered wallrock. The richer ores also contain much chalcopyrite and tennantite.

The South vein is exposed in a short crosscut from the 183 level east and on all lower levels. On the 183 level the vein dips $60^{\circ} \mathrm{N}$. and where widest (maximum width of 4 feet) shows a network of pyrite veinlets. Many parts of the South vein are low in grade, such as the above-mentioned exposure on the 183 level, where it assayed only 0.3 ounce in gold and less than 2 ounces of silver. Very good ore was also present. On the 258 level, just west of the shaft, ore yielded $\$ 112$ per ton; ore in the sill of the 316 level had an average content of 1.2 ounces of gold, 4 ounces of silver, and 4 percent copper. Ore from the 392 level assayed $\$ 95$ to $\$ 125$ per ton.

Free gold, in places forming small nuggets, was abundant in the oxidized ore of the veins above the $2 \mathrm{~d}$ level, and was found in small amounts in unoxidized ore to the greatest depths to which the veins have been worked. In a specimen from the 392 level the gold is irregularly associated with pyrite, tennantite, and quartz and is probably a primary mineral; 
at one point on this level free gold was found in a narrow watercourse which entered the vein from the north wall. It formed small veins and grains upon quartz crystals and was clearly later than the quartz and probably later than the pyrite.

\section{BONANZA MINE (F-V-18)}

Location.-On Justice Hill.

Production.-1912-54, 58.23 ounces of gold, 279 ounces of silver, 5,089 pounds of lead, 216 pounds of copper, and 198 pounds of zinc. In $1954,6.64$ tons of pitchblende ore that contained 71.69 pounds of $\mathrm{U}_{3} \mathrm{O}_{8}$ was shipped. (Published by permission of the owners of the Bonanza mine.)

Development.-Shaft, inclined steeply south, connects to levels at vertical depths of $64,78,100$, and 170 feet; the 64 level is an adit level (F-V-19).

Veins.-Bonanza: Strike, N. $70^{\circ}$ E.; dip, $60^{\circ}-80^{\circ}$ SE. Shamrock: Strike, N. $45^{\circ}$ E.; dip, $70^{\circ}$ NW. to vertical. Veins intersect at shaft on adit level.

Wallrock.-Interlayered biotite gneisses and pegmatite.

Ore and sulfide minerals.-Pyrite, chalcopyrite, sphalerite, gaiena, and pitchblende.

Gangue minerals.-Quartz.

\section{CHASE MINE (E-V-20)}

The Chase mine, on the ridge between lower Russell Gulch and Willis Gulch, about 1,000 feet N. $77^{\circ} \mathrm{W}$. from the War Dance mine, was opened in the early 1860 's ${ }^{30}$ and was last worked in 1941. The known production from the Chase mine since 1902 is given in table 60 ; this ore if produced today would have a value of about $\$ 308,000$. The property reportedly yielded $\$ 200,000$ before 1899 (Callbreath, 1899, p. 241).

The mine is opened by the Chase $(\mathrm{E}-\mathrm{V}-20)$ and Pullman (E-V-21) shafts. The Chase shaft is 500 feet deep and connects with 8 levels; the Pullman shaft connects with the 250 level through a stope (fig. 56). Extensive stopes are present on all levels; their locations are shown on figure 56. All the workings were inaccessible in 1954. Bastin and Hill (1917, p. 275-276) examined the mine and made a geologic map of the 300 and 400 levels. Most of the following is taken from their description.

Biotite-quartz-plagioclase gneiss is the dominant wall rock of the mine. Leucocratic granodiorite porphyry is exposed on the surface north of the shaft, in many places on the 400 level, and less abundantly on the 300 and 500 levels.

At least three veins are developed by the mine: the Chase, the Bosen Plume, and the Decatur. The principal development is on the Chase vein, which strikes about $\mathrm{N} .50^{\circ}$ E. and dips steeply either side

${ }^{30}$ Alsdorf, P. R., 1926, Report on the Chase Consolidated Mines Company, 5 p., report on fle in the Denver Public Library, Denver, Colo.

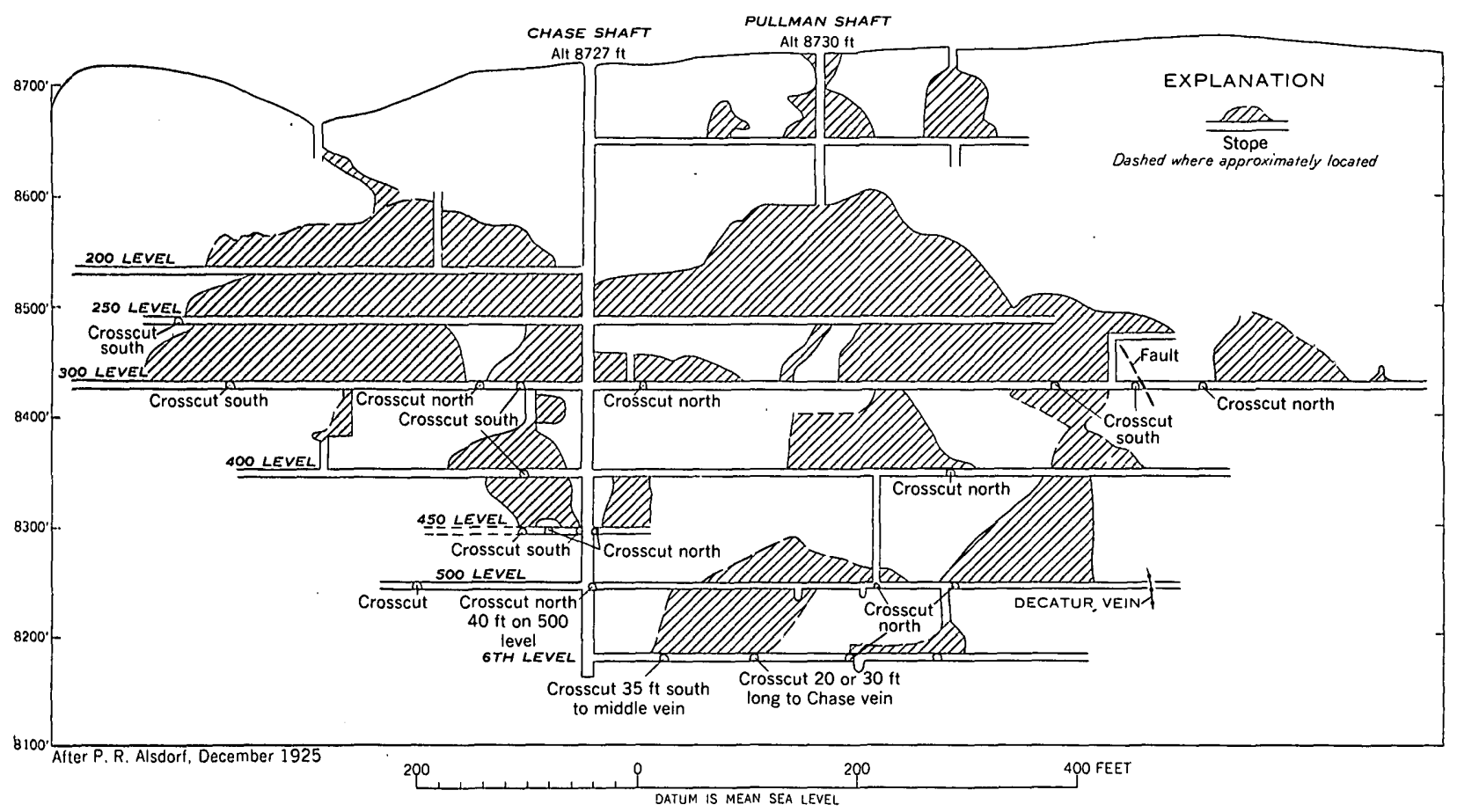

Frourd 56.-Vertical longitudinal section of the Chase mine. 
TABLE 60.-Ore produced from the Chase mine, 1902-54 ${ }^{1}$

\begin{tabular}{|c|c|c|c|c|c|c|c|}
\hline Year & $\begin{array}{c}\text { Crude } \\
\text { ore } \\
\text { shinped } \\
\text { (tons) }\end{array}$ & $\begin{array}{c}\text { Concen- } \\
\text { trates } \\
\text { shipped } \\
\text { (tons) }\end{array}$ & $\begin{array}{c}\text { Gold } \\
\text { (ounces) }\end{array}$ & $\begin{array}{l}\text { Silver } \\
\text { (ounces) }\end{array}$ & $\begin{array}{l}\text { Copper } \\
\text { (pounds) }\end{array}$ & $\begin{array}{c}\text { Lead } \\
\text { (pounds) }\end{array}$ & $\begin{array}{c}\text { Zinc } \\
\text { (pounds) }\end{array}$ \\
\hline 1904. & & $\cdots-$ & $1,184.00$ & $\begin{array}{r}296 \\
5098\end{array}$ & & & \\
\hline $\begin{array}{l}1906- \\
1906-\end{array}$ & 垔, 990 & $\cdots$ & $\begin{array}{l}1,555.01 \\
\end{array}$ & 5,615 & & & \\
\hline $\begin{array}{l}1907 \ldots \\
1908 . .\end{array}$ & $\begin{array}{r}500 \\
86\end{array}$ & $\cdots$ & $\begin{array}{l}720.01 \\
123.61\end{array}$ & $\begin{array}{r}2,000 \\
374\end{array}$ & & & \\
\hline & 145 & 22 & 124. 82 & 336 & & & \\
\hline $\begin{array}{l}1910 . \\
1911 .\end{array}$ & $\begin{array}{l}255 \\
337\end{array}$ & 10 & $\begin{array}{l}545.95 \\
842.10\end{array}$ & $\begin{array}{l}1,333 \\
1,564\end{array}$ & 612 & & \\
\hline $\begin{array}{l}1912 \\
1913\end{array}$ & $\begin{array}{r}314 \\
62\end{array}$ & $\cdots$ & $\begin{array}{l}565.68 \\
121.52\end{array}$ & $\begin{array}{r}1,496 \\
298\end{array}$ & $\begin{array}{r}204 \\
67\end{array}$ & & \\
\hline 1017 & 65 & 77 & 213.10 & 936 & 1,126 & 590 & \\
\hline 1018 & 92 & 23 & $\begin{array}{l}147.22 \\
1710\end{array}$ & $\begin{array}{c}693 \\
75\end{array}$ & 1,166 & 796 & \\
\hline $1033=$ & 20 & & 13.40 & 2 & 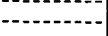 & 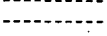 & 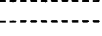 \\
\hline 1934_-..... & & & & & & & \\
\hline 1935-- & $\cdots-$. & $\begin{array}{r}1 \\
59\end{array}$ & $\begin{array}{r}1.82 \\
91.60\end{array}$ & $\begin{array}{r}2 \\
143\end{array}$ & & & 700 \\
\hline 183 & & 94 & $\begin{array}{r}114.00 \\
114.00\end{array}$ & & $\cdots$ & 87 & \\
\hline & & 233 & 242.00 & 257 & & & \\
\hline 194 & $\cdots$ & & 72.00 & & 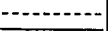 & --- & - \\
\hline Total.. & 4,919 & 614 & $8,217.16$ & 20,825 & 3,175 & 1,473 & 700 \\
\hline
\end{tabular}

1 Compiled by U.S. Bureau of Mines. Published by permission.

of vertical. At places it is narrow and barren, but commonly it is ore-bearing, as in an exposure on the 300 level, about 240 feet east of the shaft, where the vein contains 6 inches of coarse pyrite and some white quartz; the walls contain disseminated pyrite in decreasing amounts for about 6 inches from the vein. In stopes above the 500 level the vein is 8 to 12 inches wide and consists largely of coarse pyrite crystals, some of which are 2 inches across. Purple and green fluorite are abundant in places and tenantite is locally present. At places the pyrite filling is traversed by. $1 / 2^{-}$to 1-inch stringers of galena and sphalerite. On the 300 level, east of the shaft, the vein is intersected by a northwestward-trending cross fault; the east segment of the Chase vein apparently has been shifted a few feet to the north along this cross fault. A series of mineralized cross fractures that almost parallel the cross fault and dip $40^{\circ}-65^{\circ} \mathrm{NE}$. are exposed in the 300 and 400 levels, respectively 450 and 500 feet east of the shaft. The best ore shoot in the mine was found in the area of these cross fractures. It appears that the Chase mine exploited two ore shoots, one east of the shaft, and one west of the shaft; both ore shoots plunge moderately to the east (fig. 56). The factors responsible for localization of the ore shoots are not known; however, they are nearly parallel to the intersection of the Chase vein and the cross fractures.

The Bosen Plume vein is developed-by a short drift west of the shaft on the 300 level, and probably was developed on the lower levels of the mine. The vein strikes $\mathrm{N}$. $75^{\circ} \mathrm{W}$., dips $80^{\circ} \mathrm{SW}$., and is cut and offset by the Chase vein, its southeast segment being shifted a few feet to the northeast. The vein consists of 1 to 7 inches of coarse pyrite and white quartz with sparse enargite.

The Decatur vein is developed on the 300 level by a 340-foot crosscut and a short drift north of the Chase vein. It strikes about N. $70^{\circ}$ E., stands nearly vertical, and probably intersects the Chase vein east of the farthest development on the 300 level. It consists of 3 feet of coarse pyrite and quartz bordered by walls of sericitized rock that contains disseminated pyrite, and is traversed by several pyrite stringers. Movement along the vein after mineralization has locally produced 2 to 3 inches of gouge and crushed the pyrite.

Sampling-works assays of 193 tons of ore shipped from the mine between 1893 and 1908 showed: gold, 0.29 to 8.2 (average 1.98) ounces per ton; and silver, 1.9 to 28.4 (average 6.53) ounces per ton. The average content of smelting ore shipped in 1910 was 2 ounces of gold and 5 ounces of silver per ton. Few assays show more than 1.5 percent copper.

\section{EAST NOTAWAY MINE (F-V-4)}

The East Notaway mine is on the north side of lower Russell Gulch, about 500 feet N. $22^{\circ}$ E. from the Pittsburg mine. The mine was first opened in 1875 , and was worked almost continuously until 1920 . Some work was done on the property during the late 1920's and the 1930's by the operators of the Pittsburg mine. The known production from the East Notaway mine since 1902 is given in table 61 ; this ore if produced today would have a value of about $\$ 1,144,000$. The property is reported to have yielded $\$ 439,909$ prior to $1902 .^{31}$

The mine is opened by a shaft, inclined to the north, from which levels have been turned at depths of 180 , $250,300,330,420,488,555$, and 650 feet; the shaft branches at the 330 level, and levels are turned from the south branch at depths of $650,750,850$, and 900 feet (fig. 57). The north branch is known as the old shaft; and the south branch is known as the new shaft. Crosscuts from the 300 and 330 levels connect to the Cecil mine; a crosscut on the 650 level connects the workings of the new shaft to those of the old shaft. The position of the stopes in the upper old shaft workings is shown on figure 57. In 1954, all these workings were inaccessible, but Bastin and Hill (1917, p. 264-265) examined the property and much of the following is taken from their description.

\footnotetext{
s1 Schwarz, T. E., 1902, Report on the property of the Town Topics mining company, 5 p., report on file in the Denver Public Library,
} Denver, Colo. 
The wallrock of the mine is largely biotite gneiss, which contains a large quantity of interlayered granite pegmatite. Several irregular dikes of bostonite porphyry greatly complicate the geologic relations.

ТА $\mathrm{T}_{\mathrm{BLE}}$ 61.-Ore produced from the East Notaway mine, 1902-22 ${ }^{1}$

\begin{tabular}{|c|c|c|c|c|c|c|}
\hline Year & $\begin{array}{l}\text { Crude } \\
\text { ore } \\
\text { shipped } \\
\text { (tons }\end{array}$ & $\begin{array}{l}\text { Concen- } \\
\text { trates } \\
\text { shipped } \\
\text { (tons) }\end{array}$ & $\begin{array}{c}\text { Gold } \\
\text { (ounces }\end{array}$ & $\begin{array}{c}\text { Silver } \\
\text { (ounces) }\end{array}$ & $\begin{array}{l}\text { Copper } \\
\text { (pounds) }\end{array}$ & $\begin{array}{c}\text { Lead } \\
\text { (pounds) }\end{array}$ \\
\hline & 1,227 & $450^{-1}$ & $5,282.00$ & 3394 & & \\
\hline & 596 & & $\begin{array}{l}1,532.71 \\
1\end{array}$ & $\begin{array}{r}3, y, 49 \\
2,603\end{array}$ & 25,083 & \\
\hline 37 & $\begin{array}{l}405 \\
421\end{array}$ & & $\begin{array}{r}1,053 \\
99\end{array}$ & $\begin{array}{l}1,824 \\
2,315\end{array}$ & & $\ldots$ \\
\hline $1908 \ldots$ & 825 & 45 & $1,716.00$ & 3,780 & 39,167 & \\
\hline 1809. & 1,090 & 201 & 538.77 & 1,023 & 7,086 & \\
\hline $1 .$. & $\begin{array}{l}720 \\
534\end{array}$ & $\begin{array}{l}96 \\
18\end{array}$ & $\begin{array}{l}89 \\
73\end{array}$ & $\begin{array}{l}1,3 \\
1,1\end{array}$ & & $\cdots$ \\
\hline 0 & 884 & 69 & 1,200 & 2,17 & 16,181 & 8.500 \\
\hline $014 \ldots$ & $\begin{array}{l}1,391 \\
1,252\end{array}$ & 95 & $\mid \begin{array}{l}1,870.65 \\
1,39.65\end{array}$ & $\begin{array}{l}3,604 \\
3,427\end{array}$ & $\begin{array}{l}41,120 \\
77,542\end{array}$ & $\begin{array}{r}8,500 \\
512\end{array}$ \\
\hline 1915. & 209 & 40 & 35 & 758 & 2 & \\
\hline & 2,282 & $\begin{array}{l}551 \\
143\end{array}$ & & 8,279 & & 2,246 \\
\hline & $\begin{array}{r}42 \\
92\end{array}$ & & $\begin{array}{l}1,455 \\
23\end{array}$ & $\begin{array}{l}4,150 \\
580\end{array}$ & & $\begin{array}{l}2,253 \\
1,330\end{array}$ \\
\hline$N_{-}$ & $\begin{array}{l}119 \\
178\end{array}$ & $\cdots$ & $\begin{array}{l}293.00 \\
285\end{array}$ & $\begin{array}{l}312 \\
557\end{array}$ & 6.027 & 327 \\
\hline Total... & 12967 & 1810 & 259560 & 51092 & $505 \quad 775$ & $\overline{15.168}$ \\
\hline & & 1,810 & $25,956.08$ & & 595,175 & 5,168 \\
\hline
\end{tabular}

1 Production after 1992 is combined with that of the Pittsburg mine. Compiled by U.S. Bureau of Mincs. Published by permission.

The vein system developed by the mine is complex (fig. 57). In general, four major veins are present: the North (shaft) vein, the Homestake vein, the Notaway vein, and the Cecil vein. Without examining the underground workings it is difficult to correlate the structures shown in figure 57 (a company section) with those shown in Bastin and Hill (1917, fig. 47), but it is probable that the South vein is what is called the composite Homestake-Notaway vein.

The North (shaft) vein is followed by the old shaft to its sump. The vein is filled predominantly by coarse pyrite, and is characteristically low in grade. The relation of the North vein to the Cecil vein at their intersection (fig. 57) is obscure, but it appears that the upper segment of the North vein has been shifted upward a few feet along the Cecil vein. If the above inference is correct, movement along the Cecil vein had a reverse sense.

The Homestake, Notaway, and Homestake-Notaway composite vein are developed by levels from the new shaft and by crosscuts and drifts from the old shaft (fig. 57). The relation of the Homestake vein to the Notaway vein is well shown on the 555 level (fig. 57). At places the two veins are distinct, but at other places they join to form the so-called HomestakeNotaway composite vein. Where the veins occur together, the Notaway vein filling clearly cuts through the earlier Homestake filling.
The Homestake vein is filled predominantly by pyrite in a gangue of quartz or altered wallrock; chalcopyrite and tennantite are local constituents.

The Notaway vein differs in size, metal content, and mineralogy from the North and Homestake veins. On the 555 level, the vein consists of 3 or 4 subparallel stringers of very fine grained, dark-gray quartz (maximum width $1 \frac{1}{2}$ inches) in a 4 - to 6 -inch zone. In other places the Notaway vein is a single, narrow veinlet. Small vugs lined with chalcedonic quartz locally are present. The typical filling of the vein is 1 to 3 inches of dark-gray fine-grained quartz, finegrained pyrite, tennantite, and varying amounts of gold telluride and native gold. Breccia fragments of the Homestake vein are frequently present. A study of polished surfaces of rich telluride ore, supplemented by thin-section examination, shows that the predominant constituents near the border of the vein are pyrite, tennantite, and microcrystalline quartz. Toward the center of the vein these minerals decrease in abundance and a telluride (sylvanite(?)) appears, associated with native gold. Most of the sylvanite(??) occurs alone, but in places it is intergrown with tennantite. The larger crystals of sylvanite(?) are platelike or bladelike. The native gold appears to be primary and not an alteration product of sylvanite.

Most of the ore of the North and Homestake veins is low in grade and not commercially profitable. The gold content of the Notaway vein is notably irregular. One shipment from the 555 level gave a gold content of 32 ounces per ton, and the next, a shipment of similar appearance from the same stope, ran only 2 ounces per ton. Such irregularity is probably due to irregular distribution of the tellurides. Much of the ore shipped was diluted with low-grade rock from the Homestake vein, as it was necessary to mine them together at many places. The average content of 12,867 tons of smelting ore shipped from 1902 to 1920 was gold, 1.74 ounces per ton; silver, 2.6 ounces per ton; and copper, 2.1 percent. Mill concentrates (1,810 tons) shipped during the same period averaged gold, 1.93 ounces per ton; and silver, 9.8 ounces per ton.

GIBSON MINE (F-V-10)

Location.-At head of Hangman Gulch, about 880 feet S. $47^{\circ} \mathrm{W}$. from the Success shaft.

Production.-About 400 tons of smelting ore and 58 tons of concentrates shipped between 1909 and 1923 contained 54.88 ounces of gold, 575 ounces of silver, 715 pounds of copper, 13,280 pounds of lead, and 831 pounds of zinc. (Compiled by U.S. Bureau of Mines. Published by permission.) 
Development.-A 400 -foot shaft with about 500 feet of drifts.

Veins.-Gibson: Strike, N. $80^{\circ}$ E.; dip $75^{\circ}$ NW.

Wallrock.-Biotite-quartz-plagioclase gneiss, granite pegmatite, and quartz bostonite porphyry.

Ore and sulfide minerals.-Galena, sphalerite, silver, pyrite, gold, and chalcopyrite.

Gangue minerals.-Quartz and ankerite.
Tenor.-20 tons shipped between 1918 and 1923 averaged 0.10 ounce of gold per ton, 12.5 ounces of silver per ton, 33 percent lead, and 2.8 percent sphalerite.

\section{GLADSTONE MINE (D-IV-18)}

The Gladstone mine is on the ridge between Spring and Russell Gulches, about 1,650 feet S. $48^{\circ}$ E. from

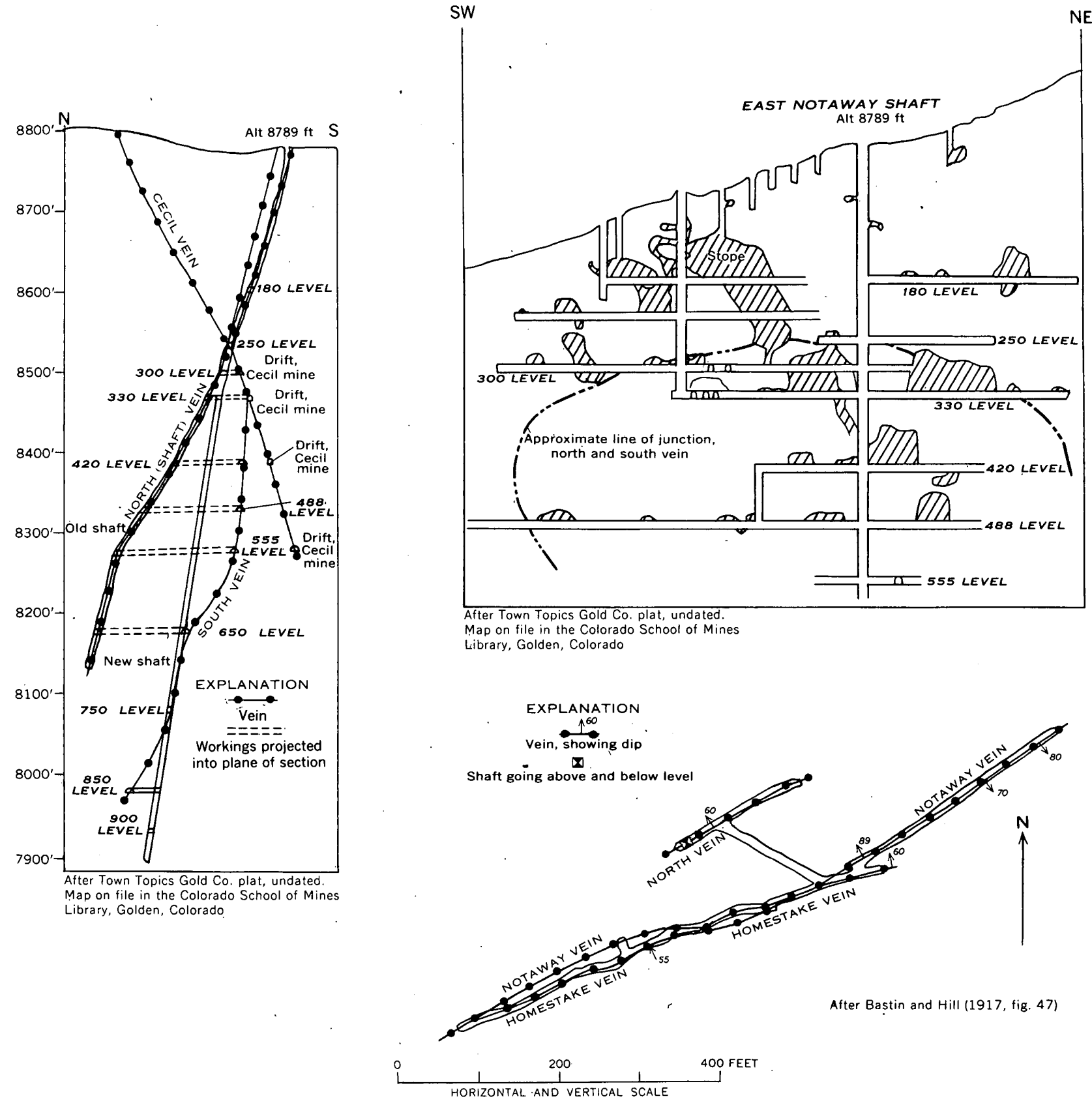

Figdra 57.-Geologic map of the 555 level, and sections of the East Notaway mine. 
the National mine. The property was probably opened around 1890, and was last worked in 1921. The known production from the mine is given in table 62 ; this ore if produced today would have a value of about $\$ 7,500$.

TABLE 62.-Ore produced from the Gladstone mine, 1902-54'

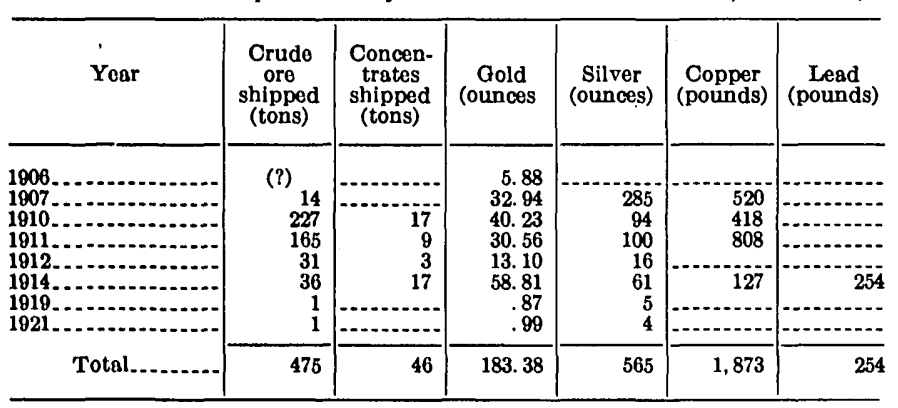

1 Complled by U.S. Bureau of Mines. Published by permission.

The mine is developed by a shaft, inclined steeply to the north, that is somewhat more than 220 feet deep. Levels have been turned from this shaft at depths of 72,160 , and 220 feet. The 72 level is about 280 feet long and is stoped to the surface for 120 feet west and 50 feet east of the shaft. The 160 level extends 200 west and 160 feet east of the shaft; stopes extend to the 72 level for about 90 feet west and 25 feet east of the shaft. The 220 level is driven 60 feet west and 50 feet east; a 10 to 20 foot stope has been extracted from the back of the west drift. A 210-foot exploratory crosscut is driven into the south wall of the 220-foot level. All these workings were inaccessible in 1954, but Bastin and Hill (1917, p. 259) examined the property, and the following is taken from their description.

The Gladstone vein strikes a few degrees north of east and dips $65^{\circ}-80^{\circ} \mathrm{NW}$. It is a tight, sharply bounded, narrow fissure vein, which averages about 3 inches in width. At places it consists of a single ore stringer, and at other places it consists of several nearly parallel stringers. Several branches pass into the walls. The principal vein mineral in most places is chalcopyrite, but pyrite is locally abundant and resinous sphalerite and galena are sparse. Sparse quartz is the dominant gangue.

Three veins, lithologically different, are exposed in the exploratory crosscut. Two of these, respectively 40 and 50 feet south of the Gladstone vein, strike nearly east and dip steeply. They are tight fissures that are filled by coarse pyrite crystals as much as three-fourths inch in diameter. The third vein strikes about $\mathrm{N} .30^{\circ} \mathrm{E}$, dips $65^{\circ} \mathrm{SE}$, and intersects the Gladstone vein about 50 feet west of the shaft. This vein is 2 to 3 inches thick and is filled by pyrite and sparse tennantite.

The metal content of 29 tons of smelting ore from the Gladstone vein, shipped between 1893 and 1910, was gold, 0.56 to 8.1 (average 1.49) ounces per ton; silver, 2.4 to 14 (average 5.35) ounces per ton; and copper 10 percent or less. The three veins exposed in the crosscut are low in grade, and have not been stoped.

\section{GULCH MINE (E-V-1)}

The Gulch mine, on the ridge between lower Russell Gulch and Lake Gulch, was opened prior to 1900 and was last worked in 1935 . The known production from the mine is given in table 63 ; this ore if produced today would have a value of about $\$ 3 \delta, 000$. The mine is developed by an inclined shaft 430 feet deep, with short levels at depths of 80,160 , and 430 feet. These workings were inaccessible in 1954; Bastin and Hill (1917, p. 265-266) examined the mine, however, and the following is taken from their description.

\begin{tabular}{|c|c|c|c|c|c|}
\hline Year & $\begin{array}{l}\text { Crude ore } \\
\text { shipped } \\
\text { (tons) }\end{array}$ & $\begin{array}{l}\text { Concen- } \\
\text { trates } \\
\text { shipped } \\
\text { (tons) }\end{array}$ & $\begin{array}{c}\text { Gold } \\
\text { (ounces) }\end{array}$ & $\begin{array}{c}\text { Silver } \\
\text { (ounces) }\end{array}$ & $\begin{array}{l}\text { Copper } \\
\text { (pounds) }\end{array}$ \\
\hline $\begin{array}{l}1904 \\
1906 \\
1907 \\
1908 \\
19090 \\
1911 \\
1912 \\
1913 \\
1935\end{array}$ & $\begin{array}{r}100 \\
100 \\
130 \\
81 \\
85 \\
817 \\
411 \\
6 \\
154 \\
4 \\
2\end{array}$ & $\begin{array}{r}20 \\
8 \\
8 \\
82 \\
15 \\
\\
\\
\end{array}$ & $\begin{array}{r}55.00 \\
73.67 \\
51.03 \\
21.62 \\
128.63 \\
231.42 \\
145.26 \\
59.78 \\
29.98 \\
.65 \\
.78\end{array}$ & $\begin{array}{r}200 \\
130 \\
121 \\
58 \\
181 \\
214 \\
173 \\
57 \\
39 \\
10 \\
-. .\end{array}$ & $\begin{array}{r}4,088 \\
2,359 \\
814 \\
3,063 \\
1,550 \\
513 \\
135 \\
\end{array}$ \\
\hline Totel & 1,890 & 73 & 797.82 & 1,183 & 12,522 \\
\hline
\end{tabular}

1 Compiled by U.S. Bureau of Mines. Published by permission.

The Gulch vein strikes about N. $63^{\circ}$ E. and dips steeply to the northwest. The vein, as exposed on the 430 level, about 60 feet east of the shaft, is narrow and is filled by $1 / 4$ to 2 inches of fine-grained quartz that contains chalcopyrite and fine-grained pyrite. This part of the vein is reported to have averaged about $\$ 2$ per ton in gold; exceptional samples showed assays as high as 28 ounces of gold per ton. In a winze, 115 feet east of the shaft, the vein consists of coarse pyrite cut by fractures filled by fine-grained gray quartz, tennantite, and fine pyrite. These finegrained quartz veinlets are less than an inch wide, contain some vugs, and contain up to 2 ounces of gold per ton. They are very similar in appearance to the Notaway vein, and probably contain tellurides. Table 64 presents selected sampling-works assays of ore from the mine, and show the considerable variation in metal content. 
TABLE 64.-Sampling-works assays of ore from the Gulch mine ${ }^{1}$

\begin{tabular}{|c|c|c|c|c|}
\hline Date & $\begin{array}{c}\text { Ore } \\
\text { (pounds) }\end{array}$ & Gold 2 & Silver ${ }^{2}$ & $\begin{array}{c}\text { Copper } \\
\text { (percent) }\end{array}$ \\
\hline $\begin{array}{l}1904 \\
1905 \\
1905 \\
1905 \\
1906 \\
1906 \\
1907 \\
1908 \\
1935\end{array}$ & $\begin{array}{l}6,156 \\
7,866 \\
3,103 \\
5,880 \\
4,856 \\
6,314 \\
8,500 \\
7,289 \\
4,380\end{array}$ & $\begin{array}{r}10.00 \\
.20 \\
4.20 \\
1.60 \\
8.74 \\
1.18 \\
1.60 \\
2.55 \\
.75\end{array}$ & $\begin{array}{r}\text { 10. } 20 \\
2.00 \\
6.80 \\
3.60 \\
8.00 \\
5.35 \\
5.40 \\
8.08 \\
7.60\end{array}$ & $\begin{array}{l}10.60 \\
9.00 \\
3.80 \\
2.50 \\
5.00 \\
6.30 \\
9.65 \\
2.50\end{array}$ \\
\hline
\end{tabular}

I Furnished by the Idaho Springs Sampling Works. Published by permission. 2 Ounces per ton.

HAMPTON MINE (F-V-12)

The Hampton mine is on the north side of lower Russell Gulch, a short distance above the confluence with Willis Gulch. The recorded production from the Hampton mine since 1902 is given in table 65; this ore if produced today would have a value of about $\$ 355,000$. The property also shipped 353.44 tons of ore and concentrates to the Idaho Springs sampling-works that sold for $\$ 15,217.73$. The mine was inaccessible in 1954. The shaft is reported to be 585 feet deep, ${ }^{32}$ but aside from a level which connects to the workings of the Silver Dollar mine, the extent of the other workings is not known.

TABLE 65.-Ore produced from the Hampton mine, 1902-54 ${ }^{1}$

\begin{tabular}{|c|c|c|c|c|c|c|c|}
\hline Year & $\begin{array}{c}\text { Crude } \\
\text { ore } \\
\text { shipped } \\
\text { (tons) }\end{array}$ & $\begin{array}{l}\text { Concen- } \\
\text { trates } \\
\text { shipped } \\
\text { (tons) }\end{array}$ & $\begin{array}{c}\text { Gold } \\
\text { (ounces) }\end{array}$ & $\begin{array}{c}\text { Silver } \\
\text { (ounces) }\end{array}$ & $\begin{array}{c}\text { Copper } \\
\text { (pounds) }\end{array}$ & $\begin{array}{c}\text { Lead } \\
\text { (pounds) }\end{array}$ & $\begin{array}{c}\text { Zinc } \\
\text { (pounds) }\end{array}$ \\
\hline & 134 & & $0 n$ & 32 & 10 & & \\
\hline & $\begin{array}{r}76 \\
200\end{array}$ & & $\begin{array}{l}12.09 \\
87.75\end{array}$ & 1,396 & $\begin{array}{l}620 \\
757\end{array}$ & 11,404 & \\
\hline & 200 & $\cdots$ & 3. 72 & , 409 & 4,840 & & \\
\hline & 58 & & 14.83 & 1,095 & & & \\
\hline 1909 & 12 & & 3.3 & 25 & & 1,219 & \\
\hline & $\begin{array}{l}75 \\
14\end{array}$ & $\ldots$ & $\begin{array}{l}\begin{array}{l}34.22 \\
11.43\end{array} \\
1.42\end{array}$ & $\begin{array}{l}774 \\
213\end{array}$ & $\begin{array}{l}2,398 \\
1,090\end{array}$ & 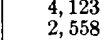 & \\
\hline 1914. & $\begin{array}{l}7 \\
4\end{array}$ & & $\begin{array}{l}3.16 \\
3.10\end{array}$ & $\begin{array}{r}110 \\
67\end{array}$ & $\begin{array}{r}1,580 \\
705\end{array}$ & & \\
\hline 1915. & 4 & 10 & 133.92 & 176 & 1,307 & 8,663 & \\
\hline & $\begin{array}{l}179 \\
434\end{array}$ & 99 & & & & $\begin{array}{l}116 \\
214\end{array}$ & \\
\hline & 年3 & $\begin{array}{l}368 \\
446\end{array}$ & $\begin{array}{l}1,816 \\
1,041\end{array}$ & $\begin{array}{l}12,063 \\
15,723\end{array}$ & & & \\
\hline 914 & 341 & 13 & 273.20 & 3,594 & 16,148 & 62,253 & 10,797 \\
\hline 1920. & 495 & 112 & 309.05 & 3,941 & 19,982 & 129,340 & $\begin{array}{r}3,593 \\
152\end{array}$ \\
\hline & & & 4. & & & & \\
\hline 1940 & 3 & 罗 & 1.00 & 21 & 西 & 360 & $\cdots$ \\
\hline Total. & 2,303 & 1,148 & $4,400.18$ & 50,042 & 167,032 & 699,944 & 14,54 \\
\hline
\end{tabular}

${ }_{1}$ Compiled by the U.S. Bureau of Mines. Published by permission.

The Hampton vein trends about N. $45^{\circ}$ E., and dips $60^{\circ} \mathrm{NW}$., and is the northeast extension of the Silver Dollar vein. According to Bastin and Hill (1917, p. 27), the ore on the dumps shows two stages of mineralization, the first consisting mainly of coarse pyrite and the second consisting of galena, sphalerite,

32 Alsdorf, P. R., 192S, Report to the Master Key tunnel association, 10 p., report on file in the Denver Public Library, Denver, Colo. tennantite, and enargite. Some of the late veinlets have a center of nearly white fine-grained quartz, suggesting that this was the last mineral deposited. The metal content of some of the ore is given in tables 66 and 67 . In general, it seems that the higher concentration of gold and silver were contained in lead-rich ore.

TABLE 66.-Sampling-works assays of some smelting ore from the Hampton mine 1

\begin{tabular}{|c|c|c|c|c|c|c|}
\hline Year & Tons & Gold 2 & Silver ${ }^{2}$ & $\begin{array}{c}\text { Copper } \\
\text { (percent) }\end{array}$ & $\begin{array}{c}\text { Lead } \\
\text { (percent) }\end{array}$ & $\begin{array}{c}\text { Zinc } \\
\text { (percent) }\end{array}$ \\
\hline 1919. & 21. 04 & 0. 56 & & 0.37 & & \\
\hline $1919 \ldots$ & 1. 17 & 7. 12 & 72.74 & 2. 37 & 32.42 & 1. \\
\hline $\begin{array}{l}1919 \ldots \\
1919 \ldots\end{array}$ & $\begin{array}{r}\text { 5. } 98 \\
\text { 13. } 58\end{array}$ & $\begin{array}{l}.77 \\
.64\end{array}$ & $\begin{array}{r}8.90 \\
10.02\end{array}$ & $\begin{array}{l}7.47 \\
3.45\end{array}$ & 25.78 & $\begin{array}{l}1.05 \\
1.62\end{array}$ \\
\hline 1919 & 6. 46 & 2. 36 & $\begin{array}{l}37.60 \\
37.60\end{array}$ & .73 & 13. 75 & \\
\hline $\begin{array}{l}1920 \ldots \\
1920 \ldots\end{array}$ & $\begin{array}{l}3.57 \\
4.88\end{array}$ & $\begin{array}{r}.69 \\
1.92\end{array}$ & $\begin{array}{r}9.80 \\
14.30\end{array}$ & $\begin{array}{l}5.15 \\
1.15\end{array}$ & 18.10 & \\
\hline 1920. & 7.46 & 3.84 & 48. 12 & .02 & 12.60 & 5. 2 \\
\hline${ }_{1921}^{1921}$ & 1. 46 & 1.33 & 15. 20 & 1. 50 & 23. 00 & \\
\hline $1939 \ldots$ & 2. 30 & $\begin{array}{r}.04 \\
.46\end{array}$ & 8.80 & & 5.40 & \\
\hline
\end{tabular}

1 Data on ore tenor furnished by the Idaho Springs Sampling Works. Published by permission.
Ounces per ton.

TABLE 67.-Sampling-works assays of some concentrates from the Hampton Mine ${ }^{1}$

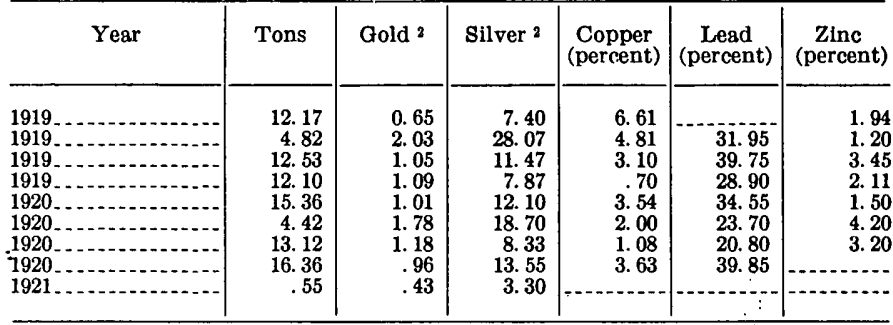

I Data on ore tenor furnished by the Idaho Springs Sampling Works. Published by permission.

\section{HAZELTINE MINE (E-VI-2)}

Location.-In South Willis Gulch, 1,080 feet southwest of Anchor mine.

Development.-Hazeltine and Hazeltine Extension (D-VI-2) shafts.

Veins.-Hazeltine: Strike, N. $75^{\circ}$ W.; vein is quite vuggy.

Wallrock.-Biotite-quartz-plagioclase gneiss and granite pegmatite.

Ore and sulfide minerals.-Pyrite, enargite, galena, sphalerite, gold, silver; enargite embays and cuts pyrite.

Gangue minerals.-Quartz and fluorite.

Tenor.-One shipment in 1925 showed gold, 0.29 ounce per ton, silver, 14 ounces per ton; and lead, 20 percent.

\section{IOWA MINE (E-V-2)}

The Iowa mine is on the north side of lower Russell Gulch, about 1,380 feet N. $73^{\circ} \mathrm{W}$. from the Pittsburg mine. The property was opened prior to 1900 , and 
was last worked in 1938. The production from the property since 1902 is given in table 68. The property is opened by a 430 -foot adit at an altitude of $8,740 \mathrm{ft}$. About 280 feet from the portal a 185-foot winze connects to short levels at vertical depths of 30,85 , and 135 feet. Small stopes were driven on the adit level and the 85 level. In 1954, the adit was caved at the portal.

TARLE 68.-Ore produced from the Iowa mine, 1902-54 ${ }^{1}$

\begin{tabular}{|c|c|c|c|c|}
\hline Yoar & $\begin{array}{l}\text { Crude oro } \\
\text { shipped } \\
\text { (tons) }\end{array}$ & $\begin{array}{l}\text { Concentrates } \\
\text { shipped } \\
\text { (tons) }\end{array}$ & $\begin{array}{c}\text { Gold } \\
\text { (ounces) }\end{array}$ & $\begin{array}{c}\text { Silver } \\
\text { (ounces) }\end{array}$ \\
\hline $\begin{array}{l}1917 \\
1934 \\
1935 \\
1937 \\
1938\end{array}$ & $\begin{array}{r}2 \\
104 \\
38 \\
149 \\
109\end{array}$ & $\begin{array}{c}2 \\
\\
\\
\end{array}$ & $\begin{array}{r}1.81 \\
49.67 \\
10.94 \\
\text { 43. } 08 \\
79.24\end{array}$ & $\begin{array}{r}4 \\
21 \\
25 \\
2 \\
75\end{array}$ \\
\hline Total.- & 402 & 2 & 184. 74 & 127 \\
\hline
\end{tabular}

1 Compiled by the U.S. Bureau of Mines. Published by permission.

The Iowa vein strikes about N. $72^{\circ} \mathrm{W}$., dips $70^{\circ}$ NE., and judging from dump samples consists almost entirely of quartz and pyrite. Chalcopyrite, sooty chalcocite, and sparse enargite are locally present. Ore from the overhand stope near the winze averaged $\$ 14.06$ per ton, and the material from the stope between the 30 and 85 sublevel averaged $\$ 31.62$ per ton..$^{33}$

\section{IROQUOIS MINE (F-V-15)}

The Iroquois mine, on the north side of lower Russell Gulch, just above the mouth of Willis Gulch, was opened in the 1860's but has not been extensively worked. The mine is reported to have shipped 3,100 tons of ore that sold for $\$ 74,000 ;{ }^{34} 13$ tons of smelting ore and 43 tons of concentrates that were shipped in 1909,1910 , and 1911 contained 17.30 ounces of gold, 540 ounces of silver, and 3,595 pounds of copper. (Compiled by U.S. Bureau of Mines. Published by permission.) The extent of the mine workings is not known.

The Iroquois vein strikes about N. $45^{\circ}$ E. and dips $70^{\circ}$ N.W. Judging from the vein material on the dump the ore consists of coarse pyrite, quartz, galena, and sphalerite; the sphalerite is "resin jack." Narrow veinlets of quartz and cherty quartz cut the sulfide ore minerals. Fluorite, ranging from colorless to green to purple, is associated with quartz, in vugs in the pyrite ore and in veinlets that cut it. Some enargite is reported from the mine. Sampling-works assays of two lots of smelting ore shipped from the

${ }^{33}$ Scott. W. I., Jr., 1939, Assuy section of the Iowa mine in a report on fle in the Denver Public Library, Denver, Colo.

is Alsdorf, P. R., 1928, Report to the Master Key Tunnel Association, 10 p., report on fle in the Denver Public Library, Denver, Colo. mine in 1910 gave respectively:- gotd, 0.16 ounce per ton; silver, 10.9 ounces per ton; lead, 6.45 percent; and gold, 0.36 ounce per ton; silver, 12.7 ounces per ton; lead, 10.15 percent.

\section{JUSTICE VEIN}

The Justice vein, one of the most persistent in the district, can be traced from Justice Hill across Lake Gulch, where one branch of it was worked in the Williams mine (pl. 1). On Justice Hill the vein was worked from four principal shafts, from southwest to northeast the Justice $1(\mathrm{~F}-\mathrm{V}-25)$, Justice 2 (F-V-26), Washington-Justice $(G-V-6)$, and the St. Louis-Justice $(\mathrm{G}-\mathrm{V}-5)$. The known workings along the vein in the Justice mine are shown in figure 58. The production from the Justice mine, since 1902, is given in table 69 .

TABLE 69.-Ore produced from the Justice mine, 1902-54 ${ }^{1}$

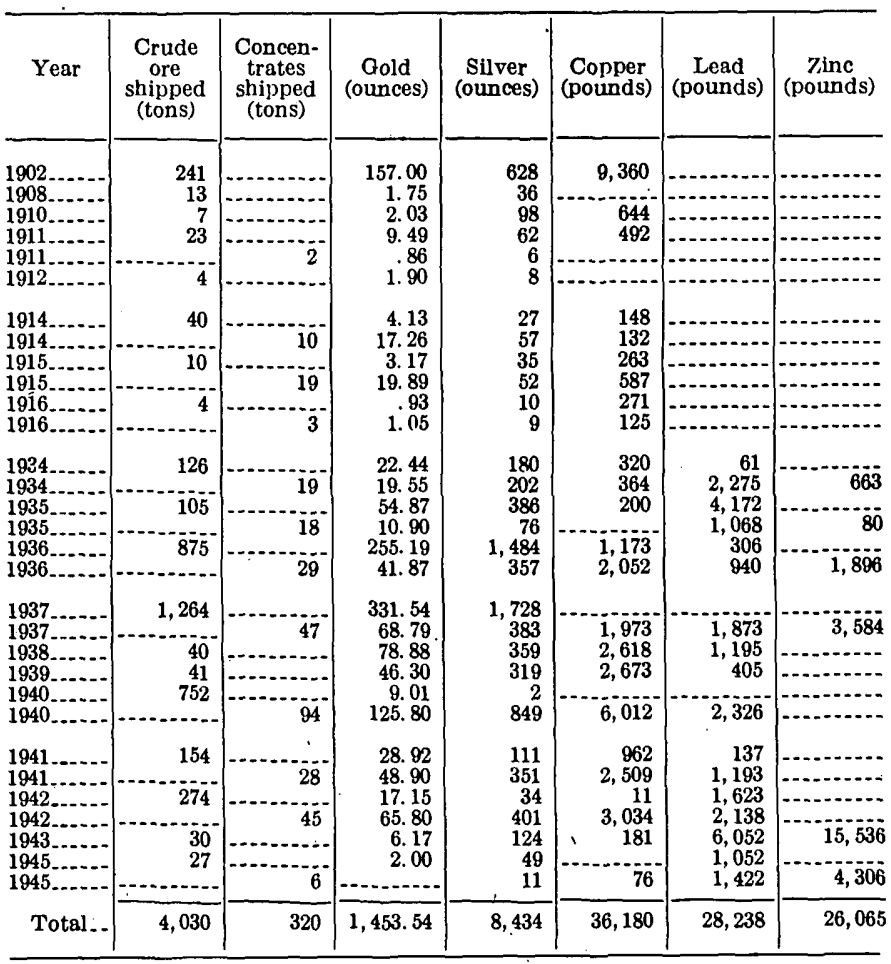

1 Compiled by the U.S. Bureau of Mines. Published by permission

The Justice vein strikes about N. $45^{\circ}$ E. and dips $75^{\circ}$ or steeper to the northwest. The vein is subparallel to the axial planes of closed folds and locally to steeply dipping limbs. Along most of its length it is within biotite gneisses, but locally its walls are pegmatite.

The vein is a pyritic type $C$. vein that contains both chalcopyrite and tennantite (Bastin and Hill, 1917, p. 266). Bastin and Hill (1917, p. 266) report 60 tons of smelting ore from the Justice mine that assayed 


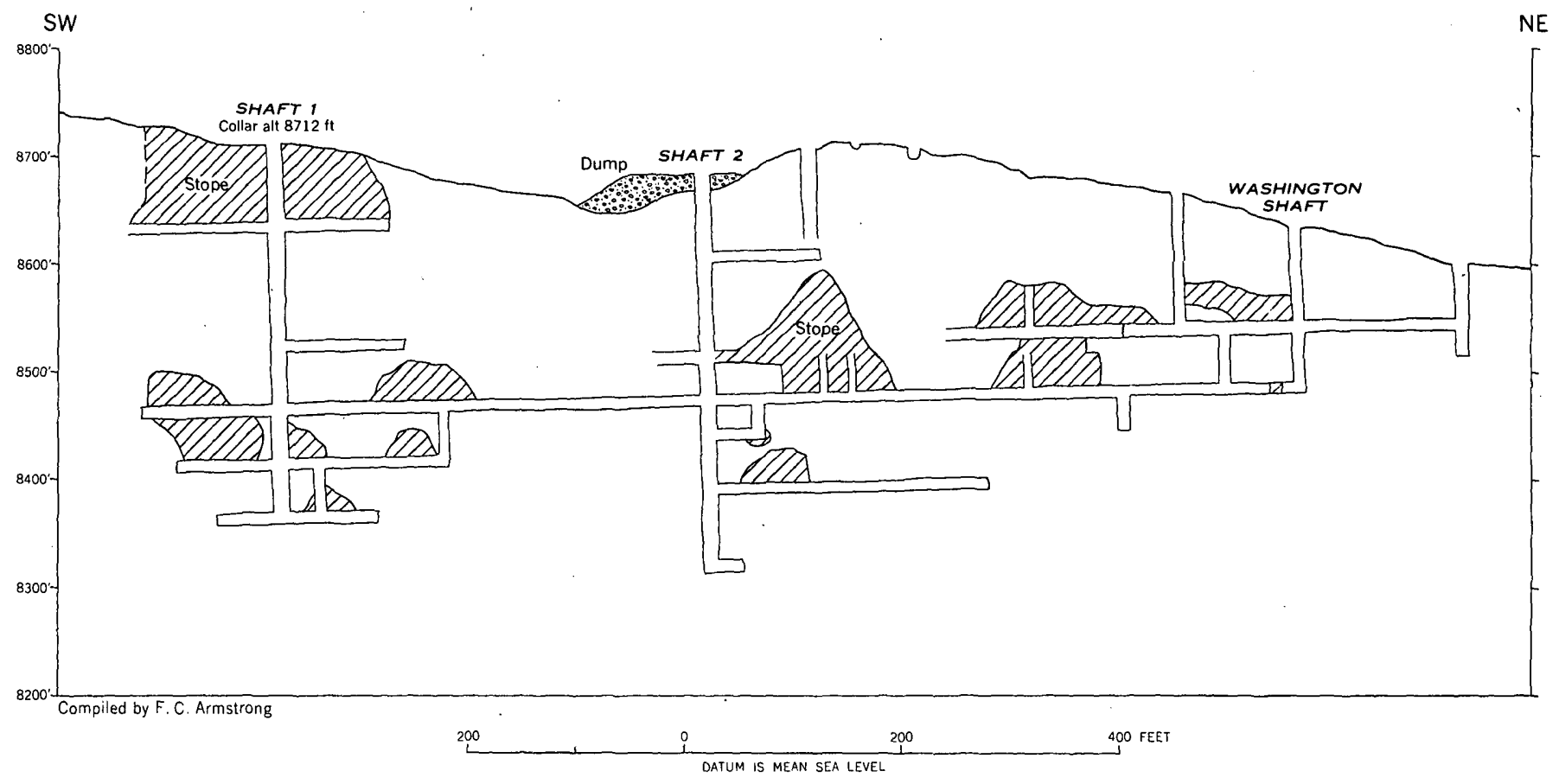

Fiavre 58.-Longitudinal projection of the Justice mine.

0.29 to 3.0 (average 1.33) ounces of gold per ton, 3.4 to 22.6 (average 12.88) ounces of silver per ton, and from less than 1.50 to 7.30 percent of copper per ton. Shipments made in 1934 gave the following results:

Sampling-works assays of some ore from the Justice mine ${ }^{1}$

\begin{tabular}{|c|c|c|c|c|c|}
\hline , Tons & Gold 2 & Silver 2 & $\begin{array}{c}\text { Lead } \\
\text { (percent) }\end{array}$ & $\begin{array}{c}\text { Copper } \\
\text { (percent) }\end{array}$ & $\begin{array}{c}\text { Zinc } \\
\text { (percent) }\end{array}$ \\
\hline $\begin{array}{l}\text { 2. } 23=- \\
\text { 4. } 35=-\end{array}$ & $\begin{array}{l}\text { 1. } 20 \\
\text { 1. } 34\end{array}$ & $\begin{array}{r}8.20 \\
14.00\end{array}$ & $9.40^{-}$ & $\begin{array}{l}1.50 \\
1.75\end{array}$ & $\begin{array}{l}0.75 \\
\text { 1. } 70\end{array}$ \\
\hline
\end{tabular}

1 Data on ore tenor furnished by the Idaho Springs Sampling Works. Published by permission.

3 Ounces per ton.

\section{KOKOMO MINE (D-VI-3)}

The Kokomo mine is on the east side of South Willis Gulch, about 1,250 feet south-southwest of the Hazeltine mine and 1,040 feet $\mathrm{N}$. $60^{\circ}$ E. from the Druid mine. The property is an old one and was probably opened prior to 1880 ; it was last worked in 1904. The production from the property is not known, but it is reported to have yielded $\$ 100,000$ prior to 1899 (Callbreath, 1899, p. 270). In 1890 the mine yielded 12.58 ounces of gold, $5,342.86$ ounces of silver, 12,308 pounds of copper, and 46,400 pounds of lead; and in 1891 it yielded 82.29 ounces of gold and $5,982.83$ ounces of silver. (U.S. Mint Reports for 1890-91.)
The Kokomo mine is opened by an inclined shaft that follows the dip of the vein, and levels have been turned at depths of $200,300,400$, and 500 feet. All the workings were inaccessible in 1954, but Bastin and Hill $(1917$, p. 274) examined the mine and much of the following is taken from their description.

The Kokomo mine workings are on the northwestward extension of the Lake-Frontenac-Druid lode of the Idaho Springs district. At the mine the vein that has been developed strikes about $\mathrm{N}$. $55^{\circ} \mathrm{E}$., dips $70^{\circ} \mathrm{NW}$., and is mineralogically similar to the Searle vein developed in the Druid mine. Certain parts of the vein consist dominantly of pyrite and are nearly barren, as on the 500 level about 170 feet southwest of the shaft, where the vein has 4 feet of coarse pyrite and sparse gangue. Other parts of the vein, as on the 400 level 200 feet west of the shaft, contain abundant enargite. Bastin and Hill $(1917$, p. 274) noted that the enargite was intergrown with pyrite, but specimens of dump ore studied by the writers under the reflecting microscope show that the enargite is dispersed through a quartz gangue and locally embays and veins pyrite. Galena and sphalerite occur sparsely in the vein. Some fluorite has been found in the northeastern part of the vein, and tellurides of gold are present locally. Assays of representative ore shipments are given in table 70. The third and fourth lots probably represent galenasphalerite rich ore, whereas the last three lots probably represent enargite-bearing ore. 
TABLE 70.-Sampling-works assays of some ore from the Kokomo mine ${ }^{1}$

\begin{tabular}{|c|c|c|c|c|c|}
\hline Year & $\begin{array}{c}\text { Ore } \\
\text { (pounds) }\end{array}$ & Gold 8 & Silver 2 & $\underset{\text { (percent) }}{\text { Lead }}$ & $\begin{array}{c}\text { Copper } \\
\text { (percent) }\end{array}$ \\
\hline $\begin{array}{l}1893 \\
1897 \\
1901 \\
1901 \\
1901 \\
1902 \\
1902\end{array}$ & $\begin{array}{r}225 \\
6,840 \\
2,049 \\
20,642 \\
5,290 \\
1,330 \\
590\end{array}$ & $\begin{array}{r}1.25 \\
1.10 \\
.18 \\
.34 \\
.32 \\
.46 \\
.32\end{array}$ & $\begin{array}{l}29.0 \\
16.9 \\
12.8 \\
13.7 \\
15.7 \\
16.5 \\
24.6\end{array}$ & \begin{tabular}{r}
11.5 \\
7.0 \\
\hdashline \\
\hdashline \\
-
\end{tabular} & $\begin{array}{r} \\
-5.0 \\
7.1 \\
4.0\end{array}$ \\
\hline
\end{tabular}

1 Bastin and IIIII, 1817, p. 274
3 Ounces per ton.

\section{MEEKER-SUCCESS MINE (FLV-6 AND F-V-7)}

The Meeker-Success mine, in Hangman Gulch, was opened prior to 1900 and was operated intermittently until 1945. It was reopened in 1950-51, and again in the winter of 1954-55, but little work was done and no ore was shipped. The known production from the Meeker-Success mine since 1902 is given in table 71; this ore if produced today would be worth about $\$ 117,000$.

The mine is developed by two shafts, the Meeker $(\mathrm{F}-\mathrm{V}-6)$ on the west and the Success or Main $(\mathrm{F}-\mathrm{V}-7)$ on the east. Five levels were driven from the Success shaft, but only the bottom three are accessible. (pl. 11 and fig. 59); the workings from the Meeker shaft are inaccessible.

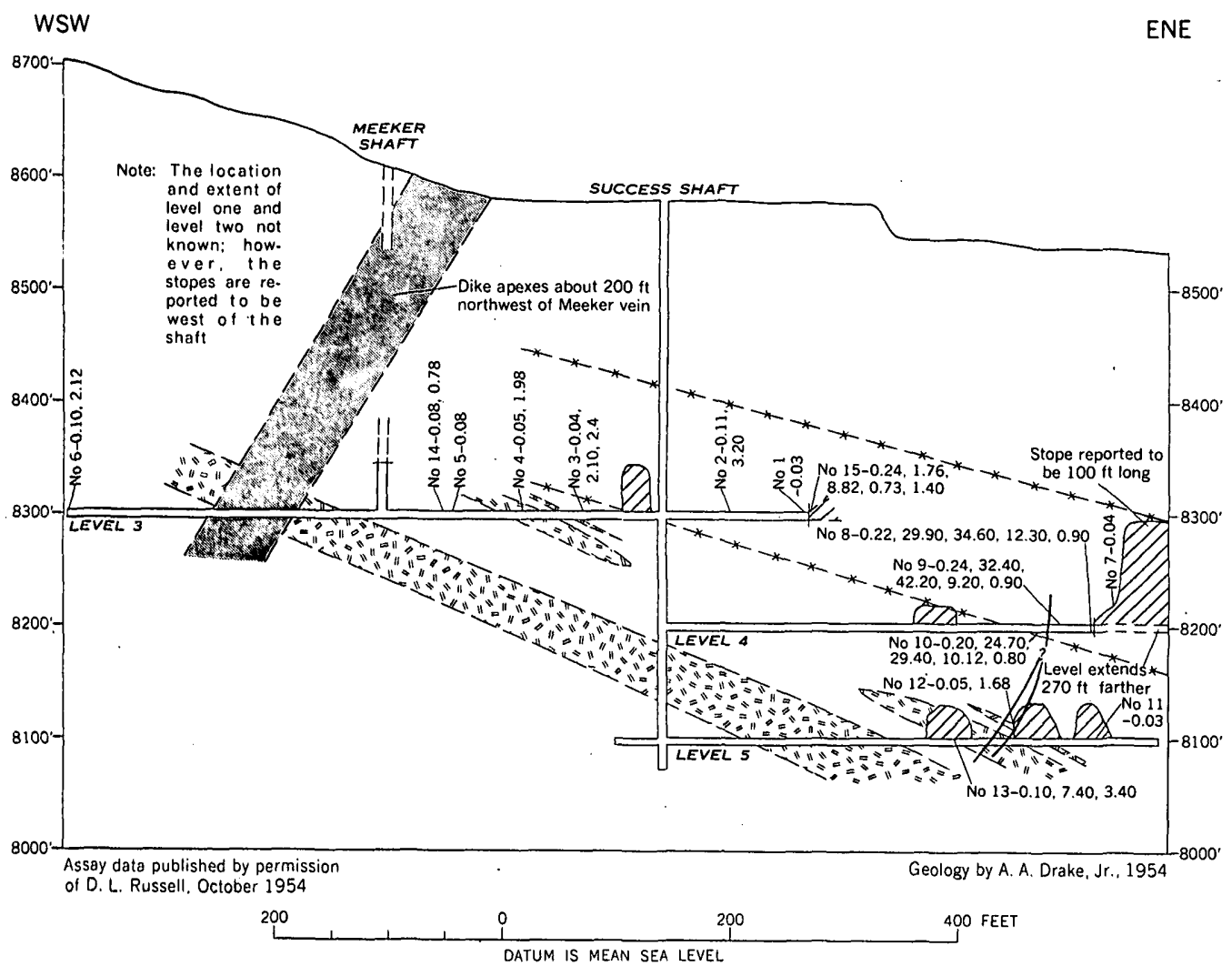

TABLE 71.-Ore produced from the Meeker-Success mine, 1902-5 $4^{1}$

\begin{tabular}{|c|c|c|c|c|c|c|c|}
\hline Year & $\begin{array}{c}\text { Crude } \\
\text { ore } \\
\text { shipped } \\
\text { (tons) }\end{array}$ & $\begin{array}{l}\text { Concen- } \\
\text { trates } \\
\text { shipped } \\
\text { (tons) }\end{array}$ & $\begin{array}{c}\text { Gold } \\
\text { (ounces) }\end{array}$ & $\begin{array}{c}\text { Silver } \\
\text { (ounces) }\end{array}$ & $\begin{array}{c}\text { Copper } \\
\text { (pounds) }\end{array}$ & $\begin{array}{c}\text { Lead } \\
\text { (pounds) }\end{array}$ & $\begin{array}{c}\text { Zinc } \\
\text { (pounds) }\end{array}$ \\
\hline $05 .-$. & 8 & & 3.00 & 150 & & & \\
\hline & 12 & & 9.01 & 219 & & & \\
\hline 13...... & $\begin{array}{l}21 \\
{ }_{13}^{3}\end{array}$ & 17 & $\begin{array}{r}1.34 \\
6.42 \\
10.39\end{array}$ & $\begin{array}{l}20 \\
231 \\
319\end{array}$ & 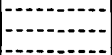 & $\begin{array}{l}5,230 \\
4,105\end{array}$ & 2.250 \\
\hline 1914.. & 7 & & 3. 37 & 77 & & & \\
\hline 1916 . & & $\begin{array}{l}12 \\
35\end{array}$ & $\begin{array}{r}9.24 \\
12.93\end{array}$ & $\begin{array}{l}101 \\
344\end{array}$ & 2,824 & 2602 & \\
\hline 1918 & & 722 & 490.89 & 6,438 & 6,552 & 135,342 & 200,838 \\
\hline 34. & $\begin{array}{l}63 \\
26\end{array}$ & & $\begin{array}{r}18.31 \\
4.00\end{array}$ & $\begin{array}{r}1,209 \\
272\end{array}$ & $\begin{array}{r}1,291 \\
52\end{array}$ & $\begin{array}{r}26,484 \\
7,327\end{array}$ & 11,100 \\
\hline 1935 . & 43 & & 9.71 & 337 & 390 & 8,225 & 146 \\
\hline & 24 & 78 & 23.71 & 1,298 & 1,404 & 58,279 & 6,921 \\
\hline & $\begin{array}{l}08 \\
80\end{array}$ & 24 & 7.31 & ${ }_{258}^{1}$ & $\begin{array}{l}1,21 \\
97\end{array}$ & $\begin{array}{l}1,102 \\
5,554\end{array}$ & 5,603 \\
\hline 1945 & 81 & 107 & $\begin{array}{l}13.01 \\
80.00\end{array}$ & $\begin{array}{r}371 \\
1,862\end{array}$ & $\begin{array}{r}3855 \\
2,523\end{array}$ & $\begin{array}{l}10,979 \\
93,689\end{array}$ & $\begin{array}{r}70,934 \\
30,159\end{array}$ \\
\hline Total.. & 440 & 1,003 & 745.84 & 14,732 & 17,158 & 364,978 & 264,951 \\
\hline
\end{tabular}

1 Compiled by the U.S. Bureau of Mines. Published by permission.

The predominant wallrocks are an interlayered succession of biotite gneisses that contain thin layers of granite pegmatite, only a few of which are mappable (pl. 11 and fig. 59). These rocks are cut by several Tertiary bostonite dikes. The Precambrian rocks trend north-northeast and dip moderately to the east (pl. 11 and fig. 59), toward a synclinal axis whose surface trace is about 600 feet east of the Success shaft. At places small, tight drag folds and

NE

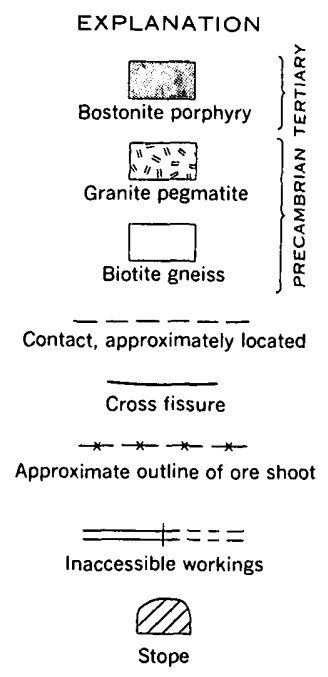

No $13-0.10,7.40,3.40$ Sample location, giving number, ounces of gold per ton, ounces of silver lead, zinc, and copper

Froure 59.-Vertical longitudinal profection showing assay data of the Meeker-Success mine. 
broad gentle warps that plunge moderately to the north-northeast are present.

The principal vein developed by the Meeker-Success mine is the east-northeastward-trending Meeker vein, but several other veins, the major one being the Jackpot (pl. 11), are present. The Jackpot is about 90 feet south of the Meeker. A vein, called the Hampton by the miners, is exposed in the breast of the 340 crosscut on the 4 th level; the writers could not examine it. A northwestward-trending fault, which cuts and offsets the Meeker vein, is exposed on the 4th and 5th levels of the mine.

The Meeker vein trends east-northeast, dips $50^{\circ}-80^{\circ}$ (average $60^{\circ}$ ) NW., and ranges in width from an inch-thin fissure to a vein nearly 4 feet thick. It is about 4 feet thick near the 340 crosscut on the 4 th level where it carries 2 feet of solid sulfides: The vein shows little tendency to split, but it appears to be horsetailing out at the west face of the $3 d$ level. A major branch splits from the vein into the footwall about 20 feet east of the shaft on the $3 \mathrm{~d}$ level, and diverges to a nearly east trend.

The Meeker vein can be traced at the surface for nearly 1,800 feet northeast from the Success shaft, where it is obscured by alluvium in Lake Gulch; it can be traced only a short distance southwest of the Meeker shaft. The northeast extension of the vein is opened by several shafts and pits, the principal shaft being the Grace Darling mine.

Two stages of mineralization are recognized in the Meeker vein, an older quartz-pyrite stage and a younger ankerite(?)-galena-sphalerite-tennantite-chalcopyrite stage. Throughout most of the mine the vein consists of massive to crystalline, white quartz and yellow pyrite cubes, but at places this filling is fractured and filled by fine-grained, brown to darkgray quartz and at other places it is crosscut by small fissures containing chalcopyrite, tennantite, galena, sphalerite, and ankerite(?). Most of the galena, sphalerite, and copper minerals are confined to the eastern part of the mine.

Movement along the fault filled by the Meeker vein was right lateral, the northwest wall having been shifted a few feet to the northeast with respect to the southeast wall. Slickensides on the vein walls are horizontal or plunge gently to the west-southwest.

The ore within the Meeker vein constitutes an ore shoot that plunges about $20^{\circ}$ east-northeast (fig. 59). This ore shoot has been mined from the Meeker shaft on the west to a point about 100 feet east of the cave on the 4th level, a plunge length of at least 850 feet; it has not been intersected on the 5th level. Lenses of ore within this shoot are reported to have been
100 feet long by 85 feet high by 4 feet thick. Although the structural control is obscure, the ore shoot seems to plunge almost parallel to the intersection of the Meeker vein with the layering of the Precambrian wallrocks.

As can be seen in table 72 and figure 59, the pyritic parts of the vein are low grade, and gold and silver concentrations are largely confined to those parts of the veins containing large amounts of the base metals.

The Jackpot vein (pl. 11) strikes about N. 50 E. and dips $60^{\circ} \mathrm{NW}$. to vertical. It is a nearly barren intensely silicified fault zone that contains sparse to moderate amounts of disseminated pyrite. The Jackpot vein is cut and displaced by the footwall branch of the Meeker vein about 55 feet east of the crosscut on the 4th level (pl. 11); the northeast segment of the Jackpot vein has not been intersected north of the footwall branch of the Meeker vein.

An ore specimen from the Meeker dump contains a $1 / 4$ to $3 / 8$ inch veinlet of pyrite and wolframite in biotite gneiss which has an unusual robins-egg blue color. A study of a polished surface of this specimen shows that the wolframite occurs on the walls of the veinlet and is dispersed through the pyrite; locally the wolframite corrodes pyrite. Minor quantities of galena and chalcopyrite are in the veinlet. The galena embays and corrodes both wolframite and pyrite. The source of this specimen is not known, but possibly it came from the intersection of the Meeker vein and cross fissure on the 5th level of the mine.

\begin{tabular}{|c|c|c|c|c|c|}
\hline Location & Gold 2 & Silver ${ }^{2}$ & $\begin{array}{l}\text { Copper } \\
\text { (Percent) }\end{array}$ & $\underset{\text { (Percent) }}{\text { Lead }}$ & $\begin{array}{c}\text { Zinc } \\
\text { (Percent) }\end{array}$ \\
\hline $\begin{array}{l}\text { Stope, sth level } \\
\text { Do } \\
\text { Gangue, } 5 \text { th level } \\
\text { Fifth level. } \\
\text { Do } \\
\text { Do } \\
\text { Do } \\
275 \text { stope, } 5 \text { th level } \\
\text { Do } \\
\text { Do } \\
\text { Just wrst of big stope, 4th level. } \\
\text { Big stope, 4th level } \\
\text { Do } \\
\text { Do } \\
\text { Do } \\
\text { Do }\end{array}$ & $\begin{array}{l}0.09 \\
.13 \\
.14 \\
.32 \\
.26 \\
.14 \\
.22 \\
.05 \\
.04 \\
.09 \\
.16 \\
.14 \\
.10 \\
.32 \\
.28 \\
.20\end{array}$ & $\begin{array}{r}1.78 \\
3.47 \\
1.76 \\
1.96 \\
3.96 \\
.94 \\
.98 \\
4.20 \\
1.40 \\
3.60 \\
1.80 \\
6.30 \\
10.90 \\
14.20 \\
11.70 \\
13.00\end{array}$ & $\begin{array}{r}0.10 \\
.23 \\
.06 \\
.10 \\
.90 \\
.12 \\
.20 \\
\hdashline 1.40 \\
\\
\hdashline \\
\hdashline \\
\hdashline \\
\hdashline\end{array}$ & \begin{tabular}{|r|}
1.80 \\
3.65 \\
.20 \\
1.90 \\
2.00 \\
2.70 \\
4.00 \\
3.90 \\
1.80 \\
3.60 \\
2.60 \\
31.60 \\
32.30 \\
29.00
\end{tabular} & $\begin{array}{r}2.85 \\
1.70 \\
\text { Tr. } \\
3.00 \\
13.60 \\
2.80 \\
11.20 \\
\hdashline 3.20 \\
16.40 \\
\hdashline 15.80 \\
\hdashline\end{array}$ \\
\hline
\end{tabular}

1 Data on ore tenor furnished by D. L. Russell. Published by permission. 2 Ounces per ton.

\section{PEARCE (MORRIS) MINE (E-V-18)}

Location.-North side of lower Russell Gulch, about 650 feet S. $68^{\circ}$ E. from the Pittsburg mine.

Development.-A 460-foot shaft with short levels at vertical depths of about 100, 200, 300, and 400 feet.

Production.-In 1903 and 1904, 502 tons of smelting ore and 170 tons of concentrates were shipped that contained 169.60 ounces of gold and 150 ounces of 
silver. (Compiled by U.S. Bureau of Mines. Published by permission.)

Veins.-Pearce: strike, N. $45^{\circ}$ E.; dip; $80^{\circ}$ SE.

Wallrock.-Predominantly interlayered biotite gneisses.

Ore and sulfide minerals.-Pyrite, gold, and silver. Gangue minerals.-Quartz.

Tenor.-The ore averaged about, $\$ 12$ per ton.

\section{PITTSBURG MINE (E-V-14)}

The Pittsburg mine, on the north side of lower Russell Gulch, was opened prior to 1880 and was worked last in 1947. The known production from the Pittsburg mine since 1902 is given in table 73; this ore if produced today would have a value of about $\$ 2,705,000$. The mine reportedly yielded about $\$ 75,000$ prior to 1899 (Callbreath, 1899, p. 286).

TABLE 73.-Ore produced from the Pittsburg mine, 1902-54 1

\begin{tabular}{|c|c|c|c|c|c|c|c|}
\hline Year & $\begin{array}{c}\text { Crude } \\
\text { oro } \\
\text { shipped } \\
\text { (tons) }\end{array}$ & $\begin{array}{l}\text { Concen- } \\
\text { trates } \\
\text { shipped } \\
\text { (tons) }\end{array}$ & $\begin{array}{c}\text { Gold } \\
\text { (ounces) }\end{array}$ & $\begin{array}{c}\text { Silver } \\
\text { (ounces) }\end{array}$ & $\begin{array}{c}\text { Copper } \\
\text { (pounds) }\end{array}$ & $\begin{array}{c}\text { Lead } \\
\text { (pounds) }\end{array}$ & $\begin{array}{c}\text { Zinc } \\
\text { (pounds) }\end{array}$ \\
\hline $\begin{array}{l}1902 \ldots \\
1903 \ldots \ldots \\
1904 \ldots \\
1905 \ldots \ldots \\
1906 \ldots \ldots\end{array}$ & $\begin{array}{r}1,700 \\
1,200 \\
800 \\
1,200 \\
531\end{array}$ & 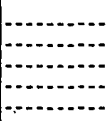 & $\begin{array}{l}1,487.17 \\
1,250.00 \\
1,080.00 \\
2,400.03 \\
3,454.75\end{array}$ & $\begin{array}{r}4,000 \\
9,600 \\
2,700 \\
11,573 \\
5,688\end{array}$ & $\begin{array}{r}142,857 \\
101,000 \\
92,571 \\
342,857 \\
103,893\end{array}$ & & - \\
\hline $\begin{array}{l}1907 \\
1808 \\
1909 \\
1910 \\
1911 .\end{array}$ & $\begin{array}{r}502 \\
2,858 \\
689 \\
859 \\
1,283\end{array}$ & $\begin{array}{r}272 \\
68 \\
63 \\
122\end{array}$ & $\begin{array}{l}1,549.89 \\
3,139.98 \\
1,936.42 \\
2,556.14 \\
1,597.69\end{array}$ & $\begin{array}{l}2,732 \\
7,697 \\
3,999 \\
4,077 \\
4,095\end{array}$ & $\begin{array}{r}53,821 \\
100,000 \\
159,856 \\
76,656 \\
54,706\end{array}$ & & \\
\hline $\begin{array}{l}1912 \ldots \\
1913 \ldots \ldots \\
1914 \ldots \\
1915 \ldots \\
1916 \ldots\end{array}$ & $\begin{array}{r}1,506 \\
1,607 \\
2,396 \\
2,141 \\
387\end{array}$ & $\begin{array}{l}363 \\
259 \\
680 \\
415 \\
142\end{array}$ & $\begin{array}{l}2,453.93 \\
3,364.74 \\
5,186.14 \\
4,294.22 \\
2,054.66\end{array}$ & $\begin{array}{l}4,417 \\
4,352 \\
7,103 \\
7,772 \\
4,651\end{array}$ & $\begin{array}{r}90,056 \\
95,130 \\
151,507 \\
149,781 \\
74,051\end{array}$ & $\begin{array}{r}282 \\
1,948 \\
1,442 \\
438\end{array}$ & \\
\hline $\begin{array}{l}1817 \ldots . . \\
1918 \ldots . \\
1023 \ldots . \\
1925 \ldots \\
1930 . . .\end{array}$ & $\begin{array}{r}609 \\
313 \\
1 \\
3 \\
100\end{array}$ & $\begin{array}{r}193 \\
41 \\
\end{array}$ & \begin{tabular}{|r}
$1,185.41$ \\
278.17 \\
5.16 \\
5.21 \\
09.81
\end{tabular} & $\begin{array}{r}2,822 \\
782 \\
7 \\
11 \\
400\end{array}$ & $\begin{array}{r}71,422 \\
3,031 \\
128 \\
125 \\
1,560\end{array}$ & 63,616 & 2,617 \\
\hline $\begin{array}{l}1831 \ldots . . \\
1832 \ldots . \\
1933 \ldots \\
1934 \ldots \\
1035 \ldots\end{array}$ & $\begin{array}{r}1,000 \\
705 \\
467 \\
14,841 \\
69,056\end{array}$ & $\begin{array}{r}175 \\
146 \\
78 \\
291 \\
4,102\end{array}$ & $\begin{array}{r}219.16 \\
151.61 \\
182.24 \\
454.50 \\
3,511.28\end{array}$ & $\begin{array}{r}195 \\
357 \\
323 \\
577 \\
4,887\end{array}$ & $\begin{array}{r}3,930 \\
2,164 \\
247 \\
18,038\end{array}$ & $\begin{array}{r}42 \\
458 \\
730\end{array}$ & \\
\hline $\begin{array}{l}1030 \ldots . . . \\
1037 \ldots . . \\
1038 \ldots . . \\
1939 \ldots \\
1040 . . .\end{array}$ & $\begin{array}{r}28,416 \\
24 \\
3 \\
17 \\
44\end{array}$ & $\begin{array}{r}1,216 \\
5\end{array}$ & $\begin{array}{r}1,401.16 \\
23.96 \\
2.28 \\
6.28 \\
429.00\end{array}$ & $\begin{array}{r}4,117 \\
36 \\
8 \\
\hdashline 385\end{array}$ & $\begin{array}{r}5,077 \\
494 \\
13,717\end{array}$ & 476 & - \\
\hline $\begin{array}{l}1941 \ldots \ldots \\
1942 \ldots \\
1943 \ldots \ldots \\
1946 \ldots \\
1047 \ldots \ldots\end{array}$ & $\begin{array}{r}81 \\
92 \\
141 \\
.5 \\
. .5\end{array}$ & $\begin{array}{r}1,590 \\
1,662 \\
377 \\
133 \\
169\end{array}$ & $\begin{array}{r}\mathbf{4}, 730.78 \\
\mathbf{3}, 664.41 \\
\mathbf{5 8 6 . 0 0} \\
\mathbf{8 8 . 0 0} \\
\mathbf{0 5 . 0 0}\end{array}$ & $\begin{array}{r}492 \\
5,616 \\
1,705 \\
317 \\
1,315\end{array}$ & $\begin{array}{r}132,202 \\
113,929 \\
33,566 \\
3,444 \\
1.036\end{array}$ & $\begin{array}{r}107 \\
321 \\
424 \\
1,051 \\
70,288\end{array}$ & \begin{tabular}{r}
12,834 \\
\hdashline 1,510 \\
54,734
\end{tabular} \\
\hline$\tau$ & 7.5 & 12,552 & $54,825.18$ & 108,808 & $2,193,752$ & 141,683 & 71.695 \\
\hline
\end{tabular}

1 Complled by U.S. Bureau of Mines. Published by permission.

The mine is opened by an inclined shaft having a vertical depth of 975 feet that connects with levels at inclined depths of $100,200,300,400,500,600,700$, $800,900,1,000$, and 1,100 feet (figs. 60, 61): Most of the development is in the eastern part of the mine. The 300 level connects by a crosscut to workings from the Meeker shaft. A crosscut from the 900 level de- velops the North and South Notaway veins. Stopes are present on all levels, but are largely in the area east of the shaft (fig. 62). These workings were all inaccessible in 1954, but Bastin and Hill (1917, p. 261-262) examined the mine and much of the following is taken from their description.

The Pittsburg vein strikes N. $65^{\circ}-70^{\circ}$ E. and dips $45^{\circ}-65^{\circ} \mathrm{NW}$. It is characteristically narrow, and typically consists mainly of coarse pyrite, with locally abundant chalcopyrite and tennantite and some enargite. Considerable lead and zinc are reported in the production figures, but although Bastin and Hill (1917, p. 262) state that galena is present in the ore, it is probable that most of the lead and zinc that are reported were obtained from one of the other properties, probably the West Notaway, which were operated by the Pittsburg company. Some gold telluride is also reported from the mine. Two types of pyrite were deposited. The first type formed coarse crystals; the second type occurs as loose aggregates of tiny anhedral grains, many of which have well-developed shrinkage(?) cracks. The latter type of pyrite is associated with quartz and often fills fractures and vugs in chalcopyrite.

The Pittsburg vein is richer in copper minerals than most other veins in the district, so it is not surprising that it is one of the few veins to show an important secondary enrichment in copper. Chalcocite was abundant in the mine above the 500 level, and small amounts were noted as deep as the 700 level. A polished surface of ore from a stope 60 feet above the 500 level showed that the chalcocite developed by replacing chalcopyrite-quartz and chalcopyrite-pyrite grain boundaries; it is also formed along fractures traversing the chalcopyrite. Vuggy parts of the vein on the upper levels contain much sooty chalcocite. The ore secondarily enriched in copper showed no increase in precious-metal concentrations.

The ore in the Pittsburg vein is confined to a single large ore shoot that plunges about $70^{\circ}$ E. (fig. 62); the stoping west of the shaft on the 400 level produced only low-grade mill dirt. According to miners who have worked in the mine, much of the gold occurs free; they also state that the ore in the sill of the 1,100 -level is as good or better than that from the upper levels. The ore shoot is described by Jack Powers (oral communication) as occuring at the intersection of the Pittsburg vein and the south-dipping Golden Wedge vein.

Sampling works assays of 243 tons of smelting ore shipped from the mine between 1894 and 1909 show gold, 0.45 to 12.72 (average 2.37) ounces per ton; silver, 1.5 to 18.3 (average 7.52) ounces per ton; and 


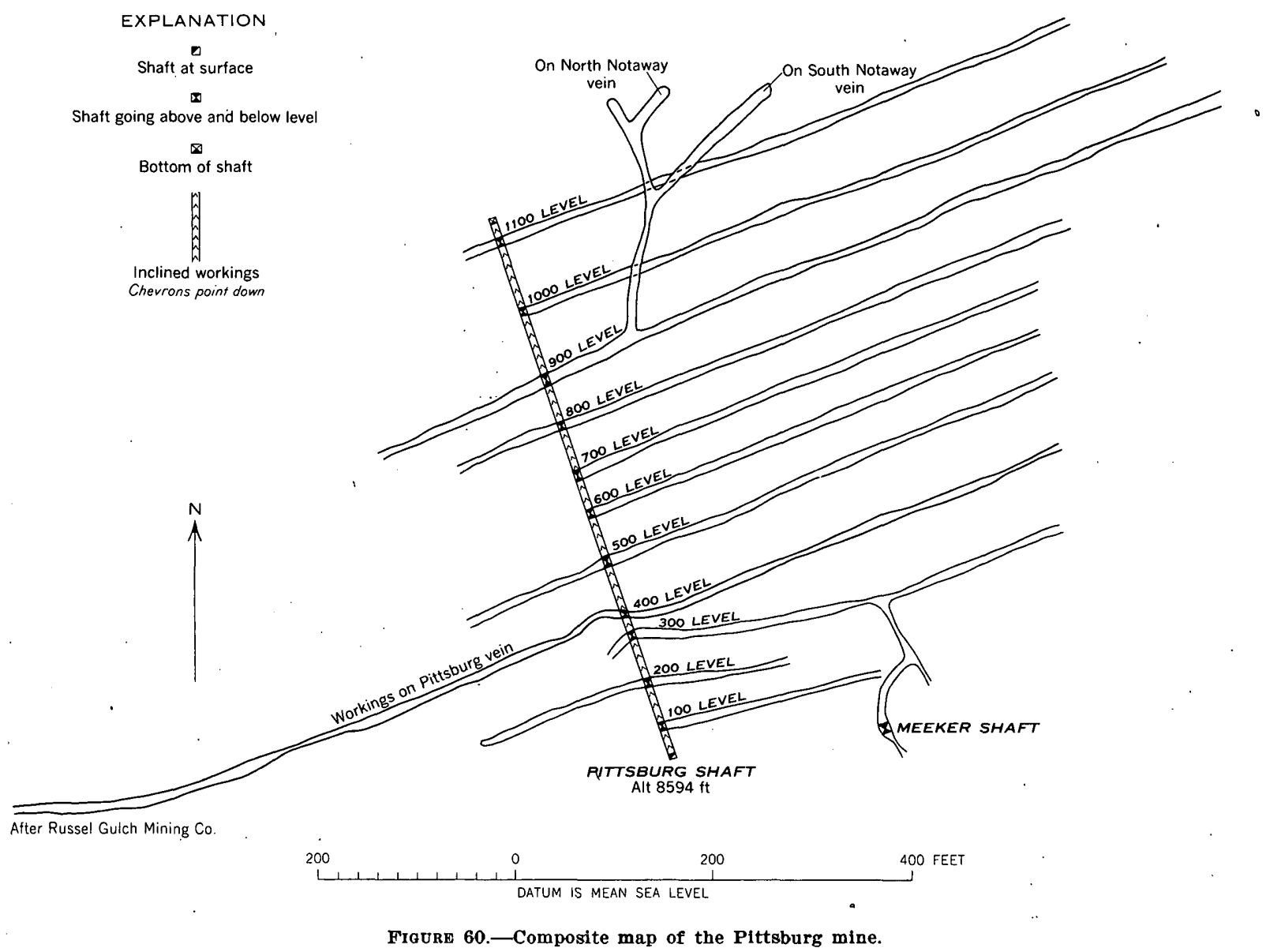

copper, not more than 16.6 percent. The average assay of 435 tons shipped in 1910 was gold, 5.77 ounces per ton; silver, 8.93 ounces per ton; and copper, 6.65 percent. Several small shipments of ore between 1921 and 1934 averaged nearly 5 ounces of gold per ton, 11 ounces of silver per ton, and 6 percent copper.

\section{POWERS MINE (F-V-14)}

The Powers mine is on the north side of Willis Gulch, about 620 feet S. $68^{\circ}$ E. from the War Dance mine. The mine was opened before 1900 and was last. worked in 1946. The production from the property since 1902 is given in tables 74 and 75 ; this ore if produced today would be worth about $\$ 332,000$. The Powers mine reportedly yielded $\$ 129,000$ before $1928^{35}$ The ore from the Powers vein is valuable chiefly for copper and silver, whereas that from the New Brunswick vein is valuable for its gold content. The mine was inaccessible in 1954 . The mine is reportedly developed by a 391-foot shaft with levels at depths of $159,225,275$, and 305 feet (J. G. McGrath, oral com-

${ }^{35}$ Alsdorf, P. R., 1928, Report to the Master Key Tunnel Association, 10 p., report on file in the Denver Public Library, Denver, Colo. munication). The 225 level connects through a stope to the 225 level of the Silver Dollar No. 1 mine (fig. 63) and to the War Dance shaft. Stopes are present on all the levels (J. G. McGrath, oral communication). The wallrock is principally biotite-quartz-plagioclase gneiss; locally it contains generally conformable pegmatites, which at most places are 1 to 5 feet thick. The rocks strike northeast and for the most part dip gently northwest or southeast.

TABLE 74.-Ore produced from the Powers vein, Powers mine, $1902-54$

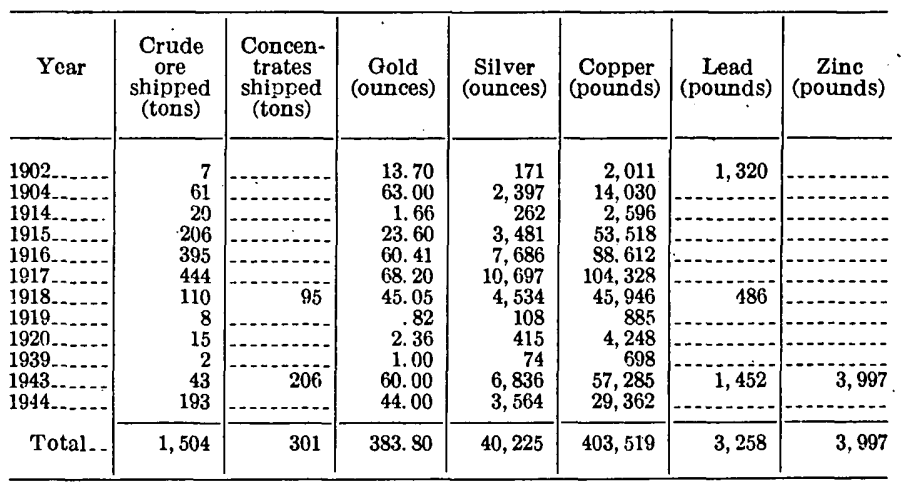

1 Compiled by the U.S. Bureau of Mines. Published by permission. 
TABLE 75.-Ore produced from the New Brunswick vein, Powers mine, 1908-54 ${ }^{1}$

\begin{tabular}{|c|c|c|c|c|c|c|c|}
\hline Yoar & $\begin{array}{c}\text { Crude } \\
\text { oro } \\
\text { shipped } \\
\text { (tons) }\end{array}$ & $\begin{array}{l}\text { Concen- } \\
\text { trates } \\
\text { shivped } \\
\text { (tons) }\end{array}$ & $\begin{array}{c}\text { Gold } \\
\text { (ounces) }\end{array}$ & $\begin{array}{l}\text { Silver } \\
\text { (ounces) }\end{array}$ & $\begin{array}{l}\text { Copper } \\
\text { (pounds) }\end{array}$ & $\underset{\text { Lead }}{\text { (pounds) }}$ & $\underset{\text { (pounds) }}{\text { Zinc }}$ \\
\hline $\begin{array}{l}1034 \ldots \ldots \\
1935 \ldots \\
1930 \\
1937 \\
1938 \ldots\end{array}$ & $\begin{array}{r}250 \\
46 \\
27 \\
549 \\
1,134\end{array}$ & $\begin{array}{r}18 \\
16 \\
9 \\
39\end{array}$ & $\begin{array}{r}54.69 \\
35.36 \\
102.24 \\
356.19 \\
499.20\end{array}$ & $\begin{array}{r}327 \\
126 \\
42 \\
40 \\
68\end{array}$ & \begin{tabular}{r}
500 \\
138 \\
\hdashline .138 \\
\end{tabular} & \begin{tabular}{r}
5,235 \\
$\quad 36$ \\
\hdashline 36 \\
\end{tabular} & \begin{tabular}{r}
2,349 \\
440 \\
261 \\
\hdashline... \\
\end{tabular} \\
\hline $\begin{array}{l}1939 \ldots \\
1040 \ldots \ldots \\
1041 \ldots \\
1942 \\
1940 \ldots\end{array}$ & $\begin{array}{r}1,103 \\
933 \\
1,336 \\
1,72 \\
1,710\end{array}$ & $\begin{array}{r}146 \\
153 \\
223 \\
25 \\
34\end{array}$ & $\begin{array}{r}725.00 \\
764.00 \\
625.00 \\
94.00 \\
67.00\end{array}$ & $\begin{array}{r}179 \\
176 \\
370 \\
55 \\
215\end{array}$ & $\begin{array}{r}-13 \\
\hdashline \\
\hdashline\end{array}$ & \begin{tabular}{c}
477 \\
\hdashline-1. \\
\end{tabular} & 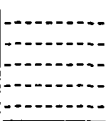 \\
\hline Total.. & 7,320 & 603 & $3,322.68$ & 1,598 & 651 & 6,148 & 3,050 \\
\hline
\end{tabular}

w

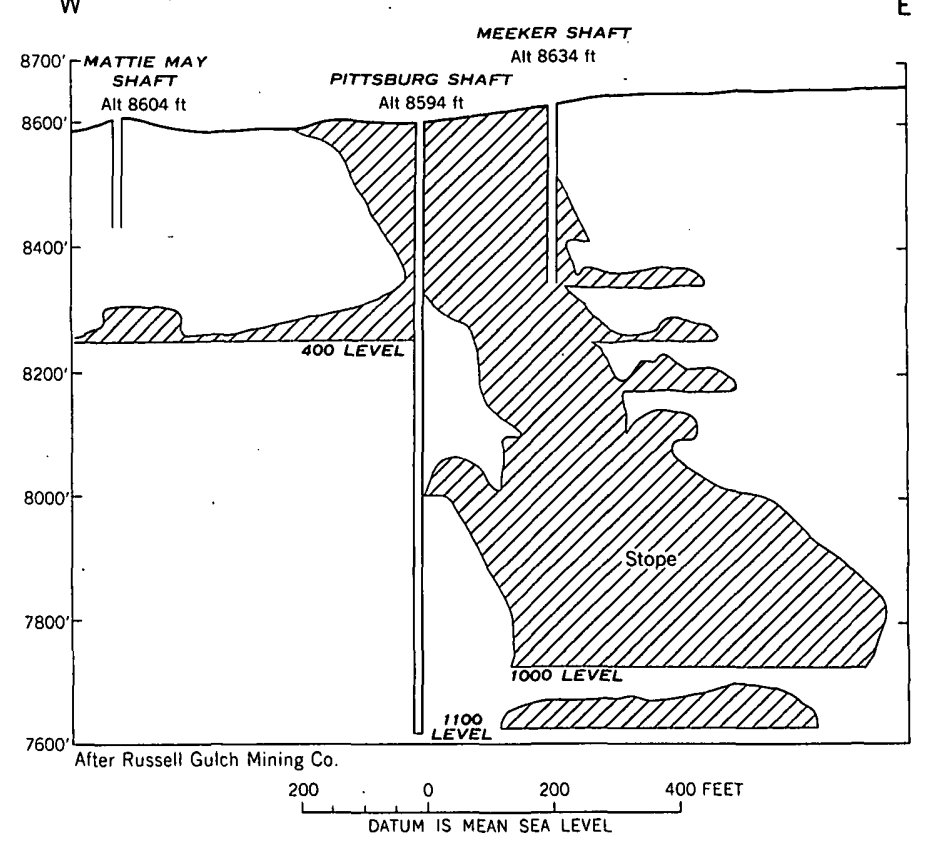

Frgore 62.-Vertical longitudinal section of the Pittsburg mine.

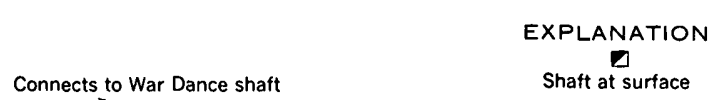

Connects to War Dance shaft Shaft at surface

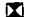

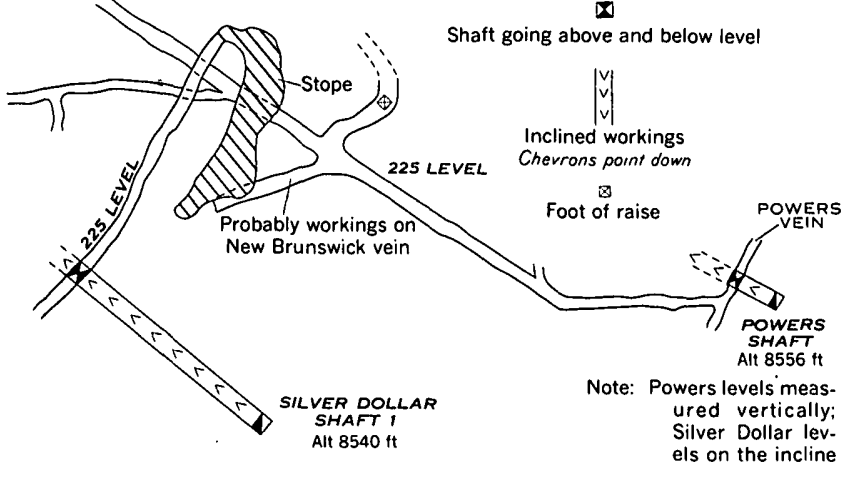

After Walter Scott, January 1946

50.-2 - $\frac{1}{\text { DATUM IS MEAN SEA LEVEL }} \frac{50}{100} \mathrm{FEET}$

Fradre 63.-Map of the 225-crosscut, Powers mine.

Two veins-the Powers and the New Brunswickare developed by the Powers mine. The Powers vein strikes on the average $\mathrm{N}$. $45^{\circ} \mathrm{E}$. and dips $55^{\circ}-80^{\circ}$ NW. The New Brunswick. vein is a poorly defined, pipelike body, which lies on the footwall of, but apparently is not related to, the Silver Dollar vein.

The mineralogy of the Powers vein is similar to that of the Silver Dollar vein (p. 156), except that fluorite is slightly more abundant and at places appears to have replaced biotite-quartz-plagioclase-gneiss wallrock. Tennantite, enargite, and pyrite are the most abundant minerals; sparse galena, sphalerite,

Frodre 61.-Section of the Pittsburg shaft. 
and chalcopyrite are also present. The metal content of ore shipments from the Powers vein is given in table 76. It can be seen that this high copper ore contains fairly high concentrations of silver, but only minor quantities of gold.

TABLE 76.-Sampling-works assays of some ore from the Powers vein $^{1}$

\begin{tabular}{|c|c|c|c|}
\hline Pounds of ore & Gold ${ }^{2}$ & Silver ${ }^{2}$ & $\begin{array}{c}\text { Copper } \\
\text { (percent) }\end{array}$ \\
\hline $\begin{array}{l}6,511 \\
6,028 \\
6,718 \\
9,978\end{array}$ & $\begin{array}{r}0.28 \\
.12 \\
.20 \\
.10\end{array}$ & $\begin{array}{l}22.0 \\
19.9 \\
20.2 \\
10.0\end{array}$ & $\begin{array}{r}19.1 \\
8.0 \\
16.0 \\
7.2\end{array}$ \\
\hline $\begin{array}{l}13,319 \ldots \\
4,334 \ldots \\
4,216 \ldots \\
1,290\end{array}$ & $\begin{array}{l}08 \\
.14 \\
.12 \\
.28\end{array}$ & $\begin{array}{l}\text { 1. } 7 \\
\text { 16. } 8 \\
\text { 12. } 9 \\
\text { 31. } 7\end{array}$ & $\begin{array}{l}\text { 15. } 3 \\
14.5 \\
11.6 \\
18.5\end{array}$ \\
\hline $\begin{array}{l}8,629 \\
1,468 \\
16,400 \\
7,930\end{array}$ & $\begin{array}{l}22 \\
.28 \\
10 \\
.22\end{array}$ & $\begin{array}{l}\text { 21. } 7 \\
22.7 \\
13.2 \\
39.6\end{array}$ & $\begin{array}{r}\text { 16. } 9 \\
18.1 \\
3.9 \\
18.4\end{array}$ \\
\hline
\end{tabular}

1 Data on ore tenor furnished by the Idaho Springs Sampling Works. Published by permission.

The New Brunswick vein, in contrast to the Powers, is not a well-defined tabular filled fracture; instead, it is a pipelike mineralized zone about 100 feet in diameter that extends from near the surface to a depth of more than 400 feet. According to Henry Ress (oral communication) the vein resembles a spider web. It consists of many irregular, branching inch-thin fractures, which at places coalesce; the wall of the pipelike body are poorly defined. The fractures locally contain native wire gold, tellurides of gold, galena, tennantite, enargite, and molybdenite. The sulfides are sparse; the concentration ratio being about 100:1. Ress states that on the 225 level, free gold occurs where the fractures cut biotite gneiss wallrocks and tellurides occur where the fractures cut pegmatite wallrocks. At greater depths, though, Ress reports that tellurides are present in greater proportions and also occur in the biotite gneiss. The predominant wallrock-biotite gneiss-in the pipelike body, is flecked with white clay minerals, probably montmorillonite. The rocks swell markedly, and according to Ress, after the mine was closed for 5 years, the track on one level where it traversed the "vein," had been elevated by the swelling about 2 feet and the timbers were splintered.

\section{SARATOGA MINE}

The Saratoga mine, on the ridge between Russell Gulch and Willis Gulch, was opened prior to 1880 and was last worked in 1946. The mine is opened by 4 shafts, from east to west-No. 1 (D-V-18), 700 feet deep; No. 2 (Main) (D-V-17), 1,000 feet deep; No. 3 (Gaston), (D-V-16), 400 feet deep; and No. 4 (Ebenezer) (D-V-15), 285 feet deep-and by the Saratoga lateral from the Argo tunnel (fig. 64). The Saratoga lateral is nearly 3,000 feet long, and connects to the 9 th and 10th levels of the shaft workings by raises. In 1931, a crosscut was being driven from the 285 level of the Ebenezer shaft to intersect the workings of the Centennial mine. ${ }^{36}$ Extensive stopes are present on all levels of the mine; their positions are shown on figure 83 . In 1954 all the workings were inaccessible. Much of the following is taken, therefore, from Bastin and Hill (1917, p. 267, 268).

The production from the Saratoga mine-since 1902 is given in table 77; this ore if produced today would be worth about $\$ 1,300,000$. The mine is reported to have yielded about $\$ 2,500,000$ prior to 1899 (Callbreath, 1899, p. 286). The total yield from the mine probably would be about $\$ 4$ million at today's metal prices.

TABLE 77.-Ore produced from the Saratoga mine, 1902-54 ${ }^{1}$

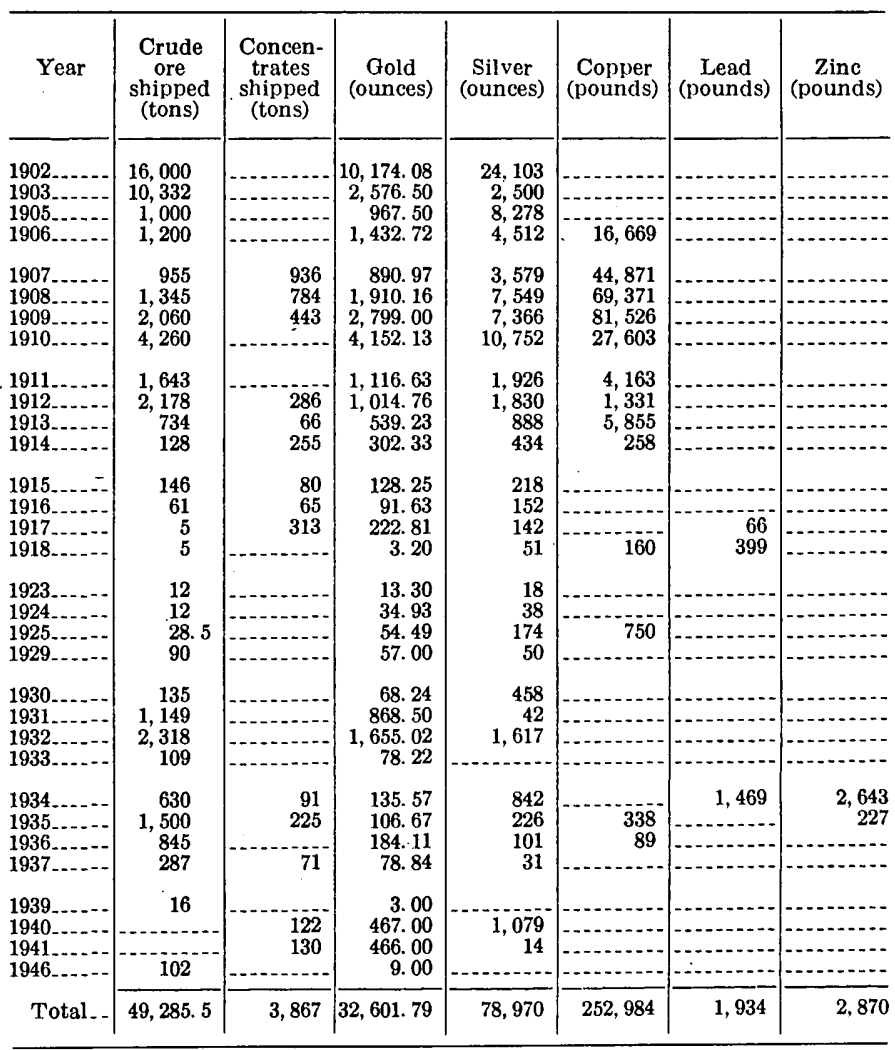

1 Compiled by the U.S. Bureau of Mines. Published by permission.

Although interlayered biotite gneisses with some intercalated pegmatite forms the wallrock at the surface, microcline-bearing gneiss should be intersected

30 Rickard, Forbes, 1931, Report to Saratoga Gold mines, Inc., 7 p., report on file in the Denver Public Library, Denver, Colo. 


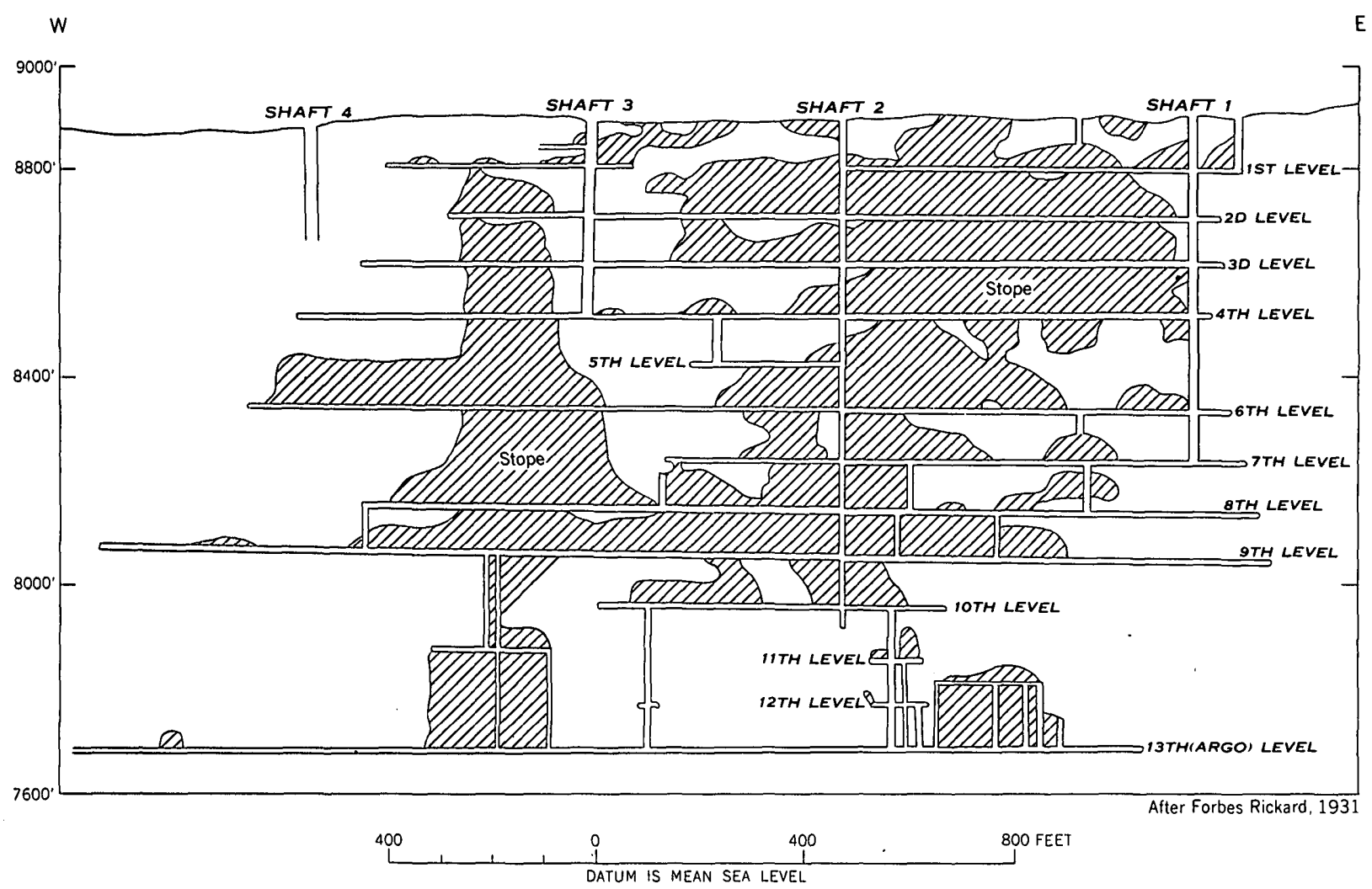

Figure 64.-Vertical longitudinal section of the Saratoga mine.

within 100 to 200 feet below the surface. Bastin and Fill (1917, p. 267) state that microcline-bearing gneiss formed the walls at the 6th and 10th levels and on the Saratoga lateral. The axis of the Pewabic Mountain syncline lies just east of the No. 3 (Gaston) shaft, and accordingly the Precambrian rocks dip gently into the axis.

The Saratoga vein strikes generally eastward, but to the west it swings to a west-northwest strike and to the east it swings to an east-northeast strike; it dips nearly vertical. The Saratoga vein branches between the Ebenezer and Gaston shafts, the Ebenezer shaft being on the north branch and the Gaston shaft on the south branch. Such branches of the vein are common, but apparently the branching is more in the nature of "run-arounds," for the branches tend to reunite along strike. ${ }^{37}$

Typically the vein consists of a few inches to as much as 2 feet of coarse pyrite and quartz that is bounded by a wide zone of altered wallrock with abundant disseminated pyrite. At places the pyritized altered wallrock zone is more than 5 feet wide. Judging from the production records (see table 77 ), the vein must also contain copper minerals,

\footnotetext{
${ }^{37}$ Rickurd, Forbes, 1931, op. cit.
}

presumably mainly chalcopyrite, and sparse galena and sphalerite. Some of the copper, however, may be in a cupriferous pyrite. During Bastin's investigation (Bastin and Hill, 1917, p. 268), samples of massive pyrite ore and altered and pyritized microclinebearing gneiss from the Saratoga lateral, about 2,900 feet from the Argo tunnel, were assayed for gold and silver. The massive pyrite ore assayed 0.16 ounces of gold per ton, 1.84 ounces of silver per ton, and 10 percent copper, whereas the pyritized wallrock assayed 0.07 ounces of gold and a trace of silver per ton. Bastin did not describe chalcopyrite from the ore, but it is probable that it was present.

Some assays of smelting ore from the Saratoga mine are shown in table 78. The metal content of ore shipped between 1893 and 1909, inclusive, was gold 0.90 ounces and silver 2.32 ounces per ton. The ore mined between the 9th and 10th levels is said to have averaged 1 ounce of gold per ton, 2 ounces of silver per ton, and 1 percent copper.

We infer from the longitudinal section of the Saratoga mine (fig. 64) that the ore occurs in nearly vertical ore shoots. The controls responsible for ore localization, however, are not known. Small ore bodies 
have been described from the junctions of subsidiary veins with the main Saratoga vein. ${ }^{38}$

TABLE 78.-Assays of some smelting ore from the Saratoga mine ${ }^{1}$

\begin{tabular}{|c|c|c|c|c|}
\hline Year & Tons. & Gold ${ }^{2}$ & Silver 2 & $\begin{array}{l}\text { Copper } \\
\text { (percent) }\end{array}$ \\
\hline $\begin{array}{l}1902 \\
1903 \\
1905 \\
1906 \\
1910\end{array}$ & $\begin{array}{r}16,000 \\
10,332 \\
1,000 \\
1,200 \\
4,260\end{array}$ & $\begin{array}{r}0.64 \\
.25 \\
.97 \\
1.20 \\
.98\end{array}$ & $\begin{array}{l}1.50 \\
.24 \\
8.28 \\
\text { 3. } 78 \\
2.52\end{array}$ & $\begin{array}{r}0.70 \\
0.37\end{array}$ \\
\hline $\begin{array}{l}1918 \\
1923 \\
1924 \\
1925 \\
1929 \\
1930\end{array}$ & $\begin{array}{r}5 \\
12 \\
5 \\
5 \\
90 \\
4\end{array}$ & $\begin{array}{r}.64 \\
\text { 1. } 10 \\
\text { 2. } 00 \\
\text { 1. } 59 \\
.63 \\
.51\end{array}$ & $\begin{array}{r}\text { 10. } 20 \\
1.50 \\
2.30 \\
1.30 \\
\text { 1. } 55 \\
\text { 1. } 66\end{array}$ & $\begin{array}{r}1.60 \\
\hdashline-80 \\
\hdashline-1.9 \\
\hdashline-10\end{array}$ \\
\hline
\end{tabular}

1 Compiled by U.S. Bureau of Mines. Published by permission.

${ }^{2}$ Ounces per ton.

\section{SILVER DOLLAR VEIN}

The Silver Dollar vein, which crops out on the ridge between lower Russell Gulch and Willis Gulch, has been worked in the Silver Dollar No. 1 mine $(\mathrm{F}-\mathrm{V}-13)$, which is 350 feet $\mathrm{S} .38^{\circ} \mathrm{W}$. from the Hampton mine, and the Silver Dollar No. 2 mine (E-V-24), which is 720 feet southwest of the Silver Dollar No. 1 mine. The production from the Silver Dollar mines since 1902 is given in table 79; the value of this ore today would be about $\$ 28,000$. The Silver Dollar No. 2 mine is reported to have yielded about $\$ 234,000$ prior to $1928 .^{39}$

TABLE 79.-Ore produced from the Silver Dollar mine, 1902-54

\begin{tabular}{|c|c|c|c|c|c|c|c|}
\hline Year & $\begin{array}{c}\text { Crude } \\
\text { ore } \\
\text { shipped } \\
\text { (tons) }\end{array}$ & $\begin{array}{l}\text { Concen- } \\
\text { trates } \\
\text { shipped } \\
\text { (tons) }\end{array}$ & $\begin{array}{c}\text { Gold } \\
\text { (ounces) }\end{array}$ & $\begin{array}{c}\text { Silver } \\
\text { (ounces) }\end{array}$ & $\begin{array}{c}\text { Copper } \\
\text { (pounds) }\end{array}$ & $\begin{array}{l}\text { Lead } \\
\text { (pounds) }\end{array}$ & $\underset{\text { (pounds) }}{\text { Zinc }}$ \\
\hline $\begin{array}{l}1907 \\
1908 \\
1910 \\
1911\end{array}$ & $\begin{array}{r}100 \\
7 \\
12 \\
15\end{array}$ & (1) & $\begin{array}{r}27.19 \\
9.34 \\
2.76 \\
4.98\end{array}$ & $\begin{array}{r}1,418 \\
14 \\
307 \\
301\end{array}$ & $\begin{array}{l}7,960 \\
1,650 \\
2,003\end{array}$ & & \\
\hline $\begin{array}{l}1912 . . . \\
1913 . \\
1915 \\
1916 . .\end{array}$ & $\begin{array}{r}70 \\
3 \\
31 \\
29\end{array}$ & $\begin{array}{r}2 \\
-30\end{array}$ & $\begin{array}{r}11.01 \\
1.70 \\
27.27 \\
7.08\end{array}$ & $\begin{array}{r}1,341 \\
76 \\
860 \\
389\end{array}$ & $\begin{array}{r}8,019 \\
609 \\
9,496 \\
4,195\end{array}$ & $\begin{array}{c}1,237 \\
-75\end{array}$ & 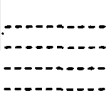 \\
\hline $\begin{array}{l}1917 \\
1918 \ldots \ldots \\
1934 \\
1936 \\
1939\end{array}$ & $\begin{array}{r}62 \\
38 \\
-14\end{array}$ & 29 & $\begin{array}{r}18.33 \\
4.18 \\
1.02 \\
4.10 \\
7.74\end{array}$ & $\begin{array}{r}947 \\
363 \\
36 \\
118 \\
1,449\end{array}$ & $\begin{array}{r}8,370 \\
4,960 \\
694 \\
4,261\end{array}$ & $\begin{array}{r}180 \\
3,408 \\
\end{array}$ & $\begin{array}{r}52 \\
\hdashline 2,156\end{array}$ \\
\hline Total . . & 381 & 63 & 126.70 & 7,619 & 52,217 & 4,900 & 2,208 \\
\hline
\end{tabular}

1 Compiled by the U.S. Bureau of Mines. Published by permission.

The Silver Dollar No. 2 shaft is 225 feet deep with levels at 93 and 185 feet (fig. 65). A 75-foot winze has been sunk 100 feet northeast of the shaft; a level is turned from the winze at a depth of 55 feet (fig. 65). The Silver Dollar No. 1 shaft is reportedly 362 feet deep; the 225 level connects through a stope to

${ }^{38}$ Rickard, Forbes, op. cit.

${ }^{39}$ Alsdorf, P. R., 1928, Report to the Master Key Tunnel Association, 8 p., report on file in the Denver Public Library, Denver, Colo. the Powers Mine (fig. 63). All these workings were inaccessible in 1954, but Draper ${ }^{40}$ and Bastin and Hill (1917, p. 278-279) examined the mines; the following is taken from their descriptions.

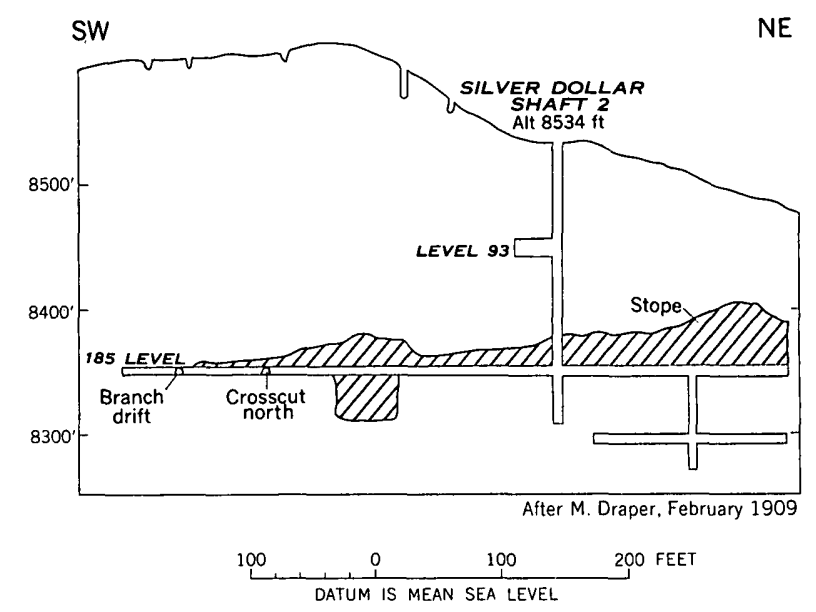

Figdre 65.--Longitudinal section in the plane of the vein, Silver Dollar mine.

The Silver Dollar vein is the southwestward extension of the Hampton vein, and it strikes about N. $45^{\circ}$. E. and dips $50^{\circ}-60^{\circ} \mathrm{NW}$. A nearly vertical parallel vein is present in the Silver Dollar No. 2 workings, but its relation to the Silver Dollar vein is not known. Near the face of the 185 level of the Silver Dollar No. 1 Mine, the Silver Dollar vein is 1 to $11 / 2$ feet wide and has tight walls. It is largely filled by pyrite and enargite, in nearly equal amounts. Vugs-maximum dimension $11 / 2$ inches-are common, and are lined with crystals of quartz, pyrite, and enargite. Galena, sphalerite, tennantite, and a little fluorite are also present in the ore. The value of selected shipments of ore is given in table 80 .

\begin{tabular}{|c|c|c|c|}
\hline Width of sample (inches) & Gold 2 & Silver ${ }^{2}$ & $\begin{array}{c}\text { Copper } \\
\text { (percent) }\end{array}$ \\
\hline 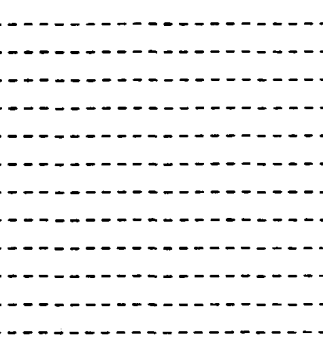 & $\begin{array}{r}0.14 \\
.22 \\
.16 \\
.08 \\
.04 \\
2.84 \\
.20 \\
.10 \\
.21 \\
.40 \\
.38 \\
.46\end{array}$ & $\begin{array}{r}12.5 \\
11.3 \\
11.1 \\
8.4 \\
2.1 \\
15.0 \\
24.0 \\
25.9 \\
24.6 \\
86.1 \\
65.9 \\
66.6\end{array}$ & $\begin{array}{r}5.6 \\
10.4 \\
7.4 \\
6.7 \\
.2 \\
6.7 \\
11.5 \\
12.6 \\
13.3 \\
24.0 \\
17.6 \\
9.4\end{array}$ \\
\hline
\end{tabular}

1 Draper, M. D., 1909, Report on the Silver Dollar Mine, report on file in the Den ver Public Library.
2 Ounces per ton.

${ }^{40}$ Draper, M. D., 1909, Report on the Silver Dollar Mine, 10 p., report on file in the Denver Public Library, Denver, Colo. 
STAR OF THE WEST MINE (F-V-9)

Location.-In Hangman Gulch, about 370 feet S. $40^{\circ}$ E. from the Success shaft.

Production.-From 1905 to 1954, 302 tons of smelting ore and 60 tons of concentrates was shipped that contained 88.68 ounces of gold, 4,877 ounces of silver, 2,220 pounds of copper, and 25,040 pounds of lead. (Compiled by U.S. Bureau of Mines. Published by permission.)

Development.-Shaft is reported to be 385 feet deep.

Veins.-Star of the West: Strike, N. $80^{\circ}$ E.; dip $70^{\circ} \mathrm{NW}$.

Wallrock.-Biotite-quartz-plagioclase gneiss and granite pegmatite.

Ore and sulfide minerals.-Galena, silver, gold, sphalerite, pyrite, and chalcopyrite.

Gangue minerals.-Quartz and ankerite(?).

Tenor. $-1,670$ tons that was shipped averaged $\$ 25$ per ton.

\section{TOGO MINE (D-VI-1)}

The Togo mine is in Willis Gulch, about 650 feet S. $45^{\circ}$ E. from the Saratoga No. 2 shaft. The property was opened prior to 1880 , and was last worked in 1917. The known production from the mine, since 1902 , is given in table 81 ; this ore if produced today would be worth about $\$ 56,500$.

Tabise 81.-Ore produced from the Togo mine, 1902-54 ${ }^{1}$

\begin{tabular}{|c|c|c|c|c|c|c|}
\hline Year & $\begin{array}{l}\text { Crude } \\
\text { ore } \\
\text { shipped } \\
\text { (tons) }\end{array}$ & $\begin{array}{l}\text { Concen- } \\
\text { trates } \\
\text { shipyed } \\
\text { (tons) }\end{array}$ & $\begin{array}{c}\text { Gold } \\
\text { (ounces) }\end{array}$ & $\begin{array}{c}\text { Silver } \\
\text { (ounces) }\end{array}$ & $\begin{array}{c}\text { Copper } \\
\text { (pounds) }\end{array}$ & $\begin{array}{c}\text { Lead } \\
\text { (pounds) }\end{array}$ \\
\hline $1910 \ldots$ & $\begin{array}{r}6 \\
98\end{array}$ & (n) & $\begin{array}{r}7.50 \\
41.19\end{array}$ & $\begin{array}{r}9 \\
1,224\end{array}$ & $\begin{array}{l}171 \\
650\end{array}$ & $\begin{array}{l}1,318 \\
1,291\end{array}$ \\
\hline 1912 & $\begin{array}{r}225 \\
3\end{array}$ & & $\begin{array}{r}68.83 \\
1.07\end{array}$ & $\begin{array}{r}1,523 \\
3\end{array}$ & 2,697 & 30,583 \\
\hline 1915 & 102 & 45 & 205.91 & 4,300 & 1,504 & 39,180 \\
\hline 1916 & $\begin{array}{r}156 \\
87\end{array}$ & 151 & $\begin{array}{l}354.55 \\
101.83\end{array}$ & $\begin{array}{l}7,657 \\
1,671\end{array}$ & 633 & 12,277 \\
\hline Total........ & 677 & 208 & 780.88 & 16,387 & 5,645 & 84,649 \\
\hline
\end{tabular}

1 Complled by U.S. Bureau of Mines. Published by permission.

The mine is opened by an inclined shaft, 220 feet deep, with levels at $100,150,200$, and 220 feet. In 1954 all the workings were inaccessible. Bastin and Hill (1917, p. 268) examined the mine, however, and the following is taken from their description.

The Togo vein has a general easterly trend and an average dip of $65^{\circ} \mathrm{N}$. The vein, as exposed in a winze 75 feet below the 100 level, shows 2 feet of fluorite, white quartz, and fine-grained pyrite on the hanging wall, below which is $11 / 2$ feet of nearly solid galena, sphalerite, pyrite, and gray quartz. In a stope 40 feet above the 200 level, the vein is filled by $11 / 2$ feet of galena, sphalerite, pyrite, and gray quartz. A little secondary hematite occurs in near-surface ore. Sam- pling-works assays of four lots of smelting ore shipped from the mine in 1907 and 1910 are given in table 82. Ore from a winze below the 200 level east is reported to have contained 1.4 ounces of gold and 90 ounces of silver per ton.

TABLE 82.-Sampling-works assays of some ore from the Togo mine ${ }^{1}$

\begin{tabular}{|c|c|c|}
\hline Pounds & Gold 2 & Silver 2 \\
\hline $\begin{array}{l}3,410 \\
2,719 \\
5,076 \\
3,878\end{array}$ & $\begin{array}{r}\text { 2. } 93 \\
\text { 3. } 05 \\
.87 \\
1.59\end{array}$ & $\begin{array}{r}\text { 14. } 25 \\
\text { 17. } 00 \\
\text { 4. } 00 \\
13.46\end{array}$ \\
\hline
\end{tabular}

1 Data on ore tenor furnished by the Idaho Springs Sampling Works. Published by permission.

\section{TWO-FORTY MINE (D-VI-4)}

The Two-Forty mine is on the south side of Willis Gulch, about 2,000 feet southwest of the Saratoga mine. The property was opened in 1891,41 and was last worked in 1936. The known production from the Two-Forty mine-nearly the total-is given in table 83 ; this ore if produced today would be worth about $\$ 230,000$.

TABLE 83.-Ore produced from the Two-Forty mine, 1897-1954 ${ }^{1}$

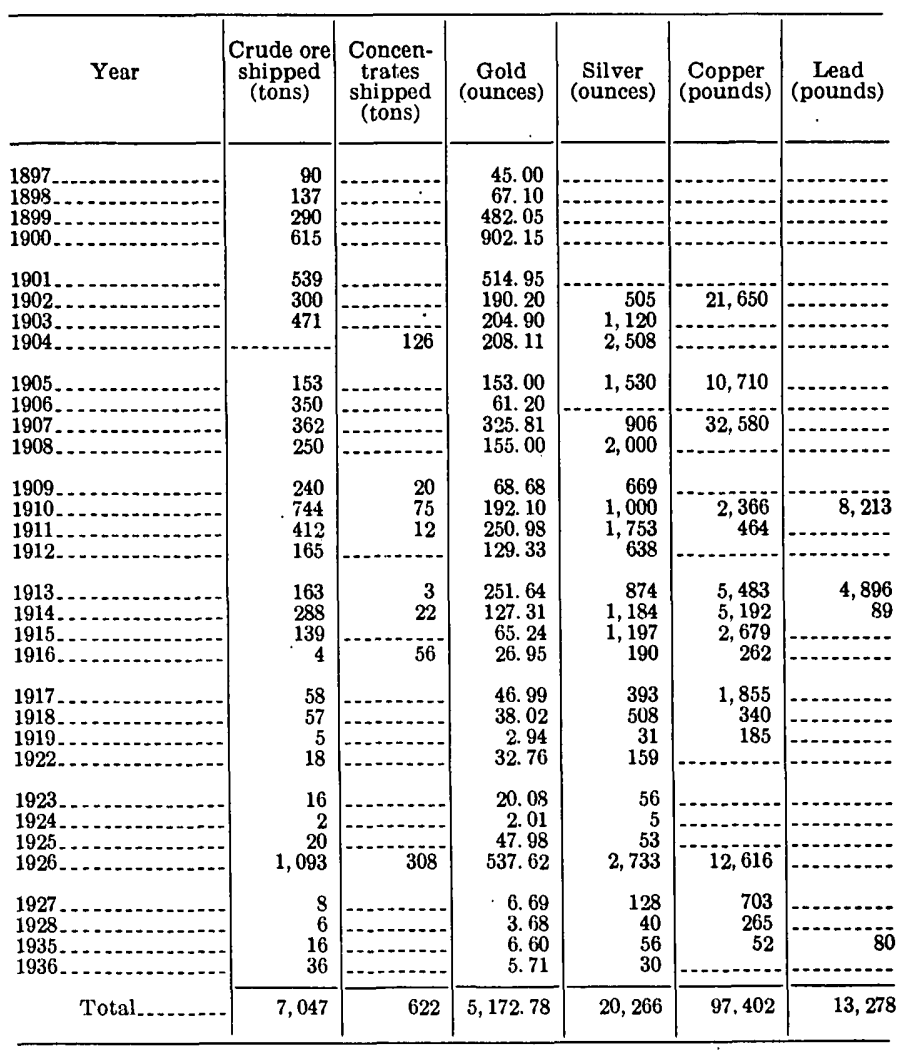

1 Compiled by the U.S. Bureau of Mines. Published by permission.

${ }^{41}$ Rickard, Forbes, 1913. Report on the Two-Forty mine, 8 p., report on file in the Denver Public Library, Denver, Colo. 
The mine is opened by an inclined shaft having a vertical depth of 310 feet, with levels at 80,160 , and 270 feet, and by 2 drift tunnels (fig. 66). The tunnel portals were not located at the surface (pl. 1). The upper tunnel is only 15 feet below the shaft collar, and the lower tunnel connects to the 80 level of the shaft workings. Most of the ground above the lower tunnel has been stoped out to the west of the shaft (fig. 66). All these workings were inaccessible in 1954, but Bastin and Hill (1917, p. 266-267) examined the mine and the following is taken from their description.

The predominant wallrock of the mine is biotitequartz-plagioclase gneiss. Bostonite porphyry dikes are exposed near the breast of the lower tunnel level, on the north wall of the same level about 690 feet west of the shaft, and on the 160 level about 350 feet west of the shaft.

The Two-Forty vein strikes about N. $63^{\circ} \mathrm{E}$. and dips $48^{\circ}-72^{\circ}$ (average $60^{\circ}$ ) NW.; at the surface it strikes N. $50^{\circ}$ E. It ranges from 2 inches to about 8 feet (average 2 feet) in width, and shows no branches. The vein consists of crushed silicified biotite gneiss that contains abundant fine-grained disseminated pyrite. Most parts of the vein contain at least one stringer of coarse pyrite and gray quartz, 1 to 8 inches wide, averaging about 2 inches. Where the vein cuts bostonite porphyry, that rock is much altered, contains some disseminated pyrite, and is

W

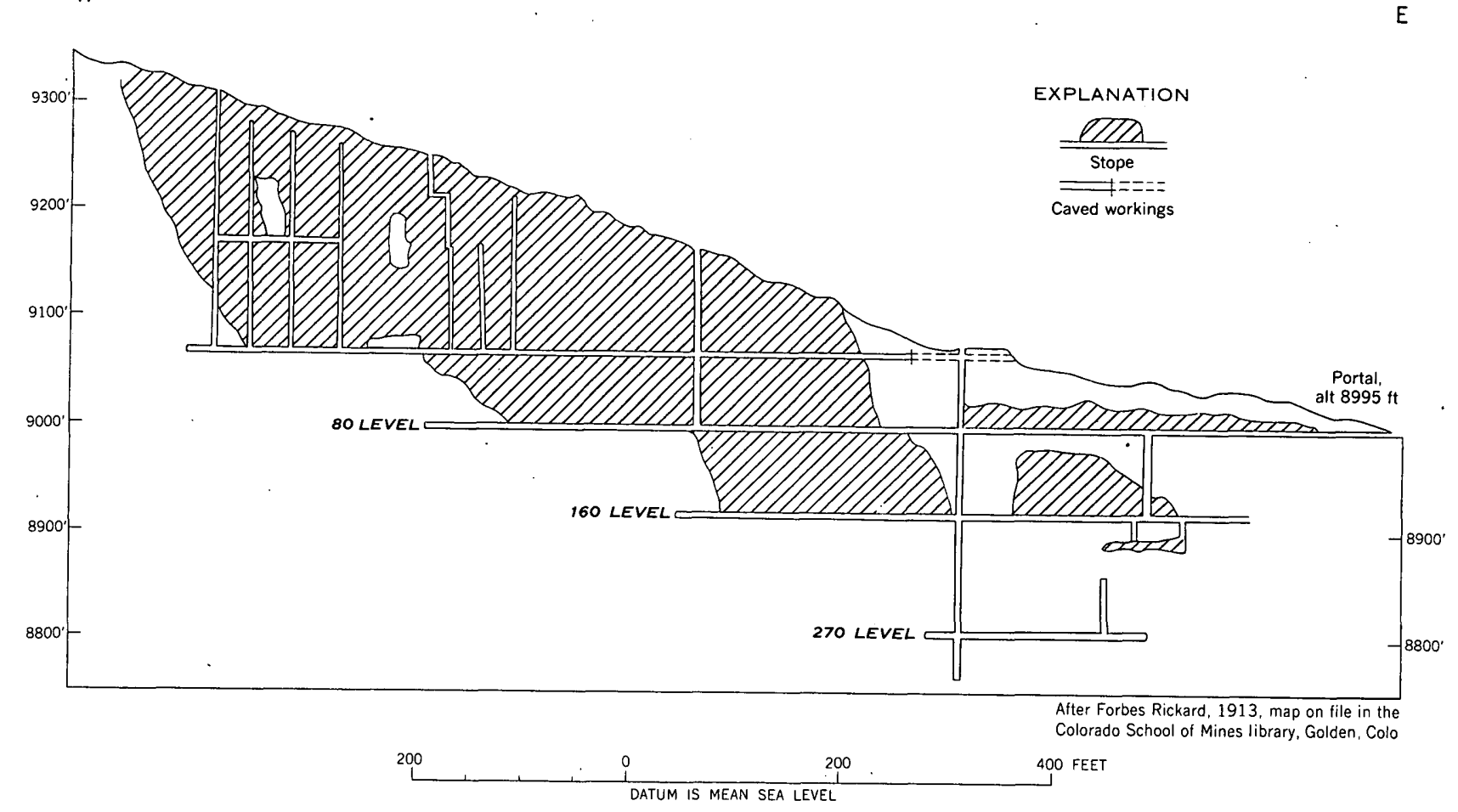

Fraure 66.-Vertical longitudinal section of the Two-Forty mine.
TABLE 84.-Sampling-works assays of some ore from the TwoForty mine i

\begin{tabular}{|c|c|c|c|c|}
\hline Year & Tons & Gold 2 & Silver & $\begin{array}{l}\text { Copper } \\
\text { (percent) }\end{array}$ \\
\hline $\begin{array}{l}1919 \\
1919 \\
1925 \\
1925 \\
1926 \\
1926 \\
1926\end{array}$ & $\begin{aligned} \text { 8. } 64 \\
\text { 4. } 67 \\
\text { 3. } 07 \\
\text { 3. } 48 \\
\text { 1. } 24 \\
\text { 1. } 96 \\
\text { 9. } 27 \\
\text { 5. } 17 \\
\text { 18. } 49 \\
\text { 3. } 90 \\
\text { 3. } 85 \\
\text { 8. } 65\end{aligned}$ & $\begin{array}{l}0.22 \\
6.63 \\
6.10 \\
.68 \\
3.18 \\
2.95 \\
.78 \\
3.15 \\
.29 \\
.84 \\
.88 \\
.30\end{array}$ & $\begin{array}{r}\text { 3. } 10 \\
6.65 \\
\text { 3. } 52 \\
\text { 3. } 30 \\
1.95 \\
2.00 \\
\text { 13. } 00 \\
22.60 \\
5.30 \\
15.10 \\
18.00 \\
6.00\end{array}$ & 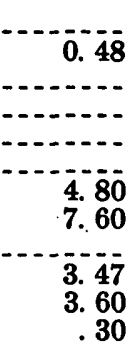 \\
\hline
\end{tabular}

1 Data on ore tenor furnished by the Idaho Springs Sampling Works. Published by permission.

traversed by tiny veinlets of pyrite, which are offshoots from the main vein. Postmineralization movement has produced abundant black gouge that contains fragments of pyrite throughout the length of the vein. In many places the massive pyrite is crushed and brecciated and the resulting openings filled by chalcopyrite, galena, and a little enargite. The content of smelting ore and concentrates shipped in different years is given in tables 84 and 85 . Few of the larger shipments from the mine contain more than 1 ounce of gold and 7 ounces of silver per ton.

Two veins parallel to and south of the Two-Forty vein are developed and stoped on the upper tunnel 
TABLE 85.-Sampling-works assays of some concentrates from the Two-Forty mine ${ }^{1}$

\begin{tabular}{|c|c|c|c|c|}
\hline Year & Tons & Gold 2 & Silver ${ }^{2}$ & $\begin{array}{c}\text { Copper } \\
\text { (percent) }\end{array}$ \\
\hline $\begin{array}{l}1922 \\
1922 \\
1922 \\
1923 \\
1923 \\
1923 \\
1925 \\
1925 \\
1926 \\
1926 \\
1926 \\
1927\end{array}$ & $\begin{array}{r}\text { 3. } 31 \\
\text { 3. } 39 \\
\text { 3. } 13 \\
\text { 5. } 18 \\
\text { 2. } 90 \\
\text { 2. } 46 \\
\text { 4. } 78 \\
\text { 2. } 63 \\
\text { 18. } 25 \\
\text { 9. } 27 \\
\text { 5. } 17 \\
\text { 3. } 90 \\
\text { 2. } 71\end{array}$ & $\begin{array}{r}\text { 3. } 84 \\
\text { 1. } 98 \\
\text { 1. } 12 \\
.74 \\
\text { 4. } 50 \\
\text { 2. } 73 \\
\text { 3. } 08 \\
.72 \\
\text { 3. } 78 \\
.15 \\
\text { 1. } 84\end{array}$ & $\begin{array}{r}\text { 12. } 20 \\
99.10 \\
\text { 5. } 70 \\
\text { 4. } 50 \\
\text { 3. } 40 \\
\text { 3. } 22 \\
\text { 3. } 70 \\
4.05 \\
\text { 10. } 40 \\
13.00 \\
22.60 \\
15.10 \\
1.60\end{array}$ & $\begin{array}{r}- \\
\hdashline \\
3.75 \\
4.80 \\
7.60 \\
3.47 \\
\hdashline\end{array}$ \\
\hline
\end{tabular}

1 Data on ore tenor furnished by the Idaho Springs Sampling Works. Published

Ounces per ton. level. One vein is 2 to 4 feet wide and is lithologically similar to the Two-Forty vein; the other vein, which is exposed about 150 feet from the portal of the lower tunnel, strikes $\mathrm{N}$. $85^{\circ} \mathrm{W}$. and dips $60^{\circ} \mathrm{N}$. It is about 8 inches wide and consists of crushed biotite gneiss containing a little disseminated pyrite, which is traversed by lenses and stringers of coarse pyrite not more than 2 inches wide.

\section{UNKNOWN MINE NUMBER F-VI-2}

A mine, name unknown, is on the south side of lower Russell Gulch about 1,730 feet S. $27^{\circ} \mathrm{W}$. from the Justice No. 1 mine $(\mathrm{F}-\mathrm{V}-25)$. The property is opened by a 250 -foot drift adit that bears about S. $67^{\circ} \mathrm{W}$. (fig. 67). No stopes are present in the mine.

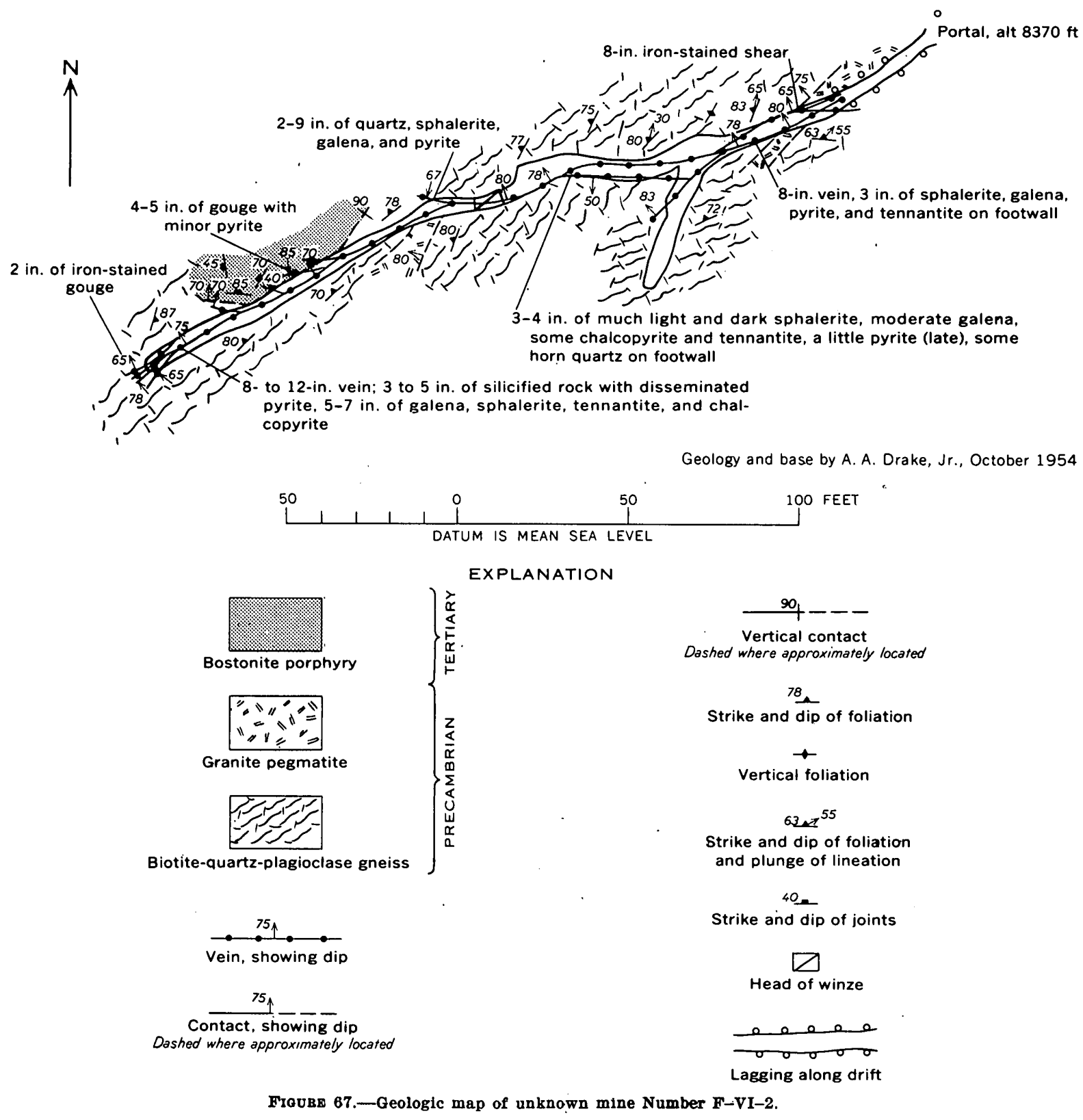


Biotite-quartz-plagioclase gneiss is the dominant rock of the mine. It is intruded by a dike of bostonite porphyry about 190 feet from the portal. The Precambrian rocks have a general east-northeastward trend, and dip steeply to the northwest.

Two veins are developed by the mine. The principal vein strikes on the average about $\mathrm{N} .75^{\circ}$ E. to a point a few feet east of the winze (fig. 67), and then swings to a $\mathrm{N} .60^{\circ} \mathrm{E}$. strike; it dips $65^{\circ}-80^{\circ} \mathrm{NW}$. The second vein enters the south wall of the drift 40 feet from the portal, swings to the north wall, and then enters the crosscut.where it passes into the southwest wall. It is cut and displaced by the major vein fissure, the north segment having been shifted about 12 inches to the southwest.

The major vein ranges from 6 to about 12 inches in width and contains as much as 7 inches of solid sulfides. About 10 feet east of the face, the vein is 12 inches wide and consists of 3 to 5 inches of silicified biotite gneiss that contains disseminated pyrite on the hanging wall, below which is 5 to 7 inches of dark and resinous sphalerite, galena, tennantite, and chalcopyrite. Several branch veins split from this vein into the hanging wall. The splits are interpreted as shear fractures and indicate that the north wall of the filled fissure moved southwest with respect to the south wall.

\section{WAR DANCE MINE (E-V-23)}

The War Dance mine, on the ridge between Willis Gulch and lower Russell Gulch, probably was opened before 1900, but the first extensive work was done in 1908. The mine was last operated in 1943. The known production from the mine is given in table 86 ; this ore if produced today would be worth about $\$ 330,000$. The mine is opened by an inclined shaft that connects to short levels at depths of $80,140,200,257,325$, and

TABLE 86.-Ore produced from the War Dance mine, 1902-54'

\begin{tabular}{|c|c|c|c|c|c|c|c|}
\hline Year & $\begin{array}{l}\text { Crude } \\
\text { ore } \\
\text { shipped } \\
\text { (tons) }\end{array}$ & $\begin{array}{l}\text { Concen- } \\
\text { trates } \\
\text { shipped } \\
\text { (tons) }\end{array}$ & $\begin{array}{c}\text { Gold } \\
\text { (ounces) }\end{array}$ & $\begin{array}{c}\text { Silver } \\
\text { (ounces) }\end{array}$ & $\begin{array}{l}\text { Copper } \\
\text { (pounds) }\end{array}$ & $\begin{array}{c}\text { Lead } \\
\text { (pounds) }\end{array}$ & $\begin{array}{c}\text { Zinc } \\
\text { (pounds) }\end{array}$ \\
\hline $\begin{array}{l}1908 \ldots \ldots \\
1909 \ldots \ldots \\
1910 \ldots \\
1911 \ldots \\
1912 \ldots\end{array}$ & $\begin{array}{r}100 \\
180 \\
68 \\
1,694 \\
376 \\
336\end{array}$ & 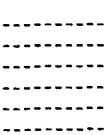 & $\begin{array}{r}1,326.74 \\
898.00 \\
656.67 \\
2,785.03 \\
1,286.43 \\
347.93\end{array}$ & $\begin{array}{r}911 \\
688 \\
536 \\
3,915 \\
1,384 \\
933\end{array}$ & $\begin{array}{r}356 \\
2,073 \\
2,254 \\
4,938\end{array}$ & 3,673 & $\begin{array}{c}\cdots \\
\cdots\end{array}$ \\
\hline $\begin{array}{l}1918 \ldots \ldots \\
1919 \ldots \ldots \\
1921 \ldots \\
1922 \ldots \ldots \\
1932 \ldots \\
1933 . \ldots\end{array}$ & $\begin{array}{r}16 \\
5 \\
20 \\
2 \\
28\end{array}$ & $\begin{array}{r}13 \\
\\
\end{array}$ & $\begin{array}{r}54.90 \\
19.20 \\
37.32 \\
53.15 \\
1.42 \\
36.68\end{array}$ & $\begin{array}{r}65 \\
111 \\
8 \\
45 \\
1 \\
106\end{array}$ & \begin{tabular}{r}
1,179 \\
\hdashline \\
-
\end{tabular} & -- & $\begin{array}{l}-\cdots \\
-- \\
-- \\
--\end{array}$ \\
\hline $\begin{array}{l}1934 \ldots \\
1935 \\
1936 \\
1939 \\
1943\end{array}$ & $\begin{array}{r}288 \\
1,460 \\
2,405 \\
615 \\
5\end{array}$ & $\begin{array}{r}71 \\
34 \\
62 \\
\\
\end{array}$ & $\begin{array}{r}113.87 \\
423.20 \\
500.16 \\
117.00 \\
3.90\end{array}$ & $\begin{array}{r}4892 \\
3,633 \\
181 \\
61 \\
11\end{array}$ & $\begin{array}{r}9,563 \\
4,629 \\
\\
19\end{array}$ & $\begin{array}{r}11,820 \\
1,123\end{array}$ & $\begin{array}{l}9,697 \\
2,581\end{array}$ \\
\hline Total. . & 7,598 & 180 & $8,661.60$ & 16,381 & 25,011 & 19,680 & 12,278 \\
\hline
\end{tabular}

1 Compiled by the U.S. Bureau of Mines. Published by permission.

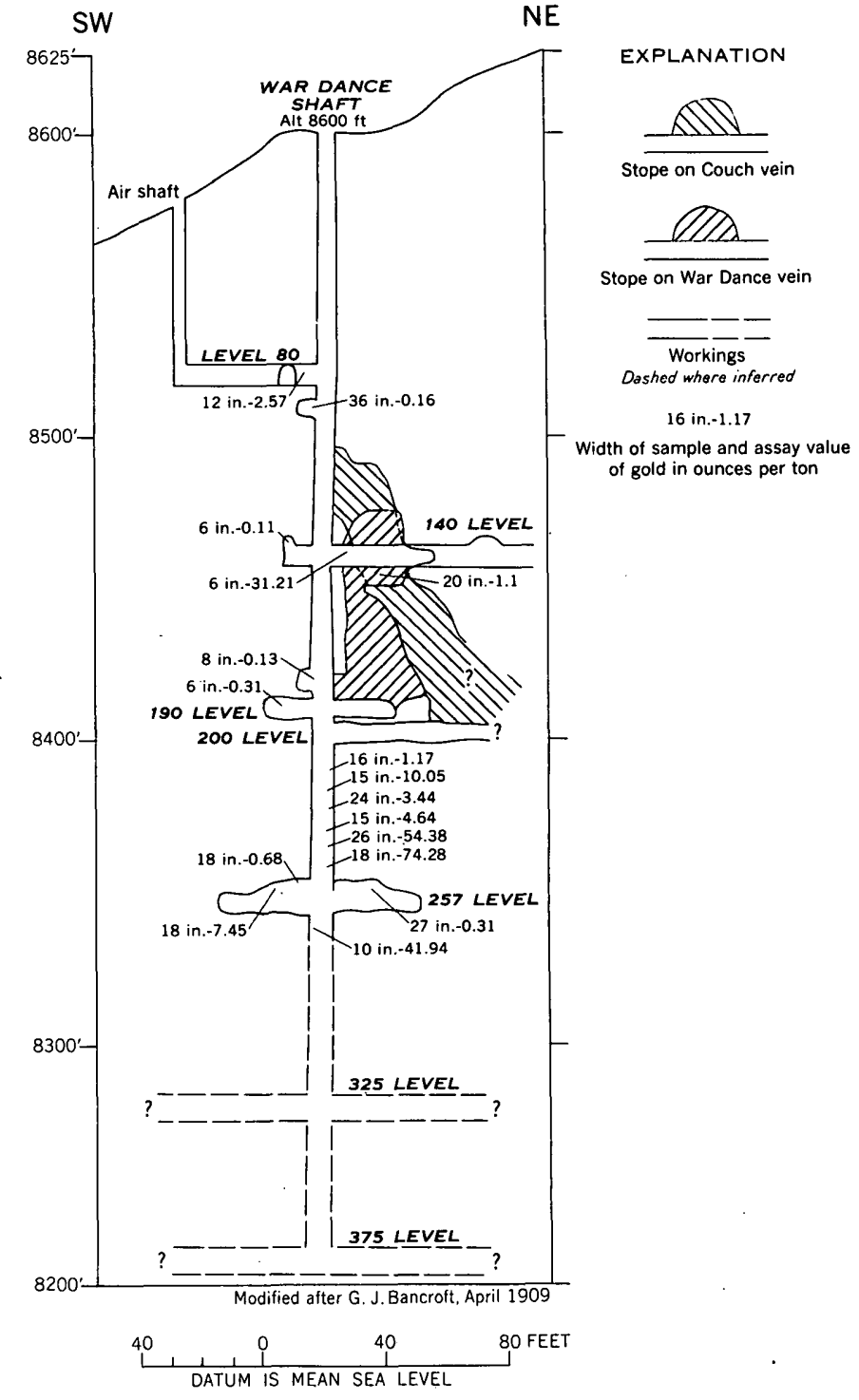

Figure 68.--Vertical longitudinal section of the War Dance mine.

375 feet (fig. 68), and is reported to be 480 feet deep..$^{42}$ The mine was inaccessible in 1954, and the following is taken largely from descriptions by Bancroft, ${ }^{43}$ and Bastin and Hill (1917, p. 277-278).

The War Dance vein is extremely variable in strike and trends on the average about N. $70^{\circ}$ E. and dips vertical to $70^{\circ} \mathrm{SE}$. The vein is filled by pyrite and gray quartz with some tennantite, galena, sphalerite, and sparse enargite. Vugs lined with crystals of the above minerals are common.

Near the shaft the War Dance vein is crossed by the Couch vein, which strikes about N. $15^{\circ}$ E. and

${ }^{42}$ Alsdorf, P. R., 1925, Report to the Master Key Tunnel Association, 8 p., report on file in the Denver Public Library, Denver, Colo. 3 Bancroft, G. J., 1909, Report on the War Dance mine, 6 p., report on fle in the Denver Public Library, Denver, Colo. 
dips nearly vertically. The Couch vein consists largely of pyrite, but it is reported also to contain a high content of copper. The intersection of the War Dance and Couch veins appears to plunge steeply to the northeast (fig. 68).

Two types of ore have been mined-sulfide ore containing moderate quantities of precious metals and telluride-bearing ore, which locally is rich in gold. The sulfide ore typically fills fissures as much as 7 inches thick. The telluride-bearing ore, in contrast, occurs in a complex network of fractures, some of which are parallel to the sulfide vein and others of which diverge from it at a large angle. The characteristic minerals of this ore are purple fluorite, pyrite, and a pale brass-yellow telluride (probably sylvanite or krennerite) that occurs in platelike crystals. Exploration, though mainly confined to the War Dance vein, has shown that rich telluride ore largely occurs along fractures and as disseminations in biotite-quartzplagioclase gneiss wallrock at some distance from the vein. The tellurides show a spotty distribution and accordingly are difficult to mine profitably.

The localization of the telluride ore is not fully known. Probably it was deposited subsequent to the major sulfide mineralization, in open spaces in preexisting veins and in later(?) fractures in the walls. The War Dance mine lies athwart the southwestward extension of the Dory Hill fault, which possibly was the conduit for the telluride-bearing ore solutions (see p. 63).

The variable tenor of the telluride ore from this mine is shown by the table 87 . The average metal content of more than 1,000 tons of this ore shipped in 1911 was reported to have been gold, 1.32 ounces and silver, 1.78 ounces per ton. Much of this ore was picked from the old dump and was below the run-ofthe mine average. Table 88 presents some assays of sulfide ore from the War Dance vein.

TABLE 87.-Assays of some telluride ore from the War Dance mine,

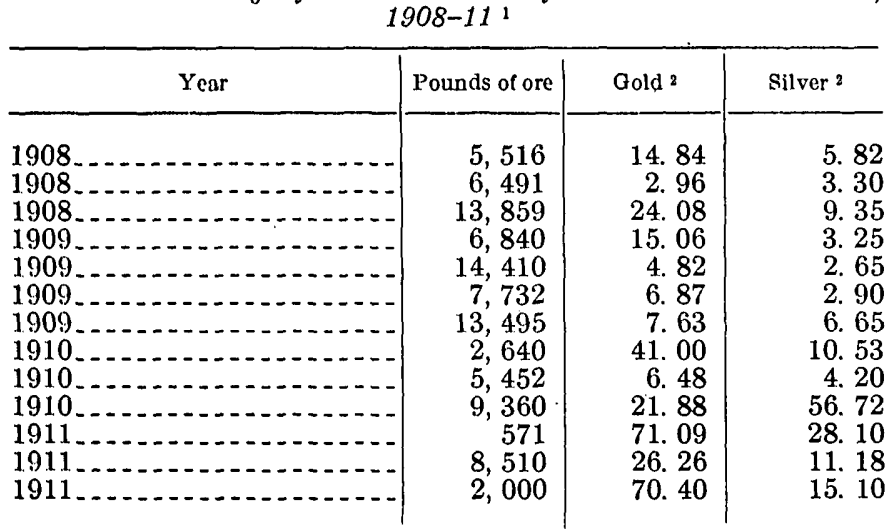

I Bastin and Hill, 1917, p. 278 .

2 Ounces per ton.
TABLE 88.-Assays of some sulfide ore from the War Dance mine

\begin{tabular}{r|r|r|r|r|r}
\hline Pounds of ore & \multicolumn{1}{|c|}{ Gold 2 } & Silver 2 & $\begin{array}{c}\text { Copper } \\
\text { (percent) }\end{array}$ & $\begin{array}{c}\text { Lead } \\
\text { (percent) }\end{array}$ & $\begin{array}{r}\text { Zinc } \\
\text { (percent) }\end{array}$ \\
\hline 2,724 & 0.43 & 69.00 & 7.5 & & \\
1,402 & .40 & 55.00 & & \\
9,000 & 55 & 31.00 & 5.2 & & \\
13,130 & 1.20 & 62.00 & 8.9 & 14.00 & 3.5 \\
\hline
\end{tabular}

1 Bastin and Hill, 1917, p. 278.

Ounces per ton.

\section{WEST NOTAWAY MINE (E-V-7)}

The West Notaway mine is on the north side of Russell Gulch, about 720 feet S. $81^{\circ} \mathrm{W}$. from the Pittsburg mine. The property probably was opened prior to 1880, and it was worked last in 1951. The known production from the mine, 1902-54, is given in the table 89 ; this ore if produced today would have a value of about $\$ 300,000$. The mine is opened by an inclined shaft that connects to levels at vertical depths of $110,160,230$, and 440 feet. These workings were inaccessible in 1954, but Bastin and Hill (1917, p. 263-264) examined the property and the following is largely taken from their description.

The West Notaway mine develops a vein that strikes on the average $\mathrm{N} .60^{\circ} \mathrm{E}$. and dips $60^{\circ}-65^{\circ} \mathrm{NW}$., and which is the westward extension of one of the veins

TABLE 89.-Ore produced from the West Notaway mine, 1902-54 ${ }^{1}$

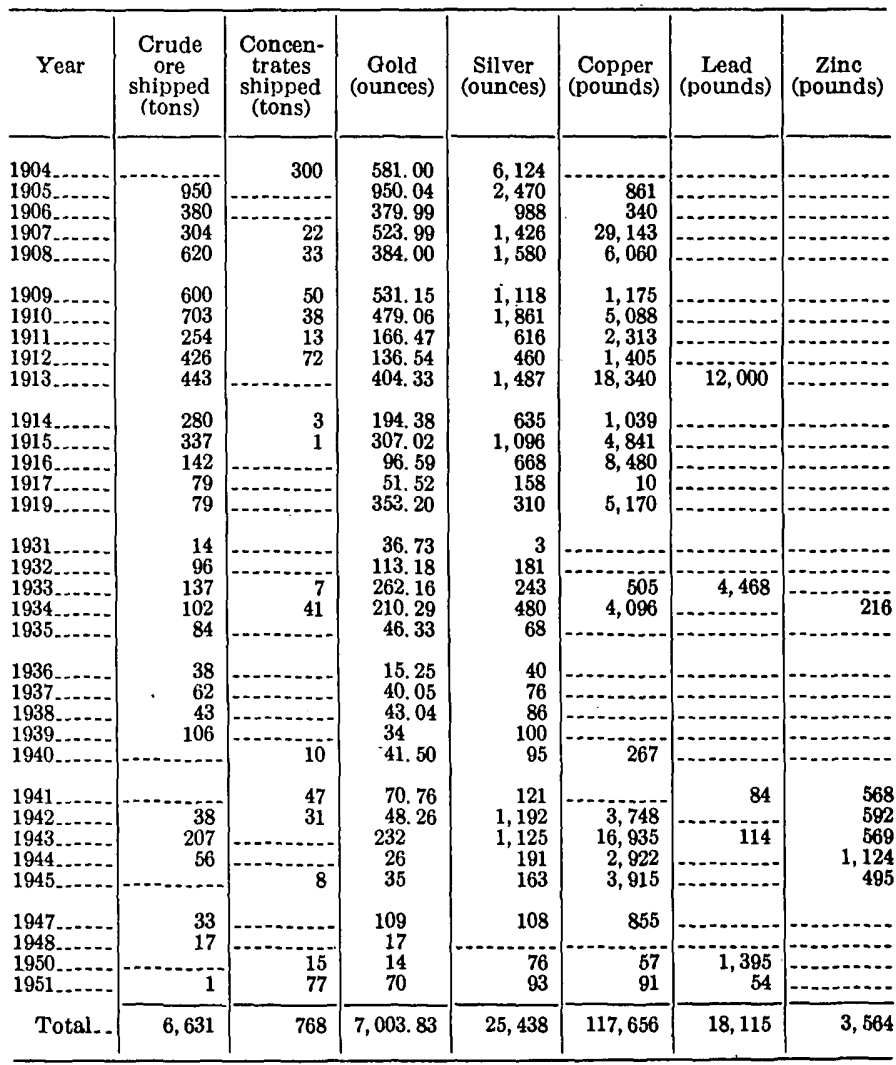

1 Compiled by U.S. Bureau of Mines. Published by permission. 
developed by the East Notaway mine. The ore was formed by two distinct stages of mineralization. An early coarse pyrite vein is locally brecciated and filled by gray, fine-grained quartz and in places large amounts of tennantite. As in the East Notaway mine, gold tellurides locally occur in siliceous veinlets that cut the sulfide ore deposited during the first period of mineralization; their presence gives the high gold content to much of the ore that was mined. Table 90 presents selected assays of ore shipped. from the property and gives the range in metal content.

TABLE 90.-Sampling-works assays of some ore from the West

\begin{tabular}{|c|c|c|c|c|}
\hline Year & $\begin{array}{c}\text { Pounds } \\
\text { of ore }\end{array}$ & Gold 2 & Silver & $\begin{array}{c}\text { Copper } \\
\text { (percent) }\end{array}$ \\
\hline $\begin{array}{l}1888 \\
1893 \\
1895 \\
1898 \\
1900 \\
1905 \\
1906 \\
1908\end{array}$ & $\begin{array}{r}3,862 \\
4,670 \\
6,319 \\
11,042 \\
12,650 \\
6,054 \\
11,958 \\
11,229 \\
5,043\end{array}$ & $\begin{array}{r}\text { 3. } 15 \\
\text { 1. } 50 \\
2.97 \\
.91 \\
\text { 1. } 43 \\
2.00 \\
.48 \\
.67 \\
7.34\end{array}$ & $\begin{array}{l}\text { 6. } 30 \\
\text { 6. } 70 \\
\text { 8. } 00 \\
\text { 2. } 80 \\
\text { 5. } 60 \\
\text { 7. } 00 \\
\text { 2. } 50 \\
\text { 3. } 20 \\
\text { 4. } 50\end{array}$ & $\begin{array}{r}3.8 \\
4.7 \\
7.0 \\
2.55\end{array}$ \\
\hline
\end{tabular}

1 Bastin and Hill, 1917, p. 264.

Ounces per ton.

WIDOW WOMAN (AMERICAN GIRL) MINE (F-VI-6)

The Widow Woman mine is on the north slope of Banta Hill in the southeastern part of the district. The mine is on the Queen Mineral Ranch, 330 feet east of the Cherokee mine; it develops the eastward extension of the Cherokee vein. The mine is opened by a shaft, inclined steeply north, and 4 principal levels at vertical depths of $122,170,203$, and 242 feet. Large stopes have been driven on all levels; west of the shaft the vein has been nearly completely mined for about 80 feet.

The mine probably was not worked extensively until the depression years of the 1930's, and at this time it was active intermittently until 1937; it was again active from 1942 to 1944 . The property was reopened in 1954, after the discovery of uranium in the adjacent Cherokee mine, and was being developed in 1955 . In 1955 the 242 level west drift was connected to the Cherokee shaft.

A description of the Cherokee vein, including the uranium occurrences, is given in a report by Sims and others (1963).

The total production from the Widow Woman mine is not known, as shipments from the mine have been combined in reports to the U.S. Bureau of Mines with that of the Cherokee and Florence mines; it is probable, however, that most of the production given in table 91 , for the years 1930 to 1950 , was taken from the Widow Woman mine. Since the mine was reopened in 1954, several hundred tons of ore have been concentrated at the Gold Ridge mill, together with ore from the nearby Cherokee and Banta Hill mines. The ore is mainly valuable for its lead, silver, and gold content. The gold content of the ore is higher than that of most of the galena-sphalerite veins.

The wallrock is dominantly biotite-quartz-plagioclase gneiss. At places the gneiss is migmatitic and locally it contains small, nearly concordant pegmatite bodies. A 6-foot dike of Tertiary quartz monzonite porphyry is exposed in the south crosscut on the 122 level. The Precambrian biotite gneiss is deformed into tight north-northeastward-trending isoclinal folds whose axes plunge steeply north-northeast (fig. 69).

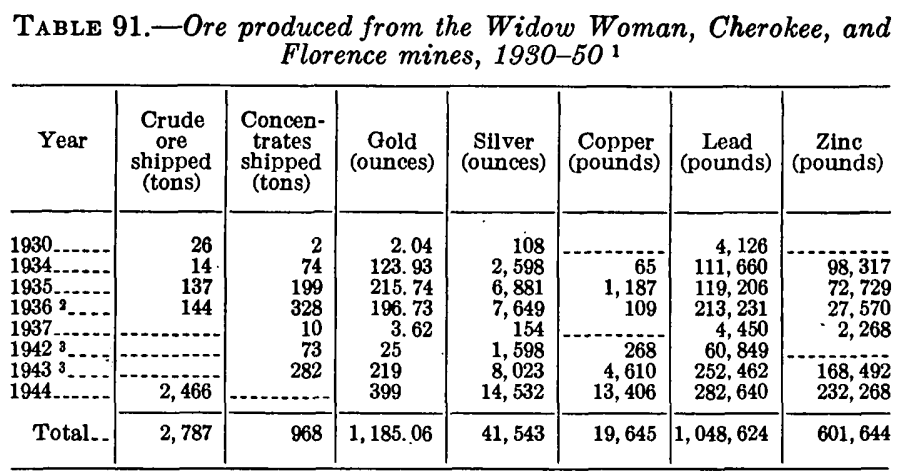

1 Compiled by U.S. Bureau of Mines. Published by permission.

2 Cherokee and Widow Woman mines.
3 Probably entirely taken from Widow Woman mine.

Three veins-the Widow Woman, an unnamed vein herein called vein $A$, and a vein that appears to correlate with the vein worked on the Gold claim-are present in the mine. The Widow Woman, which is the eastward extension of the Cherokee, is the principal vein. All three veins are galena-sphalerite.

The Widow Woman vein strikes N. $80^{\circ}-85^{\circ}$ E. and dips consistently $80^{\circ} \mathrm{N}$. to vertical (fig. 69). The vein intersects the steeply dipping, north-northeastward-trending biotite gneiss at a large angle. The vein, where exposed, is characteristically 2 to 3 feet wide and consists of bleached, silicified, and pyritized wallrock with highly irregular, generally thin seams of pyrite, quartz, and rhodochrosite, and irregular seams and clots of galena, sphalerite, and tennantite. Typically, as described above, the vein is low in grade and constitutes mill dirt. At places, as on the 203 level west of the shaft (fig. 69), the vein consists of massive sulfides, dominantly galena, in a quartz and rhodochrosite gangue; much of this ore is high in grade (smelting ore). Ore left in a pillar immediately west of the shaft on the 203 level is probably representative of much of the ore mined from the 
N

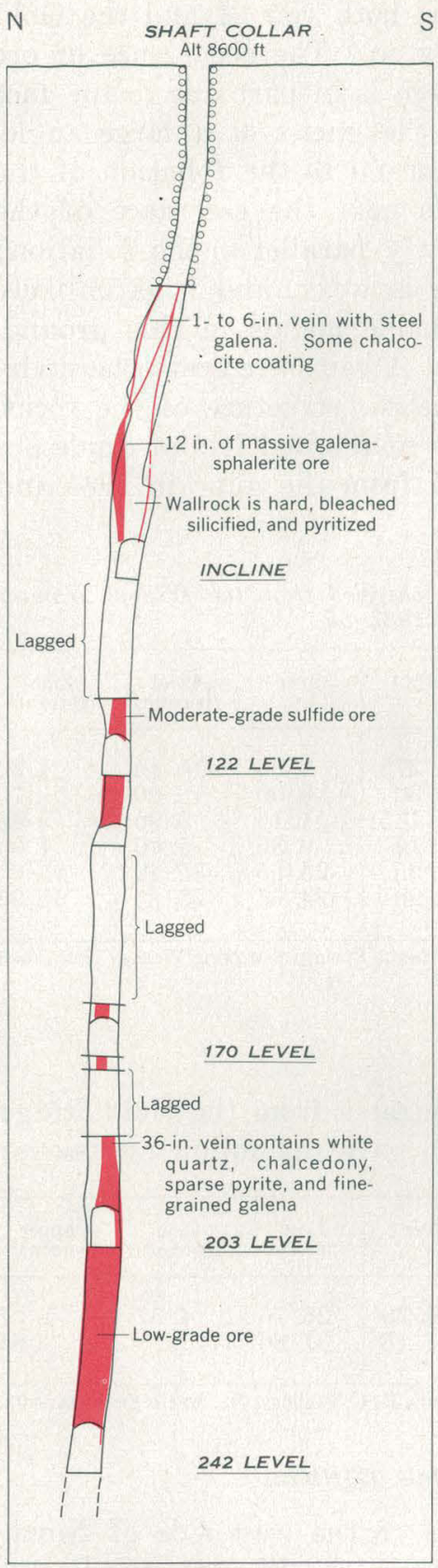

SHAFT SECTION

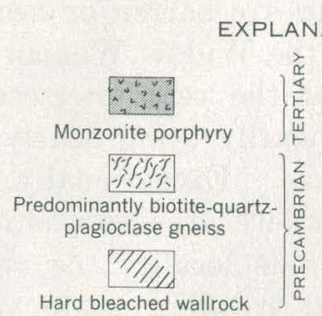

$$
\frac{1^{88}}{\uparrow^{75}}
$$

Contact, showing dip Dashed where approximately located

$$
\uparrow>6
$$

Barren fracture, showing dip 85

Strike and dip of foliation

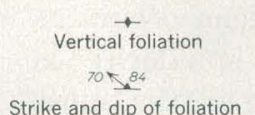

Strike and dip of foliation and plunge of lineation

\section{(1)}

Shaft going above and below levels

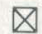

Foot of raise or winze

$\square$

Head of raise or winze

$\overline{\square-}$

Ore

Inaccessible workings

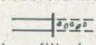

Caved or filled workings

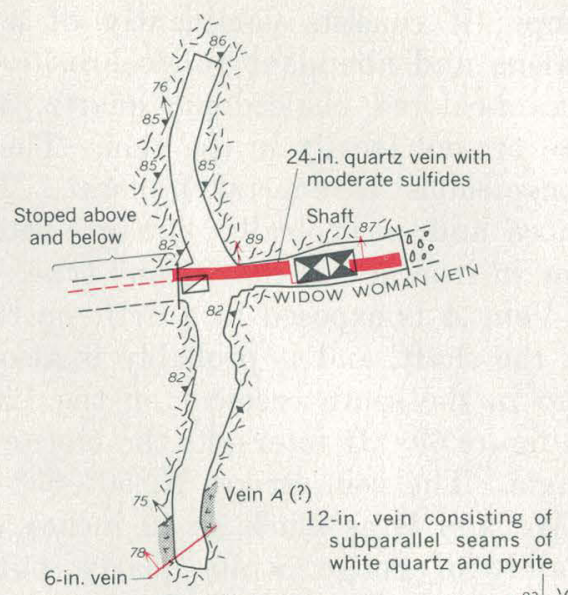

122 LEVEL

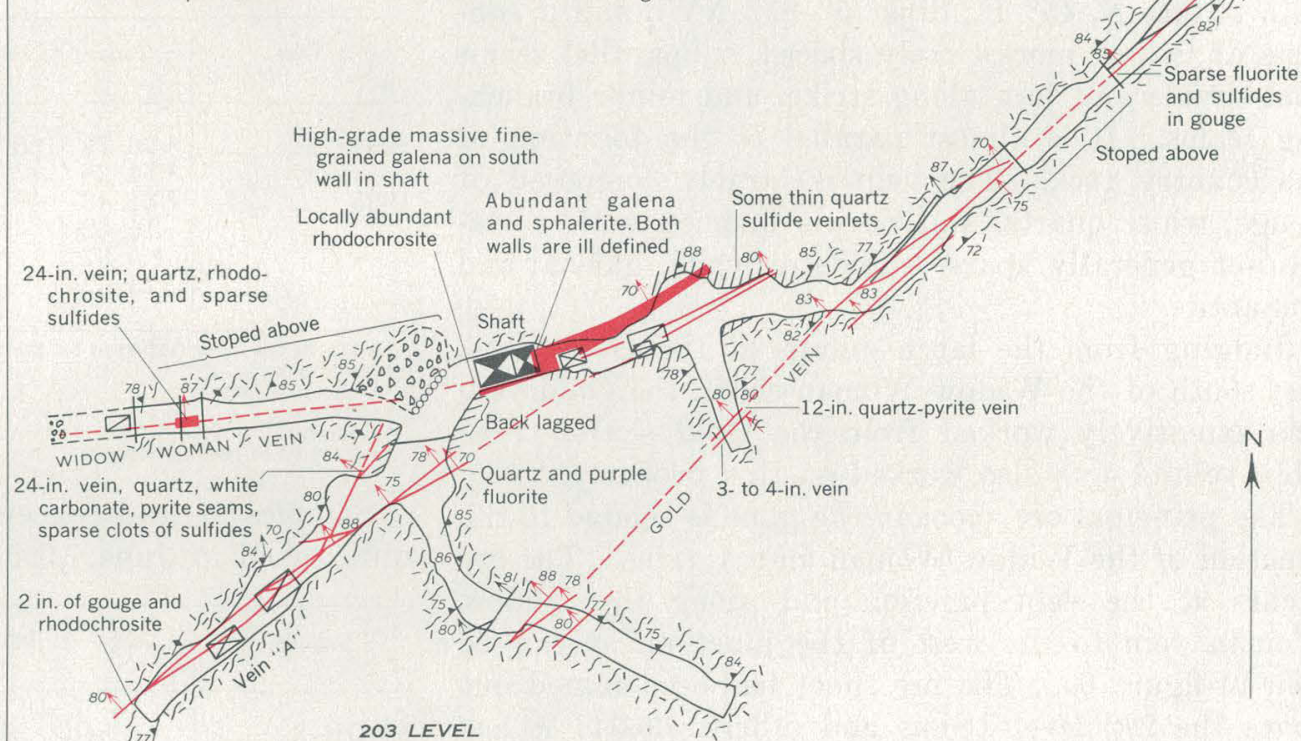

203 LEVEL

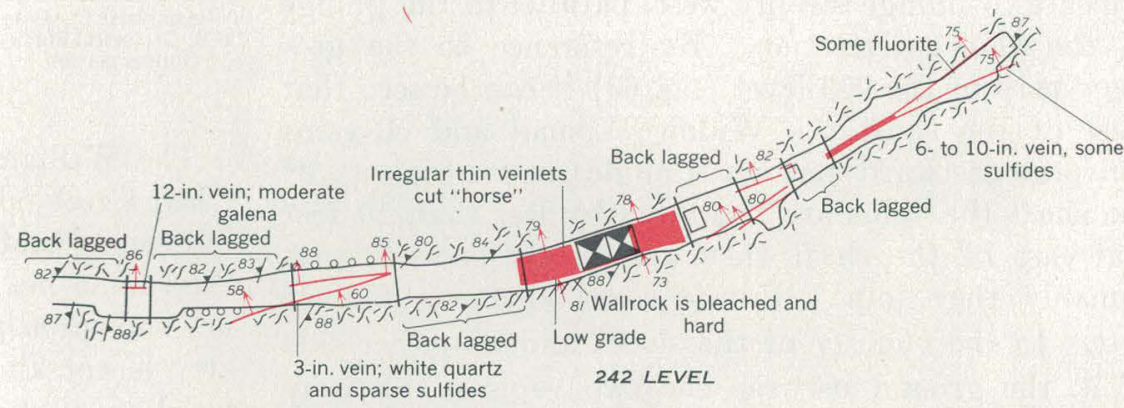

40

40

80 
stope; it consists dominantly of a foot of massive galena and abundant rhodochrosite. Purple fluorite, cream-colored chalcedonic quartz, and drusy quartz are present locally in the vein. The galena occurs as conspicuous base-metal mineral. The sphalerite is cubes and is typically fine grained; it is the most low in iron and is the "resin" type.

Vein $A$ is exposed in a drift on the 203 level, west of the shaft, and it probably is also on the 242 level and in the south crosscut on the 122 level, as shown in figure 69. It intersects the biotite gneiss at a small angle. The vein strikes N. $50^{\circ}-55^{\circ}$ E., dips $70^{\circ}-80^{\circ}$ NW., and is as much as 12 inches wide. It consists mainly of gouge, white quartz, purple fluorite, and rhodochrosite with irregular, sparse sulfides.

The Gold vein is exposed on the 203 level. The vein strikes $\mathrm{N} .45^{\circ}$ E., dips $75^{\circ}-85^{\circ} \mathrm{NW}$., and it consists of two or more closely spaced, subparallel seams that divide and join along strike, and minor branching seams. It is almost parallel to the foliation of the country rock. The vein is largely composed of gouge, white quartz, and purple fluorite, with variable but generally sparse sulfides-pyrite, galena, and tennantite.

Judging from the large dumps at the Gold mine, just south of the Widow Woman shaft, the Gold vein was extensively worked from the Gold shaft. Possibly vein $A$ was also worked on this property.

The principal ore shoot in the mine is related to the junction of the Widow Woman and $A$ veins. The ore occurs at the vein junction and along the Widow Woman vein to the west of the junction, as can be seen in figure 69 . The ore shoot has been mined out above the 242 level (Sims and others, 1963); it has an average breadth of about 120 feet. The ore shoot appears to plunge steeply west, parallel to the plunge of the vein intersection. By reference to the geologic map of the 203 level (fig. 69) it can be seen that west of the shaft the Widow Woman and $A$ veins converge eastward at a small angle; in the vicinity of the shaft the veins are separated by less than 10 feet and east of the shaft they are closely spaced; presumably they join within a short distance farther east. In the vicinity of the shaft, and on either side of it, the ground between the two veins is intensely silicified and bleached and it contains variable stringers and clots of sulfides, the whole at places constituting ore. The Widow Woman vein west of the shaft, where exposed, contains 24 inches or more of gangue and massive sulfides; it is similar in appearance west of the shaft on the upper levels.

As noted above, all of the metal concentrations aside from those related to the vein junction are in the Widow Woman vein; both vein $A$ and the Gold vein are barren or nearly so. The occurrence of ore in the Widow Woman vein is in part due to the fact that the vein intersects the gneiss at a large angle, generally being nearly normal to the foliation of the rocks. Exceptionally, as near the east face of the 242 level, the vein is nearly parallel to the foliation; at this locality the vein is weak, and it is unlikely that it will contain valuable metals in this ground. In contrast, the Gold and $A$ veins are everywhere virtually parallel to the gneissic structure of the rocks.

Sampling-works assays of selected lots of crude ore and concentrates shipped from the mine in 1934 and 1935 are given below:

Sampling-works assays of ore shipped from the Widow. Woman mine, 1934-35

\begin{tabular}{|c|c|c|c|c|c|}
\hline Year & Tons & Gold 2 & Silver ${ }^{2}$ & $\underset{\text { (percent) }}{\text { Lead }}$ & $\underset{\text { (percent) }}{\text { Zinc }}$ \\
\hline $\begin{array}{l}1934 \ldots \ldots \\
1935 \ldots \ldots\end{array}$ & $\begin{array}{rr}3 & 26.79 \\
3 & 14.25 \\
3 & 31.43 \\
16.62 \\
45.97 \\
4523.02\end{array}$ & $\begin{array}{l}0.275 \\
.20 \\
.735 \\
.14 \\
.55 \\
.90\end{array}$ & $\begin{array}{r}8.30 \\
8.00 \\
11.15 \\
6.30 \\
23.65 \\
34.65\end{array}$ & $\begin{array}{r}\text { 16. } 10 \\
18.00 \\
6.90 \\
5.00 \\
\text { 35. } 40 \\
20.85\end{array}$ & $\begin{array}{r}4.30 \\
.70 \\
7.40 \\
4.00 \\
15.60 \\
20.25\end{array}$ \\
\hline
\end{tabular}

1 Data on ore tenor furnished by the Idaho Springs Sampling Works. Published by permission.

2 Ounces per ton.

3 Crude ore.

3 Assayed 1.53 percent copper.

Samples of lead concentrates from the Gold Ridge mill, taken in June, 1955, gave the following assays:

\begin{tabular}{|c|c|c|c|c|c|}
\hline Sample 1 & Gold 2 & Silver ${ }^{2}$ & $\underset{\text { (percent) }}{\text { Lead }}$ & $\underset{\text { (percent) }}{\text { Zinc }}$ & $\begin{array}{l}\text { Copper } \\
\text { (percent) }\end{array}$ \\
\hline $\begin{array}{l}\text { M-GR-3 } \\
\text { M-GR-7 }\end{array}$ & $\begin{array}{l}\text { 1. } 54 \\
\text { 1. } 54\end{array}$ & $\begin{array}{l}\text { 36. } 70 \\
81.18\end{array}$ & $\begin{array}{l}26.75 \\
37.86\end{array}$ & $\begin{array}{l}\text { 4. } 57 \\
\text { 2. } 93\end{array}$ & $\begin{array}{r}1.27 \\
.65\end{array}$ \\
\hline
\end{tabular}

${ }^{1}$ Analysts: C. G. Angelo, H. E. Bivens, E. C. Mallory, Jr., and Robert Daywitt, U.S. Geological Survey.

\section{WILLIAMS TUNNGL}

The Williams tunnel is on the west side of North Clear Creek, about 600 feet N. $35^{\circ}$ W. from the Pewabic tunnel and a mile southeast of Black Hawk. As the tunnel lies east of the mapped area, its location is not shown on plate 1 . The early history of the property is not known, but it was reopened and rehabilitated in 1954 and in 1955 the tunnel was being extended southwest toward Justice Hill. The mine is a drift tunnel, about 945 feet long, that bears about S. $35^{\circ} \mathrm{W}$. (fig. 70). About 270 feet from the portal a short spur drift and stope are present, and at 380 feet a short crosscut and drift have been driven into the northwest wall. At 650 feet, an exploration heading that bears $\mathrm{S} .45^{\circ} \mathrm{W}$. is turned from the tunnel. The predominant wallrock of the mine is an inter- 


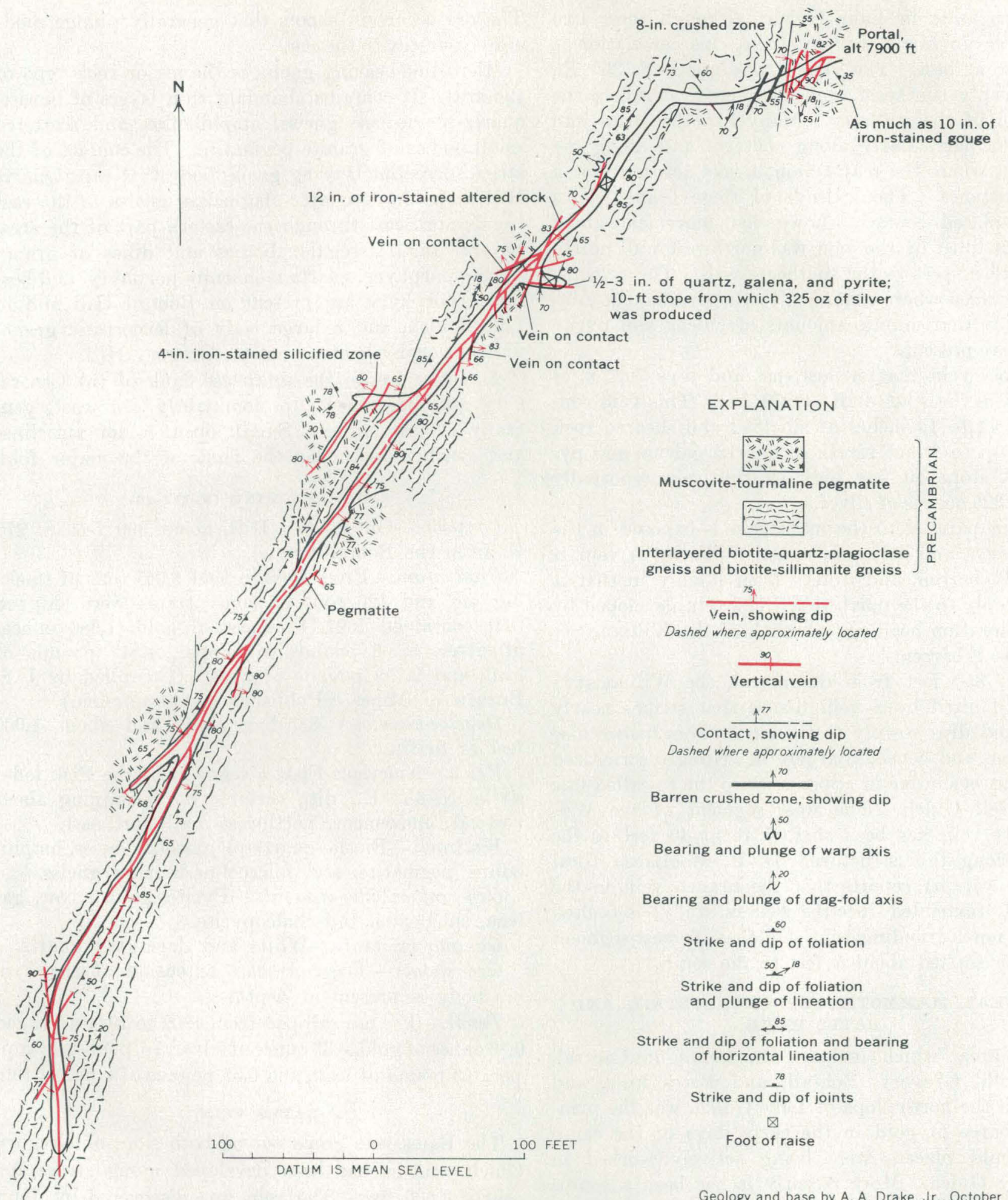

Geology and base by A. A. Drake, Jr., October 1954

FigURE 70.-Geologie map of the Williams tunnel.

layered sequence of biotite-quartz-plagioclase gneiss and sillimanitic biotite-quartz gneiss. Intercalated with the biotite gneisses are several conformable bodies of muscovite-tourmaline pegmatite. These rock strike about N. $35^{\circ}$ E. and dip steeply southeast. Locally the rocks are deformed by cross warps that plunge moderately to the northwest, and by overturned drag folds that plunge moderately to the northeast.

The vein developed by the tunnel is correlated by the property owners with the one developed by the 
Williams mine in Lake Gulch; although these two veins line up fairly well in strike, this correlation is tentative at best. The vein strikes about N. $35^{\circ}$ E., dips steeply southeast, and in general parallels the foliation of the wallrock. Many branches pass into the wall, particularly along contacts and along the foliation where the major vein breaks across it for a short distance. The attitude of these branch veins and displaced contacts shows that movement along the fault filled by the vein was northwest wall northeast with respect to the southeast wall. The vein fissure is barren where examined by the writers, but miners report that minute amounts of galena and pyrite locally are present.

A cross vein that strikes east and dips $70^{\circ} \mathrm{N}$. is exposed in the spur drift at 270 feet. This vein consists of 12 to 15 inches of silicified and sheared rock with a $1 / 2$ - to 3 -inch streak of quartz, galena, and pyrite. A stope 10 feet high on this vein reportedly yielded 325 ounces of silver.

A vein parallel to the main vein is exposed in the 380 crosscut and drift. Like the Williams(?) vein, it is nearly barren, and differs from it only in that it dips steeply to the northwest. The vein developed by the exploration heading, a branch of the Williams(?) vein, also is barren.

About 850 feet from the portal, the Williams(?) vein is faulted by a vein fissure that strikes nearly north and dips steeply to the east. This fissure also is barren, and consists largely of strongly sericitized rock that is similar in appearance to the so-called talc of Russell Gulch. The west segment of the Williams(?) vein has been shifted about 40 feet to the south along this structure. D. R. MacLaren (oral communication) reports that the branch vein in the $650 \mathrm{drift}$ (extended since the writers' study) is faulted by this north-trending vein, and that its west segment has been shifted about 2 feet to the south.

\section{CENTRAL, MAMMOTH, GREGORY, BOBTAIL, AND} BATES HILLS

This area, which includes the mines on Central, Mammoth, Gregory, Bobtail, and Bates hills, and those on the north slope of Lake Gulch, was the principal source of gold in the early days of the camp when gold placers were being actively worked in Gregory Gulch. More recently it has been a source of lode ore, and several mines have yielded large tonnages. The veins are of the pyrite type, and locally contain copper, lead, and zinc sulfides. Gold tellurides are reported to be present in the Sleepy Hollow mine. Although most of the primary ore below the enriched zone is comparatively low in grade, some veins, as the Bobtail and Sleepy Hollow, contain good ore at depth.
The ore occurs in shoots that generally plunge moderately steeply to the east.

Microcline-bearing gneiss is the major rock type of the area. It contains abundant thin layers of biotitequartz-plagioclase gneiss, amphibolite, and scattered small bodies of granite pegmatite. The contact of the large microcline-bearing gneiss body that caps Quartz Hill with biotite-quartz-plagioclase gneiss to the east trends northeast through the eastern part of the area. Several small irregular bodies and dikes of granodiorite porphyry, quartz monzonite porphyry, and bostonite porphyry are present on Bobtail Hill and in Lake Gulch, and a large body of leucocratic granodiorite porphyry crops out on Gregory Hill.

As rocks are on the southeast flank of the Central City anticline, they dip dominantly southeast, generally at low angles. Small, open, minor anticlines and synclines occur on the flank of the major fold.

\section{AMERICUS MINE (F-III-10)}

Location.-On Bobtail Hill, about 390 feet S. $27^{\circ}$

E. from the Bobtail tunnel.

Production.-From 1902 to 1941 5,047 tons of smelting ore and 120 tons of concentrates were shipped that contained 1521.71 ounces of gold, 1,680 ounces of silver, 8,503 pounds of copper, 4,549 pounds of lead, and 2,792 pounds of zinc. (Compiled by U.S. Bureau of Mines. Published by permission.)

Development.-A 835-foot shaft and about 1,000 feet of drifts.

Veins.-Americus-Fisk, a segment of the Fisk lode: strike N. $45^{\circ} \mathrm{E}$.; dip, variable but averaging about vertical; movement, northwest wall northeast.

Wallrock.-Biotite-quartz-plagioclase gneiss, amphibolite, pegmatite, and microcline-bearing gneiss.

Ore and sulfide minerals.-Pyrite, gold, silver, galena, sphalerite, and chalcopyrite.

Gangue minerals.-White and dark-gray quartz.

Ore shoots.-The northeast extension of the Fisk ore body is present at depth.

Tenor.-The ore shipped from 1902 to 1941 averaged 0.30 ounce of gold, 0.33 ounce of silver, 1.7 pounds of copper, 0.9 pound of lead, and 0.55 pounds of zinc per ton.

\section{BATES VEIN}

The Bates vein crops out on both sides of Gregory Gulch, and it has been developed along strike for nearly 3,500 feet. The vein was discovered by John H. Gregory, the discoverer of the Gregory Lode, on May 19, 1859 (Fossett, Frank, 1876, p. 233). He found extremely rich ore at the surface (Fossett, Frank, 1876, p. 234). When the rich surface oxidized ore was exhausted, the vein was developed by several deep shafts, the most important of which are the 
Bates-Hunter (E-III-10), Becker-Bates (E-III-13), and Sayre-Bates (E-III-16). The Bates-Hunter shaft is 740 feet deep, and has levels at 60, 163, 202, $290,373,436,510,568,642$, and 740 feet (fig. 88). The 60 -level connects with a tunnel whose portal is in Gregory Gulch, and the 510-level connects with the 430-level of the Becker-Bates mine. The Becker-Bates shaft is 430 feet deep with levels at 70,265, 320, and 430 feet (fig. 71). The Sayre-Bates shaft is about 510 feet deep with levels at 110, 210,350, and 500 feet. The vein was largely stoped above a depth of about 300 feet from a point southwest of the Bates-Hunter shaft across Bates Hill; the position of the stopes on the lower levels of the Bates-Hunter and Becker-Bates mines is shown on figure 71. In 1954 the workings were all inaccessible.

The Bates vein is reported to have yielded $\$ 600,000$ prior to 1880 (Fossett, 1880, p. 584) and about $\$ 3$ million before 1899 (Callbreath, 1899, p. 240). The pro-. duction from the vein since 1902 is given in table 92 ; this ore if produced today would have a value of about $\$ 180,000$.
The Bates vein strikes about N. $50^{\circ}$ E., dips steeply to the southeast, and appears to be the same lode as that developed in the McAllister mine and probably also in the Klein-German mine, on Mammoth hill. The vein ranges from 2 to 20 feet in width and averages about 5 feet (Fossett, 1876, p. 235). To the southwest it branches into several segments, the McAllister and the German being the most important commercially. Judging from the plan of the 430 level of the Becker-Bates mine, the vein has 2 principal strike directions about $20^{\circ}$ apart, and a branch vein enters the hanging wall where the vein strikes more easterly than normal. Stopes are localized along the intersection of this branch with the main (Bates) vein and along east-northeastward-striking parts of the Bates vein. The vein is largely filled by quartz and pyrite, but it also contains chalcopyrite, tennantite, galena, and sphalerite. The relation of the base metals to the quartz-pyrite filling is not known, but it is inferred that these minerals fill structurally controlled openings in the quartz-pyrite vein. The quantity of basemetal sulfides appears to decrease to the southwest.

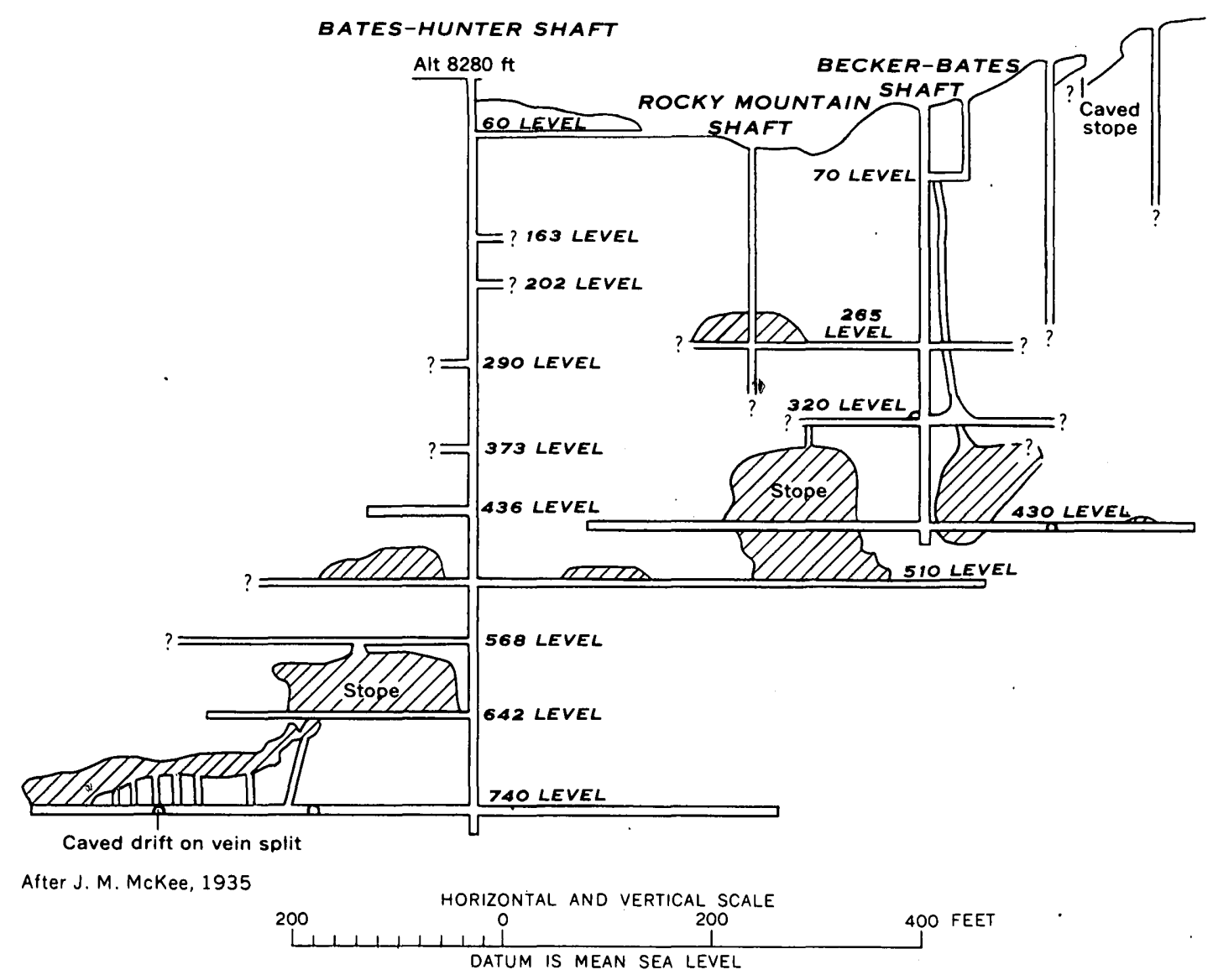

Figore 71.-Vertical longitudinal section of the Bates-Hunter and Becker-Bates mines. 
TABLE 92.-Ore produced from the Bates vein, 1902-54 ${ }^{1}$

\begin{tabular}{|c|c|c|c|c|c|c|c|}
\hline Year & $\begin{array}{c}\text { Crude ore } \\
\text { shipped (tons) }\end{array}$ & $\begin{array}{c}\text { Concentrates } \\
\text { shipped (tons) }\end{array}$ & $\begin{array}{c}\text { Gold } \\
\text { (ounces) }\end{array}$ & $\begin{array}{c}\text { Silver } \\
\text { (ounces) }\end{array}$ & $\begin{array}{c}\text { Lead } \\
\text { (pounds) }\end{array}$ & $\begin{array}{c}\text { Copper } \\
\text { (pounds) }\end{array}$ & Remarks \\
\hline $\begin{array}{l}1908 \ldots \\
1909 \ldots \\
1910 \ldots \\
1911 \ldots\end{array}$ & $\begin{array}{r}20 \\
1 \\
27 \\
----\end{array}$ & $\begin{array}{r}20 \\
3 \\
1 \\
9\end{array}$ & $\begin{array}{r}36.61 \\
5.24 \\
23.79 \\
5.39\end{array}$ & $\begin{array}{r}261 \\
24 \\
4 \\
32\end{array}$ & & 404 & $\begin{array}{l}\text { From Bates-German. } \\
\text { Do. } \\
\text { From Bates-German. } \\
\text { and Bates-Hunter. }\end{array}$ \\
\hline $\begin{array}{l}1912 \ldots \\
1913 \ldots \\
1914 \ldots \\
1915 \ldots\end{array}$ & $\begin{array}{r}607 \\
1,455 \\
2,289 \\
441\end{array}$ & $\begin{array}{r}44 \\
137 \\
302 \\
44\end{array}$ & $\begin{array}{r}315.77 \\
458.79 \\
1,024.53 \\
949.83\end{array}$ & $\begin{array}{r}619 \\
2,303 \\
5,856 \\
8,652\end{array}$ & $\begin{array}{r}7,709 \\
10,461 \\
25,743\end{array}$ & $\begin{array}{r}1,508 \\
12,892 \\
18,166 \\
25,861\end{array}$ & \multirow{3}{*}{$\begin{array}{l}\text { From Bates-Hunter. } \\
\text { Do. } \\
\text { Do. } \\
\text { Do. } \\
\text { Do. } \\
\text { Do. } \\
\text { Do. } \\
\text { From Becker-Bates. } \\
\text { Do. }\end{array}$} \\
\hline $\begin{array}{l}1916 \\
1917 \\
1918 \\
1940\end{array}$ & $\begin{array}{r}66 \\
257 \\
95 \\
12 \\
77\end{array}$ & $\begin{array}{r}80 \\
\hdashline 15 \\
\hdashline-10 \\
\hdashline\end{array}$ & $\begin{array}{r}\text { 136. } 30 \\
466.1 .1 \\
179.47 \\
1.07 \\
48.00\end{array}$ & $\begin{array}{r}812 \\
3,318 \\
1,236 \\
-86\end{array}$ & $\begin{array}{r}2,255 \\
17,557\end{array}$ & $\begin{array}{r}733 \\
5,459 \\
712 \\
- \\
\end{array}$ & \\
\hline Total & 5,347 & 655 & $3,650.90$ & 23,203 & 63,725 & 65,735 & \\
\hline
\end{tabular}

1 Complled by U:S. Bureau of Mines. Published by permission.

Although the oxidized surface ore from the mine was very rich, the ore produced since 1900 was relatively low in grade, averaging between 0.33 and 0.50 ounce of gold per ton and 1 and 2 ounces of silver per ton.

\section{BOBTAIL TUNNEL (F-III-9)}

The Bobtail tunnel, on the south side of Gregory Gulch, was started in 1863 (Bastin and Hill, 1917, p. 225), but it was not used extensively until 1874 , when most of the mines on Bobtail Hill were consolidated under one ownership, the Fifty Gold Mines Co. Since that date most of the mining in this area was done through the Bobtail tunnel and its connecting workings, the Cook shaft and the Gregory incline. In 1955 , only the Bobtail tunnel was accessible.

The vein pattern at the surface is difficult to determine because many pits, shafts, and large dumps obscure large parts of the ground. Accordingly, the veins as mapped on plate 1 are necessarily generalized and it is difficult to correlate these veins with those observed on the Bobtail tunnel level.

The Bobtail tunnel workings consist principally of a 1,150-foot crosscut and the Bobtail drift, which extends westward from the crosscut. Several drifts and the long Rogers crosscut are turned from the Bobtail drift (pl. 12). The vertical, 3-compartment, Cook shaft intersects the tunnel workings about 850 feet west of the crosscut. The Bobtail tunnel is the 365 level of the shaft.

The production from the Bobtail tunnel workings is estimated to have a value of about $\$ 10$ million. The known production, since 1902 (table 93) has a value today of about $\$ 2,050,000$. The reported yield from the Bobtail lode to 1879 was $\$ 5,138,837$ (Fossett, 1880 , p. 310-311).
TABLE 93.-Ore produced from the Bobtail tunnel, 1902-54 ${ }^{1}$

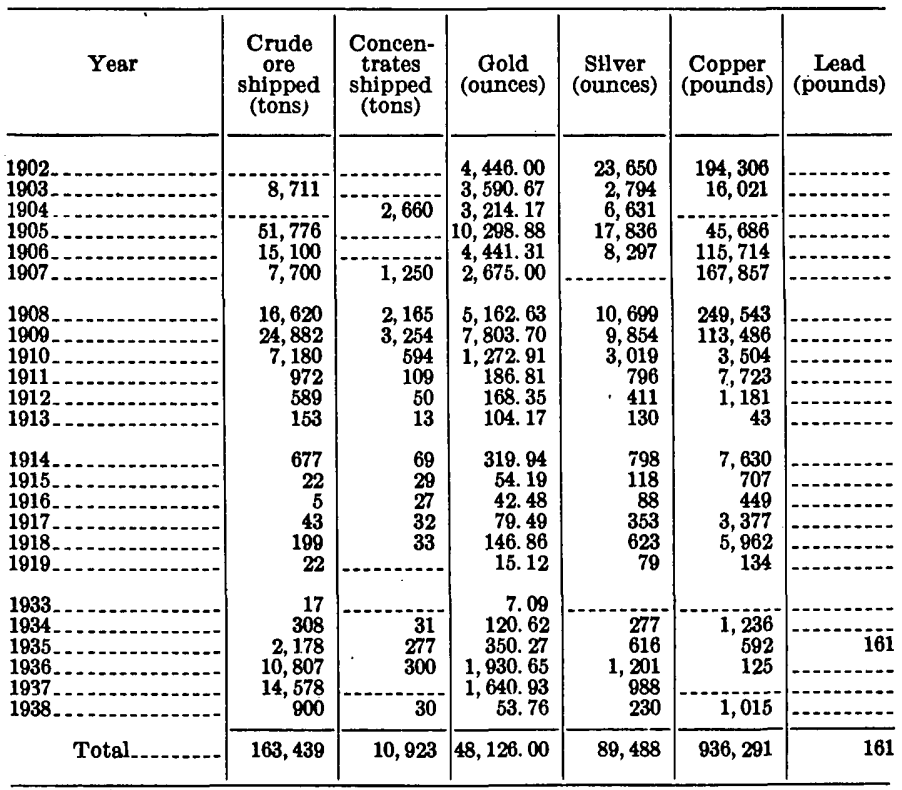

1 Complled by U.S. Bureau of Mines. Published by permission.

The wallrock of the mine is mainly microcline-bearing gneiss, which contains many thin interlayers of biotite-quartz-plagioclase gneiss, especially in the Rogers crosscut. The contact between the microclinebearing gneiss body and overlying biotite-quartzplagioclase gneiss is cut in the Bobtail tunnel, just southeast of the point where the Bobtail drift is turned to the west (pl. 12). In the tunnel the Precambrian rocks trend northeastward and generally dip gently to moderately to the southeast; but locally they are deformed into minor warps and drag folds that plunge gently to the northeast or northwest. In the drifts the structure of the wallrocks could not be determined. In the Rogers crosscut, several minor 
northeastward-trending fold axes are intersected, and about 530 feet northwest of the Bobtail drift a major north-northeastward-trending syncline, the Pewabic Mountain syncline (fig. 4), is cut. A small dike of leucocratic granodiorite porphyry, which strikes about N. $40^{\circ}$ E. and $\operatorname{dips} 65^{\circ} \mathrm{NW}$, is cut about 110 feet from the portal, and probably is the eastward extension of the Cook dike mapped on the surface. The probable northeastern extremity of the Gregory Hill leucocratic granodiorite porphyry plug is exposed in the tunnel between the O'Neil drift and the Rogers crosscut.

The principal veins cut in the Bobtail tunnel workings (pl. 12) are: Fisk, Puzzle, Cook, Ground Hog, Bobtail, Denmark(?), Cotton(?), Mammoth, O'Neil, Gregory, German, McAllister, and Epizootic.

The Fisk vein strikes N. $42^{\circ}$ E., dips $75^{\circ}-85^{\circ}$ SE., and is cut in the Bobtail tunnel about 560 feet from the portal. It is developed by a short drift that crosses the tunnel and by a drift that extends northeast from the Bobtail drift. Where exposed in the Bobtail tunnel, the vein is about 2 feet thick and consists of abundant irregular pyrite veinlets that traverse strongly silicified and sericitized gneiss. Northeast of the crosscut several horsetailing fractures pass from the vein into the hanging wall, forming a 20 - to 30 -foot zone of altered wallrock with abundant $1 / 32$ to $1 / 8$ inch pyrite stringers. About 650 feet southwest of the Bobtail tunnel, the vein splits into 2 segments, the Fisk vein and the Puzzle (New Jersey)-Cook vein (pl. 12). Both these veins are cut.and offset by the Bobtail vein, and the displaced segments are developed south of the Bobtail vein by short drifts. The Fisk segment consists of 2 feet of fractured and altered gneiss with sparse to moderate disseminated pyrite; the Cook vein is stoped out and could not be observed.

About 85 feet southwest of the Bobtail tunnel, the Fisk vein fissure cuts and offsets the west-northwestward-trending Ground Hog vein, the northwest wall of the Fisk vein having been displaced about 23 feet northeast with respect to the southeast wall. The Fisk vein also is developed on several levels of the Cook shaft (E-IV-6), and according to the description by Bastin and Fill (1917, p. 225) it must reverse dip between the Bobtail tunnel level and the 8 th level of the shaft. According to Farish ${ }^{44}$ the average yield of 177,717 tons of ore extracted from the Fisk and Cook veins was $\$ 7.03$ per ton; 2.6 percent of this ore was smelting ore, and the remainder was mill dirt. Alder-

\footnotetext{
4 Farish, W. A., 1905, Report on the Gregory, Bobtail, Fisk Mammoth group of veins, 6 p., report on fle in the Denver Public Library, Denver, Colo.
}

son ${ }^{45}$ reports that the average value of a 400 -foot block of ore in the Fisk vein on the 1400 level of the Cook shaft was $\$ 20$ per ton.

The Ground Hog vein, cut by the Bobtail tunnel about 87 feet south of the Fisk vein, strikes about N. $70^{\circ}$ W., dips $80^{\circ}-87^{\circ} \mathrm{SW}$., and as described earlier is faulted by the Fisk vein fissure. It is developed by a west-northwest trending drift that extends at least 180 feet beyond the Fisk drift (Lovering and Goddard, 1950, pl. 15), but as these workings are inaccessible the exact position of this drift is not known. The Ground Hog vein is similar mineralogically to the Fisk vein, but it is less heavily mineralized. About 175 feet west of its intersection with the Fisk vein, it is $\mathbf{1 6}$ inches wide and includes a one-half-inch veinlet of pyrite bordered by 2 inches of silicified gneiss; the remainder of the vein consists of pyrite-impregnated wallrock.

A vein thought to be the Denmark vein is cut by the Bobtail tunnel about 1,080 feet from the portal. It strikes about N. $45^{\circ}$ E. and is nearly vertical. Where exposed the vein consists of 6 to 12 inches of gray quartz containing disseminated pyrite that is bordered by sericitized and pyritized wallrock. The vein intersects and displaces the Bobtail vein, the northwest wall having been displaced about 55 feet northeast relative to the southeast wall.

The Bobtail lode, probably the widest and most persistent lode of the Central City district, is cut by the tunnel a short distance southwest of the Denmark lode (pl. 12). It can be traced on the surface westward to Spring Gulch; that part of the vein between the Cook shaft and. Spring Gulch is known as the Mammoth. West of Spring Gulch, the lode is represented by the National and Hecla veins. Near the Patch, the lode splits into two principal segments, the Gardner and the Rhoderick Dhu. The Gardner segment emerges west of the Patch and forms the great California-Hidden Treasure lode.

The Bobtail lode was one of the first lodes discovered in the district, and its surface dirt was very rich. The early miners used a bobtailed ox to haul the rich surface dirt down to the creek for sluicing; therefore, John H. Gregory named the lode Bobtail (Fossett, 1876, p. 223). After the surface dirt was exhausted, several of the claims along the lode were sold for "a song"; the original location, including the bobtailed ox "went for a trifle," and half-interests in two other claims were traded for a sack of flour and an old pistol (Fossett, 1876, p. 224).

\footnotetext{
${ }^{45}$ Alderson, V. C., 1925, Report on the Kingdom of Gilpin mines, report on file in the Denver Public Library, Denver, Colo.
} 
The east segment of the Bobtail vein is exposed in the Bobtail crosscut about 60 feet southeast of the Denmark vein; it strikes east-northeast and dips about $78^{\circ} \mathrm{SE}$. All the development on the vein in this part of the mine is inaccessible. Several veins subparallel to the Bobtail are developed by short drifts from the crosscut (pl. 12), and these veins were interpreted by Lovering and Goddard (1950, pl. 15) as horsetails from the Bobtail vein; the present writers prefer to interpret these veins as related shear fractures.

The principal segment of the Bobtail vein is followed west by the Bobtail drift. About 400 feet from the Bobtail tunnel the fissure intersects and displaces the east-northeastward-trending Cotton vein. This vein fissure, although developed by a short drift southwest of the Bobtail vein, is largely barren. Near the Cook shaft the Bobtail vein cuts the Fisk and PuzzleCook veins. Lovering and Goddard (1950, pl. 15) interpret the Fisk vein to have been offset by the Bobtail vein. The Bobtail vein makes a sharp right-angle strike change to the south, forming the Cook vein; and the Puzzle vein makes a sharp bend to the west, forming the Mammoth vein. This interpretation is not borne out by the relations of the intersecting stopes; the stopes on the Puzzle and Fisk veins dip to the southeast and those on the Bobtail dip to the north. In the critical area the southeast-dipping stopes swing into a large north-dipping stope, which continues through to the west without interruption. The present writers thus prefer the interpretation shown on plate 12; that is, the Mammoth vein is the direct westward continuation of the Bobtail vein, and both the Fisk and Puzzle-Cook veins have been faulted so that their north segments have been shifted several feet to the west.

West of the Cook shaft the Bobtail-Mammoth vein is deflected toward the south at several places. The vein seems to be stronger in the deflected segments, as it theoretically should be from the determined lefthand direction of movement. Several steep to vertical branches split into the south wall of the Mammoth vein in the vicinity of these changes in strike. The Mammoth vein cuts and offsets the O'Neil vein at the Rogers crosscut, shifting the north. segment about 34 feet to the west. The Mammoth-Bobtail vein is stoped almost continuously to the east of this intersection, but near its intersection with the O'Neil vein it is 3 to 4 feet wide and consists of sheared strongly altered microcline-bearing gneiss heavily impregnated with pyrite, and cut by several $1 / 4$ - to 2 -inch pyrite stringers. At the breast of the drift, the mineralized zone is wider than the drift and shows a 6 -inch vein of coarse pyrite on the south wall that dips $83^{\circ} \mathrm{S}$. ; some of the pyrite is sheared and streaked out by postmineralization movement. Another 6-inch vein of pyrite and sparse chalcopyrite that dips $84^{\circ}$ $\mathrm{N}$. is exposed on the north wall. The ground between these veins contains abundant disseminated pyrite. The walls and back of the drift are covered with an efflorescence of copper and arsenic.

The Bobtail-Mammoth vein consists chiefly of pyrite and quartz, but considerable copper has been produced from scattered chalcopyrite and tennantite. Farish ${ }^{46}$ reports that copper is relatively abundant in the high-grade ore, and that the copper content seems to be higher at depth. Alderson ${ }^{47}$ reports that a 4-foot streak on the footwall of the Bobtail vein on the 1,400 level assayed 14 percent copper. The average ore produced from the mine was relatively low in grade, and similar ore appears to persist at depth. Farish's ${ }^{48}$ sampling of the Mammoth vein on the 1,400 level showed 0.12 to 0.52 ounce of gold and 4 to 4.28 ounces of silver per ton, with an average of about 0.3 ounce of gold and 2 ounces of silver per ton for a width of 3 to 6 feet. Assays of a solid sulfide veinlet showed a maximum of 5 ounces at depth, but to date it has been uneconomic to extract it.

The first vein cut in the Rogers crosscut is the $O^{\prime} N$ eil hanging-wall vein, which strikes N. $60^{\circ}$ E. and dips about $73^{\circ} \mathrm{NW}$. It consists of a 6 -inch streak of quartz and pyrite.

The Gregory vein is cut about 208 feet northwest of the O'Neil hanging-wall vein. It strikes about $\mathrm{N}$. $50^{\circ} \mathrm{E}$., dips $50^{\circ}-88^{\circ} \mathrm{NW}$, and where observed, is a nearly barren 2-foot zone of fractured and altered rock that contains scarce quartz, pyrite, and sooty chalcocite. Several horsetail branches from the vein pass into the hanging wall.

The German vein is cut by the crosscut about 667 feet northwest of the Gregory vein. It strikes about N. $55^{\circ}$ E. and dips $78^{\circ}-80^{\circ}$ NW. Generally it consists of inch-thin fractures in a 2- to 3 -foot silicified zone heavily impregnated with pyrite; near the cave in the east drift a 6- to 12-inch streak of quartz and pyrite is present on the footwall. As the vein is largely stoped, it must have contained moderately high concentrations of gold.

The McAllister vein, cut about 40 feet northwest of the German vein, is nearly parallel to the German vein and dips $75^{\circ} \mathrm{NW}$. As exposed in a stope pillar

\footnotetext{
${ }^{46}$ Farish, W. A.., 1909, Report on Gregory. Bobtail, Fisk and Mammoth group of mines, 12 p., report on file in the Denver Public Library, Denver, Colo.

47 Alderson, V. C., 1925, Report on the Kingdom of Gilpin mines, 6 p., report on fle in the Denver Public Library, Denver, Colo.

${ }^{48}$ Farish, W. A., 1909, Report on Gregory, Bobtail, Fisk and Mammoth group of mines, 6 p., report on fle in the Denver Public Li-
} brary, Denver, Colo. 
near the cave in the west drift, it consists of 3 feet of quartz and pyrite. For a further discussion of this vein the reader is referred to the description of the McAllister mine (p. 177).

The Epizootic vein is cut by the crosscut just a few feet away from the breast. It strikes about. N. $60^{\circ}$ E. and dips $75^{\circ}$ NW. It is the proved northeastward continuation of the O.K. vein - the west drift is the 400 level of the O.K. mine. The vein is largely stoped, and rich ore was reportedly having been taken from the east drift. As exposed at the cave in the west drift, the vein consists of 26 inches of softened and sericitized wallrock with disseminated pyrite. The quantity of pyrite seem to increase toward the northeast.

\section{BROOKLYN MINE (E-IV-11)}

Location.-In saddle between Mammoth and Bobtail hills.

Production.-Callbreath $(1899$, p. 241$)$ reports that ore valued at about $\$ 100,000$ was shipped prior to 1899.

Development.-A 570-foot shaft with levels at depths of $81,156,249,370$, and 470 feet. The shaft follows the vein to the 370 -foot level, below which it is vertical and in the footwall.

Veins.-Washington: strike, N. $80^{\circ}$ E.; dip, $70^{\circ}$ SE. Cashier: strike, N. $65^{\circ}$ E.; dip, near vertical. The Cashier vein is developed by a drift from a crosscut on the 249 level.

Wallrock.-Microcline-bearing gneiss.

Ore and sulfide minerals.-Pyrite and sparse chalcopyrite and tennantite.

Gangue minerals.-Quartz.

Tenor.-Probably low grade.

\section{BUELL (U.P.R.) MINE (E-III-9)}

Location.-In Gregory Gulch, about 350 feet N. $85^{\circ}$ $W$. from the Bates-Hunter mine.

Production.-About $\$ 100,000$ prior to 1899 (Callbreath, 1899); 78,021 tons of smelting ore and 4,268 tons of concentrates between 1902 and 1928 that contained 28,416.09 ounces of gold, 82,238 ounces of silver, and 1,201,374 pounds of copper (almost all copper produced in 1905). (Compiled by the U.S. Bureau of Mines. Published by permission.)

Development.-A 700-foot shaft and more than 5,000 feet of drifts.

Veins.-Leavitt: strike, N. $50^{\circ}$ E.; dip $75^{\circ}-80^{\circ}$ SE.; apparently the same vein developed by the Vasa mine to the southwest and the Wain mine to the northeast.

Wallrock.-Microcline-bearing gneiss.

Ore and sulfide minerals.-Pyrite, gold, silver, and chalcopyrite.

Gangue minerals.-Quartz.
Tenor.-Average content about 0.33 ounce of gold and 1.25 ounces of silver per ton; copper negligible except for one shipment.

\section{CARR VERN}

The Carr vein crops out near the summit of Gregory Hill and in Bobtail Gulch. It has an average strike of $\mathrm{N} .45^{\circ} \mathrm{E}$. and dips nearly vertical. It is developed by 3 shafts, from northeast to southwest, the ChicagoCarr (E-IV-20), Colorado-Carr (E-IV-19), and Katie (E-IV-17). In 1954, all these workings were inaccessible, and no record of the amount of development could be found. Arthur Collins ${ }^{49}$ and Bastin and Hill $(1917$, p. 227) have given brief descriptions of the vein, however, and the following is taken from their reports.

The Carr vein was discovered early in 1864, and in the summer of that year yielded $\$ 25,000$ from shallow surface workings. By 1890, the vein had been worked to a depth of about 175 feet, but there are no records of production for that period. From 1890 to 1897 the vein yielded ore valued at $\$ 108,452$. The properties along the vein were last operated in 1940 . The known production from the vein is given in tables 94 and 95 ; this ore if produced today would have a value of about $\$ 627,000$. The total output from the vein probably is about $\$ 1$ million.

TABLE 94.-Ore produced from the Colorado-Carr mine, 1902-54 ${ }^{1}$

\begin{tabular}{|c|c|c|c|c|c|c|c|}
\hline Year & $\begin{array}{c}\text { Crude } \\
\text { ore } \\
\text { shipped } \\
\text { (tons) }\end{array}$ & $\begin{array}{c}\text { Concen- } \\
\text { trates } \\
\text { shipred } \\
\text { (tons) }\end{array}$ & $\begin{array}{c}\text { Gold } \\
\text { (ounces) }\end{array}$ & $\begin{array}{c}\text { Silver } \\
\text { (ounces) }\end{array}$ & $\begin{array}{c}\text { Copper } \\
\text { (pounds) }\end{array}$ & $\begin{array}{c}\text { Lead } \\
\text { (pounds) }\end{array}$ & $\begin{array}{c}\text { Zinc } \\
\text { (pounds) }\end{array}$ \\
\hline 1902. & 6,753 & & $2,381.00$ & 1,342 & 208,590 & & \\
\hline 1900 & 250 & $\mid$ & 125.00 & 209 & $=-1+4$ & & $\cdots$ \\
\hline $\begin{array}{l}1907 \\
1910\end{array}$ & $\begin{array}{r}15 \\
2\end{array}$ & - & $\begin{array}{r}31.49 \\
1.83\end{array}$ & $\begin{array}{r}126 \\
6\end{array}$ & 5,400 & & $\cdots$ \\
\hline 1911. & 1 & & .36 & 1 & 32 & & \\
\hline 1914 & 516 & 66 & 867.60 & 1,950 & 36,859 & 960 & . \\
\hline $\begin{array}{l}1915 \ldots \ldots . . . \\
1916 \ldots \ldots\end{array}$ & $\begin{array}{r}67 \\
182\end{array}$ & $\begin{array}{r}84 \\
171\end{array}$ & $\begin{array}{l}229.76 \\
555.61\end{array}$ & $\begin{array}{l}530 \\
947\end{array}$ & $\begin{array}{r}6,765 \\
19,930\end{array}$ & 2,765 & \\
\hline 1017. & 379 & 40 & 613.42 & 1,878 & 51,755 & & \\
\hline 1018 & 150 & 5 & 295.48 & 588 & 8,830 & 210 & \\
\hline $\begin{array}{l}1934 . . \\
1940\end{array}$ & & 4 & $\begin{array}{r}.44 \\
1.70\end{array}$ & 7 & & $\cdots$ & 10 \\
\hline Total.. & 8,317 & 370 & $5,103.69$ & 7,585 & 338,161 & 3,944 & 16 \\
\hline
\end{tabular}

I Compiled by U.S. Bureau of Mines. Published by permission.

Except for the ore shoots, the Carr vein is thin and barren. In the Colorado-Carr mine three ore shoots are present, one on each side of the shaft-average length 100 feet-and one at the west breast of the $3 d$ level. Within these shoots the vein averages about 18 inches in width and consists mainly of pyrite and chalcopyrite, the proportion of chalcopyrite in the vein being above average for veins of the area. The

${ }^{40}$ Collins, A. L., undated, Report on the Carr mine and adjolning Katie Claim, 4 p., report on fle in the Denver Public Library, Denver, Colo. 
sulfides occur both in sharp-walled fissure fillings with quartz and disseminated in the altered rock along the vein fissure. Galena and sphalerite veinlets locally cut sharply across the pyrite ore. Subsequent to the galena-sphalerite mineralization, the vein was reopened and partly healed by gray fine-grained silica, which commonly encloses angular fragments of the metallic minerals. The ore on the upper workings of the mine was completely oxidized and high in grade. Four hundred tons of smelting ore shipped between 1893 and 1910 had an average content of 2.88 ounces of gold and 7.62 ounces of silver per ton; the maximum copper content of the ore was 11.7 percent. Concentrating ore shipped from the Chicago-Carr mine during 1910 averaged about 0.18 ounces of gold and 0.30 ounces of silver per ton.

TABLE 95.-Ore produced from the Chicago-Carr mine, 1902-54 ${ }^{1}$

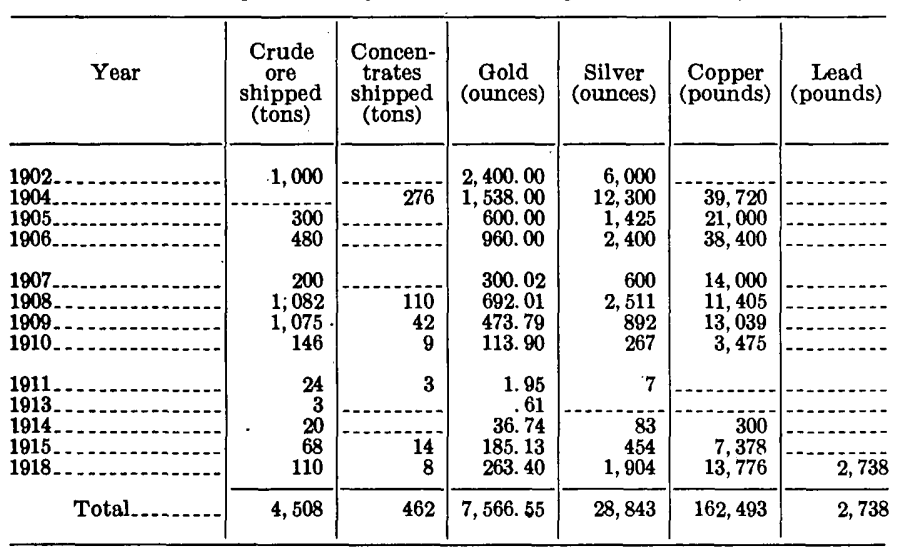

I Compiled by U.S. Bureau of Mines. Published by permission.

\section{CHEMUNG-BELMONT MINE (F-IV-10)}

Location.-Near the head of Running Gulch, about 1,320 feet $\mathrm{N}$. $7^{\circ} \mathrm{W}$. from the Clay County mine.

Production.-About $\$ 500,000$ prior to 1912 (Bastin and Hill, 1917, p. 228); 14 tons between 1912 and 1940 that contained 8.32 ounces of gold and 4 ounces of silver. (Compiled by U.S. Bureau of Mines. Published by permission.)

Development.-Shaft, 820 feet deep and 10 levels.

Veins.-Chemung-Belmont: Strike, N. $55^{\circ}-73^{\circ}$ E.; lode forks near shaft and reunites to west and in depth; north branch in Chemung mine and south branch in Belmont mine.

Wallrock.-Biotite-quartz-plagioclase gneiss, granite pegmatite, bostonite porphyry, and quartz monzonite porphyry.

Ore and sulfide minerals.-Pyrite, gold, silver, tennantite, galena, sphalerite, and chalcopyrite.

Gangue minerals.-Quartz.

Ore shoots.-Most of the ore came from Chemung vein above the 620 level.
Tenor.-95 tons shipped betwen 1889 and 1902 averaged 1.74 ounces of gold and 16.03 ounces of silver per ton, copper ranged from 1.5 to 7.5 percent.

\section{CLAY COUNTY MINE (F-IV-8)}

Location.-On the north side of Lake Gulch, about 1,320 feet $\mathrm{S}$. $7^{\circ} \mathrm{E}$. from the Chemung-Belmont mine.

Production.-Estimated to be $\$ 600,000$ to $\$ 700,000$ prior to 1912 (Bastin and Hill, 1917, p. 228) ; 6,060 tons of smelting ore and 1,033 tons of concentrates shipped between 1905 and 1941 contained 2,009.84 ounces of gold, 14,454 ounces of silver, 31,318 pounds of copper, and 38,074 pounds of lead. (Compiled by U.S. Bureau of Mines. Published by permission.)

Development.-Shaft; National tunnel connects with the 6th level.

Veins.-Clay County: Strike, N. $21^{\circ}$ E.; dip, steeply NW.; fractured country rock contains stringers and disseminations of sulfides, sulfosalts, and quartz, brecciated and cemented by base-metal sulfides.

Wallrock.-Biotite-quartz-plagioclase gneiss, granite pegmatite, and bostonite porphyry.

Ore and sulfide minerals.-Pyrite, gold, silver, enargite, tennantite, chalcopyrite, galena, and sphalerite.

Gangue minerals.-Quartz.

Ore shoots.-Production chiefly came from above the $3 \mathrm{~d}$ level.

T'enor.-57.5 tons of smelting ore, 1891-99, averaged 0.63 ounce of gold and 11.28 ounces of silver per ton; copper ranged from 1.5 to 6 percent; no lead was quoted.

\section{COUSIN JACK MINE (E-III-11)}

The Cousin Jack mine, on the south side of Gregory Hill, about 360 feet S. $75^{\circ}$ E. from the Bates-Hunter mine, was last worked in 1939 . The known production from the mine is given in table 96. This ore if produced today would have a value of about $\$ 6,000$. Between 1928 and 1935 an additional 17.89 tons of smelting ore that sold for $\$ 207.05$ was shipped to the Idaho Springs Sampling Works.

TABLE 96.-Ore produced from the Cousin Jack mine, 1902-54'

\begin{tabular}{|c|c|c|c|c|c|c|}
\hline Year & $\begin{array}{l}\text { Crude } \\
\text { ore } \\
\text { shipped } \\
\text { (tons) }\end{array}$ & $\begin{array}{c}\text { Gold } \\
\text { (ounces) }\end{array}$ & $\begin{array}{c}\text { Silver } \\
\text { (ounces) }\end{array}$ & $\begin{array}{c}\text { Copper } \\
\text { (pounds) }\end{array}$ & $\begin{array}{c}\text { Lead } \\
\text { (pounds) }\end{array}$ & $\begin{array}{c}\text { Zinc } \\
\text { (pounds) }\end{array}$ \\
\hline & $\begin{array}{l}38 \\
32\end{array}$ & $\begin{array}{l}21.74 \\
38.68\end{array}$ & $\begin{array}{r}64 \\
112\end{array}$ & $\begin{array}{r}76 \\
444\end{array}$ & & 192 \\
\hline 0 & 31 & $\begin{array}{l}37.86 \\
17.86\end{array}$ & 44 & & & \\
\hline$\because$ & $\begin{array}{r}189 \\
9\end{array}$ & $\begin{array}{r}38.94 \\
7.33\end{array}$ & ${ }_{22}^{48}$ & & 1,153 & 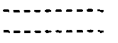 \\
\hline & $\begin{array}{r}2 \\
43\end{array}$ & $\begin{array}{r}2.30 \\
12.69\end{array}$ & 35 & $\begin{array}{l}85 \\
50\end{array}$ & 119 & \\
\hline$\cdots$ & 10 & 5. 55 & 16 & & & \\
\hline & & & 11 & 41 & -....... & - \\
\hline Total. & 359 & 148.52 & 353 & 696 & 1,272 & 227 \\
\hline
\end{tabular}

1 Compiled by U.S. Bureau of Mines. Published by permission. 
The mine is developed by a 400 -foot drift tunnel that bears on the average S. $37^{\circ}$ E. (fig. 72). Extensive overhand stopes are present from a point about 140 feet from the portal to the face. A winze, about 50 feet deep, is present about 270 feet from the portal; it connects to a sublevel, but could not be entered in 1954.

The wallrock of the mine is microcline-bearing gneiss. As the mine is on the southeast flank of the
Pewabic Mountain syncline, the rocks generally dip moderately to the northwest, but are deformed by a series of broad, gentle, northwestward-plunging cross warps.

The Cousin Jack vein strikes about N. $40^{\circ}$ E., dips steeply either side of vertical, and possibly is the southwestward extension of the vein developed by the Gaston mine on the north side of Gregory Gulch. The vein has a flat S-shape in plan (fig. 72), some parts

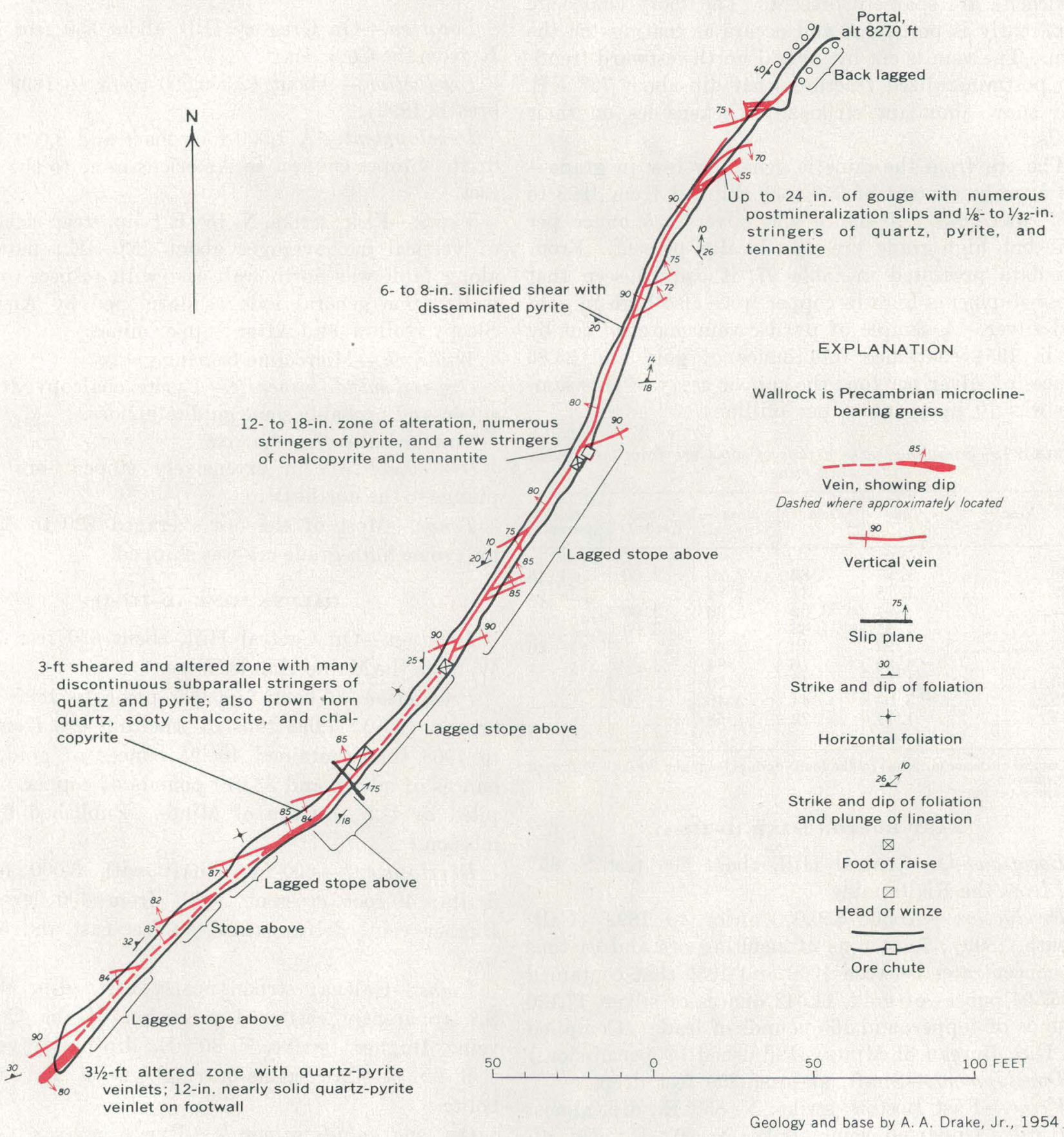

FIgURE 72.-Geologic map of the Cousin Jack mine. 
striking about N. $25^{\circ}$ E. and others striking N. $45^{\circ} \mathrm{E}$. It is characterized by a large number of branches that split from the main vein and enter both the hangingwall and footwall (fig. 72).

The Cousin Jack vein is a typical pyrite vein. It consists of as much as 42 inches of sheared, sericitized, and silicified wallrock that contains disseminated pyrite and is crossed by $1 / 32^{-}$to 12 -inch veinlets of quartz and sulfide minerals. Pyrite is the most abundant sulfide mineral but chalcopyrite, tennantite, and sooty chalcocite are sparsely present. The sooty chalcocite apparently is post-mine and occurs as coatings on the vein. The vein is cut by several northwestward-trending postmineralized fractures that dip about $75^{\circ} \mathrm{NE}$. and show abundant strike-slip slickensides on their walls.

The ore from the mine is generally low in gradethe average content of 359 tons shipped from 1928 to 1939 was gold 0.40 ounce and silver 0.95 ounce per ton-but high-grade ore was locally present. From the data presented in table 97 , it can be seen that those shipments high in copper were also high in gold and silver. A sample of pyritic vein material cut by us in 1954 contained 0.14 ounce of gold and 23.86 ounces of silver per ton; the copper assay of this sample was $70 \mathrm{ppm}$ (parts per million).

TABLE 97.-Sampling-works assays of some ore from the Cousin

\begin{tabular}{|c|c|c|c|c|c|}
\hline Year & Tons & Gold ${ }^{2}$ & Silver ${ }^{2}$ & $\begin{array}{c}\text { Copper } \\
\text { (percent) }\end{array}$ & $\underset{\text { (percent) }}{\text { Zinc }}$ \\
\hline $\begin{array}{l}1928 \\
1929 \\
1930 \\
1934 \\
1935 \\
1935 \\
1935 \\
1935 \\
1935\end{array}$ & $\begin{array}{l}\text { 1. } 87 \\
\text { 1. } 78 \\
.94 \\
\text { 1. } 41 \\
\text { 1. } 92 \\
\text { 4. } 59 \\
\text { 1. } 53 \\
\text { 3. } 04 \\
1.11\end{array}$ & $\begin{array}{r}3.86 \\
.31 \\
3.02 \\
1.63 \\
.30 \\
.16 \\
.42 \\
.44 \\
.22\end{array}$ & $\begin{array}{r}\text { 7. } 20 \\
\text { 1. } 84 \\
\text { 5. } 90 \\
.92 \\
\text { 2. } 00 \\
.84 \\
\text { 3. } 00 \\
2.40 \\
.58\end{array}$ & $\begin{array}{r}2.00 \\
2.00 \\
3.00 \\
\hdashline .70 \\
\hdashline\end{array}$ & 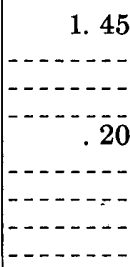 \\
\hline
\end{tabular}

1 Data on ore tenor furnished by the Idaho Springs Sampling Works. Published by permission.

\section{EAST BOSTON MINE (D-III-4)}

Location-On Central Hill, about 600 feet S. $65^{\circ}$ $\mathrm{W}$. from the Rialto mine.

Production.-About $\$ 50,000$ prior to 1899 (Callbreath, 1899); 7,284 tons of smelting ore and 94 tons of concentrates between 1902 and 1935 that contained $2,357.94$ ounces of gold, 11,543 ounces of silver, 17,120 pounds of copper, and 165 pounds of lead. (Compiled by U.S. Bureau of Mines. Published by permission.)

Development.-Shaft, at least 300 feet deep.

Veins.-East Boston: strike, N. $85^{\circ}$ E., dip, almost . vertical. Unnamed vein: strike, N. $60^{\circ}$ E.; dip, almost vertical.
Wallrock.-Microcline-bearing gneiss.

Ore and sulfide minerals.-Pyrite, gold, silver, chalcopyrite, and a little galena and sphalerite.

Gangue minerals.-White, light-gray, and tan quartz.

Ore shoots.-Apparently occur at vein intersections.

Tenor.-6,705 tons of smelting ore shipped between 1902 and 1905 averaged 0.31 ounce of gold per ton, 1.5 ounces of silver per ton, and 0.12 percent copper.

\section{FISK MINE (E-IV-5)}

Location.-On Gregory Hill, about 350 feet N. $45^{\circ}$ E. from the Cook shaft.

Production.-About $\$ 2,500,000$ prior to 1899 (Callbreath, 1899).

Development.-A 1,000-foot shaft and 8,000 feet of drift. Stopes connect to Americus mine to the northeast.

Veins.-Fisk: strike, N. $45^{\circ}$ E.; dip, steep either side of vertical but averages about $75^{\circ}$ SE.; movement along fault was north wall east with respect to south wall; same general lode as developed by Americus, Sleepy Hollow, and After Supper mines.

Wallrock.-Microcline-bearing gneiss.

Ore and sulfide minerals.-Pyrite, chalcopyrite, gold, silver, and probably some gold tellurides.

Gangue minerals.-Quartz.

Ore shoots.-Vein extensively stoped, ore shoots plunge to the northeast.

Tenor.-Most of the ore averaged $\$ 20$ to $\$ 25$ per ton; some high-grade ore was shipped.

\section{GALENA MINE (D-III-1)}

Location.-On Central Hill, about 630 feet N. $85^{\circ}$ W. from the Maine-Hamlet mine.

Production.-About $\$ 100,000$ prior to 1899 (Callbreath, 1899); 1,098 tons of smelting ore from 1902 to 1908 that contained 460.94 ounces of gold, 1,663 ounces of silver, and 33,010 pounds of copper. (Compiled by U.S. Bureau of Mines. Published by permission.)

Development.-600-foot shaft with 3,000 feet of drifts; 40-foot crosscut north from 400 level cuts Bugher vein; drifts extend 50 feet east and 50 feet. west.

Veins.-Galena: strike, nearly east; dip, $80^{\circ}-85^{\circ}$ S.; apparently eastward extension of the Corydon vein. Bugher: strike, N. $80^{\circ}$ E., dip nearly vertical.

Wallrock.-Microcline-bearing gneiss and amphibolite.

One and sulfide minerals.-Pyrite, gold, silver, galena, sphalerite, chalcopyrite, and tennantite. 
Gangue minerals.-White and light-gray quartz.

Tenor.-Ore shipped between 1902 and 1908 averaged 0.42 ounce of gold per ton, 1.51 ounces of silver per ton, and 1.65 percent copper.

\section{GASTON MINE (E-III-12)}

The Gaston mine, on Bates Hill, about 410 feet east of the Becker-Bates mine, was last worked in 1938; it was inaccessible in 1954 . The mine is opened by an inclined shaft, 210 feet deep vertically, with levels at inclined depths of 65,100 , and 200 feet. Most of the stopes are above the 100 level. The mine is reported to have yielded $\$ 30,000$ prior to 1899 (Callbreath, 1899, p. 256). The property was open for short periods in 1916, 1935, and 1938, and during these years 52 tons of ore was shipped that contained 4.79 ounces of gold, 13 ounces of silver, and 51 pounds of copper.

The Gaston vein strikes about N. $53^{\circ}$ E., dips $80^{\circ}$ SE., and possibly is the northeastward extension of the Cousin Jack vein developed on the south side of Gregory Gulch. Vein material on the dump of the mine and stored in the shaft house consists largely of quartz and pyrite; however, several specimens contain chalcopyrite, tennantite, and sooty chalcocite. Much strongly bleached and sericitized microclinebearing gneiss that contains abundant disseminated pyrite was noted on the dump. Most of the ore mined from the property was probably oxidized as the stopes are relatively near the surface and sooty chalcocite is known to be present in the ore. The veins of this area were rich near surface, and passed into almost barren rock, "cap," at depth. Further development may uncover ore in this vein at depth, as in the Gregory, Bobtail, and Bates veins.

\section{GERMAN MINE (E-IV-2)}

Location.-On Mammoth Hill, about 1,300 feet southwest of the Bates-Hunter mine.

Production.-About $\$ 2,250,000$ prior to 1899 (Callbreath, 1899); 1,649 tons of smelting ore and 214 tons of concentrates shipped between 1909 and 1922 contained 670.05 ounces of gold, 2,229 ounces of silver, and 56,172 pounds of copper. (Compiled by U.S. Bureau of Mines. Published by permission.)

Development.-Klein-German shaft 400 feet deep, and the German shaft 745 feet deep. German shaft connects with German drift from the Bobtail tunnel.

Veins.-German (probably a branch of the Bates vein) : Strike, N. $55^{\circ}$ E.; dip, steep either side of vertical; consists of 2 to 4 feet of altered wallrock containing disseminated pyrite that is cut by abundant quartz-sulfide stringers as much as 8 inches wide.
Wallrock.-Microcline-bearing gneiss.

Ore and sulfide minerals.-Pyrite, chalcopyrite, tennantite, gold, and silver.

Gangue minerals.-Quartz.

Tenor.-Ore from upper levels averaged $\$ 42$ per ton (gold at $\$ 20$ per ounce) ; ore mined between 1920 and 1922 averaged 1.13 ounces of gold, 4.65 ounces of silver, and 8.05 percent copper.

\section{GREGORY LODE}

The Gregory lode crops out on Bates Hill, in Gregory Gulch, and on Gregory Hill (pl. 1). It can be traced northeastward to North Clear Creek and southwestward to the Great Mammoth mine. Southwest of Gregory Gulch the lode splits into several segments, the most important of which is the Briggs vein; this vein is known as the O'Neil vein on Gregory Hill.

The Gregory, the first gold lode discovered in Colorado, was located by John H. Gregory on May 6, 1859 (Fossett, 1876, p. 209). The surface dirt of the lode was exceedingly rich, yielding as much as $\$ 400$ per cord (Fossett, 1876, p. 211). Mining continued downward until primary vein material was reached. When the miners found that the gold in this type of ore could not be saved by sluicing, many of them sold their properties. Others, however, were foresighted enough to continue their efforts, and with the advent of the stamp mill, made fortunes. The Gregory properties were combined with those on the Bobtail, Mammoth, and Fisk veins about 1885 , and were worked as one unit until they were closed.

The Gregory vein is developed by a drift tunnel, the Gregory tunnel (F-III-7), that extends through Bates Hill, by many shafts on Bates and Gregory Hills, and by the Gregory incline (F-III-6). The Gregory incline slopes downward for 1,709 feet at an angle of about $25^{\circ}$ and cuts the Gregory vein at a depth of 700 feet (Bastin and Hill, 1917, p. 225-226); crosscuts from the 11th level cut the New Jersey (Maverick), Fisk, and Bobtail veins. ${ }^{50}$ The Gregory lode also is developed by a drift from the Rogers crosscut of the Bobtail tunnel (pl. 12) and by crosscuts from the lower levels of the Cook shaft. ${ }^{51}$ Most of the stopes on the lode are above a depth of 500 feet (fig. 73). In 1954, only that part of the Gregory drift exposed in the Bobtail tunnel workings was accessible.

\footnotetext{
50 Farish, W. A, 1909, Report on the Gregory, Bobtall, Fisk, and Mammoth group of mines, 12 p., report on fle in the Denver Public Library, Denver, Colo.

"1 Alderson, V. C., 1925, Report on the Kingdom of Gilpln mines, 6 p., report on file in the Denver Public Library, Denver, Colo.
} 


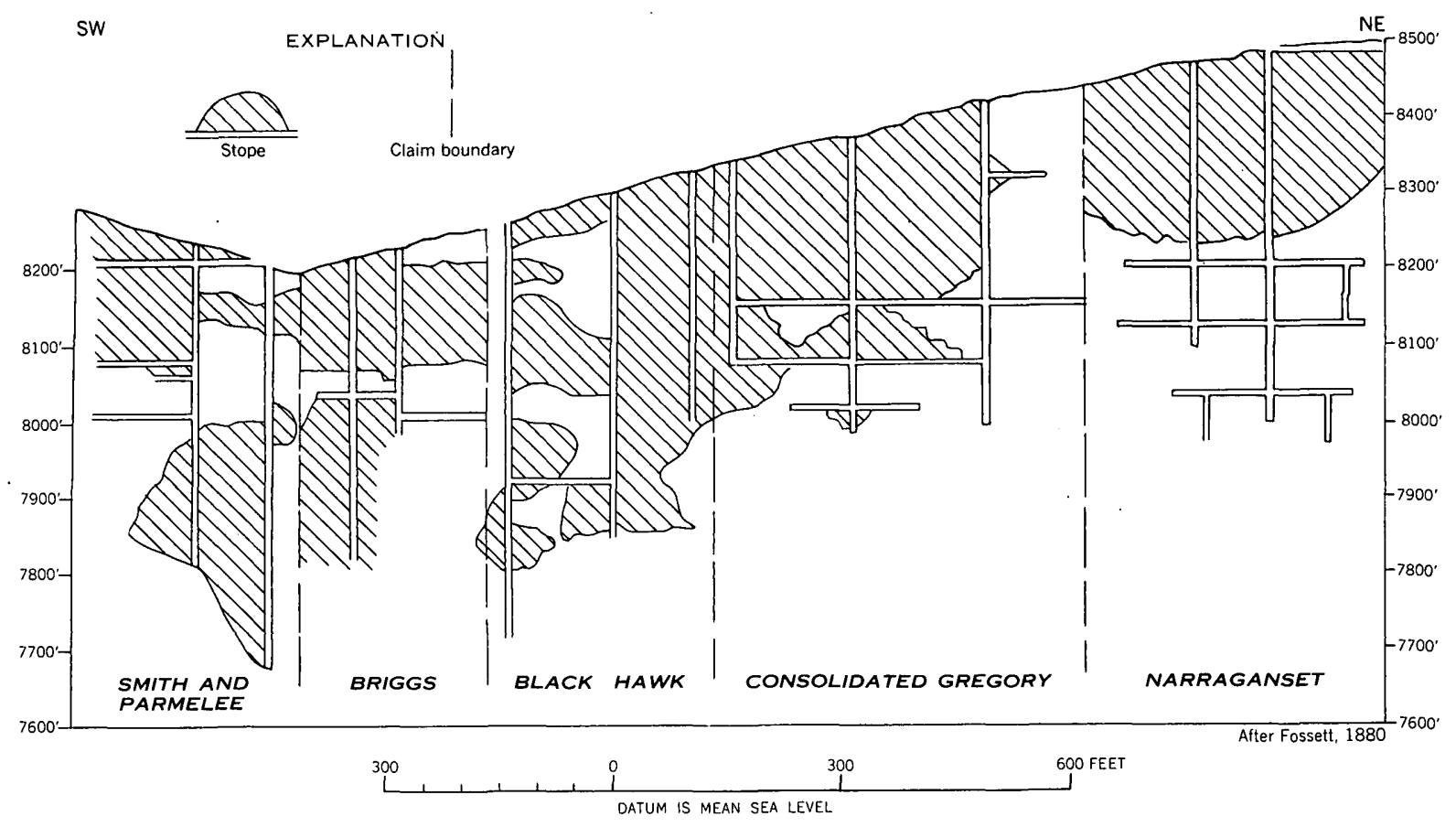

Figurn 73.-Vertical longitudinal section of the Gregory lode.

On Bates Hill, the Gregory lode trends about N. $40^{\circ}$ E. and dips $70^{\circ}-80^{\circ}$ SE. Southwest of Gregory Gulch, the lode swings to an east-northeasterly course and splits into several veins, many of which dip northwest. Fossett (1880, p. 299-300) describes the vein as follows:

The width between walls has usually been several feet, and sometimes ten or twelve, and even twenty. The distribution of ore is variable, occurring in seams of from a few inches to two or more feet, with intervening bands of poor rock, and sometimes for short distances it has pinched out or given place to vein matter of barren quartz and feldspar.

The walls are not regular, being sometimes smooth and well defined and again rugged and uneven.

Seams and pockets of ore of surprising richness have occasionally been found on both upper and lower workings, and a large amount of nugget and wire gold:

The vein consists chiefly of pyrite, and where mined, it contained some copper. The dumps on the east slope of Bates Hill contain noticeable quantities of galena and sphalerite.

The ore shoots in the Gregory lode are largely concentrated between the crest of Bates Hill and the O'Neil mine; it is reported that the vein is nearly barren east of the Gregory-Briggs split. ${ }^{52}$ These veins diverge downdip, and the width of the veins lessens with depth. Although much of the ore mined was secondarily enriched in gold, high concentrations were also found at depth; and from data obtained else-

${ }^{52}$ Collins, G. E., undated, Early mining history of Gilpin County, 12 p., report on file in the Denver Public Library, Denver, Colo. where in the district, it can be inferred that such ore occurred in structurally controlled ore shoots. The stoping was done on those parts of the vein that are deflected to the left; such locations are favorable for the occurrence of ore in veins formed by left-hand movement. The stopes as outlined on figure 73 appear to plunge to the west.

The Gregory lode yielded about $\$ 8$ million prior to 1876 (Fossett, 1876, p. 209). Collins reports that the total yield from the mine was about $\$ 10$ million. The ore on the lower levels is comparatively low in grade; ore from the Gregory vein on the 1,400 level of the Cook shaft averaged $\$ 12$ to $\$ 15$ per ton.

\section{HARTFORD TUNNEL (E-III-6)}

The Hartford tunnel, in Packard Gulch, was driven prior to 1900 and was last worked in 1937. It was inaccessible in 1954. The tunnel extends about 657 feet on a general westward trend. ${ }^{53}$ Although several veins are cut by the tunnel, the property has produced only a small quantity of ore.

The Hartford vein, which is developed by the tunnel, is one of the veins worked in the Next President mine on the east side of Packard Gulch; it strikes nearly east, dips an average of $73^{\circ} \mathrm{N}$., and has an average width of 2 feet. It consists largely of quartz and pyrite, but in places contains a little chalcopyrite and much gouge and crushed rock. At the breast of

${ }^{53}$ Knight, D. A., undated, Report on the McAllister mine, 8 p., report on file in the Denver Publlc Library, Denver, Colo. 
the tunnel, the Hartford vein has pinched to 16 inches, is tight, and contains abundant quartz. An assay of a sample from the breast showed gold, 0.34 ounce per ton and silver, 0.36 ounce per ton.

About 350 feet from the portal, a branch vein cuts and intersects the Hartford vein. This vein strikes N. $75^{\circ}$ E., dips steeply SE., is about 4 feet wide, and consists largely of sheared and silicified gneiss that contains some disseminated pyrite. The vein is cut by rare half-inch pyrite stringers.

The German vein, cut by the tunnel about 550 feet from the portal, strikes about N. $50^{\circ}$ E., dips $80^{\circ} \mathrm{NW}$., and consists of about 2 feet of silicified gneiss with several pyrite veinlets. Where cut by the Hartford vein, the northeast segment of the German vein has been shifted about 8 feet to the east.

The McAllister vein is cut about 590 feet from the portal. The vein is cut and offset by the Hartford vein; its north segment has been shifted about 10 feet to the east. The reader is referred to discussion of the McAllister mine (p. 178) for a description of the vein.

At 605 feet, a 30-foot zone of brecciated rock that contains several small veinlets of pyrite is exposed. The zone strikes about N. $30^{\circ}$ E. and dips nearly vertical.

\section{HOMER MINE (D-IV-18)}

\section{Location.-On Central Hill.}

Production.-Shipments between 1910 and 1935 consisted of 1,421 tons of crude ore and 317 tons of concentrates that contained $1,332.45$ ounces gold, 3,899 ounces silver, 101,276 pounds of copper, and 186 pounds of lead. (Compiled by U.S. Bureau of Mines. Published by permission.)

Development.-Shaft reported to be about 400 feet deep; workings from shaft not known.

Vein.-Homer: Strike N. $45^{\circ}$ E.; dip, nearly vertical. Possibly is southwest extension of the McAllister vein.

Wallrock.-Microcline-bearing gneiss.

Ore and sulfide minerals.-Gold, silver, pyrite, chalcopyrite, sparse amount of galena and sphalerite.

Gangue minerals.-Quartz.

Tenor.-A shipment of 2.6 tons, made in 1920 to the Idaho Springs Sampling Works, assayed 0.06 ounces gold per ton, 5.50 ounces silver per ton, and 8.1 percent copper.

\section{MÄINE-HAMLET MINE (E-III-7)}

The Maine-Hamlet mine, on Central Hill, was opened in the early days of the district and was last worked in 1914. The mine is reported to have yielded $\$ 70,000$ prior to 1899 (Callbreath, 1899, p. 270); 429 tons of smelting ore and 24 tons of concentrates that contained 345.62 ounces of gold, 1,513 ounces of silver, and 344 pounds of copper were shipped from the mine after 1902. (Compiled by U.S. Bureau of Mines. Published by permission.) The property is opened by a shaft with levels at depths of $178,210,310$, and 410 feet; a tunnel connects with the 178 level. These workings were all inaccessible in 1954 , but Bastin and Hill (1917, p. 222-223) examined the mine, and the following is taken from their description.

The mine develops two veins that are nearly parallel in strike but which have opposing dips. The shaft follows the north vein. Both veins are developed on the 178 and 410 levels but only the north vein is developed on the 210 and 310 levels The north vein strikes about $\mathrm{N}$. $75^{\circ} \mathrm{E}$. and $\operatorname{dips} 75^{\circ}-80^{\circ} \mathrm{NW}$; ; the south vein strikes parallel to the ncrth vein and dips $80^{\circ}$ SE. Branch veinlets connect the veins. Both veins consist of several sharp-walled sulfide veinlets, which unite in places to form a single wide vein. The predominant vein minerals are quartz and pyrite, but galena, sphalerite, and chalcopyrite are present locally and notably increase the value of the ore above the average for the vein. Data are not available from which to estimate the average value of the ore, but table 98 gives some idea of its range.

$\mathrm{T}_{\mathrm{ABLE}}$ 98.-Assays of some ore from the Maine-Hamlet mine ${ }^{1}$

\begin{tabular}{|c|c|c|c|c|}
\hline Date & $\begin{array}{c}\text { Pounds } \\
\text { of ore }\end{array}$ & Gold 2 & Silver? & $\begin{array}{l}\text { Copper } \\
\text { (percent) }\end{array}$ \\
\hline $\begin{array}{l}1888 \\
1888 \\
1888 \\
1896 \\
1899 \\
1902 \\
191110\end{array}$ & $\begin{array}{r}1,544 \\
2,584 \\
2,822 \\
6,777 \\
20,370 \\
830,000 \\
20,000 \\
8,000\end{array}$ & $\begin{array}{r}11.95 \\
2.30 \\
3.20 \\
.67 \\
.48 \\
.79 \\
.55 \\
.99\end{array}$ & $\begin{array}{r}\text { 22. } 00 \\
11.00 \\
6.00 \\
5.50 \\
\text { 1. } 50 \\
\text { 3. } 38 \\
2.70 \\
\text { 8. } 00\end{array}$ & \begin{tabular}{r}
6.00 \\
4.50 \\
3.00 \\
\hdashline$-1 .-$ \\
-60
\end{tabular} \\
\hline
\end{tabular}

1 Bastin and Hill, 1917, p. 222.
2 Ounces per ton.

\section{ALLISTER MINE (F-III-6)}

The McAllister mine, on Mammoth Hill, was located in 1872 but was closed at the time of the study of Bastin and Hill (1917). It was reopened in 1930 and was worked until 1935. The known production from the mine, since 1902, is given in table 99. The mine is opened by a nearly vertical shaft, 582 feet deep, with levels at depths of $80,120,150,260,340,440$, 500 , and 600 feet. The 150 level connects with the Hartford tunnel, and the 340 level connects with the Rogers crosscut from the Bobtail tunnel. Stopes have been driven on the $260,340,440,500$, and 600 levels. In 1954 all the workings on the McAllister vein, except for a few feet of the 340 level near the Rogers 
crosscut in the Bobtail tunnel (pl. 12), were inaccessible; D. A. Knight, ${ }^{54}$ however, examined the mine and the following discussion is taken from his report.

TABLE 99.-Ore produced from the McAllister mine, 1902-54 ${ }^{1}$

\begin{tabular}{|c|c|c|c|c|c|c|}
\hline Year & $\begin{array}{c}\text { Crude } \\
\text { ore } \\
\text { shipped } \\
\text { (tons) }\end{array}$ & $\begin{array}{c}\text { Concen- } \\
\text { trates } \\
\text { shipped } \\
\text { (tons) }\end{array}$ & $\begin{array}{l}\text { Gold } \\
\text { (ounces) }\end{array}$ & $\begin{array}{c}\text { Silver } \\
\text { (ounces) }\end{array}$ & $\begin{array}{l}\text { Copper } \\
\text { (pounds) }\end{array}$ & $\begin{array}{l}\text { Lead } \\
\text { (pounds) }\end{array}$ \\
\hline $\begin{array}{l}1930 \ldots \\
1931\end{array}$ & \multirow{3}{*}{$\begin{array}{r}15 \\
11 \\
269 \\
26 \\
25 \\
24\end{array}$} & \multirow{3}{*}{$\begin{array}{l}5 \\
\vdots \\
3 \\
3 \\
\vdots \\
\vdots\end{array}$} & $\begin{array}{r}17.74 . \\
5.20\end{array}$ & $\begin{array}{r}12 \\
9\end{array}$ & 133 & \\
\hline $\begin{array}{l}1932- \\
1933- \\
1034\end{array}$ & & & 19.87 & 142 & $970^{\circ}$ & 25 \\
\hline 1935 & & & 3. 95 & 罗 & 每 & | \\
\hline Total... & 101 & - & 53.80 & 163 & 1,103 & 25 \\
\hline
\end{tabular}

1 Compiled by U.S. Bureau of Mines. Published by permission. 269 tons to Chain $\mathrm{O}^{\prime}$ Mines mill. No record of content.

The McAllister vein is probably the southwestward extension of the Bates vein. It strikes about N. $55^{\circ}$ E., dips steeply either side of vertical, and is filled by pyrite and quartz, with sparse chalcopyrite, galena, and sphalerite. The vein has an average width of about 2 feet, and on the upper levels had an average content of about 0.75 ounce of gold per ton. On the 150 level, the McAllister vein is cut and offset by the Hartford vein fissure; its southwest segment has been shifted about 10 feet to the west in relation to its northeast segment. About 30 feet from this intersection, the McAllister vein swings to a more easterly course, and a branch vein enters the southeast wall. The vein is reported to have assayed 18.5 ounces of gold per ton at this locality. On the 260 level, the McAllister vein is joined by another vein that comes in from the footwall. The ground near this intersection has been stoped; it assayed 0.80 ounce of gold and 1.90 ounces of silver per ton. On the 440 level, the vein is 2 feet wide and showed an 8-inch streak of pyrite that assayed 0.46 ounce of gold and 3.74 ounces of silver per ton on the footwall, above which was 10 inches of altered microcline-bearing gneiss carrying disseminated pyrite, 4 inches of pyrite that assayed 1.16 ounces of gold and 1.38 ounces of silver per ton, a small band of altered microcline-bearing gneiss, and 3 inches of pyrite. A 2-foot sample of altered country rock carrying disseminated pyrite and several tiny pyrite stringers assayed 0.76 ounce of gold and 1.12 ounces of silver per ton. Although the vein contains high-grade ore everywhere it is exposed in the mine, the best ore apparently occurs near or at vein intersections.

\footnotetext{
${ }^{64}$ Knight, D. A., undated, Report on the McAllister mine, 8 p.
} report on file in the Denver Public Library, Denver, Colo.
NATIONAL TUNNFI (G-IV-G)

Location.-Near the junction of Running Gulch with North Clear Creek, about 640 feet N. $28^{\circ}$ E. from the Running Lode mine.

Production.-From 1905 to 19374,401 tons of smelting ore and 770 tons of concentrates were shipped. This ore contained 1,422.44 ounces of gold, 7,880 ounces of silver, 43,637 pounds of copper, 963 pounds of lead, and 134 pounds of zinc. (Compiled by U.S. Bureau of Mines. Published by permission.)

Development.-Tunnel 3,130 feet long on a general trend of S. $25^{\circ} \mathrm{W}$.; connects to Senator shaft and to 6th level of Clay County mine.

Veins.-Clay County: Strike, N. $25^{\circ}$ E.; dip, steeply west.

Wallrock.-Biotite-quartz-plagioclase gneiss, granite pegmatite, monzonite porphyry, and bostonite porphyry.

Ore and sulfide minerals.-Pyrite, gold, silver, tennantite, enargite, chalcopyrite, and a little galena and sphalerite.

Gangue minerals.-Quartz.

Tenor.-Shipments between 1905 and 1937 totalling 4,301 tons of ore averaged 0.60 ounce of gold per ton, 2 ounces of silver per ton, and less than 1 percent copper.

\section{NEMAHA-COTTON MINE (EXACT LOCATION NOT} KNOWN)

The Nemaha-Cotton mine, on Bobtail Hill southeast of the portal of the Bobtail tunnel, is opened by four shafts, from east to west the Liddecoat, Nemaha: New Cotton, and West Cotton (fig. 74); we could not; however, identify the separate shafts at the surface (pl. 1). The Nemaha shaft connects with three levels, the New Cotton shaft with one level, and the West Cotton shaft with one level; the Liddecoat shaft connects with the Nemaha 1st level (fig. 75). An intermediate level, 38 feet above the Bobtail tunnel connects to the Cotton $2 d$ level through a stope (fig. 75). The positions of the stopes are shown on figures 75 and 76. These workings were all inaccessible in 1954 The known production from the mine is given in table 100.

Three veins are developed by the mine, the Cotton, the Nemaha, and the Bobtail. The Nemaha vein strikes about N. $50^{\circ} \mathrm{E}$.; dips about $80^{\circ} \mathrm{NW}$., and is developed by the Nemaha 1st, $2 \mathrm{~d}$, and $3 \mathrm{~d}$ levels and the Cotton $2 d$ level. The mine apparently exploited a vertical ore shoot that extended from the surface to the $2 \mathrm{~d}$ level of the Nemaha shaft. The Nemaha vein fissure intersects and apparently offsets the Cot- 
ton vein; the intersection plunges steeply to the southwest (fig. 75). The Nemaha vein also intersects the Bobtail vein on the $2 \mathrm{~d}$ and $3 \mathrm{~d}$ levels of the Nemaha mine, and this intersection plunges nearly vertical.

The Cotton vein strikes about N. $62^{\circ}$ E., dips steeply either side of vertical, and is developed by the $\mathrm{New}$ Cotton and West Cotton shafts, by the $2 \mathrm{~d}$ level of the Nemaha mine, and by the intermediate level above the Bobtail tunnel (fig. 75). It also is developed by short drifts from the Bobtail tunnel. The Cotton vein is cut and offset by the Bobtail vein (pl. 12). The stope pattern along the Cotton vein suggests that the ore occurred in an ore shoot that plunges about $75^{\circ} \mathrm{W}$.
TABLE 100.-Ore produced from the Nemaha-Cotton mine, 1902-54 ${ }^{1}$

\begin{tabular}{|c|c|c|c|c|c|c|}
\hline Year & $\begin{array}{l}\text { Crude } \\
\text { ore } \\
\text { shipped } \\
\text { (tons) }\end{array}$ & $\begin{array}{l}\text { Concen- } \\
\text { trates } \\
\text { shipped } \\
\text { (tons) }\end{array}$ & $\begin{array}{c}\text { Gold } \\
\text { (ounces) }\end{array}$ & $\begin{array}{c}\text { Silver } \\
\text { (ounces) }\end{array}$ & $\begin{array}{c}\text { Copper } \\
\text { (pounds) }\end{array}$ & $\underset{\text { (pounds) }}{\text { Zinc }}$ \\
\hline $\begin{array}{l}1904 \\
1905 \\
1906 \\
1908\end{array}$ & $\begin{array}{r}25 \\
37 \\
29 \\
97 \\
107\end{array}$ & $\begin{array}{l}\because \\
\because- \\
-\end{array}$ & $\begin{array}{r}248.00 \\
239.45 \\
215.51 \\
339.50 \\
38.70\end{array}$ & $\begin{array}{r}321 \\
637 \\
573 \\
800 \\
42\end{array}$ & $\begin{array}{l}9,360 \\
8,166 \\
4,850\end{array}$ & \begin{tabular}{c}
$-\cdots$ \\
\hdashline$-\cdot$ \\
\hdashline.- \\
\end{tabular} \\
\hline $\begin{array}{l}1909 \\
1910 \\
19112 \\
1913\end{array}$ & $\begin{array}{r}285 \\
83 \\
118 \\
36 \\
46\end{array}$ & $\begin{array}{r}11 \\
4 \\
2 \\
\\
\end{array}$ & $\begin{array}{r}69.22 \\
13.62 \\
25.60 \\
32.81 \\
7.88\end{array}$ & $\begin{array}{r}119 \\
32 \\
65 \\
54 \\
13\end{array}$ & $\begin{array}{c}605 \\
-510 \\
51-\end{array}$ & {$[--$} \\
\hline $\begin{array}{l}1914 \\
1915 \\
19165\end{array}$ & $\begin{array}{r}91 \\
1 \\
1 \\
19\end{array}$ & $\begin{array}{l}7 \\
4 \\
1 \\
-\end{array}$ & $\begin{array}{r}20.50 \\
6.70 \\
2.67 \\
4.60\end{array}$ & $\begin{array}{r}24 \\
17 \\
3 \\
28\end{array}$ & \begin{tabular}{r}
81 \\
21 \\
\hdashline \\
\hdashline-1 \\
\end{tabular} & \begin{tabular}{c}
$-\ldots$. \\
\hdashline$-\cdot$ \\
\hdashline$-\cdot$ \\
\end{tabular} \\
\hline Total.- & 975 & 29 & $1,264.76$ & 2,728 & 23,593 & 29 \\
\hline
\end{tabular}

1 Compiled by U.S. Bureau of Mines. Published by permission.

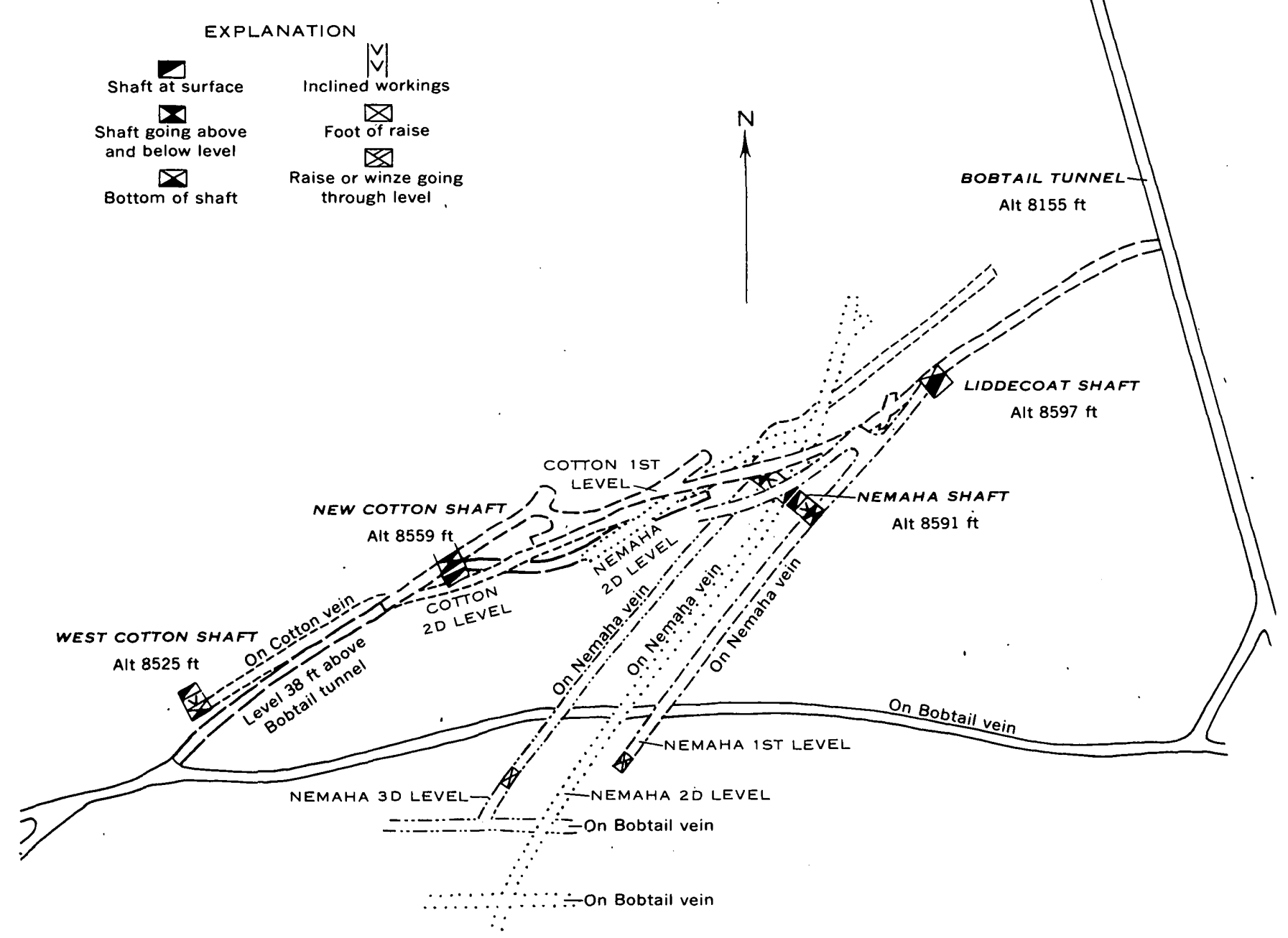

After E. E. Chase, November 1894

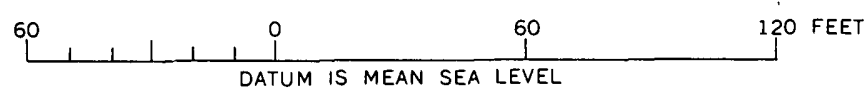

Figure 74.-Composite map of the Nemaha-Cotton mine. 

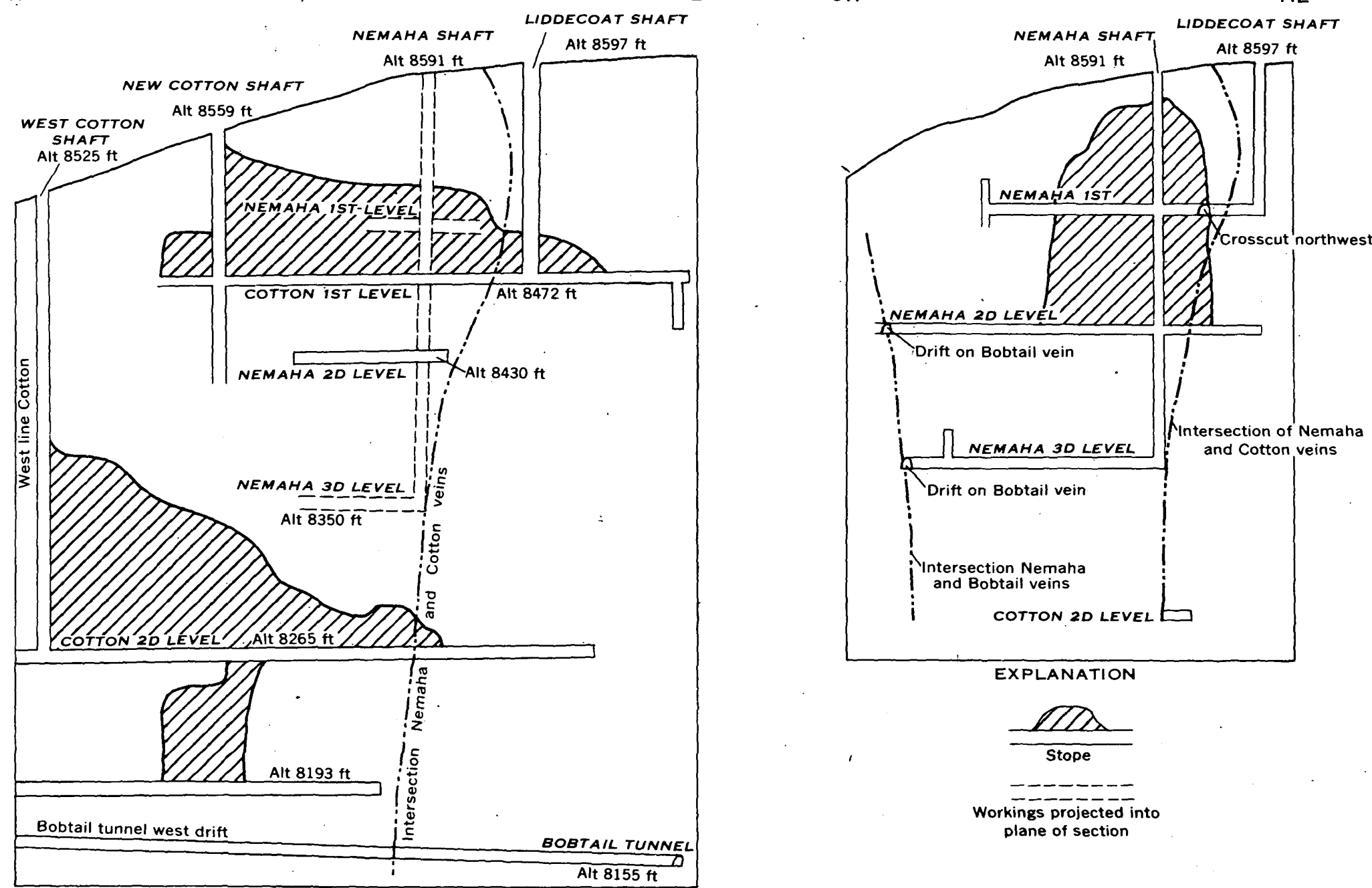

After E. E. Chase, November 1894

100 
Ore shipped from the mine between 1904 and 1907, aggregating 188 tons, averaged 4.47 ounces of gold and 12.4 ounces of silver per ton; this probably represents ore residually enriched in gold. Ore shipped between 1908 and 1935, 208 tons, averaged 0.40 ounce of gold and 0.66 ounce of silver per ton.

\section{NEXT PRESIDENT MINE (D-III-A)}

Location.-On east side of Packard Gulch, about 370 feet N. $31^{\circ} \mathrm{W}$. from the O'Neil mine.

Production.-From 1902 to 19543,412 tons of smelting ore and 311 tons of concentrates were shipped. This ore contained 906.37 ounces of gold, 776 ounces of silver, 196 pounds of copper, and 736 pounds of lead. (Compiled by U.S. Bureau of Mines. Published by permission.) Production from 1931 to 1935 combined with Patch.

Development.-Shaft with levels at depths of 100 , $160,260,360$, and 460 feet.

Veins.-Hartford (a footwall branch of the Gregory lode): Strike, N. $80^{\circ}$ E.; dip, nearly vertical. Next President: Strike, N. 43. E. ; dip, nearly vertical. Veins intersect near shaft; intersection plunges steeply eastward.

Wallrocks.-Microcline-bearing gneiss.

Ore and sulfide minerals.-Pyrite, gold, silver, and a little chalcopyrite, tennantite, galena, and sphalerite.

Gangue minerals.-White and dark-gray quartz.

Tenor.-Ore sold to sampling-works from 1901 to 1910 averaged 1.04 ounces of gold per ton, 3.75 ounces of silver per ton, and 1.21 percent copper.

\section{O.K. MINE (E-IV-1)}

The O.K. mine, on Central Hill, was 325 feet deep in 1880 (Fossett, 1880, p. 320) and was last worked during the 1930's by the Chain O' Mines. In 1912 the shaft was 500 feet deep with levels at depths of $50,115,200,225,285,400$, and 500 feet (Bastin and Hill, 1917, p. 223); the 400 level connects with the Bobtail tunnel (Bastin and Hill, 1917, p. 223). The known production from the property is given in table 101 (production from 1929 to 1935 is combined with that from the Patch); this ore if produced today would have a value of about $\$ 422,000$.

The O.K. vein strikes about N. $55^{\circ}$ E. and dips almost vertically. It is the same vein as the Epizootic, which is developed by the Bobtail tunnel (pl. 12). Judging from the vein material on the dump, the vein is of pyrite type but contains some sphalerite and chạlcopyrite. Sampling-works assays of 29 lots of smelting ore shipped from 1893 to 1908 show gold, 0.30 to 4.28 (average 1.13) ounces per ton; silver 3.40 to 10.20 (average 5.59) ounces per ton; and copper,
2 to 10.25 percent. The average recovery as bullion and concentrates from concentrating ore shipped in 1910 was gold 0.17 ounce and silver 0.32 ounce per ton.

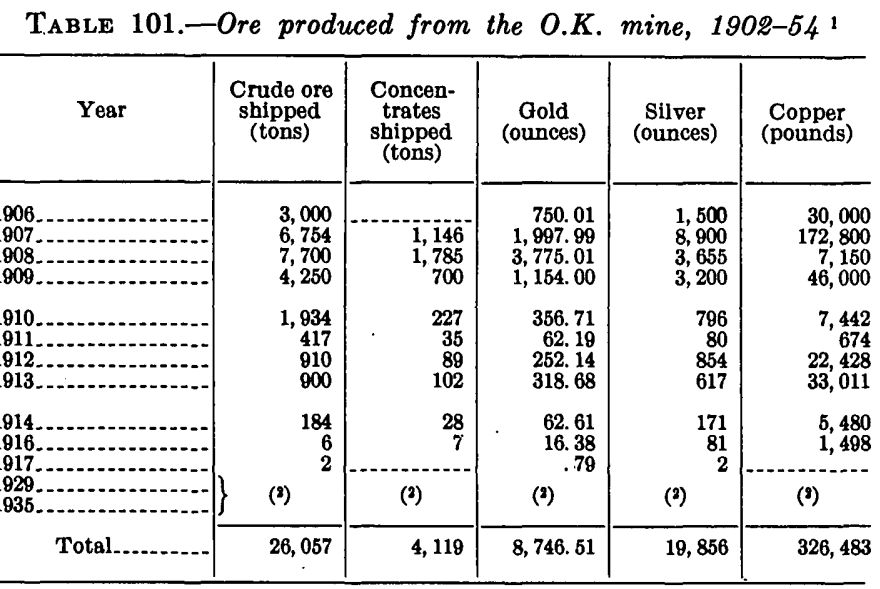

1 Compiled by U.S. Bureau of Mines. Published by permission. See Patch.

O'NEIL MINE (E-III-2)

The O'Neil mine is on Gregory Hill, about 670 feet N. $48^{\circ} \mathrm{W}$. from the Cook shaft. The mine was last worked in 1938; it was inaccessible in 1954. The shipping ore, valued largely for its gold content (table 102 ) would have a value of about $\$ 206,500$ today. The property is reported to have yielded $\$ 40,000$ prior to 1899 (Callbreath, 1899, p. 286). The mine is opened by a 890 -foot shaft with levels at depths of $100,200,270,358,464,566,664,762$, and 860 feet (fig. 76 ); the 358 level east connects to the Bobtail tunnel. Stopes are present on all levels, but most are in the upper part of the mine.

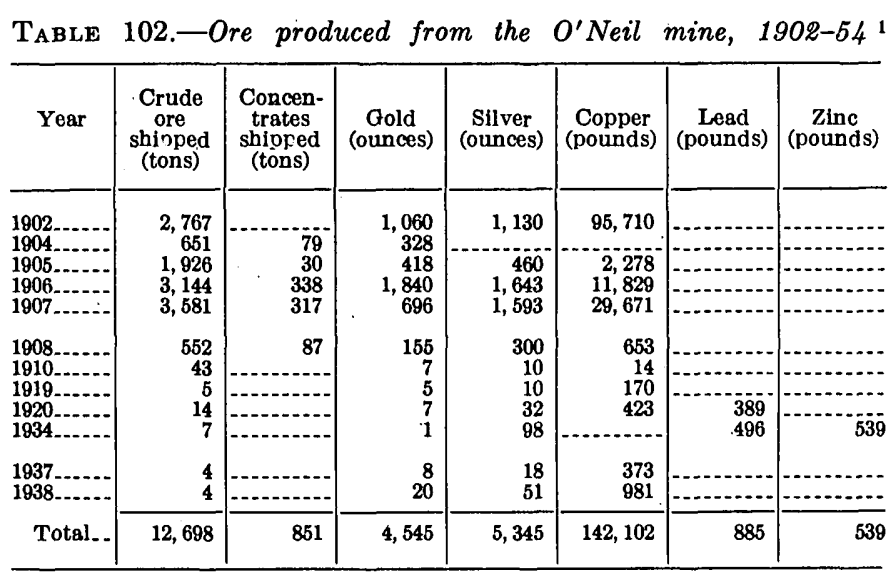

${ }^{1}$ Compiled by U.S. Bureau of Mines. Published by permission.

The O'Neil vein is the south branch of the Gregory lode. It strikes about N. $40^{\circ}$ E. and dips $80^{\circ} \mathrm{NW}$. Another vein that splits from the O'Neil vein and then rejoins it also is present in the mine. On the 
Bobtail tunnel level, both of these veins are present and are cut and offset by the Mammoth vein fissure (p. 170). Pyrite is the chief ore mineral in the vein, but considerable chalcopyrite and sparse galena and sphalerite are present locally. Free gold enclosed in galena and quartz is reported to have been found on the 860 level (Bastin and Hill, 1917, p. 225). Most of the ore in the mine appears to have been taken from an ore shoot that plunges about $50^{\circ}$ to the southwest (fig. 76), and which possibly occurs at a vein intersection. This shoot has not been opened as yet below the 566 level. The average value of smelting ore mined between 1897 and 1906 is said to have been about $\$ 70$ per ton; 48 tons sold between 1897 and 1908, averaged 3.10 ounces of gold, 7.13 ounces of silver, and 5 percent copper per ton (Bastin and Hill, 1917, p. 225). The concentrating ore for the same period averaged about $\$ 10$ per ton.

\section{RIALTO MINE (E-III-22)}

Location.-In Gregory Gulch.

Production.-About $\$ 400,000$ prior to 1899 (Callbreath, 1899).

Development.-A 530-foot shaft with about 4,000 feet of drifts.

Veins.-Rialto: Strike, N. $35^{\circ}$ E.; dip, nearly vertical; smelting streak 2 to 3 feet wide; probably same vein as developed by Freedom mine on Winnebago Hill.

Wallrock.-Microcline-bearing gneiss.

Ore and sulfide minerals.-Pyrite, gold, silver, chalcopyrite, galena, and sphalerite.

Gangue minerals.-Quartz.

Ore shoots.-Ore shoot cut east of shaft on 225 level, and in the shaft on 300 level; probably plunges to the southwest.

Tenor.-Ore on 300 level assayed $\$ 130$ in gold and silver, and $\$ 4.40$ in copper (1890 prices).

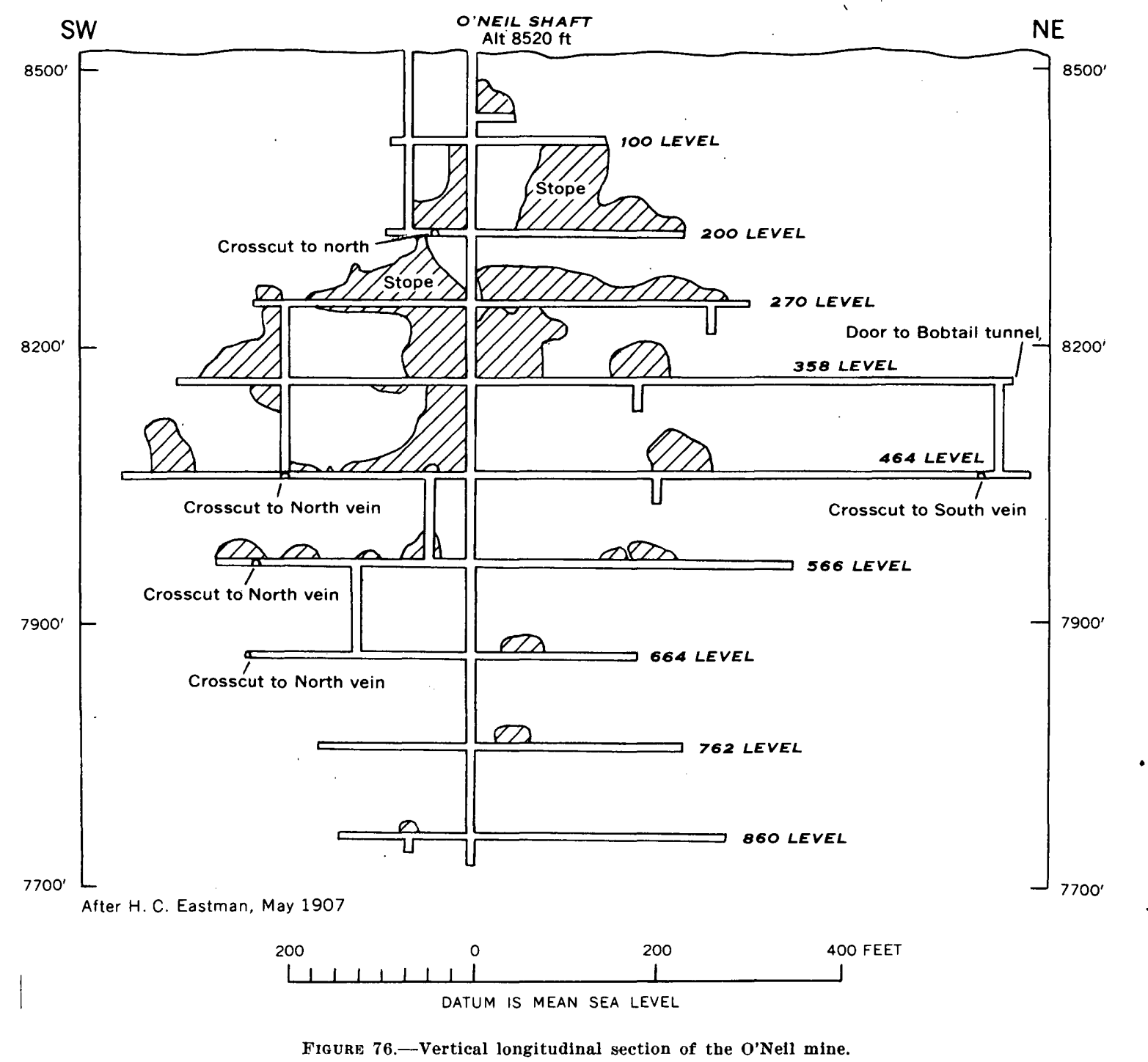




\section{RIALTO EXTENSION MINE (D-III-2)}

Location.-On Central Hill, about 500 feet S. $43^{\circ}$ W. from the Rialto mine.

Development.-A 166 -foot shaft with 400 feet of drifts.

Veins.-Rialto Extension: strike, N. $80^{\circ}$ E.; dip, vertical.

Wallrock.-Microcline-bearing gneiss.

Ore and sulfide minerals.-Pyrite, gold, silver, some chalcopyrite.

Gangue minerals.-White and dark-gray quartz.

\section{RUNNING LODE MINE (G-IV-1)}

Location.-Near the head of Running Gulch, about 1,480 feet N. $43^{\circ}$ E. from the Chemung-Belmont mine.

Production.-About $\$ 500,000$ prior to 1899 (Callbreath, 1899); 17,160 tons of smelting ore and 1,291 tons of concentrates shipped between 1902 and 1941 contained 16,956.19 ounces of gold, 662,033 ounces of silver, $1,170,756$ pounds of copper, $1,139,862$ pounds of lead, and 259,576 pounds of zinc. (Compiled by U.S. Bureau of Mines. Published by permission.)

Development.-A 1,400-foot vertical shaft and 1,000foot drift tunnel.

Veins.-Several segments of the Running Lode: Strike, east to east-northeast; dip, steep either side of vertical; movement, north wall west with respect to the south wall.

Wall rock.-Biotite-quartz-plagioclase gneiss, granite pegmatite, and bostonite porphyry.

Ore and sulfide minerals.-Galena, sphalerite, pyrite, chalcopyrite, tennantite, gold, and silver.

Gangue minerals.-Quartz.

Ore shoots.-Stopes appear to occur on strike deflections to the north (left).

Tenor.-16,958 tons of smelting ore shipped between 1902 and 1912 averaged 0.54 ounces of gold per ton, 28 ounces of silver per ton, 3.44 percent copper, and 2.8 percent lead.

\section{SLEEPY HOLLOW MINE (F-III-11)}

The Sleepy Hollow mine is on the north slope of Bobtail Hill, about 530 feet N. $86^{\circ}$ E. from the Bobtail tunnel. The property was opened and extensively worked prior to 1900 ; it was last operated in 1925 . The known production from the property since 1902 is given in table 103; this ore if produced today would have a value of about $\$ 100,000$. The property is reported to have yielded $\$ 800,000$ prior to 1912 (Bastin and Hill, 1917, p. 227). The mine is opened by a twisting inclined shaft, vertical depth 969 feet, and 11 levels at vertical depths of $120,245,315,385,450$, $515,590,680,755,845$, and 885 feet (fig. 77). The position of the stopes is shown on figure 77; large stopes are reported on the 1st and $2 \mathrm{~d}$ levels, but their position is not known. In 1954 all the workings were inaccessible.

TABLE 103.-Ore produced from the Sleepy Hollow mine, 1902-54'

\begin{tabular}{|c|c|c|c|c|c|c|}
\hline Year & $\begin{array}{l}\text { Crude ore } \\
\text { shipped } \\
\text { (tons) }\end{array}$ & $\begin{array}{l}\text { Concen- } \\
\text { trates } \\
\text { shipped } \\
\text { (tons) }\end{array}$ & $\begin{array}{c}\text { Gold } \\
\text { (ounces) }\end{array}$ & $\begin{array}{c}\text { Silver } \\
\text { (ounces) }\end{array}$ & $\begin{array}{c}\text { Copper } \\
\text { (pounds) }\end{array}$ & $\underset{\text { (pounds) }}{\text { Lead }}$ \\
\hline $\begin{array}{l}1905 \\
1906 \\
1908 \\
1909 \\
1910\end{array}$ & $\begin{array}{r}850 \\
131 \\
40 \\
3,889 \\
2,570 \\
2,342\end{array}$ & $\begin{array}{r}10 \\
511 \\
315 \\
210\end{array}$ & $\begin{array}{r}38.70 \\
38.02 \\
38.00 \\
445.10 \\
634.97 \\
483.27\end{array}$ & $\begin{array}{r}15 \\
12 \\
1,467 \\
2,007\end{array}$ & 134 & $\begin{array}{l}--\cdot \\
-\cdot \\
-\cdots \\
--.\end{array}$ \\
\hline $\begin{array}{l}1911 \\
1912 \\
1921 \\
1923 \\
1925\end{array}$ & $\begin{array}{r}356 \\
682 \\
45 \\
180 \\
50 \\
50\end{array}$ & 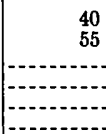 & $\begin{array}{r}156.88 \\
426.38 \\
15.42 \\
90.49 \\
25.11 \\
29.66\end{array}$ & $\begin{array}{r}4,092 \\
4,323 \\
382 \\
20 \\
9 \\
10\end{array}$ & $\begin{array}{r}10,397 \\
226\end{array}$ & $\begin{array}{r}-70 \\
\\
\\
\end{array}$ \\
\hline Total. & 11,185 & 1,141 & $2,422.00$ & 12,337 & 10,757 & 70 \\
\hline
\end{tabular}

1 Compiled by U.S. Bureau of Mines. Published by permission.

The Sleepy Hollow vein apparently is the northeast extension of the Fisk lode. It also was developed in the After Supper (Banzai) mine, about 1,000 feet to the northeast, and in the Americus mine, about 720 feet to the southwest. The Sleepy Hollow vein strikes about N. $45^{\circ} \mathrm{E}$., and is highly irregular in dip. It dips about $80^{\circ} \mathrm{SE}$. from the surface to the $2 \mathrm{~d}$ level, and it dips about $75^{\circ} \mathrm{NW}$. from the $2 \mathrm{~d}$ level to a short distance below the 4th level, at which point it is joined from the north by the Americus-Fisk vein (fig. 77). Below this junction the vein is known as the United Fisk vein, a nearly vertical vein that splits just below the 9th level; the north branch, which the shaft follows, dips $70^{\circ} \mathrm{NW}$. and is called the Fisk hanging-wall vein (fig. 78); the south branch, the Main Fisk vein, is nearly vertical and is developed by crosscuts south from the shaft. The Sleepy Hollow vein was formed by two stages of mineralization. The original pyrite vein and the pyritized and silicified wallrock surrounding it was cut and veined by white and gray quartz, galena, sphalerite, and chalcopyrite.

On the 9th and 11th levels the Main Fisk vein is cut and offset by the "Bob" vein fissure (fig. 78), which strikes about N. $22^{\circ}$ E., dips $65^{\circ}-80^{\circ}$ NW., and is probably the downward extension of the Dory Hill fault (pl. 1). On the 11th level, the northeast segment of the Fisk vein is shifted about 75 feet to the north along the fault; the faulted segment was not found on the 9th level, but should be only a few feet north of the present face (fig. 78). The line of intersection of the Bob and Main Fisk veins plunges about $52^{\circ}$ to the southwest (fig. 77).

The ore in the Sleepy Hollow-Fisk lode apparently occurred in an ore shoot that plunged about $60^{\circ} \mathrm{NE}$. 


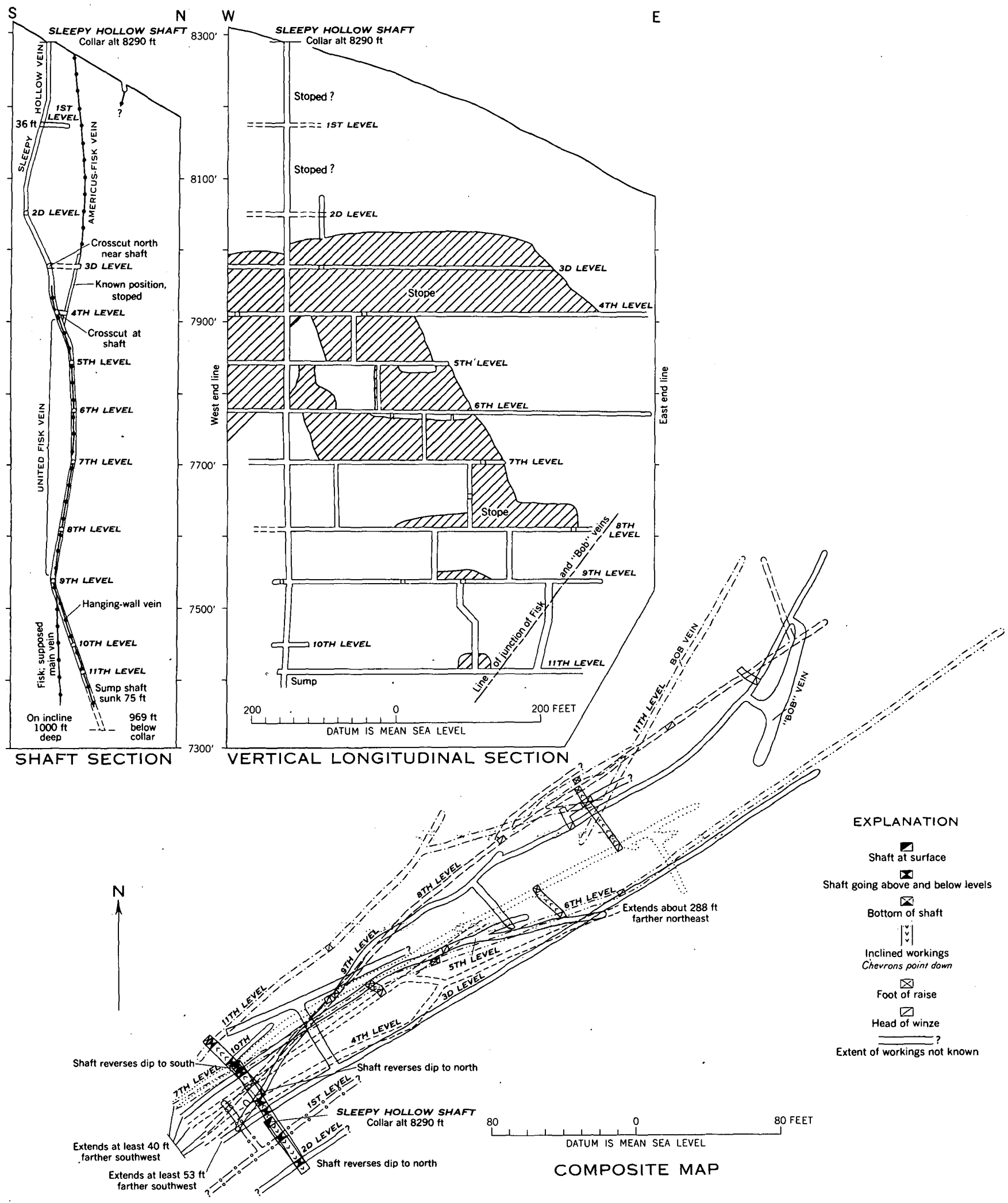

After W. A. Funk, June 1907 


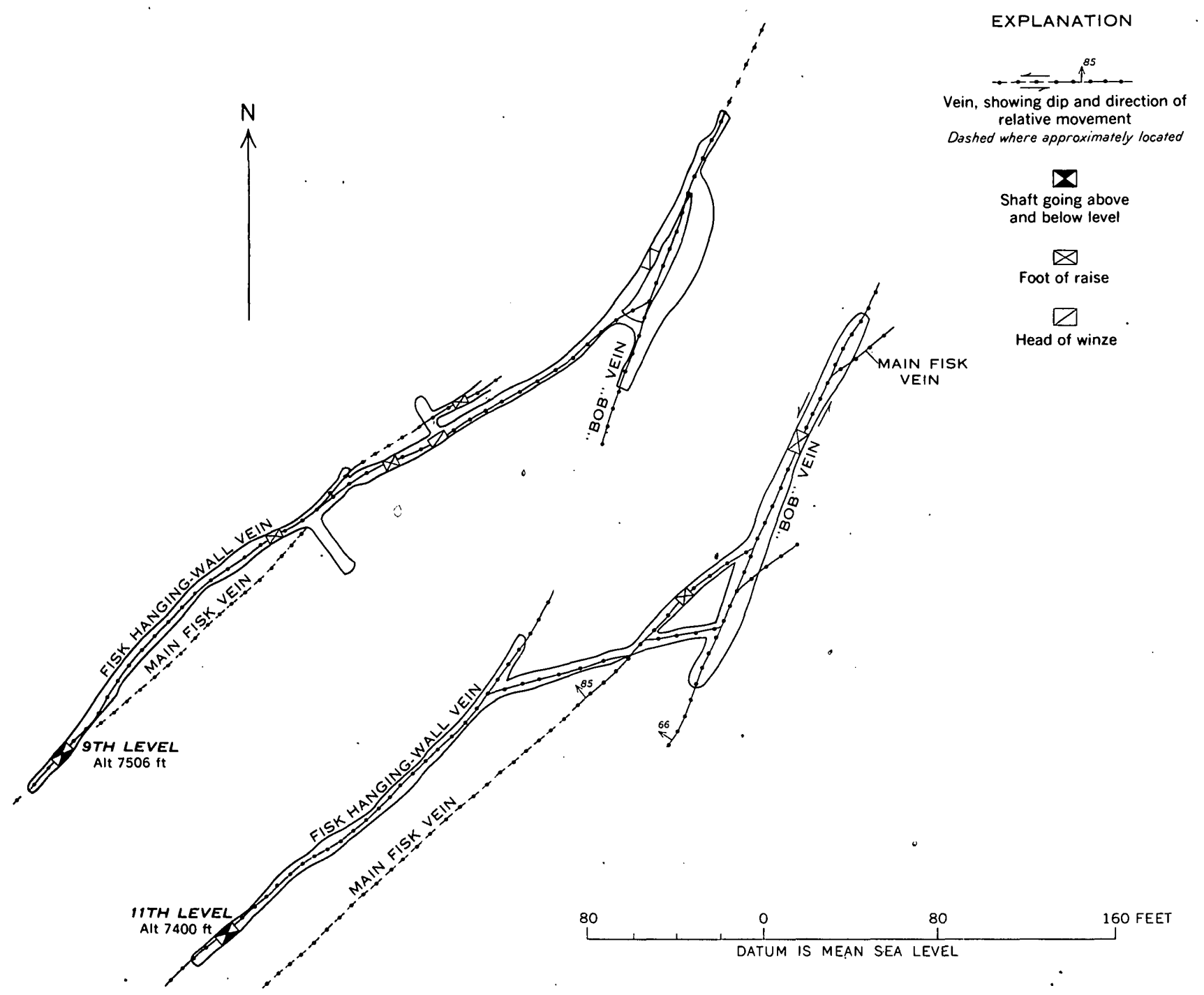

Figure 78.-Veln maps of the 9 th and 11 th levels, Sleepy Hollow mine. After W. A. Funk, 1908; map on fle in the Denver Public Library, Denver, Colo.

Ore bodies developed by the Fisk mine are reported to have had similar attitudes. ${ }^{55}$ The structural control of the ore body is not definitely known, but probably is related to the intersection of the vein with the foliation of the wallrocks, for the calculated average plunge of the line of intersection would plunge moderately northeast. The very large stope on the 4th level possibly is at the intersection of the Sleepy Hollow and Americus veins. The "Bob" vein apparently cuts off the main ore shoot (fig. 77), but the writers can see no reason why its extension should not be present east of the fault.

Gold telluride ores have been reported at places in the vein, and the high gold content of some shipments

collins, G. E., undated, Eurly mining history of Gllpin County, 12 p., report on fle in the Denver Public Library, Denver, Colo.

\footnotetext{
654827 O-63-14
}

was probably due to their presence (Bastin and Hill, 1917 , p. 227). Some ore from the upper levels had a high silver content (as high as 492 ounces) and was probably secondarily enriched in silver (Bastin and Hill, 1917, p. 227). The precious-metal content of the ore ranged from 0.28 to 34.25 ounces of gold and 2 to 492 ounces of silver per ton. In most of the smelting ore gold averaged about 2 ounces and silver about 10 ounces per ton. A few lots of smelting ore contained as much as 20 percent lead and 5.7 percent copper.

\section{TIERNEY (CENTENNIAL) TUNNEY (E-IIY-28)}

The Tierney tunnel, also known as the Centennial tunnel and the M.L.-G.C. mine, is on the north slope of Mammoth Hill. The tunnel was worked last in 1937. The known production from the mine since 
1902 is given in table 104; this ore if produced today would have a value of about $\$ 13,000$. The mine was operated by the Chain O' Mines during the 1930's, so an additional tonnage of concentrates was probably produced from the property during that period. The tunnel is reported to have yielded ore that sold for about $\$ 410,000$ prior to 1889 (Callbreath, 1899 , p. 240, $300)$.

TABLE 104.-Ore produced from the Tierney tunnel, 1902-54 ${ }^{1}$

\begin{tabular}{|c|c|c|c|c|c|c|}
\hline Year & $\begin{array}{l}\text { Crude ore } \\
\text { shipped } \\
\text { (tons }\end{array}$ & $\begin{array}{c}\text { Concentrates } \\
\text { shipped } \\
\text { (tons) }\end{array}$ & $\begin{array}{c}\text { Gold } \\
\text { (ounces) }\end{array}$ & $\begin{array}{c}\text { Silver } \\
\text { (ounces) }\end{array}$ & $\begin{array}{l}\text { Copper } \\
\text { (pounds) }\end{array}$ & Remarks \\
\hline $\begin{array}{l}1914 \\
1915 \\
1916 \\
1917 \\
1918 \\
1934 \\
1935 \\
1936 \\
1937\end{array}$ & $\begin{array}{r}28 \\
23 \\
17 \\
13 \\
40 \\
\\
35 \\
6 \\
25\end{array}$ & 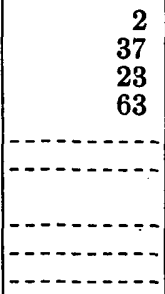 & $\begin{array}{r}1.78 \\
98.40 \\
77.42 \\
80.34 \\
16.89 \\
15.14 \\
\\
\text { 20. } 31 \\
4.31 \\
5.62\end{array}$ & $\begin{array}{r}7 \\
209 \\
198 \\
186 \\
44 \\
30 \\
4 \\
8\end{array}$ & 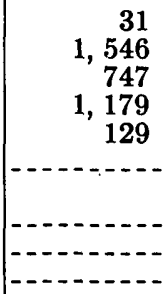 & \multirow[t]{2}{*}{$\begin{array}{l}\text { Probably from Tierney vein. } \\
\text { Probably largely from Hamlet vein. } \\
\text { Do. } \\
\text { Do. } \\
\text { Do. } \\
\text { Probably from Mountain Lion-Gilpin County } \\
\text { vein. } \\
\text { Do. } \\
\text { Do. } \\
\text { Do. }\end{array}$} \\
\hline Total & 187 & 125 & 320.21 & 686 & 3,632 & \\
\hline
\end{tabular}

1 Compiled by U.S. Bureau of Mines. Published by permission.

The Tierney tunnel is a crosscut that was driven nearly south, reportedly for 700 feet, (Callbreath, 1899 , p. 241), but in 1954 (fig. 79) it was caved about 405 feet from the portal.

The dominant wallrock of the mine is microclinebearing gneiss which contains thin layers of biotitequartz-plagioclase gneiss and amphibolite (fig. 79). These rocks generally strike northeast and dip moderately to the southeast, but locally they are deformed by a series of warps that plunge gently northeast, generally parallel to the major fold axes in the area, and by a series of broad gentle northwestward-plunging cross warps. A small upright anticline is near the portal of the tunnel (fig. 79).

The principal veins developed by the Tierney tunnel are the Maine-Hamlet, Mountain Lion-Gilpin County, Vasa, and Tierney. W. C. Russell, Jr. (oral communication) informed the writers that miners who worked the property considered the vein developed by the $220 \mathrm{drift}$ to be the Tierney and accordingly these names are used in this report.

A vein, possibly the Maine-Hamlet, is cut about 125 feet from the portal; but as this part of the workings is lagged it could not be examined. For a description of the Maine-Hamlet vein the reader is referred to page 177 .

The Mountain Lion-Gilpin County vein of the miners is cut about 220 feet from the portal. It strikes nearly east and dips $60^{\circ}-87^{\circ} \mathrm{N}$. East of the tunnel one segment is about $2 \frac{1}{2}$ feet thick, but near the crosscut the vein splits into several subparallel segments. The attitudes of these horsetailing branches suggest that the vein fills a fault along which the north wall was displaced relatively east. As exposed near the cave in the east drift, the vein is 24 to 30 inches wide and consists of several 1- to 4 -inch veinlets of white quartz and pyrite separated by strongly bleached, sericitized, and silicified wall rock that contains moderate to abundant disseminated pyrite. The branching veins near the face of the west drift are 2 to 8 inches thick and contain considerable quartz and coarse pyrite. Too little of the vein is exposed to determine the ore controls, but the stoped ground is limited to the segment marked by a single vein. It was also noted that the general dip of the vein is flatter in this segment than in its other parts.

The Vasa vein strikes about N. $70^{\circ}$ E. and dips $75^{\circ}$ NW. In the back of the crosscut it is 18-24 inches wide and consists of abundant 1- to 2-inch streaks of quartz and pyrite separated by altered wallrock. It evidently contained valuable ore in this part of the mine, for it is stoped on both sides of the crosscut.

The Tierney vein, cut about 400 feet from the portal, strikes about $\mathrm{N} .65^{\circ} \mathrm{E}$. and dips highly irregularly in both directions. The vein may consist of two separate filled fissures, for the hanging wall and footwalls have opposing dips near the crosscut. These walls converge to the west into a single vein that dips $80^{\circ} \mathrm{NW}$., which in turn, split into two oppositedipping segments. Near the face of the drift these segments again reunite into a single vein that dips $85^{\circ} \mathrm{SE}$. The vein is largely stoped except near the face of the west drift, where it is seen to consist of 5 inches of altered rock containing disseminated pyrite, 1 inch of gouge, 6 inches of white and gray quartz with coarsely crystalline pyrite, and 24 inches 


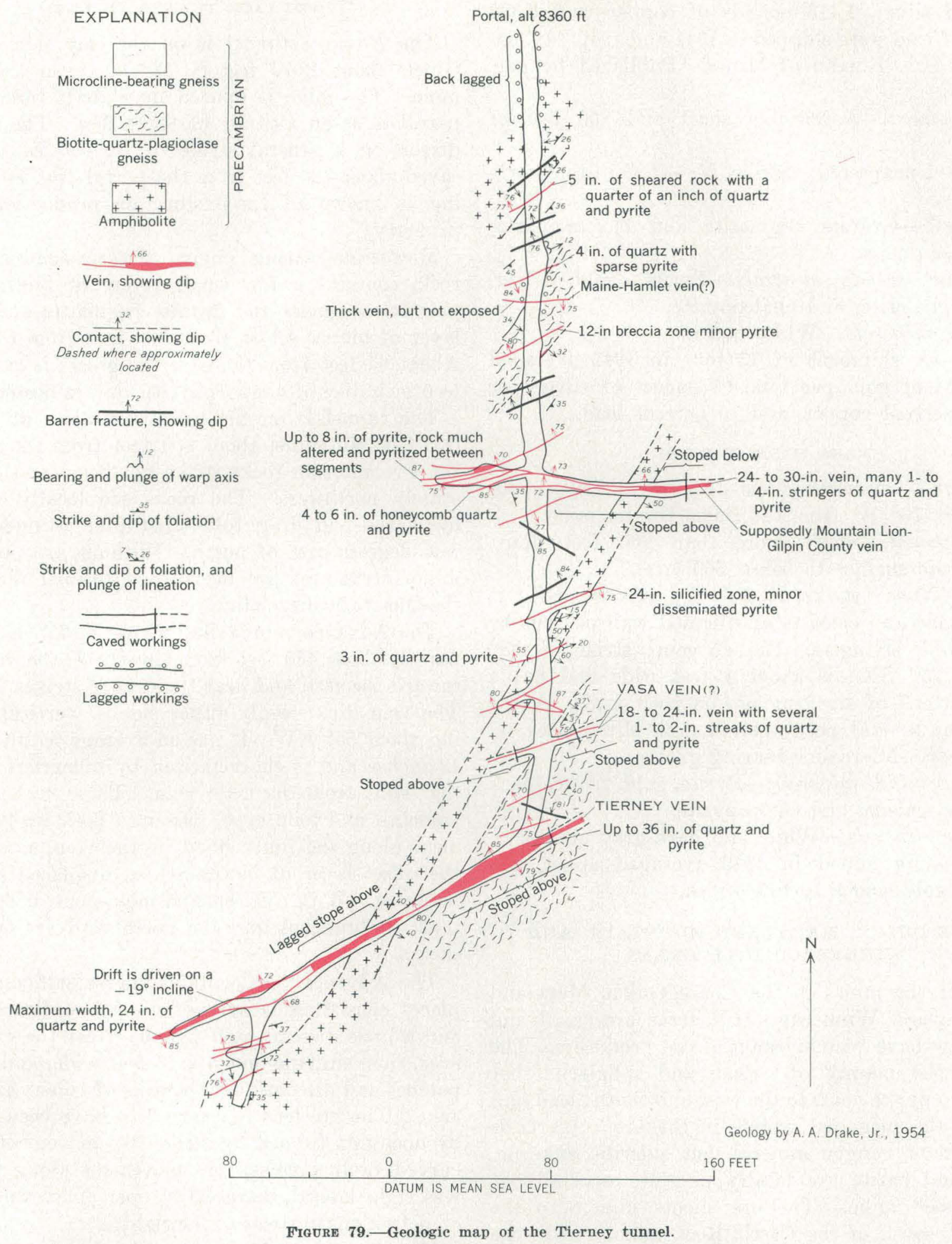

of altered wallrock that is traversed by several stringers of quartz and pyrite. Stoped ground along this vein is confined to those sections where the footwall and hanging-wall segments are sufficiently close together for the intervening horse to be highly fractured and mineralized.

\section{UNEXPECTED MINE (F-IV- - )}

Location.-On the north side of Lake Gulch, about 870 feet S. $57^{\circ}$ E. from the Colorado-Carr mine.

Production.-About $\$ 50,000$ prior to 1899 (Callbreath, 1899); 13 tons of smelting ore and 10 tons of concentrates that contained 13.20 ounces of gold, 182 
ounces of silver, 1,413 pounds of copper, and 5,333 pounds of lead were shipped in 1941 and 1942. (Compiled by U.S. Bureau of Mines. Published by permission.)

Development.-A 300 -foot shaft and 250 feet of drifts.

Veins.-Unexpected: Strike, N. $53^{\circ}$ E.; dip, nearly vertical.

Wallrock.-Granite pegmatite and biotite-quartzplagioclase gneiss.

Ore and sulfide minerals.-Pyrite, gold, silver, galena, sphalerite, and chalcopyrite.

Gangue minerals.-White quartz.

Tenor.-A shipment of 13 tons in 1942 averaged 0.51 ounce of gold per ton, 9.5 ounces of silver per ton, 3.9 percent copper, and 15 percent lead.

\section{VASA MINE (E-III-8)}

Location.-On north slope of Central Hill, about 760 feet S. $70^{\circ} \mathrm{W}$. from the Bates-Hunter mine.

Development.-Shaft more than 260 feet deep; stoped from surface to below 260 level.

Veins.-Vasa: strike, N. $50^{\circ}$ E.; dips $80^{\circ} \mathrm{SE}$; is 10 feet wide and consists of silicified wallrock cut by many sulfide stringers. Branch vein: strike, N. 55 E.; dip, $75^{\circ} \mathrm{SE}$; is about 4 feet wide and has a narrow streaki of smelting ore on both walls. Veins are cut by several postmineralization slip planes.

Wallrock.-Microcline-bearing gneiss.

Ore and sulfide minerals.-Pyrite, gold, silver, black sphalerite, galena, and chalcopyrite.

Gangue minerals.-White and dark-gray quartz.

Tenor.-Ore mined in 1912 averaged about 0.38 ounce of gold over a 10 -foot width.

\section{CHASE GULCH, MARYLAND MOUNTAIN, AND WINNEBAGO HILL AREAS}

Most of the mines in the Chase Gulch, Maryland Mountain, and Winnebago Hill areas are small and only a few have been substantial ore producers. The veins consist mainly of galena and sphalerite, but grade into pyrite veins to the west and south; lead and gold are the principal metals in the ore. Quartz is the dominant gangue mineral, but siderite, ankerite, calcite, and barite are locally present, especially at the Hayseed mine. The ore shoots plunge to the northeast, south of the Castle Rock mine, and to the southwest, north of the Castle Rock mine.

Microcline-bearing gneiss is the principal wallrock. It contains many thin, lenticular layers of biotitequartz-plagioclase gneiss and amphibolite and several small pegmatite bodies. A small dike of nonporphyritic quartz bostonite crosses the area along the line of the Gulnare mine-Advance tunnel.

\section{ADVANCE TUNNEL (D-II-8)}

The Advance tunnel is on the east side of Chase Gulch about 1,070 feet S. $18^{\circ}$ E. from the Tucker mine. The mine is opened by a drift tunnel whose portal is at an altitude of 8,520 feet. The tunnel is driven on a general strike of $\mathrm{N}$. $70^{\circ} \mathrm{E}$., and it is caved about 780 feet from the portal (fig. 80). Nothing is known of the history or production of the property.

Microcline-bearing gneiss, the predominant wallrock, contains a few small layers of biotite-quartzplagioclase gneiss and granite pegmatite and a small layer of biotite schist about 530 feet from the portal. About 65 feet from the cave the gneiss is cut by a 4to 6 -inch dike of nonporphyritic quartz bostonite.

The tunnel is on the northwest flank of the Central City anticline, about 800 feet from the axis, and the Precambrian rocks strike northeast and dip moderately northwest. The rocks are locally deformed by warps and drag folds that plunge moderately a few degrees east of north. Without exception these minor structures are overturned toward the axis of the Quartz Hill anticline.

The Advance vein strikes about N. $65^{\circ}$. E. near the portal.; about 460 feet from the portal the vein bends toward the east, and near the cave it strikes N. $85^{\circ} \mathrm{E}$. The vein dips steeply either side of vertical, averaging about $85^{\circ} \mathrm{NW}$. It has an average width of about 12 inches and is characterized by numerous branches that split from the main vein. These branches, both horsetail and loop type, pass into both walls. Movement along the fault, filled by the vein, as shown by the offset layer of biotite schist, displaced the north wall east. With this sense of movement, it is inferred that the branches into the north wall are subsidiary shears.

The Advance vein contains sparse sulfides, at most places consisting largely of altered wallrock, gouge, and a little disseminated pyrite. Near the cave, however, the vein is as much as 3 feet wide, and contains patches and discontinuous streaks of galena and sphalerite. The ore lens is inferred to have been localized by openings formed by strike-slip movement along a curved fault surface. As movement along the fault was right lateral, the greatest open space would occur on deflections in strike to the right.

The Advance vein is cut and offset by two northwestward-trending faults (fig. 80). The first, about 125 feet from the portal, strikes about N. $60^{\circ}$ W., dips $75^{\circ} \mathrm{NE}$, and shifts the northeast segment of the Advance vein about 14 inches to the northwest. The second fault, about 170 feet southwest of the cave, strikes N. $50^{\circ} \mathrm{W}$., stands vertical, and is barren. The 


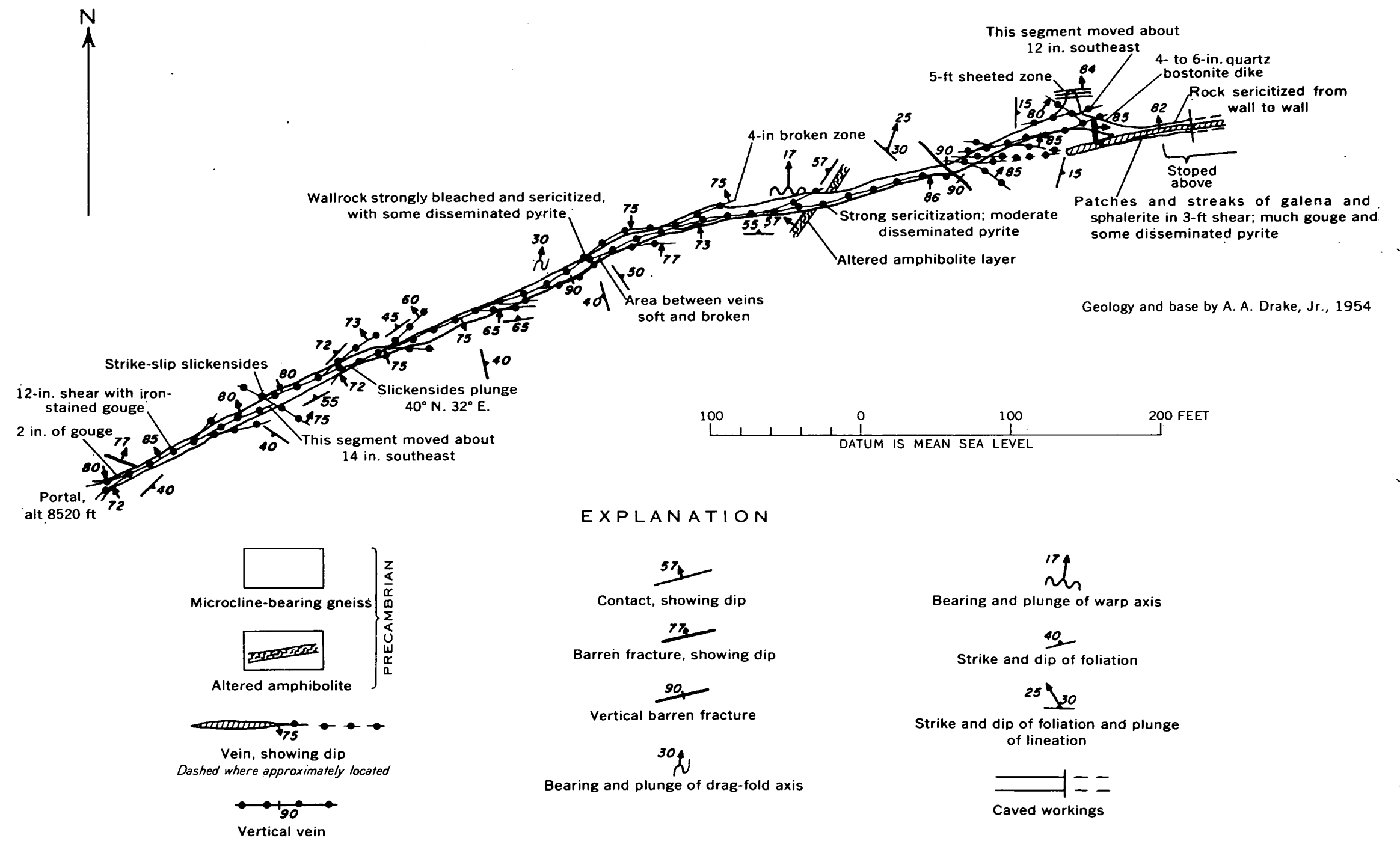

Figure 80.-Geologic map of the Advance tunnel. 
Advance vein is frayed near this fault, but its northeast segment has been shifted 10 to 15 feet to the northwest.

\section{ALLIE TUNNEL (D-II-8)}

The Allie tunnel, on the north side of Chase Gulch, about 700 feet N. $84^{\circ}$ E. from the Castle Rock mine, was last operated in 1942. The known production from the Allie tunnel is small (table 105). The mine is opened by a 45 -foot crosscut, from which an 845foot drift bearing about N. $70^{\circ} \mathrm{E}$. has been turned (fig. 81). A raise 410 feet from the crosscut connects to the Katherine shaft, and a raise 110 feet from the face connects through a stope to the Sans Souci tunnel (William C. Russell, Jr., oral communication).

TABLE 105.-Ore produced from the Allie tunnel, 1902-54

\begin{tabular}{|c|c|c|c|c|c|}
\hline Year & $\begin{array}{l}\text { Crude ore } \\
\text { shipped } \\
\text { (tons) }\end{array}$ & $\underset{\text { (ounces) }}{\text { Gold }}$ & $\begin{array}{c}\text { Silver } \\
\text { (ounces) }\end{array}$ & $\begin{array}{c}\text { Copper } \\
\text { (pounds) }\end{array}$ & $\begin{array}{l}\text { Lead } \\
\text { (pounds) }\end{array}$ \\
\hline $\begin{array}{l}1932 \\
1933 \\
1934 \\
1940 \\
1941 \\
1942\end{array}$ & $\begin{array}{r}10 \\
1 \\
22 \\
52 \\
4 \\
6\end{array}$ & $\begin{array}{r}\text { 7. } 50 \\
2.97 \\
11.89 \\
5.97 \\
\text { 3. } 69 \\
\text { 5. } 00\end{array}$ & $\begin{array}{r}3 \\
1 \\
5 \\
1 \\
1 \\
96\end{array}$ & 149 & 3,563 \\
\hline Total & 95 & 37. 02 & 107 & 149 & 3,563 \\
\hline
\end{tabular}

1 Compiled by U.S. Bureau of Mines. Published by permission.

Microcline-bearing gneiss is the dominant wallrock in the mine. A few layers of biotite-quartz-plagioclase gneiss occur in the gneiss, but only one layer was sufficiently large to map (fig. 81).

The Allie vein strikes about N. $70^{\circ}$ E. and dips $65^{\circ}-85^{\circ} \mathrm{SE}$. It is one of the veins developed by the Sans Souci mine (E-II-6) on Maryland Mountain and probably correlates with the Freiburg vein on Winnebago Hill (pl. 1). The vein, properly termed a lode, consists of a series of subparallel, branching filled fissures (fig. 81). Individual veins are marked by 2 to about 12 inches of altered rock cut by stringers of quartz, sphalerite, pyrite and sparse tennantite. Where they unite, they form very wide fracture zones. Local vugs in the vein contain well-defined cubes of galena.

Ninety-five tons of smelting ore shipped between 1932 and 1942 averaged 0.39 ounce of gold per ton, 1.12 ounces of silver per ton, 0.07 percent copper, and 1.8 percent lead. The gold and silver content is probably representative of the ore from the mine, but it is thought that the lead was discarded during the 1930 's and that the 6 tons shipped in 1942 which contained 29 percent lead was probably more representative of the ore.

\section{BELDEN TUNNEL (D-II-2)}

The Belden tunnel is on the south side of Chase Gulch, about 350 feet S. $40^{\circ}$ E. from the Castle Rock mine. The portal is at an altitude of 8,462 feet. The tunnel was caved at the portal in 1954, but it was mapped by Bastin and Hill (1917, p. 209) ; figure 28 of their report is reproduced as figure 82 of this report. The following description also is taken largely from the report by Bastin and Hill.

The Belden tunnel cuts across several veins, and extensive drifts were driven on the Ellery vein, a vein herein termed vein $A$-probably the southwest extension of the Centennial vein-and the Casto vein. Several veins were stoped from the tunnel workings, but the production is not known.

The Ellery vein, cut 115 feet from the portal, strikes N. $62^{\circ}$ E. and dips $63^{\circ}-80^{\circ}$ (average $75^{\circ}$ ) SE. The vein ranges from a few inches to 4 feet in width, but in most places it consists of 8 to 10 inches of crushed, bleached microcline-bearing gneiss that locally contains small quantities of disseminated pyrite.

Vein $A$, cut at 690 feet, was drifted for about 900 feet. At most places it is 6 to 10 inches wide and nearly barren. Commonly sparse pyrite is disseminated through the wallrock adjacent to the vein. At a point 140 feet west of the crosscut tunnel, at the bend in the drift, a small seam of galena, sphalerite, and chalcopyrite cuts the pyrite vein at an acute angle.

A vein, almost parallel to vein $A$ and about 40 feet southeast of it, was cut in the crosscut from vein $A$ drift 250 feet southwest of the crosscut tunnel. The vein is about 2 feet wide; it dips $87^{\circ} \mathrm{NW}$. and it consists of crushed wallrock containing some disseminated pyrite and cut by sparse thin veinlets of pyrite. It was stoped above and below the level for about 60 feet either direction from the crosscut.

Vein $A$ joins the Casto vein 80 feet northeast of the Casto shaft. Near the shaft the Casto vein consists of altered wallrock containing disseminated pyrite, which is cut by stringers of coarse pyrite. Small stringers of galena, sphalerite, pyrite, and chalcopyrite are frozen to the walls. The vein was stoped for a width of 5 feet near the shaft.

The veins cut in the Belden tunnel are pyrite veins containing sphalerite, galena, and copper minerals, but, judging from the data given by Bastin and Hill (1917), the base-metal minerals are sparse.

\section{BILLINGS-ALCES MINE (E-III-19)}

The Billings-Alces mine, on the south side of Chase Gulch, is opened by a drift tunnel that bears about S. $55^{\circ} \mathrm{W}$.; it is caved about 405 feet from the portal 
EXPLANATION

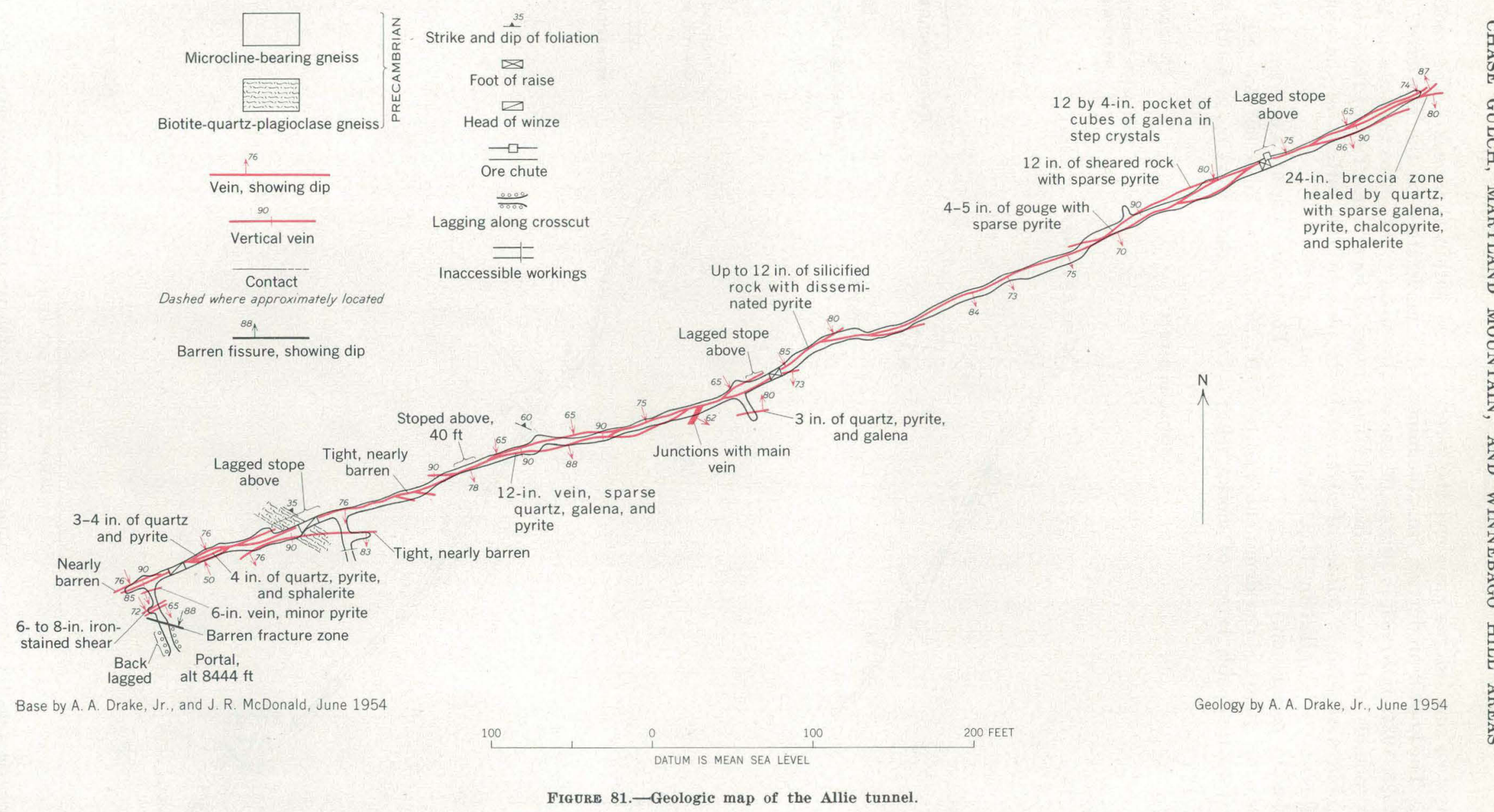

FigURE 81.-Geologic map of the Allie tunnel. 
(fig. 83). Only two small stopes are above the accessible workings. The known production from the mine, for the years 1925, 1934, and 1935, is 19 tons of smelting ore and 500 pounds of concentrates that contained a total of 9.09 ounces of gold, 37 ounces of silver, and 999 pounds of lead. (Compiled by U.S. Bureau of Mines. Published by permission.)

Microcline-bearing gneiss is the dominant wallrock of the mine. Two mappable layers of biotite schist occur within this rock. The rocks strike northeast, dip moderately to the southeast, and are deformed by broad cross warps that plunge gently to the northwest or southeast. Two of these warps are well shown in plan by the outlines of the biotite schist contacts on figure 83 .

The tunnel portal is on vein $A$, which trends about N. $50^{\circ}$ E. and dips $50^{\circ}-55^{\circ}$ SE. The vein ranges from 2 to about 6 inches in width and consists largely

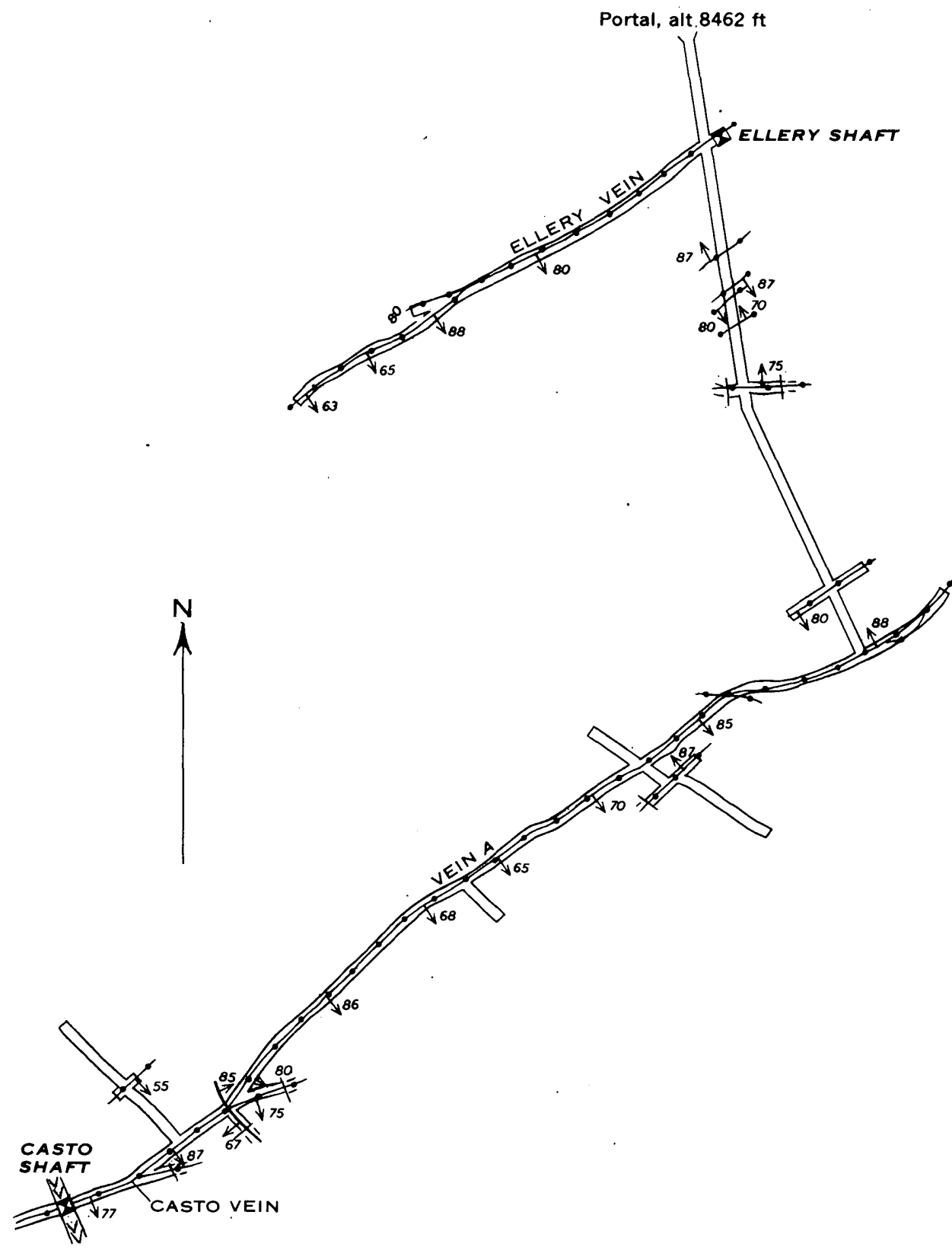

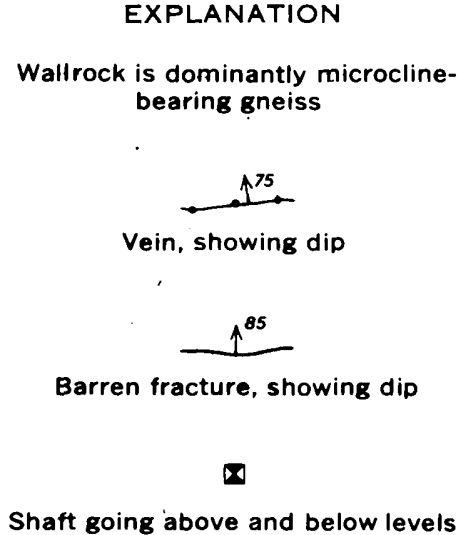

Shaft going above and below levels

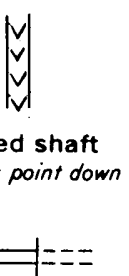

Inaccessible workings

After Bastin and Hill (1917, fig. 28)

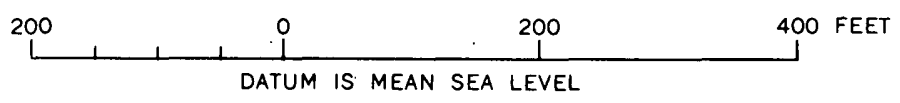

FIG URE 82.-Geologic map of the Belden tunnel. Wallrock is dominantly Precambrian microcline-bearing gnelss. From Bastin and Hill (1917). 


\section{EXPLANATION}

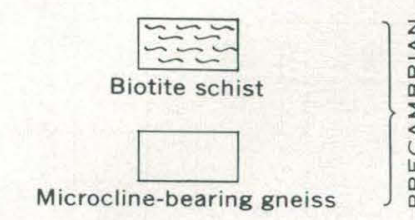

$$
601+60
$$

Vein, showing dip, bearing, and

plunge of slickensides

plunge of slickensides
Dashed where approximately located

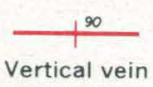

Vertical vein

$$
\frac{{ }_{15}^{15}}{\text { Contact, showing dip }}
$$

Dashed where approximately located

Strike and dip of foliation
15

Bearing and plunge of lineation

$\bigotimes$

Foot of raise

$\square$

Head of winze

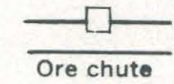

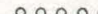

$\overline{00000000}$

Lagging along drift

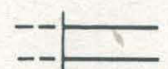

Caved workings

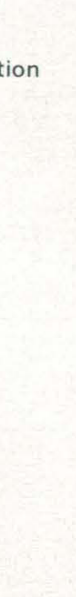

(n)

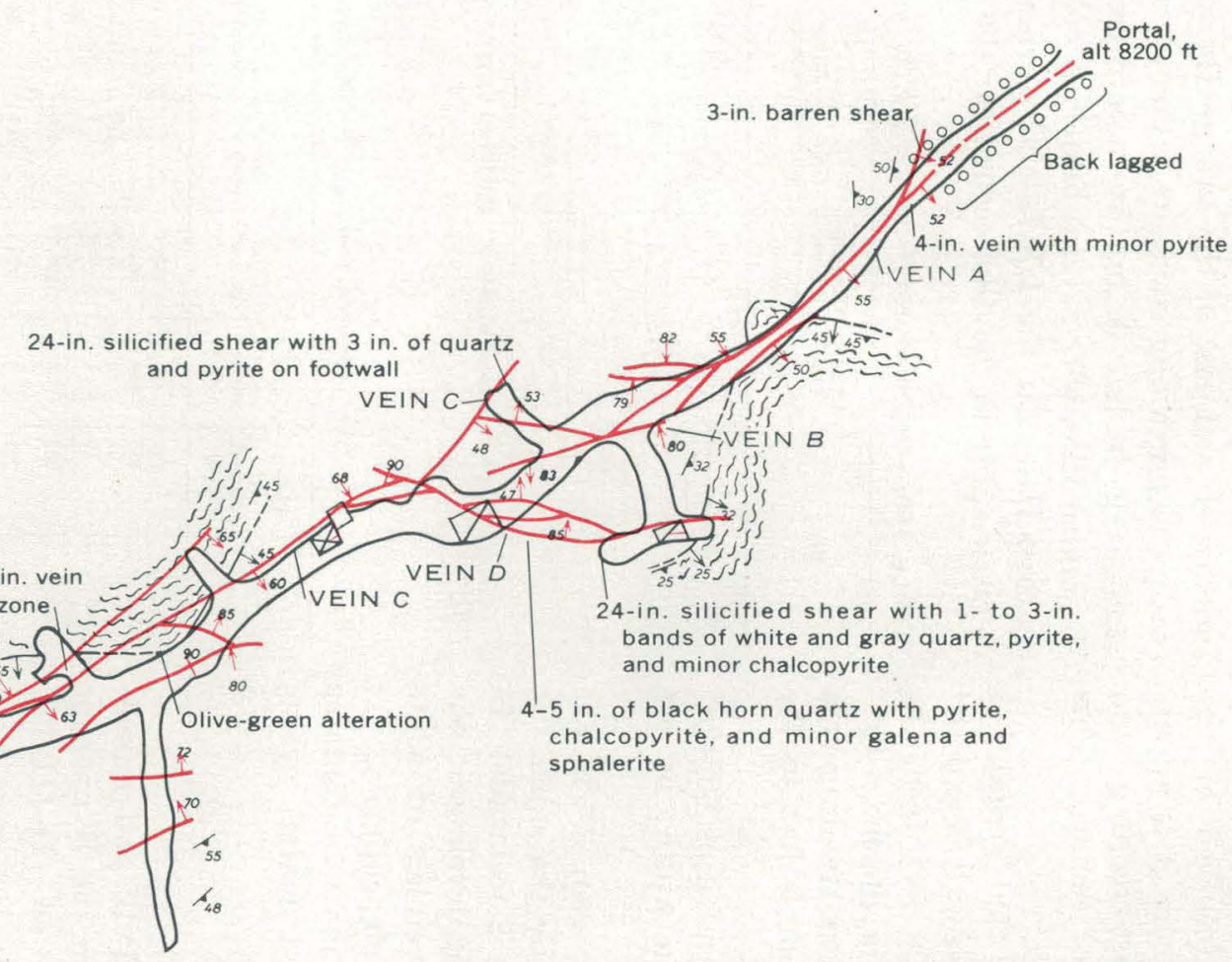

Lagged stope a

pso

Back

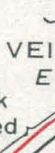

Lagged stope abov

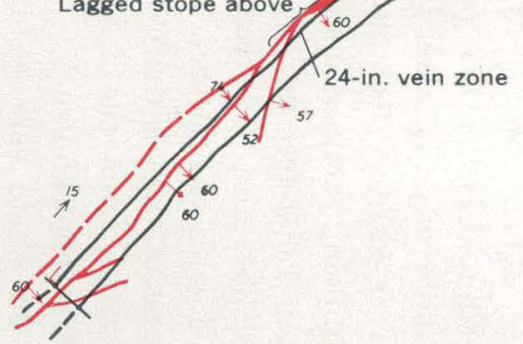

50

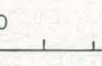

DATUM IS MEAN SEA LEVEL

Base by A. A. Drake, Jr., and J. R. McDonald, June 1954 
of sheared, altered wallrock that contains only sparse disseminated pyrite. The vein is followed by the tunnel to the crosscut at 110 feet, where it is apparently faulted out by an east-northeast-trending vein, vein $B$, that dips steeply either side of vertical. This vein is not followed by any workings.

A 24-inch silicified zone, vein $C$, that contains 3 inches of quartz and pyrite on the footwall is exposed in the breast of a short crosscut 120 feet from the portal. This vein is exposed again in the main tunnel and is faulted by the west-northwest-trending vein $D$. Its east segment is shifted about 3 feet to the north along vein $D$.

Vein $E$ strikes about N. $50^{\circ}$ E. and dips $60^{\circ}-70^{\circ}$ SE. It ranges from 1 to 3 feet in width; no ore minerals were noted in the vein.

The west-northwestward-trending vein $D$ is the strongest filled structure developed by the mine. It dips $85^{\circ} \mathrm{NE}$. to vertical and is about 2 feet wide. In the west breast of the short drift that develops it, the vein contains several 1 - to 3 -inch veinlets of white and gray quartz, pyrite, and minor chalcopyrite. At the point where it enters the main drift, it contains 4 to 5 inches of black, fine-grained quartz, pyrite, chalcopyrite, galena, and sphalerite.

\section{CAsto VeIN}

The Casto vein, on Winnebago Hill, and numerous branch veins, were worked from the Winnebago (D-III-15), Casto (D-III-16), Review (D-III-17), and I.X.L. (D-III-18) mines. For the most part, these mines were active prior to 1885 and little is known concerning the mines. All the mines were inaccesible in 1954. The Casto shaft workings were examined by Bastin and Hill (1917, p. 208), and much of the following description is taken from their report.

The Casto shaft is 420 feet deep and follows the dip of the Casto vein, being inclined an average of $80^{\circ} \mathrm{S}$. Levels aggregating 1,000 feet in length are at depths of $178,214,283,334$, and 402 feet. The 283 level connects eastward with the Belden tunnel (fig. 82); the 334 level connects with a drift from the Review shaft. The workings from the I.X.L., Review, and Winnebago shafts are not known.

The mines on the Casto vein system probably were the largest producers on Winnebago Hill. The known production is given in tables 106, 107, and 108. Most of the metal concentrations are in gold, but some are in silver, copper, and lead.

The country rock is mainly microcline-bearing gneiss. The axis of the Central City anticline lies just west of the Review shaft, and west of the axis the microcline-bearing gneiss generally dips gently northwest, and east of the axis gently southeast. Locally the prevailing structure is complicated by warps and drag folds. A northwestward-trending quartz bostonite dike, with several branches, cuts across Winnebago Hill near the I.X.L. and Review shafts. Numerous splits in the dike occur near the Review shaft.

TABLE 106.-Ore produced from the I.X.L. mine, 1889-1954'

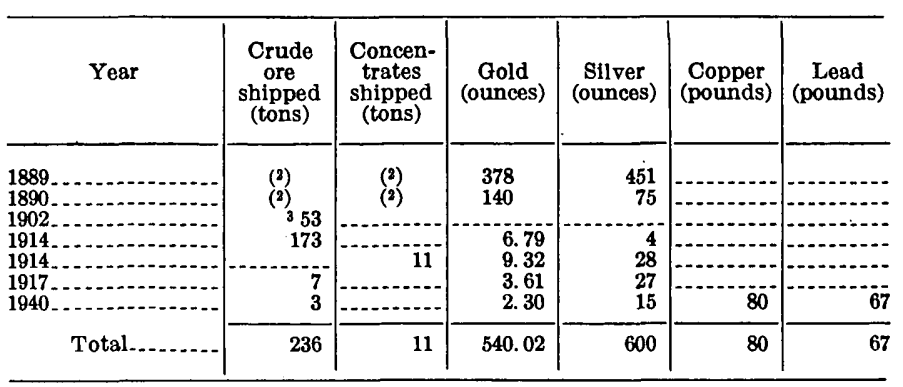

1 Compiled by U.S. Bureau of Mines. Published by permission. 3 Total value $\$ 462.49$.

TABLE 107.-Ore produced from the Winnebago mine, 1905-54 ${ }^{1}$

\begin{tabular}{|c|c|c|c|c|c|c|c|}
\hline Year & $\begin{array}{c}\text { Crude } \\
\text { ore } \\
\text { shipped } \\
\text { (tons) }\end{array}$ & $\begin{array}{l}\text { Concen- } \\
\text { trates } \\
\text { shipped } \\
\text { (tons) }\end{array}$ & $\begin{array}{c}\text { Gold } \\
\text { (ounces) }\end{array}$ & $\begin{array}{c}\text { Silver } \\
\text { (ounces) }\end{array}$ & $\begin{array}{c}\text { Copper } \\
\text { (pounds) }\end{array}$ & $\begin{array}{l}\text { Lead } \\
\text { (pounds) }\end{array}$ & $\begin{array}{c}\text { Zinc } \\
\text { (pounds) }\end{array}$ \\
\hline & & 48. 20 & & & & & \\
\hline 1907 . & $\begin{array}{r}435 \\
94\end{array}$ & ${ }_{3}^{140.00}$ & $\begin{array}{l}264 \\
37.54\end{array}$ & 125 & & & \\
\hline $\begin{array}{l}1908 \\
1911 .\end{array}$ & 19 & & $\begin{array}{l}2.45 \\
5.19\end{array}$ & $\begin{array}{r}5 \\
16\end{array}$ & 82 & & \\
\hline 1912 & 235 & 3 & 122. 17 & 206 & & & \\
\hline 1913 & $\begin{array}{l}223 \\
114\end{array}$ & $\begin{array}{l}5 \\
6\end{array}$ & $\begin{array}{r}201.34 \\
89.95\end{array}$ & 563 & 36 & $\begin{array}{r}1,863 \\
59\end{array}$ & \\
\hline 1915 & 27 & 37 & $\begin{array}{r}201.52 \\
\end{array}$ & 254 & & & \\
\hline $\begin{array}{l}1916 . \\
1917\end{array}$ & ${ }_{37}^{471}$ & $\begin{array}{l}288 \\
17\end{array}$ & $\begin{array}{l}422.74 \\
228.45\end{array}$ & 253 & $1,1,111$ & $\begin{array}{l}628 \\
244\end{array}$ & 521 \\
\hline 1918. & & & 16.97 & 179 & & & \\
\hline 1924 & 2 & $\cdots$ & 3. 48 & 45 & & 1,411 & 62 \\
\hline 190 & 3 & (-) & 8.70 & 33 & 27 & & \\
\hline 1935 & & 1 & $\begin{array}{l}1.50 \\
3.47\end{array}$ & 4 & ....... & & 56 \\
\hline Total. & 1,813 & 289. 20 & $1,724.83$ & 2,446 & 1,311 & 6,054 & 639 \\
\hline
\end{tabular}

1 Compiled by U.S. Bureau of Mines. Published by permission.

TABLE 108.-Ore produced from the Dean and Casto mines, 1907-54 ${ }^{1}$

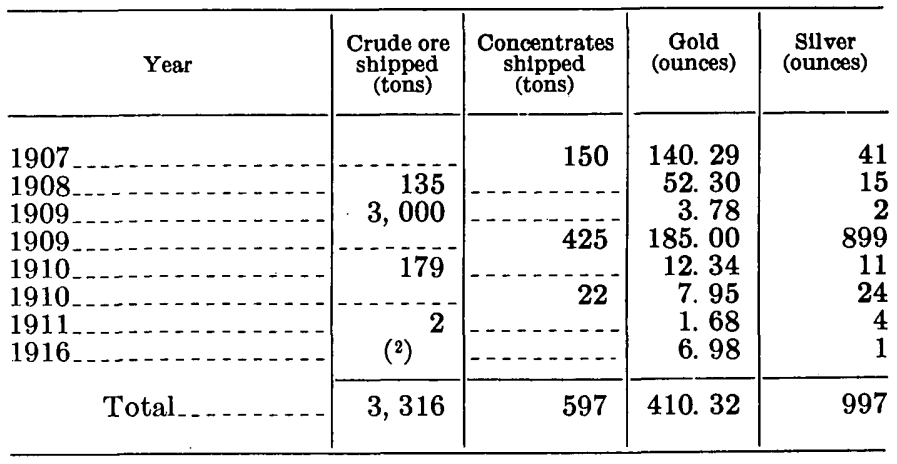

1 Compiled by U.S. Bureau of Mines. Published by permission. 3 Not known. 
At the surface the Casto vein trends east-northeastward, and the Virginia-Robert Emmet vein (pl. 1) may be its northeast extension. The vein has many splits, but too little is known to determine the relations of the branching veins to the Casto vein. In the Casto mine the vein strikes about $\mathrm{N} .70^{\circ} \mathrm{E}$., and dips on the average about $80^{\circ} \mathrm{SE}$. (Bastin and Hill, 1917 , p. 208). The vein ranges in width from 2 inches to 4 feet and averages about 2 feet. Bastin and Hill $(1917$, p. 208) describe the vein as consisting of crushed country rock, somewhat silicified, which contains coarse disseminated pyrite and local specks of galena and small branching stringers of pyrite. Postmineralization gouge seams occur at places. Bastin and Hill (1917, p. 208) state that

the main ore shoot of the (Casto) mine seems to follow in a general way the junction of a northern vein, which is traceable into the Review workings, and which has a branch vein coming in at a small angle from the south. The exact junction is not readily determined, but seems to lie about 60 feet west of the shaft on the second level, 45 feet west on the fourth level, and in the shaft between the fourth and fifth levels. This ore shoot has been stoped for 100 feet west of the shaft more or less continuously to the fifth level, and has also been stoped east of the shaft between the third and fifth levels. At the junction on the fourth level, a width of $\mathbf{1 0}$ feet of ore has been stoped.

The vein is a pyrite vein; judging from the description of Bastin and Hill (1917, p. 208) and from the production data the vein contains some sphalerite, galena, and chalcopyrite, but these minerals are nowhere abundant.

\section{Centennial TUNNEL (B-II-8)}

The Centennial tunnel, on the south side of Chase Gulch, about 1,220 feet N. $68^{\circ} \mathrm{W}$. from the portal of the Bonanza tunnel, is opened by a drift tunnel that is reportedly 864 feet long. ${ }^{.6}$ In 1954 the portal was caved and access was gained through the Centre tunnel (fig. 84). The Centennial tunnel bears about $\mathrm{S}$. $55^{\circ} \mathrm{W}$. and is caved at 710 feet. An inclined shaft cuts the tunnel near the southwest end of the accessible workings. The shaft-connects to 3 levels which respectively are 93 and 143 feet above the tunnel ${ }^{57}$ and 57 feet below the tunnel. ${ }^{58}$ About 320 feet from the portal of the Centennial tunnel, a cross drift connects the mine to the Centre tunnel. The position of the stopes is shown on fig. 84 . The mine reportedly

${ }^{50}$ Schwarz, T. E., 1894, the First Centennial mine, 7 p., report on fle In the Denver Public Library, Denver, Colo.

${ }^{67}$ Lange, J. N., 1894, A description of the First Centennial mine, 7 p., report on fle in the Denver Public Library, Denver, Colo.

ss Schwarz, T. E., 1894, The First Centennial mine, 7 p., report in the Denver Public Library, Denver, Colo. yielded $\$ 100,000$ before 1899 (Callbreath, 1899, p. 241).

Microcline-bearing gneiss, containing minor layers and pods of biotite-quartz-plagioclase gneiss and amphibolite, is the dominant wallrock of the mine. The prevailing strike of the rocks in the area is eastnortheast, and the average dip is moderately to the southeast. The tunnel apparently was driven near the axis of a tight anticline; the axis bears about $\mathrm{N}$. $60^{\circ} \mathrm{E}$.

The first vein cut by the Centennial tunnel strikes nearly east and dips $45^{\circ}-55^{\circ} \mathrm{S}$. (fig. 84). It is 12 to 18 inches thick and contains sparse amounts of disseminated pyrite. About 10 feet southwest of this vein another vein which strikes about $\mathrm{N} .76^{\circ} \mathrm{E}$. and dips steeply either side of vertical enters the tunnel from the east. The vein is about 6 inches wide and contains a 1-inch streak of pyrite, galena, sphalerite, and quartz on its hanging wall. It is followed by the tunnel to a point about 150 feet from the portal where it intersects the Centennial vein (fig. 84). The veins cross with very little offset, but it appears that the north segments of the Centennial vein have been displaced 1 or 2 inches toward the west.

The Centennial vein strikes northeast, dips $60^{\circ}-85^{\circ}$ $\mathrm{SE}$, and ranges from a tight 5 -inch filled fracture to a 24 inch-wide vein. The Centre vein enters the tunnel near the shaft; it probably joins the Centennial vein a short distance west of the cave at the southwest part of the workings. At one place, just east of the shaft, the Centre vein is about 3 feet wide and shows 2 feet of gouge and altered rock on the hanging wall, below which is a foot of solid quartz and pyrite.

West of the cave the Centennial vein is described by Schwarz ${ }^{59}$ as follows:

* * * the back of the stope for the last 100 feet of the adit shows 31 inches of iron and mill dirt; the smelting streak is particularly strong in the sill for 80-100 feet west of the shaft, showing 6-10 inches of solid iron. The breast of the adit shows 3 feet of mill dirt, and on the sublevel an average of 18 inches of ore showing well in smelting iron occurs for 75 feet $* *$

Quartz and pyrite were the only minerals noted along the vein in the mine, and presumably they are the principal constituents. The stopes, which are along the wider parts of the vein, occur where the vein strikes east-northeast rather than northeast (fig. 84).

The Centennial vein is intersected and offset by a northwestward-trending vein that is developed by the cross drift; its east segment has been shifted about 10 feet to the northwest. For a description of the

\footnotetext{
"9 Schwarz, T. E, 1894, op. cit.
} 


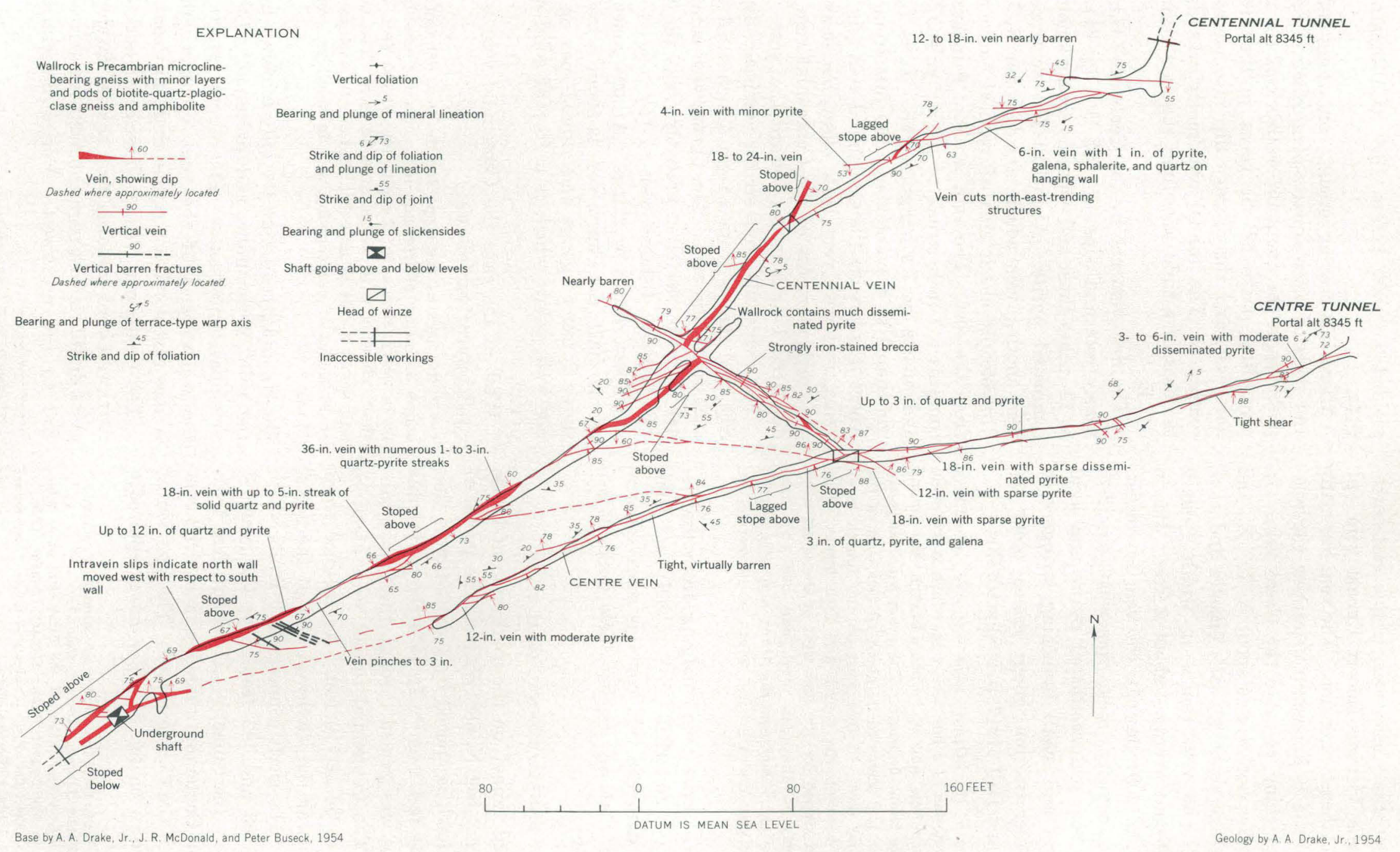


northwestward-trending vein, the reader is referred to the description of the Centre tunnel.

The average metal content of the ore from the Centennial tunnel is not known. Lange, ${ }^{60}$ however, reports that 42 cords (about 336 tons) of development ore obtained from sinking the shaft from the $2 \mathrm{~d}$ level to the tunnel level contained 268 ounces of gold; and 4.34 ounces of gold was recovered from 744 tons of ore extracted in sinking the shaft from the tunnel level to the sublevel.

\section{CENTRE TUNNEL (E-II-2)}

The Centre tunnel is on the south side of Chase Gulch about 1,100 feet N. $73^{\circ}$ W. from the Bonanza tunnel. The mine is opened by a 599 -foot drift tunnel that bears about S. $70^{\circ} \mathrm{W}$.; it connects to the Centennial tunnel by a branch drift (fig. 84). A winze was sunk about 270 feet from the portal, and 2 small overhand stopes were driven near the winze. The mine is reported to have yielded $\$ 50,000$ prior to 1899 (Callbreath, 1899, p. 241) ; 5 tons of ore shipped in 1937 contained 1.6 ounces of gold and 2 ounces of silver. (Published by permission.)

Microcline-bearing gneiss, containing minor layers and pods of biotite-quartz-plagioclase gneiss and amphibolite, is the dominant wallrock of the mine. It strikes generally east-northeastward and dips moderately to steeply to the southeast. The tunnel apparently follows a synclinal axis that plunges moderately $\mathrm{N} .60^{\circ}$ E., but this inferred relation cannot be proved.

The Centre vein strikes about N. $70^{\circ} \mathrm{E}$. and dips $72^{\circ} \mathrm{NW}$. to vertical. It ranges from 6 to about 18 inches in thickness and contains sparse sulfides. Typically the vein consists of gouge and sheared and sericitized wallrock that contains sparse quantities of disseminated pyrite. In a few places this barren fissure zone is traversed by veinlets of quartz and pyrite as much as 3 inches thick. Near the winze tiny veinlets of quartz and galena fill fractures that cut the earlier vein material.

At the winze the Centre vein intersects a northwestward-trending vein that dips $83^{\circ} \mathrm{NE}$. to vertical. This vein is developed by a short drift that connects with the Centennial tunnel (fig. 84). The northwestwardtrending vein is generally a poorly defined shear zone consisting of many parallel to subparallel branching fractures that contain iron-stained gouge. South of the Centre vein, however, it contains 12 inches of quartz and sparse pyrite.

${ }^{00}$ Lnnge, T. N., 1894, A description of the First Centennial mine, 7 p., report on file on the Denver Publtc Library, Denver, Colo.
West of the vein intersection, several major branches from the Centre vein enter the hanging wall, and a few minor splits enter the footwall. The hanging wall branches are inferred to join the Centennial vein in the Centennial tunnel (fig. 84).

The stopes on the Centre vein occur at and near its intersection with the northwestward-trending vein, and the writers infer that fractures near the intersection provided favorable openings for the deposition of ore minerals.

\section{CLIFF TUNNEL (D-II-9)}

The Cliff tunnel, in Chase Gulch, about 770 feet S. $20^{\circ}$ E. from the Tucker mine, was last worked in 1925. The known production from the mine is small; in 1924 and 1925, 8 tons of smelting ore that contained 1.46 ounces of gold, 81 ounces of silver, 3,990 pounds of lead, and 1,975 pounds of zinc were shipped. (Compiled by U.S. Bureau of Mines. Published by permission.) The mine is opened by a 370-foot drift tunnel that trends northeast. The location of the stopes is shown on figure 85 .

The dominant wallrock of the mine is microclinebearing gneiss. Some of this rock contains numerous layers of biotite-quartz-plagioclase gneiss, and the larger bodies are shown on figure 85. As the mine is on the northwest flank of the Central City anticline, about 1,050 feet from the axis, the rocks generally strike northeast and dip moderately to the northwest.

The Cliff vein strikes generally northeast, but it has a flat S-shape, with the end of the $S$ striking east-northeast and the center part striking northeast. It dips steeply either side of vertical, and averages about $80^{\circ} \mathrm{SE}$. The southwestward extension of the vein is probably developed by the Cliff Extension mine, on the west side of Chase Gulch. Several branches split from the vein; the attitude of these branches suggests that movement along the structure displaced the northwest wall southwest. The vein is nearly barren where it strikes. east-northeast, and generally contains only a little disseminated pyrite. The vein is wider and contains sulfides where it strikes northeast, and near the winze it is 18 inches wide and contains several patches and discontinuous streaks of sphalerite and galena. The combined sulfides constitute about 5 percent of the vein material in the richer parts. The observed ore and the stopes are located on the northeastward-trending parts of the vein, and confirm the inference that movement along the Cliff vein displaced the northwest wall southwest. The average grade of 8 tons of ore shipped in 1924 and 1925 was 0.18 ounce of gold per ton, 10.5 ounces of silver per ton, 25 percent lead, and 12 percent zinc. 

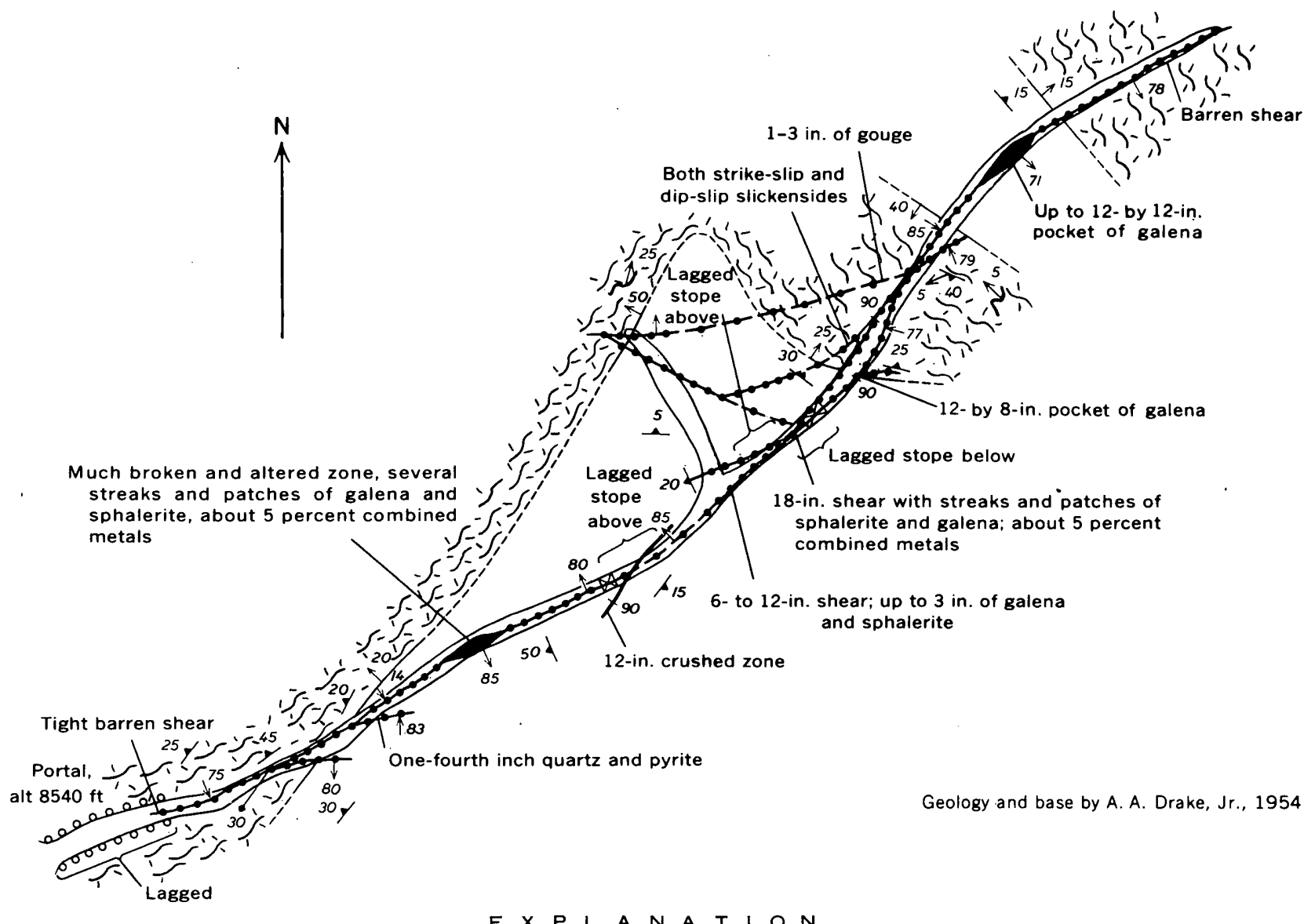

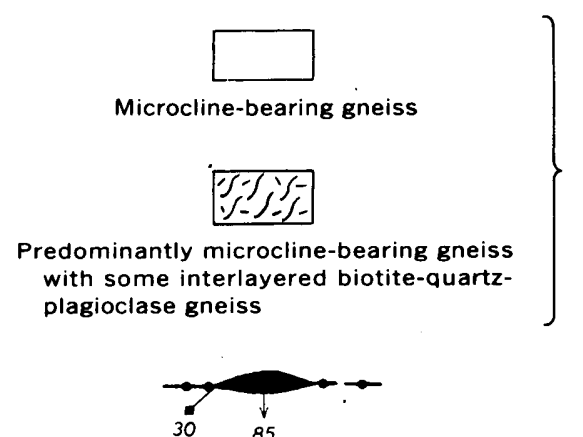

Vein, showing dip, bearing, and plunge of slickensides

Dashed where approximately located

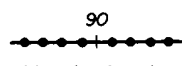

Vertical vein

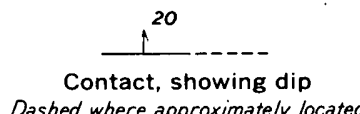

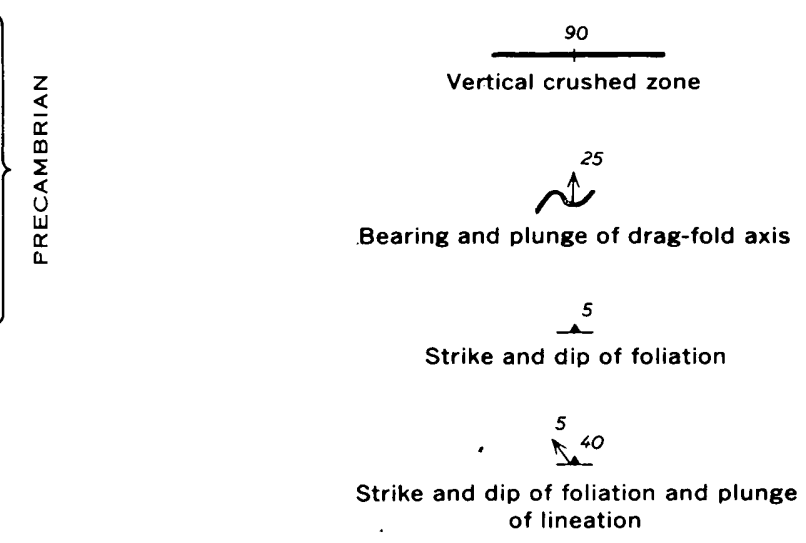

$\otimes$

Foot of raise

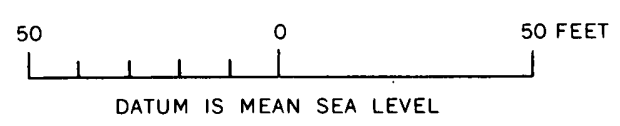

Fraure 85.-Geologic map of the Cliff tunnel. 
CLIFF EXTENSION MINE (D-II-10)

The Cliff Extension mine, on the west side of Chase Gulch, is opened by a 400-foot drift tunnel that trends about S. $60^{\circ}$ W. (fig. 86). No record of any production from the mine could be found, but some ore must have been shipped, as fairly large stopes are in the southwestern part of the mine.

Microcline-bearing gneiss is the dominant wallrock, and locally it contains layers of biotite-quartz-plagioclase gneiss (fig. 86). The rocks strike east-northeastward, and dip moderately to the northwest. Locally they are deformed by warps and small overturned drag folds.

Near the portal the tunnel follows an east-northeastward-trending vein, probably the Cliff vein, that dips steeply to the southeast. About 100 feet from the portal this vein is cut and offset by a northeastward-trending vein, the east segment being shifted about 4 inches northeast relative to the west segment. The Cliff vein consists largely of sheared wallrock, but a three-fourths inch seam of comb quartz was noted at one place.

About 200 feet from the portal the northeastwardtrending vein is joined from the east by a vein that trends about N. $65^{\circ} \mathrm{E}$. and dips $61^{\circ}-86^{\circ} \mathrm{NW}$. Where it first enters the drift, the vein consists wholly of iron-stained gouge, but southwest of its junction with the northeastward-trending vein it widens to 2 feet and contains many stringers of pyrite, galena, and sphalerite. The vein has been stoped locally southwest of the vein junction.

\section{FREEDOM MINE (B-III-21)}

Location.-On Winnebago Hill about 1,390 feet $\mathrm{N}$. $45^{\circ} \mathrm{W}$. of the Bates-Hunter mine.

Production.-From 1902 to 1911, 6,072 tons of smelting ore and 63 tons of concentrates were shipped. This ore contained 1,066.61 ounces of gold, 1,536 ounces of silver, and 348 pounds of copper. (Compiled by U.S. Bureau of Mines. Published by permission.)

Development.-Shaft more than 800 feet deep and several drift tunnels, one of which is 940 feet long.

Veins.-Freedom (northeastward extension of the Rialto vein) : Strike, N. $45^{\circ}$ E.; dip, $80^{\circ}$ SE.

Wallrock.-Dominant microcline-bearing gneiss.

Ore and sulfide minerals.-Pyrite, gold, silver, galena, sphalerite, chalcopyrite.

Gangue minerals.-Quartz.

Tenor.-156,728 pounds shipped between 1899 and 1904 averaged gold, 2.19 ounces per ton and silver, 4.47 ounces per ton.
GOLD CUP AND KEYSTONE GROUTP

The Gold Cup (D-II-16), Keystone (C-II-5), Buckeye, and Bullion mines, a quarter of a mile west of the Hayseed tunnel in Upper Chase Gulch, have been substantial producers of lead and other metals. In 1954, the mines were all inaccessible and nothing is known of the workings and little is known concerning the veins. The combined production of the Bullion and Gold Cup mines, $1908-47$, is given in table 109. The Buckeye mine in the years 1915, 1916, and 1933 shipped 57 tons of crude ore and 103 tons of concentrates that contained 232.51 ounces of gold, 1,807 ounces of silver, 493 pounds of copper, 102,307 pounds of lead, and 4,432 pounds of zinc. The Keystone mine from 1907 to 1911, shipped 141 tons of crude ore and 3 tons of concentrates that contained 76.22 ounces of gold, and 387 ounces of silver. A shipment of 1 ton from the East Keystone mine in 1914 yielded 0.97 ounce of gold, 27 ounces of silver, and 189 pounds of lead.

TABLE 109.-Ore produced from the Bullion and Gold Cup mines,

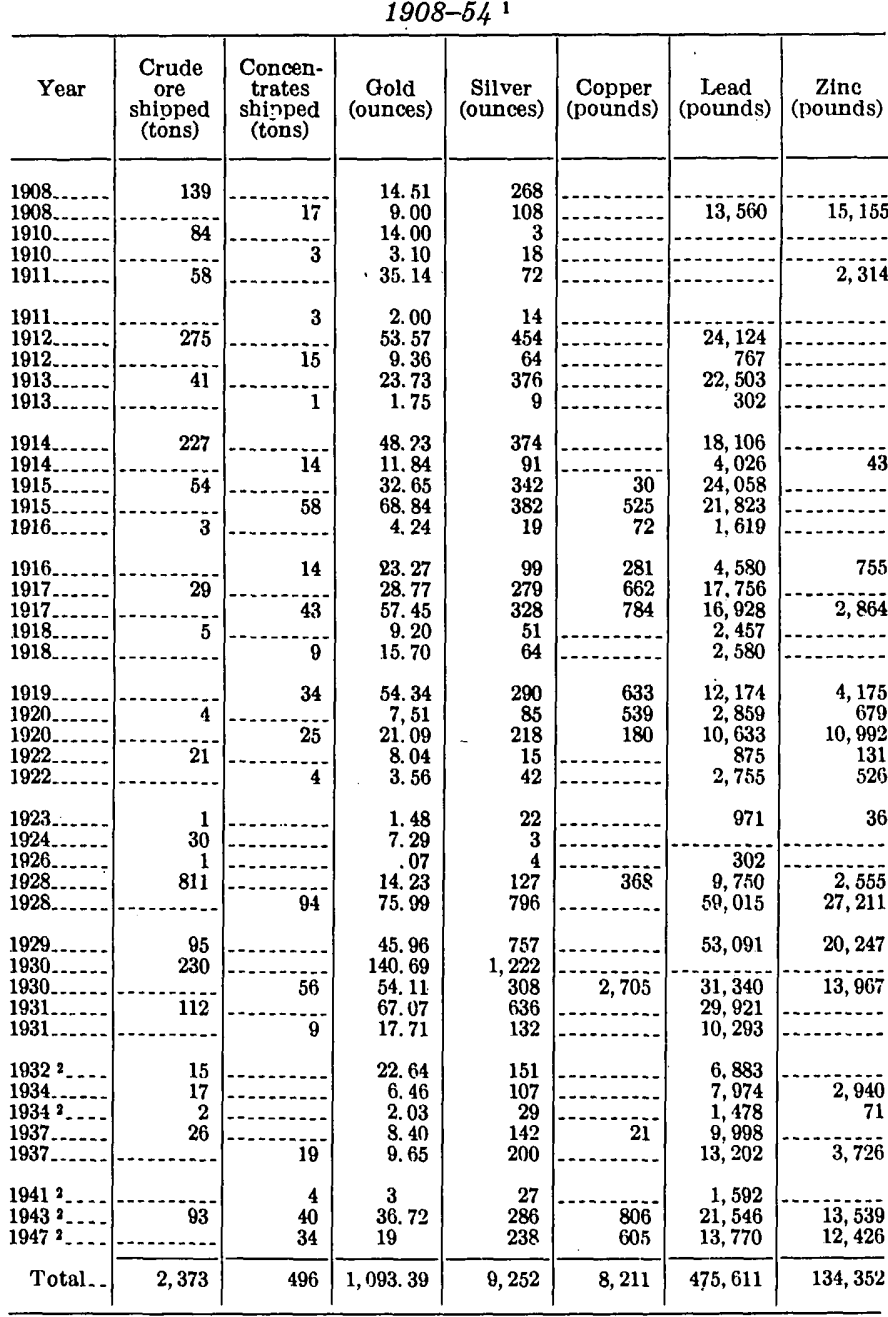

1 Compiled by U.S. Bureau of Mines. Published by permission. 


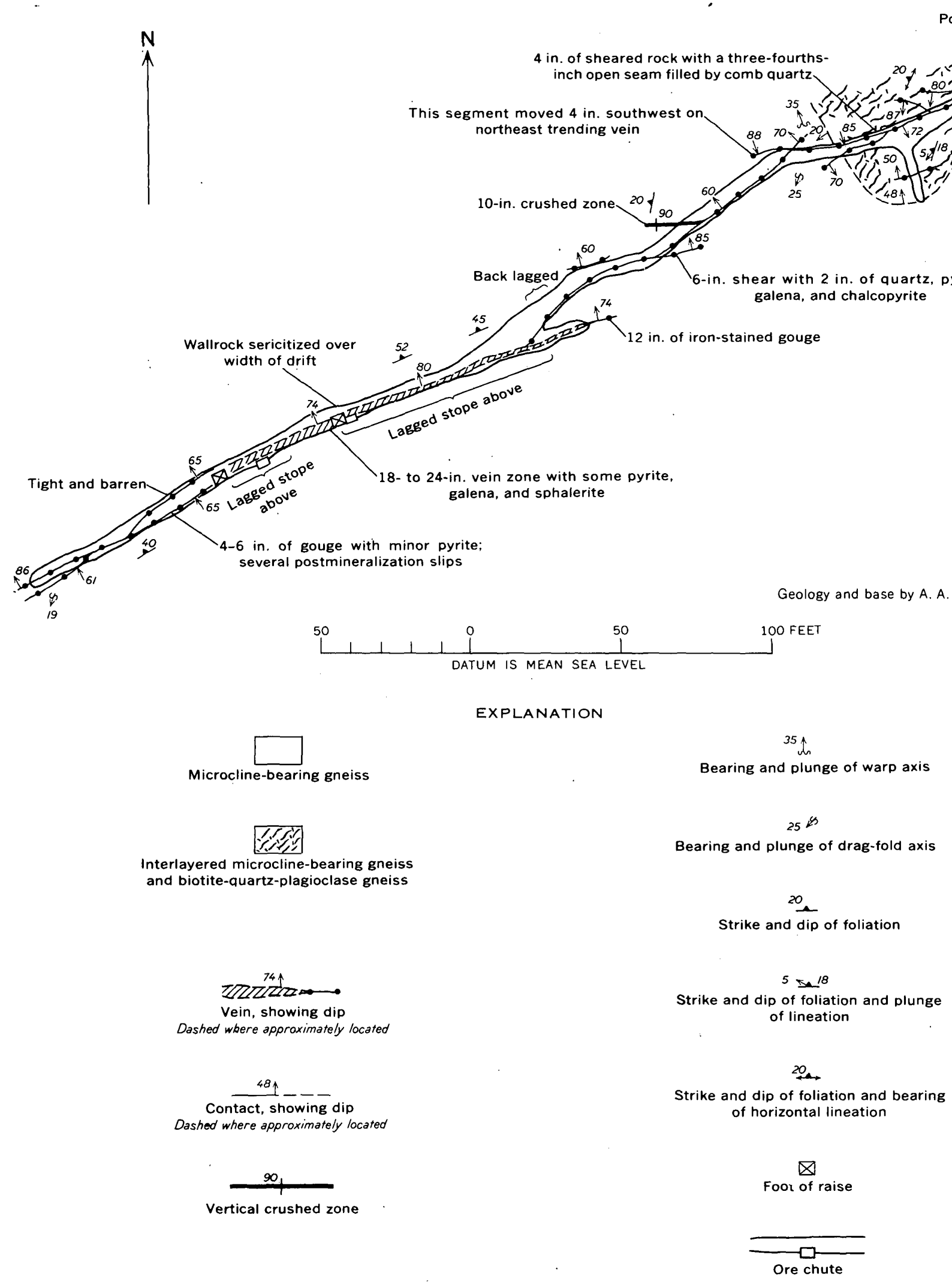

Figure 86.-Geologic map of the Cliff Extension mine. 
The mines are at the south end of an oval-shaped plug of intrusion breccia, which is surrounded by Precambrian microcline-bearing gneiss and minor biotite gneisses and pegmatite (pl. 1). The intrusion breccia is composed of fragments of Precambrian country rock-biotite gneiss, pegmatite, and microcline-bearing gneiss-in a matrix of Tertiary monzonite porphyry. Although most of the country rock fragments are 1 or 2 inches in diameter, some blocks, particularly near the east edge of the breccia plug, are 2 to 3 feet in diameter.

The veins strike east or east-northeastward and, where observed, dip steëply. Nowhere are the veins sufficiently exposed in pits to determine their character and width. The veins consist of galena-sphalerite, but gold is more abundant than in most veins of this type.

Representative shipments of crude ore and concentrates sent to the Idaho Springs Sampling Works from 1919 to 1929 are given in table 110.

TABLE 110.-Sampling-works assays of selected shipments of crude ore and concentrates from the Gold Cup mine, 1919-291

\begin{tabular}{|c|c|c|c|c|c|c|}
\hline Year & T'ype of ore & Tons & Gold 2 & Silver 2 & $\underset{\text { (percent) }}{\text { Lead }}$ & $\underset{\text { (percent) }}{\text { Zinc }}$ \\
\hline $\begin{array}{l}1019 \ldots \\
1023 \\
1028 \\
1029\end{array}$ & 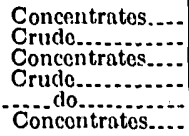 & $\begin{array}{r}12.13 \\
1.30 \\
6.26 \\
3.90 \\
10.11 \\
2.30\end{array}$ & $\begin{array}{r}1.88 \\
1.14 \\
1.27 \\
.56 \\
.77 \\
1.41\end{array}$ & $\begin{array}{r}11.35 \\
17.25 \\
12.00 \\
11.51 \\
9.45 \\
11.00\end{array}$ & $\begin{array}{l}20.60 \\
35.90 \\
51.50 \\
43.85 \\
26.80 \\
36.80\end{array}$ & $\begin{array}{r}9.30 \\
1.50 \\
7.65 \\
11.44 \\
17.90 \\
6.15\end{array}$ \\
\hline
\end{tabular}

1 Data on ore tenor furnished by the Idaho Springs Sampling Works. Published by permission.

\section{GULNARE MINE (D-II-6)}

The Gulnare mine, in Chase Gulch, probably was opened prior to 1880 ; it is not known when it was last worked. The property is opened by a drift tunnel, about 700 feet long, which trends slightly south of west (fig. 87). A small shaft bottoms in the tunnel about 110 feet from the portal. The property yielded ore that sold for $\$ 7,000$ prior to 1899 (Callbreath, 1899, p. 257) ; as only one small stope is in the mine (fig. 87) this probably is the total yield from the property.

The wallrock of the mine is microcline-bearing gneiss. The foliation of the rock trends northeastward and dips moderately. to the northwest. The portal of the mine is about 650 feet northwest of the axis of the Central City anticline, and the rocks are locally highly contorted by numerous cross warps and drag folds. The cross warps plunge gently to the north-northwest, and the drag folds plunge gently to the northeast. The drag folds are overturned to the southeast, toward the axis of the Central City anticline.

\footnotetext{
$6548270-63-15$
}

The Gulnare vein strikes N. $75^{\circ} \mathrm{E}$. for the first 360 feet of the tunnel, and then swings to an easterly strike; it dips $46^{\circ}-75^{\circ} \mathrm{S}$. It ranges from 6 inches to a maximum of 24 inches in width, and is characterized by abundant subsidiary veins that branch into the footwall (fig. 87). Where observed, the vein contains only minor quantities of quartz and pyrite. Near the stope it is about 2 feet wide and consists largely of gouge with scattered pyrite. One specimen found on the dump contains sphalerite, galena, a moderate amount of chalcopyrite, sparse chalcocite, and abundant covellite; the covellite replaces chalcopyrite, galena, and to a lesser extent, sphalerite. The chalcocite seems to replace galena.

\section{HAYSEED TUNNEL (D-II-12)}

The Hayseed tunnel, in Chase Gulch about 160 feet S. $13^{\circ} \mathrm{W}$. from the Tucker mine, was opened in 1897 (Bastin and Hill, 1917, p. 212) and was operated intermittently until 1937. The known production from the property is given in table 111; this ore if produced today would have a value of about $\$ 40,000$. The property reportedly yielded $\$ 7,000$ prior to 1912 . The Hayseed tunnel is a drift; about 560 feet long, that bears N. $36^{\circ} \mathrm{E}$. for 100 feet, then bears about N. $75^{\circ}$ E. (fig. 88). Stopes have been driven both above and below the tunnel level.

The wallrock of the mine is microcline-bearing gneiss, which strikes generally east-northeastward and dips moderately to the northwest. Locally, the rock is deformed by broad cross warps that plunge gently to the north-northwest.

TABLE 111.-Ore produced from the Hayseed tunnel, 1902-54 ${ }^{1}$

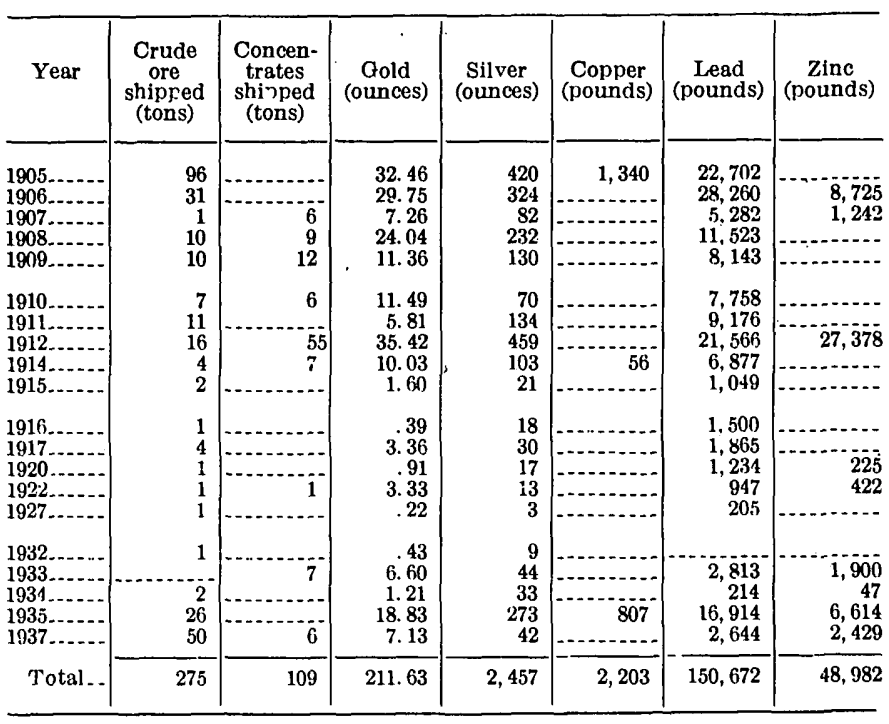

1 Compiled by U.S. Bureau of Mines. Published by permission. 

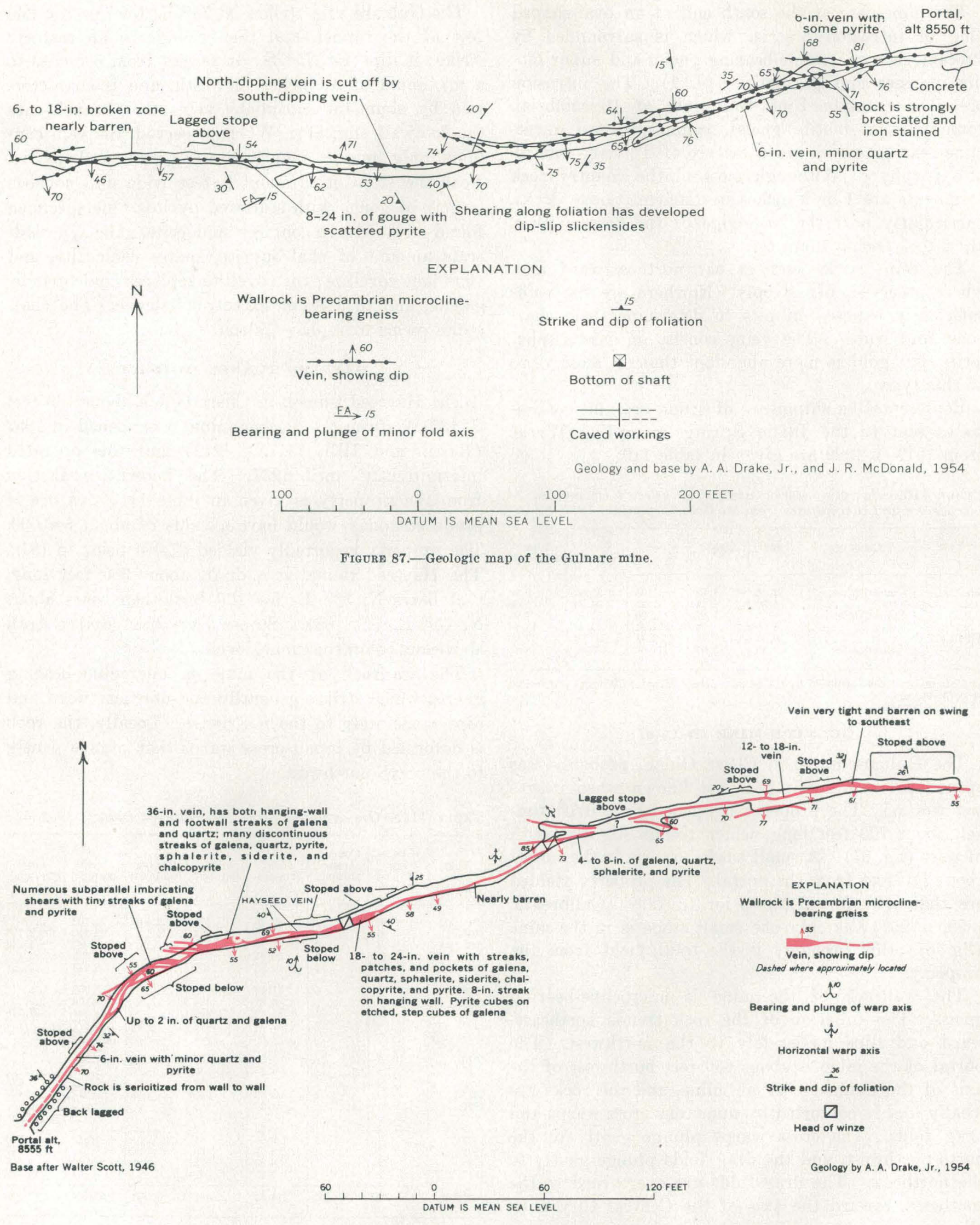

Figure 88.-Geologic map of the Hayseed tunnel. 
Near the portal the tunnel exposes a vein that strikes N. $35^{\circ}$ E. and dips $65^{\circ}-74^{\circ}$ SE. About 110 feet from the portal, this vein joins the Hayseed vein which has an average strike of $\mathrm{N} .75^{\circ} \mathrm{E}$. and dips $49^{\circ}-77^{\circ}$ (average about $55^{\circ}$ ) SE. (fig. 88). About 360 feet from the portal the Hayseed vein is joined by two eastward-trending veins that dip steeply south.

The vein near the portal is about 6 inches wide and is poorly filled, at one point showing only 2 inches of quartz and galena. West of the intersection, the Hayseed vein is made up of several subparallel veinlets of galena and pyrite. At the intersection it is 3 feet wide and contains 4- to 5-inch streaks of sulfides on both walls. East of the intersection the vein ranges from $1 \frac{1}{2}$ to 3 feet wide. At a distance of 110 feet from the intersection the Hayseed vein changes strike to the northeast and pinches to a tight, nearly barren fracture. Where it is joined by the eastward-trending veins 360 feet from the portal, the Hayseed vein again widens to 3 feet, and contains a streak of solid sulfides as much as 8 inches thick. From this point to the breast the vein averages about 1 to $11 / 2$ feet in width.

Galena is the most abundant vein mineral, and sphalerite is next in abundance; other minerals include chalcopyrite, pyrite, quartz, siderite, and ankerite(?). The vein is vuggy, and some vugs are several inches across in the plane of the vein. A few of the vugs contain beautiful step crystals of galena and others contains comb crystals of clear quartz associated with galena. Siderite and quartz frequently coat the metallic minerals in the vugs. Many of the galena crystals have been etched, and a few of the etched surfaces have been coated by siderite and quartz. Most of the pyrite apparently formed after the galena, much of it occurring in cubes or pyritohedrons on galena.

The ore seems to occur at vein intersections. Also, the vein is wider where it strikes more nearly east, suggesting that recurrent strike-slip movements may have taken place and aided in the formation of open spaces for ore deposition.

Most of the ore shipped from the mine was handcobbed, and was said to average about 45 to 55 percent lead, 12 ounces of silver to the ton, and about 0.75 ounce in gold to the ton (Bastin and Hill, 1917, p. 212).

\section{HUDDLESTON MINE (D-III-24)}

Location.-On Winnebago Hill, 500 feet east of the Winnebago shaft. Another shaft, probably on the same claim is 800 feet S. $55^{\circ} \mathrm{W}$. of the main shaft.

Production.-1906-38, 517 tons of smelting ore and 24 tons of concentrates that contained 196.39 ounces of gold and 202 ounces of silver. (Compiled by U.S. Bureau of Mines. Published by permission.)

Mine workings.-Two principal shafts; workings from shafts not known.

Veins.-The vein worked in the mine seems to be the northeast extension of the James Henry vein. It strikes about N. $50^{\circ} \mathrm{E}$; t the dip is not known.

Wallrock.-Dominantly microcline-bearing gneiss.

\section{MONT D'ORO TUNNEL (D-II-11)}

The Mont d'Oro tunnel is on the west side of Chase Gulch about 450 feet S. $20^{\circ} \mathrm{W}$. from the Tucker mine. In 1954, the mine was inaccessible, but Bastin and Hill (1917, p. 210) examined it and the following is taken from their description.

The mine is opened by a 590 -foot drift tunnel that bears west. A 40 -foot crosscut is turned from the drift at 280 feet, and a short branch drift is turned at 400 feet. Little ore has been produced from the mine, but it is reported that 2 tons that contained 5.03 ounces of gold were shipped in 1906. (Compiled by U.S. Bureau of Mines. Published by permission.)

The tunnel enters on the Delight vein. The vein is vertical, generally 2 inches to $21 / 2$ feet wide, and nearly barren. Locally, however, it contains as much as 6 inches of gray quartz with scattered pyrite. The vein is bordered by altered microcline-bearing gneiss containing disseminated pyrite which is cut by small stringers of galena and sphalerite.

The New Century vein joins the Delight vein about 500 feet from the portal. The vein strikes about N. $45^{\circ}$ E., dips $55^{\circ} \mathrm{NW}$, and consists of several small stringers and bunches of galena and sphalerite that cut altered wallrock containing disseminated pyrite.

\section{ROBERT EMMET MINE (E-II- $-\boldsymbol{\sigma}$ )}

Location.-On Maryland Mountain about 1,110 feet S. $74^{\circ}$ E. from the Sans Souci mine.

Production.- $\$ 263,000$ prior to 1912 (Bastin and Hill, 1917, p. 212); 1,752 tons of smelting ore and 57 tons of concentrates shipped between 1902 and 1922 contained 771.44 ounces of gold, 12,994 ounces of silver, 1,011 pounds of copper, and 270 pounds of lead. (Compiled by U.S. Bureau of Mines. Published by permission.)

Development.-Two shaits, one 525 feet deep with levels at $100,200,335$, and 425 feet; other shaft 270 feet deep.

Veins.-Robert Emmet: Strike, N. $45^{\circ}$ E.; dip, $85^{\circ} \mathrm{SE}$.

Wallrock.-Microcline-bearing gneiss.

Ore and sulfide minerals.-Galena, sphalerite, pyrite, gold, silver, chalcopyrite, and tennantite.

Gangue minerals.-Quartz. 
Tenor.-Ore shipped between 1889 and 1904 averaged 1.75 ounces of gold per ton and 18 ounces of silver per ton.

\section{SANS SOUCI MINE (E-II-6)}

The Sans Souci mine, on Maryland Mountain, is opened by a short crosscut and a 250-foot drift tunnel that bears about N. $60^{\circ}$ E. (fig. 89). An overhand stope, open to the surface, is about 50 feet from the portal, and underhand stopes are 50 and 90 feet respectively from the portal. A raise from the Allie tunnel reportedly connects to the stope 90 feet from the portal (W. C. Russell, Jr., oral communication). The total production from the property is not known, but 30 tons of ore shipped in 1921-22 contained 28.50 ounces of gold, 231 ounces of silver, 528 pounds of copper, and 9,553 pounds of lead. (Compiled by U.S. Bureau of Mines. Published by permission.) The zinc in the ore probably was discarded.

The wallrock of the mine is microcline-bearing gneiss. The mine is on the southeast flank of the Central City anticline, about 250 feet from the axis.
The rocks strike generally west-northwest, and dip moderately to the southwest.

The probable extension of the Allie vein is cut by the tunnel at the portal and is developed by a short spur drift (fig. 89). It strikes about N. $70^{\circ}$ E., dips steeply either side of vertical, and is nearly barren.

The principal vein developed by the mine is cut near the face of the crosscut, and probably is the northeast extension of the Castle Rock vein. The vein trends about N. $60^{\circ}$ E., but in detail it consists of segments that strike either nearly east or northeast (fig. 89). It dips steeply either side of vertical, and is characterized by many horsetail and looping branches.

The vein cut at the portal (Allie? vein) is 12 to 18 inches wide and contains a 6 - to 8 -inch streak of galena with subordinate quantities of sphalerite, pyrite, chalcopyrite, tennantite, and siderite. Galena is disseminated and forms one-eighth-inch streaks in the altered gneiss wallrock that borders the vein. The main vein is nearly barren where it strikes northeast,

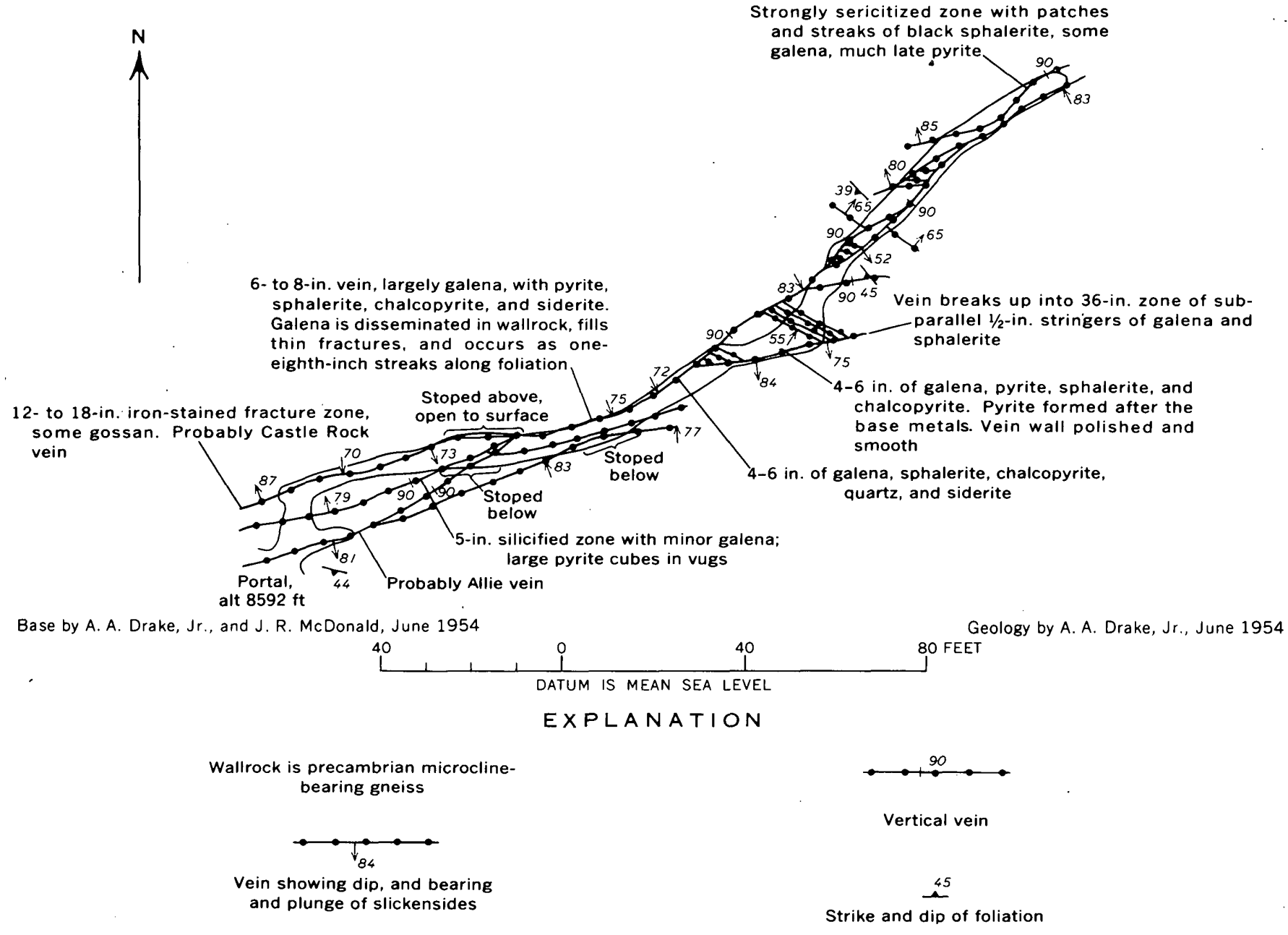


but it contains as much as 6 inches of galena, pyrite, sphalerite, and chalcopyrite and locally has been stoped where it trends more easterly. Much of the pyrite is later than galena; it forms crystals on and fills open spaces in the galena cubes.

The metal content of the minable vein material is indicated by the average grade of 30 tons of ore shipped in 1921 and 1922. This ore contained on the average 0.95 ounce of gold and 7.7 ounces of silver per ton, 0.88 percent copper, and 15.9 percent lead.
SARAH E MINE (D-II-5)

The Sarah $\mathrm{E}$ mine is on the south slope of Maryland Mountain, about 840 feet N. $48^{\circ}$ E. from the Castle Rock mine. The mine is opened by a double drift tunnel. The south branch is about 210 feet long and trends east, and the north branch is driven 205 feet on a bearing of $\mathrm{N} .44^{\circ}$ E. (fig. 90). The mine has produced little if any ore; only one small stope is in the mine (fig. 90).

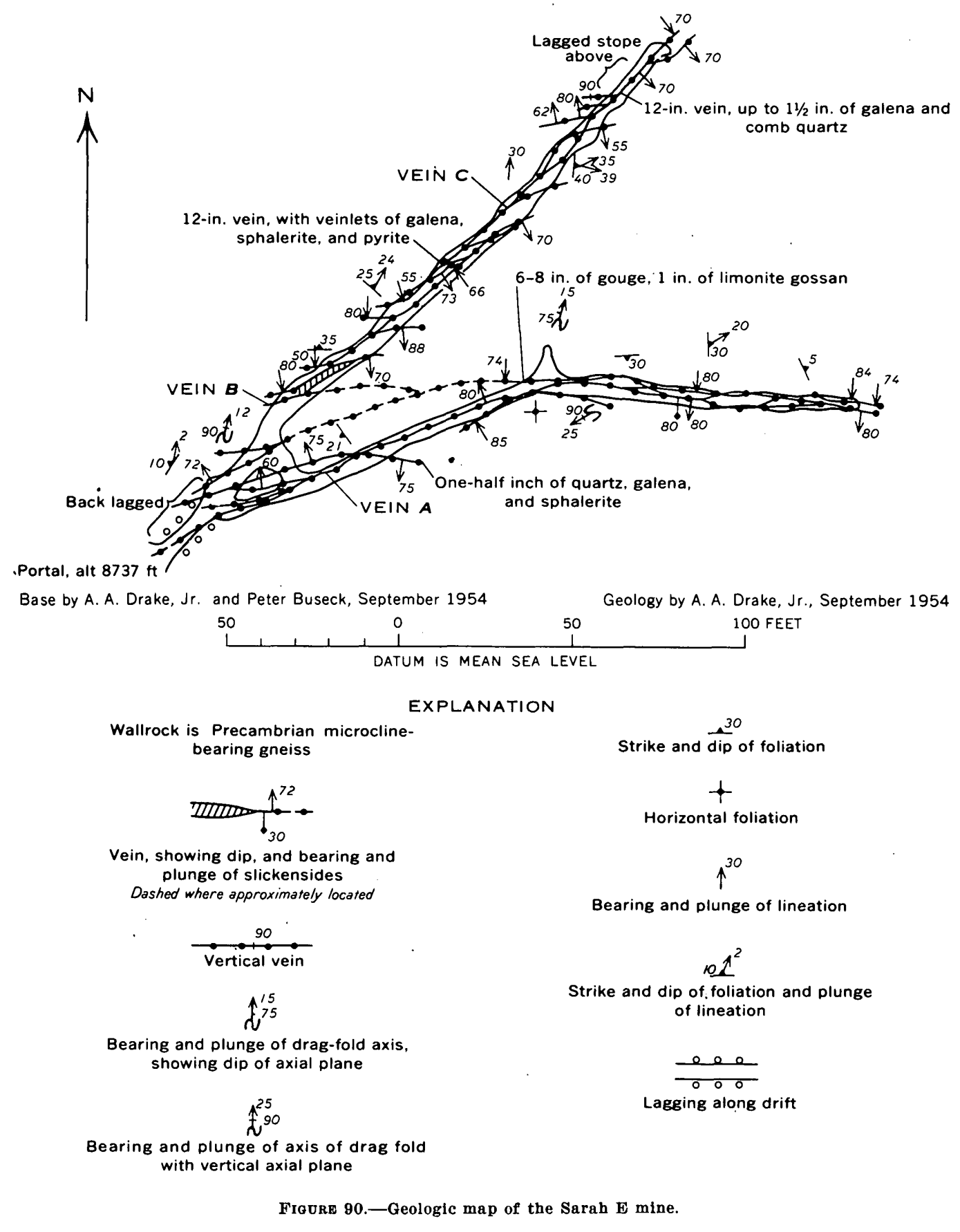


The wallrock of the mine is microcline-bearing gneiss. The foliation, in general, strikes northeast and dips moderately to the northwest. The rock locally is deformed by warps that plunge gently to the northwest, and by tight, overturned to upright, drag folds that plunge moderately to the northnortheast and west-southwest.

Near the portal the tunnel follows vein $A$ (fig. 90), which strikes about N. $70^{\circ} \mathrm{E}$. and $\operatorname{dips} 80^{\circ} \mathrm{NW}$. The south branch of the tunnel follows this vein for about 130 feet, at which point the vein changes to an easterly trend, and is joined from the west by vein $B$. The combined vein is then followed to the breast of the drift. Vein $A$ and the combined vein, where observed, are nearly barren of sulfide minerals, although one south wall branch of vein $A$ contains half an inch of quartz, galena, and sphalerite.

Vein $B$ is cut by the north drift about 60 feet from the portal. It strikes east and dips $70^{\circ}-80^{\circ} \mathrm{S}$. The vein is nearly barren, but locally contains sparse disseminated pyrite.

Vein $C$, which strikes about N. $44^{\circ}$ E. and dips $50^{\circ}-73^{\circ}$ SE., is cut in the north drift about 10 feet northeast of vein $B$. The vein consists largely of gouge and altered wallrock that contains some disseminated pyrite. About 120 feet from the portal the vein is 12 inches wide and contains a few discontinuous veinlets of galena and sphalerite, and near the stope (fig. 90) it has an inch and a half streak of galena and comb quartz on the footwall.

The ore is all from the galena-sphalerite veins.

\section{TROUBLESOME MINE (D-III-14)}

Location.-On Winnebago Hill, 350 feet north of the Casto shaft. The collar is at an altitude of 8,750 feet.

Prnduction.-From 1907-38, 3,599 tons of smelting ore and 559 tons of concentrates were shipped that contained 2,395.70 ounces of gold, 4,843 ounces of silver, 10,107 pounds of copper, 9,484 pounds of lead, and 3,515 pounds of zinc. (Compiled from the U.S. Bureau of Mines. Published by permission.) The principal shipments were made from 1908 to 1914.

Development.-Two shafts; workings from shafts are not known. The northeast (main) shaft was accessible in 1953.

Veins.-Troublesome, strikes about N. $60^{\circ}$ E. and dips at the surface $60^{\circ}-75^{\circ} \mathrm{SE}$.

Wallrock.-Microcline-bearing gneiss. The mine is near the axis of the Central City anticline.

Ore and sulfide minerals.-Gold, silver, pyrite, sphalerite, chalcopyrite, and galena.

Gangue.-Quartz.

\section{TUCKER MINE (D-II-18)}

The Tucker mine is in Chase Gulch about 160 feet $\mathrm{N} .15^{\circ}$ E. from the Hayseed tunnel. The mine was opened prior to 1900 , and was last worked in 1907 . The property is opened by an inclined shaft with levels at vertical depths of $65,200,300,400$, and 500 feet. A large stope that connected to the surface was driven east of the shaft on the 200 level. These workings were all inaccessible in 1954. The known production from the mine is given in table 112. The property yielded $\$ 60,000$ prior to 1899 (Callbreath, 1899, p. 299).

\begin{tabular}{|c|c|c|c|c|c|}
\hline Lead & $\begin{array}{l}\text { Crude ore } \\
\text { shipped } \\
\text { (tons) }\end{array}$ & $\underset{\text { (ounces) }}{\text { Gold }}$ & $\begin{array}{c}\text { Silver } \\
\text { (ounces) }\end{array}$ & $\begin{array}{l}\text { Copper } \\
\text { (pounds) }\end{array}$ & $\underset{\text { (pounds) }}{\text { Lead }}$ \\
\hline $\begin{array}{l}1902 \\
1903 \\
1906 \\
1907\end{array}$ & $\begin{array}{r}500 \\
400 \\
1,000 \\
40\end{array}$ & $\begin{array}{r}500 \\
40\end{array}$ & $\begin{array}{r}500 \\
400 \\
9,000 \\
520\end{array}$ & 40,000 & $\begin{array}{r}215,000 \\
139,448 \\
330,000 \\
34,720\end{array}$ \\
\hline Total__. & 1,940 & 540 & 10,420 & 40,000 & 719,168 \\
\hline
\end{tabular}

Cnmpiled by U.S. Bureau of Mines. Published by permission.

The Tucker vein strikes N. $70^{\circ} \mathrm{E}$. and dips on the average $40^{\circ} \mathrm{SE}$. The mine also develops the Gundy vein, a parallel fissure 40 feet to the south, and the Hayseed vein. ${ }^{61}$ The ore on the dump of the mine is similar in character to that from the Hayseed tunnel (p. 201). The ore from the stope above the 200 level is said to have averaged 55 per cent lead, 12 ounces of silver to the ton, and 0.75 ounces of gold to the ton. Ore shipped between 1902 and 1907 (1,940 tons) averaged 0.28 ounce of gold per ton, 5.45 ounces of silver per ton, 1.03 percent copper, and 18.5 percent lead.

\section{SILVER HILL AREA}

The area includes Silver Hill, North Clear Creek above Fourmile Gulch, Fourmile Gulch, and Silver Gulch. Aside from a few adits in North Clear Creek and Fourmile Gulch and the workings on the Blackhawk lode No. 2 claim (F-II-12), the mines were all inaccessible in 1955 . The principal mines were inaccessible also at the time of the Geological Survey's previous investigation (Bastin and Hill, 1917), and accordingly relatively little is known of the ore deposits.

The ore deposits of the area are dominantly galenasphalerite veins and are valued chiefly for their silver content. The oxidized parts of some veins on Silver Hill and in Silver Gulch are rich in silver. Some gold

\footnotetext{
(1 Foster, E. I., undated, Report on the Tucker mine, 2 p., report
} on file in the Denver Public Library, Denver, Colo. 
and variable quantities of lead and zinc occur in the veins; copper is sparse. Ferberite was produced from one mine, the Chihuahua (E-I-9), at the north edge of the area. Uranium occurs in a few veins, particularly on the Blackhawk lode No.' 2 claim on Silver Hill; a detailed description of these occurrences is given in a report by Sims and others (1963).

The silver-bearing veins on Silver Hill were discovered in 1877 or 1878 and reportedly yielded about $\$ 150,000$ annually for several succeeding years (Bastin and Hill, 1917, p. 211). These mines, however, have not been worked much since 1900, for the high metal concentrations were exhausted at depths of about 300 feet or less. The veins on the hill between Fourmile Gulch and Silver Gulch, however, have been extensively worked since the turn of the century and have been important sources of high-grade silver ore. Within the Silver Hill area the most productive mines have been the Cyclops and After Supper mines on Silver Hill, the Brack Hollow mine in North Clear Creek, and the Champion, Democrat, Wheeler, Coaley, and Jennie Blanche mines in Silver Gulch.

The Silver Hill area is mainly on the southeast flank of the Central City anticline (fig. 4 and pl. 1); accordingly, the rocks generally strike northeastward and dip southeastward. Microcline-bearing gneiss, which includes small layers and lenses of amphibolite, lime-silicate gneiss, and pegmatite, is the dominant host rock in the northwestern part of the area, whereas biotite-quartz-plagioclase gneiss, sillimanitic biotitequartz gneiss, amphibolite, and pegmatite are the dominant host rocks elsewhere.

Most of the ore deposits occur in northeastwardtrending faults which generally strike N. $40^{\circ}-50^{\circ} \mathrm{E}$. and dip steeply. Locally these vein fissures are intersected by veins that strike east-northeast, but the nature of the intersections is not known. Many of the northeastward-trending veins. on Silver Hill are almost parallel to the axial planes of the folds or to foliation planes of the wallrock and dip steeply to the northwest. East of Black Hawk where the country rocks have a gentle southeasterly dip the veins cut sharply across the structure of the wallrocks; most of these veins dip steeply northwest to vertical. The northeastward-trending veins on Silver Hill appear to terminate at the northwestward-trending Blackhawk fault.

The veins contain variable but generally small amounts of sphalerite, galena, and pyrite and sparse amounts of chalcopyrite and tennantite. Silver-bearing minerals have been described (Bastin and Hill, 1917 , p. 211) and probably account for the bonanza silver ore, but were not observed by the writers. In addition to altered wallrock, quartz is the dominant gangue, but carbonate minerals-siderite, ankerite, or rhodochrosite-are present along many of the veins. Cockade ore seems to comprise much of the ore along certain veins, and ore of this type was found on the dumps of the Fannie and Cyclops mines.

The area does not appear favorable as a future source of ore, but veins in the vicinity of Silver Gulch may well continue to yield local pockets of highgrade silver ore. Some of these veins also are potential sources of small quantities of base-metal ores.

\section{AFTER SUPPFR (BANZAI) (AFTER DINNER) MINE (F-III-5)}

The After Supper mine, also known as the Banzai or After Dinner mine, is on the northeast slope of North Clear Creek, about 1,150 feet N. $40^{\circ}$ E. from the Sleepy Hollow mine. The mine was opened prior to 1900 , and was last operated in 1922 . The recorded production from the property is given in table 113; this ore, if produced today, would be worth $\$ 17,000$. The property is credited prior to 1912 with a yield of $\$ 80,000$ (Bastin and Hill, 1917, p. 227). The mine is opened by an inclined shaft that connects to levels at depths of $10,138,237,535,635$, and 714 feet (fig. 91). A tunnel connects to the 100 level, and a 90 -foot crosscut is driven into the north wall of the west breast of the 714 level. The position of the only known stope is shown on figure 91 . In 1954, the workings were all inaccessible.

TABLE 113.-Ore produced from the After Supper mine,
$1899-1954^{1}$

ICompiled by U.S. Bureau of Mines. Published by permission.

The After Supper vein, the northeast extension of the Fisk lode, strikes about N. $60^{\circ}$ E., dips $70^{\circ} \mathrm{SE}$., and is about 5 feet wide. It consists of silicified and crushed wallrock impregnated with pyrite, cut by narrow stringers of galena, sphalerite, and chalcopyrite. Quartz that contains native gold is locally present. ${ }^{62}$ The best ore found in the mine occurred near the winze and stope between the 138 and 237 levels. At this

62 Tyler, S. W., 1904, Report on the After Supper mine, 6 p., report on fle in the Denver Public Library, Denver, Colo. 


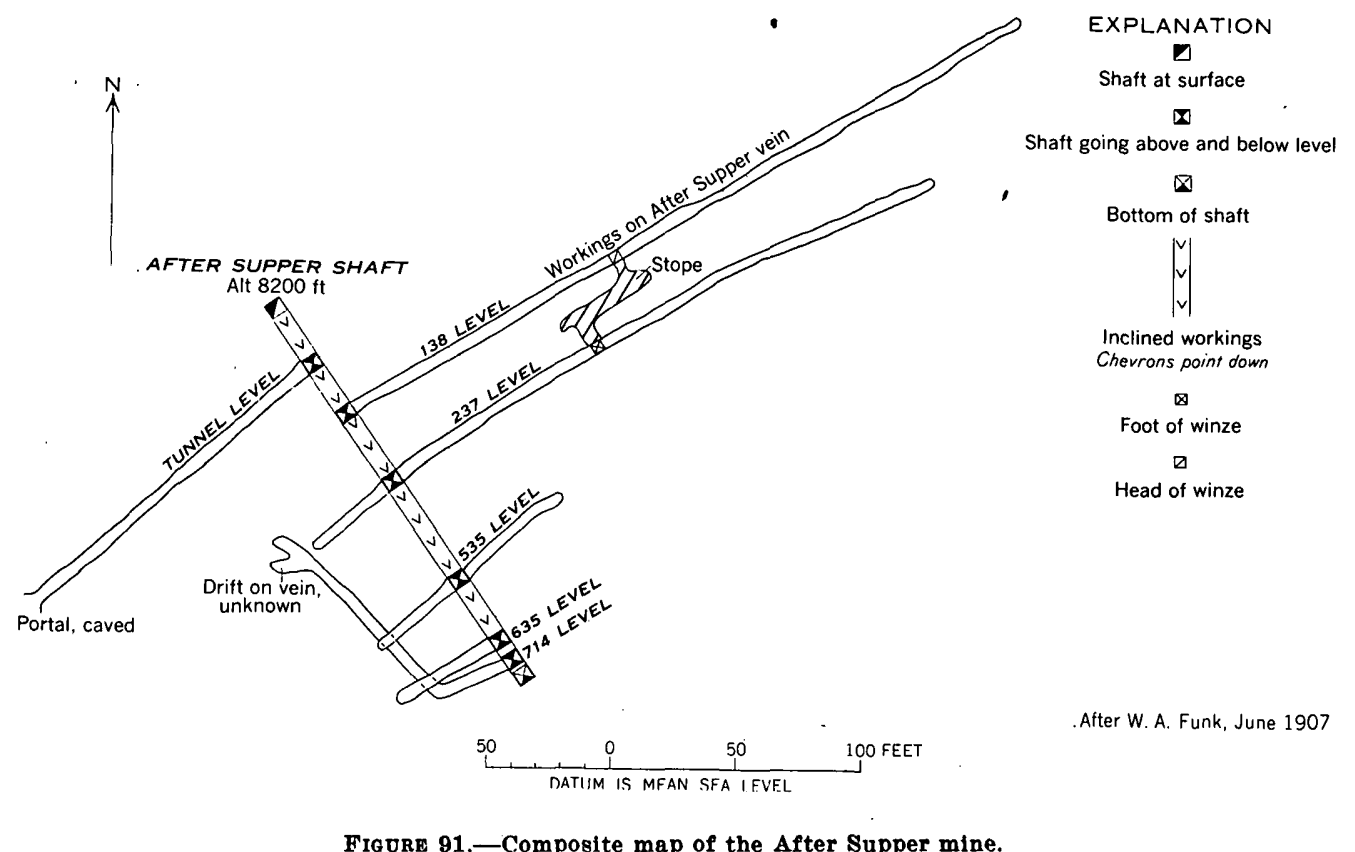

locality the vein was 6 feet wide, and contained 12 to 18 inches of galena, sphalerite, and pyrite on the footwall; a 2-inch streak of similar ore minerals occurred on the hanging wall. (op. cit). Variation of metal content of the ore of the After Supper mine is shown in table 114. Shipments from 1899 to March 1902, aggregating 59.58 tons, had an average assay of 2.34 ounces of gold per ton and 46.97 ounces of silver per ton.

TABLE 114.-Assays of some ore from the After Supper mine"

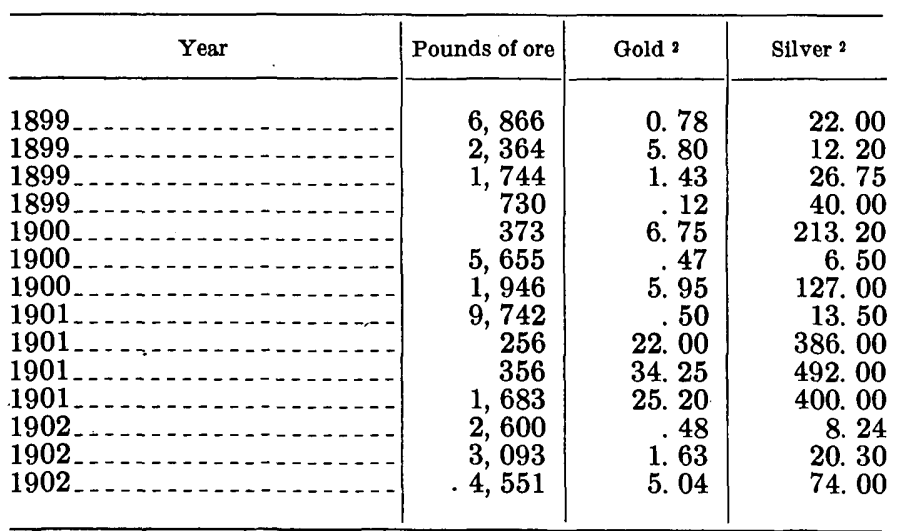

1 S. W. Tyler, 1904, Report on the After Supper mine, 6 p., report on fle in th

Denver Public Library, Denver, Colo.
z Ounces per ton.

\section{AMERICAN EAGLE TUNNEL (F-II-8)}

The American Eagle tunnel is in Fourmile "Gulch, three-fifths of a mile north of its junction with North Clear Creek. The portal is on the east side of the gulch at an altitude of about 8,300 feet. A caved tunnel, probably several hundred feet long, is devel- oped on the same vein about 100 feet vertically above the American Eagle tunnel (pl. 1). Both tunnels have been closed for many years. The record of production from the mine is given in table 115.

\begin{tabular}{|c|c|c|c|c|c|c|c|}
\hline$T_{A B L E}$ & 115. - & e pro & ced $f$ & $\begin{array}{l}n \text { the } \\
54{ }^{1}\end{array}$ & Americ & Eagl & e mine \\
\hline Year & $\begin{array}{c}\text { Crude } \\
\text { ore } \\
\text { shipped } \\
\text { (tons) }\end{array}$ & $\begin{array}{c}\text { Concen- } \\
\text { trates } \\
\text { shipped } \\
\text { (tons) }\end{array}$ & $\begin{array}{c}\text { Gold } \\
\text { (ounces) }\end{array}$ & $\begin{array}{c}\text { Silver } \\
\text { (ounces) }\end{array}$ & $\begin{array}{c}\text { Copper } \\
\text { (pounds) }\end{array}$ & $\begin{array}{c}\text { Lead } \\
\text { (pounds) }\end{array}$ & $\begin{array}{c}\text { Zinc } \\
\text { (pounds) }\end{array}$ \\
\hline $\begin{array}{l}1910 \ldots \\
1911 \\
1912 \\
1913 \\
1920 \\
1924\end{array}$ & $\begin{array}{l}3 \\
1 \\
1 \\
1.5 \\
13 \\
4\end{array}$ & $\begin{array}{r}10 \\
9\end{array}$ & $\begin{array}{r}2.95 \\
.23 \\
.09 \\
.91 \\
1.93 \\
1.70\end{array}$ & \begin{tabular}{r|}
73 \\
18 \\
36 \\
18 \\
315 \\
249
\end{tabular} & $\begin{array}{r}26 \\
\\
\end{array}$ & $\begin{array}{r}1,798 \\
538 \\
1,032 \\
464 \\
20,855 \\
11,384\end{array}$ & $\begin{array}{r}-\mathbf{3}, \mathbf{3 7 5} \\
\mathbf{3}, 705\end{array}$ \\
\hline Total. . & 23.5 & 19 & 7.81 & 709 & 26 & 36,071 & 7,080 \\
\hline
\end{tabular}

1 Compiled by U.S. Bureau of Mines. Published by permission.

The American Eagle tunnel trends N. $45^{\circ}$ E.; it is reported to be 1,600 feet long (Harry Blake, oral communication), but in 1954 it was caved 439 feet from the portal (fig. 92). A crosscut to the northwest, 65 feet from the portal, connects with short drifts on the Cape Cod(?) vein and a branch vein. The only stope in the accessible workings begins 395 feet from the portal and extends beyond the cave; where accessible, the stope has a maximum height of about 30 feet.

The country rock is largely biotite-quartz-plagioclase gneiss, in part containing sparse, thin, conformable seams of pegmatite. A layer of garnetiferous biotite-quartz-plagioclase gneiss, not distinguished on figure 92 , forms the southeast wall of the drift near the stope. The rocks are folded into a series of small, 


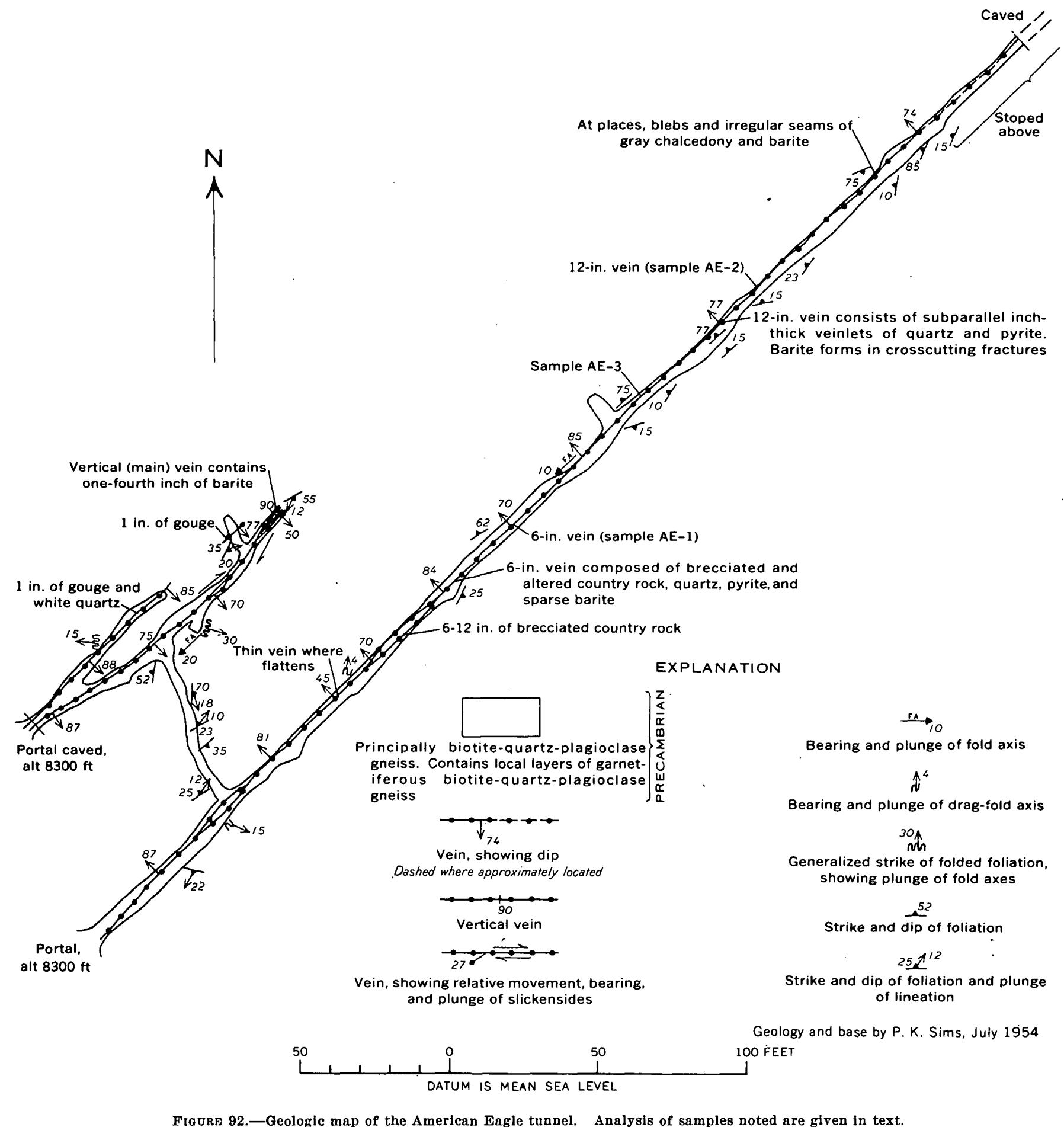

strongly asymmetric folds that plunge gently southwest, or locally northeast, and which are overturned to the northwest. The fractures, now filled with veinforming minerals, cut across these folds; locally the fractures parallel the steep parts of the drag folds.

The American Eagle vein strikes N. $45^{\circ}$ E. and dips generally $70^{\circ}$ to $80^{\circ}$ northwest. It is remarkably uniform in strike, but it has some irregularities in dip, locally flattening to about $45^{\circ}$. The deflections along the dip seem to be largely due to the vein rolling into foliation planes in the country rock. The vein generally is thin and weakly mineralized. Typically it is 1 to 12 inches thick and consists of broken and altered fragments of country rock and veinlets or clots of white quartz and sulfides, principally pyrite and less commonly sphalerite and galena. Gray, 
chalcedonic quartz and ankerite occur locally just southwest of the stope. At places small vugs, a maximum of a few inches across, are present. Cockade ore is the dominant type of ore. It consists of subangular fragments of altered country rock surrounded by as much as half inch of quartz and sufides. A thin film of gouge is common along one or both walls. Pyrite is the most abundant sulfide mineral; it is disseminated through the altered fragments of the country rock that have been incorporated in the vein and also forms inch-thin stringers. Sphalerite and galena are visible locally; tennantite is sparse.

According to Harry Blake (oral communication), the ore that was extracted owed its metal content chiefly to silver and lead. Grab samples of vein material, which were selected because they contained visible sulfides, gave the following results:

\begin{tabular}{|c|c|c|c|c|c|c|}
\hline Sample & $\begin{array}{c}\text { Equiva- } \\
\text { lent } \\
\text { uranium } \\
\text { (percent) }\end{array}$ & Gold 1 & Silver 1 & $\begin{array}{c}\text { Copper } \\
\text { (percent) }\end{array}$ & $\underset{\text { (percent) }}{\text { Lead }}$ & $\begin{array}{c}\text { Zinc } \\
\text { (percent) }\end{array}$ \\
\hline $\begin{array}{l}\text { AE-1 } \\
\text { AE-2 } \\
\text { AE-3 }\end{array}$ & $\begin{array}{r}0.001 \\
.001 \\
.002\end{array}$ & $\begin{array}{l}0.01 \\
\dot{\mathrm{Tr}}\end{array}$ & $\begin{array}{r}0.87 \\
1.19 \\
.18\end{array}$ & $\begin{array}{r}0.03 \\
.03 \\
.06\end{array}$ & $\begin{array}{r}1.72 \\
.99 \\
.10\end{array}$ & $\begin{array}{r}2.44 \\
1.93 \\
.08\end{array}$ \\
\hline
\end{tabular}

1 Ounces per ton.

Analysts: S. P. Furman, J. E. Wilson, and E. C. Mallory, Jr.

Spectrographic analyses by N. M. Conklin indicate as much as $0.0 \mathrm{X}$, cadmium; 0.00 , gallium; $0.000 \mathrm{X}$, scandium; and $0.000 \mathrm{X}$, germanium in the ores.

The Cape Cod vein and the branch vein to the northwest are almost parallel to the American Eagle vein, but they dip steeply to the southeast. The veins are narrow, generally not more than 6 inches wide, and consist largely of altered country rock and quartz with lesser quantities of pyrite and ankerite. At places gouge constitutes the entire width of the vein.

\section{BLACKJ ACK MINE (G-III-6)}

The Blackjack mine, in Silver Gulch, has been a substantial source of silver, gold, and lead and ranks as one of the major producers in the Silver Hill area. The recorded production is given in table 116. The mine was worked prior to World War II; it was closed and inaccessible in 1955.

The mine was worked from two shafts inclined steeply northwest. The workings are extensive, judging from the size of the dump, but neither the nature of the workings nor the veins that were mined are known.

Assays of selected shipments of crude ore, shipped to the Idaho Springs sampling-works, as given in the table 117 , indicate that the ore contains high concentrations of silver; lead and zinc are present in nearly equal amounts.
TABLE 116.-Ore produced from the Blackjack mine, 1902-541

\begin{tabular}{|c|c|c|c|c|c|c|c|}
\hline Year & $\begin{array}{l}\text { Crude } \\
\text { ore } \\
\text { shisred } \\
\text { (tons) }\end{array}$ & $\begin{array}{c}\text { Concen- } \\
\text { trates } \\
\text { shinped } \\
\text { (tons) }\end{array}$ & $\begin{array}{c}\text { Gold } \\
\text { (ounces) }\end{array}$ & $\begin{array}{c}\text { Silver } \\
\text { (ounces) }\end{array}$ & $\begin{array}{l}\text { Copper } \\
\text { (pounds) }\end{array}$ & $\begin{array}{c}\text { Lead } \\
\text { (pounds) }\end{array}$ & $\begin{array}{c}\text { Zinc } \\
\text { (pounds) }\end{array}$ \\
\hline 0 & 2 & & $\begin{array}{l}0.30 \\
42\end{array}$ & $\begin{array}{l}47 \\
40\end{array}$ & & 200 & \\
\hline 年 & $\begin{array}{l}63 \\
70 \\
60\end{array}$ & & $\begin{array}{l}42.24 \\
36.60 \\
20.00\end{array}$ & $\begin{array}{l}9,001 \\
8,075 \\
4,319\end{array}$ & $\begin{array}{l}-170^{-} \\
241 \\
134\end{array}$ & $\begin{array}{r}24,482 \\
17,620 \\
13486\end{array}$ & $\cdots$ \\
\hline 22. & 104 & & $\begin{array}{r}21.50 \\
6.30\end{array}$ & $\begin{array}{l}9,859 \\
1,141\end{array}$ & 236 & $\begin{array}{r}28,976 \\
4,682\end{array}$ & \\
\hline $\begin{array}{l}1923- \\
1923- \\
1925-\end{array}$ & $\begin{array}{r}20 \\
107 \\
9 \\
24\end{array}$ & & $\begin{array}{r}16.50 \\
4.96 \\
4.82\end{array}$ & $\begin{array}{r}1,141 \\
7,716 \\
735 \\
1,710\end{array}$ & $43^{-1}$ & $\begin{array}{r}4,082 \\
30,661 \\
2,003 \\
5,860\end{array}$ & $\begin{array}{l}-4,896 \\
2,652\end{array}$ \\
\hline 1926 & $\gamma$ & & .88 & 677 & & 1,534 & \\
\hline 1937. & & 208 & & $\begin{array}{r}636 \\
12.393\end{array}$ & 243 & $\begin{array}{r}2.011 \\
61.731\end{array}$ & \\
\hline $\begin{array}{l}1938 . \\
1942 \ldots\end{array}$ & & 91 & & $\begin{array}{r}7,205 \\
61\end{array}$ & $\begin{array}{r}285 \\
3\end{array}$ & ${ }_{(2)}^{37,717}$ & . \\
\hline Total.. & 484 & 300 & 292.79 & 63,615 & 1,355 & 230,963 & 8,058 \\
\hline
\end{tabular}

1 Compiled by U.S. Bureau of Mines. Published by permission. 2 Not known.

TABLE 117:-Sampling-works assays of ore from the Blackjack mine, $1923-34^{1}$

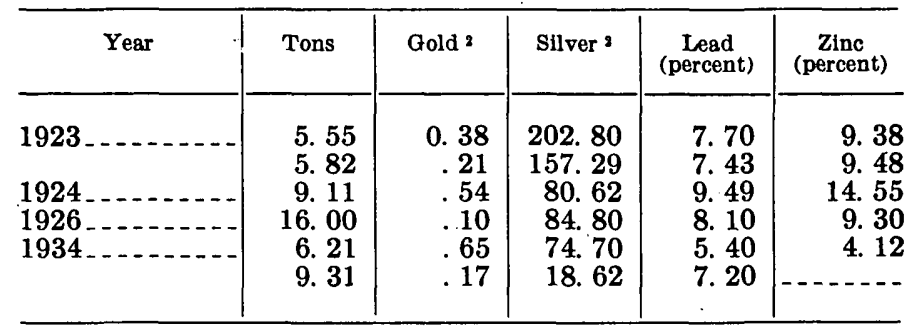

${ }^{1}$ Data on ore tenor furnished by the Idaho Springs Sampling Works. Published by permission.

\section{BOER TUNNEL (F-III-2)}

The Boer tunnel is on the east side of Fourmile Gulch, one-third of a mile north of State Highway 119, at an altitude of about 8,223 feet. The workings consist of a drift 647 feet long that trends northeast and an eastward-trending cross drift, 470 feet from the portal, that is 290 feet long (fig. 93). So far as known, no stoping was done in the tunnel; the workings are wholly exploration drifts.

The tunnel cuts interlayered biotite gneisses, which locally are migmatitic, and pegmatite. The pegmatite seems to be conformable to the biotite gneiss. The rocks dip gently, principally to the southeast, and trend northeast, except locally. The axis of a small, open syncline lies just east of the intersection of the drifts; an asymmetric anticline, overturned to the northwest, is near the portal.

Two vein sets were worked in the mine, a westnorthwestward-striking vein and several northeastward-striking veins. Possibly the northeastwardtrending veins shown on figure 93 belong to a single vein, which splits at the junction with the northwestward-trending vein.

All the veins are similar mineralogically. They consist of gouge, some breccia, quartz, and sparse but 
variable sulfides. The sulfides-sphalerite, galena, and pyrite-form small pods and lenses in the veins.

Selected samples of the sulfide-rich parts of the veins gave the following assays

\begin{tabular}{|c|c|c|c|c|c|c|}
\hline Sample & $\begin{array}{c}\text { Equiva- } \\
\text { lent } \\
\text { uranium } \\
\text { (percent) }\end{array}$ & Gold 1 & Silver ${ }^{1}$ & $\begin{array}{c}\text { Copper } \\
\text { (percent) }\end{array}$ & $\underset{\text { (percent) }}{\text { Lead }}$ & $\underset{\text { (percent) }}{\text { Zine }}$ \\
\hline $\begin{array}{l}4-9-1 \\
4-9-2 \\
4-9-4\end{array}$ & $\begin{array}{r}0.001 \\
.001 \\
.002\end{array}$ & $\begin{array}{l}0.02 \\
.02 \\
.02\end{array}$ & $\begin{array}{l}5.30 \\
4.24 \\
1.12\end{array}$ & $\begin{array}{l}0.09 \\
.04 \\
.06\end{array}$ & $\begin{array}{r}10.53 \\
18.41 \\
3.37\end{array}$ & $\begin{array}{l}3.98 \\
4.80 \\
9.88\end{array}$ \\
\hline
\end{tabular}

1 Ounces per ton.

Analysts: S. P. Furman, E. C. Mallory, Jr., Mary Finch, U.S. Geol. Survey.
BRACK HOLLOW MINE (F-II-18)

Location.-Three-quarters of a mile north of Black Hawk, on the west side of North Clear Creek.

Production.-From 1903 to 1917 the mine yielded 762.5 tons of smelting ore and 325 tons of concentrates that contained 546.98 ounces of gold, 3,241 ounces of silver, 1,775 pounds of copper, 130,961 pounds of lead, and 27,985 pounds of zinc. (Compiled by U.S. Bureau of Mines. Published by permission.)

Development.-Mine workings are not known. The workings are reported (Claude McKay, oral com-

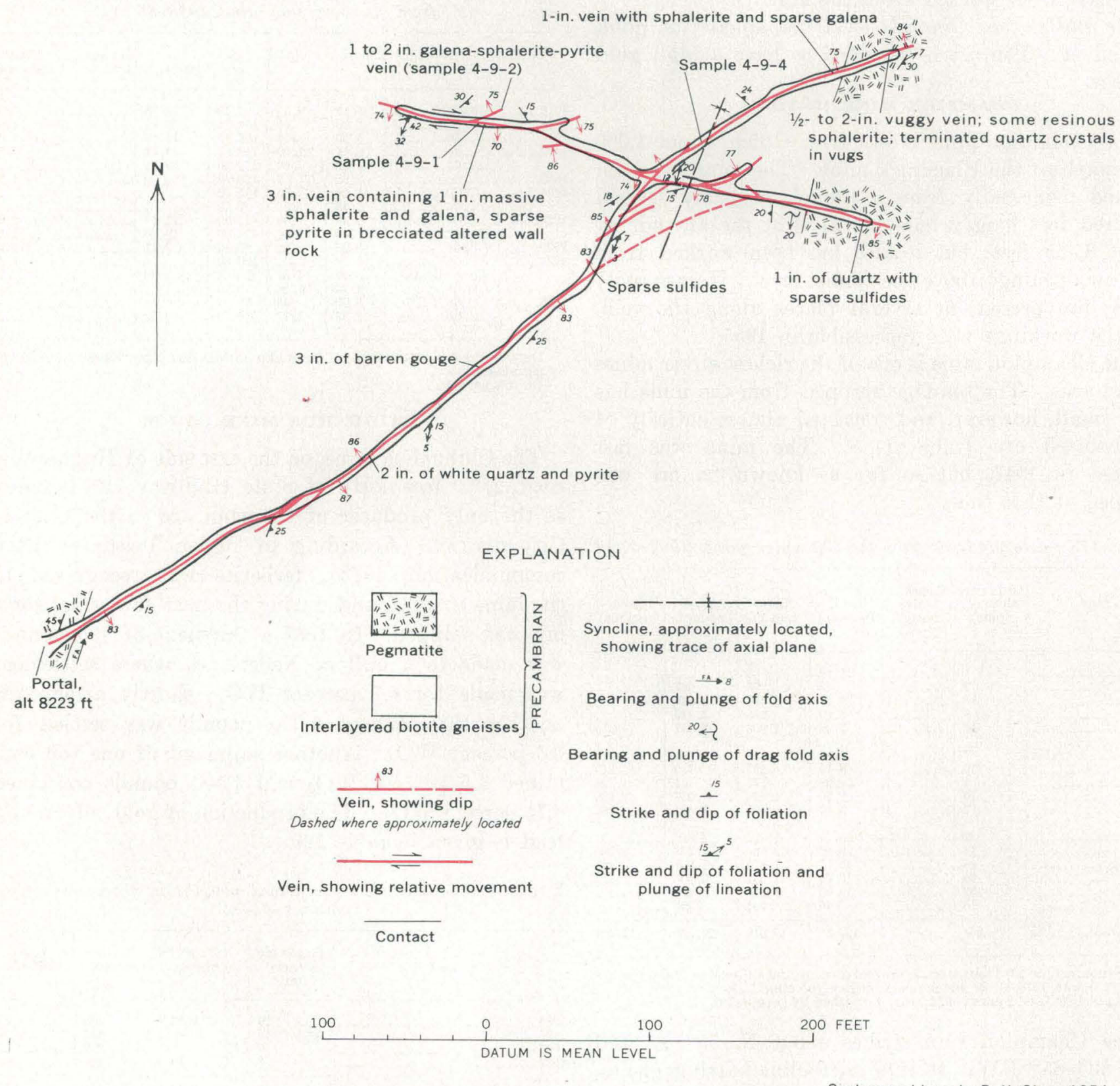

Geology and base by P. K. Sims, 1954

Figure 93.-Geologic map of the Boer tunnel. Analyses of samples noted are given in text. 
munication) to connect through raises to the Bonanza tunnel.

Veins.-Not known.

\section{BRYAN TUNNEL (G-III-2)}

Location.-In Fourmile Gulch, 400 feet north of State Highway 119.

Production.-Not known.

Development.-An adit that trends southwestward, reported to be 1,200 feet long, and a 200-foot shaft.

Veins.-The adit is driven on a vein that strikes N. $50^{\circ}$ E. and dips nearly vertically. Other veins may have been worked from the adit.

Ore and sulfide minerals.-Galena, sphalerite, gold, and silver. The ore is reported to have a high gold content.

\section{CHAMPION MINE (G-III-4)}

The Champion mine is in Silver Gulch, about 1,000 feet north of the Biackjack mine. The mine has been worked principally from a tunnel, probably several hundred feet long, whose portal is at the altitude of about 8,455 feet; but it also has been worked from shallow openings above the tunnel level. "Grass root" stopes are present at several places along the vein. All the workings were inacessible in 1955 .

The Champion mine is one of the richest silver mines in the area. The tonnage shipped from the mine has been small, however, and consisted almost entirely of hand-sorted ore (table 118). The mine was last worked in 1947, but so far as known no ore was shipped at that time.

TABLE 118.-Ore produced from the Champion mine, 1902-54 12

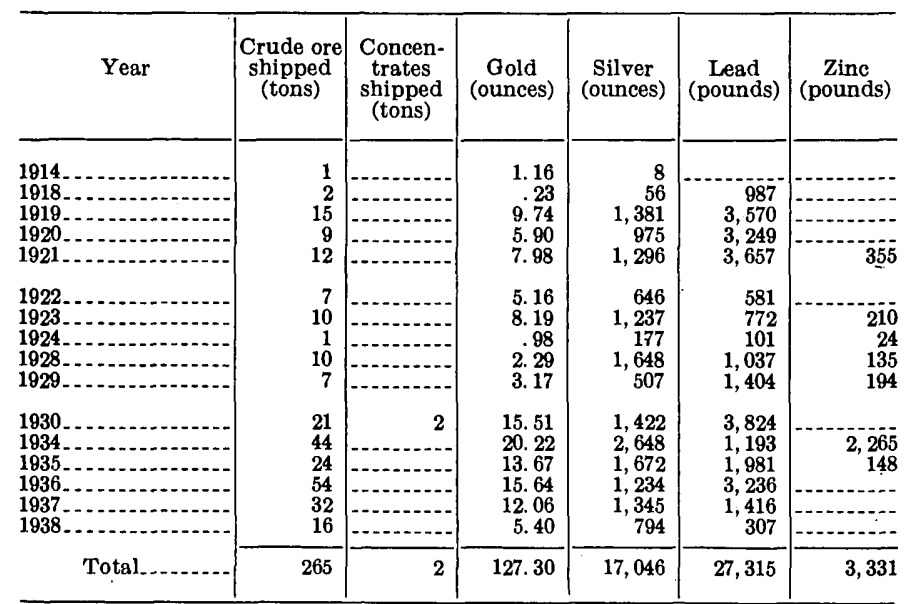

1 Does not include 260.3 tons of crude ore and concentrates shipped to Idaho Springs Smelting Works, 1918-35, for which operators received $\$ 10,777.29$.

The Champion vein strikes about N. $55^{\circ}$ E. and dips $80^{\circ}-85^{\circ} \mathrm{NW}$. It cuts microcline-bearing gneiss, pegmatite, and interlayered biotite gneisses that dip gently eastward. Where exposed at the surface, the vein is a foot or less wide, and it appears to contain sparse sulfides. One dump contains fragments of altered country rock that are cemented by dark-gray chalcedony.

Sparse sphalerite and pyrite form. small clots in the vein; sphalerite occurs in vugs, coated by terminated quartz crystals. White quartz is a common gangue on the dump of the main tunnel. Judging from the sampling-works assays (table 119), galena is the dominant sulfide. It is probable that sulfosalts of silver occur in the rich ore.

TABLE 119.-Sampling-works assays of selected shipments of ore from the Champion mine, 1918-35 ${ }^{1}$

\begin{tabular}{|c|c|c|c|c|c|c|c|}
\hline Year & Type of ore & Tons & Gold 2 & $\begin{array}{l}\text { Sil- } \\
\text { ver }{ }^{2}\end{array}$ & $\underset{\text { (percent) }}{\text { Lead }}$ & $\begin{array}{c}\text { Copper } \\
\text { (percent) }\end{array}$ & $\underset{\text { (percent) }}{\text { Zinc }}$ \\
\hline $\begin{array}{l}1918 .- \\
1919 . \\
1921-. \\
1922 .-\end{array}$ & $\begin{array}{l}\text { Crude... } \\
-\ldots \text { do } \\
-. . \text { do }\end{array}$ & $\begin{array}{l}4.19 \\
5.90 \\
5.20 \\
2.16 \\
.29\end{array}$ & $\begin{array}{r}0.55 \\
.91 \\
.79 \\
1.00\end{array}$ & $\begin{array}{r}92.40 \\
114.05 \\
124.50 \\
119.97\end{array}$ & $\begin{array}{r}13.78 \\
8.45 \\
17.56 \\
4.11\end{array}$ & & $\begin{array}{l}1.00 \\
1.43 \\
1.05 \\
1.50\end{array}$ \\
\hline $\begin{array}{l}1923 \\
1924\end{array}$ & - & $\begin{array}{l}1.29 \\
2.85 \\
1.24\end{array}$ & $\begin{array}{l}.60 \\
.67 \\
.55\end{array}$ & $\begin{array}{r}126.30 \\
195.00\end{array}$ & $\begin{array}{r}1.24 \\
2.32 \\
-\end{array}$ & & 1.05 \\
\hline 1928. & .....do............... & $\begin{array}{l}1.43 \\
1.30\end{array}$ & $\begin{array}{l}.92 \\
.05\end{array}$ & $\begin{array}{r}2.00 \\
640.00\end{array}$ & 21.50 & & 2. 00 \\
\hline $\begin{array}{l}1929 . \\
1934 .\end{array}$ & $\begin{array}{l}\text { Concentrates } \\
\text { Crude- }\end{array}$ & $\begin{array}{l}.43 \\
2.90 \\
5.19\end{array}$ & $\begin{array}{l}.07 \\
.42\end{array}$ & $\begin{array}{r}419.00 \\
89.19 \\
100.50\end{array}$ & $\begin{array}{r}19.00 \\
3.17\end{array}$ & & $\begin{array}{l}1.52 \\
1.23 \\
1.10\end{array}$ \\
\hline & Concentrates & 3. 27 & 1.64 & 169.96 & 1.60 & 1 & .75 \\
\hline 1935 & $\ldots . . . d$ & 5. & .68 & 81.07 & 6. & & $\ldots$ \\
\hline & 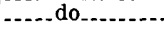 & 1 & 1.17 & 116.70 & 7 & & \\
\hline
\end{tabular}

1 Data on ore tenor furnished by the Idaho Springs Sampling Works. Published by permission.

\section{ChIHUAhuA MINE (E-I-9)}

The Chihuahua mine, on the east side of Hughesville road, 2,000 feet north of State Highway 119, is. noted as the only producer of tungsten ore in the Central City district. According to Ogden Tweto (written communication, 1943), ferberite was recognized in the mine in 1937, and during the next few years some ore was shipped. In 1937 a shipment of 795 pounds was made to a mill at Nederland, where settlement was made for 6.7 percent $\mathrm{WO}_{3}$; shortly afterwards another shipment of 1,329 pounds was settled for 6.3 percent $\mathrm{WO}_{3}$. Another shipment of one ton contained 1.5 percent $\mathrm{WO}_{3}$ and 1,500 pounds contained 0.75 percent $\mathrm{WO}_{3}$. The production of gold, silver, and lead is given in table 120 .

TABLE 120.-Gold, silver, and lead production from Chihuahua mine, $1934-54^{1}$

\begin{tabular}{r|r|r|r|r}
\hline Year & $\begin{array}{c}\text { Crude ore } \\
\text { shipped } \\
\text { (tons }\end{array}$ & $\begin{array}{c}\text { Gold } \\
\text { (ounces) }\end{array}$ & $\begin{array}{c}\text { Silver } \\
\text { (ounces) }\end{array}$ & $\begin{array}{r}\text { Lead } \\
\text { (pounds) }\end{array}$ \\
\hline & 24 & 0.45 & 753 & 316 \\
\hline Total & 16 & .40 & 843 & 103 \\
\hline 1934 & 3 & 1.59 & 289 & \\
\hline & 52 & 2.44 & 2,145 & 419 \\
\hline
\end{tabular}

1 Compiled by U.S. Bureau of Mines. Published by permission. 
TABLE 121.-Semiquantitative spectrographic analyses of vein samples, Chihuahua mine

\begin{tabular}{|c|c|c|c|c|c|c|c|c|c|c|}
\hline Sample & $\begin{array}{l}\text { Laboratory } \\
\text { serial No. }\end{array}$ & $\begin{array}{c}\text { Size of } \\
\text { chip sample } \\
\text { (inches) }\end{array}$ & $\mathrm{Ag}$ & Ba & $\mathrm{Cd}$ & $\mathrm{Cu}$ & $\mathrm{Pb}$ & w & $\mathrm{Zn}$ & $\mathrm{Zr}$ \\
\hline $\begin{array}{r}\text { C-1 } \\
2 \\
3 \\
4 \\
5 \\
6\end{array}$ & $\begin{array}{l}231093 \\
231094 \\
231095 \\
231096 \\
231097 \\
231098\end{array}$ & (1) $\begin{array}{r} \\
12 \\
3 \\
1.5 \\
2 \\
8 \\
8\end{array}$ & $\begin{array}{l}0.00015 \\
0 \\
.00015 \\
0 \\
0 \\
.015\end{array}$ & $\begin{array}{l}0.15 \\
.15 \\
.03 \\
.07 \\
.15 \\
.7\end{array}$ & $\begin{array}{l}0 \\
0 \\
0 \\
0 \\
0 \\
.3\end{array}$ & $\begin{array}{l}0.007 \\
.003 \\
.003 \\
.003 \\
.003 \\
.03\end{array}$ & $\begin{array}{l}0.0015 \\
.0015 \\
.007 \\
.003 \\
.007 \\
.15\end{array}$ & $\begin{array}{l}0.015 \\
.015 \\
.015 \\
.007 \\
.03 \\
0\end{array}$ & $\begin{array}{r}0.07 \\
.03 \\
.03 \\
.07 \\
.03\end{array}$ & $\begin{array}{l}0.015 \\
.015 \\
.007 \\
.007 \\
.007 \\
.0015\end{array}$ \\
\hline
\end{tabular}

1 Grab sample from dump.

Analyst: R. G. Havens.

The workings on the claim consist of four small adits within a vertical interval of 400 feet. Most of the mining was done from the lower adit (altitude 8,580 feet), which is 400 feet long (fig. 94). The 2 stopes, 80 feet and 225 feet respectively from the portal of the lower adit, were driven vertically.

At the surface the Chihuahua vein strikes about N. $85^{\circ}$ W., and can be traced (pl. 1) for about 1,300 feet. The wallrock is microcline-bearing gneiss, which for the most part strikes northward and dips gently westward.

In the lower adit (fig. 94) the Chihuahua vein ranges in strike from N. $80^{\circ} \mathrm{E}$. to N. $65^{\circ} \mathrm{W}$. Throughout most of its exposed length, however, the vein strikes N. $80^{\circ}-85^{\circ}$ E. and dips $75^{\circ} \mathrm{N}$. to vertical. Two hundred sixty-five feet from the portal the vein is cut and displaced by a vertical fault filled with quartz and carbonate that strikes N. $45^{\circ} \mathrm{W}$.; the apparent horizontal displacement is 15 feet, the east segment having moved southeast.

The vein is 12 to 30 inches wide and typically consists of 1-inch-thick quartz-ankerite(?)-sulfide stringers that cut altered and fractured wallrock. Pyrite, galena, sphalerite, and ferberite are sparse. .Much of the quartz is cryptocrystalline and resembles the horn quartz of the Boulder County tungsten district (Lovering and Tweto, 1953, p. 44-45). East of the northwestward-trending fault the vein contains a black, finegrained sphalerite.

Ferberite was not observed by us, but according to Tweto (written communication, 1943), it occurs as small clots and veinlets within the gray horn quartz. Most of the ore was taken from the stope adjacent to the raise on the lower adit level (fig. 94); some, however, came from the small stope to the east of the raise, and some from the uppermost of the 4 adits.

Spectrographic analyses (table 121) of vein samples from the lower tunnel indicate that small amounts of tungsten are present in many parts of the vein. The locations of the samples are given on figure 94 .
Assays of crude ore shipped to the Idaho Springs Sampling Works in 1934 and 1939 are given below :

Sampling-works assays of ore from the Chihuahua mine, 1934 and 19391

\begin{tabular}{|c|c|c|c|c|}
\hline Year & Tons & Gold 2 & Silver ${ }^{2}$ & $\underset{\text { (percent) }}{\text { Zinc }}$ \\
\hline $\begin{array}{l}1934 \\
1939\end{array}$ & $\begin{array}{l}\text { 4. } 72 \\
\text { 1. } 43\end{array}$ & $\begin{array}{l}0.02 \\
\text { 1. } 04\end{array}$ & $\begin{array}{l}27.57 \\
71.40\end{array}$ & $\begin{array}{r}0.45 \\
-\end{array}$ \\
\hline
\end{tabular}

1 Data on ore tenor furnished by the Idaho Springs Sampling Works. Published by permission.

COALEY MINE

Location.-In Silver Gulch, south of Blackjack mine. The exact locations of the openings are not known.

Production.-The recorded production from 1910 to 1936 is 1,285 tons of smelting ore and 91.5 tons of concentrates that contained 427.51 ounces of gold, 14,409 ounces of silver, 12,256 pounds of copper, 66,984 pounds of lead, and 1,065 pounds of zinc. (Compiled by U.S. Bureau of Mines. Published by permission.) Some production from the vein has been included in the records for the Wheeler tunnel.

Ore and sulfide minerals.-Galena, sphalerite, copper minerals, gold, and silver.

\section{CYCLOPS MINE (F-II-21)}

The Cyclops vein was worked on three claimsCyclops (patent no. 787), Cyclops No. 2 (patent no. 788), and Cyclops No. 3 (patent no. 1033). Most of the workings are on the Cyclops and Cyclops No. 2 claims, and consist of six principal shafts and an adit which enters the west side of Silver Hill (altitude 8,390 feet) above the Sensenderfer millsite in North Clear Creek. The main Cyclops shaft (pl. 1) is east of the crest of Silver Hill at an altitude of 8,730 feet. The mine was inaccessible in 1954. According to the U.S. Mint report for 1884 the main shaft was 498 feet deep in 1883, and 2,200 feet of levels had been driven on the vein. At that time a system of winzes and shafts on either side of the main shaft connected from the surface to the 375 and 440 levels. 


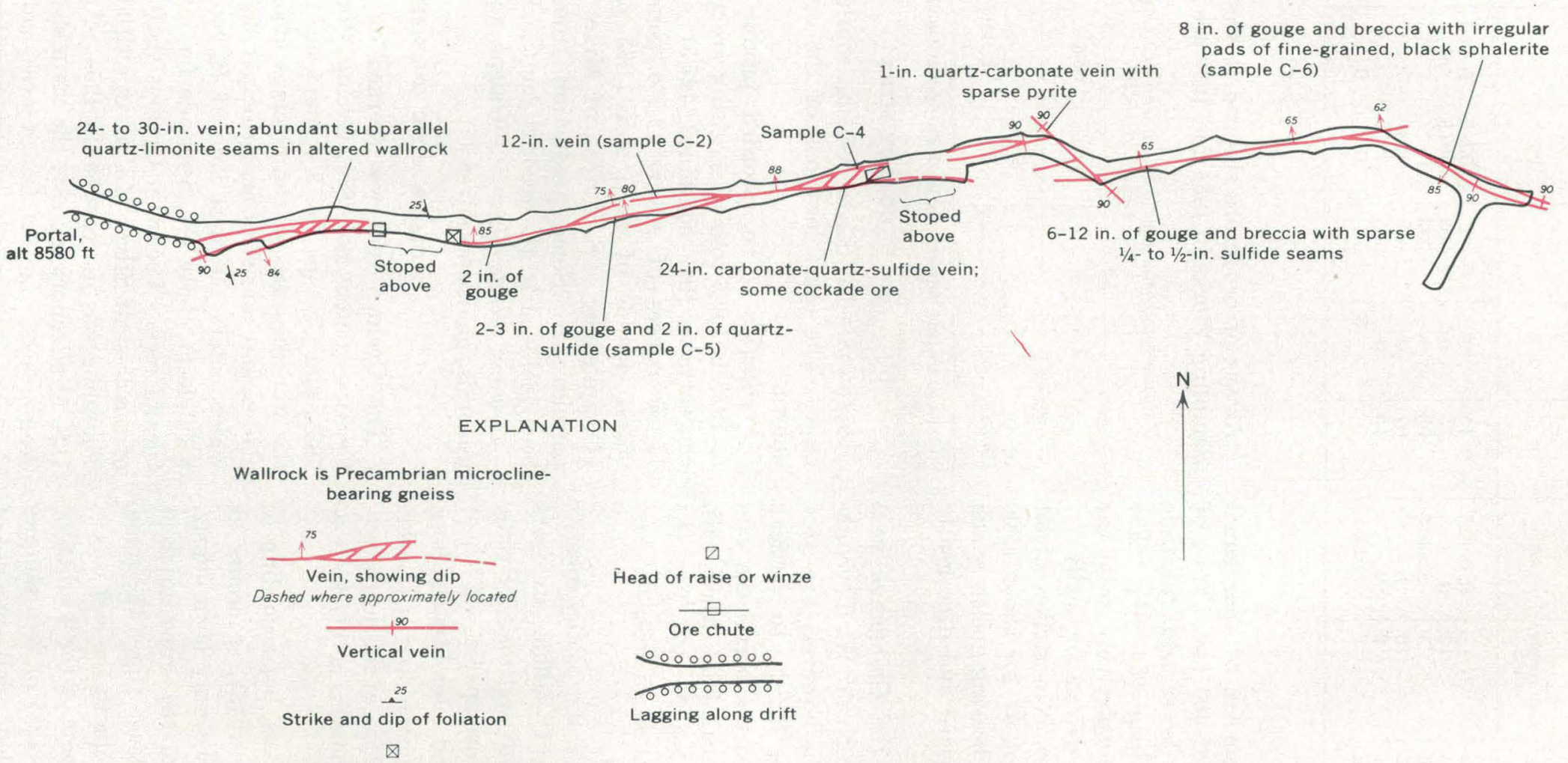

Bottom of raise or winze

$\underbrace{50 \quad 100 \text { FEeT }}_{\text {DATUM IS MEAN SEA LEVEL }}$

Geology and base by P. K. Sims, 1955

FiguRE 94.-Geologic map of the lower audit, Chihuahua mine. Analyses of samples noted are given in text. 
The production from the Cyclops vein is reported to be $\$ 700,000$ to 1883 (Burchard, 1884, p. 308); since 1902 , according to the records of the U.S. Bureau of Mines (table 122), the mine has yielded moderate quantities. of silver and lead, and lesser amounts of gold, copper, and zinc. Sampling-works assays which indicate the grade of some of the ore mined in 1890-91 are given in table 123; samplingworks assays of ore mined in 1923 are given in table 124.

The Cyclops vein strikes N. $45^{\circ} \mathrm{E}$. and dips $82^{\circ} \mathrm{NW}$. to vertical, except locally where it dips steeply south-

TABLE 122.-Ore produced from the Cyclops mine, 1911-54 ${ }^{1}$

\begin{tabular}{|c|c|c|c|c|c|c|c|}
\hline Yoar & $\begin{array}{c}\text { Crude } \\
\text { ore } \\
\text { shipjed } \\
\text { (tons) }\end{array}$ & $\begin{array}{l}\text { Concen- } \\
\text { trates } \\
\text { shipred } \\
\text { (tons) }\end{array}$ & $\begin{array}{c}\text { Gold } \\
\text { (ounces) }\end{array}$ & $\begin{array}{c}\text { Silver } \\
\text { (ounces) }\end{array}$ & $\begin{array}{c}\text { Copper } \\
\text { (pounds) }\end{array}$ & $\begin{array}{c}\text { Lead } \\
\text { (pounds) }\end{array}$ & $\begin{array}{c}\text { Zinc } \\
\text { (pounds) }\end{array}$ \\
\hline 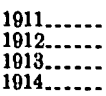 & $\begin{array}{r}2 \\
38 \\
1 \\
19\end{array}$ & $\begin{array}{c}1 \\
1 \\
2\end{array}$ & $\begin{array}{r}0.71 \\
12.33 \\
.17 \\
2.54\end{array}$ & $\begin{array}{r}26 \\
177 \\
11 \\
21\end{array}$ & & $\begin{array}{r}806 \\
5,297 \\
269 \\
654\end{array}$ & $\begin{array}{r}50 \\
479\end{array}$ \\
\hline $\begin{array}{l}1916 \ldots \\
1920 \ldots . \\
1921 \\
1822\end{array}$ & $\begin{array}{r}1 \\
65 \\
8\end{array}$ & $\begin{array}{r}2 \\
75 \\
75 \\
220\end{array}$ & $\begin{array}{r}2.45 \\
32.43 \\
34.60 \\
34.00\end{array}$ & $\begin{array}{r}80 \\
5,432 \\
3,103 \\
10,407\end{array}$ & $\begin{array}{r}235 \\
181 \\
1,318\end{array}$ & $\begin{array}{r}42,700 \\
18,958 \\
134,372\end{array}$ & a.. \\
\hline $\begin{array}{l}1923 \\
1924 \\
1925 \\
1926 \\
1928\end{array}$ & \begin{tabular}{r}
11 \\
4 \\
\hdashline 1 \\
2
\end{tabular} & $\begin{array}{r}55 \\
-15 \\
-51 \\
43 \\
\end{array}$ & $\begin{array}{r}39.83 \\
11.73 \\
14.56 \\
10.90 \\
2.94\end{array}$ & $\begin{array}{r}1,514 \\
255 \\
754 \\
448 \\
50\end{array}$ & $\begin{array}{r}36,148 \\
\end{array}$ & $\begin{array}{r}17,419 \\
11,640 \\
14,653 \\
17,850 \\
\end{array}$ & $\begin{array}{r}3,248 \\
7,690 \\
12,732 \\
\end{array}$ \\
\hline Total.. & 152 & 540 & 199.19 & 22,278 & 37,882 & 264,618 & 24,199 \\
\hline
\end{tabular}

1 Complled by the U.S. Bureau of Mines. Published by permission.

$\mathrm{T}_{\mathrm{ABLE}}$ 123.-Sampling-works assays of ore from Cyclops vein $1890-91$

\begin{tabular}{|c|c|c|}
\hline Ore (net pounds) & Gold 2 & Silver 2 \\
\hline 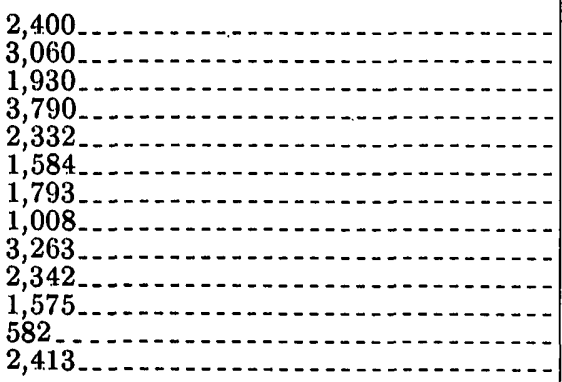 & $\begin{array}{r}0.05 \\
\hdashline \\
\hdashline \\
\hdashline\end{array}$ & $\begin{array}{l}87.00 \\
30.00 \\
22.00 \\
52.00 \\
79.00 \\
31.00 \\
27.00 \\
41.50 \\
40.27 \\
75.00 \\
87.00 \\
48.00 \\
26.00\end{array}$ \\
\hline
\end{tabular}

1 Bastin and Hill, 1917, p. 211.

TABLE 124.-Sampling-works assays of crude ore from Cyclops mine, 19231

\begin{tabular}{c|c|r|r|r}
\hline Tons & Gold 2 & Silver 2 & $\begin{array}{c}\text { Lead } \\
\text { (percent) }\end{array}$ & \multicolumn{1}{c}{$\begin{array}{c}\text { Zinc } \\
\text { (percent) }\end{array}$} \\
\hline $\begin{aligned} 5.38 \\
1.80\end{aligned}$ & & $\begin{array}{r}81.68 \\
7.70\end{array}$ & $\begin{array}{r}16.40 \\
17.50\end{array}$ \\
\hline
\end{tabular}

1 Data on ore tenor furnished by the Idaho Springs Sampling Works. Published by pormission. east. The vein has been traced across Silver Hill for 2,000 feet. It appears to terminate at the northwestward-trending Blackhawk fault (pl. 1). The vein is almost parallel to axial planes of tightly folded interlayered microcline-bearing gneiss, lime-silicate gneiss, amphibolite, and biotite-quartz-plagioclase gneiss. Because the workings are inaccessible, nothing is known of the character and relative mineral content of the vein in the various types of wallrocks.

As the vein could not be examined underground, little is known of its character, structure, and mineralogy. Specimens on the dump contain sparse pyrite, sphalerite, galena, chalcopyrite, tennantite, quartz, and siderite(?). Commonly the vein minerals coat brecciated wallrock fragments to constitute cockade ore. The quartz is partly milky white and forms terminated crystals and is partly white to green and fine grained. The sphalerite is pale-green and resinous; the galena is fine grained. Some specimens of vein material contain stringers of hematite in quartz gangue.

Bastin and Hill (1917, p. 211) state that the Cyclops vein was. "rich to a depth of about 300 feet and notably lower grade below that. The rich ore carried wire silver and much so-called brittle silver (possibly pearceite) and a very little ruby silver (proustite). The native silver is said to have been confined mainly to the upper 100 feet of the vein."

\section{DEMOCRAT MINE (G-III-8)}

Location.-On hill between Fourmile Gulch and Silver Gulch, at an altitude of 8,535 feet.

Production.-From 1902 to 1913 the mine yielded $1,737.5$ tons of crude ore and 305 tons of concentrates that contained 406.72 ounces of gold, 26,759 ounces of silver, 201.466 pounds of lead, and 119,800 pounds of zinc. (Compiled by U.S. Bureau of Mines. Published by permission.) Very probably the mine was in production prior to 1902 . Since 1913 production from the Democrat vein was. reported to the U.S. Bureau of Mines under the Coaley mine.

Development.-Mine opened by a shaft, inaccessible in 1955, that near surface is inclined an average of $77^{\circ} \mathrm{N}$. The underground workings are not known.

Veins.-Democrat vein; where exposed at the surface, strikes N. $90^{\circ} \mathrm{E}$. and dips $70^{\circ}-80^{\circ} \mathrm{N}$.

Ore and sulfide minerals.-Galena, sphalerite, pyrite, gold, and silver; dump specimens show the galena to be fine grained and cubic; the sphalerite is an amber variety, and the pyrite is fine grained and cubic or pyritohedral in habit.

Gangue minerals.-Altered wallrock and quartz. 


\section{DUMAS-KINNEY TUNNEL (F-II-16)}

The Dumas-Kinney tunnel, on the Dumas claim, is a mile north of Black Hawk on the west side of North Clear Creek at an altitude of 8,280 feet (pl. 1). The tunnel trends about S. $65^{\circ} \mathrm{W}$. and extends for 360 feet under the northeast slope of Maryland Mountain (fig. 95). Small stopes above the tunnel level are 60 to 150 feet from the portal. The tunnel was worked primarily during the twenties; the recorded production is given in table 125 .

TABLE 125.-Ore produced from the Dumas claim, 1902-54 ${ }^{1}$

\begin{tabular}{|c|c|c|c|c|c|c|c|}
\hline Year & $\begin{array}{c}\text { Crude } \\
\text { ore } \\
\text { shipped } \\
\text { (tons) }\end{array}$ & $\begin{array}{l}\text { Concen- } \\
\text { trates } \\
\text { shioped } \\
\text { (tons) }\end{array}$ & $\begin{array}{c}\text { Gold } \\
\text { (ounces) }\end{array}$ & $\begin{array}{c}\text { Silver } \\
\text { (ounces) }\end{array}$ & $\begin{array}{c}\text { Copper } \\
\text { (pounds) }\end{array}$ & $\begin{array}{c}\text { Lead } \\
\text { (pounds) }\end{array}$ & $\begin{array}{c}\text { Zinc } \\
\text { (pounds) }\end{array}$ \\
\hline $\begin{array}{l}1926 \ldots \\
1927-\ldots \\
1928 \ldots \\
1949 \ldots\end{array}$ & $\begin{array}{r}40 \\
4 \\
2 \\
7\end{array}$ & 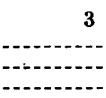 & $\begin{array}{l}5.82 \\
1.65 \\
1.67 \\
3.00\end{array}$ & $\begin{array}{l}36 \\
42 \\
27 \\
46\end{array}$ & 36 & $\begin{array}{l}3,032 \\
2,067 \\
1,641 \\
2,380\end{array}$ & $\begin{array}{r}3,447 \\
387 \\
140\end{array}$ \\
\hline Total. & 53 & 3 & 12. 14 & 151 & 36 & 9,120 & 3. 974 \\
\hline
\end{tabular}

1 Compiled by U.S. Bureau of Mines. Published by permission.

The tunnel largely intersects microcline-bearing gneiss. Biotite-quartz-plagioclase gneiss forms sparse, small lenses, and pegmatite forms thin conformable layers in the gneiss. In the tunnel the rocks dip $40^{\circ}-70^{\circ} \mathrm{NW}$. The mine is in a belt of tight, nearly isoclinal folds that are overturned slightly to the southeast, but the exact position of the tunnel in relation to individual folds is not known. The Dumas vein is nearly parallel to the axial planes of the known folds in this area, and possibly it follows along the axis of a small fold. At places it is parallel to foliation planes of the microcline-bearing gneiss.

The vein strikes on the average $\mathrm{N} .70^{\circ} \mathrm{E}$. and dips $45^{\circ}-80^{\circ} \mathrm{NW}$. It is thickest where it strikes N. $65^{\circ} \mathrm{E}$. or more easterly and dips $65^{\circ}$ or greater. It characteristically splits around horses of the wallrock; also it is common for splits to extend into the walls.

The main vein generally ranges from 6 to 12 inches in width and consists of brecciated fragments of the wallrock, gouge, and veinlets and knots of quartz, pink to brown siderite and sulfides. The fine-grained, whitish gray quartz appears to be virtually contemporaneous with the carbonate minerals. Where stoped, near the portal, the vein probably was about 2 feet wide. Sphalerite and pyrite are the conspicuous and widespread sulfides; galena is present at places and chalcopyrite is sparse.

A selected sample of the vein, a foot wide, assayed by E. C. Mallory, Jr., of the U.S. Geological Survey, Denver laboratory gave:

\begin{tabular}{|c|c|c|c|c|c|}
\hline \multirow[b]{2}{*}{ Sample } & \multicolumn{2}{|c|}{ Ounces per ton } & \multicolumn{3}{|c|}{ Percent } \\
\hline & Gold & Silver & Copper & Lead & $\overline{Z i n c}$ \\
\hline$K-5$ & 0.04 & 2. 92 & 0.05 & 11. 02 & 0.03 \\
\hline
\end{tabular}

Semiquantitative spectrographic analyses of the same sample indicated $0.0 \mathrm{X}$ percent $\mathrm{Sb}$; possibly the $\mathrm{Sb}$ is present in gray copper.

Ore shipments from the Dumas claim during the years 1922 and 1928 gave the following samplingworks assays :

\begin{tabular}{|c|c|c|c|c|c|}
\hline Sampling-works & assays of & ore fron & Dumas & claim, & $1922-28^{1}$ \\
\hline Year & Tons & Gold ${ }^{2}$ & Silver 8 & $\underset{\text { (percent) }}{\text { Lead }}$ & $\begin{array}{c}\text { Zinc } \\
\text { (percent) }\end{array}$ \\
\hline $1922^{3}$ & $\begin{array}{l}0.46 \\
1.30\end{array}$ & $\begin{array}{r}0.43 \\
.68\end{array}$ & $\begin{array}{l}\text { 12. } 23 \\
13.70\end{array}$ & $\begin{array}{l}23.50 \\
41.75\end{array}$ & $\begin{array}{r}11.60 \\
4.10\end{array}$ \\
\hline
\end{tabular}

1 Data on ore tenor furnished by the Idaho Springs Sampling Works. Published by permission. 2 Ounces per ton.

3 Crude ore.

1 Concentrates.

\section{ELSINORE MINE (F-II-14)}

The Elsinore mine is three-fourths of a mile north of Black Hawk, on the east side of the valley of North Clear Creek. The portal of the lower tunnel (fig. 96) is just above the highway at an altitude of 8,205 feet. The mine workings consist of a nearly vertical shaft and three tunnels; in 1954 only the lower tunnel was accessible (fig. 96). The lower tunnel trends about $\mathrm{N} .53^{\circ} \mathrm{E}$. and is 605 feet long. At 145 feet from the portal a 100-foot crosscut to the northwest connects with a short adit, and 300 feet from the portal a short crosscut to the southeast connects with a small drift on a barren fracture. Unless the vein was stoped adjacent to the raise 285 feet from the portal, there has been no stoping from the lower tunnel level. So far as known the workings on the lower tunnel level do not connect with the shaft.

The country rock is microcline-bearing gneiss that contains sparse, small lenses of biotite-quartz-plagioclase gneiss and a layer of other metasedimentary gneisses. These rocks are folded into tight, overturned folds that strike northeast; the axial planes $\operatorname{dip} 65^{\circ}$ to $85^{\circ} \mathrm{NW}$. The folds and linear elements within the rocks generally plunge $10^{\circ}$ to $20^{\circ} \mathrm{SW}$., but locally plunge gently northeasterly. The veins generally occupy fractures that are nearly parallel to fold axes; at places, however, they are more nearly parallel to the foliation than to the fold axes.

The Elsinore vein strikes about N. $53^{\circ}$ E. and, except locally, dips steeply northwest to vertical. Splits in the vein surrounding horses of altered wallrock are common. For the most part the vein is thin and weakly mineralized. It commonly consists of 1 to 6 inches of gouge and sparse quartz and sulfides, but at places it is a foot or more wide and contains a greater proportion of quartz and visible seams of sulfides. Fragments 'of country rock within the vein 


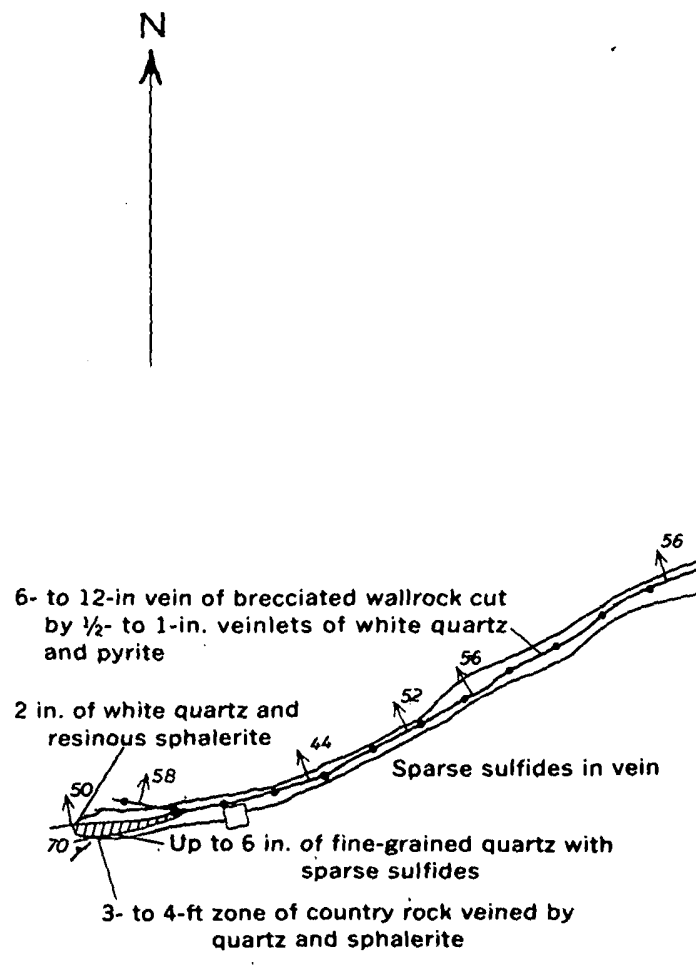

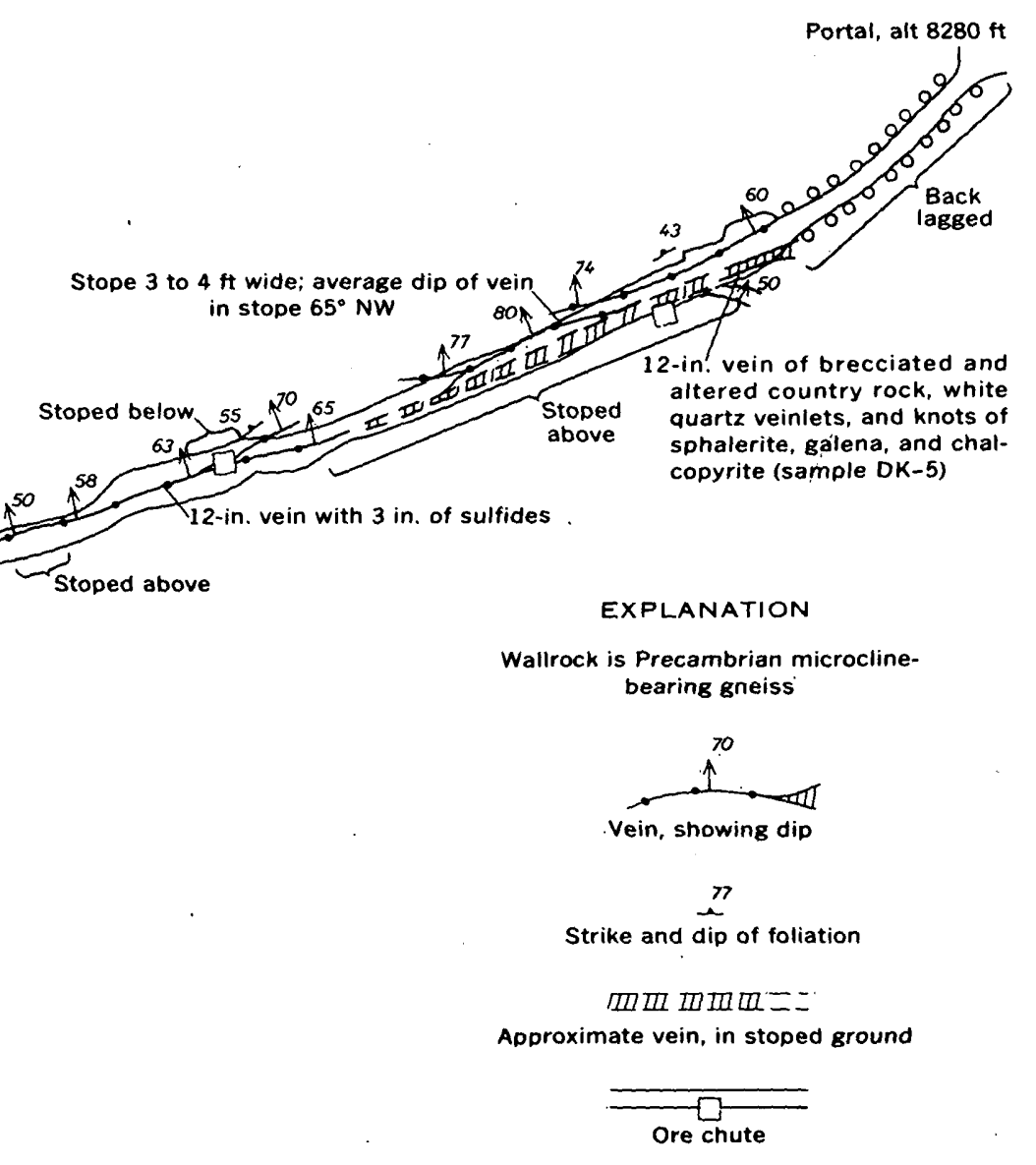

Geology and base by P. K. Sims, July 1954

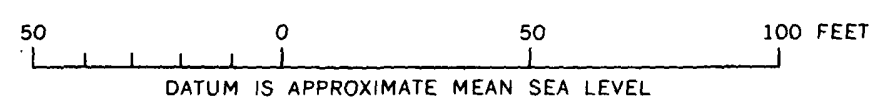

Frodra 95.-Geologic map of the Dumas-Kinney tunnel. Analyses of samples noted are given in text.

or in the horses are partly altered and contain disseminated pyrite. At the raise the vein is 12 to 18 inches thick and contains small, broken fragments of wallrock and gouge cut by sparse veinlets of quartz and sulfides; an inch of gouge occurs on the hanging wall and footwall fractures that bound the vein. Near the face of the drift, a strong vein split that strikes N. $20^{\circ}-25^{\circ}$ E. and which cuts across the structure of the wallrock, is composed of about 6 inches of massive, dense, gray quartz that contains clots of sulfides. Except for disseminated pyrite, sphalerite is the most abundant sulfide; galena cubes are conspicuous in the N. $20^{\circ}$ E. vein and chalcopyrite, sparse tennantite and emplectite(?) can be seen under the microscope in polished sections. Pyrite also at places occurs in veinlets with the other sulfides. The gangue is dominantly quartz but locally siderite(?). Terminated quartz crystals at places fill vugs in the vein.

For the most part the vein is low in grade. Selected grab samples from the vein where visible sulfides are present gave the following results.

\begin{tabular}{|c|c|c|c|c|c|c|c|}
\hline Sample No. ${ }^{1}$ & $\begin{array}{c}\text { Labora- } \\
\text { tory } \\
\text { sérial } \\
\text { No. }\end{array}$ & $\begin{array}{l}\text { Equiva- } \\
\text { lent } \\
\text { urainimm } \\
\text { (percent) }\end{array}$ & Gold 2 & $\begin{array}{c}\text { Silver }{ }^{2} \\
\vdots \\
\vdots\end{array}$ & $\begin{array}{l}\text { Copper } \\
\text { (percent) }\end{array}$ & $\underset{\text { (percent) }}{\text { Lead }}$ & $\underset{\text { (percent) }}{\text { Zinc }}$ \\
\hline $\begin{array}{r}\mathrm{E} 1-3 \ldots \\
4 \ldots \\
5\end{array}$ & $\begin{array}{l}211013 \\
211014 \\
211015\end{array}$ & $\begin{array}{r}0.002 \\
: 001 \\
.001\end{array}$ & $\begin{array}{l}\text { Tr. } \\
\text { Tr. } \\
.30\end{array}$ & $\begin{array}{r}0.02 \\
2.38 \\
2.56\end{array}$ & $\begin{array}{r}0.01 \\
.01 \\
.06\end{array}$ & $\begin{array}{c}0.03 \\
.91 \\
6.32\end{array}$ & $\begin{array}{l}0.11 \\
.76 \\
2.89\end{array}$ \\
\hline
\end{tabular}

1 Analysts: S. P. Furman, J. E. Wilson, and E. C. Mallory, Jr, Sample locations shown' on figure 96 .

The vein in the drift northwest of the Elsinore drift is similar in structure and mineralogy to the Elsinore vein, but it contains a visible pink to brown carbonate mineral.

Concentrates shipped in 1947 and 1948 are listed below. The ore must have come.from workings above the lower tunnel level. 


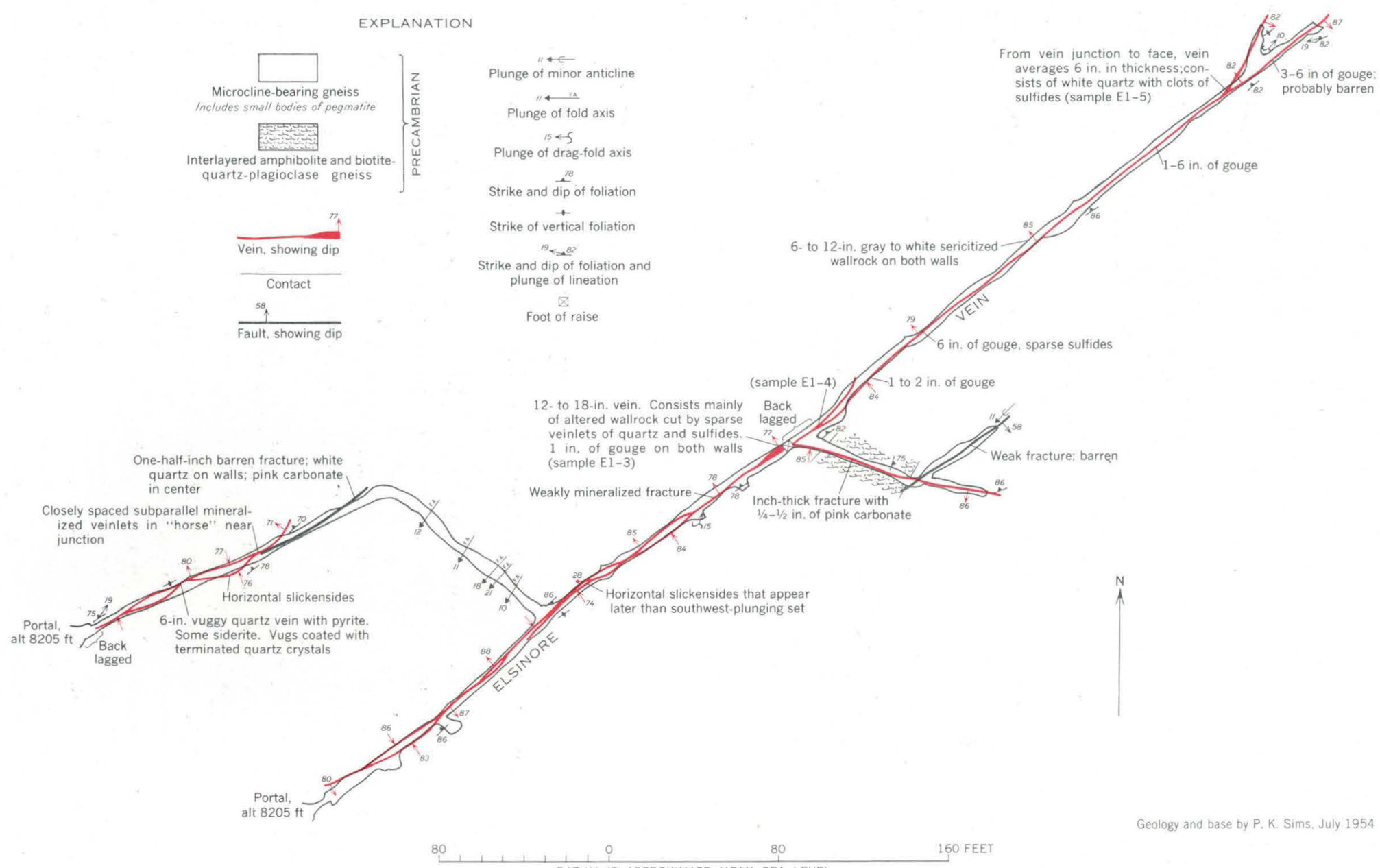

FIGURE 96.-Geologic map of the Elsinore tunnel. Analyses of samples noted are given in the text. 
Concentrates shipped from Elsinore vein, 1947-48

\begin{tabular}{r|r|r|r|r|r}
\hline Yenr & $\begin{array}{r}\text { Concen- } \\
\text { trates } \\
\text { shipped } \\
\text { (tons) }\end{array}$ & $\begin{array}{r}\text { Gold } \\
\text { (ounces) }\end{array}$ & $\begin{array}{r}\text { Silver } \\
\text { (ounces) }\end{array}$ & $\begin{array}{r}\text { Copper } \\
\text { (pounds) }\end{array}$ & $\begin{array}{r}\text { Lead } \\
\text { (pounds) }\end{array}$ \\
\hline 1947.57 & 23 & 1,145 & 1,144 & $\begin{array}{r}23,842 \\
104\end{array}$ \\
\hline Total....... & 400 & 114 & 1,248 & 26,942 \\
\hline
\end{tabular}

1 Data on oro tenor furnished by the Idaho SpringsSampling Works. Published by permission.

\section{FANNIE MINE (F-II-2)}

Location.-A mile north-northeast of Black Hawk at an altitude of 8,555 feet.

Development.- In 1883 the main shaft was 200 feet deep and levels at various depths totaled about 200 feet. The mine has been worked subsequently but nothing is known concerning the workings. Inaccessible in 1954.

Production.-The mine is reported to have yielded about 27,500 ounces silver to 1883 (U.S. Mint report for 1884). Production since that time is not known.

Vein.-Strikes N. $40^{\circ}$ E. and dips $70^{\circ} \mathrm{NW}$. At shaft collar, vein appears to be about 2 feet thick. The vein is almost parallel to axial plane of tight folds in the Precambrian country rocks.

Vein and ore minerals.-The dump contains abundant cockade ore, which consists of subangular fragments of altered wallrock surrounded by $1 / 8$ - to $1 / 4$-inch rims of siderite, quartz, and pyrite (see fig. 10).

Gangue minerals.-Siderite and sparse calcite.

Tenor.-Seven lots of smelting ore shipped between 1888 and 1904 gave the following sampling-works assays :

Sampling-works assays of ore from Fannie mine, 1888-1904"

\begin{tabular}{|c|c|c|c|c|}
\hline Yoar & $\begin{array}{l}\text { Ore (net } \\
\text { pounds) }\end{array}$ & Gold, & Silver? & $\underset{\text { (percent) }}{\text { Lead }}$ \\
\hline $\begin{array}{l}1888 \\
1889 \\
1889 \\
1903 \\
1903 \\
1903 \\
1904\end{array}$ & $\begin{array}{l}1,950 \\
1,123 \\
4,669 \\
1,497 \\
3,270 \\
2,472 \\
2,462\end{array}$ & $\begin{array}{r}-1 \overline{2} \\
.25 \\
.10 \\
.07 \\
.10 \\
.14\end{array}$ & $\begin{array}{r}115.00 \\
78.20 \\
140.00 \\
308.00 \\
148.30 \\
75.00 \\
176.00\end{array}$ & $\begin{array}{r}6 \\
-14 \\
\hdashline-14\end{array}$ \\
\hline
\end{tabular}

t Bastin and Fill, 1917, p. 211

Ounces per ton.

\section{JENNIE BLANCEE MINE (G-IH-1)}

The Jennie Blanche mine, on the hill between Fourmile Gulch and Silver Gulch, east-southeast of Black Hawk, consists of two principal shafts at altitudes respectively of 8,256 and 8,340 feet and an unknown amount of underground workings. The production since 1902 is given in table 126. Most of the metal concentrations in gold, silver, and lead.
TABLE 126.-Ore produced from the Jennie Blanche claim $19.08-54^{1}$

\begin{tabular}{|c|c|c|c|c|c|c|c|}
\hline Year & $\begin{array}{c}\text { Crude } \\
\text { ore } \\
\text { shipped } \\
\text { (tons) }\end{array}$ & $\begin{array}{c}\text { Concen- } \\
\text { trates } \\
\text { shipped } \\
\text { (tons) }\end{array}$ & $\begin{array}{c}\text { Gold } \\
\text { (ounces) }\end{array}$ & $\begin{array}{c}\text { Silver } \\
\text { (ounces) }\end{array}$ & $\begin{array}{c}\text { Copper } \\
\text { (pounds) }\end{array}$ & $\begin{array}{c}\text { Lead } \\
\text { (pounds) }\end{array}$ & $\begin{array}{c}\text { Zinc } \\
\text { (pounds) }\end{array}$ \\
\hline $\begin{array}{l}1908 . \\
1908 .\end{array}$ & 310 & 74 & 86.00 & 2,000 & & 90,881 & \\
\hline 09. & 8 & & 3. 40 & 28 & 223 & 3,126 & \\
\hline 1923 & 68 & 5 & $\begin{array}{r}.30 \\
16.80\end{array}$ & $\begin{array}{r}1 \\
2,265\end{array}$ & 21 & 47,043 & \\
\hline $\begin{array}{l}1924 \\
1925 \\
1926 \\
1927 \\
1928\end{array}$ & $\begin{array}{r}55 \\
43 \\
30 \\
8 \\
18\end{array}$ & & $\begin{array}{r}15.40 \\
15.55 \\
7.40 \\
1.60 \\
2.80\end{array}$ & $\begin{array}{r}1,162 \\
1,274 \\
751 \\
156 \\
317\end{array}$ & & $\begin{array}{r}29,567 \\
22,470 \\
12,379 \\
3,445 \\
8,652\end{array}$ & \\
\hline $1930 \ldots$ & 34 & 7 & 3. 97 & 256 & & $\begin{array}{r}20,466 \\
4,390\end{array}$ & 865 \\
\hline & 6 & & .60 & 122 & 115 & $\begin{array}{l}\text {. } 712 \\
\end{array}$ & 0,000 \\
\hline & 14 & 8 & 1. 40 & 253 & 131 & 15,316 & $\therefore$ \\
\hline 1950 & 3 & & & 94 & 11 & 1,782 & \\
\hline Total & 597 & 94 & 177.04 & 10,700 & 501 & 266,229 & 8,650 \\
\hline
\end{tabular}

1 Compiled by U.S. Bureau of Mines. Published by permission.

The vein cuts Precambrian biotite-quartz-plagioclase gneiss, sillimanitic biotite-quartz gneiss, and pegmatite, which are folded along north-northeastward-trending axes. Dips in the rocks generally are gentle.

The Jennie Blanche vein strikes N. $60^{\circ}$ E. and dips $55^{\circ}-75^{\circ} \mathrm{NW}$ : Where exposed in the grass-roots stope the vein appears to be 1 to 2 feet thick. It consists of pyrite, galena, and sphalerite in quartz gangue. The sphalerite is dominantly the pale green, resinous variety.

Shipments of crude ore from the Jennie Blanche mine during 1925 gave the following sampling-works assays :

Sampling-works assays of ore from Jennie Blanche mine, 19251

\begin{tabular}{r|r|r|r|r|r}
\hline Year & Tons & Gold 3 & Silver & $\begin{array}{r}\text { Lead } \\
\text { (percent) }\end{array}$ & $\begin{array}{r}\text { Zinc } \\
\text { (percent) }\end{array}$ \\
\hline 1925 & $\begin{aligned} 7.71 \\
10.21\end{aligned}$ & $\begin{array}{c}0.38 \\
.315\end{array}$ & $\begin{array}{r}23.13 \\
24.80\end{array}$ & $\begin{array}{r}22.70 \\
19.50\end{array}$ & $\begin{array}{r}2.65 \\
.73\end{array}$ \\
\hline
\end{tabular}

1 Data on ore tenor furnished by Idaho Springs Sampling Works. Published by perr.ission.

\section{LITTLE GIANT MINE (F-III-4)}

Location.-The mine is on Silver Hill, a third of a mile north of the junction of State Highways 119 and 279 at Black Hawk.

Development.-The known workings consist of an adit, which trends N. $30^{\circ}$ E., and a two-compartment shaft, 125 feet east of the adit. Both were inaccessible in 1954 .

Vein.-Specimens on 'the dump' consist of disseminated pyrite in quartz gangue and veinlets of sphalerite and galena. J ark-gray, chalcedonic quartz is present locally. 
Wallrock.-Microcline-bearing gneiss and amphibolite.

Tenor.-Shipments of crude ore from the Little Giant mine gave the following sampling-works assays:

Sampling-works assays of ore from Little Giant mine, 1919-20 ${ }^{1}$

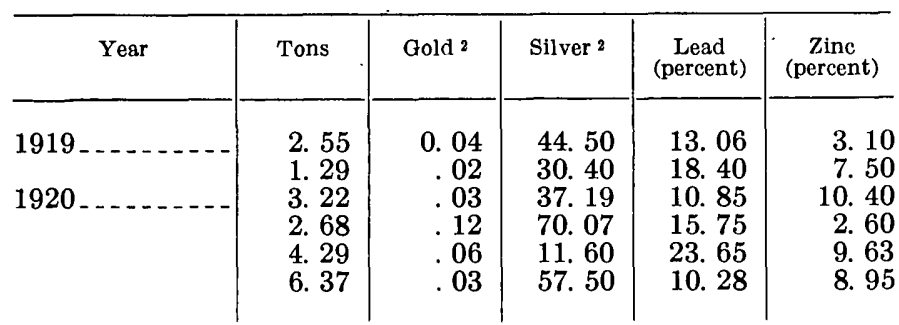

1 Data on ore tenor furnished by the Idaho Springs Sampling Works. Published by permission
2 Ounces per ton.

\section{MARQUETTE MINE (E-I-8)}

Location.-North side of North Clear Creek, a mile northwest of Black Hawk, on State Highway 119.

Development.-Two adits, 80 feet apart, at altitudes respectively of 8,350 feet and 8,370 feet. Upper adit was caved in 1955 .

Production.-Production probably small. In 1927, 4.2 tons of crude ore and concentrates were shipped to the Idaho Springs Sampling Works.

Vein.-Sparse pitchblende(?) found on dump; associated with quartz gangue and sparse pyrite.

Wallrock.-Microcline-bearing gneiss.

Tenor.-Given in the following table:

Sampling-works assays of crude ore and concentrates shipped from Marquelte mine, $1927^{1}$

\begin{tabular}{|c|c|c|c|c|}
\hline Tons & Gold 2 & Silver 2 & $\underset{\text { Lead }}{\text { (percent) }}$ & $\underset{\text { (percent) }}{\text { Zinc }}$ \\
\hline $\begin{array}{l}2.66^{3} \\
0.92^{4} \\
0.62^{5}\end{array}$ & $\begin{array}{l}0.05 \\
3.60 \\
1.09\end{array}$ & $\begin{array}{l}\text { 13. } 50 \\
18.90 \\
58.00\end{array}$ & $\begin{array}{l}1.40 \\
2.70\end{array}$ & $\begin{array}{l}\text { 3. } 00 \\
\text { 3. } 65 \\
\text { 7. } 30\end{array}$ \\
\hline
\end{tabular}

1 Data on ore tenor furnished by Idaho Springs Sampling Works. Published by permission.

2 Ounces per ton

3 Crude ore.

4 Concentrates.

$\checkmark$ Filters.

\section{MAYFLOWER MINE (F-I-2)}

The Mayflower mine is on the crest of Silver Hill, a mile north of Black Hawk. The shaft, at an altitude of 8,990 feet, is 1,900 feet southeast of the Polly shaft. The mine has not been worked so far as known since 1934, and the workings were inaccessible in 1955. It was active in 1919 and 1920 and in 1934. In 1945,25 tons of crude ore were shipped that contained 17.40 ounces of gold, 97 ounces of silver, 356 pounds of copper, and 347 pounds of lead. Sampling- works assays of ıypical shipments of ore for the years $1919-20$ are given below:

Sampling-works assays of selected shipments of ore from the Mayflower mine, 1919-20

\begin{tabular}{|c|c|c|c|c|c|c|}
\hline Year & Tons & Gold ${ }^{2}$ & Silver ${ }^{2}$ & $\begin{array}{c}\text { Lead } \\
\text { (percent) }\end{array}$ & $\begin{array}{l}\text { Copper } \\
\text { (percent) }\end{array}$ & $\underset{\text { Zinc }}{\text { (percent }}$ \\
\hline 1919 & $\begin{array}{r}3.66 \\
.88 \\
91\end{array}$ & $\begin{array}{r}0.21 \\
.09\end{array}$ & $\begin{array}{l}\text { 19. } 26 \\
16.20\end{array}$ & $\begin{array}{r}6.53 \\
50.00\end{array}$ & & 11.3 \\
\hline 1920 & 1.0 & .49 & $\begin{array}{l}48.42 \\
18.42\end{array}$ & $\begin{array}{l}12.20 \\
12.15\end{array}$ & $0.90^{\circ}$ & 2. \\
\hline
\end{tabular}

1 Data on ore tenor furnished by Idaho Springs Sampling Works. Published by 2 Ounces per ton.

\section{PERU MINE (F-II-13)}

Location.-Three quarters of a mile north of Black Hawk, on the east side of North Clear Creek.

Production.-The mine has a reported production of 10 tons of crude ore and 17 tons of concentrates that contained 43.5 ounces of gold, 343 ounces of silver, 144 pounds of copper, 13,280 pounds of lead, and 566 pounds of zinc. (Compiled by U.S. Bureau of Mines. Published by permission.) This does not include shipments made to sampling works and apparently is a small percentage of the total shipments.

Development.-Two shafts and a crosscut adit; underground workings are not known.

Vein.-The vein strikes N. $50^{\circ}$ E. and dips $70^{\circ}-75^{\circ}$ SE. At the surface it is about 2 feet wide. The vein is virtually parallel to the foliation of interlayered amphibolite, lime-silicate gneiss, biotite-quartz-plagioclase gneiss, and microcline-bearing gneiss.

Vein and ore minerals.-Pyrite, sphalerite, galena, gold, and silver.

Gangue minerals.-Quartz.

Tenor.-Shipments of crude ore and concentrates from the Peru mine for the years 1924-34, gave the following sampling-works assays (table 127).

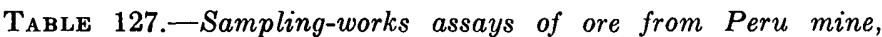
$1924-34^{1}$

\begin{tabular}{|c|c|c|c|c|c|c|c|}
\hline Date & Type of ore & Tons & Gold ${ }^{2}$ & Silver ${ }^{2}$ & $\underset{\text { (percent) }}{\text { Copper }}$ & $\underset{\text { (percent) }}{\text { Lead }}$ & $\underset{\text { (percent) }}{\text { Zinc }}$ \\
\hline $1924 \ldots$ & Crude..... & 3. 28 & 0.26 & 18. 20 & & 38. 35 . & 5. 20 \\
\hline \multirow[t]{2}{*}{$1925 \ldots$} & Concentrates. & $\begin{array}{r}4.75 \\
18.52\end{array}$ & $\begin{array}{l}.25 \\
.23\end{array}$ & $\begin{array}{l}13.80 \\
22.50\end{array}$ & & $\begin{array}{l}28.20 \\
11.40\end{array}$ & $\begin{array}{l}12.00 \\
16.80\end{array}$ \\
\hline & do & 18.35 & .35 & 8. 30 & & 16.85 & 7.95 \\
\hline \multirow[t]{6}{*}{$1926 \ldots$} & $\begin{array}{l}\text { Floats } \\
\text { Zinc concen- }\end{array}$ & $\begin{array}{l}14.40 \\
10.69\end{array}$ & $\begin{array}{l}.15 \\
.10\end{array}$ & $\begin{array}{r}12.35 \\
2.10\end{array}$ & & $\begin{array}{r}10.00 \\
1.87\end{array}$ & $\begin{array}{l}26.40 \\
30.10\end{array}$ \\
\hline & $\begin{array}{l}\text { trates. } \\
\text { Iead concen- }\end{array}$ & 15.08 & 395 & 12.60 & & 30,17 & 9.30 \\
\hline & trates. & & & & & & \\
\hline & Crude.... & 62 & .26 & 13.90 & & 21.00 & 15.00 \\
\hline & Concentrates. & 6.65 & .51 & 17.85 & $\ldots$ & 42.10 & 9.43 \\
\hline & $\begin{array}{l}\text { Zinc conce } \\
\text { trates. }\end{array}$ & 9. 57 & .135 & 11.40 & & 6.50 & 33.00 \\
\hline $1929 \ldots$ & Concentrates... & 5. 30 & 79 & 36. 20 & & 30.06 & 6.80 \\
\hline & Crud & 4.82 & .15 & $\begin{array}{l}35.20 \\
85.30\end{array}$ & 2.70 & $\begin{array}{l}63.65 \\
39.12\end{array}$ & 4.68 \\
\hline 1934 & ............. & 2.15 & .25 & 95 & & & 6.84 \\
\hline
\end{tabular}

1 Data on ore tenor furnished by the Idaho Springs Sampling Works. Published by permission. 


\section{POLLY MINE}

The Polly mine is on the northwest part of Silver Hill, more than a mile north of Black Hawk. The mine, now inaccessible, was worked from a shaft (E-I-1) situated in a saddle on Silver Hill at an altitude of 8,947 feet and an adit (E-I-2) driven north into the hill from the gulch below the shaft. The adit is at an altitude of 8,740 feet. Judging from the size of the dumps, the mine contains several hundred feet of underground workings. The known production from the mine for the years 1914-24 is given in table 128; most of the metal concentrations are in silver.

The vein near the shaft strikes N. $65^{\circ}$ E., and dips $80^{\circ} \mathrm{NW}$; it is not exposed on the steep hill slope below the shaft. The vein cuts microcline-bearing gneiss.

TABLE 128.-Ore produced from the Polly mine, 1902-54'

\begin{tabular}{|c|c|c|c|c|c|c|}
\hline Year & $\begin{array}{c}\text { Crude ore } \\
\text { shipped } \\
\text { (tons) }\end{array}$ & $\begin{array}{c}\text { Concen- } \\
\text { trates } \\
\text { shipped } \\
\text { (tons) }\end{array}$ & $\begin{array}{c}\text { Gold } \\
\text { (ounces) }\end{array}$ & $\begin{array}{c}\text { Silver } \\
\text { (ounces) }\end{array}$ & $\begin{array}{c}\text { Lead } \\
\text { (pounds) }\end{array}$ & $\begin{array}{c}\text { Zinc } \\
\text { (pounds) }\end{array}$ \\
\hline $\begin{array}{l}1014 \ldots \ldots \ldots \\
1915 \ldots \ldots \\
1017 \ldots \ldots \\
1024 \ldots \ldots\end{array}$ & \begin{tabular}{c}
1 \\
4 \\
\hdashline 1 \\
\end{tabular} & 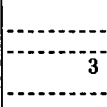 & $\begin{array}{r}0.23 \\
.33 \\
2.12 \\
.09\end{array}$ & $\begin{array}{r}12 \\
44 \\
105 \\
73\end{array}$ & $\begin{array}{r}1,106 \\
2,008 \\
423\end{array}$ & \\
\hline Total....... & 6 & 3 & 2.77 & 234 & 3,537 & 2 \\
\hline
\end{tabular}

I Compiled by U.S. Bureau of Minos. Published by permission.

Weathered specimens of vein material on the dumps are black, and accordingly the dumps differ markedly in appearance from other dumps on Silver Hill. The black color results from the oxidation of manganiferous siderite(?), the most abundant gangue. Some of the vein material also contains. a brownish-pink carbonate mineral, probably rhodochrosite. Altered fragments of country rock, surrounded by carbonate and ore minerals in cockade growth, are common in much of vein material. The ore minerals are sparse in specimens observed and consist of pyrite, galena, sphalerite, and chalcopyrite. The pyrite is dispersed through the carbonate gangue and principally occurs as pyritohedrons; the galena occurs as small aggregates of cubes. At places postsulfide(?) chalcedonic quartz and sugary-textured quartz are present.

\section{PRIDE OF THE WEST MINE (F-I-1)}

Location.-About 11/8 mile north of Black Hawk.

Development.-Three prospect shafts and several shallow pits. The deepest shaft is more than 50 feet deep; the other's probably are not more than 25 feet deep.

Production.-So far: as known, there has been no production from the claim.
Veins.-The vein is along one of several subparallel fractures within the Blackhawk fault zone. It strikes generally N. $45^{\circ} \mathrm{W}$. and dips $80^{\circ}-85^{\circ} \mathrm{SW}$. The vein consists of several closely spaced, mineralized shears which intersect and bifurcate in a complex manner. The fractures contain hematite in a white quartz silicified zone and brown, fine-grained, chalcedonic quartz. Vugs contain terminated quartz crystals. Pyrite is abundantly disseminated through much of the silicified rock. There is some limonite at the surface.

Wallrock.-Microcline-bearing gneiss.

\section{SILENT FRIEND MINE (F-II-5)}

Location.-Near crest of Silver Hill, 2,000 feet north-northeast of Black Hawk, at an altitude of 8,690 feet.

Development.-An unpublished map by George J. Bancroft indicates that the vertical shaft is 105 feet deep; a stub drift is at a depth of 90 feet. Inaccessible in 1954.

Production.-In 1912, 2 tons of crude ore was shipped that yielded 0.11 ounces of gold and 24 ounces of silver. (Compiled by Bureau of Mines. Published by permission.)

Vein.-Strikes N. $50^{\circ}$ E. and dips $87^{\circ}$ SE. to vertical. Vein extends southwestward onto the Tippecanoe and Black Hawk lode No. 2 claims.

Wallrock.-Dominantly amphibolite which contains small lenses of biotite-quartz-plagioclase gneiss and pods of pegmatite.

Ore and sulfide minerals.-Sphalerite, pyrite, galena, sparse chalcopyrite, and kasolite (?)

Gangue minerals.-Some of vein consists of cockade ore-fragments of wallrock are coated with siderite(?) and ore minerals.

Radioactivity.-An analysis of selected vein material from the dump gave 0.057 percent equivalent uranium and 0.004 percent uranium.

\section{SIXTEEN-TO-ONE MINE (B-I-6)}

The Sixteen-to-One mine is on the east side of the Hughesville road, 1,500 feet north of State Highway 119 and 500 feet south of the Chihuahua mine. The workings consist of a crosscut adit, 140 feet long, and a drift $\mathbf{1 7 5}$ feet long. The adit portal, at an altitude of 8,530 feet, is about 20 feet above road level.

The mine was opened prior to 1915 , and from 1915 to 1942 yielded small quantities of gold- and silverbearing lead ore (table 129). All the ore came from a small stope 70 feet long and 25 feet high. 
TABLE 129.-Ore produced from the Sixteen-to-One mine, 1902-5 $4^{1}$

\begin{tabular}{|c|c|c|c|c|c|c|c|}
\hline Year & $\begin{array}{c}\text { Crude } \\
\text { ore } \\
\text { shipped } \\
\text { (tons) }\end{array}$ & $\begin{array}{c}\text { Concen- } \\
\text { trates } \\
\text { shipped } \\
\text { (tons) }\end{array}$ & $\begin{array}{c}\text { Gold } \\
\text { (ounces) }\end{array}$ & $\begin{array}{c}\text { Silver } \\
\text { (ounces) }\end{array}$ & $\begin{array}{c}\text { Copper } \\
\text { (pounds) }\end{array}$ & $\underset{\text { (pounds) }}{\text { Lead }}$ & $\begin{array}{c}\text { Zinc } \\
\text { (pounds) }\end{array}$ \\
\hline $\begin{array}{l}1915 \ldots \\
1917 \ldots \\
1921 \\
1941 \\
1942\end{array}$ & $\begin{array}{l}2 \\
2.5 \\
4 \\
3\end{array}$ & 5 & $\begin{array}{l}0.81 \\
.09 \\
1.27 \\
.20 \\
3.30\end{array}$ & $\begin{array}{r}5 \\
8 \\
123 \\
27 \\
72\end{array}$ & 90 & $\begin{array}{l}1,037 \\
3,095 \\
6,985\end{array}$ & $\mid$\begin{tabular}{l}
- \\
\hdashline
\end{tabular} \\
\hline Total. . & 11.5 & 5 & 5.67 & 235 & 90 & 11,117 & 198 \\
\hline
\end{tabular}

1 Compiled by U.S. Bureau of Mines. Published by permission.

The vein cuts microcline-bearing gneiss, which, contains small bodies of pegmatite and amphibolite as much as a foot wide. The foliation in the gneiss generally dips $25^{\circ}$ or less. Adjacent to the vein the wallrock is bleached for as much as 6 inches.

The vein strikes $\mathrm{N}$. $86^{\circ} \mathrm{W}$. and dips $60^{\circ}-85^{\circ} \mathrm{N}$. It is narrow, not exceeding 5 inches in width, and only locally contains visible sulfides. At most places the vein consists of sparse. disseminated pyrite in a gangue of white quartz and ankerite. Chalcedonic quartz is a sparse gangue. In the stope pillars the vein contains as much as 3 inches of massive galena. Polished sections of the ore examined under the reflecting microscope are seen to contain sparse chalcopyrite, locally with narrow rims of chalcocite. Both the galena and the chalcopyrite vein and embay the pyrite.

Judging from exposures in the mine, the preciousmetal-bearing galena ore occurs where the vein dips $75^{\circ}$ or more; the ore shoots appear to be too small, however, for profitable mining at 1955 prices.

WHEELER TUNNEL (G-III-5)

Location.-In Silver Gulch, 225 feet north of Blackjack shaft.

Production.-The recorded production for the years 1906 to 1926 is 3,499 tons of smelting ore and 306 tons of concentrates that contained 540.94 ounces of gold, 39,416 ounces of silver, 8,265 pounds of copper, 538,414 pounds of lead, and 400,874 pounds of zinc. (Compiled by U.S. Bureau of Mines. Published by permission.) These figures include some production from the Bryan tunnel and the Democrat and Coaley veins.

Development.-An adit that trends S. $52^{\circ}$ W. Adit was caved in 1955 at a stope about 100 feet from the portal. Extent of workings is not known.

Veins.-The vein on which the tunnel was driven strikes N. $52^{\circ}$ E. and dips $88^{\circ} \mathrm{NW}$. At the portal it is a 6-inch wide gossan.

Ore and sulfide minerals.-Galena, sphalerite, copper minerals, gold, and silver.

Gangue minerals.-Quartz.
WHEEL OF FORTUNE MINE (F-II-16)

Location.-Across North Clear Creek, opposite the Dumas-Kinney tunnel.

Development.-Two adits, now inaccessible, develop the vein.

Production.-Small.

Vein.-Strikes east and dips $70^{\circ} \mathrm{N}$.

Ore and sulfide minerals.-Sphalerite and galena.

Walırock.-Dominantly microcline-bearing gneiss.

Tenor.-Crude ore shipped from the 'Wheel of Fortune mine to the Idaho Springs Sampling Works in 1922 and 1924 gave the following assays:

Sampling-works assays of ore from the Wheel of Fortune mine, 1922 and $1924^{1}$

\begin{tabular}{c|r|r|r|r|r}
\hline Year & Tons & Gold 2 & Silver 2 & $\begin{array}{r}\text { Lesd } \\
\text { (percent) }\end{array}$ & $\begin{array}{r}\text { Zinc } \\
\text { (percent) }\end{array}$ \\
\hline 1922 & $\begin{array}{rr}0.45 \\
2.22\end{array}$ & $\begin{array}{r}1.11 \\
.16\end{array}$ & $\begin{array}{r}53.00 \\
7.40\end{array}$ & $\begin{array}{r}15.00 \\
7.00\end{array}$ & $\begin{array}{r}\text { 1. 25 } \\
1924\end{array}$ \\
\hline
\end{tabular}

1 Data on ore tenor furnished by the Idaho Springs Sampling Works. Published by permission.

Ounces per ton.

\section{NIGGER HIIL AREA}

The mines on Nigger Hill are small and have not contributed significantly to the metal output of the district. Several mines, were worked until about 1900 , largely for gold in the shallow enriched zone, but most were inactive until recent years. In 1951 uranium was discovered in the area (Sims and others, 1955) and as a result of the discovery the Carroll, Claire Marie, Two Sisters, St. Anthony, and R.H.D. mines were rehabilitated and examined. Subsequently, small quantities of pitchblende and metatorbernite ores were shipped (Sims and others, 1963).

The country rock is mainly microcline-bearing geniss; west of the Boodle mine it is interlayered biotite gneisses and pegmatite. The rocks have a prevailing gentle or moderate westward dip.

The veins on Nigger Hill trend east, east-northeast, and west-northwest and $\operatorname{dip} 60^{\circ}$ or more. They are galena-sphalerite veins and are chiefly valuable for lead and uranium. The known ore shoots plunge westward.

\section{BON TON MINE (C-II-1)}

The Bon Ton mine, on the northwest side of Nigger Hill, has been a small producer of gold- and silverbearing lead ore (table 130). The ore that was mined consisted almost entirely of direct shipping ore and contained more than 20 percent lead and a high content of gold and silver. The smelting ore shipped in 1902 contained an ounce of gold and 32 ounces of silver per ton. In 1953 the shaft was filled with water and nothing is known concerning the mine 
workings. Judging from the size of the dump, however, the mine is small.

The Bon Ton shaft, inclined $80^{\circ} \mathrm{SE}$., is on a vein that strikes N. $68^{\circ} \mathrm{E}$. The vein is not exposed at the surface. Ore and sulfide specimens on the dump consist of pale-green sphalerite, galena, some pyrite, and siderite (?). The pyrite is in aggregates largely associated with the carbonate minerals, but some pyrite replauss silicified wallrocks. The sphalerite is fractured and veined by white crytocrystalline quartz.

TABLE 130.-Ore produced from Bon. Ton mine, Nigger Hill,

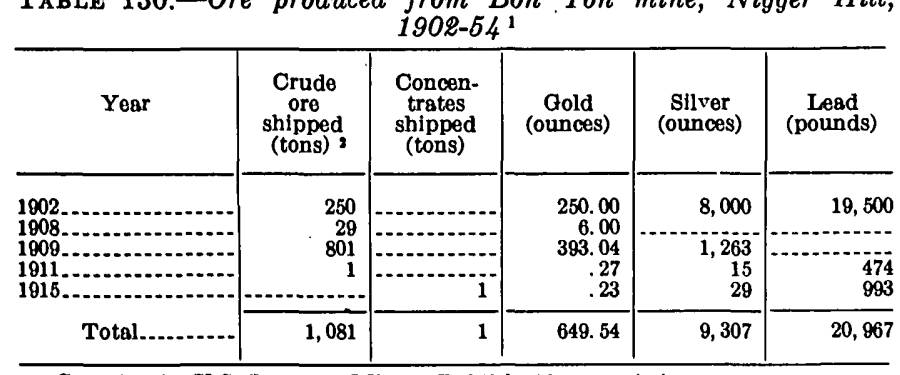

1. Complled by U.S. Bureau of Mines. Published by permission.
All crude ore shipped directly to smelter except 17 tons in 1909 which was milled BOODLE MINE (B-II- - )

Location.-West side of Nigger Hill.

Development.-Shaft inclined about $65^{\circ} \mathrm{NW}$.; underground development not known, but judging from the dump the workings are extensive.

Production.-From 1908 to 1949 a total of 1859 tons of crude ore and 151 tons of concentrates yielded 216.34 ounces of gold, 7,879 ounces of silver, 2,864 pounds of copper, 246,321 pounds of lead, and 127,804 pounds of zinc. (Compiled by U.S. Bureau of Mines. Published by permission.)

Vein.-Boodle: Strike N. $80^{\circ}$ E., dip about $65^{\circ}$ NW.

Wallrock.-Microcline-bearing gneiss, interlayered biotite gneisses, and pegmatite.

Ore and sulfide minerals.-Galena, sphalerite, sparse amount of chalcopyrite, silver, and gold.

Gangue minerals.-Quartz.

\section{CARROLL MINE (C-II-4)}

The Carroll mine was worked considerably prior to 1900 but was closed from 1903 to 1953 . In 1953 and 1954 the mine was rehabilitated to determine the value of the uranium occurrences indicated by the pitchblende-bearing ore on the dump (Sims and others, 1955, p. 20) ; and in 1954 and $1955,62.57$ tons of crude ore and 106.83 tons of concentrates were shipped (published by permission) that yielded 55.04 ounces of gold, 1,713.94 ounces of silver, 843.6 pounds of copper, 52,905 pounds of lead, 56,767 pounds of zinc, and 348.96 pounds of $\mathrm{U}_{3} \mathrm{O}_{8}$. During this period of operation the mine was mapped and sampled in detail. A brief description of the pitchblende deposits was given previously
(Sims, 1956, p. 751-753), and a detailed description of the mine is given in the report by Sims and others (1963).

The mine is opened by a shaft, inclined about $65^{\circ}$ NE., and by levels at vertical depths of $102,177,228$, and 278 feet. Stopes are present west of the shaft above the 228 level and east of the shaft above the 177 level. All the production for the years 1954 and 1955 came from the stope on the 228 level.

The mine workings are in Precambrian microclinebearing gneiss, but the gneiss contains abundant thin conformable layers of biotite-quartz-plagioclase gneiss, migmatite, and pegmatite; and at places the rocks are interlayered on a fine scale (Sims, 1956, fig. 6). Except locally, the rocks strike northeast and dip moderately northwest.

Although four veins are present in the mine, the Carroll, Boodle, Claire Marie, and an unnamed northwestward-trending structure, most of the mine development has been on the Carroll vein.

The Carroll vein strikes about N. $70^{\circ} \mathrm{W}$. and dips about $65^{\circ} \mathrm{NE}$. It is generally 2 to 4 feet wide, but at the stope on the 228 level the vein is commonly 4 to 6 feet wide and locally as much as 9 feet wide. Generally the vein consists of two or more principal subparallel vein fissures that are separated by fractured, brecciated, and altered wallrock which is mineralized to different degrees. The sulfides, galena, sphalerite, and sparse pyrite, chalcopyrite, and tennantite, together with quartz, occur as massive seams along the fractures and as coatings around breccia fragments. The pitchblende is in distinct fractures in the walls of the sulfide vein or within the vein closely associated with but crosscut by the sulfide minerals.

The uranium ore in the vein occurs in shoots and smaller lenses within a zone of ore shoots that plunges about $35^{\circ}$ W. (Sims, 1956, fig. 6). The zone of ore shoots has an average breadth of about 60 feet and a known plunge length of more than 300 feet. The separate shoots are small bodies that are arranged en-echelon within the zone of ore shoots. The largest shoot, on the 228 level west, has a height of about 50 feet, a stope length of as much as 50 feet, and an average thickness of about 6 inches.

The base-metal sulfide ore bodies generally coincide with the zone of uranium ore shoots, but the sulfide ore shoot on the 228 level has a stope length much greater than the stope length of the zone of uranium ore shoots. The grade of the base-metal sulfide ore on the 228 level was given previously (fig. 14).

The westward plunge of the zone of uranium ore shoots is nearly parallel to the trace of the intersec- 
tion of the Carroll vein with the layering of the wallrocks (Sims, 1956, fig. 6). Although the sulfide ore bodies may also be related in part to the same structural control, the ore on the 228 level appears to be localized primarily at the junction of the Boodle and Carroll veins (fig. 14).

\section{CLAIRE MARIE MINE (C-II-7)}

Location.-On Nigger Hill 520 feet northeast of the Carroll mine.

Production.-Small.

Development.-A 216-foot shaft and 2 short levels at vertical depths of 124 and 206 feet. Workings connect through stope with Two Sisters mine.

Vein.-Claire Marie vein: strike, N. $70^{\circ}-90^{\circ}$ E.; $\operatorname{dip}, 85^{\circ} \mathrm{SE}$.

Wallrock.-Precambrian microcline-bearing gneiss, granite, pegmatite, amphibolite; Tertiary quartz bostonite.

Ore and sulfide minerals.-Galena, sphalerite, silver, gold, pitchblende, and pyrite.

Gangue minerals.-Quartz.

\section{FREIBURG MINE (C-III-5)}

The Freiburg mine, on the southeast side of Nigger Hill, about 500 feet north of the road in Eureka Gulch, is one of the larger mines on Nigger Hill, but little is known concerning the workings or its production. According to Howard Wherry (oral communication), the main shaft, now covered by dump, is more than 500 feet deep. In 1883 (U.S. Mint report for 1884, p. 306) the shaft was 278 feet deep, with an aggregate of 300 feet of drifts. In 1928 and 1929, Howard Wherry sunk a new shaft about 20 feet east of the old, main shaft to a depth of about 75 feet; a shallow drift was driven to the east about 40 feet, and the ground above the drift was stoped. These workings yielded 70 tons of crude ore that contained 44.08 ounces of gold, 294 ounces of silver, 4,980 pounds of lead, and 4,906 pounds of zinc (compiled by U.S. Bureau of Mines; published by permission).

Crude ore shipments in 1928 gave the following sampling-works assays:

Sampling-works assays of ores from the Freiburg mine, $1928^{1}$

\begin{tabular}{|c|c|c|c|c|}
\hline Tons & Gold 2 & Silver ${ }^{2}$ & $\underset{\text { (percent) }}{\text { Lead }}$ & $\underset{\text { (percent) }}{\text { Zinc }}$ \\
\hline $\begin{array}{l}\text { 2. } 87 \\
\text { 2. } 04 \\
\text { 4. } 50 \\
\text { 8. } 63 \\
0.94 \\
12.73\end{array}$ & $\begin{array}{l}\text { 1. } 08 \\
\text { 1. } 22 \\
\text { 1. } 31 \\
\text { 1. } 29 \\
\text { 2. } 40 \\
.75\end{array}$ & $\begin{array}{r}11.90 \\
12.98 \\
\text { 7. } 70 \\
6.10 \\
10.10 \\
\text { 3. } 03\end{array}$ & $\begin{aligned} \text { 14. } 90 \\
13.05 \\
\text { 7. } 10 \\
6.48 \\
18.25 \\
3.13\end{aligned}$ & $\begin{array}{r}\text { 3. } 90 \\
7.68 \\
9.80 \\
8.80 \\
13.69 \\
7.88\end{array}$ \\
\hline
\end{tabular}

1 Data on ore tenor furnished by the Idaho Springs Sampling Works. Published by permission.
The vein strikes north of east and near the shaft $\operatorname{dips} 65^{\circ} \mathrm{N}$. At the main shaft the vein cuts limesilicate gneiss and amphibolite; at depth this rock should give way to microcline-bearing gneiss. According to Wherry, the vein where mined averages 3 to 4 feet in width. The gold and silver concentrations are in the galena- and sphalerite-bearing ore.

\section{MAGGIE M MINE (C-II-2)}

The Maggie $\mathbf{M}$ mine is on Nigger Hill just east of the city cemetery and 275 feet north of the. Carroll mine. The workings consist of a shaft about 250 feet deep and short levels at depths of about 60, 120, and 160 feet. These were inaccessible in 1953. The production from the mine is probably small; it was included with that from the Spur Daisy group of mines (table 131).

The mine develops a vein that strikes $\mathrm{N} .75^{\circ} \mathrm{W}$. and dips $60^{\circ} \mathrm{NE}$. Judging from the dump at the main shaft, the vein cuts microcline-bearing gneiss wallrocks that contain layers of biotite-quartz-plagioclase gneiss and pegmatite. Where exposed in surface pits, the vein is less than a foot wide. It contains galena, sphalerite, pyrite, and sparse chalcopyrite and tennantite. Some pyrite is in veins and is later than both galena and sphalerite.

TABLE 131.-Ore produced from Maggie $M$, Spur Daisy, Claire Marie, and Two Sisters mines, 1892-1954 ${ }^{1}$

\begin{tabular}{|c|c|c|c|c|c|c|c|}
\hline Year & $\begin{array}{l}\text { Crude } \\
\text { ore } \\
\text { shipned } \\
\text { (tons) }\end{array}$ & $\begin{array}{c}\text { Concen- } \\
\text { trates } \\
\text { shinged } \\
\text { (tons) }\end{array}$ & $\begin{array}{c}\text { Gold } \\
\text { (ounces) }\end{array}$ & $\begin{array}{c}\text { Silver } \\
\text { (ounces) }\end{array}$ & $\begin{array}{c}\text { Copper } \\
\text { (pounds) }\end{array}$ & $\begin{array}{c}\text { Lead } \\
\text { (pounds) }\end{array}$ & $\begin{array}{c}\text { Zinc } \\
\text { (pounds) }\end{array}$ \\
\hline $\begin{array}{l}1892 \\
1904\end{array}$ & 546 & 2 & $\begin{array}{r}1,500.00 \\
513.54\end{array}$ & & & & \\
\hline 06 & 15 & & 12.24 & 6 & & 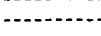 & - \\
\hline 191 & 4 & $\cdots-$ & $\begin{array}{l}0.00 \\
2.96\end{array}$ & 19 & -- & 670 & \\
\hline . & 17 & & 12.47 & 119 & & 4,229 & \\
\hline & 42 & 1 & 8. 37 & 88 & $\cdots$ & 3,379 & 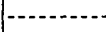 \\
\hline & ${ }_{3}^{4}$ & .5 & .58 & 48 & -- & 1,400 & 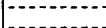 \\
\hline & 1 & 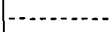 & 4.65 & 11 & & 247 & $\ldots$ \\
\hline & 1 & $\ldots$ & .23 & 2 & & & \\
\hline & 17 & $\cdots$ & 6.87 & 144 & & 4,655 & $\mid--$ \\
\hline & $\begin{array}{l}25 \\
43\end{array}$ & $\cdots$ & $\begin{array}{r}1.40 \\
54.40\end{array}$ & $\begin{array}{r}60 \\
.61\end{array}$ & 47 & $\begin{array}{l}1,995 \\
2,276\end{array}$ & $-\cdots$ \\
\hline & 22 & 1 & 77.90 & 126 & & 2,185 & \\
\hline & 2 & 4 & 4.41 & 83 & $\ldots$ & 4,650 & 1,118 \\
\hline & 16 & | & 7. & $\begin{array}{l}75 \\
49 \\
40\end{array}$ & $\cdots$ & $\begin{array}{r}2,777 \\
2,931\end{array}$ & 400 \\
\hline & & & & & & & \\
\hline Total.. & 793 & 8.5 & $2,216.40$ & 993 & 47 & 31,394 & 1,515 \\
\hline
\end{tabular}

1 Compiled by U.S. Bureau of Mines. Published by permission.

2 Reported from St. Anthony shaft, Two Sisters claim.

\section{polar star Claim (B-V-40)}

Location.-Northeast slope of Nigger Hill, 1,200 feet east of the Two Sisters shaft.

Development.-Several shallow pits.

Production.-In 1940 and 1941, 3 tons of crude ore and 3 tons of concentrates were shipped that contained 13.90 ounces of gold, 18 ounces of silver, 102 
pounds of copper, and 66 pounds of lead. (Complied by U.S. Bureau of Mines. Published by permission.)

$V$ ein.-Strike N. $70^{\circ}$ E.; dip vertical.

Wallrock.-Dominantly microcline-bearing gneiss.

Ore and sulfide minerals.-Gold, silver, galena, and sphalerite.

Gangue minerals.-Quartz.

\section{ROOSEVELT MINE (C-II-11)}

Location.-North slope of Nigger Hill.

Development.-Vertical shaft 190 feet deep; a short level at 80 feet. Inaccessible in 1954.

Production.-In 1923 a ton of crude ore was shipped that contained 2.59 ounces of gold and 1 ounce of silver. (Compiled by U.S. Bureau of Mines. Published by permission.)

Vein.-Strike N. $50^{\circ}$ E.; dip vertical. Van McKay (oral communication) reports a vein junction southwest of shaft. Workings are in supergene zone; cerussite forms 2- to 4 -inch streak for 40 feet southwest of shaft.

Wallrock.-Principally microcline-bearing gneiss.

\section{ST. ANTHONY AND R.H.D. MINES}

Location.-North slope of Nigger Hill.

Production.-Small.

Development.-St. Anthony mine (C-II-9) is opened by a 230 -foot shaft (C. R. McKay, oral communication). The R.H.D. mine (C-II-10) is opened by the R.H.D. shaft (91 feet deep) and the McKay shaft (42 feet deep) (Sims and others, 1955, p. 24-26). The workings of the 2 mines are connected on the 53 level of the R.H.D. shaft and the 103 level of the St. Anthony shaft.

Veins.-R.H.D. vein: strike, N. $60^{\circ}-80^{\circ}$ W.; dip, nearly vertical. Easton vein: strike, N. $60^{\circ}$ E.; dip, $80^{\circ}$ NW. to vertical. Claire Marie vein (see Two Sisters mine) and Ravenswood vein.

Wallrock.-Dominantly microcline-bearing gneiss with small layers of pegmatite, biotite-quartz-plagioclase gneiss, and amphibolite.

Ore and sulfide minerals.-Galena, sphalerite, kasolite, metatorbernite, pyrite.

Gangue minerals.-Quartz.

\section{TOM MARTIN MINE (C-II-18)}

Location.-Near crest of Nigger Hill.

Development.-Shaft, inclined $85^{\circ} \mathrm{N}$., is reported to be more than 100 feet deep (Noah Williams, oral communication).

Production.-In 1909 and 1913 a total of 43 tons of crude ore and 13 tons of concentrates were shipped that contained 5.28 ounces of gold, 25 ounces of silver, and 1,113 pounds of lead. (Compiled by U.S. Bureau of Mines. Published by permission.)

$V$ ein.-Strikes N. $70^{\circ}$ E.; dip, steep to north.

Wallrock-Microcline-bearing gneiss.

Ore and sulfide minerals.-Galena, sphalerite, and pyrite.

Gangue minerals.-Quartz.

TWO SISTERS MINE (C-II-8)

Location.-North slope of Nigger Hill.

Production.-Gold ore valued at about $\$ 100,000$ is reported (Daniel Munday, written communication) to have been taken from stope east of shaft; value of remainder of production is not known. In 1953 a small shipment of metatorbernite-bearing ore was made from dump.

Development.-Shaft is reported (Daniel Munday, written communication) to be 700 feet deep; levels at vertical depths of 105,179 , and 320 feet. Stopes are driven on all levels.

Veins.-Two Sisters: Strike, N. $90^{\circ}$ E.; dips, $80^{\circ} \mathrm{S}$. Claire Marie: Strike, N. $75^{\circ}-80^{\circ}$ E.; dips, $75^{\circ} \mathrm{S}$. Veins intersect near shaft.

Wallrock.-Microcline-bearing gneiss, biotite-quartzplagioclase gneiss, pegmatite, amphibolite.

Ore and sulfide minerals.-Galena, sphalerite, gold, silver, kasolite, pitchblende, and pyrite.

Gangue minerals.-Quartz.

\section{UPPER CHASE GULCH AREA}

A few veins have been developed on the hill north of upper Chase Gulch, mainly in the search for silver, but so far as known, production has been negligible. The principal mine openings are shown on plate 1 .

The veins strike northeast or east and dip steeply. They appear weakly mineralized and consist of brecciated country rock and sparse quartz, siderite, and sulfides. Sphalerite and galena are the principal ore minerals, but judging from dump specimens, they are sparse and nowhere sufficiently abundant to constitute massive sulfide ore.

In 1954, small quantities of radioactive vein material were found on the dumps at the Mint and Estella mines, but the quantity of the material probably is small (Șims and others, 1963).

\section{BOSS VEIN}

The Boss vein, mined to shallow depths on the Boss (C-I-2) and Boss No. 2 (C-I-3) claims, is on the hill north of Upper Chase Gulch, 1,600 feet northwest of the Estella mine. The main dump (C-I-2) is visible from the road to Apex. The production from the mine is not known but probably is small. 
The Boss vein strikes N. $75^{\circ}-80^{\circ}$ E. and generally dips $60^{\circ}-85^{\circ} \mathrm{NW}$. Little is known of the mineralogic character of the vein, but judging from the dump samples the vein consists of a small amount of quartz containing sparse visible sulfides.

\section{ESTELAA MINE (C-I-E)}

The Estella mine is 3,200 feet north of the Two Sisters mine, on Nigger Hill. Production, if any, from the mine has been small.

Two subparallel, northeastward-trending veins have been worked on the property by small shafts' and prospect pits. The northwest vein, probably the main vein, dips $65^{\circ} \mathrm{NW}$. at the main shaft and $70^{\circ}-80^{\circ} \mathrm{SE}$. at a shaft to the southwest. The southeast vein, where observed, dips steeply northwest. Both veins cut Precambrian microcline-bearing gneiss.

The veins belong to the galena-sphalerite type, but visible sulfides are sparse. Two types of vein material were observed on the Estella dump. Most of the material consists of quarter-inch siderite veinlets in weakly altered, slightly pyritized wallrock and narrow veinlets and clots of fine-grained, steely galena and resin sphalerite. Another type of ore consists of coarse-grained, cubic galena with lesser quantities of pyrite, chalcopyrite, and tennantite(?) in brecciated country rock. Chalcedonic quartz is present at places in the ore. Some chalcocite is present in the dump samples.

A small quantity of radioactive vein material was found on the main dump in 1954. A sample gave 0.010 percent equivalent uranium and 0.012 percent uranium.

\section{GALLUP MINE (C-I-6)}

The Gallup mine is 400 feet north of the most westerly plug of monzonite porphyry on the north side of upper Chase Gulch. The main shaft, now caved, is 220 feet east of the Estella mine. There is no recorded production from the mine.

The Gallup vein strikes N. $85^{\circ}-90^{\circ}$ E. and dips $65^{\circ} \mathrm{N}$. It cuts microcline-bearing gneiss. Dump specimens of vein material consist of brecciated, partly silicified, vuggy wallrock with irregular clots of resintype sphalerite and traces of pyrite. White, terminated quartz crystals coat sphalerite in small vugs.

\section{MINT MINE (C-I-1)}

The Mint mine is near the crest on the north side of the hill north of upper Chase Gulch, 800 feet north of the Boss shaft. There are two main shafts and a small adit on the property. The most southwestern shaft was open in 1954, but was inaccessible because the ladders were out; the most northeastern shaft was caved at the collar.

Two steeply dipping, eastward-trending veins were developed. Judging from dump samples the veins contain sparse amounts of galena, sphalerite, and pyrite in weakly altered wallrock. Some dump fragments contain manganiferous(?) siderite.

A dump sample from the most northeasterly shaft assayed 0.035 percent equivalent uranium and 0.003 percent uranium. The source of the radioactivity is not known.

\section{REFERENCES CITED}

Alsdorf, P. R., 1916, Occurrence, geology, and economic value of the pitchiblende deposits of Gilpin County, Colorado: Econ. Geology, v. 11, p. 266-275.

Ball, S. H., 1906, Precambrian rocks of the Georgetown quadrangle, Colorado: Am. Jour. Sci., 4th ser., v. 21, p. 371389.

Bastin, E. S., 1915, Geology of the pitchblende ores of Colorado: U.S. Geol. Survey Prof. Paper 90, p. 1-5.

— 1916, Discussion. Occurrence, geology, and economic value of the pitchblende deposits of Gilpin County, Colorado: Econ. Geology, v. 11, p. 681-685.

1950, Interpretation of ore textures: Geol. Soc. America Mem. 45.

Bastin, E. S., and Hill, J. M., 1917, Economic geology of Gilpin County and adjacent parts of Clear Creek and Boulder Counties, Colorado: U.S. Geol. Survey Prof. Paper 94, 379 p.

Bowen, N. L., 1922, The reaction principle in petrogenesis: Jour. Geology, v. 30, p. 177-198.

Burchard, H. C., 1884, Report of the Director, U.S. Mint for 1883.

Callbreath, J. F., Jr., 1899, The mineral resources of Clear Creek County, Colorado: Mining Reporter, v. 40, Denver, Colo.

Collins, G. E., 1904, The relative distribution of gold and silver values in the ores of Gilpin County, Colorado: Trans. Inst. Mining and Metallurgy, v. 12, p. 480-495.

1910, Lessons from Gilpin County practice: Mining and Sci. Press, v. 101, p. 366-371.

- 1913, Application of genetic theories to the search for local enrichments in veins: Colorado Sci. Soc. Proc., v. 10, p. 211-232.

1930, Discussion. Localization of ore in the schists and gneisses of the mineral belt of the Front Range, Colorado: Colorado Sci. Soc. Proc., v. 12, no. 7, p. 252268.

Conolly, H. J. C., 1936, A contour method of revealing some ore structures: Econ. Geology, v. 31, p. 259-271.

Downey, C. J., 1911, A modern type of concentrator in Gilpin County: Mining Sci., v. 64, p. 52.

Drake, A. A., Jr., 1957, Geology of the Wood and East Calhoun mines, Central City district, Gilpin County, Colorado: U.S. Geol. Survey Bull. 1032-C, p. 129-170.

Draper, M. D., 1911, Cyanidation in Colorado: Mining and Sci. Press, v. 103, p. 684.

Edwards, A. B., 1954, Textures of the ore minerals and their significance: Melbourne, Australasian Inst. Min. and Metallurgy.

Egleston, T., 1876, Boston and Colorado smelting works: Am. Inst. Min. Eng. Trans., v. 4, p. 276-298. 
Endlich, F. M., 1874, Report on the mining districts of Colorado and on the geology of the San Luis district: U.S. Geol. and Geog. Survey of Territories (Hayden), Ann. Rept. for 1873 , p. 276-348.

Faul, Henry, (ed.), 1954, Nuclear geology, New York, John Wiley \& Sons, $414 \mathrm{p}$.

Fleischer, Michael, 1955, Minor elements in some sulfide minerals: in Bateman, A. M., Fiftieth ann. volume, Econ. Geol., p. 970-1024.

Fossett, Frank, 1876, Colorado, its gold and silver mines: 1st ed., Crawford, N.Y.

1880, Colorado, its gold and silver mines: 2d ed., Crawford, N.Y.

Fyfe, W. S., Turner, F. J., and Verhoogen, Jean, 1958, Metamorphic reactions and metamorphic facies: Geol. Soc. America Mem. 73, $259 \mathrm{p}$.

Hague, J. D., 1870, Mining industry: in King, Clarence, U.S. Geol. Explor. 40th Parallel, (King) v. 3.

Hall, Frank, 1889-95, History of the State of Colorado (4 v.).

Harrison, J. E., and Wells, J. D., 1956, Geology and ore deposits of the Freeland-Lamartine district, Clear Creek County, Colo.: U.S. Geol. Survey Bull. 1032-B, p. 33-127.

Hollister, O. J., 1867, The mines of Colorado, Springfield, Mass.: S. Bowles and Co., p. 141-226.

King, R. U., Leonard, B. F., Moore, F. B., and Pierson, C. T., 1953, Uranium in the metal mining districts of Colorado: U.S. Geol. Survey Circ. $215,10 \mathrm{p}$.

Koch, G. S., Jr., 1956, The Frisco mine, Chihuahua, Mexico: Econ. Geology, v. 51, p. 1-40.

Leonard, B. F., 1952, Relation of pitchblende deposits to hypogene zoning in the Front Range mineral belt, Colorado [abs.] : Geol. Soc. America Bull., v. 63, no. 12, pt, 2, p. $127 \dot{4}-1275$.

Lindgren, Waldemar, 1933, Mineral deposits: 4th ed., New York, McGraw-Hill Book Co.

Lovering, T. S., 1930, Localization of ore in the schists and gneisses of the mineral belt of the Front Range, Colorado: Colorado Sci. Soc. Proc., v. 12, no. 7.

- 1942, The mineral belt of the Colorado Front Range: in Newhouse, W. H., ed., Ore deposits as related to structural features, Princeton Univ. Press, p. 79-93.

Lovering, T. S., and Goddard, E. N., 1950, Geology and ore deposits of Front Range, Colorado: U.S. Geol. Survey Prof. Paper 223, 319 p.

Lovering, T. S., and Tweto, Ogden, 1953, Geology and ore deposits of the Boulder County tungsten district, Colorado: U.S. Geol. Survey Prof. Paper 245, 199 p.

McKinstry, H. E., 1948, Mining geology: New York, PrenticeHall.

McKinstry, H. E., and Svendsen, R. H., 1942, Control of ore by rock structure in a Coeur d'Alene mine: Econ. Geology, v. 37, p. $215-230$.

Mining Reporter, 1899, v. 40, Denver, Colo.

Moore, F. B., and Butler, C. R., 1952, Pitchblende deposits at the Wood and Calhoun mines, Central City mining district, Gilpin County, Colorado: U.S. Geol. Survey Clrc. $186,8 \mathrm{p}$.

Moore, R. B., and Kithil, K. L., 1913, A preliminary report on uranium, radium, and vanadium: U.S. Bur. Mines Bull. 70, Mining Tech. 2, p. 43-67.

Murray, H. F., 1956, Migration of the Colorado Front Range drainage divide [abs.]: Geol. Soc. America Bull., v. 67, p. 1799.
Newhouse, W. H., 1940, Openings due to movement along a curved or irregular fault: Econ. Geology, v. 35, p. 445464.

Palache, Charles, Berman, Harry, and Frondel, Clifford, 1951, Dana's System of Mineralogy: 7th ed., v. 2, New York, John Wiley \& Sons.

Park, C. F., Jr., 1955, The zonal theory of ore deposition: in Bateman, A. M., Fiftieth ann. volume, Econ. Geology, p. 226-248.

Parmalee, H. C., 1912, Cyaniding by continuous decantation in Clear Creek County, Colo.: Metall. and Chem. Eng., v. 10, p. 27-31.

Parmalee, H. C., 1915, Cyanidation of low-grade sulphide ores in Colorado, Metall. and Chem. Eng., v. 13, p. 421-425.

Pearce, J. A., 1914, Cyanidation of Clear Creek and Gilpin County sulphides, Mining and Sci. Press, v. 109, p. 833837.

1916, Refining cupriferous precipitate, Mining and Sci. Press, v. 112, p. 270-272.

Pearce, Richard, 1890, The association of gold with other metals in the west: Trans. Am. Inst. Mining Eng., v. 18, p. $447-457$.

Pearce, Richard, 1898, Some notes on the occurrence of uraninite in Colorado: Colorado Sci. Soc. Proc., v. 5, p. 156-158.

Phair, George, 1952, Radioactive Tertiary porphyries in the Central City district, Colorado, and their bearing upon pitchblende deposition: U.S. Geol. Survey TEI-247, issued by U.S. Atomic Energy Comm. Tech., Inf. Service, Oak Ridge, Tenn.

Raymond, R. W., 1870, Statistics of mine and mining in the States and Territories west of the Rocky Mountains (1869) : U.S. Treasury Dept., p. 347-348.

Rickard, Forbes, 1898, Notes on the vein formation and mining of Gilpin County, Colorado: Am. Inst. Mining Eng. Trans., v. 28, p. 108-126.

Rickard, Forbes, 1913, Pitchblende from Quartz Hill, Gilpin County, Colorado: Mining and Sci. Press (San Francisco, Calif.), v. 106, no. 23, p. 851-856.

Rickard, T. A., 1893, The limitations of the gold stamp mill: Am. Inst. Mining Eng. Trans., v. 23, p. 137-147.

- 1897, The development of Colorado's mining industry: Am. Inst. Mining Eng. Trans., v. 26, p. 193-214.

Rogers, A. N., 1883, The mines and mills of Gilpin County, Colo. : Am. Inst. Mining Eng. Trans., v. 11, p. 29-55.

Roller, A. H., and Curran, H. T., 1914, Ore treatment at the Argo mill : Eng. and Mining Jour., v. 98, p. 1.

Sims, P. K., 1956, Paragenesis and structure of pitchblendebearing veins, Central City district, Colo.: Econ. Geology, v. 51 , p. $739-756$.

Sims, P. K., and Barton, P. B., Jr., 1961, Some aspects of the geochemistry of sphalerite, Central City district, .Colo.: Econ. Geology, v. 56, p. 1211-1237.

1962, Hypogene zoning and ore genesis Central City district, Colo.: Geol. Soc. America, Buddington volume, p. $373-396$.

Sims, P. K., and others, 1963, Geology of uranium and associated ore deposits, central part of Front Range mineral belt, Colorado: U.S. Geol. Survey Prof. Paper 371, in press.

Sims, P. K., Osterwald, F. W., and Tooker, E. W., 1955, Uranium deposits in the Eureka Gulch area, Central City district, Gilpin County, Colorado: U.S. Geol. Survey.Bull. 1032-A, p. 1-32. 
Sims, P. K., and Tooker, E. W., 1956, Pitchblende deposits in the Central City district and adjoining areas, Gilpin and Clear Creek counties, Colorado, in Proc. United Nations International Conf. Peaceful Uses of Atomic Energy, v. 6, Geol. of uranium and thorium, p. 265-269; also in U.S. Geol. Survey Prof. Paper 300, p. 105-111 (Contributions to the geology of uranium and thorium by the United States Geological Survey and Atomic Energy Commission for the United Nations International Conference on Peaceful uses of Atomic Energy, Geneva, Switzerland, 1955, compiled by L. R. Page, H. E. Stocking, and H. B. Smith, 739 p.).

Spurr, J. E., 1923, The ore magmas, v. 2, New York, McGrawHill Book Co.

Tooker, E. W., 1956, Altered wall rocks along vein deposits in the Central City-Idaho Springs region, Colorado: in Swineford, Ada, Fourth Natl. Clay Conf., The Penn. State Univ., Natl. Acad. Sci. Pub. 456, p. 348-361.

1963, Altered wall rocks in the central part of the Front Range mineral belt, Gilpin and Clear Creek Counties, Colorado: U.S. Geol. Survey Prof. Paper 439, in press.

Vanderwilt, J. W., editor, 1947, Mineral Resources of Colorado, Denver, Colo. Mineral Resources Board.

Waring, C. L., and Annell, C. S., 1953, Semiquantitative spectrographic method for analysis of minerals, rocks, and ores: Anal. Chem., v. 25, p. 1174-1179.

Wells, J. D., 1960, Petrography of radioactive Tertiary igneous rocks, Front Range mineral belt, Colorado: U.S. Geol. Survey Bull. 1032-E, p. 223-272. 


\section{INDEX}

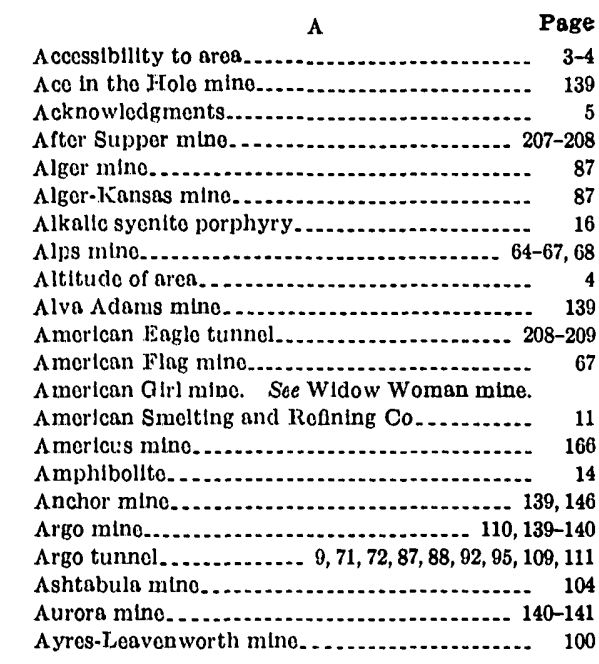

Bangor mine................................ 118, 124

Banta Fill mine........................................ 162

Barker mine.

Barnes mino.

BastIn, E. S., quoted.................. 10, 11, 128, 195

Bates lode...................................... 8

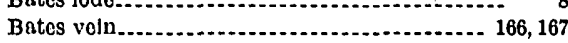

Bates-Junter mine............................ 167

Baxter mine......................................... 68-69

Becker-Bates mine............................ 167

Becky Sharp mine...................... 118, 124, 125, 135

Bolcher mine......................................... 83, 84

Bclmont mino..................................... 80

Bezant mine... 69-71

Bibliography.................................. 226-228

Big Fivo tunnel.

Blotite-muscovite granite

Black Fawk, population of

Blackhawk fault .

Black Hawk lodo No. 2......................... 221

Blackjack mine................................. 210

Blanche $M$ mine............................... 71

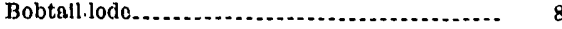

Bobtall tunnol............................... 168, 177

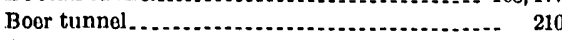

Bon Ton mine.............................. 71, 222-223

Bonanza mine................................... 141

Boodle mino...

Bostonlto porphyry

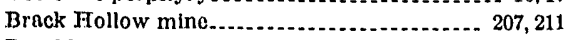

Brooklyn mine................................. 171

Bryan tunnel..................................... 212

Buoll (U.P.R.) mine........ 171

Buckeyo mino.................................. 199

Bullion mino................................. 199

Burro mine........................................ 71

Burroughs lode................................ 71-72

Callfornia dlke................................ 94

Californin-Fidden Treasure-Gardner lode....... 72-74 Caltitornia mine........................... 8. 72,73, 74

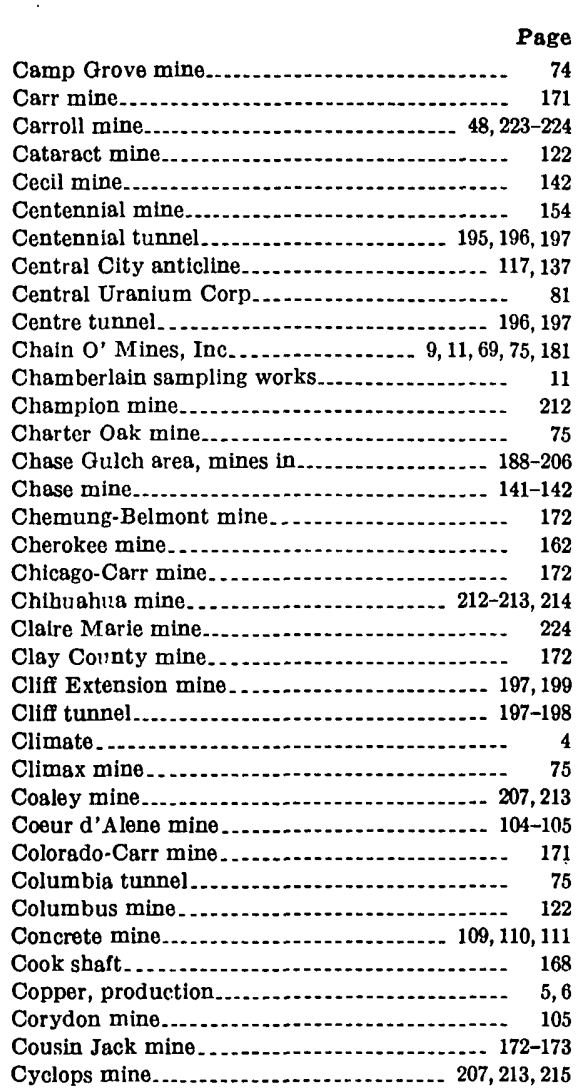

D

Delmonico mine............................ 67, 75-76, 80 Democrat mine.................................. 215

Denbigh shaft................................... 138

Discovery shaft................................ 91, 92

Dory Hill fault............ 161

Drainage.

Druid mine.... 148

Dumas-Kinney tunnel ........................ 216, 217

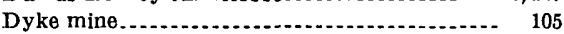

East Boston mine.

East Calhoun mine..

(196, 76, 84

$140,142-143,144,162$

East Pewabic mine................... 118-119, 134, 135

East Whiting mine....................... 117

Ebenezer shaft................................. 154

Edinborough mine . . .

Egyptian mine............................ 76-79, 99

Eldorado mine.............................. 79

Elsinore mine... .............................. 216-219

Endlich, F. M., quoted...................... 87

Essex mine ............................... 105-106, 108

Estella mine.

Ethan Allen mine

Eureka mine. ......................... 48,49, 106-108

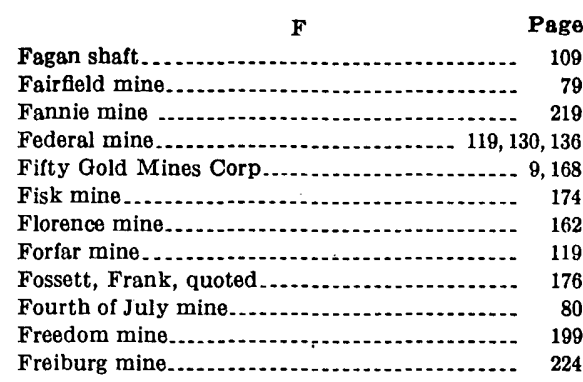

G

Galena mine..................................... 174

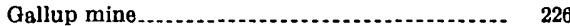

Gardner mine

Gaston mine.......... 173, 175

Gauntlet mine.................................. 80

Gem mine................................... 80, 82-83

Geologic studies, previous. . ...................

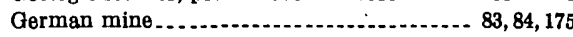

Gettysburg mine............................. 128,120

Gibson mine.................................. 143-144

Gilpin-Eureka shaft........................... 107

Gladstone mine.............................. 144-145

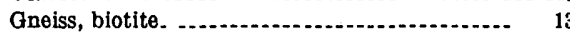

cordierite-amphibole................................ 11,

lime-silicate............................... 11, 14

microcline-quartz-plagioclase-biotite

Gold, discovery, date of ..........................

production

Gold Coin mine ........................ 75, 88, 89, 97

Gold Collar mine.............................. 108-109

Gold Cup mine.............................. 190

Gold mine............ 164

Gold Patch mine..... 84

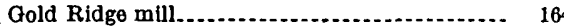

Gold Rock mine. See Springdale mine.

Golden Dollar mine......................... 80-82

Golden Opportunity tunnel .

Golden Treasure shaft......................... 100

Gopher mine....-.-

Grand Army mine.

Grand Central mine............................ 117

Granite porphyry, trachytic.......... 16

Granodiorite........................................ 14

Granodiorite porphyry .................... 15-16

Great Mammotb claim..................... 84

Gregory lode.............................. 166, 175-176, 181

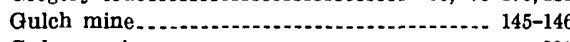

Gulnare mine.................................... 201

Gunnell lode.................................. 100-111

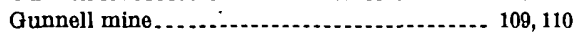

Haguie, J. 'D., quoted ..................... 72

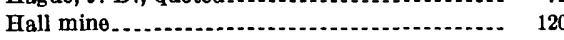

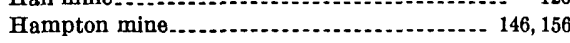
Harsh mine ................. 84 Hartford tunnel..................... 176-177 Hayes and Wheeler tunnel .............. 14, 84-86, 128 Hayseed tunnel. . . . . . . . . Hazeltine mine................................ 146

Hecla mine......................................... 86, 88

Hidden Treasure mine.................. Hill, J. M., quoted..... 10,11, 128, 195 


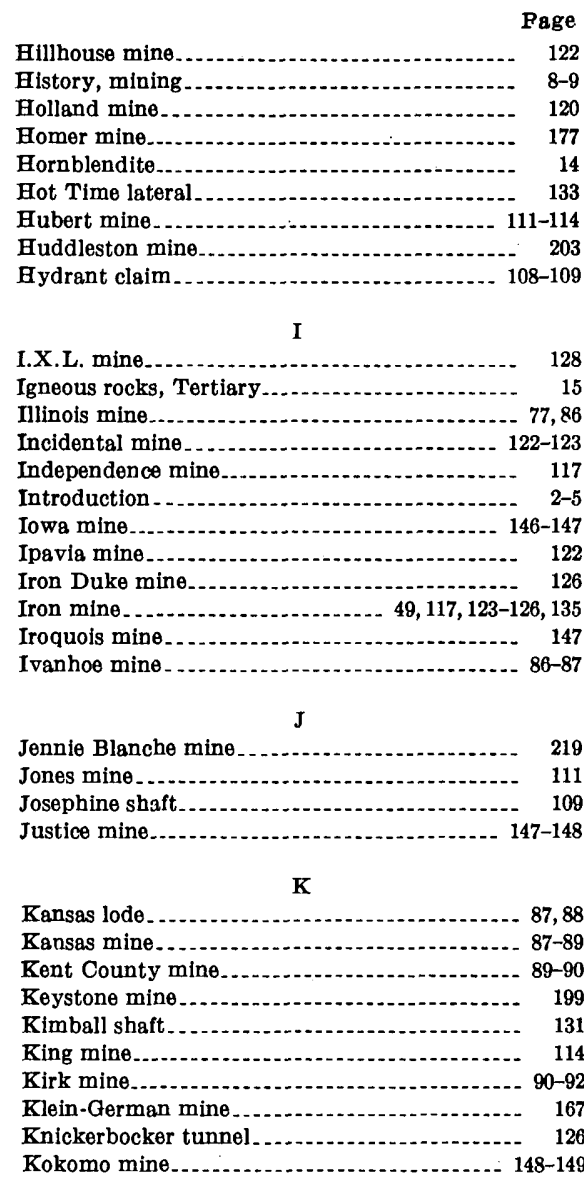

L

LaCrosse tunnel....................... 71, 87, 92-95, 97 Lake-Frontenac-Druid lode.................. 148 Lamberson mine Last Chance mine................................ 95 Leavenworth mine. ............................. 100 Lead, production Lillian mine............ 126 Little Giant mine . ....................... 219-220 Location of area..................... $3-4$ Lotus mine.............................. 126-128, 12 Lower Russell Gulch area, mines in...........138-166 Lucanis tunnel Lutz mine 128

\section{M}

McAllister mine McKay shaft Mackle mine shaft................................ Magrie M mine_...................... 224 Main shaft Maine-Hamlet mine........................... 177 Mammoth mine Marquette mine............................ 220 Maryland Mountain area, mines in............ 188-206 Mayflower mine Meeker-Success mine.......................... 149-150 Mercer County mine Mines, list of............. 7 Minnesota mine......................... 127, 128, 129 Mint mine Missouri mine.................................. 97, 129 Modoc stopes................................... 92 Mont D'Oro tunnel ........................... 203

Murray mine..................................... 76
National mine

National tunnel

Nemaha-Cotton mine

, 84, 98

Newfoundland mine............................ 114 Next President mine............................... 181

Niagara shaft................................... 128

Nigger Hill area, mines in ..................... 222-225 Nigger Hill dike.................................... 16, 17 North Clear Creek.

122 Old Town mine...... 117, 118, 119, 129-133, 136 O'Neil mine...................................... 181-182 Ophir mine.................. 72

Oranoake mine............................... 115

Outer (East) shaft......................... 91, 92

Patch, the. 9, 75, 92, 94-95

Patterson shaft

Pearce (Morris) mine..... 150-151

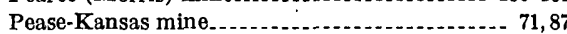

Pegmatites, varieties.

Pendleton shaft

Perrin mine . .............. 122, 123

Perrin mine

Peru mine
Pewablc dike

Pewablc mine........................ 117, 118, 131, 133-135

Pewabic Mountain syncline............... 155, 169, 173

Phoenix mine . .................................. 92

Pitchblende $. . . .84,90,92,104,125,130,132,138,223$

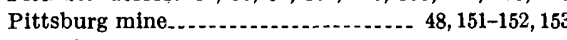
Polar Star claim ............................. 224-225

Polly mine........................................ 221

Post Hole mine.............................. 115

Powers mine . . . ............ 48, 152-154

Pozo inine.

Precambrian rocks, mineral assemblages in..... 11

Pride of the West mine................... 221

Primary ore, depth to ..................... 10

Prize mine...

Production, total ore values.................. 2, 5-7 See also particular mines.

Prompt Pay mine........................ 97-98

Prosser Gulch area, mines in . .

Prosser Gulch dike............................. 16, 17

Protection shaft.

Pullman shaft

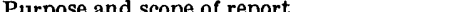

\section{Q}

Quartz diorite..

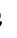

Quartz Hill dike.

Quartz Hill mine. See Eldorado mine

Quartz Hill tunnel.
Quartz Mill mine. See Bezant mine.

Quartz monzonite porphyry.

R.H.D. mine ................................. 225

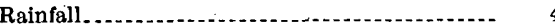
Ralls County mine............................ 76-78, 99 Ready Cash mine. ............................ 117

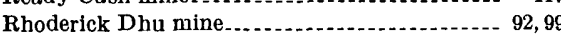
Rialto mine. . .................................... 182 Richardson mine................. 118, 123, 124, 125, 135

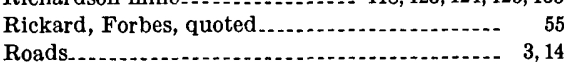
Roads. Rocky Mountain Terror mine................ Rogers crosscut. Rogers crosscut........ $\begin{array}{lr}\text { Rome mine } & 92 \\ \text { Roosevelt mine } & 2 . \ldots \ldots \ldots \ldots \ldots \ldots\end{array}$ Royal shaft....................................... 128

Running Lode mine............................ 178, 183
Page

Russell Gulch................................ 3,4,8,10 Russell Gulch syncline..................... 117, 131, 133 Russell mine.................................. 130, 135

St. Anthony mine San Juan mine......................... 92, 95, 99-100 Sans Souci mine.................................. 204 Santiago mine.................................... 125 Sarah E mine. Saratoga mine.............................. 154-156 Sayre-Bates shaft............................ 167 Schwarz, T, E., quoted............. 195 Seuderberg shaft.................................. $\quad 115$ Shafts mine. Sierra Madre mine. Silent Friend mine. ............................. 221 Silver, production ........................... 5,6 Silver Dollar mine ............................ 152,156 Silver Hill area, mines in . . . Sixteen-to-One mine........................... 221-222 Slaughter House shaft ......................... 109

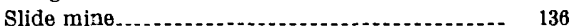
Spectrographic analyses, Chihuahua vein samples_.................. 213 Springdale (Gold Rock) mine _........... 16, 136-138 Spur Daisy mines. ......................... 224

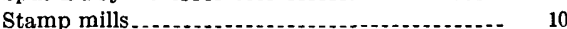
Star of the West mine Stewart mine.

Submarine shaft Symonds Fork mine

\section{$\mathrm{T}$}

Taylor mine...................................... 100 Telegraph mine. Temperature of area.......................... 4

Togo mine........................................... 157

Tom Martin mine.....

Topeka dike.............. 16, 17 Topeka mine ....... 71, 100-103 Topography...

Towns in area

Transportation ................................ 3,8

Troublesome mine................. 206

Tucker mine . .

Tungsten

Two-Forty mine $\ldots \ldots-157-159$

Two Sisters mine........................... 224, 225

Upper chase gulch area, mines in ............. 225-226 Upper Russell Gulch area, mines in .......... 117-138

Vegetation . . . Veins:

A................................ 85, 86, 162, 164 Alger-Kansas........... 87 Allie

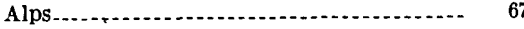
Alva Adams . . . . American Flag. ............................ 67 Americus-Fisk ............. 160 Anchor

Argo . . Ashtabula. ................................ 104, 115 Aurora B........ 86 Baker. ............... 94, 97 Bangor ...................................... 118, 124 Barnes .

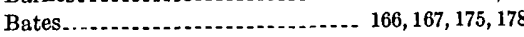
Baxter ............................................ 68, 69 Bloomfield. . .................................. 120 


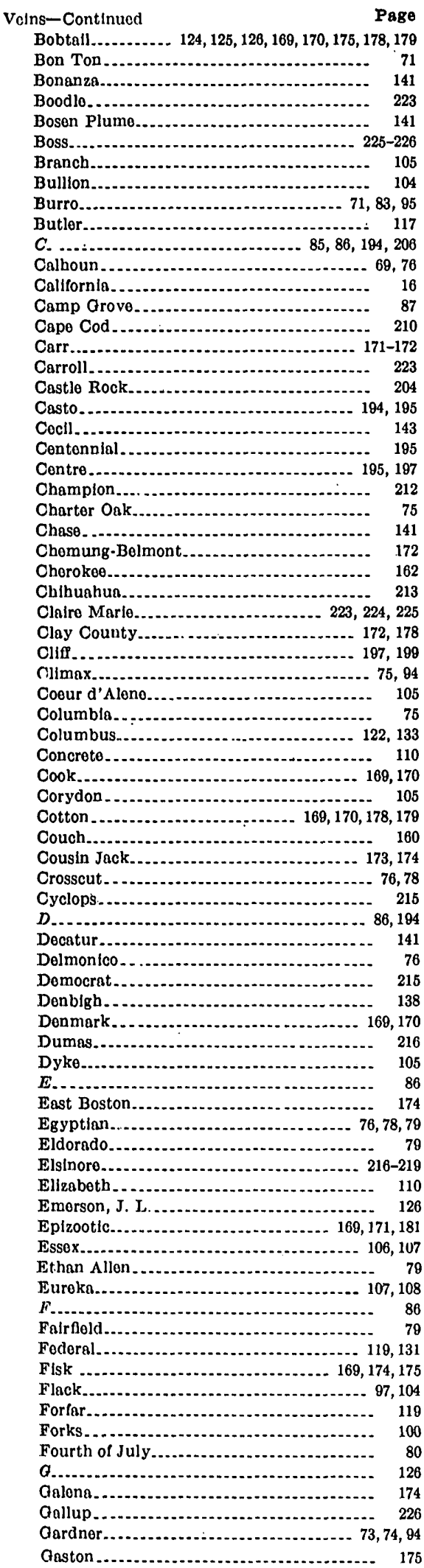

Voins-Continued

Page Gauntlet _as

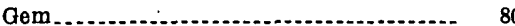
German ............................. 83, 169, 170, 175 Gettysburg ................................. 128, 129 Gibson......................................... 68, 144

Gladstone.................................. 145

Gold.....

Gold Rock.

Golden Treasure.

Golden Wedge...

Gopher

Grand Old Man

Grand Ol

Gregory $169,170,18$

Ground Hog

Gulch Hog- 145

Gunnel (veins)

Hall . . . .

Hampton ...................................... 146

Harsh ................ 84

Hartford............................ 176, 177, 181

Hattie ......................................... 110

Hayseed............. 203

Hazeltine........................................ 146

Hecla......................................... 86, 88

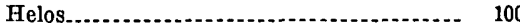

Hillhouse

Hogan.

Homer.

Homestake.

Hubert...... 111, 113

111,113
.-
-

Hydrant.

Illinois . . .............................. 76, 78, 80

Incidental........................... 120, 123, 131

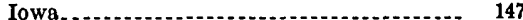

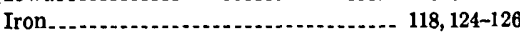

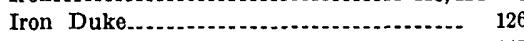

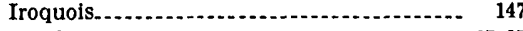

Ivanhoe..................................... 67,87

Jackpot . . . . . . . . . . . .

James Henry......... 203

Jennie Blanche.......................... 219

Justice........................................ 147

Kansas......... 9,72,88

Kent County............................. 89, 90

Kirk

Klondike................ 102

Knowles....................................... 69

Last Chance............................. $71,83,9$

Leavenworth....................... 79, 100, 102, 103

Lillian........................................ 126, 136

Lotus................................... 127, 128

Lutz . . ................................ 128, 131, 133

Mackie......................................... 67

McAllister.

Mammoth................. 95, 169, 170, 175, 182

Mars......................................... 120,125

Meeker...................................... 150

Michigan Boy ........................... 122, 128

Middle..................................... 111, 113

Minnesota............................. 127, 128, 129

Missouri.................................. 94, 97

Mount Lincoln............................. 117

Nemaha............................... 178, 179

New Brunswick......................... 48, 153-154

Newfoundland. . . .

Niagers . .

North.......................... 102, 107, 140, 143

North Missouri............................. 128

North Notaway ......................... 151

Notaway........... 143, 145

0.K................ 171, 181

Old Town................... 118, 1£3, 129, 131-133

O'Nell............................. 169, 170, 175, 181
Veins-Continued Page

Parole.......... 113

Pearce................ 151

Pease-Kansas....................................... 94

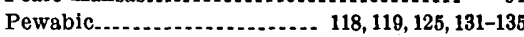

Phoenix-Burroughs......................... 94, 97

Phoenix-Kansas............................. 88

Pittsburg

Powers............. 152-154

Pozo

Prize....................................... 115, 116

Prompt Pay

Puzzle

Quartz Mill....................... 69, 76

R.H.D. vein ............................... 226

Ralls County .................... 76, 77, 78, 79, 99

Rara A vis.................................. 104

Ravenswood. .

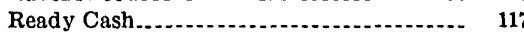

Rhoderick Dhu................. 94, 89

Rialto

Richardson............................. 124, 125, 135

Rocky Mountain Terror....-.- 124, 125, 131, 133, 138

Royal . . . . .............................. 127, 128

Russell................................. 131, 135-136

San Juan............................... 94, 89

Saratoga.................. 155

Scandia. ............ 76, 78

Seuderberg............................ 113, 115, 116

Shaft....................................... 102

Shafts.................................... 111, 113

Shamrock

Silver Dollar........... 146, 153, 156

Slaughter House............................. 110

Sleepy Hollow............................. 160

Slide....................................... 136

South

South Notaway . . ......................... 151

Spur.................................. 107, 108, 126

Star of the West........................ 157

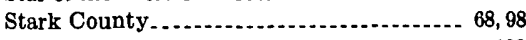

Telegraph....................................... 100

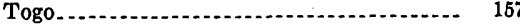

Topeka_................................... 102, 103

Two-Forty............................ 126, 158

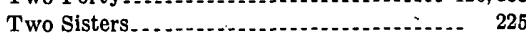

War Dance..... 160

Washington................................. 171

Watercourse.............................. 76

Wautauga.............................. 129, 131, 132

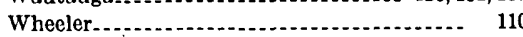

Whiting

Widow Woman . ........................ 162, 164

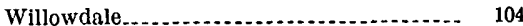

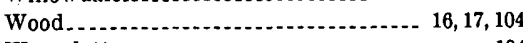

Wyandotte.......... 104

War Dance mine............................ 160-161

Warren mine................................ 114

Wautauga mine .............................. 129, 130

West Flack mine............................. 103-10

West Notaway mine... 161-162

Wheel of Fortune mine..................... 222

Wheeler tunnel.................................... 222

Whiting mine

Widow Woman (American Girl) mine...... 49, 162-164

Williams tunnel........................... 164-166

Willis Gulch area, mines in .................. 138-166

Winnebago Hill area, mines in ............... 188-206

Wood mine...................................... 104

Wyandotte mine.............................. 104

Z

Zinc, production.............................. 5,6 